\title{
PRELIMINARY FEASIBILITY STUDY ON \\ STORAGE OF RADIOACTIVE WASTES \\ IN COLUMBIA RIVER BASALTS \\ (Two Volumes) \\ Volume I I
}

Research and Engineering Division

November 1976

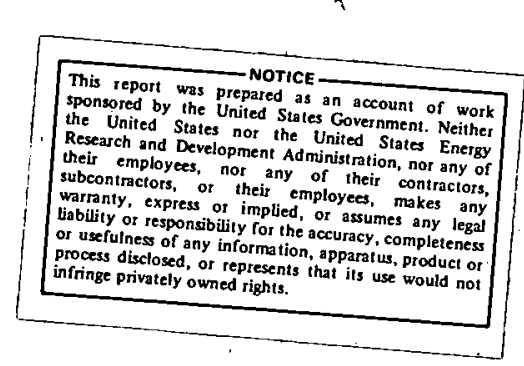

Prepared for the National Waste Terminal Storage Program of the U.S. Energy Research and Development Administration by Atlantic Richfield Hanford Company under Contract $E(45-1)-2130$
Atlantic Richfield Hanford Company Richland, Washington 99352 


\section{DISCLAIMER}

This report was prepared as an account of work sponsored by an agency of the United States Government. Neither the United States Government nor any agency Thereof, nor any of their employees, makes any warranty, express or implied, or assumes any legal liability or responsibility for the accuracy, completeness, or usefulness of any information, apparatus, product, or process disclosed, or represents that its use would not infringe privately owned rights. Reference herein to any specific commercial product, process, or service by trade name, trademark, manufacturer, or otherwise does not necessarily constitute or imply its endorsement, recommendation, or favoring by the United States Government or any agency thereof. The views and opinions of authors expressed herein do not necessarily state or reflect those of the United States Government or any agency thereof. 


\section{DISCLAIMER}

Portions of this document may be illegible in electronic image products. Images are produced from the best available original document. 
VOLUME II

APPENDICES

TABLE OF CONTENTS

$\underline{\text { Page }}$

Appendix A. ANALYTICAL DATA AND SAMPLE LOCATIONS. . . . . A-I FOR BASALT FLOW TYPE LOCALITIES

ICE HARBOR BASALT MEMBER . . . . . . . . . . . . . A-2

ELEPHANT MOUNTAIN BASALT MEMBER. . . . . . . . . . . . A-7

POMONA BASALT MEMBER .................... . . . A-14

GABLE MOUNTAIN BASALT MEMBER . . . . . . . . . . . . ' A-18

HUNTIZINGER BASALT MEMBER. . . . . . . . . . . . . . . A-24

UMATILLA BASALT MEMBER . . . . . . . . . . . . . . . . A-30

PRIEST RAPIDS BASALT MEMBER. . . . . . . . . . . . . . . A-35

ROZA BASALT MEMBER ..................... . . . A-42

FRENCHMAN SPRINGS BASALT MEMBER. . . . . . . . . . . A-50

HIGH MgO CHEMICAL TYPE OF THE LOWER YAKIMA BASALTS . . . . . A-58

REFERENCES ..................... . ${ }^{A-64}$

Appendix B. ANALYTICAL DATA AND SAMPLE LOCATIONS FOR. . .. B B-I

MEASURED FIELD SECTIONS IN YAKIMA BASALTS

SILLUSI BUTTE FIELD SECTION. . . . . . . . . . . . B-2

RUSH CANYON FIELD SECTION. . . . . . . . . . . . . . B-7

SPUKSHOWKI CANYON FIELD SECTION. . . . . . . . . . . . B-12

BLAIR POINT FIELD SECTION. . . . . . . . . . . . . . B-I7 
TABLE OF CONTENTS (continued)

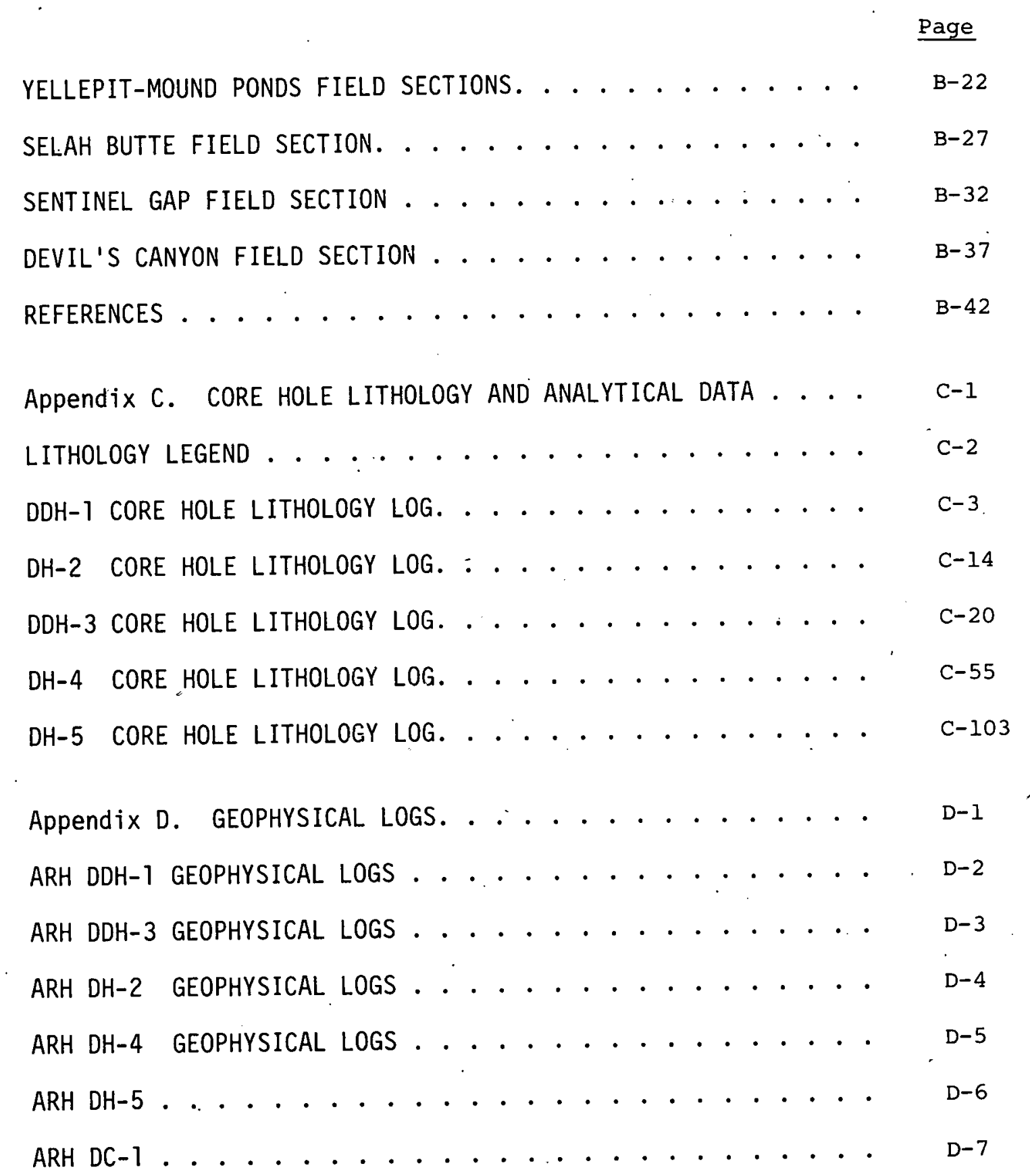


APPENDIX A

\section{ANALYTICAL DATA AND SAMPLE LOCATIONS \\ FOR BASALT FLOW TYPE LOCALITIES}

This appendix is a detailed documentation of type localities for named basalt flows and members. It includes tabulations of analytical data, location maps, and site photographs showing sample points for the type localities. The original type locality reference is cited together with additional distinguishing chemical and petrographic data gathered and interpreted by personnel from Atlantic Richfield Hanford Company.

The location maps show the type locality sites sampled in reference to the Hanford Reservation. Sample serial numbers such as A1275 shown on the sample point photographs indicate the actual location sampled. Tabulations of analytical data do not include corrections for weight loss on heating. Weight loss on heating to $900^{\circ} \mathrm{C}$ is abbreviated in the Tables as Vlty \%, (Volatility per cent.). The sumation of oxides analyzed or material balance is abbreviated as Mtl Bal \%. The "Elemental Roses" graphically depict average analytical values of major and trace elements for the type localities. For stratigraphic nomenclature refer to Chapter IV. 


\section{ICE HARBOR BASALT MEMBER}

The type locality for the Ice Harbor Member is near Ice Harbor Dam about three kilometers downstream on the south bank of the Sriake opposite Goose Island and upstream on the north bank of the river. ${ }^{[A-1]}$ Figure $A-1$ is a location map of this area and Figure A-2 shows the location of points sampled.

At least two chemically and petrographically different flows make up the Ice Harbor Member.

- The lower or Ice Harbor I flow is porphyritic with irregular phenocrysts up to $1 \mathrm{~cm}$ in diameter with plagioclase microlites about $1-2 \mathrm{~mm}$ by $1 \mathrm{~cm}$. The flow is in contact with a flow identified by Swanson as Elephant Mountain. Analyses of this underlying flow are comparable to those of the Elephant Mountain at its type locality.

- The upper flow, Ice Harbor II, is sparsely prophyritic with profuse plagioclase microlites. The flow is seen in dikes cutting Ice Harbor I and directly overlying it.

Ice Harbor II differs from Ice Harbor I in $\mathrm{CaO}, \mathrm{MgO}, \mathrm{Fe} 0, \mathrm{~K}_{2} \mathrm{O}$, lanthanum, samarium, cobalt, scandium; chromium, europium, thorium, hafnium and barium. $\mathrm{TiO}_{2}$ values appear to be similar. Ice Harbor II is higher in $\mathrm{Fe} 0$ than any other of the Yakima Basalts present in the stratigraphic section. Table A-I is a tabulation of data for the two Ice Harbor flows and Figures A-3 and A-4 are graphical representations of analytical data for the flows in the form of "El emental Roses." 

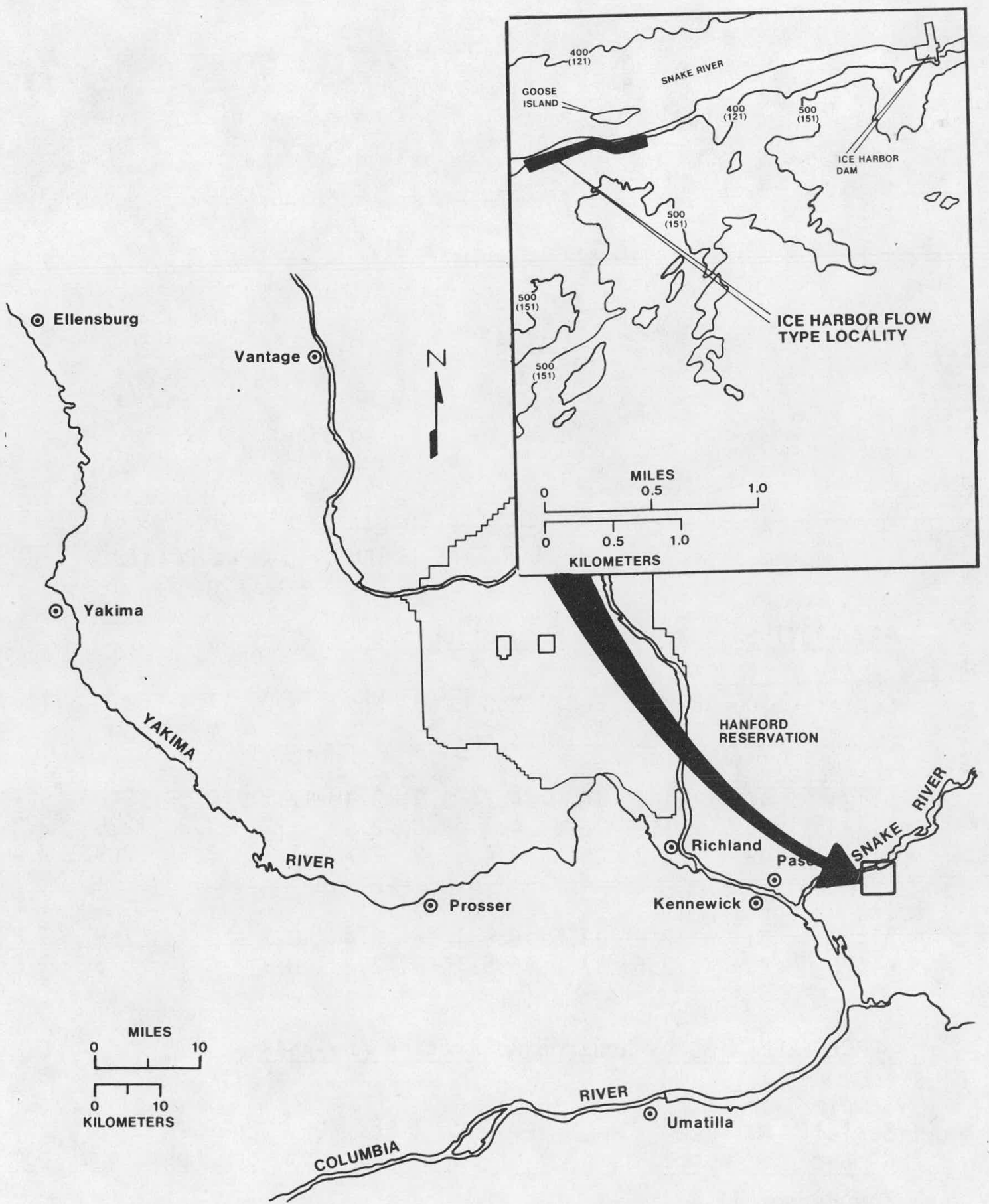

FIGURE A-1

ICE HARBOR TYPE LOCALITY LOCATION MAP 


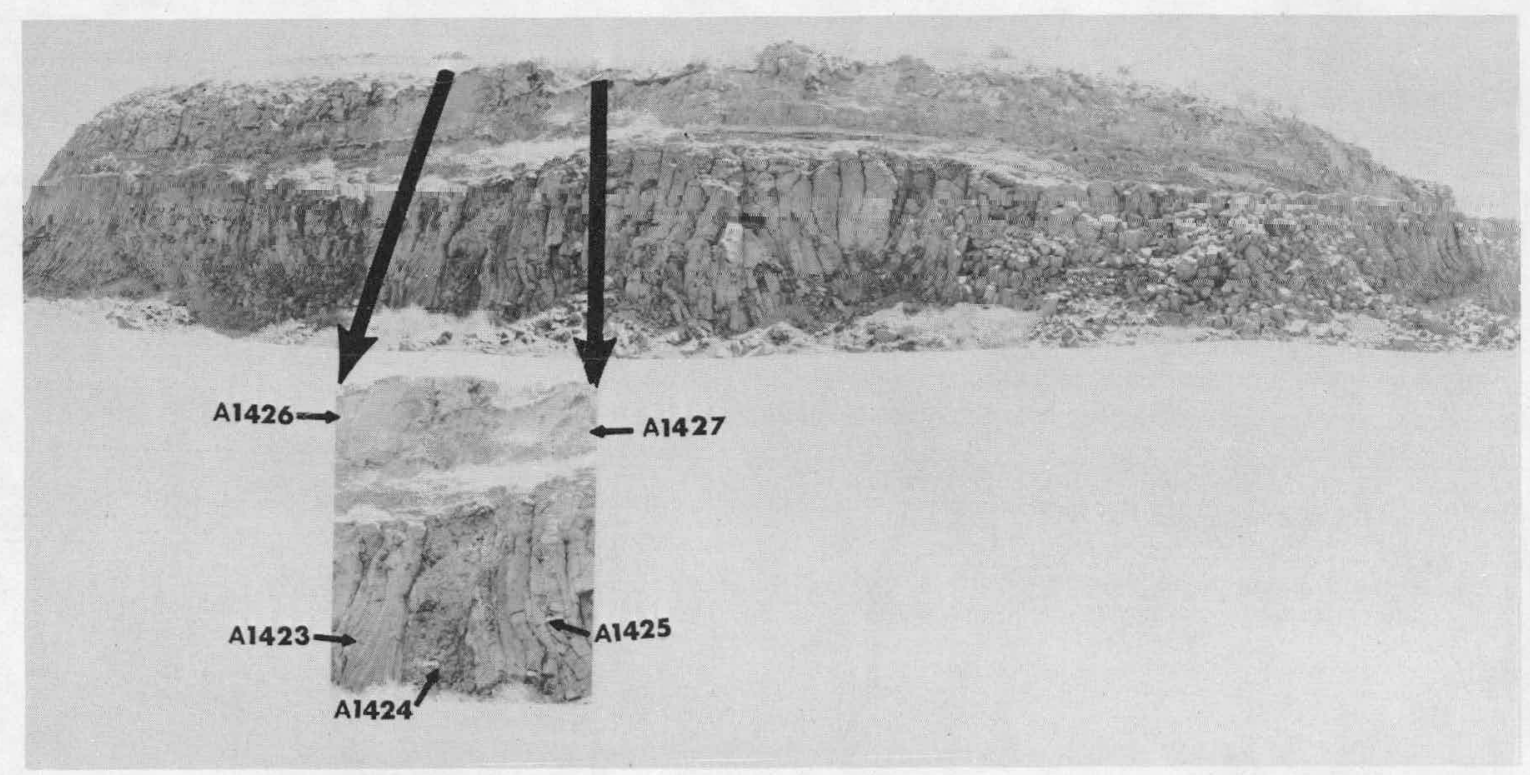

FIGURE A-2

ICE HARBOR TYPE LOCALITY SAMPLE POINTS

MAJOR OXIDES, by Atomic Absorption Spectrometer

Sample

Serial

Number

$\mathrm{SiO}$

$\mathrm{Al}_{2} \mathrm{O}_{3} \quad \mathrm{FeO}$

$\mathrm{Fe} 0$

Mg0 $\mathrm{CaO} \quad \mathrm{Na} 2 \mathrm{O}$

$\mathrm{K}_{2} \mathrm{O} \quad \mathrm{TiO}_{2}$

$\mathrm{Ba}$

Ice Harbor II

$\begin{array}{ll}\text { A1424 } & 47 \\ \text { A1426 } & 49\end{array}$

$11.4 \quad 16.0$

4.7

$\%$

$\%$

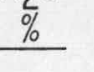

$\% \quad \mathrm{ppm}$

Vlty Mt

A1426

$11.2 \quad 16.5$

4.7

$\begin{array}{ll}8.9 & 2.4 \\ 8.8 & 2.5\end{array}$

1.2

3.31240

$\begin{array}{lll}8.8 & 2.5 & 1.2\end{array}$

3. 31225

3.51269

$3.7 \quad 98.6$

A1427

49

$11.2 \quad 16.3$

4.49 .2

$2.7 \quad 1.1$

$$
3.5
$$

2.299 .4

$2.4 \quad 99.8$

Ice Harbor I

$\begin{array}{ll}\text { A1425 } & 49\end{array}$

$\begin{array}{ll}12.8 & 13.6 \\ 12.6 & 13.6\end{array}$

$\begin{array}{lll}6.9 & 10.6 & 2.4\end{array}$

0.7

3. 1799

$1.8 \quad 102.9$

$\begin{array}{llll}12.6 & 13.6 & 6.9 & 10.3\end{array}$

2.2

0.8

3.

875

TRACE ELEMENTS, by Neutron Activation Analysis

Sample

Serial $\mathrm{Na}$ La $\mathrm{Sm}$ Fe $\mathrm{Co} \quad \mathrm{Sc} \quad \mathrm{Cr} \quad \mathrm{Eu}$ Th Tb Hf Ta Number $\% \quad$ ppm ppm $\%$ ppm ppm ppm ppm ppm ppm ppm ppm Ice Harbor II

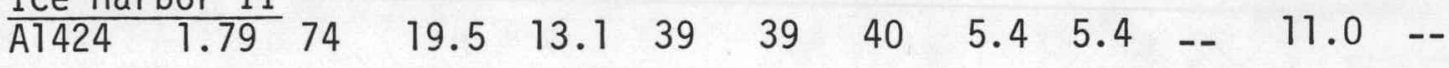
$\begin{array}{llllllllllllll}\text { Ice Harbor I } & & & & & & & & & \end{array}$

TABULATION OF ANALYTICAL UATA FOR THE ICE HARBOR BASALT MEMBER TYPE LOCALITY 


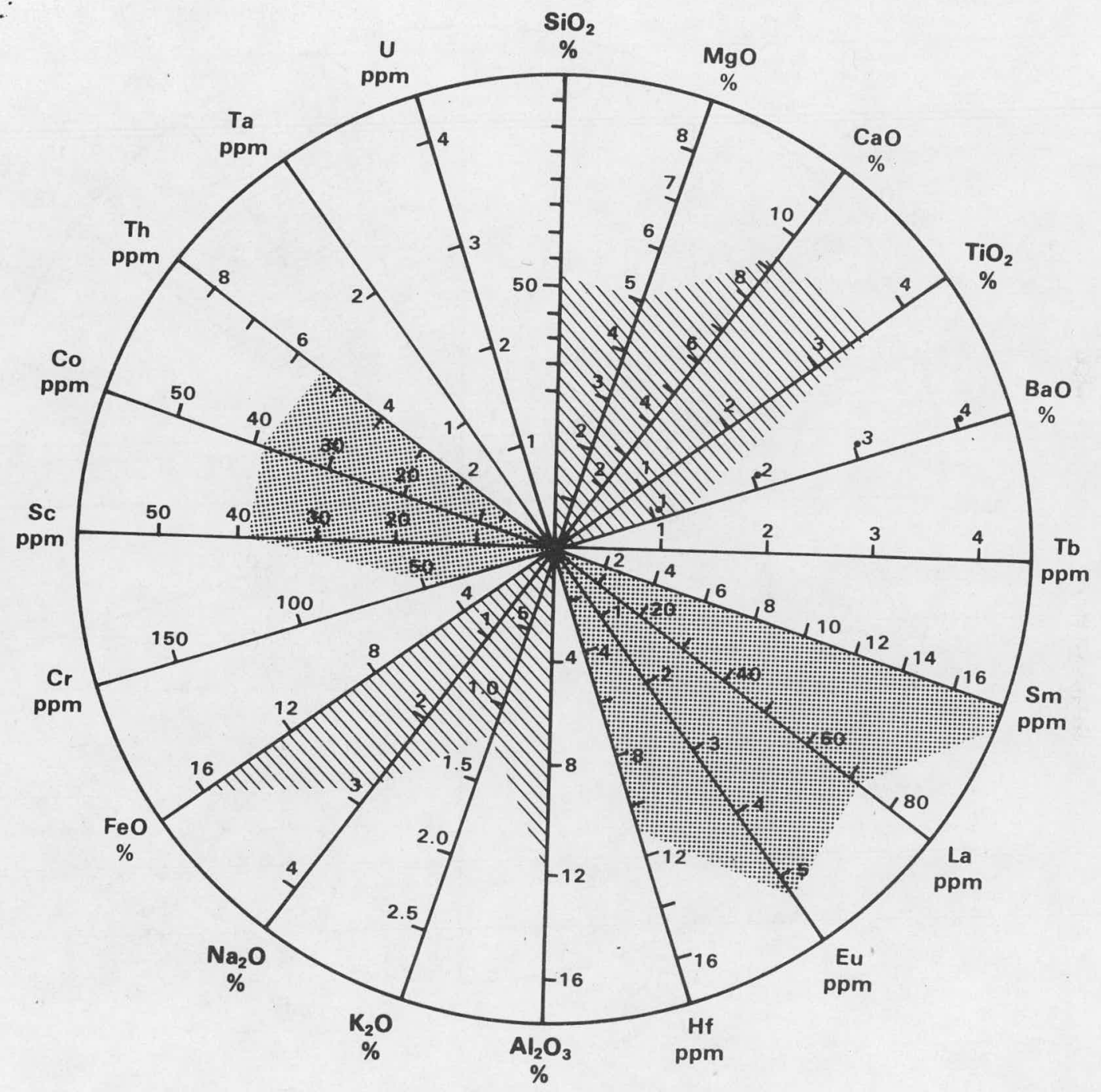

FIGURE $A-3$

ICE HARBOR II BASALT FLOW TYPE LOCALITY. ELEMENTAL ROSE 


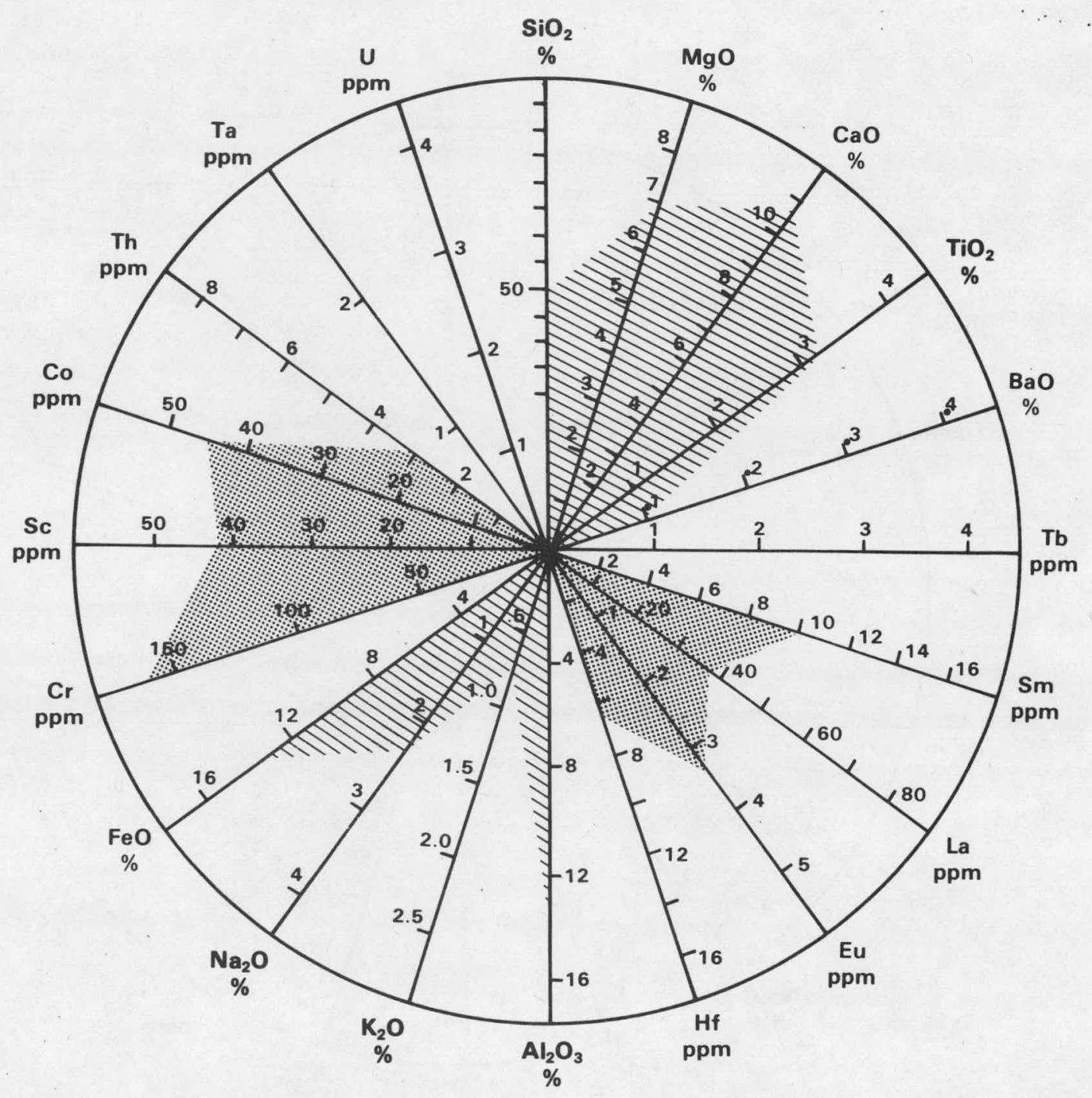

FIGURE $A-4$

ICE HARBOR I BASALT FLOW TYPE LOCALITY, ELEMENTAL ROSE 


\section{ELEPHANT MOUNTAIN BASALT MEMBER}

The Elephant Mountain Basalt Member as used in this report consists of two flows, the Ward Gap overlying the Elephant Mountain. The flows are chemically and petrographically similar and can only be differentiated by stratigraphic position at this time.

The Ward Gap Flow was described and named by Schmincke. [A-2] The type locality for the flow is Ward Gap $6.5 \mathrm{~km}$ west of Prosser, Washington (Figure A-5). The Ward Gap occurs in direct contact with an underlying flow identified by Schmincke as the Elephant Mountain Flow, (Figure A-6). Chemical analyses show that the flow appears to be comparable to the Elephant Mountain at its type locality. At the Ward Gap type locality, the flow is about 7.5 meters thick, columnar in its lower part and marked by vesicle sheets, (tabular layers of vesicles), in its upper part. It weathers a dark gray-brown and tends to form slopes in the vesicular zone. Table A-II is a tabulation of analytical data for the Ward Gap Flow. Figure A-7 is a graphical depiction of the analytical data in the form of an "Elemental Rose".

The Elephant Mountain Flow, (Figures A-8, A-9) was first described and named by waters $[A-3]$ from hogbacks on the south flank of Rattlesnake Ridge about $8 \mathrm{kms}$ east of Donald Pass. Its thickness varies from nine to twelve meters generally and is about 10.5 meters at the type locality. It weathers gray-brown or black. It is comprised of an upper colonnade that forms less than one third of the flow, an entablature that shows abrupt contacts with the upper and lower colonnades and makes up about one half of the flow and the lower colonnade that makes less than a third of the flow. A tabulation of analytical data for the Elephant Mountain Flow is given in Table A-III. Figure A-10 is a graphical depiction of the data in the form of an "Elemental Rose".

The most unique chemical characteristics of the two flows are their high $\mathrm{TiO}_{2}$ content, (about 3.3\%) and their low chromium content (15-27 ppm). 


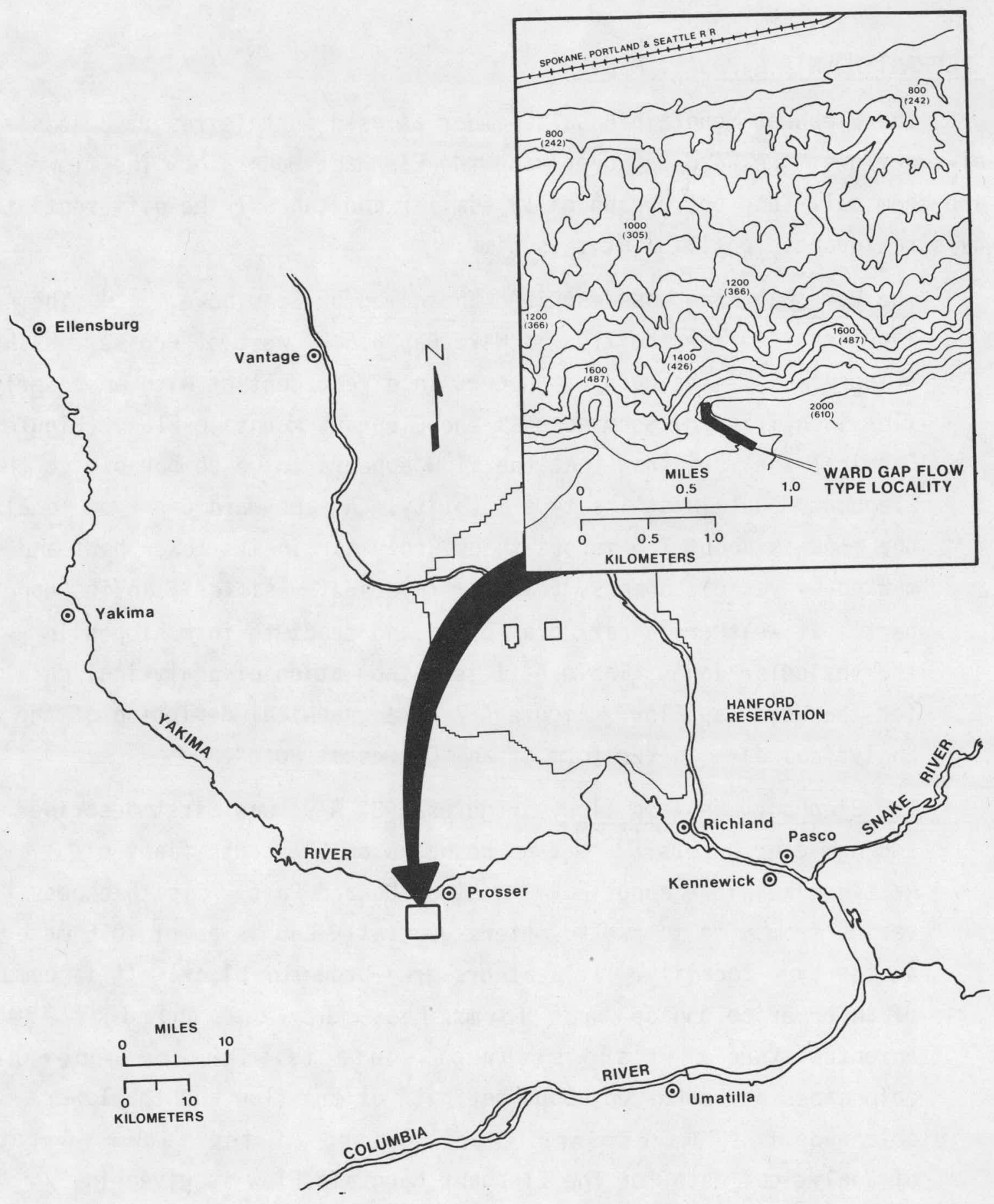

FIGURE A-5

WARD GAP TYPE LOCALITY LOCATION MAP 


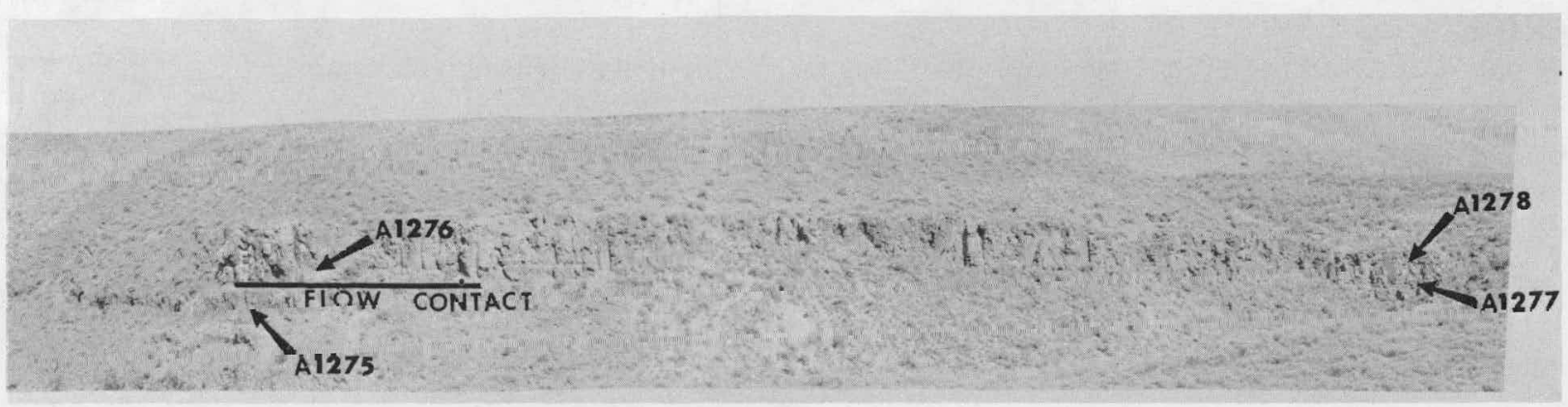

FIGURE A-6

WARD GAP TYPE LOCALITY SAMPLE POINTS

MAJOR OXIDES AND TRACE ELEMENTS, by Atomic Absorption Spectrometer

Sample

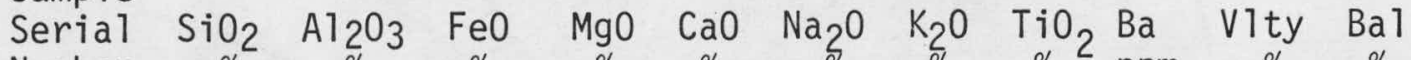

$\frac{\text { Number }}{\text { A1276 }} \frac{\%}{53} \frac{\%}{13.1} \frac{\%}{13.9} \frac{\%}{4.8} \frac{\%}{8.2} \frac{\%}{2.5} \frac{\%}{1.1} \frac{\%}{2.9} \frac{p p m}{600} \frac{\%}{1.9} \frac{\%}{101.4}$

$\begin{array}{llllllllllll}\text { A1276 } & 53 & 13.1 & 13.9 & 4.8 & 8.2 & 2.5 & 1.1 & 2.9 & 600 & 1.9 & 101.4 \\ \text { A1277 } & 51 & 12.8 & 15.0 & 4.5 & 8.2 & 2.5 & 1.1 & 2.7 & 656 & 2.6 & 100.4\end{array}$

$\begin{array}{llllllllllll}\text { A1278 } & 50 & 12.5 & 14.9 & 4.6 & 8.3 & 2.5 & 1.2 & 2.8 & 585 & 2.0 & 98.8\end{array}$

Flow Below Ward Gap

\begin{tabular}{llllllllllll}
\hline A1275 & 52 & 13.1 & 14.7 & 4.5 & 8.0 & 2.5 & 1.2 & 2.8 & 616 & 3.6 & 102.4
\end{tabular}

Sample

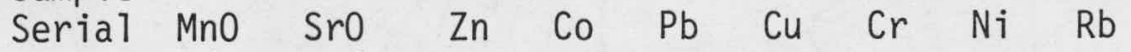

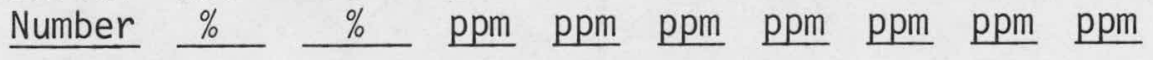

$\begin{array}{llllllllll}\text { A1276 } & 0.21 & 0.017 & 165 & 40 & 55 & 235 & 20 & 10 & 37\end{array}$

$\begin{array}{llllllllll}\text { A1277 } & 0.21 & 0.018 & 165 & 60 & 75 & 235 & 15 & 15 & 37\end{array}$

$\begin{array}{llllllllll}\text { A1278 } & 0.21 & 0.017 & 170 & 60 & 70 & 260 & 15 & 5 & 42\end{array}$

Flow Below Ward Gap

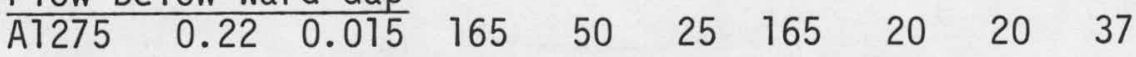

TRACE ELEMENTS, by Neutron Activation Analysis.

Sample

Serial $\mathrm{Na}$ La Sm Fe Co Sc Cr Eu Th Tb Hf Ta

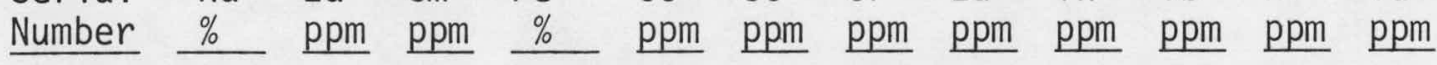

$\begin{array}{lllllllllllll}\text { A1276 } & 1.82 & 31 & 8.1 & 10.1 & 43 & 31 & 22 & 3.0 & 6.5 & 1.7 & 7.7 & 2.3\end{array}$

$\begin{array}{lllllllllllll}\text { A1277 } & 1.76 & 31 & 8.3 & 11.2 & 42 & 31 & 23 & 2.6 & 6.7 & 1.2 & 6.5 & 2.2\end{array}$

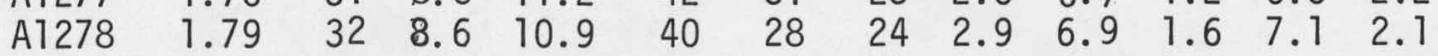




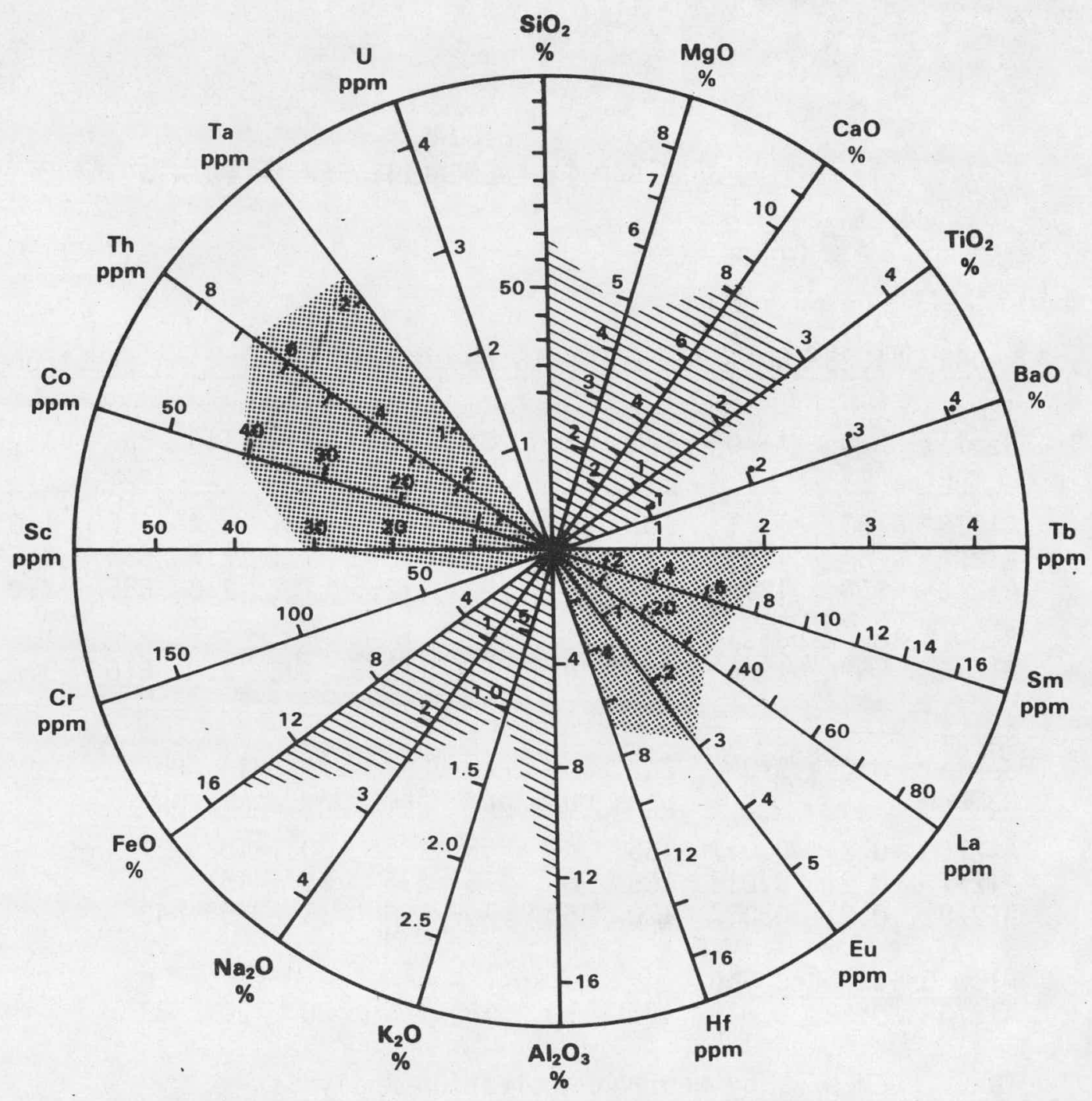

FIGURE A-7

WARD GAP BASALT FLOW TYPE LOCALITY, ELEMENTAL ROSE 


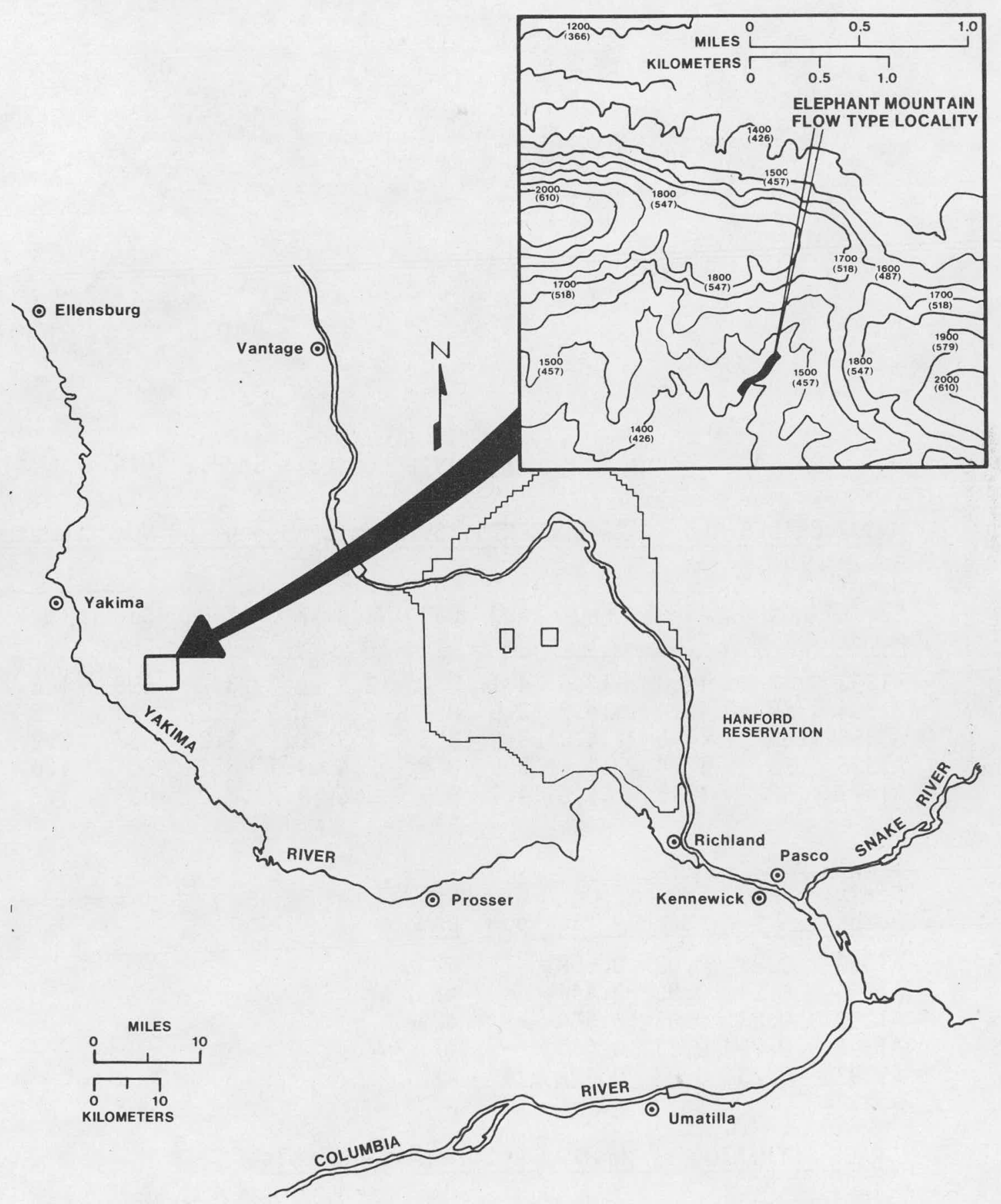

FIGURE A-8 


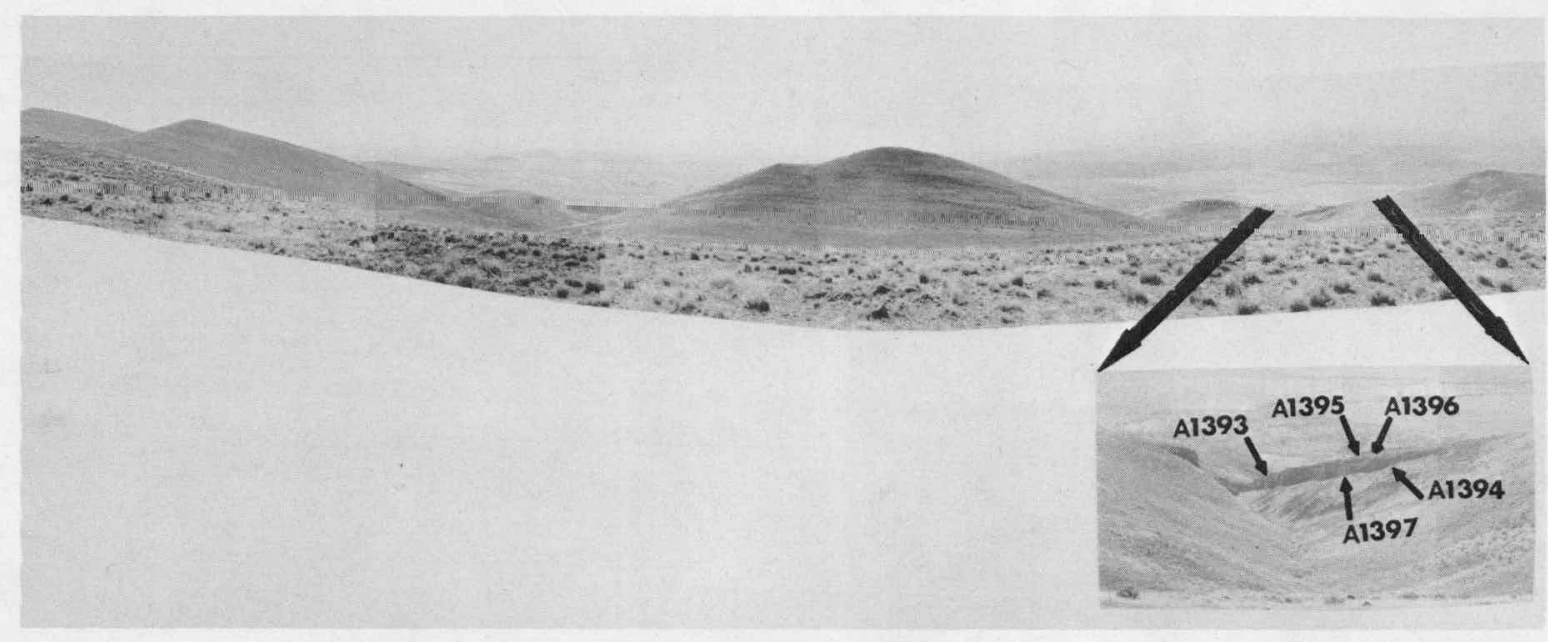

FIGURE A-9

ELEPHANT MOUNTAIN TYPE LOCALITY SAMPLE POINTS

MAJOR OXIDES AND TRACE ELEMENTS, by Atomic Absorption Spectrometer

Sample

Serial

Number

A1393

A1394

A1395

A1396

A1397

$\mathrm{SiO}_{2} \quad \mathrm{Al}_{2} \mathrm{O}_{3} \quad \mathrm{FeO}$

$\begin{array}{lll}\mathrm{MgO} & \mathrm{CaO} & \mathrm{Na} \\ 0 & & \end{array}$

\begin{tabular}{|c|c|c|c|c|c|}
\hline $\begin{array}{c}\mathrm{Na}_{2} \mathrm{O} \\
\%\end{array}$ & $\begin{array}{r}\mathrm{K}_{2} \mathrm{O} \\
\%\end{array}$ & $\underset{\%}{\mathrm{TiO}_{2}}$ & $\begin{array}{l}\mathrm{Ba} \\
\mathrm{ppm}\end{array}$ & $\begin{array}{c}\text { V1ty } \\
\%\end{array}$ & $\begin{array}{c}\mathrm{Bal} \\
\%\end{array}$ \\
\hline & 0. & 3. & 698 & & 100 \\
\hline & & & & & \\
\hline & 0 . & 3. & 687 & 2.2 & 100 \\
\hline & 1. & 3. & 701 & 1.6 & \\
\hline 2. & 1. & 3.2 & 693 & 1.7 & 10 \\
\hline
\end{tabular}

Sample

Serial

Number

A1393

A1394

A1395

A1396

A1397

\begin{tabular}{|c|c|c|c|c|}
\hline $\begin{array}{c}\mathrm{MnO} \\
\%\end{array}$ & $\begin{array}{c}\text { Sro } \\
\%\end{array}$ & $\mathrm{P}_{2} \mathrm{O}_{\%}$ & $\begin{array}{l}\mathrm{Cr} \\
\mathrm{ppm}\end{array}$ & $\begin{array}{l}\mathrm{Rb} \\
\mathrm{ppm}\end{array}$ \\
\hline & 0.03 & 0.508 & 27 & 42 \\
\hline & & 0.444 & & 42 \\
\hline 0.2 & 0.03 & 0.544 & - & 42 \\
\hline 0.2 & 0.02 & 0.469 & - & 47 \\
\hline 0.23 & 0.03 & 0.432 & - & 47 \\
\hline
\end{tabular}

TRACE ELEMENTS, by Neutron Activation Analys is

Sample

Serial $\mathrm{Na}$ La Sm Fe Co Sc Cr Eu Th Tb Hf Ta Number $\% \quad \mathrm{ppm} \quad \mathrm{ppm} \%$ ppm ppm ppm ppm ppm ppm ppm ppm $\begin{array}{lllllllllllll}\text { A1393 } & 1.87 & 37 & 9.0 & 11.5 & 48 & 33 & 27 & 2.9 & 6.2 & - & 6.3 & \text {-- }\end{array}$ TABLE A-III 


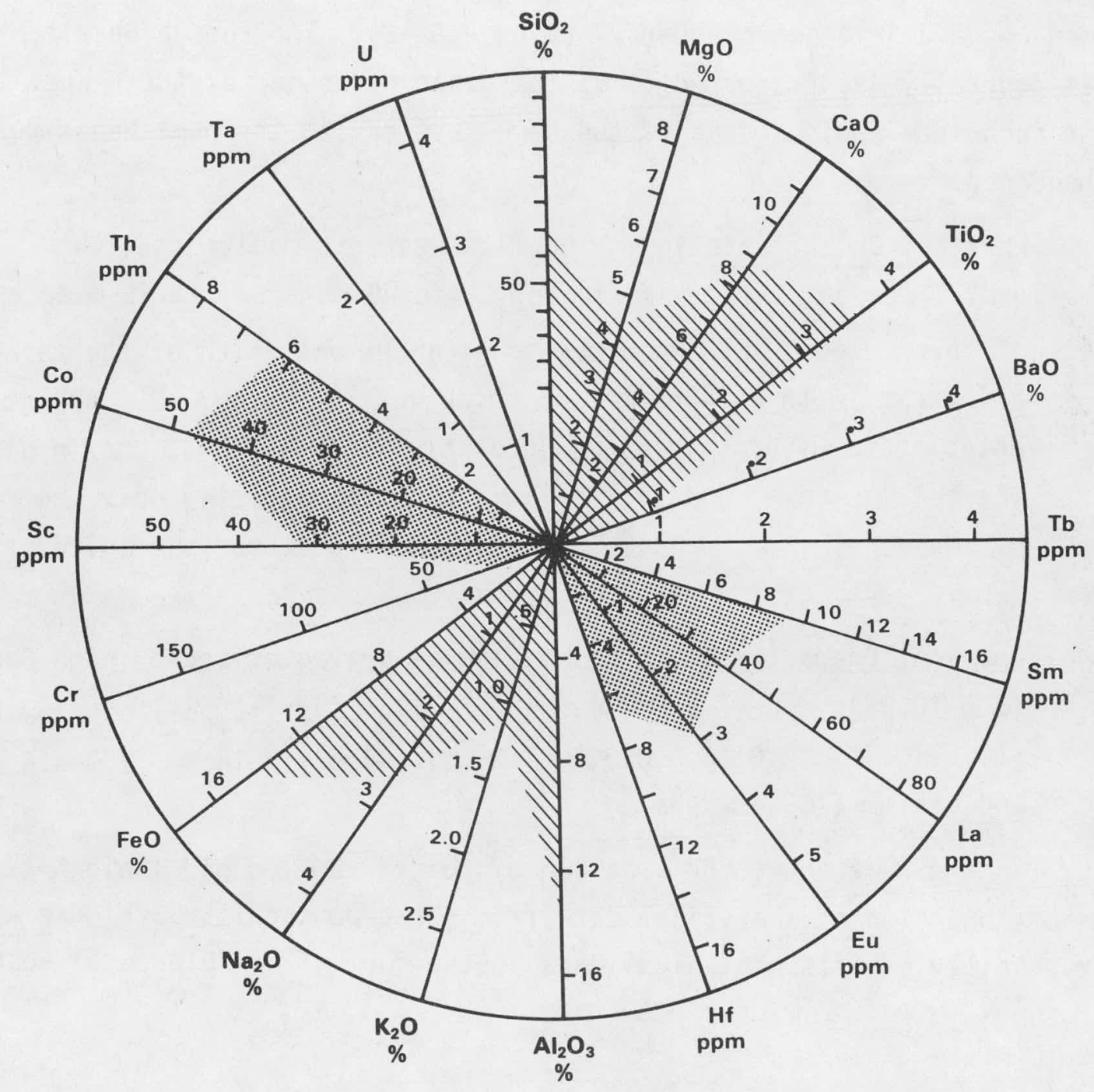

FIGURE $A-10$

ELEPHANT MOUNTAIN BASALT FLOW TYPE LOCALITY, ELEMENTAL ROSE 


\section{POMONA BASALT MEMBER}

The Pomona Basalt Member was defined by Schmincke ${ }^{[A-2]}$ as the upper flow in the southern entrance of the Yakima River Canyon 10 kilometers north of Yakima, Washington where it is well exposed in a U.S. Highway 97 road-cut and in a nearby quarry, (Figure A-12). The Pomona Basalt Member has generally been. referred to as the Wenas or as one of the Wenas flows but incorrect applications of the name have caused the name Wenas to be abandoned.

Physical Characteristics: The flow weathers medium-to-light gray. Its thickness varies from 30 to 40 meters. It is made up of three zones: 1. An upper zone, about one fifth of the total thickness, with a 1.5-3 meters thick vesicular top. 2. A central entablature with conspicuous undulating columns 15-30 cms in diameter. The columns form composite columns with fan-jointing near the top of the zone. 3. A basal zone consisting of about one third of the flow.

Chemical Characteristics: The flow is characterized by high Ca0 (9.6-10.2\%), MgO (7.3-8.1\%), and chromium (90-110 ppm) but 1 ow $\mathrm{FeO}$ $(10.5-10.9 \%), \mathrm{K}_{2} \mathrm{O}(0.5-0.8 \%), \mathrm{TiO}_{2}(1.5-1.6 \%$, hafnium $(2.9-3.4 \mathrm{ppm}$ and barium (400-630 ppm).

Figure A-13 shows the location of points sampled and Table A-IV is a tabulation of analytical data from the type locality. Figure A-14 graphically depicts analytical data in the form of an "Elemental Rose." 


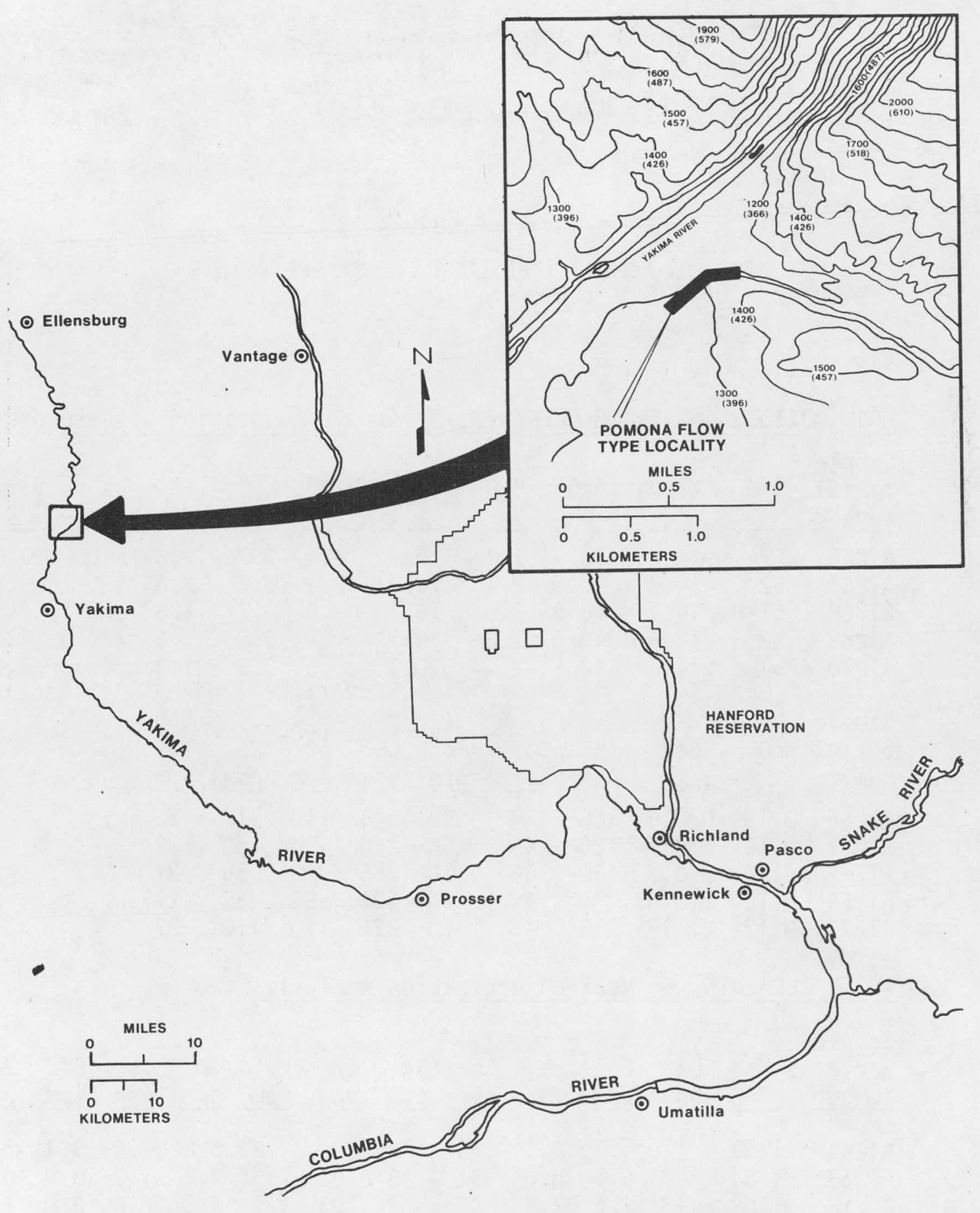

FIGURE' A-12

POMONA TYPE LOCALITY LOCATION MAP 


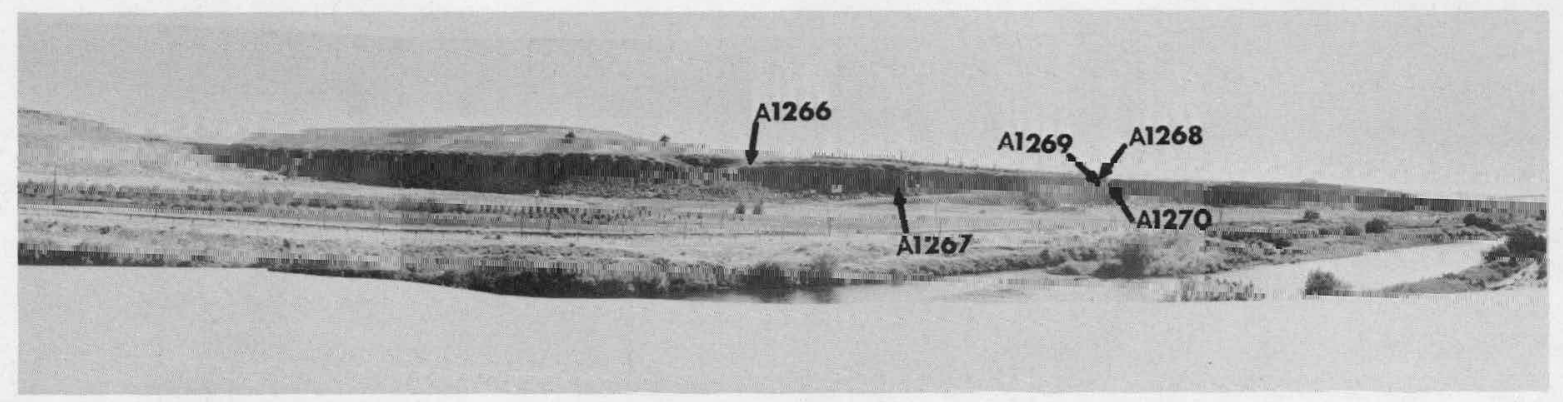

FIGURE $A-13$

POMONA TYPE LOCALITY SAMPLE POINTS

MAJOR OXIDES AND TRACE ELEMENTS, by Atomic Absorption Spectrometer

\begin{tabular}{|c|c|c|c|c|c|c|c|c|c|c|c|}
\hline $\begin{array}{l}\text { Sample } \\
\text { Serial } \\
\text { Number }\end{array}$ & $\begin{array}{r}\mathrm{SiO}_{2} \\
\end{array}$ & $\mathrm{Al}_{\%} \mathrm{Al}_{3}$ & $\begin{array}{c}\mathrm{Fe} 0 \\
\% \\
\end{array}$ & $\begin{array}{c}\mathrm{MgO} 0 \\
\%\end{array}$ & $\begin{array}{c}\text { CaO } \\
\% \\
\end{array}$ & $\begin{array}{r}\mathrm{Na}_{2} \mathrm{O} \\
\% \\
\end{array}$ & $\begin{array}{l}\mathrm{K}_{2} \mathrm{O} \\
\% \\
\end{array}$ & $\begin{array}{l}\mathrm{TiO}_{2} \\
\%\end{array}$ & $\begin{array}{l}\mathrm{Ba} \\
\mathrm{ppm}\end{array}$ & $\begin{array}{c}\text { V1ty } \\
\%\end{array}$ & $\begin{array}{c}\text { Mtl } \\
\mathrm{Bal} \\
\%\end{array}$ \\
\hline $\begin{array}{l}1266 \\
1267 \\
1268 \\
1269\end{array}$ & $\begin{array}{l}52 \\
52 \\
51 \\
52 \\
51\end{array}$ & $\begin{array}{l}14.3 \\
14.7 \\
14.1 \\
14.5 \\
14.2\end{array}$ & $\begin{array}{l}10.9 \\
10.8 \\
10.9 \\
10.7 \\
10.5\end{array}$ & $\begin{array}{l}7.7 \\
8.1 \\
7.8 \\
7.8 \\
7.3\end{array}$ & $\begin{array}{l}9.6 \\
10.2 \\
10.1 \\
10.1 \\
10.1\end{array}$ & $\begin{array}{l}2.4 \\
2.3 \\
2.5 \\
2.4 \\
2.5\end{array}$ & $\begin{array}{l}0.7 \\
0.7 \\
0.7 \\
0.8 \\
0.5\end{array}$ & $\begin{array}{l}1.6 \\
1.6 \\
1.6 \\
1.6 \\
1.5\end{array}$ & $\begin{array}{l}630 \\
399 \\
428 \\
427 \\
560\end{array}$ & $\begin{array}{l}1.1 \\
1.5 \\
1.6 \\
1.5 \\
2.6\end{array}$ & $\begin{array}{l}100.3 \\
101.9 \\
100.3 \\
101.4 \\
100.2\end{array}$ \\
\hline
\end{tabular}

Sample

Serial MnO SrO $\mathrm{Zn}$ Co $\mathrm{Pb} \quad \mathrm{Cu} \quad \mathrm{Cr} \quad \mathrm{Ni} \quad \mathrm{Rb}$

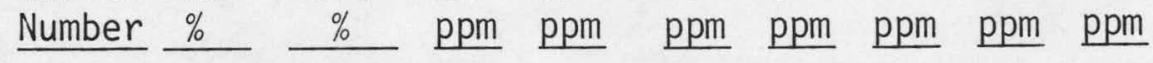

$\begin{array}{llllllllll}\text { A1266 } & 0.19 & 0.016 & 105 & 35 & 50 & 245 & 110 & 110 & 32\end{array}$

$\begin{array}{llllllllll}\text { A1267 } & 0.19 & 0.017 & 125 & 45 & 50 & 240 & 100 & 60 & 32\end{array}$

$\begin{array}{llllllllll}\text { A1268 } & 0.18 & 0.016 & 110 & 40 & 70 & 285 & 90 & 55 & 27\end{array}$

$\begin{array}{lllrrrrrrr}\text { A1269 } & 0.18 & 0.016 & 95 & 45 & 40 & 230 & 90 & 35 & 27\end{array}$

$\begin{array}{llllllllll}A 1270 & 0.17 & 0.016 & 115 & 45 & 70 & 220 & 110 & 110 & 27\end{array}$

TRACE ELEMENTS, by Neutron Activation Analysis

Sample

Serial $\mathrm{Na}$ La Sm Fe Co Sc Cr Eu Th Tb Hf Ta

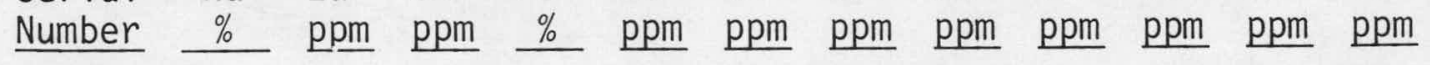

$\begin{array}{lllllllllllll}\text { A1266 } & 1.59 & 21 & 4.5 & 8.1 & 40 & 32 & 100 & 1.7 & 5.2 & 1.0 & 3.1 & 1.1\end{array}$

$\begin{array}{lllllllllllll}\text { A1267 } & 1.64 & 20 & 5.0 & 8.0 & 41 & 33 & 102 & 1.3 & 4.6 & 1.3 & 3.2 & 0.9\end{array}$

$\begin{array}{lllllllllllll}\text { A1268 } & 1.69 & 19 & 4.6 & 7.8 & 43 & 33 & 103 & 1.7 & 4.8 & 0.9 & 3.0 & 1.0\end{array}$

$\begin{array}{lllllllllllll}\text { A1269 } & 1.61 & 19 & 5.1 & 8.2 & 41 & 33 & 106 & 1.3 & 6.0 & 1.3 & 3.4 & 1.0\end{array}$

$\begin{array}{lllllllllllll}\text { A1270 } & 1.66 & 18 & 4.5 & 8.1 & 43 & 34 & 104 & 1.7 & 6.8 & 0.8 & 2.9 & 1.1\end{array}$

TABLE A-IV

TABULATION OF ANALYTICAL DATA FOR THE POMONA BASALT MEMBER TYPE LOCALITY 


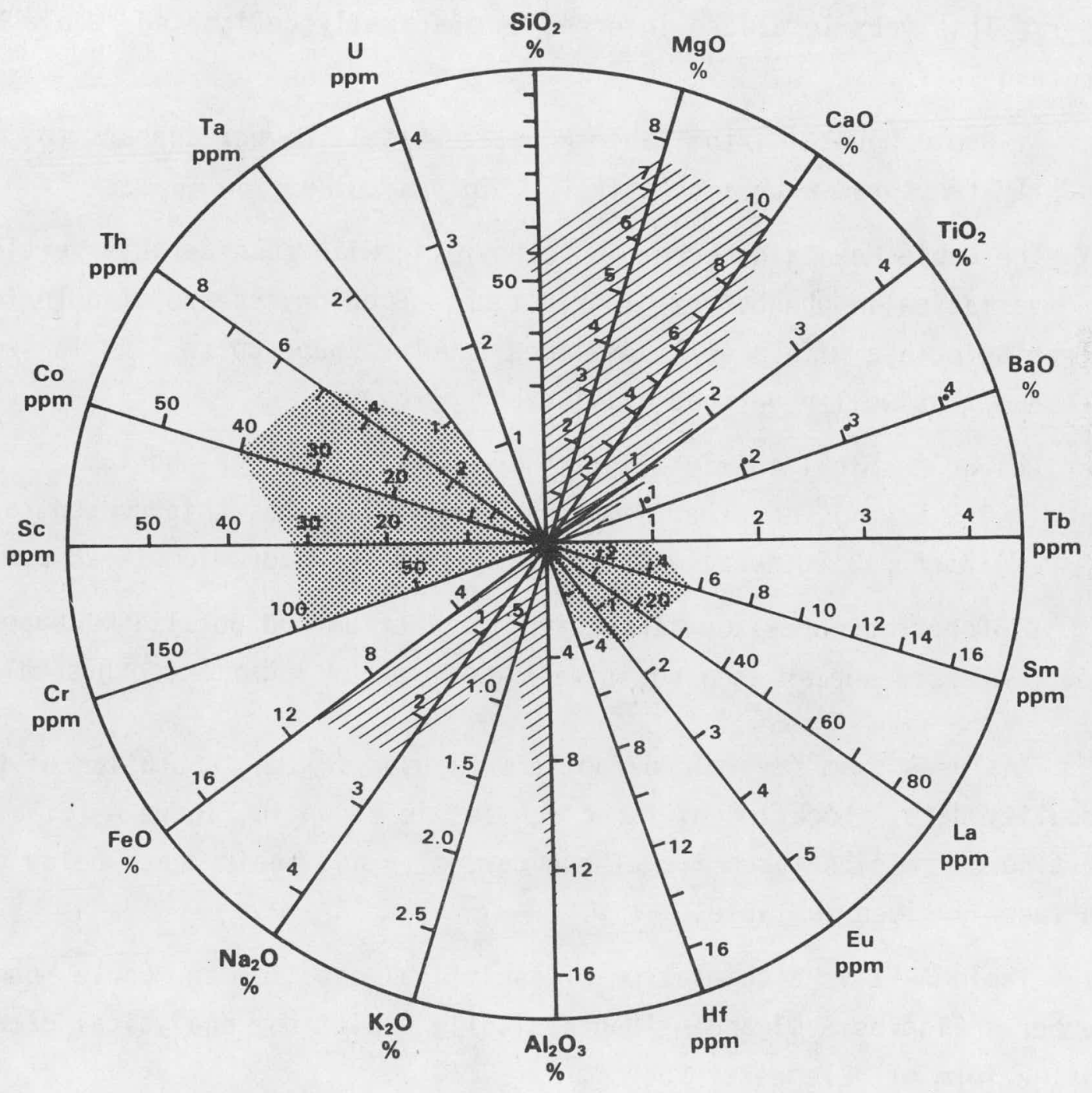

FIGURE A-14

POMONA BASALT MEMBER TYPE LOCALITY, ELEMENTAL ROSE 
GABLE MOUNTAIN BASALT MEMBER

This basalt member is made up of at least two very similar flows. One or both of the flows are found in several coreholes on the Hanford Reservation and at Gable Mountain in surface exposures (Figures A-15 and $A-16)$. The two flow units are separated by a discontinuous tuff layer. This very localized interbed is informally designated "Gable Mountain Tuff".

At Gable Mountain, the Gable Mountain Basalt Member appears to be blockily fractured with a relatively thin vesicular flow top.

- The Gable Mountain Member is porphyritic with considerable vertical variation in phenocryst distribution. Phenocrysts are of colorless plagioclase with a well developed tabular shape up to $3 \mathrm{~cm}$ in length and less well developed olivine and pyroxene.

- Unique chemical characteristics are: (1) very high thorium (7.3-9.5 ppm), no other member in the section has this concentration, (2) high $\mathrm{K}_{2} \mathrm{O}$ (generally $1.5-2.0 \%$ ) and (3) low chromium (8-26 ppm).

Higher than normal concentrations of thorium and potassium cause this member to appear as a positive high on natural gamma geophysical logs.

Analyses from several coreholes were used in the tabulation of type locality data. Location of the coreholes is shown in Figure A-15, a 1 isting of samples taken from these coreholes and their depth below ground surface is given in Table A-V.

Table A-VI is a tabulation of analytical data for the Gable Mountain Member. Figures A-17 and A-18 graphically depict the analytical data in the form of "Elemental Roses".

TABLE A-V. Core Hole Samples Used as Gable Mountain Basalt Member Type Locality Samples

\begin{tabular}{|c|c|c|c|}
\hline & DB-1 Core Hole & DDH-1 Core Hole & DDH-3 Core Hole \\
\hline $\begin{array}{l}\text { Sample } \\
\text { Seria } 1 \\
\text { Numbers } \\
\text { and } \\
\text { Depths }\end{array}$ & $\begin{array}{l}\text { D1007-638'/194.5m } \\
\text { D1008-652'/198.7m } \\
\text { D1009-666'/203.0m } \\
\text { D1010-694'/211.5m } \\
\text { D1011-720'/219.4m }\end{array}$ & $\begin{array}{l}\text { D2009-644'/196.3m A1037-500'/152.4m } \\
\text { D2010-672'/205.0m A1038-548'/167. Im } \\
\text { D2011-682'/208.0m A1039-588'/179.2m }\end{array}$ & $\begin{array}{l}\text { A2017-726'/221.3m } \\
\text { A2018-740'/225.6m } \\
\text { A2019-752'/229.2m }\end{array}$ \\
\hline
\end{tabular}




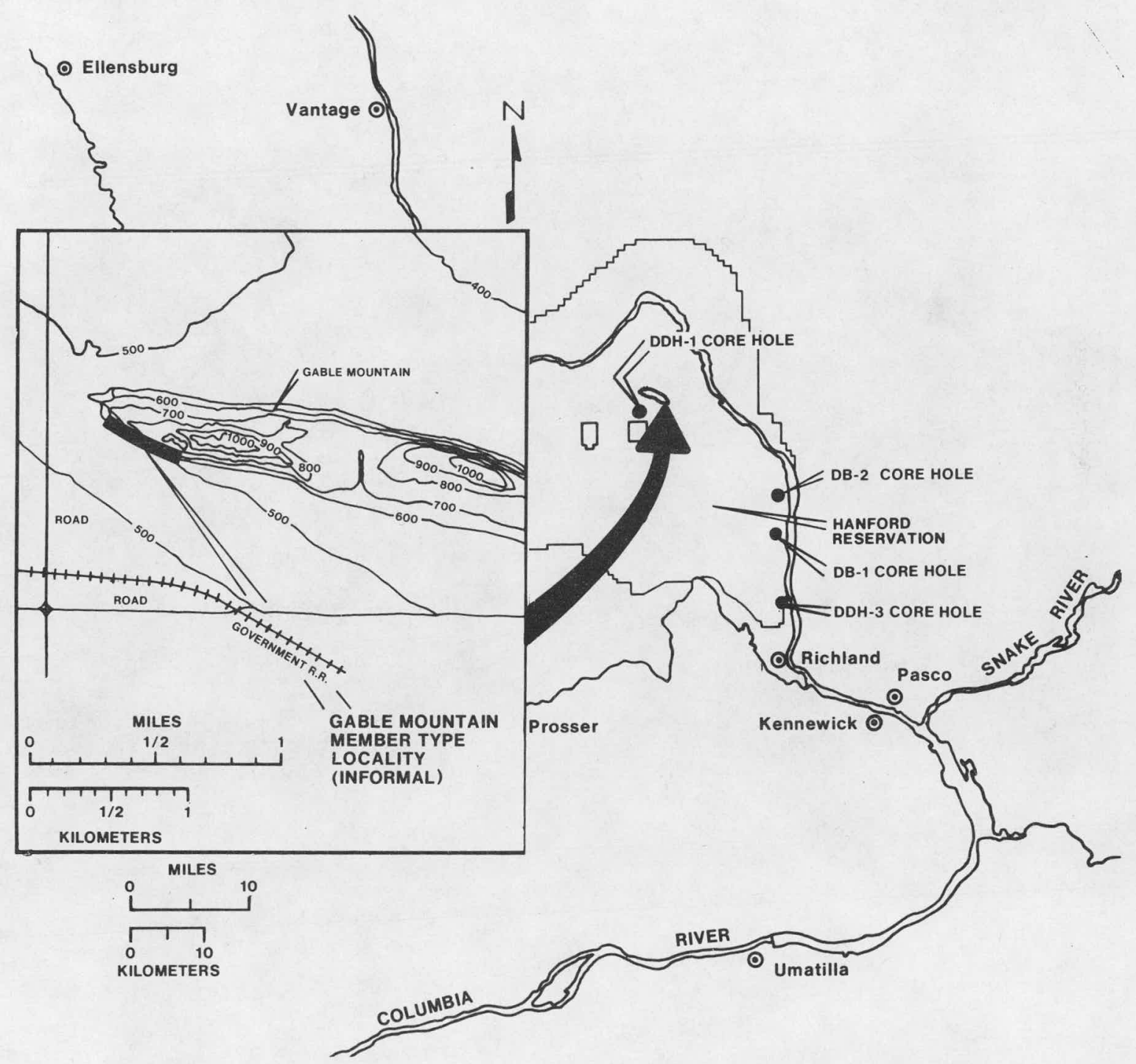

FIGURE A-15

GABLE MOUNTAIN TYPE LOCALITY LOCATION MAP 


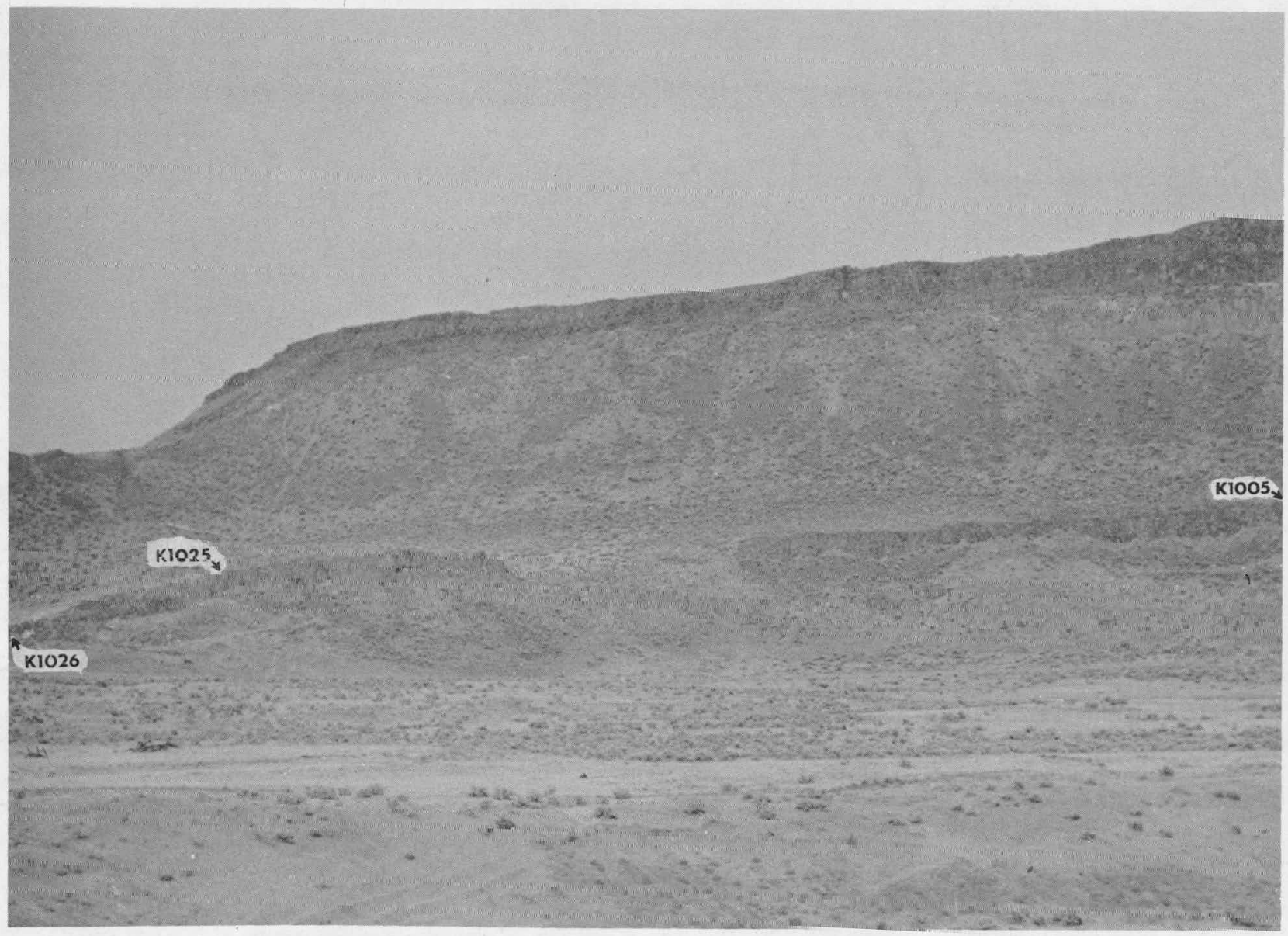

FIGURE A-16

GABLE MOUNTAIN TYPE LOCALITY SAMPLE POINTS 
MAJOR OXIDES, by Atomic Absorption Spectrometer

$\begin{array}{llllllllllll}\text { Sample } & & & & & & & & \\ \text { Serial } & \mathrm{SiO}_{2} & \mathrm{Al}_{2} \mathrm{O}_{3} & \mathrm{Fe} 0 & \mathrm{MgO} & \mathrm{CaO} & \mathrm{Na}_{2} \mathrm{O} & \mathrm{K}_{2} \mathrm{O} & \mathrm{TiO}_{2} & \mathrm{Ba} & \text { Vlty } & \mathrm{Bal}\end{array}$

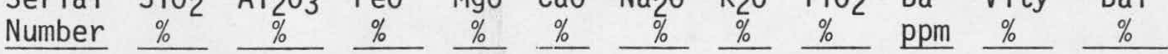

Gable Mountain Samples

$\begin{array}{llllllllllll}\mathrm{K} 1005 & 52 & 13.0 & 13.9 & 4.2 & 6.9 & 2.9 & 1.5 & 2.8 & 550 & 1.4 & 98.6 \\ \mathrm{~K} 1025 & 52 & 12.9 & 12.7 & 3.9 & 7.0 & 2.8 & 1.3 & 2.5 & 646 & 2.7 & 97.8\end{array}$

$\begin{array}{llllllllllll}\mathrm{K} 1026 & 52 & 12.8 & 13.0 & 4.0 & 7.1 & 2.8 & 1.3 & 2.5 & 656 & 2.8 & 98.3\end{array}$

Core Well Samples

Core Wells DDH-1 and DDH-3, One Flow Unit Only

$\begin{array}{lllllllllllr}\text { A1037 } & 52 & 13.2 & 13.0 & 4.1 & 7.1 & 2.7 & 2.0 & 2.4 & 788 & 1.4 & 97.9 \\ \text { A1038 } & 52 & 12.9 & 13.6 & 4.0 & 8.6 & 2.6 & 1.5 & 2.6 & 630 & 1.4 & 99.2 \\ \text { A1039 } & 52 & 12.8 & 13.3 & 4.1 & 7.9 & 2.7 & 1.5 & 2.6 & 683 & 1.0 & 97.9 \\ \text { A2017 } & 54 & 12.7 & 14.9 & 4.2 & 7.4 & 2.6 & 1.8 & 2.8 & 600 & 2.8 & 103.2 \\ \text { A2018 } & 54 & 13.5 & 14.2 & 4.1 & 7.9 & 2.8 & 1.6 & 2.5 & 630 & 1.9 & 102.5 \\ \text { A2019 } & 53 & 13.1 & 14.6 & 3.8 & 7.3 & 2.6 & 1.7 & 2.6 & 700 & 1.9 & 100.6\end{array}$

Core Wells DB-1 and DB-2, Two Flow Units Separated by Interbed

Upper Unit - Gable Mountain II

$\begin{array}{llllllllllll}\text { D1007 } & 52.7 & 12.9 & 11.3 & 4.0 & 7.7 & 2.9 & 1.6 & 2.6 & 813 & 1.7 & 97.8\end{array}$

$\begin{array}{llllllllllll}\text { D1008 } & 52.5 & 13.2 & 11.7 & 4.0 & 7.7 & 2.9 & 1.6 & 2.6 & 926 & 1.5 & 98.2\end{array}$

$\begin{array}{llllllllllll}\text { D1009 } & 53.4 & 13.1 & 12.0 & 3.9 & 7.7 & 3.1 & 1.7 & 2.8 & 909 & 1.2 & 99.5\end{array}$

$\begin{array}{llllllllllll}\text { D2009 } & 53.5 & 12.9 & 11.1 & 3.7 & 7.3 & 2.9 & 1.6 & 2.5 & 847 & 1.2 & 97.1\end{array}$

Lower Unit - Gable Mountain I

$\begin{array}{llllllllllll}\text { D1010 } & 52.3 & 14.5 & 12.4 & 4.0 & 8.1 & 2.9 & 1.4 & 3.0 & 92.1 & 1.6 & 100.8\end{array}$

$\begin{array}{llllllllllll}\text { D1011 } & 52.1 & 13.2 & 12.6 & 4.1 & 7.9 & 2.9 & 1.5 & 2.9 & 750 & 1.2 & 99.0\end{array}$

$\begin{array}{llllllllllll}\text { D2010 } & 50.7 & 13.0 & 14.3 & 4.1 & 8.0 & 2.6 & 1.4 & 2.9 & 638 & 1.4 & 99.2\end{array}$

TRACE ELEMENTS, by Neutron Activation Analysis

Sample

Serial $\mathrm{Na}$ La Sm Fe Co Sc Cr Eu Th Tb Hf Ta

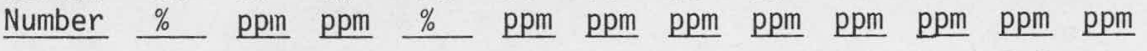

$\begin{array}{llllllllllllll}\text { A2017 } & 1.91 & 37 & 8.9 & 11.0 & 45 & 31 & 8 & 2.3 & 8.6 & -- & 5.8 & \text {-- }\end{array}$

$\begin{array}{lllllllllllll}\text { A2018 } & 2.09 & 35 & 8.5 & 10.9 & 42 & 27 & 9 & 2.3 & 9.0 & -- & 6.2 & -\end{array}$

Core Wells DB-1 and DB-2, Two Flow Units Separated by Interbed

Upper Unit - Table Mountain II

$\begin{array}{lllllllllllll}\text { D1007 } & 1.98 & 36 & 7.1 & 9.2 & 40 & 27 & 26 & 2.1 & 8.1 & -- & 6.9 & --\end{array}$

$\begin{array}{lllllllllllll}\text { D1008 } & 1.96 & 36 & 7.0 & 9.3 & 39 & 27 & 21 & 2.1 & 8.9 & -- & 7.1 & --\end{array}$

$\begin{array}{lllllllllllll}D 1009 & 1.99 & 36 & 7.1 & 9.8 & 42 & 28 & 11 & 1.9 & 9.5 & -- & 7.5 & --\end{array}$

$\begin{array}{lllllllllllll}\text { D2009 } & 2.26 & 42 & 8.3 & 11.1 & 48 & 31 & 8 & 2.7 & 9.5 & -- & 9.6 & -\end{array}$

Lower Unit - Gable Mountain I

$\begin{array}{lllllllllllll}\text { D1010 } & 1.95 & 34 & 7.0 & 10.0 & 45 & 29 & 23 & 2.0 & 7.4 & -- & 6.3 & --\end{array}$

$\begin{array}{lllllllllllll}D 1011 & 1.85 & 33 & 6.7 & 10.3 & 45 & 28 & 19 & 2.1 & 7.3 & -- & 5.8 & --\end{array}$

$\begin{array}{lllllllllllll}\text { D2010 } & 2.11 & 38 & 7.9 & 11.6 & 53 & 32 & 31 & 2.8 & 8.0 & -- & 7.0 & \text {-- }\end{array}$

TABLE A-VI

TABULATION OF ANALYTICAL DATA FOR THE GABLE MOUNTAIN BASALT IIEMBER TYPE LOCALITY 


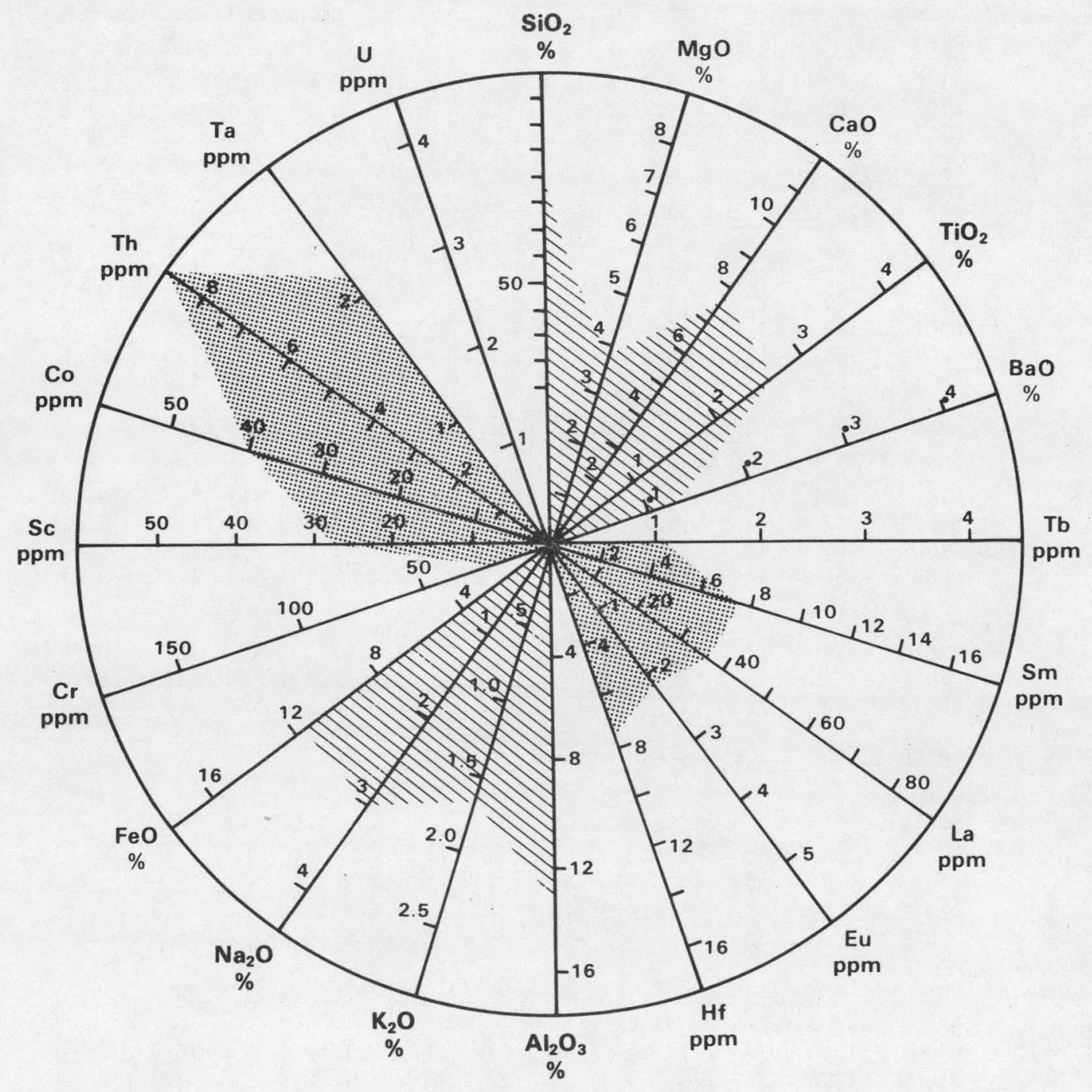

FIGURE $A-17$

GABLE MOUNTAIN II BASALT FLOW, ELEMENTAL ROSE 


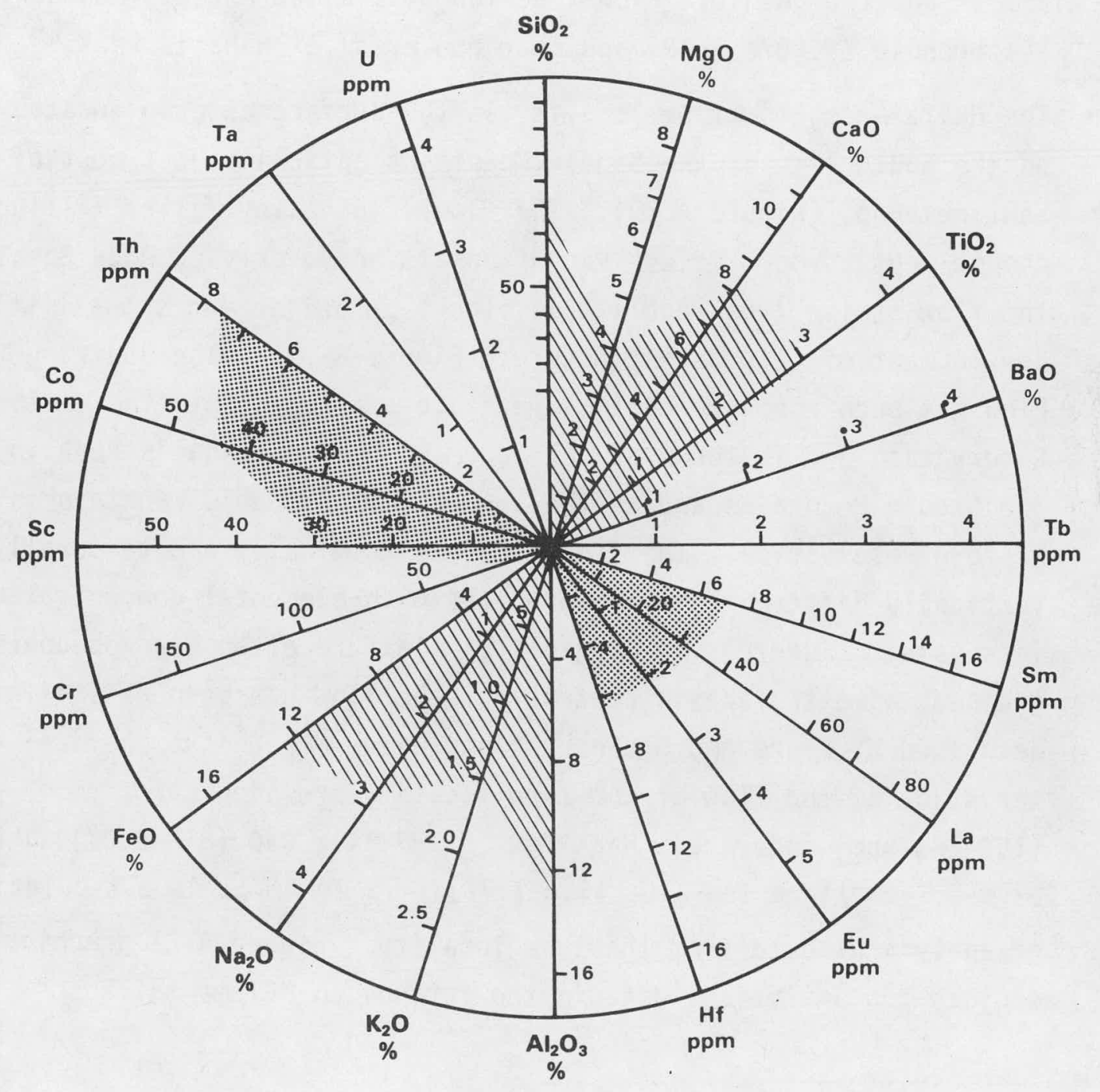

FIGURE $A-18$

GABLE MOUNTAIN I BASALT FLOW, ELEMENTAL ROSE 


\section{HUNTZINGER BASALT MEMBER}

The Huntzinger Basalt Member consists of the Huntzinger flow of Mackin ${ }^{[A-4]}$ and the "Wahluke Flow", a flow of 1 imited extent found only in $\mathrm{DH}-4$ corehole (Figure A-19) and near the crest of Wahatis Peak. ${ }^{[\mathrm{A}-5]}$

- The Huntzinger Flow type locality is the surface outcrop located on the south limb of the Saddle Mountains anticline just west of Sentinel Gap, (Figure A. 20).* The flow is a valley filler filling a channel cut through Priest Rapids Basalt and overlying Roza Basalt. [A-4] The flow at its type locality is black, aphanitic and shows little development of columnar structure, (Figure A-20). The Huntzinger Flow has been encountered in several core holes within the Hanford Reservation and is found as the upper unit of of Wahatis Peak in the Saddle Mountains and as the lowest unit at Gable Mountain on the Hanford Reservation. The flow tends to chemically and texturally vertically differentiate in coreholes with elemental concentration increasing or decreasing marginally. Texture often becomes coarse grained, almost diabasic centrally. The flow has been extensively described by Myers and Brown $[A-6]$ and Ward ${ }^{[A-5]}$. Unique chemical characteristics of the flow at the type locality are high chromium (163-188 ppm) moderately high Mg0 (6.7-7.1\%), Ca0 (8.9-9.0\%), hafnium (4.4-5.1 ppm) and low $\mathrm{TiO}_{2}(1.6-1.7 \%)$. Table A-VII is a tabulation of analytical data from the type locality. Figure A-21 graphically depicts the analytical data in the form of an "Elemental Rose"

* See Figure 2, Chapter II. 
- The "Wahluke Flow" occurs in DH-4 corehole within the extreme northeast part of the Hanford Reservation and crops out near the top of Wahatis Peak near the crest of the Saddle Mountains north of the Hanford Reservation. Analytical data show that the flow is not equivalent to any other known flow in the Pasco Basin. The flow is topped by a soil horizon and overlies an interbed. Distinctive chemical characteristics of the flow are relatively low $\mathrm{TiO}_{2}$ and high $\mathrm{K}_{2} \mathrm{O}(1.9+\%)$. It is informally assigned the name "Wahluke Flow Unit" of the Huntzinger Basalt Member from its occurrence beneath the Wahluke Slope and possible genetic association with the Huntzinger Flow. No type locality has been assigned to this flow. Table A-VII contains a tabulation of analytical data from samples taken in $\mathrm{DH}-4$ corehole and Figure A-22 graphically presents the data in the form of an "Elemental Rose". The samples were taken at the following depth below ground surface in $\mathrm{DH}-4$ core hole: A4016-364 feet (109.2 meters), A4017-392 feet (117.6 meters). 


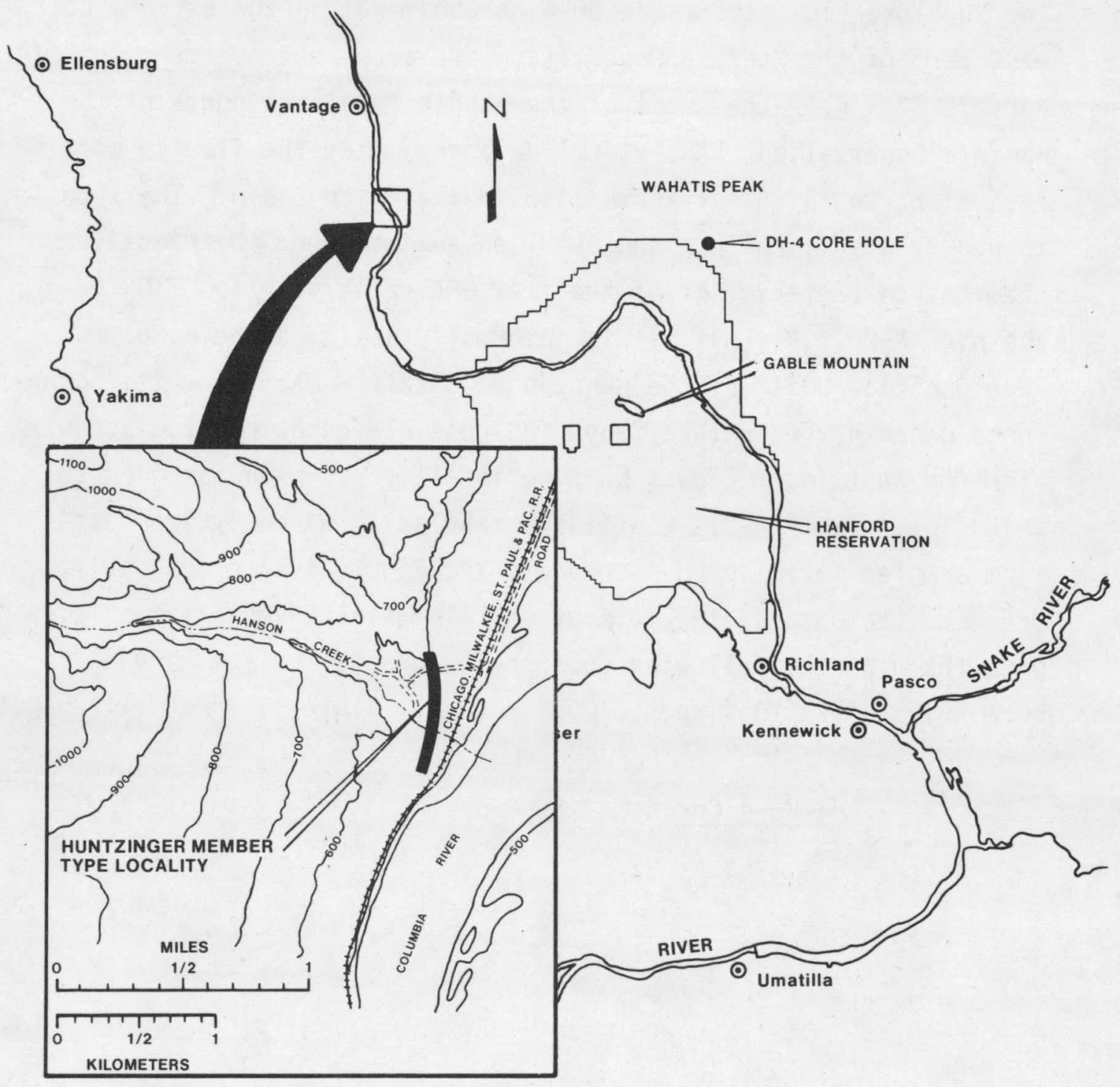

FIGURE A-19 


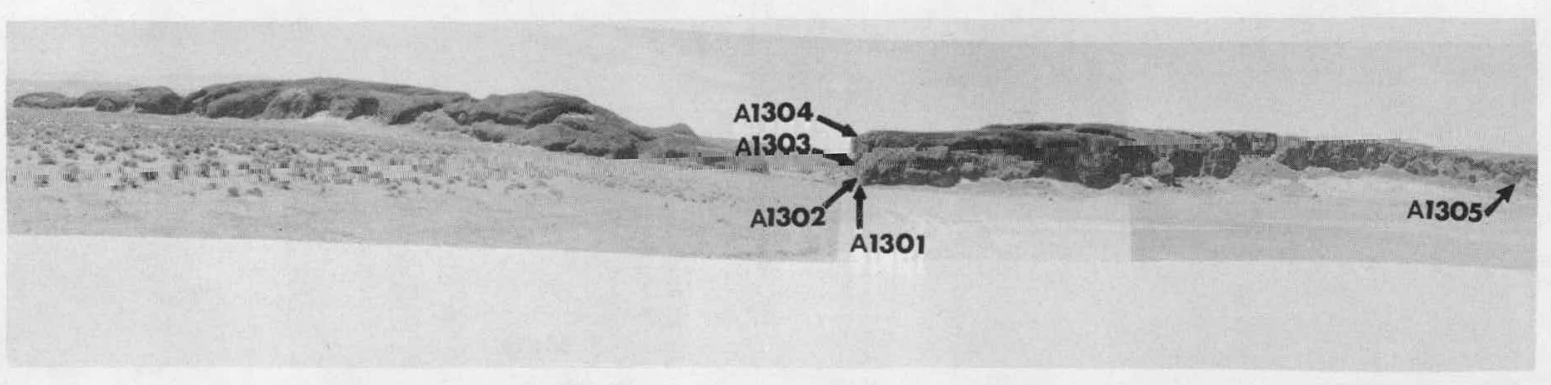

FIGURE $A-20$

HUNTZINGER FLOW TYPE LOCALITY SAMPLE POINTS

MAJOR OXIDES, by Atomic Absorption Spectrometer

$\begin{array}{llllllllllll}\text { Sample } & \mathrm{SiO}_{2} & \mathrm{Al}_{2} \mathrm{O}_{3} & \mathrm{FeO} & \mathrm{MgO} & \mathrm{CaO} & \mathrm{Na}_{2} \mathrm{O} & \mathrm{K}_{2} \mathrm{O} & \mathrm{TiO}_{2} & \mathrm{Ba} & \mathrm{Vl} & \mathrm{Mtl} \\ \text { Serial } & \mathrm{Bal} & \\ \%\end{array}$ Number $\% \quad \% \quad \% \quad \% \quad \% \quad \% \quad \%$

Huntzinger Flow Type Locality

\begin{tabular}{lrlllllllllr}
\hline A1301 & 52 & 15.2 & 10.6 & 6.8 & 8.9 & 2.4 & 1.0 & 1.6 & 578 & 1.2 & 99.7 \\
A1302 & 52 & 15.3 & 10.7 & 7.1 & 8.9 & 2.4 & 1.0 & 1.6 & 491 & 1.2 & 100.2 \\
A1303 & 52 & 15.4 & 10.5 & 7.1 & 9.0 & 2.4 & 1.0 & 1.7 & 597 & 1.1 & 100.2 \\
A1304 & 52 & 15.1 & 10.7 & 7.0 & 9.0 & 2.4 & 1.0 & 1.6 & 525 & 1.2 & 100.0 \\
A1305 & 52 & 15.0 & 10.4 & 6.7 & 8.9 & 2.6 & 1.0 & 1.6 & 593 & 1.7 & 99.9
\end{tabular}

"Wahluke Flow" from DH-4 Corehole

$\begin{array}{rrrrrrrrrrrr}\text { A4016 } & 53 & 13.9 & 11.6 & 5.1 & 8.1 & 2.8 & 2.0 & 1.8 & 1079 & 0.9 & 99.4 \\ \text { A4017 } & 53 & 13.6 & 12.2 & 5.3 & 8.1 & 2.8 & 1.9 & 1.8 & 998 & 1.3 & 100.2\end{array}$

TRACE ELEMENTS, by Neutron Activation Analysis

Sample

Serial $\mathrm{Na} L a \mathrm{Sm} F \mathrm{Fe}$ Co Sc Cr Eu Th Tb Hf Ta

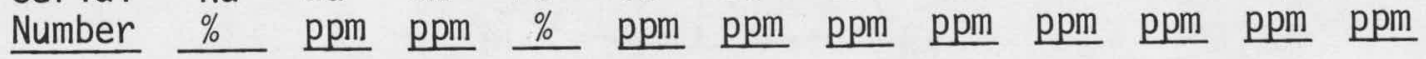

Huntzinger Flow Type Locality

\begin{tabular}{lllllllllllll}
\hline A1301 & 1.74 & 24 & 5.7 & 8.0 & 41 & 28 & 163 & 1.8 & 6.4 & 0.9 & 4.6 & 1.0 \\
A1302 & 1.79 & 24 & 6.2 & 8.1 & 41 & 28 & 181 & 1.6 & 6.2 & 0.9 & 4.3 & 1.0 \\
A1303 & 1.75 & 25 & 5.8 & 8.1 & 42 & 28 & 173 & 2.1 & 6.5 & 1.2 & 5.0 & 1.1 \\
A1304 & 1.76 & 23 & 6.1 & 8.1 & 43 & 27 & 188 & 1.6 & 6.4 & 1.1 & 4.4 & 1.0 \\
A1305 & 1.86 & 25 & 5.8 & 7.7 & 40 & 27 & 168 & 1.7 & 6.3 & 0.7 & 5.1 & 0.9
\end{tabular}

"Wahluke Flow" from DH-4 Corehole

\begin{tabular}{lllllllllllll}
\hline A4016 & 1.82 & 41 & 7.9 & 8.5 & 37 & 25 & 31 & 2.0 & 6.0 & - & 7.9 & - \\
A4017 & 1.80 & 38 & 6.9 & 8.9 & 38 & 26 & 41 & 2.1 & 6.4 & - & 8.1 & -
\end{tabular}




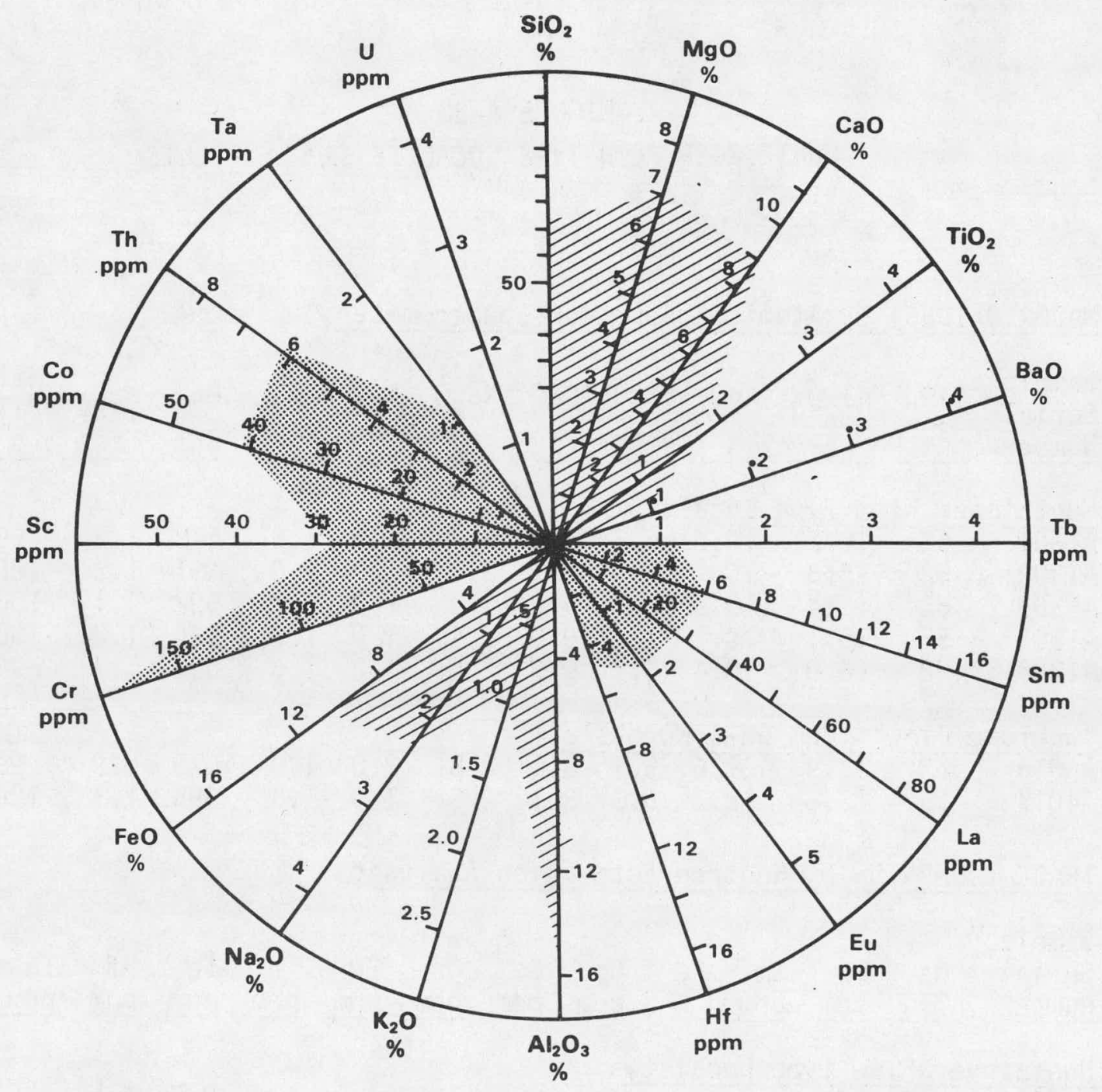

FIGURE $A-21$

HUNTZINGER BASALT FLOW TYPE LOCALITY, ELEMENTAL ROSE 


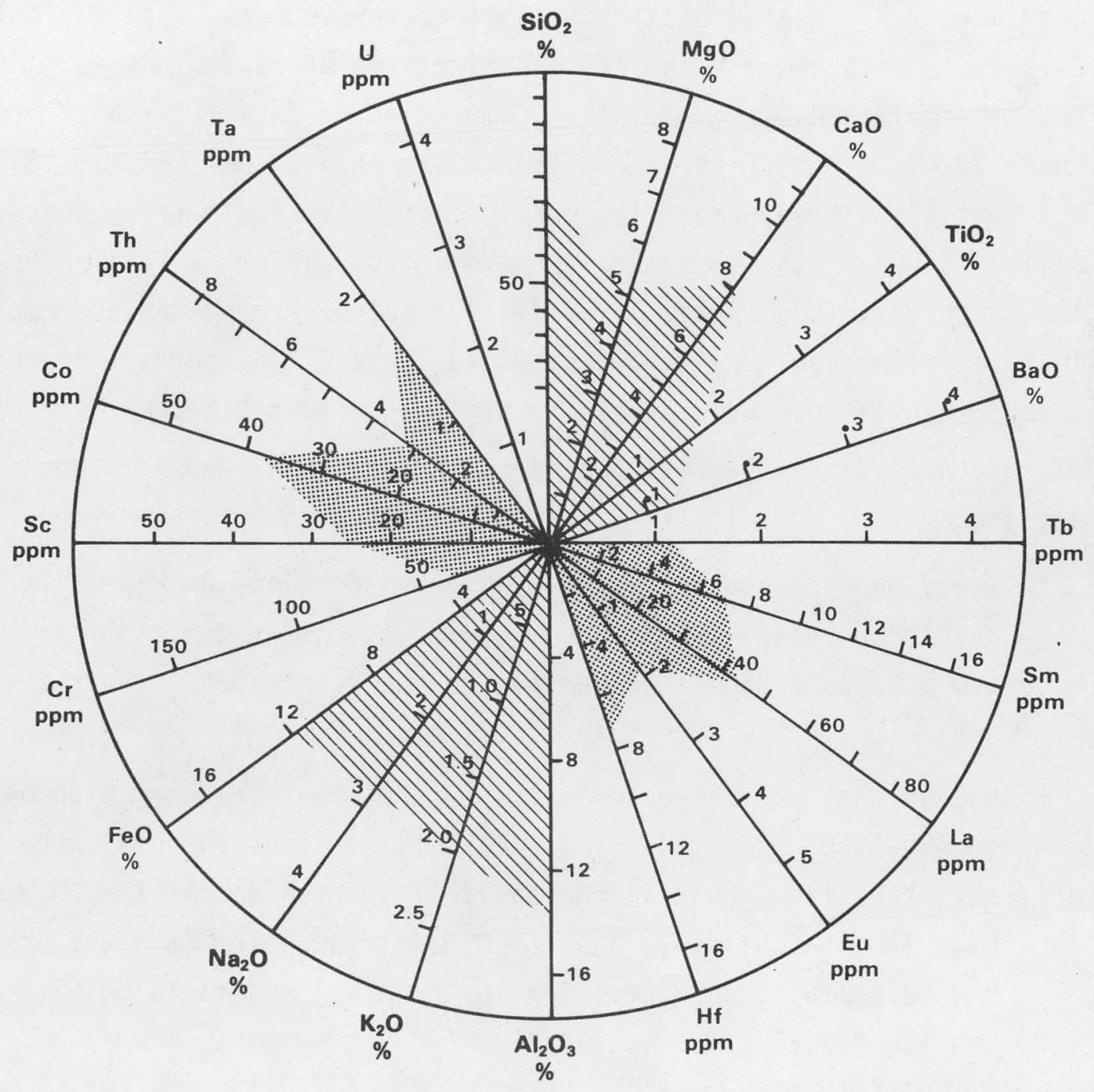

FIGURE $A-22$

WAHLUKE BASALT FLOW, ELEMENTAL ROSE 


\section{UMATILLA BASALT MEMBER}

Lava $^{[A-7]}$ described two unique flows at the Sillusi Butte-McNary Dam locality (Figure A-23). These flows he termed the Sillusi overlying the Umatilla and assigned them as flow units of the Priest Rapids Member. Schmincke ${ }^{[\mathrm{A}-2]}$ equated Laval's Sillusi to the Pomona. This was not Laval's intent, however, as he recognized the Wenas in this section and positioned it above the Sillusi. Comparison of data from this type locality with that of the following Priest Rapids show that the Sillusi and Umatilla are separate flow units, chemically and petrographically very similar to each other, chemically unique from all other Yakima Basalts in the Pasco Basin and chemically different to the Priest Rapids Member and in fact not present in the Priest Rapids area. Therefore, this report considers the Sillusi and Umatilla to be flow units of the Umatilla Member of the Upper Yakima Basalt Formation. Figures A-23 and A-24 show location of the type locality and sampling points.

- The flows are characterized by blocky jointing, an extensively developed vesicular rubbly flow tocoming palagonitic on occasion, and a black aphanitic appearance in hand specimen. Their thickness may be up to 100 meters in core holes.

- Unique chemical characteristics of the flows are very high barium (3,500-4,000 ppm, this is at least three times the concentration of any other flow found in the section), very high hafnium (9.8-12.6 ppm); high $\mathrm{SiO}_{2}$ (about $\left.55 \%\right), \mathrm{Na}_{2} \mathrm{O}(3.0-3.4 \%)$, europium $(4.0-4.7 \mathrm{ppm})$, $\mathrm{K}_{2} \mathrm{O}(2.5-2.8 \%),{ }^{40} \mathrm{~K}$ about $\left.2 \times 10^{-2} \mu \mathrm{Ci} / \mathrm{kg}\right)$ and tantal um $(2.6-2.8 \mathrm{ppm})$; and low $\mathrm{MgO}(2.2-3.5 \%), \mathrm{CaO}(5.2-6 \%)$, chromium ( $\sim 6 \mathrm{ppm})$ and nickel ( $<10 \mathrm{ppm})$.

Table A-VIII is a tabulation of analytical data for the Umatilla Basalt Member. Figure A-25 is a graphical depiction of the analytical data in the form of an "Elemental Rose". 


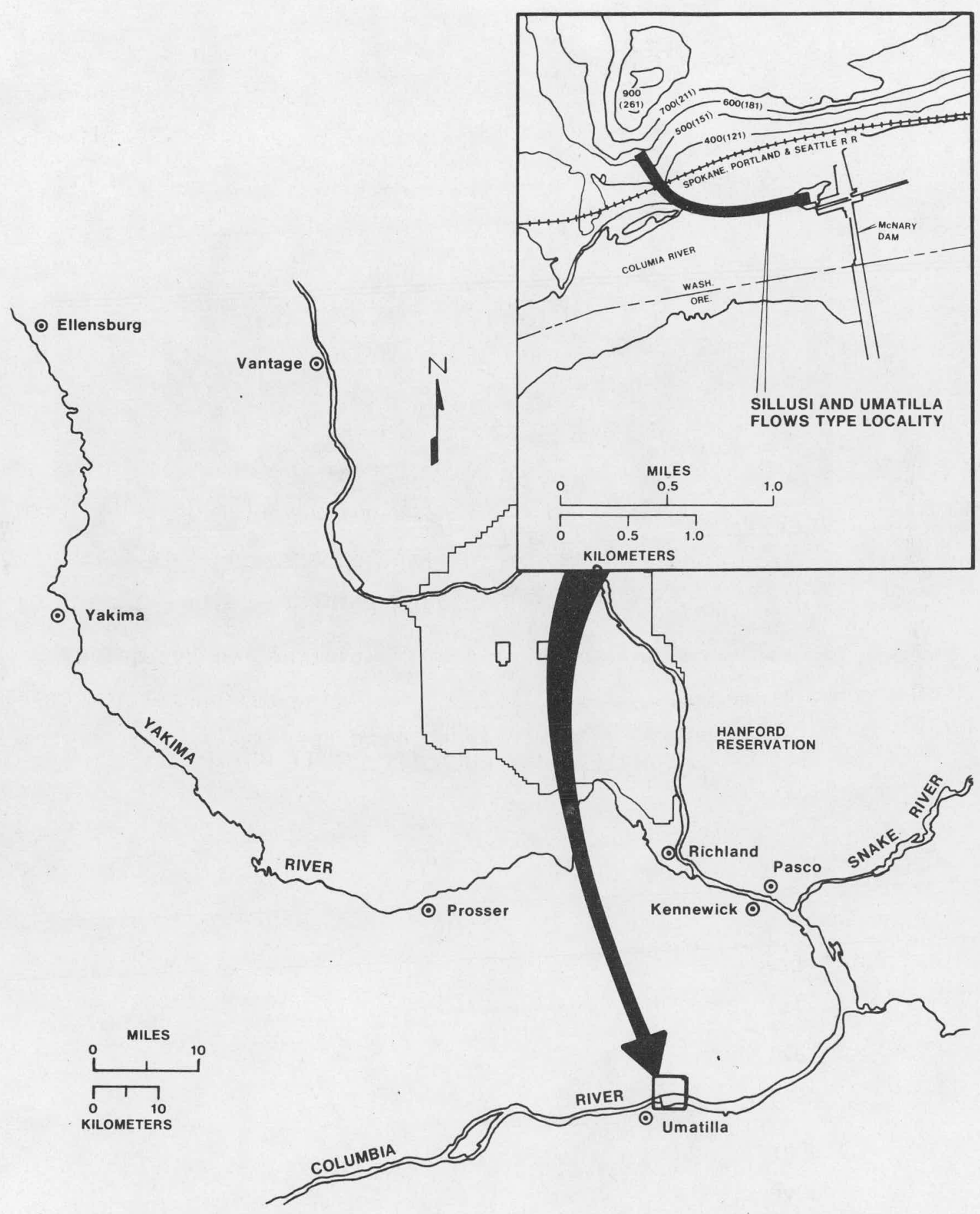

FIGURE A-23

UMATILLA TYPE LOCALITY LOCATION MAP 


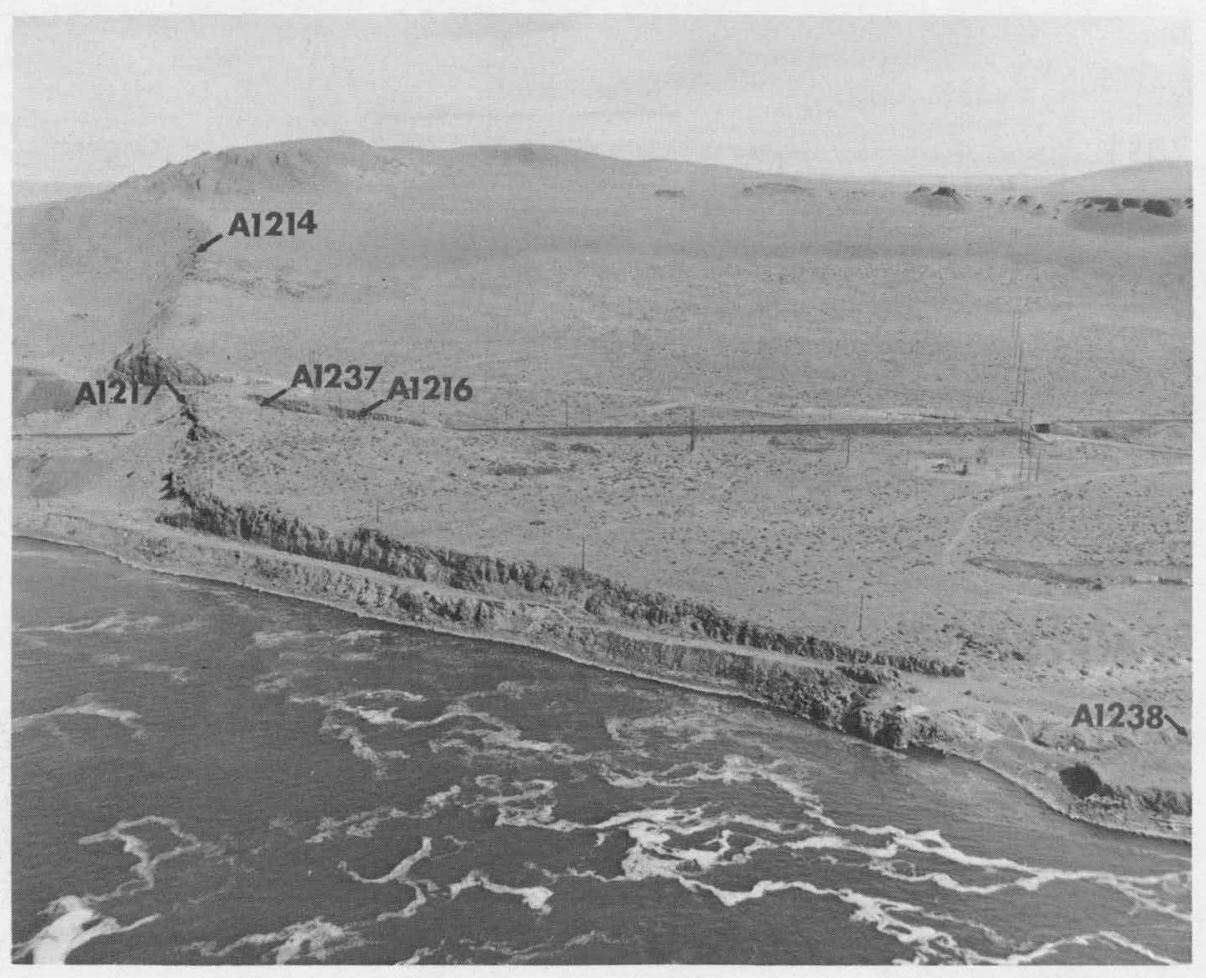

FIGURE $A-24$

UMATILLA TYPE LOCALITY SAMPLE POINTS 
MAJOR OXIDE CONTENT, by Atomic Absorption Spectrometer

Sample

Serial

Number

Sillusi

A1214

A1216

A1238

$\begin{array}{lllllllllll}\mathrm{SiO}_{2} & \mathrm{Al}_{2} \mathrm{O}_{3} & \mathrm{FeO} & \mathrm{MgO} & \mathrm{CaO} & \mathrm{Na}_{2} \mathrm{O} & \mathrm{K}_{2} \mathrm{O} & \mathrm{TiO}_{2} & \mathrm{Ba} & \text { Vlty } & \mathrm{Bal}\end{array}$

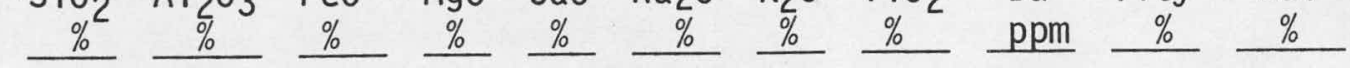

$\begin{array}{rrrrrrrrrrr}53 & 12.9 & 12.3 & 3.5 & 5.7 & 3.3 & 2.8 & 2.4 & 4025 & 2.3 & 98.2 \\ 55 & 13.8 & 12.1 & 2.5 & 5.8 & 3.1 & 2.5 & 2.5 & 3442 & 2.9 & 100.2 \\ 56 & 13.3 & 12.5 & 2.8 & 5.7 & 3.2 & 2.7 & 2.2 & 3549 & 1.8 & 100.2\end{array}$

Umatilla
A1237
A1217
$\begin{array}{llll}57 & 13.4 & 11.6 & 2.5\end{array}$
5.7
3.0
2.6
$2.3 \quad 3792$
$3.4 \quad 101.5$

$\begin{array}{llll}55 & 13.6 & 11.9 & 2.2\end{array}$
$\begin{array}{lll}5.2 & 3.1 & 2.6\end{array}$
$2.5 \quad 3675$
2.999 .0

NATURALLY OCCURRING RADIOACTIVE ISOTOPES, by Gamma Energy Analysis

\begin{tabular}{|c|c|c|c|}
\hline $\begin{array}{l}\text { Sample } \\
\text { Serial } \\
\text { Number }\end{array}$ & $\begin{array}{c}40_{K} \\
\mu \mathrm{Ci} / \mathrm{kg} \times 10^{-3}\end{array}$ & $\begin{array}{c}{ }^{226} \mathrm{Ra}+\text { daughters } \\
\mu \mathrm{Ci} / \mathrm{kg} \times 10^{-3} \\
\end{array}$ & $\begin{array}{c}{ }^{228} \mathrm{Th}+\text { daughters } \\
\mu \mathrm{Ci} / \mathrm{kg} \times 10^{-3}\end{array}$ \\
\hline $\begin{array}{l}\text { Sil1usi } \\
\text { A1214 } \\
\text { A1216 }\end{array}$ & $\begin{array}{l}21.4 \pm 11 \% \\
18.0 \pm 12\end{array}$ & $\begin{array}{l}0.60 \pm 18 \% \\
0.62 \pm 17\end{array}$ & $\begin{array}{l}1.00 \pm 6.6 \% \\
1.06 \pm 6.7\end{array}$ \\
\hline$\frac{\text { Umati11a }}{A 1217}$ & $19.9 \pm 12$ & $0.51 \pm 18$ & $0.88 \pm 6.7$ \\
\hline
\end{tabular}

TRACE ELEMENTS, by Neutron Activation Analysis

Sample

Serial $\mathrm{Na}$ La Sm $\mathrm{Fe}$ Co Sc $\mathrm{Cr}$ Eu Th Tb Hf Ta

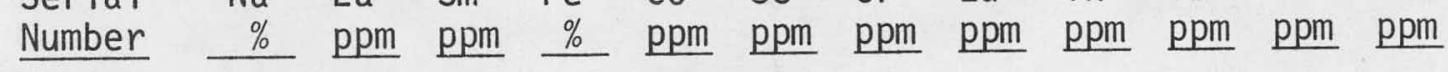

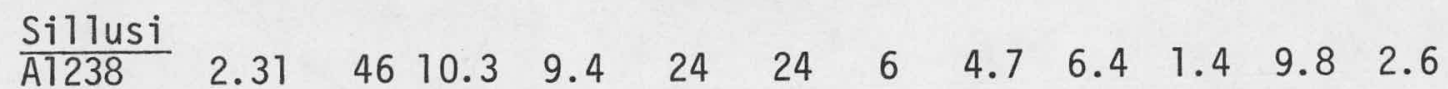

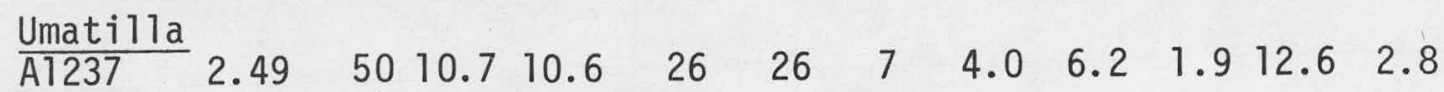
TRACE ELEMENTS, by Emission Spectrometer

Sample

Serial $\mathrm{Ba} \quad \mathrm{Cr} \quad \mathrm{Ni} \quad \mathrm{Rb} \quad \mathrm{Sc} \quad \mathrm{Sn} \quad \mathrm{V} \quad \mathrm{Zn} \quad \mathrm{Zr}$ Number $\mathrm{ppm} \quad \mathrm{ppm} \mathrm{ppm} \quad \mathrm{ppm} \quad \mathrm{ppm} \quad \mathrm{ppm} \quad \mathrm{ppm} \quad \mathrm{ppm} \quad \mathrm{ppm}$ Sillusi

$\begin{array}{llllllllll}\text { A1214 } & >2500 & <1 & & 62 & 28 & 22 & 285 & 115 & 680 \\ \text { A1216 } & >2500 & <1 & <10 & 46 & 65 & 19 & 430 & 180 & 800 \\ \text { A1238 } & >2500 & <1 & <10 & 35 & 60 & 23 & 248 & 220 & 590\end{array}$

Umatilla

\begin{tabular}{lllllllllr}
\hline A1237 & $>2500$ & $<1$ & $<10$ & 46 & 88 & 18 & 350 & 270 & 790 \\
A1217 $>2500$ & $<1$ & $<10$ & 54 & 55 & 16 & 292 & 175 & 1025
\end{tabular}

TABLE A-VIII

TABULATION OF ANALYTICAL DATA FOR THE UMATILLA BASALT MEMEER TYPE LOCALITY 


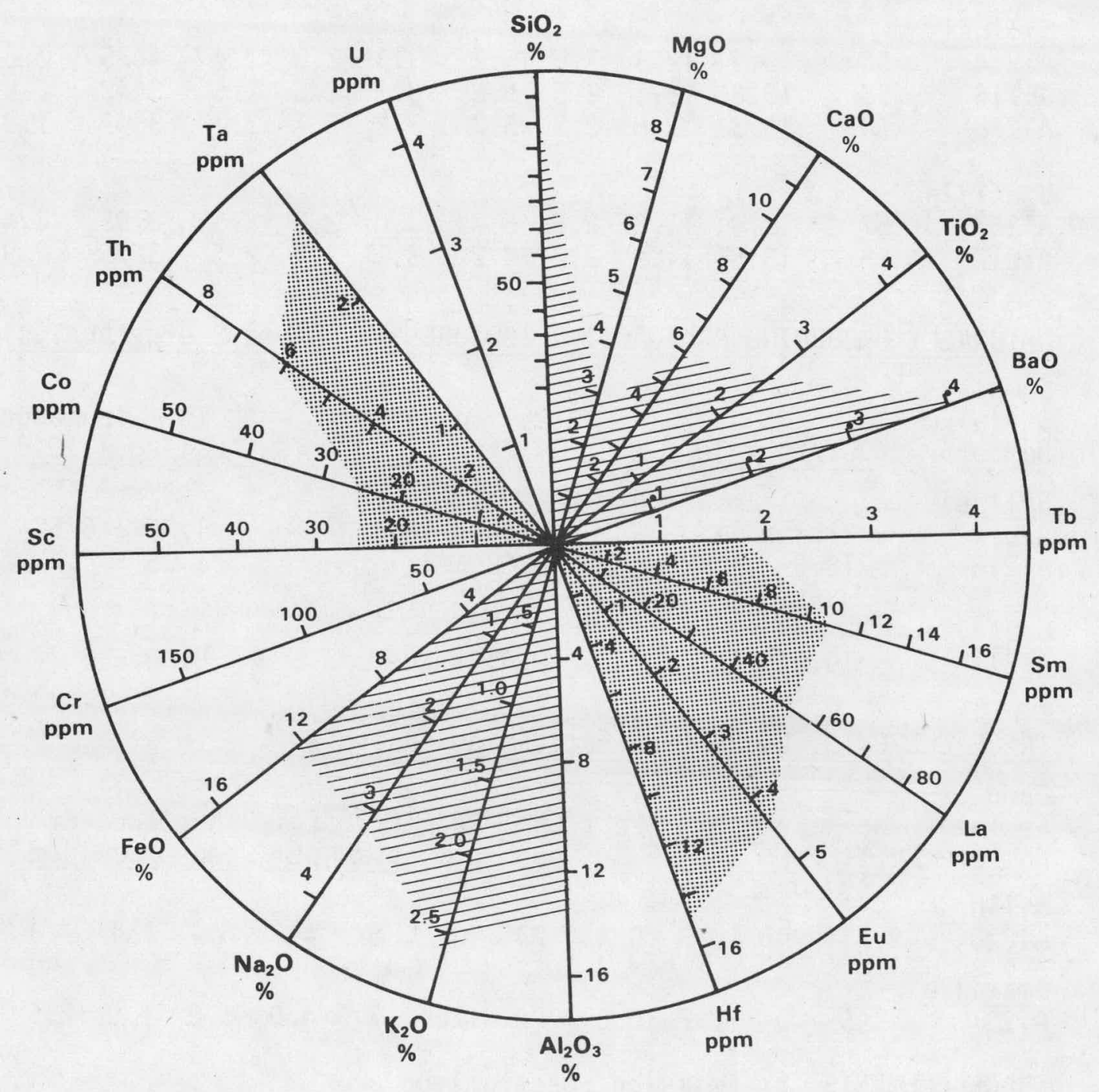

FIGURE A-25

UMATILLA BASALT MEMEER TYPE LOCALITY, ELEMENTAL ROSE 


\section{PRIEST RAPIDS BASALT MEMBER}

The following description of the Priest Rapids flows at their type locality is abstracted from Mackin. [A-4]

Four flows that overlie the Roza: Basalt Member at Priest Rapids Dam are referred to collectively as the Priest Rapids Basalt Member, for the practical reason that a family resemblance between them is so strong that they cannot be identified separately except where the full sequence is present. Thicknesses based on diamond drill holes at the dam site are from the base upward: Priest Rapids flow No. 1: $30 \pm 5$ feet, (1) No. $2: 40 \pm 5$ feet, ${ }^{(2)}$ No. $3: 60 \pm 5$ feet, $(3)$ and No. $4: 90 \pm 10$ feet. $^{(4)}$ Priest Rapids flow No. 4 is overlain directly by the Ellensburg Formation or by basalt flows interbedded in the Ellensburg. Much of the dam site area is now covered by buildings or water, but the Roza and Priest Rapids flows and the El lensburg Formation are exposed in a south-dipping homocline on the west side of the reservoir.

As indicated earlier, the Priest Rapids flows are closely similar to the Roza flow in lithology, differing only in the virtual absence of phenocrysts; Roza-type phenocrysts are present but are very rare. Except in the vesicular tops and chilled bases, the flows are medium to coarse grained and contain a high percentage (15 to 20) of diktytaxitic openings. The columns of the colonnade are very large in diameter; in the thinner flows, columns that are only a few tens of feet in height may be as much as 10 feet $^{(5)}$ in diameter. Depending on the degree of development of the platy

1. $9.2 \pm 1.5$ meters

2. $12.2+1.5$ meters

3. $18.4 \pm 1.5$ meters

4. $27.5 \pm 1.5$ meters

5. 3 meters 
parting, the flows range from very weak to very resistant; the rapids in the Columbia River at the dam site were held up by relatively massive columns in Priest Rapids flow No. 4. As in the case of the Roza flow, the weathering color is red-brown.

The flows are similar to each other and to the other members of the Middle Yakima Basalts with the exception of Priest Rapids IV, which is higher in MgO and chromium.

Core holes and outcrops at Priest Rapids Dam are the type localities for these flows. Figure A-26 shows the location of the core holes and the configuration and topography before the construction of the Priest Rapids Dam. PRE- 1 and PRK-3 are foundation coreholes at the dam site. The Priest Rapids flows in the core holes ${ }^{[\mathrm{A}-4]}$ have been sampled and analyzed and considered informally as the Priest Rapids Type Locality because the original type locality ${ }^{[A-4]}$ was flooded by the Priest Rapids reservoir.

Figure A-27 shows diagrammatic lithologic logs of the coreholes after Mackin ${ }^{[A-4]}$ showing sampling locations. Table A-IX is a tabulation of analytical data for the Priest Rapids Member. Figures A-28 and A-29 are graphical depictions of analytical data in the form of "Elemental Roses". 


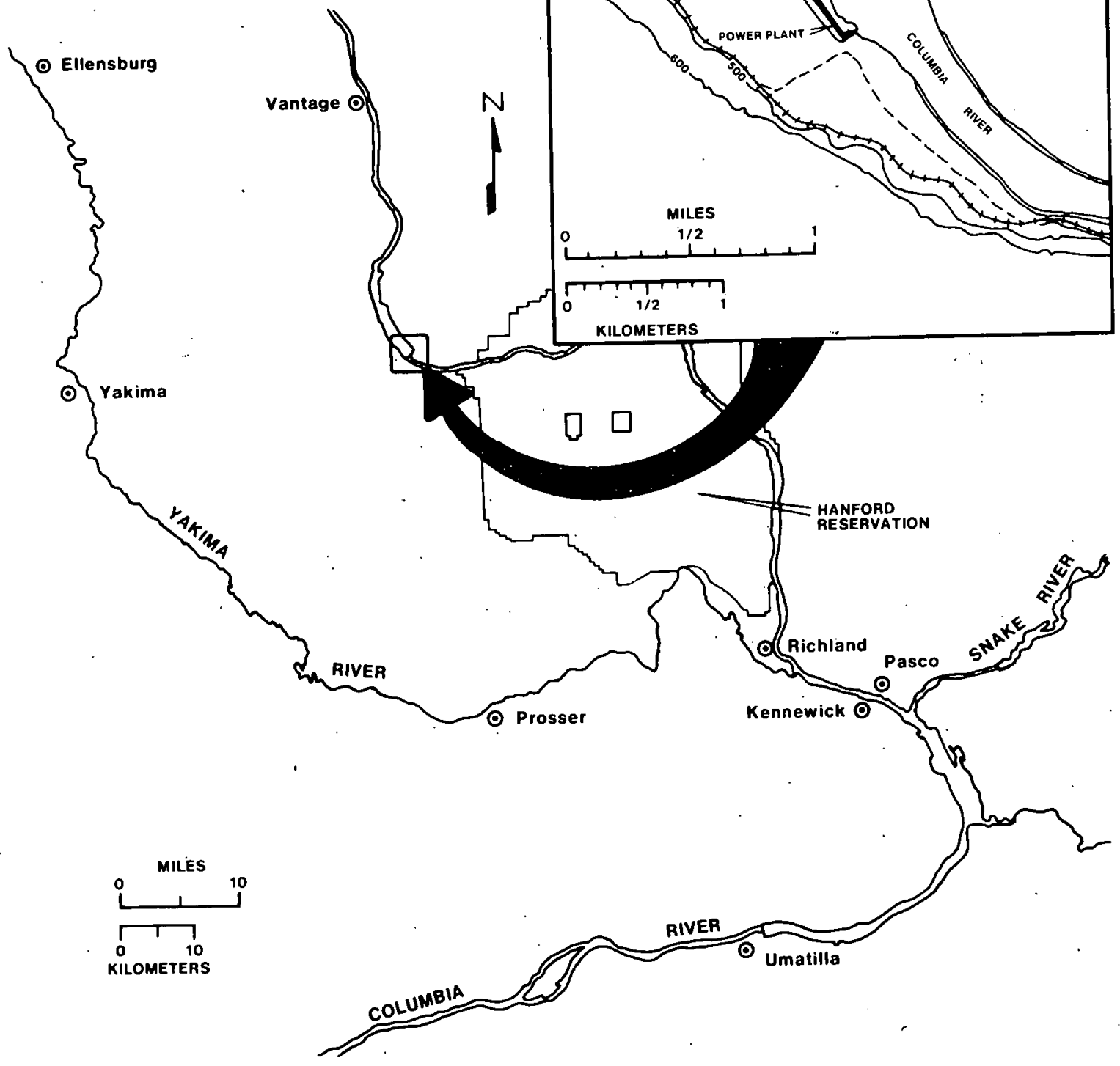

FIGURE A-26

PRIEST RAPIDS TYPE LOCALITY LOCATION MAP 
PRIEST RAPIDS CORE HOLES LITHOLOGIC LOGS SHOWING SAMPLE POINTS

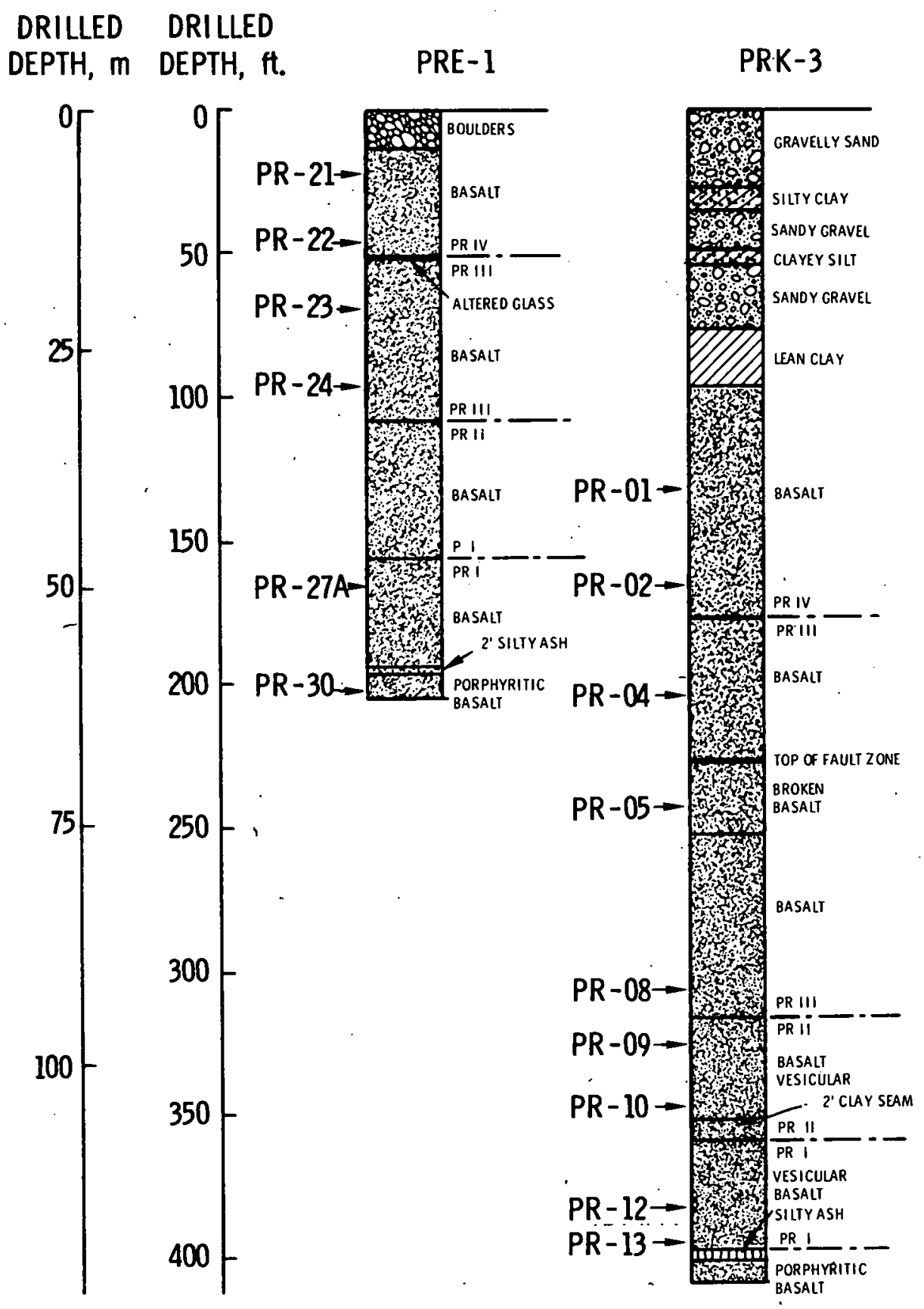

FIGURE $A-27$

PRIEST RAPIOS TYPE LOCALITY SAMPLE POINTS 
MAJOR OXIDE CONTENT, by Atomic Absorption Spectrometer

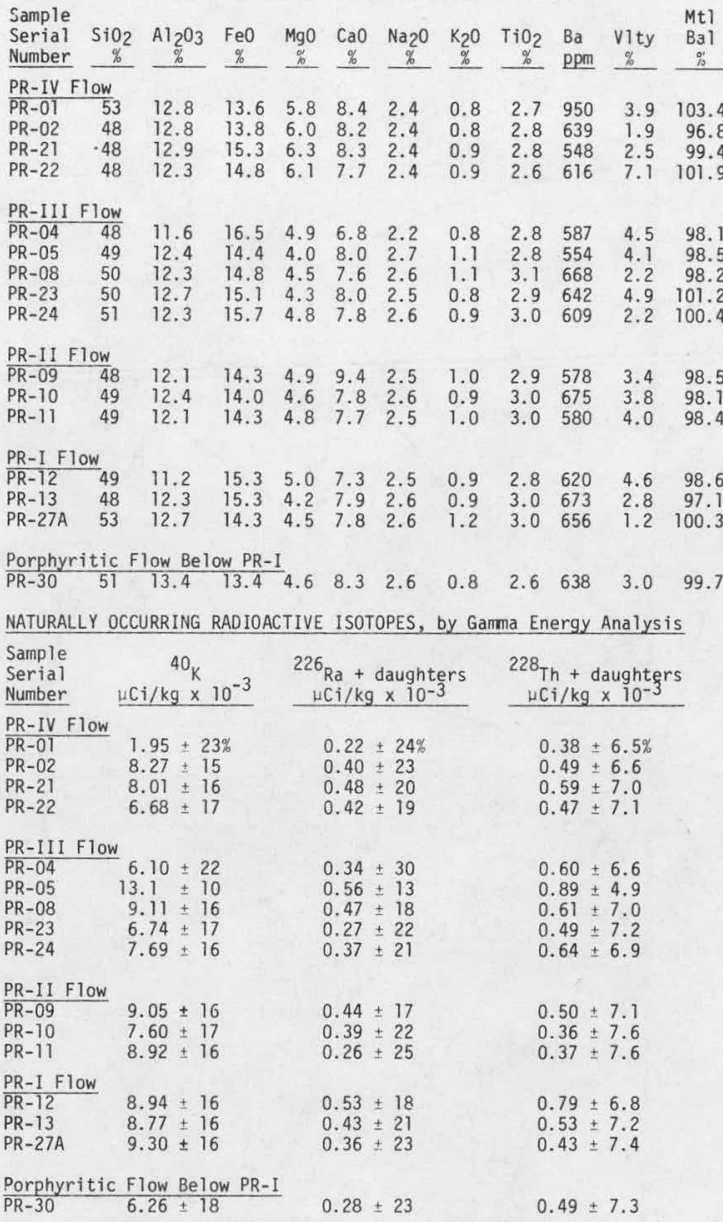

TRACE ELEMENTS, by Neutron Activation Analysis

Serial $\mathrm{Na}$ La Sm $\mathrm{Fe}$ Co Sc $\mathrm{Cr}$ Eu Th Tb Hf Ta

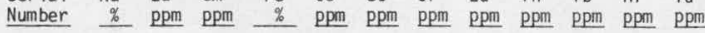
PR-IV Flow

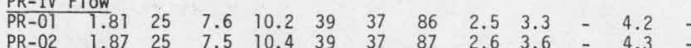
$\begin{array}{llllllllllll}\mathrm{PR}-02 & 1.87 & 25 & 7.5 & 10.4 & 39 & 37 & 87 & 2.6 & 3.6 & - & 4.3 \\ \mathrm{PR}-21 & 1.96 & 26 & 7.7 & 10.8 & 42 & 38 & 87 & 2.9 & 4.2 & - & 4.6\end{array}$ $\begin{array}{lllllllllllll}P R-21 & 1.96 & 26 & 7.7 & 10.8 & 42 & 38 & 87 & 2.9 & 4.2 & - & 4.6 & = \\ P R-22 & 1.85 & 25 & 7.2 & 10.5 & 40 & 36 & 82 & 2.8 & 3.4 & - & 4.8 & -\end{array}$

\begin{tabular}{llllllllllll} 
PR-III Fl OW & & & & & & & & & \\
\hline PR-04 & 1.64 & 32 & 9.1 & 12.5 & 40 & 36 & 7 & 2.9 & 4.2 & - & 5.4
\end{tabular} $\begin{array}{llllrlllllll}\mathrm{PR}-05 & 1.86 & 29 & 8.2 & 9.7 & 37 & 37 & 14 & 2.9 & 4.2 & - & 5.4 \\ \mathrm{PR}-08 & 1.98 & 26 & 8.6 & 11.0 & 38 & 38 & 15 & 3.0 & 4.1 & - & 5.3\end{array}$ $\begin{array}{llllllllllll}P R-08 & 1.98 & 26 & 8.6 & 11.0 & 38 & 38 & 15 & 3.0 & 4.7 & - & 5.3 \\ P R-23^{*} & 0.63 & 20 & 6.0 & 11.1 & 41 & 40 & 15 & 3.0 & 4.0 & - & 5.4\end{array}$ *PR-23 High volatility and anomalous values may indicate leaching. PR-II Flow \begin{tabular}{llllllllllll}
\hline PR-09 & 1.84 & 27 & 7.8 & 11.0 & 38 & 36 & 18 & 2.7 & 3.5 & - & 4.9
\end{tabular}

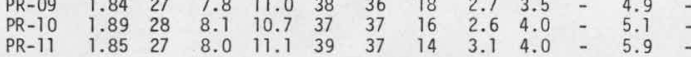

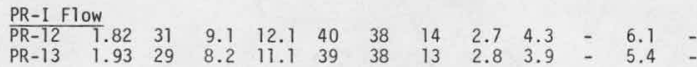

TRACE ELEMENTS, by Emission Spectrometer $\begin{array}{llllllllll}\text { Sample } & \text { Serial Ba } & \mathrm{Cr} & \mathrm{Ni} & \mathrm{Rb} & \mathrm{SC} & \mathrm{Sn} & \mathrm{V} & \mathrm{Zn} & \mathrm{Zr}\end{array}$ Number ppm ppm ppm ppm ppm ppm ppm ppm ppm

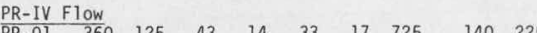
$\begin{array}{llllllllrl}\text { PR-01 } & 360 & 125 & 43 & 14 & 33 & 17 & 725 & 140 & 225 \\ \text { PR-02 } & 390 & 148 & 86 & 32 & 73 & 14 & 750 & 40 & 255\end{array}$ $\begin{array}{llllllllrl}\mathrm{PR}-02 & 390 & 148 & 86 & 32 & 73 & 14 & 750 & 40 & 255 \\ \mathrm{PR}-21 & 400 & 140 & 67 & 28 & 33 & 15 & 700 & 108 & 262\end{array}$ $\begin{array}{llllllllll}P R-22 & 1350 & 130 & 65 & 46 & 155 & 30 & 820 & >1000 & 275\end{array}$ $\begin{array}{lrllllllll}\text { PR-III } & \text { Flow } & & & & & & & & \\ \text { PR-04 } & 990 & 14 & 13 & 21 & 115 & 23 & 755 & 225 & 378 \\ \text { PR-05 } & 800 & 10 & 15 & 18 & 90 & 19 & 624 & 115 & 290\end{array}$ $\begin{array}{llllllllll}\mathrm{PR}-08 & 840 & 14 & 13 & 14 & 70 & 19 & 625 & 250 & 225 \\ \mathrm{PR}-23 & 275 & 14 & 17 & 66 & 35 & 35 & 720 & 175 & 225\end{array}$ $\begin{array}{llllllllll}\mathrm{PR}-23 & 275 & 14 & 17 & 66 & 35 & 35 & 720 & 175 & 225 \\ \mathrm{PR}-24 & 380 & 14 & 17 & 62 & 41 & 23 & 780 & 170 & 225\end{array}$

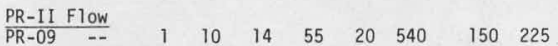
$\begin{array}{llllllllll}\mathrm{PR}-10 & 510 & 28 & 20 & 35 & 59 & 21 & 760 & 185 & 250 \\ \mathrm{PR}-11 & 475 & 10 & 15 & 21 & 41 & 15 & 755 & 159 & 295\end{array}$

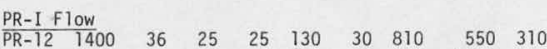
$\begin{array}{lrrrrrrrrr}P R-12 & 1400 & 36 & 25 & 25 & 130 & 30 & 810 & 550 & 310 \\ P R-13 & 1490 & 14 & 14 & 6 & 200 & 42 & 600 & >1000 & 270\end{array}$

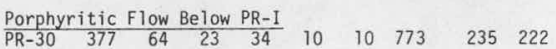




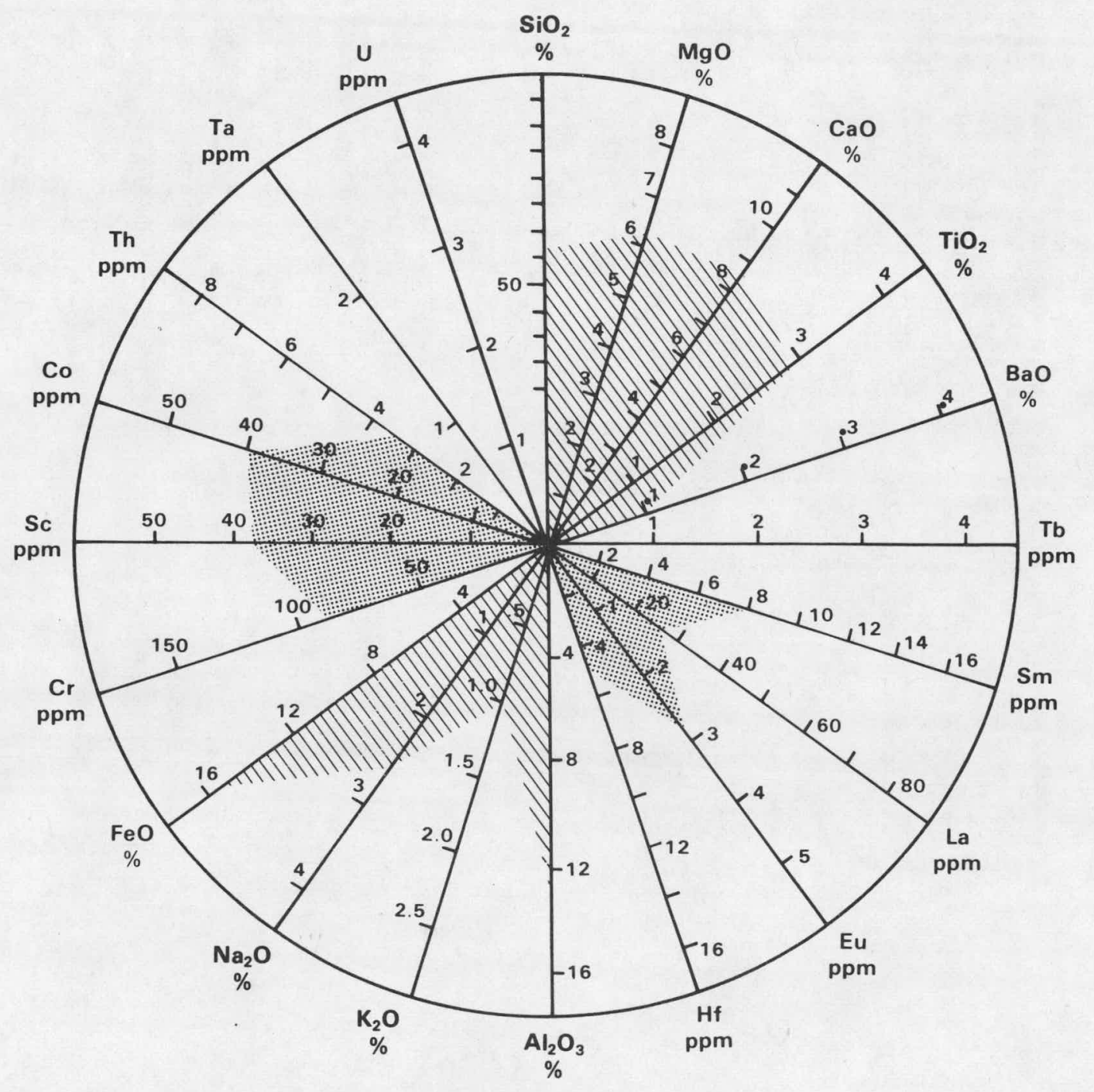

FIGURE A-28

PRIEST RAPIDS FLCW UNIT IV TYPE LOCALITY, ELEMENTAL ROSE 


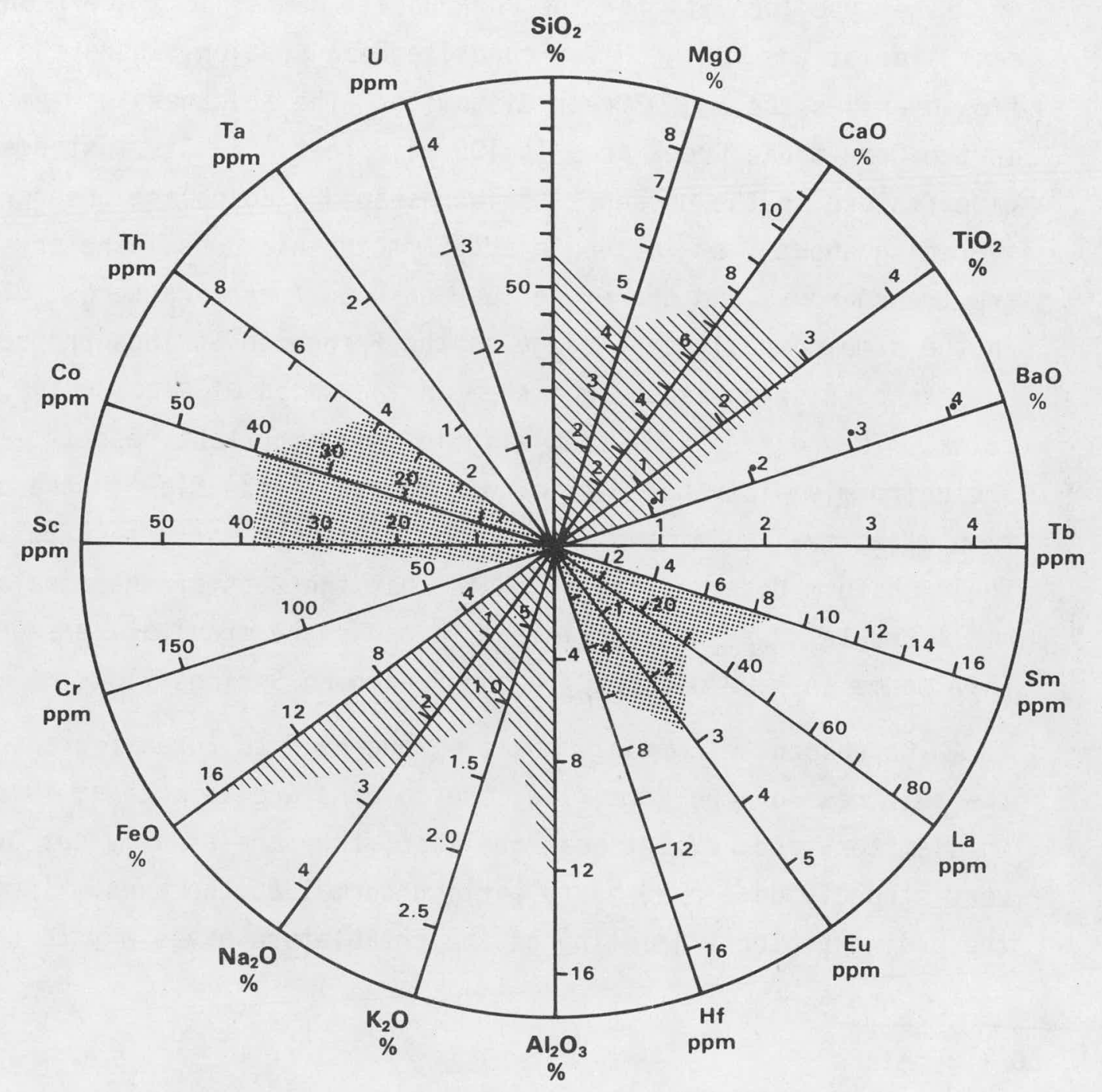

FIGURE A-29

PRIEST RAPIDS FLOW UNITS I, II, AND III TYPE LOCALITY, ELEMENTAL ROSE 


\section{ROZA BASALT MEMBER}

The following description of the Roza Basalt Member at its type locality is taken from Mackin.

The type locality for the Roza Basalt Member is a scarp on the east side of the Yakima River opposite Roza Station, where the Roza flow overlies the Squaw Creek diatomite. The thickness of the flow in the Roza-Squaw Creek area is $100 \pm 10$ feet. (1) Its most distinctive feature is the presence of lath-shaped plagioclase phenocrysts averaging about $1 \mathrm{~cm}$ in length and $5 \mathrm{~mm}$ in thickness. The crystals are transparent, and therefore look dark on fresh fractures. They are in the same compositional range as the Frenchman Springs phenocrysts but can be distinguished from them on the basis of size, shape, and color. They differ from them also in this important respect -- they are uniformly distributed from base to top of the flow in the proportion of several to a hand specimen. They are clearly intratelluric; their uniform distribution suggests that the mass of these relatively small crystals was not sufficient to cause the gravitative segregation that seems to have occurred in the Frenchman Springs flows.

The colonnade commonly makes up one-half to three-fourths of the thickness of the Roza flow; the columns are as much as 10 feet $^{(2)}$ in diameter, and, except near the base, they are usually cut by a very strongly developed platy parting normal to the axes. In many places the ordinary blocky jointing of the entablature gives way to sharply

1. $30 \pm 3$ meters

2. 3 meters 
recurved and swirling patterns of plates, suggesting that directional stresses were set up in still viscous lava by a surge of movement after partial consolidation of the colonnade. Chiefly because of the platy jointing, the lower and middle parts of the flow are easily eroded, forming covered slopes surmounted by ledge outcrops of short massive columns near the top. The surface, in the few places where it has been seen, is ropy, locally displaying some upbuckling and splitting of pressure ridges. Except for a fine-grained vesicular zone at the top, the rock is medium to coarse grained and contains 10 to 20 percent diktytaxitic openings. It weathers to a deep red-brown color.

Reference samples were taken from opposite Roza Station, (Figures A-30 and $A-31$ ) and from near the old highway tunnel southwest of Selah Butte, (Figures $A-32$ and $A-33$ ). Table $A-X$ is a tabulation of analytical data for the Roza type locality and Figure A-34 depicts the analytical data in the form of an "Elemental Rose". 


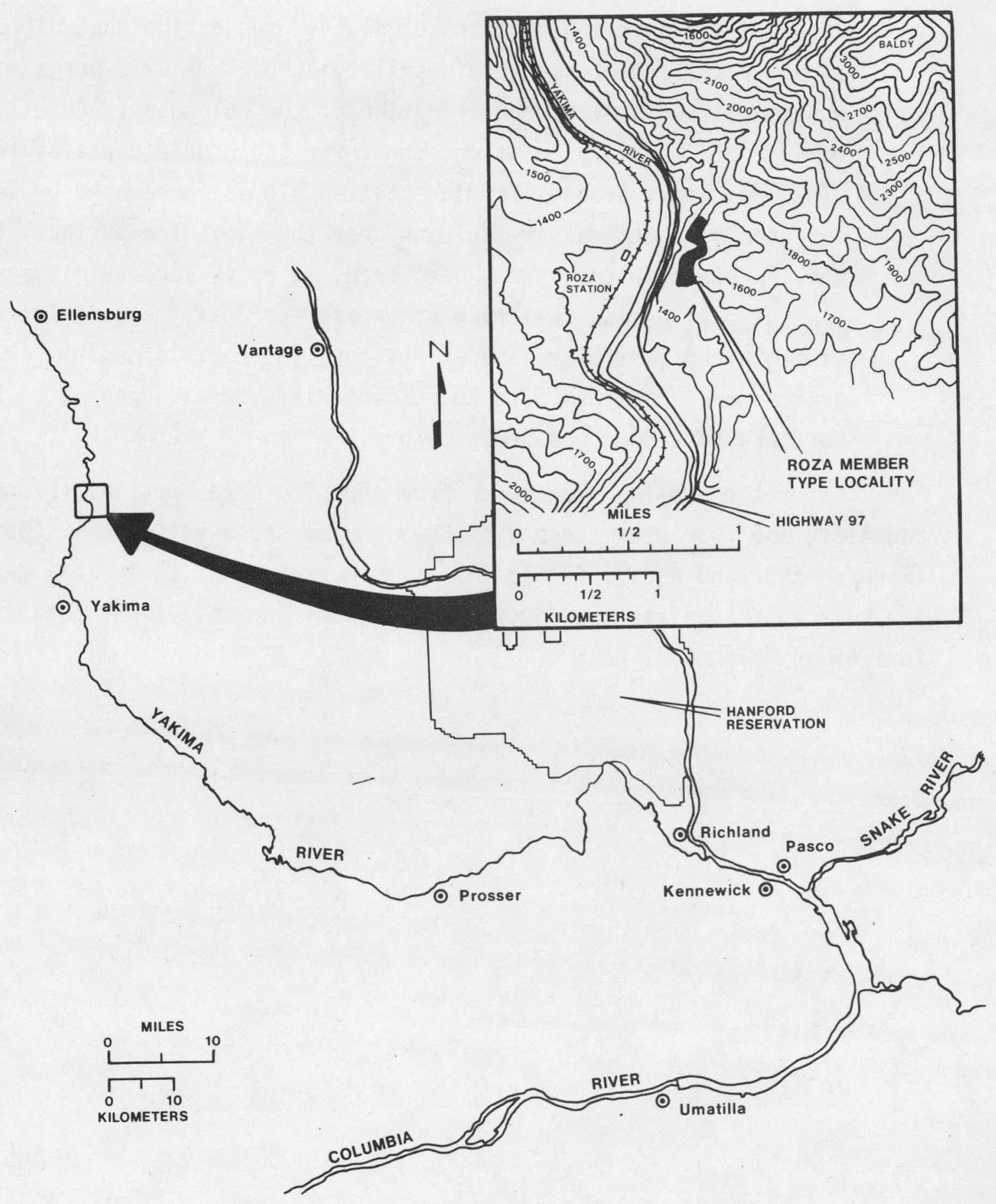

FIGURE $A-30$

ROZA TYPE LOCALITY LOCATION MAP 


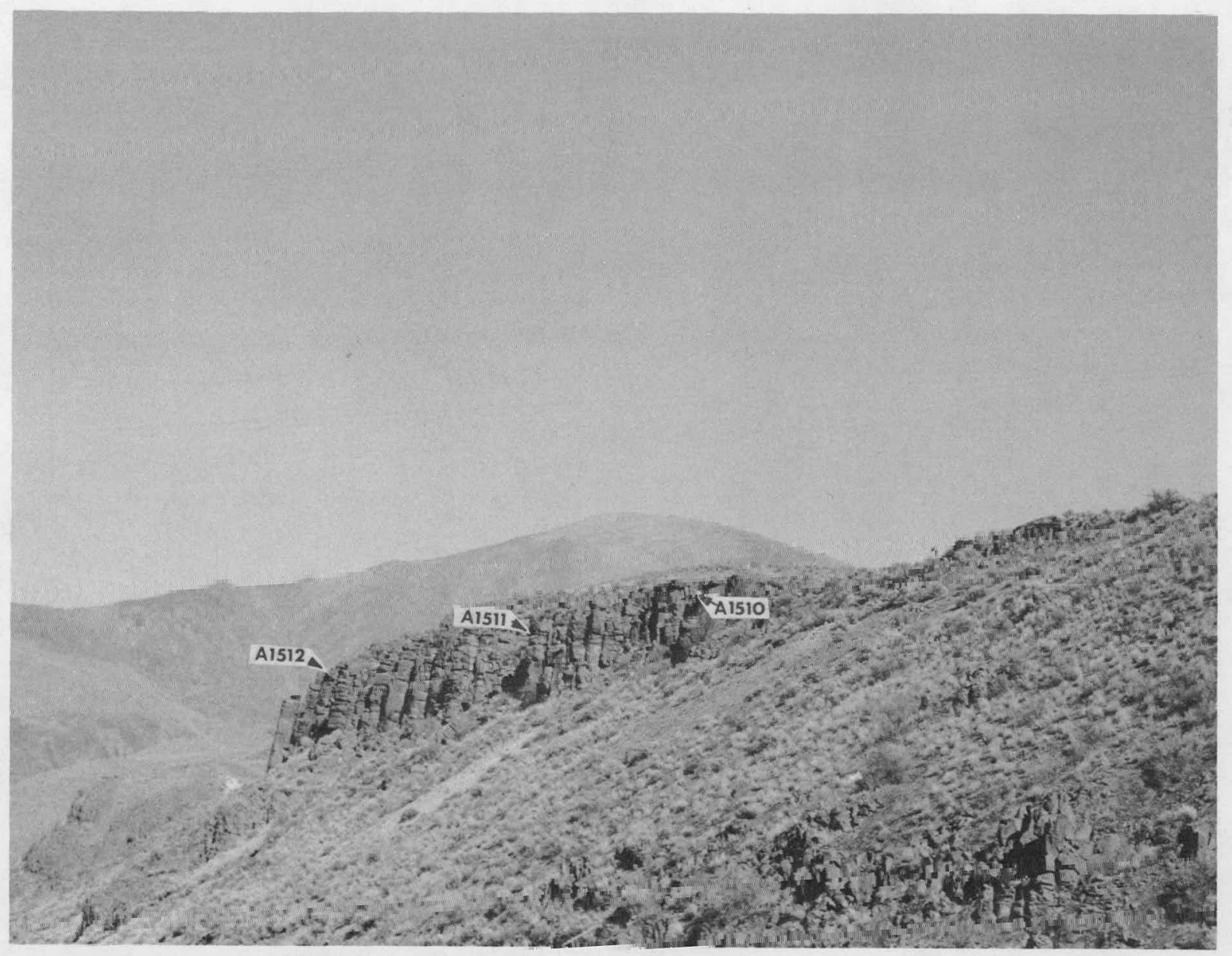

FIGURE $A-31$

ROZA TYPE LOCALITY SAMPLE POINTS 


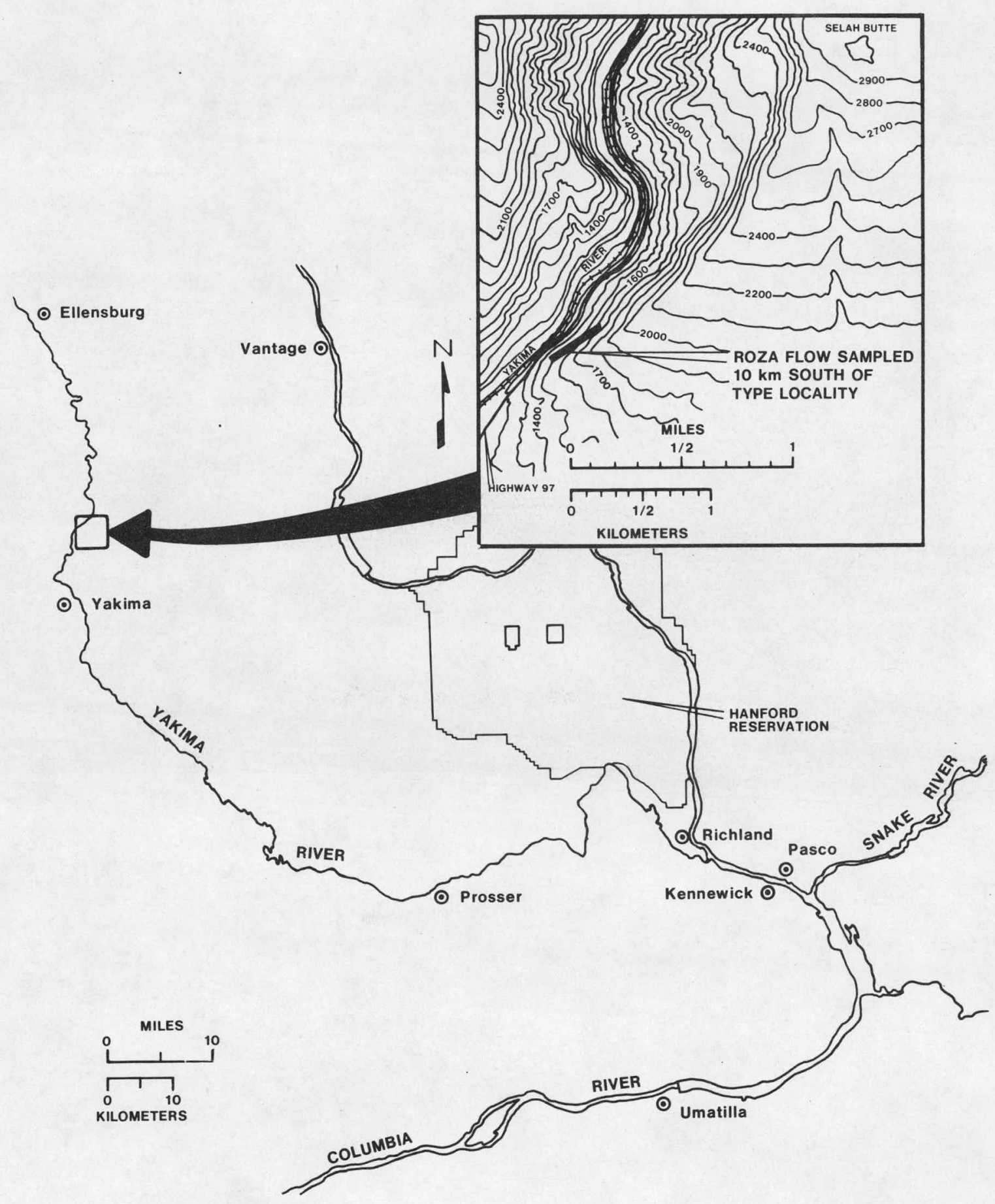

FIGURE A-32

ROZA 10 KMS SOUTH OF TYPE LOCALITY 


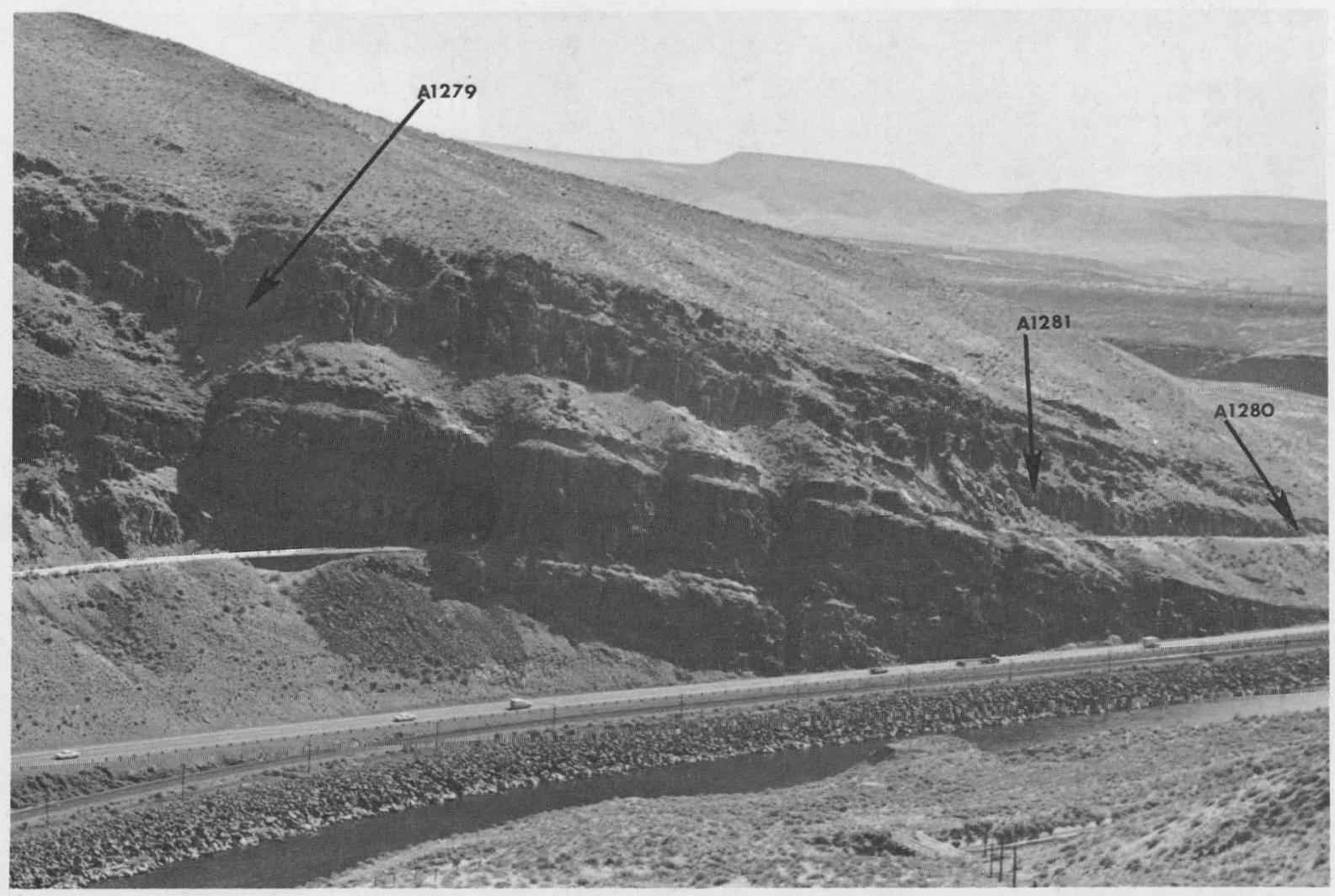

FIGURE $A-33$

SAMPLE POINTS FROM ROZA 10 KMS SOUTH OF TYPE LOCALITY 
MAJOR OXIDES AND TRACE. ELEMENTS, by Atomic Absorption Spectrometer

\begin{tabular}{|c|c|c|c|c|c|c|c|c|c|c|c|}
\hline $\begin{array}{l}\text { Sample } \\
\text { Serial } \\
\text { Number } \\
\end{array}$ & $\begin{array}{c}\mathrm{SiO}_{2} \\
\% \\
\end{array}$ & $\begin{array}{l}\mathrm{Al}_{2} \mathrm{O}_{3} \\
\end{array}$ & $\begin{array}{l}\mathrm{Fe} 0 \\
\% \\
\end{array}$ & $\begin{array}{l}\mathrm{Mg0} \\
\% \\
\end{array}$ & $\begin{array}{c}\mathrm{CaO} \\
\% \\
\end{array}$ & $\begin{array}{c}\mathrm{Na}_{2} \mathrm{O} \\
\% \\
\end{array}$ & $\begin{array}{l}\mathrm{K}_{2} \mathrm{O} \\
\% \\
\end{array}$ & $\begin{array}{r}\mathrm{TiO}_{2} \\
\% \\
\end{array}$ & $\begin{array}{l}\mathrm{Ba} \\
\mathrm{ppm}\end{array}$ & $\begin{array}{c}\text { V1ty } \\
\% \\
\end{array}$ & $\begin{array}{c}\mathrm{Mtl} \\
\mathrm{Bal} \\
\%\end{array}$ \\
\hline $\begin{array}{l}\text { A1279 } \\
\text { A1280 } \\
\text { A1281 }\end{array}$ & $\begin{array}{l}52 \\
50 \\
50\end{array}$ & $\begin{array}{l}13.1 \\
13.0 \\
13.1\end{array}$ & $\begin{array}{l}14.1 \\
14.4 \\
14.4\end{array}$ & $\begin{array}{l}5.1 \\
4.7 \\
4.8\end{array}$ & $\begin{array}{l}8.0 \\
8.0 \\
8.0\end{array}$ & $\begin{array}{l}2.7 \\
2.8 \\
2.8\end{array}$ & $\begin{array}{l}1.3 \\
1.1 \\
1.2\end{array}$ & $\begin{array}{l}2.4 \\
2.6 \\
2.6\end{array}$ & $\begin{array}{l}626 \\
673 \\
735\end{array}$ & $\begin{array}{l}1.3 \\
1.5 \\
1.5\end{array}$ & $\begin{array}{r}100.0 \\
98.1 \\
98.4\end{array}$ \\
\hline $\begin{array}{l}\text { A1510 } \\
\text { A1511 } \\
\text { A1512 }\end{array}$ & $\begin{array}{l}50 \\
49 \\
50\end{array}$ & $\begin{array}{l}13.1 \\
13.1 \\
12.8\end{array}$ & $\begin{array}{l}13.8 \\
13.7 \\
13.6\end{array}$ & $\begin{array}{l}4.5 \\
4.7 \\
4.4\end{array}$ & $\begin{array}{l}8.5 \\
8.1 \\
8.1\end{array}$ & $\begin{array}{l}2.7 \\
2.7 \\
2.7\end{array}$ & $\begin{array}{l}1.1 \\
1.0 \\
1.1\end{array}$ & $\begin{array}{l}3.0 \\
3.1 \\
3.2\end{array}$ & $\begin{array}{l}587 \\
597 \\
630\end{array}$ & $\begin{array}{l}1.4 \\
2.0 \\
1.9\end{array}$ & $\begin{array}{l}98.3 \\
97.7 \\
98.1\end{array}$ \\
\hline
\end{tabular}

Sample

Serial MnO Sro $\mathrm{P}_{2} \mathrm{O}_{5} \quad \mathrm{Zn}$ Co $\mathrm{Pb} \quad \mathrm{Cn} \quad \mathrm{Cr} \quad \mathrm{Ni} \quad \mathrm{Rb}$

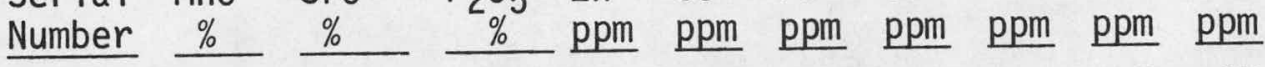

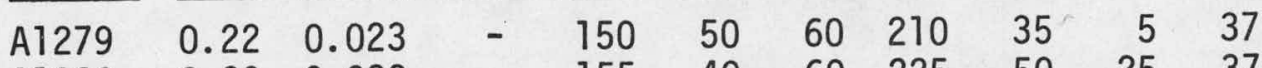

$\begin{array}{lllllllllll}\text { A1280 } & 0.23 & 0.022 & - & 155 & 40 & 60 & 225 & 50 & 25 & 37 \\ \text { A1281 } & 0.22 & 0.023 & - & 160 & 45 & 65 & 210 & 30 & 15 & 37\end{array}$

$\begin{array}{lllllllllll}\text { A1510 } & 0.25 & 0.038 & 0.589 & - & - & - & - & 100 & - & 42 \\ \text { A1511 } & 0.23 & 0.037 & 0.614 & - & - & - & - & 116 & - & 42 \\ \text { A1512 } & 0.23 & 0.036 & 0.348 & - & - & - & - & 69 & - & 47\end{array}$

NATURALLY OCCURRING RADIOACTIVE ISOTOPES, by Gamma Energy Analysis

\begin{tabular}{|c|c|c|c|}
\hline $\begin{array}{l}\text { Sample } \\
\text { Serial } \\
\text { Number }\end{array}$ & $\begin{array}{c}40_{\mathrm{K}} \\
\mu \mathrm{Ci} / \mathrm{kg} \times 10^{-3}\end{array}$ & $\begin{array}{c}{ }^{226} \mathrm{Ra}+\text { daughters } \\
\mu \mathrm{Ci} / \mathrm{kg} \times 10^{-3} \\
\end{array}$ & $\begin{array}{l}{ }^{228} \mathrm{Th}+\text { daughters } \\
\mu \mathrm{Ci} / \mathrm{kg} \times 10^{-3} \\
\end{array}$ \\
\hline $\begin{array}{l}A 1279 \\
\text { A1280 } \\
\text { A1281 }\end{array}$ & $\begin{array}{c}11.1 \pm 14 \% \\
8.1 \pm 16 \\
10.5 \pm 16\end{array}$ & $\begin{array}{l}0.61 \pm 17 \% \\
0.42 \pm 19 \\
0.80 \pm 18\end{array}$ & $\begin{array}{l}0.59 \pm 7.2 \% \\
0.32 \pm 8.2 \\
0.61 \pm 8.0\end{array}$ \\
\hline
\end{tabular}

TRACE ELEMENTS, by Neutron Activation Analys is

Sample $\mathrm{Na}$ La Sm Fe Co Sc Cr Eu Th. Tb Hf Ta

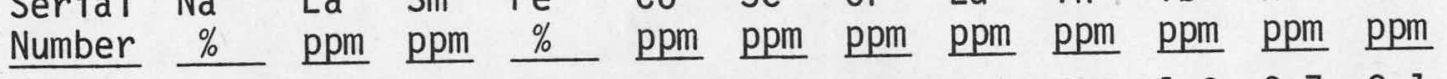
$\begin{array}{lllllllllllll}\text { A1279 } & 1.99 & 21 & 6.6 & 10.3 & 39 & 35 & 60 & 2.2 & 6.0 & 1.0 & 3.7 & 2.1\end{array}$ $\begin{array}{lllllllllllll}\text { A1280 } & 2.05 & 25 & 7.4 & 10.2 & 35 & 33 & 34 & 2.4 & 6.4 & 1.4 & 5.3 & 1.3\end{array}$ $\begin{array}{lllllllllllll}\text { A1281 } & 1.92 & 25 & 8.1 & 10.8 & 39 & 35 & 35 & 2.6 & 6.6 & 1.4 & 5.3 & 1.5\end{array}$

TABLE A-X

TABULATION OF ANALYTICAL DATA FROM THE ROZA BASALT MEMBER FROM THE TYPE LOCALITY AND FROM 10 KMS SOUTH OF THE TYPE LOCALITY 


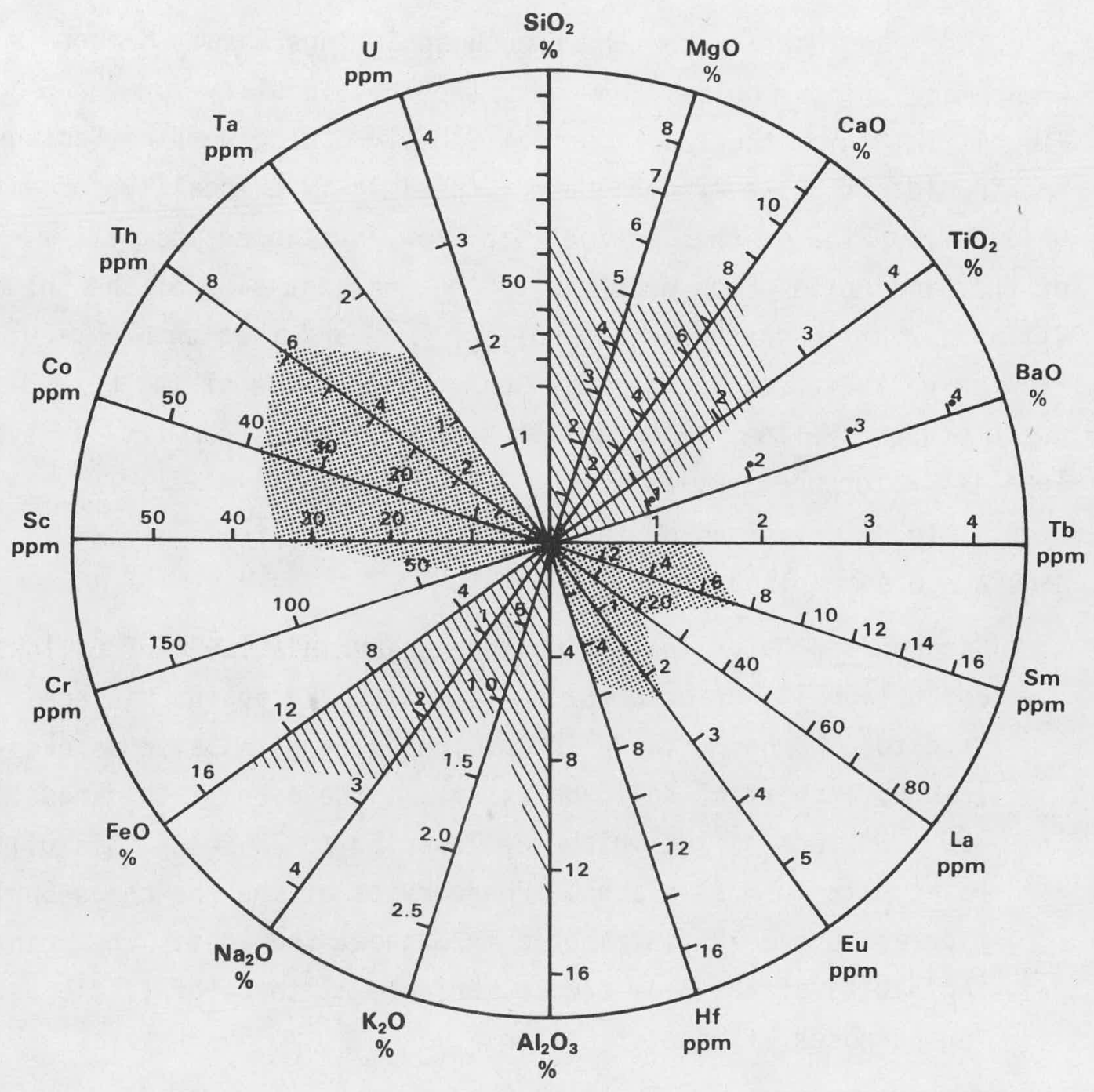

FIGURE $A-34$

ROZA MEMBER FLOW TYPE LOCALITY, ELEMENTAL ROSE 
FRENCHMAN SPRINGS BASALT MEMBER

Mackin ${ }^{[A-4]}$ assigned the formal name Frenchman Springs Basalt Member and subdivided it into three separate flows: the Gingko Flow, the Sand Hollow Flow and the Sentinel Gap Flow. Myers ${ }^{[A-8]}$ has entensively chemically and petrographically characterized the member.

The type locality for the Frenchman Springs Basalt Member is Frenchman Springs Coulee. However, the type locality for the Gingko Flow is in ". . . the lower part of Schebly Coulee west of Vantage. Mackin did not, however designate a specific type locality for either the Sand Hollow Flow or the Sentinel Gap Flow, but noted that cliff exposures of the Sand Hollow Flow occur ". . . on the east side of the Columbia Valley north and south of Sand Hollow" ${ }^{[A-4]}$ and that the Sentinel Gap Flow is well exposed in the scarp on the east side of the Columbia River north of Sand Hollow. Figure A-35 shows locations sampled for type local ity reference samples.

Field descriptions of the Frenchman Springs flows given by Mackin are summarized below: $[A-4]$

Gingko Flow ". . . petrified logs occur in a layer of pillows and palagonite breccia which rests directly on the Vantage Sandstone Member ..." The pillow palagonite layer is overlain by a sheet of solid basalt. . . The overall thickness is $150 \pm 20$ feet, ${ }^{(1)}$ of which the lower 50 to 75 feet $^{(2)}$ is pillowpalagonite in most places. Phenocrysts of the Frenchman Springs type are unevenly distributed throughout the unit. The jointing habits of the flow are so variable as to be of little use for purposes of identification.

1. $45 \pm 6$ meters

2. 15 to 22.5 meters 
Sand Hollow Flow "The field term for this unit, the double barreled flow, expresses the jointing habit that is its most distinctive feature . . the colannade consisting of regular prismatic columns 4 to 6 feet (?) in diameter and 20 to 30 . feet ${ }^{(2)}$ in height is almost exactly matched by a columnar zone 30 to 40 feet ${ }^{(3)}$ thick near the top of the flow... The entablature consisting of one or more thick tiers of small columns, is about 30 feet $^{(4)}$ thick. . . The top of the flow... is a jumble of broken blocks and rafted slabs of scoriaceous lava, with local relief as much as 5 feet.

Sentinel Gap Flow ". . . the Sentinel Gap flow terminates within the Vantage-Priest Rapids area . . . the distal mile, well exposed in the scarp on the east side of the Columbia River north of Sand Hollow, is a gradually tapering wedge of palagonite breccia made up of pillows and lava slabs arranged in a northwarddipping foreset structure ..."

Plagioclase phenocrysts and glomerophenocrysts are irregularly distributed in both glassy selvages and interiors of individual flow units in the Gingko Flow. Diktytaxitic cavities are common in most flow units but their distribution like that of plagioclase phenocrysts, is not uniform. The diktytaxitic cavities are usually filled or lined with what was originally a mineraloid subsequently altered to reddishorange fillings of clay minerals and iron oxides. This coloration causes the cavities to stand in sharp contrast to the gray groundmass basalt.

1. 1.2 to 1.8 meters

2. 6 to 9 meters

3. 9 to 12 meters

4. 9 meters

5. 1.5 meters 
Flow phase rocks in the Sentinel Gap flow also contain plagioclase phenocrysts but they are generally smaller in size and more widely spaced than those in the Gingko Flow. Diktytaxitic cavities are common; they have an appearance and distribution similar to those of the Ginko Flow.

The Sand Hollow Flow is also porphyritic, but the size, shape and distribution of the plagioclase phenocrysts is different than in the Gingko Flow. Most phenocrysts in the Gingko Flow are grouped together in glomeroporphyritic clots whereas the phenocrysts in the Sand Hollow Flow commonly occur as isolated, single crystals except near the base of the flow where glomerophenocrysts locally occur. Also, the phenocrysts in the Gingko Flow are abundant -- locally only 2 to $3 \mathrm{~cm}$ apart -- but their distribution is very irregular. On the contrary, phenocrysts in the Sand Hollow Flow are much less abundant, but their spacing is more uniform, about one-half meter apart on a two dimensional surface except in the porphyritic zone near the base where they are locally more abundant. The size, shape and distribution of the phenocrysts in the Sand Hollow Flow is similar to that in the Sentinel Gap Flow except for the greater concentration of glomerophenocrysts in the base of the Sand Hollow Flow. ${ }^{[A-8]}$

Chemically the flows are very similar to each other and to most of the other members of the Middle Yakima Basalts. There does appear to be a significant variation in chromium values from type locality samples. The Sand Hollow Flow chromium values are 45-58 ppm while those of the Sentinel Gap and Ginko Flows are from 17-33 ppm.

Table A-XI is a tabulation of analytical data from the Frenchman Springs Basalt Member. Figures A-36, A-37 and A-38 graphically depict analytical data for the individual flows in the form of "Elemental Roses". 


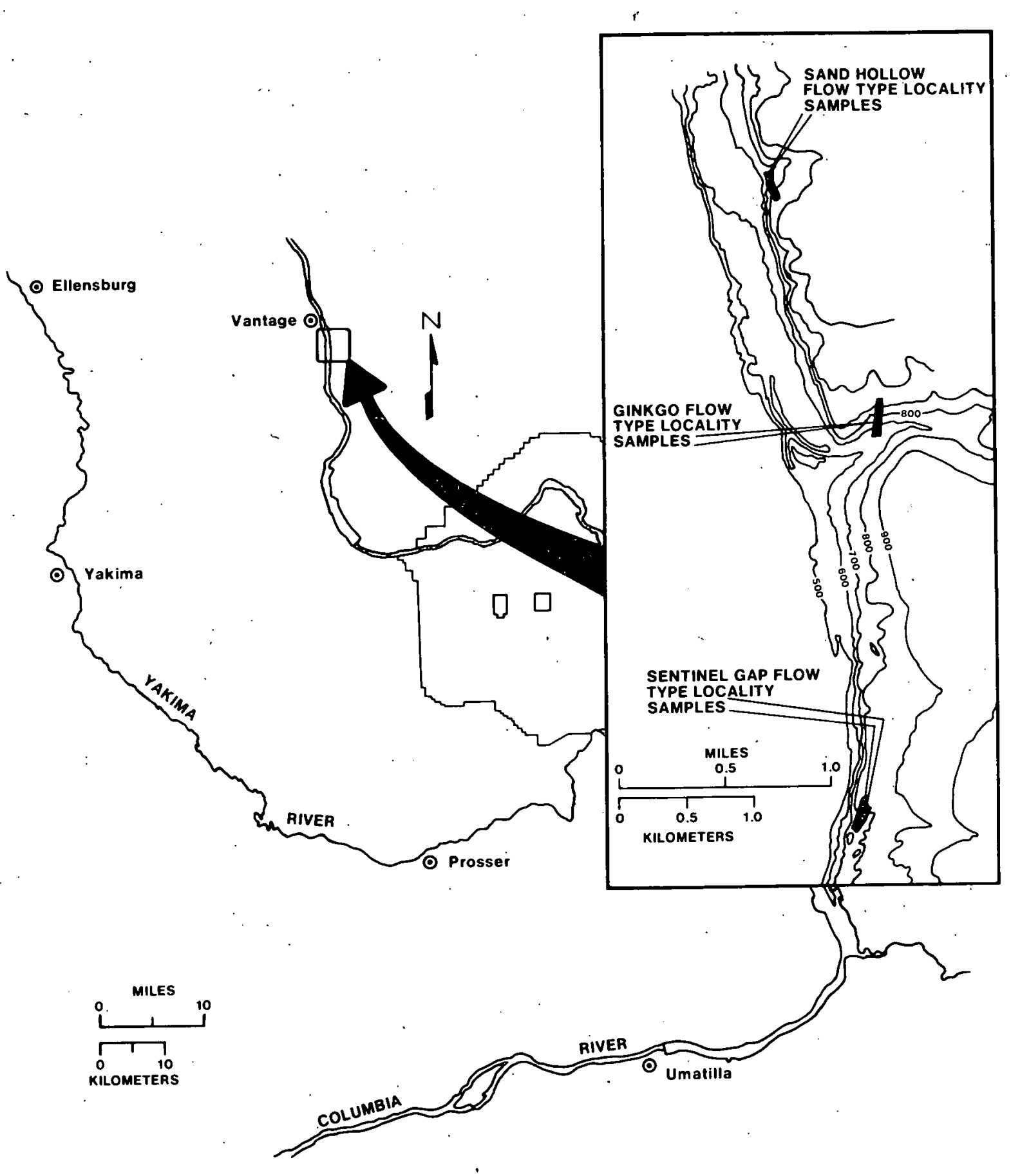

FIGURE A-35

LOCATION MAP FOR FRENCHMAN SPRINGS BASALT MEMBER 
MAJOR OXIDES, by Atomic Absorption Spectrometer

\begin{tabular}{|c|c|c|c|c|c|c|c|c|c|c|c|}
\hline $\begin{array}{l}\text { Sample } \\
\text { Serial } \\
\text { Number }\end{array}$ & $\begin{array}{r}\mathrm{SiO}_{2} \\
\frac{\%}{2} \\
\end{array}$ & $\begin{array}{c}\mathrm{Al}_{2} \mathrm{O}_{3} \\
\end{array}$ & $\begin{array}{c}\mathrm{Fe0} \\
\% \\
\end{array}$ & $\begin{array}{c}\mathrm{Mg0} \\
\% \\
\end{array}$ & $\begin{array}{c}\mathrm{CaO} \\
\% \\
\end{array}$ & $\begin{array}{r}\mathrm{Na}_{2} \mathrm{O} \\
\% \\
\end{array}$ & $\begin{array}{c}\mathrm{K}_{2} \mathrm{O} \\
\% \\
\end{array}$ & $\begin{array}{r}\mathrm{TiO}_{2} \\
\% \\
\end{array}$ & $\begin{array}{l}\text { Ba } \\
\mathrm{ppm}\end{array}$ & $\begin{array}{c}\text { Vity } \\
\% \\
\end{array}$ & $\begin{array}{c}\mathrm{Mtl} \\
\mathrm{Bal} \\
\%\end{array}$ \\
\hline $\begin{array}{l}\text { Sentine } \\
\text { K5032 } \\
\text { K5033 } \\
\text { K5034 } \\
\text { K5035 } \\
\text { K5036 }\end{array}$ & $\begin{array}{l}\text { Gap } \\
52 \\
51 \\
52 \\
51 \\
51\end{array}$ & $\begin{array}{r}\text { Flow } \\
12.9 \\
12.8 \\
12.9 \\
13.1 \\
12.5\end{array}$ & $\begin{array}{l}14.2 \\
14.3 \\
14.4 \\
14.4 \\
14.7\end{array}$ & $\begin{array}{l}4.3 \\
4.4 \\
4.5 \\
4.6 \\
4.6\end{array}$ & $\begin{array}{l}7.7 \\
7.5 \\
7.5 \\
7.6 \\
7.4\end{array}$ & $\begin{array}{l}2.7 \\
2.8 \\
2.8 \\
2.8 \\
2.8\end{array}$ & $\begin{array}{l}1.2 \\
1.3 \\
1.3 \\
1.3 \\
1.2\end{array}$ & $\begin{array}{l}2.6 \\
2.6 \\
2.7 \\
2.6 \\
2.6\end{array}$ & $\begin{array}{l}829 \\
708 \\
722 \\
652 \\
722\end{array}$ & $\begin{array}{l}1.4 \\
1.3 \\
1.2 \\
1.0 \\
1.1\end{array}$ & $\begin{array}{l}99.2 \\
98.2 \\
99.5 \\
98.6 \\
98.2\end{array}$ \\
\hline $\begin{array}{l}\text { Sand Ho } \\
\text { K5001 } \\
\text { K5002 } \\
\text { K5003 } \\
\text { K5005 } \\
\text { K5007 } \\
\text { K5009 }\end{array}$ & $\begin{array}{r}110 \mathrm{w} \\
52 \\
52 \\
53 \\
52 \\
52 \\
52\end{array}$ & $\begin{array}{r}\text { low } \\
12.5 \\
12.5 \\
12.5 \\
13.1 \\
12.8 \\
12.5\end{array}$ & $\begin{array}{l}13.7 \\
14.0 \\
13.3 \\
13.6 \\
13.8 \\
14.0\end{array}$ & $\begin{array}{l}4.6 \\
4.8 \\
4.4 \\
5.0 \\
4.8 \\
4.9\end{array}$ & $\begin{array}{l}8.0 \\
8.1 \\
7.9 \\
8.0 \\
7.9 \\
7.9\end{array}$ & $\begin{array}{l}2.7 \\
2.8 \\
3.0 \\
2.8 \\
2.9 \\
2.9\end{array}$ & $\begin{array}{l}1.0 \\
1.0 \\
1.0 \\
0.9 \\
1.0 \\
0.9\end{array}$ & $\begin{array}{l}2.5 \\
2.6 \\
2.6 \\
2.5 \\
2.6 \\
2.6\end{array}$ & $\begin{array}{l}579 \\
875 \\
716 \\
718 \\
656 \\
583\end{array}$ & $\begin{array}{l}2.3 \\
1.1 \\
1.9 \\
1.8 \\
1.6 \\
1.4\end{array}$ & $\begin{array}{l}99.5 \\
99.1 \\
99.8 \\
99.9 \\
99.6 \\
99.3\end{array}$ \\
\hline $\begin{array}{l}\text { Gingko } \\
\text { K5012 } \\
\text { K5014 } \\
\text { K5015 } \\
\text { K5017 } \\
\text { K5020 }\end{array}$ & $\begin{array}{r}\text { Flow } \\
49 \\
50 \\
50 \\
50 \\
50\end{array}$ & $\begin{array}{r}12.9 \\
12.9 \\
13.1 \\
13.0 \\
12.7\end{array}$ & $\begin{array}{l}14.7 \\
14.8 \\
14.7 \\
15.1 \\
14.4\end{array}$ & $\begin{array}{l}4.1 \\
4.5 \\
4.5 \\
4.4 \\
4.4\end{array}$ & $\begin{array}{l}7.6 \\
7.6 \\
7.7 \\
7.4 \\
7.7\end{array}$ & $\begin{array}{l}2.6 \\
2.7 \\
2.8 \\
3.6 \\
2.8\end{array}$ & $\begin{array}{l}0.9 \\
1.0 \\
1.1 \\
1.2 \\
1.3\end{array}$ & $\begin{array}{l}2.6 \\
2.6 \\
2.6 \\
2.7 \\
2.6\end{array}$ & $\begin{array}{l}634 \\
656 \\
805 \\
678 \\
788\end{array}$ & $\begin{array}{l}3.5 \\
2.9 \\
2.4 \\
1.8 \\
2.4\end{array}$ & $\begin{array}{l}98.0 \\
99.2 \\
99.1 \\
99.4 \\
98.5\end{array}$ \\
\hline
\end{tabular}

TRACE ELEMENTS, by Neutron Activation Arialysis

\begin{tabular}{|c|c|c|c|c|c|c|c|c|c|c|c|c|}
\hline $\begin{array}{l}\text { Sample } \\
\text { Serial } \\
\text { Number } \\
\end{array}$ & $\begin{array}{r}\mathrm{Na} \\
\% \\
\end{array}$ & $\begin{array}{l}\text { La } \\
\text { ppm }\end{array}$ & $\begin{array}{l}\mathrm{Sm} \\
\mathrm{ppm}\end{array}$ & $\begin{array}{r}\mathrm{Fe} \\
\% \\
\end{array}$ & $\begin{array}{l}\text { Co } \\
\mathrm{ppm}\end{array}$ & $\begin{array}{l}\text { Sc } \\
\text { ppm }\end{array}$ & $\begin{array}{l}\mathrm{Cr} \\
\mathrm{ppm}\end{array}$ & $\begin{array}{l}\text { Eu } \\
\text { ppm }\end{array}$ & $\begin{array}{l}\text { Th } \\
\text { ppm }\end{array}$ & $\begin{array}{l}\text { Tb } \\
\text { ppm }\end{array}$ & $\begin{array}{l}\mathrm{Hf} \\
\mathrm{ppm}\end{array}$ & $\begin{array}{l}\text { Ta } \\
\mathrm{ppm}\end{array}$ \\
\hline $\begin{array}{l}\text { Sentine } \\
\text { K5032 } \\
\text { K5033 } \\
\text { K5034 } \\
\text { K5035 } \\
\text { K5036 }\end{array}$ & $\begin{array}{l}1 \text { Gap } \\
1.95 \\
1.95 \\
1.93 \\
1.92 \\
1.92\end{array}$ & $\begin{array}{l}\frac{F l o w}{29} \\
26 \\
30 \\
28 \\
28\end{array}$ & $\begin{array}{l}7.9 \\
8.6 \\
7.9 \\
7.7 \\
7.3\end{array}$ & $\begin{array}{l}10.8 \\
10.9 \\
11.3 \\
10.9 \\
11.1\end{array}$ & $\begin{array}{l}39 \\
39 \\
39 \\
38 \\
38\end{array}$ & $\begin{array}{l}35 \\
35 \\
36 \\
34 \\
34\end{array}$ & $\begin{array}{l}27 \\
27 \\
29 \\
25 \\
18\end{array}$ & $\begin{array}{l}2.1 \\
2.3 \\
2.2 \\
2.2 \\
2.1\end{array}$ & $\begin{array}{l}4.9 \\
3.6 \\
4.1 \\
3.6 \\
3.9\end{array}$ & $\begin{array}{l}- \\
- \\
- \\
-\end{array}$ & $\begin{array}{l}5.3 \\
5.5 \\
5.0 \\
4.8 \\
4.6\end{array}$ & - \\
\hline $\begin{array}{l}\text { Sand Ho } \\
\text { K5001 } \\
\text { K5002 } \\
\text { K5003 } \\
\text { K5005 } \\
\text { K5007 } \\
\text { K5009 }\end{array}$ & $\begin{array}{l}110 \mathrm{~F} \\
1.92 \\
1.96 \\
2.12 \\
1.95 \\
1.91 \\
2.07\end{array}$ & $\begin{array}{r}\text { low } \\
23 \\
24 \\
24 \\
24 \\
23 \\
24\end{array}$ & $\begin{array}{l}6.8 \\
7.2 \\
7.7 \\
6.7 \\
7.2 \\
7.0\end{array}$ & $\begin{array}{l}11.5 \\
10.6 \\
10.8 \\
11.4 \\
11.3 \\
11.4\end{array}$ & $\begin{array}{l}40 \\
38 \\
39 \\
40 \\
39 \\
39\end{array}$ & $\begin{array}{l}36 \\
35 \\
37 \\
36 \\
36 \\
36\end{array}$ & $\begin{array}{l}58 \\
56 \\
42 \\
48 \\
48 \\
45\end{array}$ & $\begin{array}{l}2.1 \\
2.2 \\
2.3 \\
2.2 \\
2.2 \\
2.1\end{array}$ & $\begin{array}{l}4.9 \\
3.4 \\
5.1 \\
4.6 \\
4.5 \\
4.6\end{array}$ & $\begin{array}{l}- \\
- \\
- \\
- \\
-\end{array}$ & $\begin{array}{l}4.2 \\
4.9 \\
4.7 \\
4.5 \\
4.8 \\
4.3\end{array}$ & $\begin{array}{l}- \\
- \\
- \\
- \\
-\end{array}$ \\
\hline $\begin{array}{l}\text { Gingko } \\
\text { K5012 } \\
\text { K5014 } \\
\text { K5015 } \\
\text { K5017 } \\
\text { K5020 }\end{array}$ & $\begin{array}{l}\text { Flow } \\
1.86 \\
1.88 \\
1.94 \\
1.97 \\
1.99\end{array}$ & $\begin{array}{l}27 \\
26 \\
24 \\
25 \\
26\end{array}$ & $\begin{array}{l}7.5 \\
6.8 \\
6.8 \\
7.6 \\
7.5\end{array}$ & $\begin{array}{l}11.2 \\
11.1 \\
11.2 \\
11.1 \\
11.1\end{array}$ & $\begin{array}{l}36 \\
38 \\
39 \\
36 \\
38\end{array}$ & $\begin{array}{l}35 \\
33 \\
34 \\
35 \\
35\end{array}$ & $\begin{array}{l}30 \\
28 \\
19 \\
17 \\
33\end{array}$ & $\begin{array}{l}2.2 \\
2.3 \\
2.1 \\
2.2 \\
2.5\end{array}$ & $\begin{array}{l}3.6 \\
3.8 \\
3.4 \\
4.2 \\
3.6\end{array}$ & $\begin{array}{l}- \\
- \\
- \\
-\end{array}$ & $\begin{array}{l}4.5 \\
4.6 \\
4.1 \\
4.0 \\
5.2\end{array}$ & $\begin{array}{l}- \\
- \\
-\end{array}$ \\
\hline
\end{tabular}
TYPE LOCALITIES 


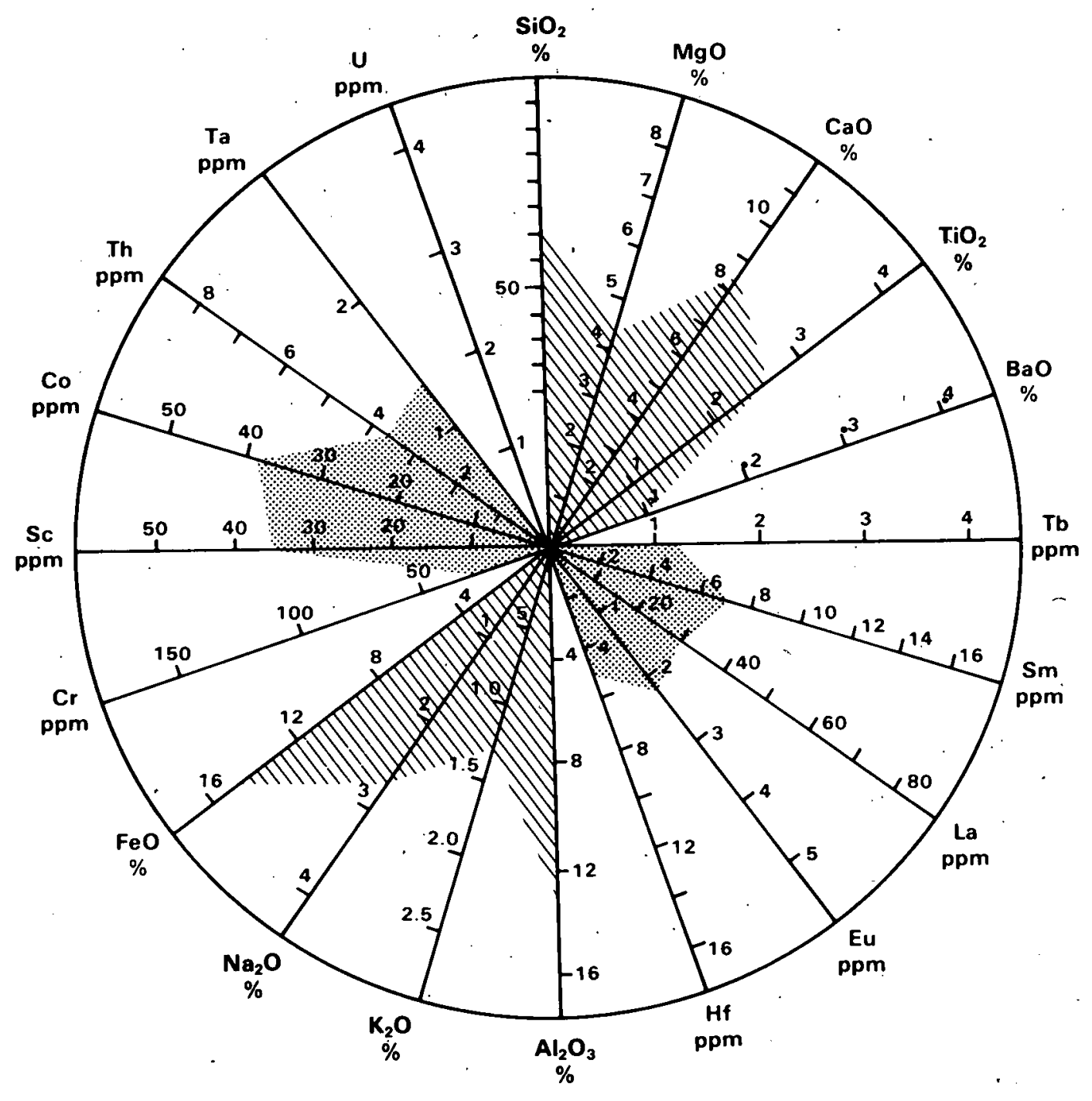

FIGURE $A-36$

SENTINEL GAP BASALT FLOW TYPE LOCALITY. ELEMENTAL ROSE 


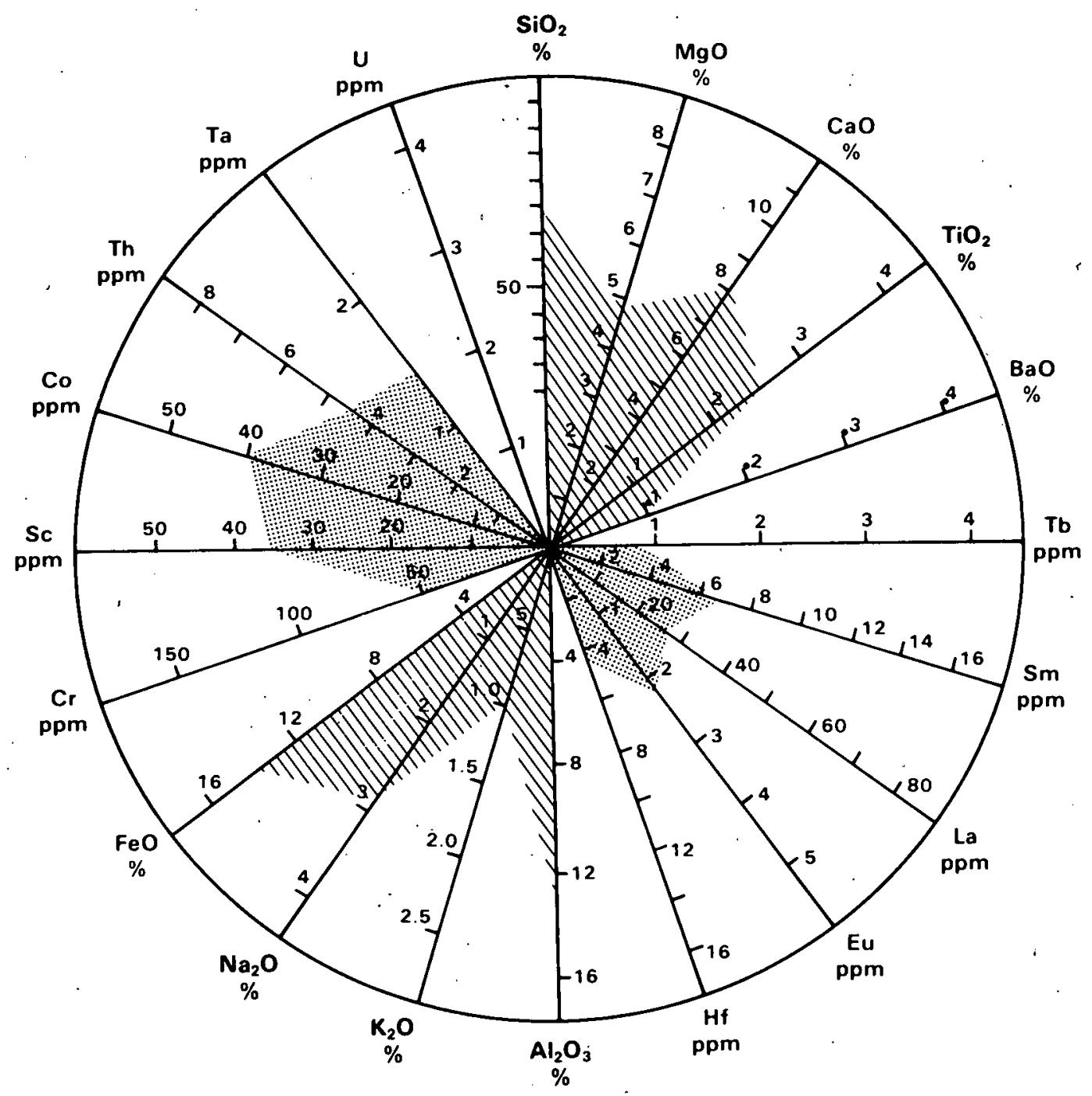

FIGURE $A-37$

SAND HOLLOW BASALT FLOW TYPE LOCALITY, ELEMENTAL ROSE 


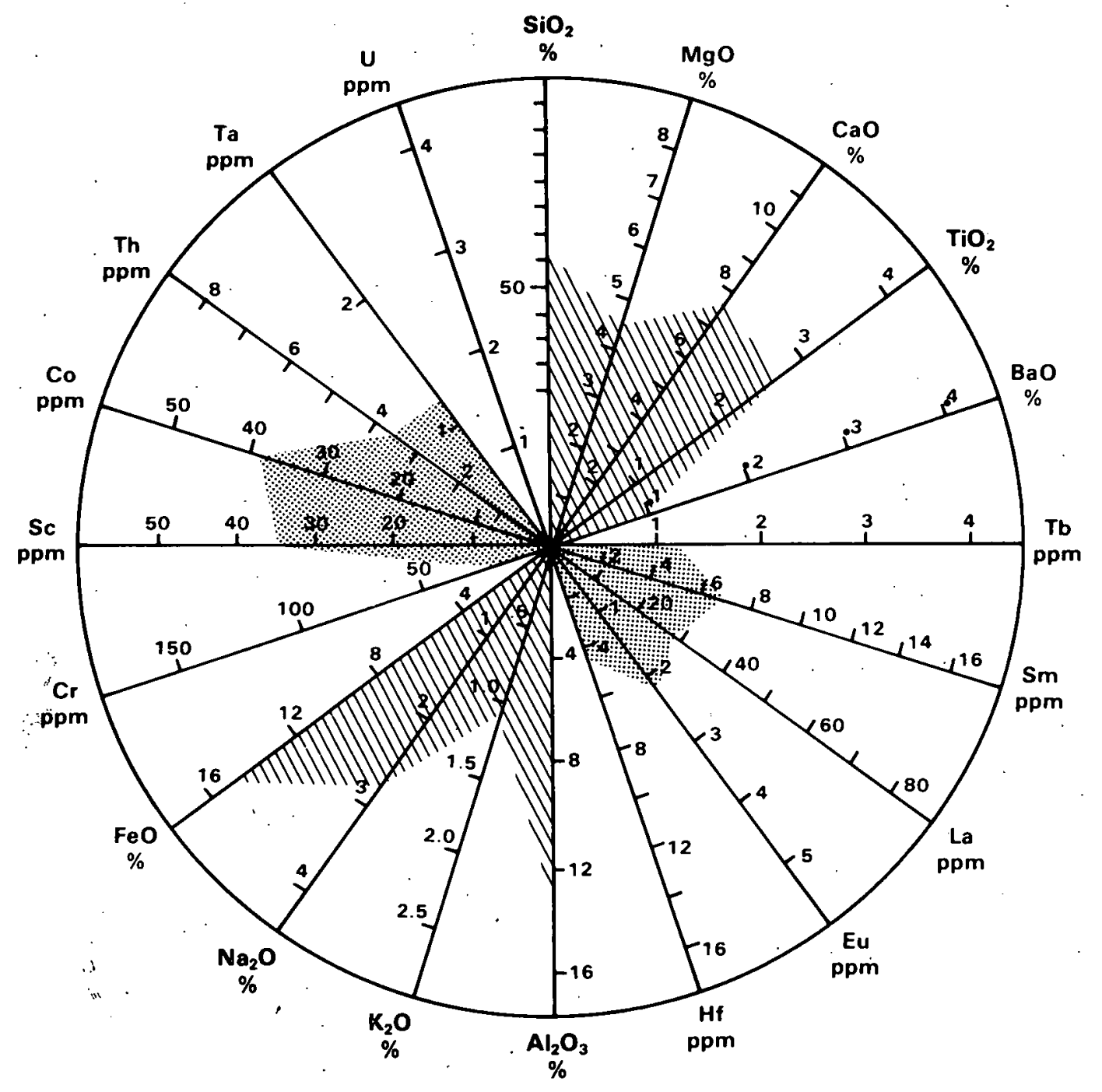

FIGURE A-38

GINKGO BASALT FLOW TYPE LOCALITY, ELEMENTAL ROSE 
HIGH Mg CHEMICAL TYPE OF THE LOWER YAKIMA BASALTS

Two flows of the basalts below the Vantage Sandstone Member; (Vantage Sandstone Formation) were named and described by Mackin in the Vantage area: $[A-4]$ (See Figure A-39) These flows are the Museum and the Rocky Coulee. They were sampled and appear to conform to the HIGH Mg chemical type of the Lower Yakima Basalts of Wright et ai. [A-9] Descriptions of the two flows are adapted from Mackin.

The Museum Basalt type locality is the Washington State Gingko Petrified Forest Museum southwest of Vantage; the Museum building is on a stripped structural surface developed on the basal 3 to 6 meters of the colonnade of the Museum flow. The contact between the top of the flow and the overlying Vantage Sandstone is exposed in highway cuts just to the west, and scattered outcrops on the sides of Rocky Coulee provides a poor composite section, but the middle and upper parts of the flow usually form soil-covered slopes. The flow is best known from holes drilled on the Columbia valley floor in a $6.5 \mathrm{~km}$ segment south of Vantage during an investigation of alternative sites for the Wanapum Dam. Several complete core sections of the Museum flow indicate that it is $27 \pm 1.5$ meters thick; that the vesicles are similar in size, shape and distribution to those of the underlying Rocky Coulee flow; that it is crowded with feldspar laths 1 to $2 \mathrm{~mm}$ in length, making it medium-grained; and that the lower, nonvesicular part is notably open textured, with as much as 15 percent of microvesicles by volume. Feldspar phenocrysts as much as $5 \mathrm{~mm}$ in length are present but very rare. 
The Rocky Coulee Basalt Flow type locality is at the mouth of Rocky Coulee, just west of Vantage, but the flow is best exposed in a deep highway cut on the east side of the Columbia River about $1.6 \mathrm{~km}$ south of Vantage. Its thickness in the Vantage-Priest Rapids area is $60 \pm 3$ meters. Its lithology is not distinctive except that the flow is somewhat finer grained than other Yakima flows of comparable thickness in this area. Its plagioclase microlites are commionly less than $0.3 \mathrm{~mm}$ in length. Feldspar phenocrysts as much as $5 \mathrm{~mm}$ long are present, but are so extremely rare as to be of little use for purposes of identification.

Table A-XII is a tabulation of analytical data for the sampled flows of this chemical type. Figures $A-40$ and $A-41$ are graphical depictions of the analytical detail in form of "Elemental Roses". 


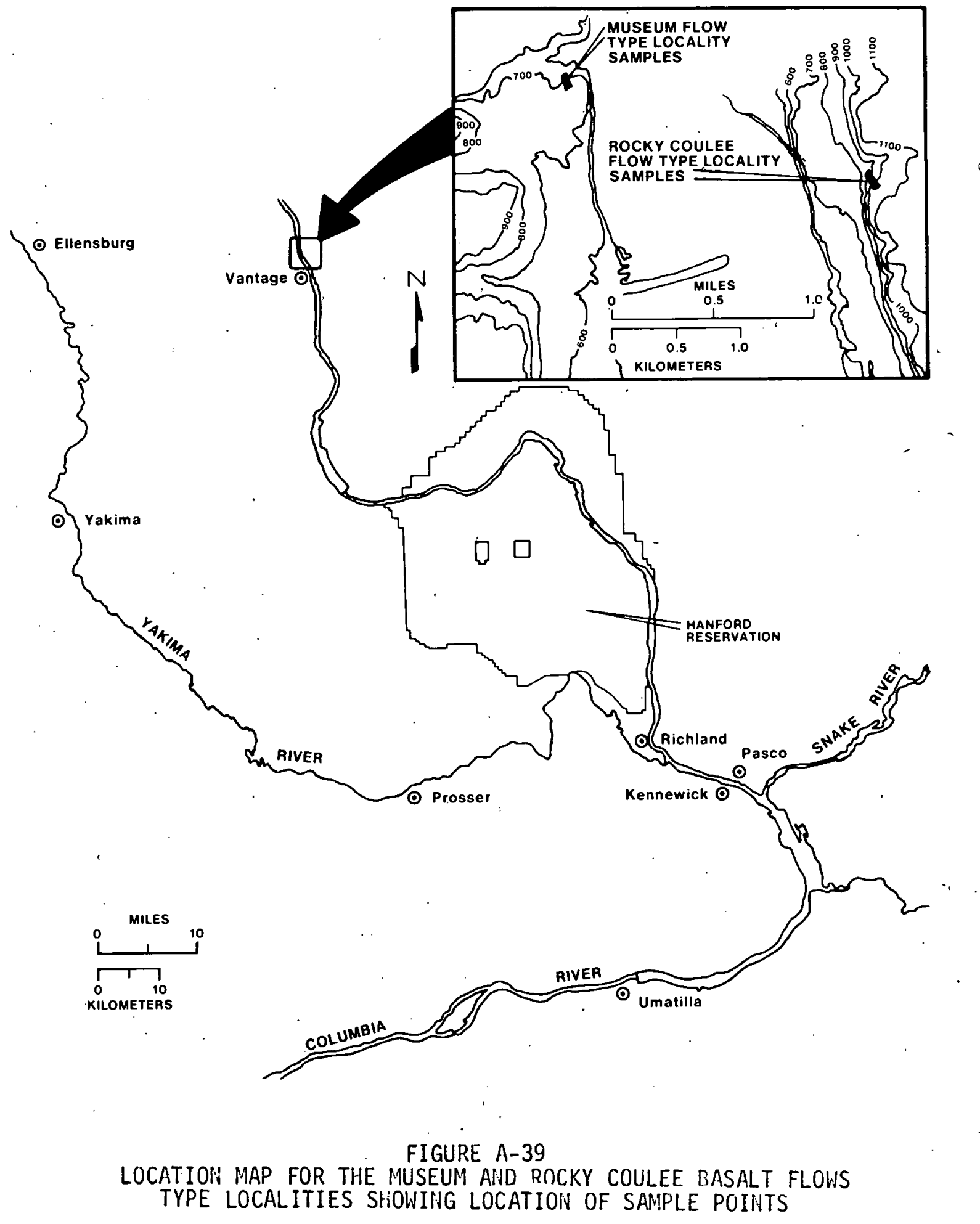


MAJOR OXIDES, by Atomic Absorption Spectrometer

\begin{tabular}{|c|c|c|c|c|c|c|c|c|c|c|c|}
\hline $\begin{array}{l}\text { Sample } \\
\text { Serial } \\
\text { Number }\end{array}$ & $\begin{array}{r}\mathrm{SiO}_{2} \\
\% \\
\end{array}$ & $\mathrm{Al}_{\%}{ }_{\%} \mathrm{O}_{3}$ & $\begin{array}{c}\mathrm{Fe0} \\
\% \\
\end{array}$ & $\begin{array}{c}\text { Mg0 } \\
\% \\
\end{array}$ & $\begin{array}{c}\mathrm{CaO} \\
\% \\
\end{array}$ & $\begin{array}{c}\mathrm{Na}_{2} \mathrm{O} \\
\end{array}$ & $\begin{array}{c}\mathrm{K}_{2} \mathrm{O} \\
\% \\
\end{array}$ & $\begin{array}{c}\mathrm{TiO}_{2} \\
\% \\
\end{array}$ & $\begin{array}{l}\mathrm{Ba} \\
\mathrm{ppm}\end{array}$ & $\begin{array}{c}\text { V1ty } \\
\% \\
\end{array}$ & $\begin{array}{c}\mathrm{Mt1} \\
\mathrm{Bal} \\
\%\end{array}$ \\
\hline $\begin{array}{l}\text { Museum } \\
\text { A1369 } \\
\text { A1370 } \\
\text { K5010 } \\
\text { K5011 }\end{array}$ & $\begin{array}{r}\text { Flow } \\
54 \\
54 \\
52 \\
52\end{array}$ & $\begin{array}{l}13.6 \\
13.3 \\
14.0 \\
13.8\end{array}$ & $\begin{array}{l}11.0 \\
11.7 \\
10.3 \\
11.4\end{array}$ & $\begin{array}{l}4.8 \\
5.0 \\
4.7 \\
5.4\end{array}$ & $\begin{array}{l}8.0 \\
8.2 \\
7.9 \\
8.1\end{array}$ & $\begin{array}{l}2.9 \\
2.9 \\
2.8 \\
2.0\end{array}$ & $\begin{array}{l}1.1 \\
0.9 \\
0.9\end{array}$ & $\begin{array}{l}1.7 \\
1.6 \\
1.6 \\
1.7\end{array}$ & $\begin{array}{l}770 \\
675 \\
710 \\
662\end{array}$ & $\begin{array}{l}2.4 \\
1.6 \\
3.0 \\
2.7\end{array}$ & $\begin{array}{l}99.7 \\
99.4 \\
97.4 \\
99.1\end{array}$ \\
\hline $\begin{array}{l}5 \\
6 \\
7 \\
8\end{array}$ & $\begin{array}{r}53 \\
53 \\
52 \\
53 \\
51\end{array}$ & $\begin{array}{l}13.8 \\
13.9 \\
13.4 \\
13.2 \\
12.7\end{array}$ & $\begin{array}{l}11.0 \\
10.6 \\
11.1 \\
10.9\end{array}$ & $\begin{array}{l}4.8 \\
5.1 \\
4.9 \\
5.0 \\
4.8\end{array}$ & $\begin{array}{l}8.0 \\
8.0 \\
8.6 \\
7.8 \\
7.8\end{array}$ & $\begin{array}{l}2.9 \\
2.8 \\
3.0 \\
2.8 \\
2.6\end{array}$ & $\begin{array}{l}1 . \\
1 . \\
1 .\end{array}$ & $\begin{array}{l}1.7 \\
1.7 \\
1.7 \\
1.7 \\
1.7\end{array}$ & $\begin{array}{l}675 \\
718 \\
700 \\
656 \\
604\end{array}$ & $\begin{array}{l}2.4 \\
2.7 \\
2.7 \\
2.9 \\
8.7\end{array}$ & $\begin{array}{r}98.7 \\
98.9 \\
98.5 \\
98.4 \\
100.1\end{array}$ \\
\hline
\end{tabular}

TRACE ELEMENTS, by Neutron Activation Analysis

Sample

Serial $\mathrm{Na}$ La Sm Fe Co Sc $\mathrm{Cr}$ Eu Th Tb Hf Ta

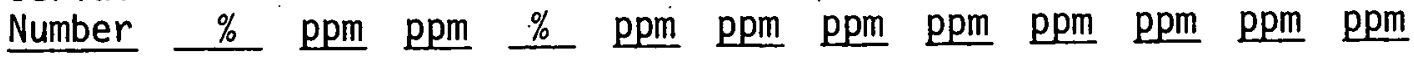

Museum Flow

$\begin{array}{lllllllllllll}\mathrm{K} 5010 & 2.01 & 28 & 4.7 & 7.4 & 39 & 33 & 71 & 1.6 & 3.0 & 0.9 & 3.7 & 0.7 \\ \mathrm{~K} 5011 & 2.01 & 23 & 4.7 & 8.2 & 39 & 35 & 40 & 1.6 & 3.4 & 0.9 & 4.3 & 1.1\end{array}$

\begin{tabular}{lllllllllllll} 
Rocky & Coulee Flow & & & & & & & & & \\
\hline K5025 & 2.09 & 23 & 5.6 & 8.3 & 34 & 33 & 70 & 1.6 & 3.6 & - & 4.2 & - \\
K5026 & 2.02 & 22 & 5.4 & 8.3 & 36 & 34 & 35 & 1.6 & 3.5 & - & 3.6 & - \\
K5027 & 2.13 & 23 & 5.9 & 8.2 & 34 & 32 & 43 & 1.6 & 3.1 & - & 3.6 & - \\
K5028 & 2.06 & 23 & 5.4 & 8.3 & 35 & 33 & 40 & 1.5 & 3.4 & - & 4.6 & - \\
K5029 & 1.97 & 22 & 5.8 & 8.4 & 34 & 33 & 52 & 1.4 & 3.5 & - & 3.6 & -
\end{tabular}




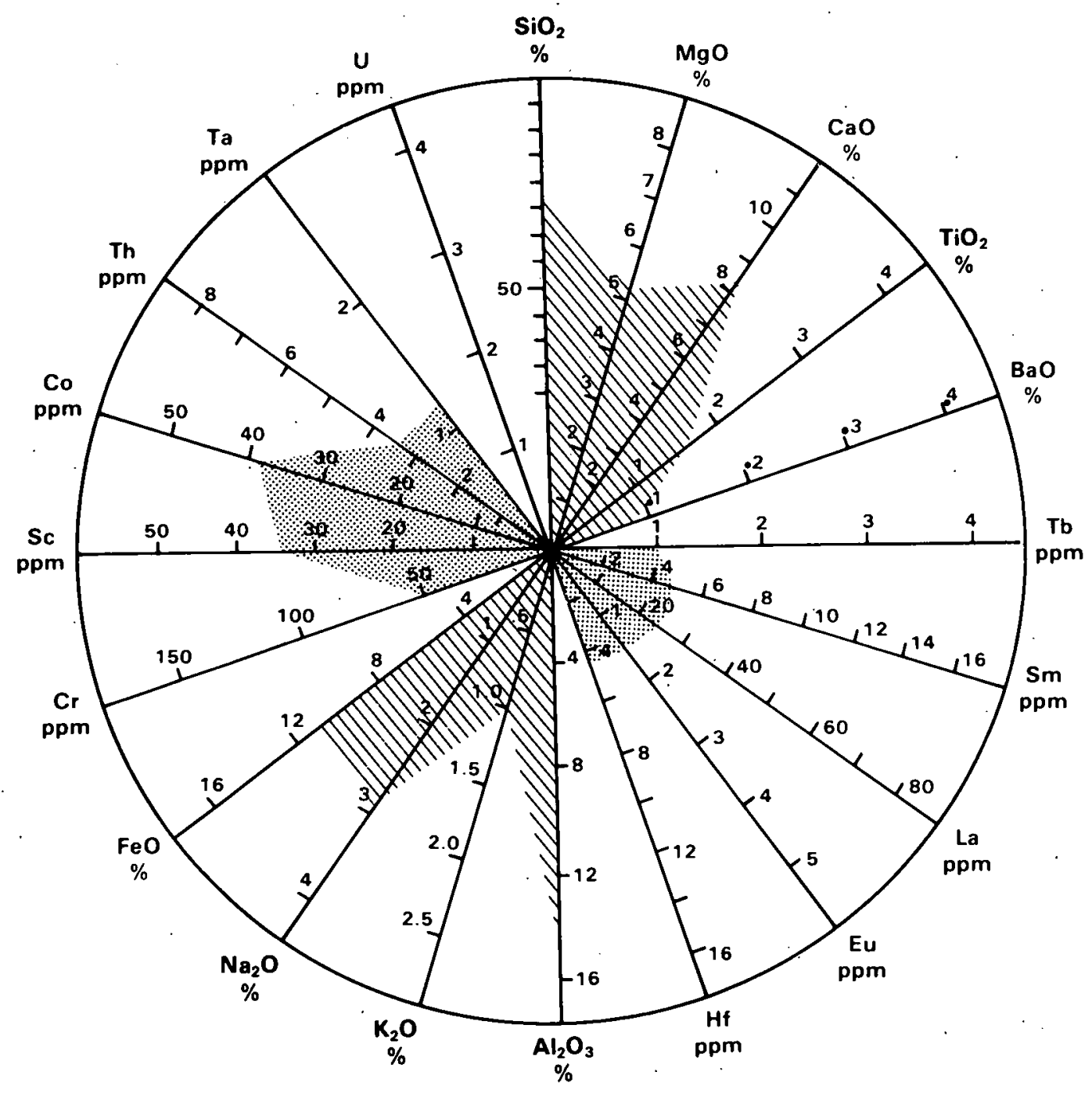

FIGURE $A-40$

MUSEUM BASALT FLOW TYPE LOCALITY, ELEMENTAL ROSE 


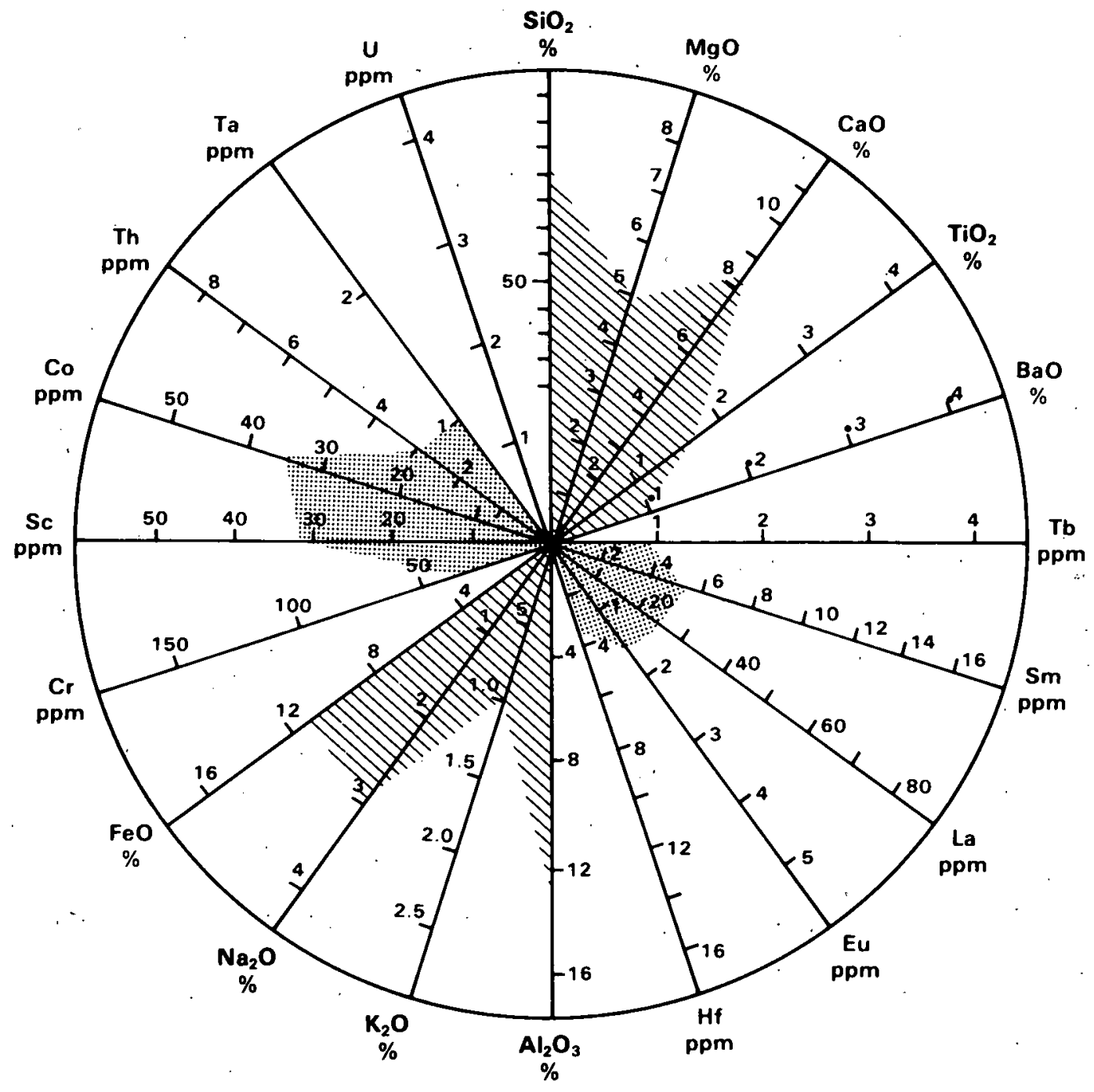

FIGURE A-41

ROCKY COULEE BASALT FLOW TYPE LOCALITY, ELEMENTAL ROSE 
APPENDIX IIIA

REFERENCES

A-I D. A. Swanson and others, Feeder Dikes for Yakima Basalt Near Pasco, Washington (Abstract), Geol. Soc. America, Abstracts with Programs, v.4-3:245 (1972).

A-2 H. U. Schmincke, Stratigraphy and Petrography of Four Upper Yakima Basalt Flows in South-Central Washington, Geol. Soc. of America Bulletin 78:1385-1422, (1967).

A-3 A. C. Waters, Geomorphology of South-Central Washington, il lustrated by The Yakima East Quadrangle, Geol. Soc. of Americal Bulletin, $66 ; 663-384$ (1955).

A-4 J. H. Mackin, A Stratigraphic Section in the Yakima Basalt and the El lensburg Formation in South Washington, Washington Division of Mines and Geology, Invest Report 19 (1967)

A-5 A. W. Ward, Petrology and Chemistry of the Huntzinger Flow, Columbia River Basalt, Washington, Masters Thesis, University of Washington, Seattle, WA (1975)

A-6 C. W. Myers and D. J. Brown, Stratigraphy of the Yakima Basalt in the Pasco Basin, Washington, (abs), Geological Society of America, Abstracts with Programs, v. $5-1 ; 80$ (1973)

A-7 W. N. Laval, Stratigraphy and Structural Geology of Portions of South-Central Washington, Ph. D. Dissertation, University of Washington, Seattle, WA (1956)

A-8 C. W. Myers, Yakima Basalt Flows near Vantage and From Coreholes in the Pasco Basin, Washington, Ph. D: Dissertation, University of California, Santa Cruz, CA 147 pages (1973).

A-9 T. L. Wright, J. J. Grolier, D. A. Swanson, Chemical Variations Related to the Stratigraphy of the Columbia River Basalt, Geological Society of America Bulletin, 84:371-386 (1973). 
APPENDIX B

\author{
ANALYTICAL DATA AND SAMPLE LOCATIONS \\ FOR MEASURED FIELD SECTIONS IN YAKIMA BASALTS
}

This appendix is a detailed documentation of field sections taken for correlation and lateral stratigraphic relationships of basalt flows of the Columbia River Basalt Group. It includes tabulations of analytical data, location maps, site photographs showing sample points and lithologic cross-sectional drawings.

The location maps show the field sections specific locations in reference to the Hanford Reservation. Sample serial numbers such as Al211 shown on the sample point photographs and cross-sections indicate the point sampled. Tabulations of analytical data do not include corrections for weight loss on heating. Weight loss on heating to $900^{\circ} \mathrm{C}$ is referred to as Volatility Per Cent and is abbreviated in the tables as VIty \%. The summation of oxides analyzed or material balance is abbreviated as Mtl Bal\%. The cross-sections are diagrammatic representations of the field appearance of the basalt flows encountered. For stratigraphic nomenclature refer to Chapter IV. 


\section{SILLUSI BUTTE FIELD SECTION}

Three basalt flows are present in the Sillusi Butte section. The upper flow is black, hackly and shows poorly developed columns associated with an upper vesicular zone which is about 3 meters thick. Chemical analyses of this flow show that it is relatively:

- Low in $\mathrm{K}_{2} \mathrm{O}^{40} \mathrm{~K}, \mathrm{TiO}_{2}$ and barium

- High in $\mathrm{CaO}, \mathrm{MgO}$ and chromium

Comparison of these and other analytical values with those of the type localities show that this flow is of Pomona chemical type. [B-l]

The two lower flows are marked by rubble and palagonite zones, vesicles, glassy margins, pahoehoe and aa features and massive poorly developed columns. Chemically they are relatively:

- Very high in barium

- High in $\mathrm{K}_{2} \mathrm{O},{ }^{40} \mathrm{~K}, \mathrm{Ha}_{2} \mathrm{O}$, europium, thorium, hafnium and tantalum

- Low in $\mathrm{CaO}, \mathrm{MgO}$ and chromium

These values mark the type locality and characteristic chemical values for the Sillusi and Umatilla Flows of the Umatilla Basalt Member of the Yakima Basaits. ${ }^{[B-2]}$

Figure $B-1$ is a location map of the area, Figure B-2 is a composite cross-section of the area using those samples taken in the measured sections. Several other samples were taken in the Sillusi Butte vicinity for confirmation of the section (A1213, A1215, A1240-46, A1282, and A1283). A11 samples are tabulated in Table B-I. Figure B-3 shows aerial photographs of the entire area with location of all points indicated by serial numbers and arrows. 


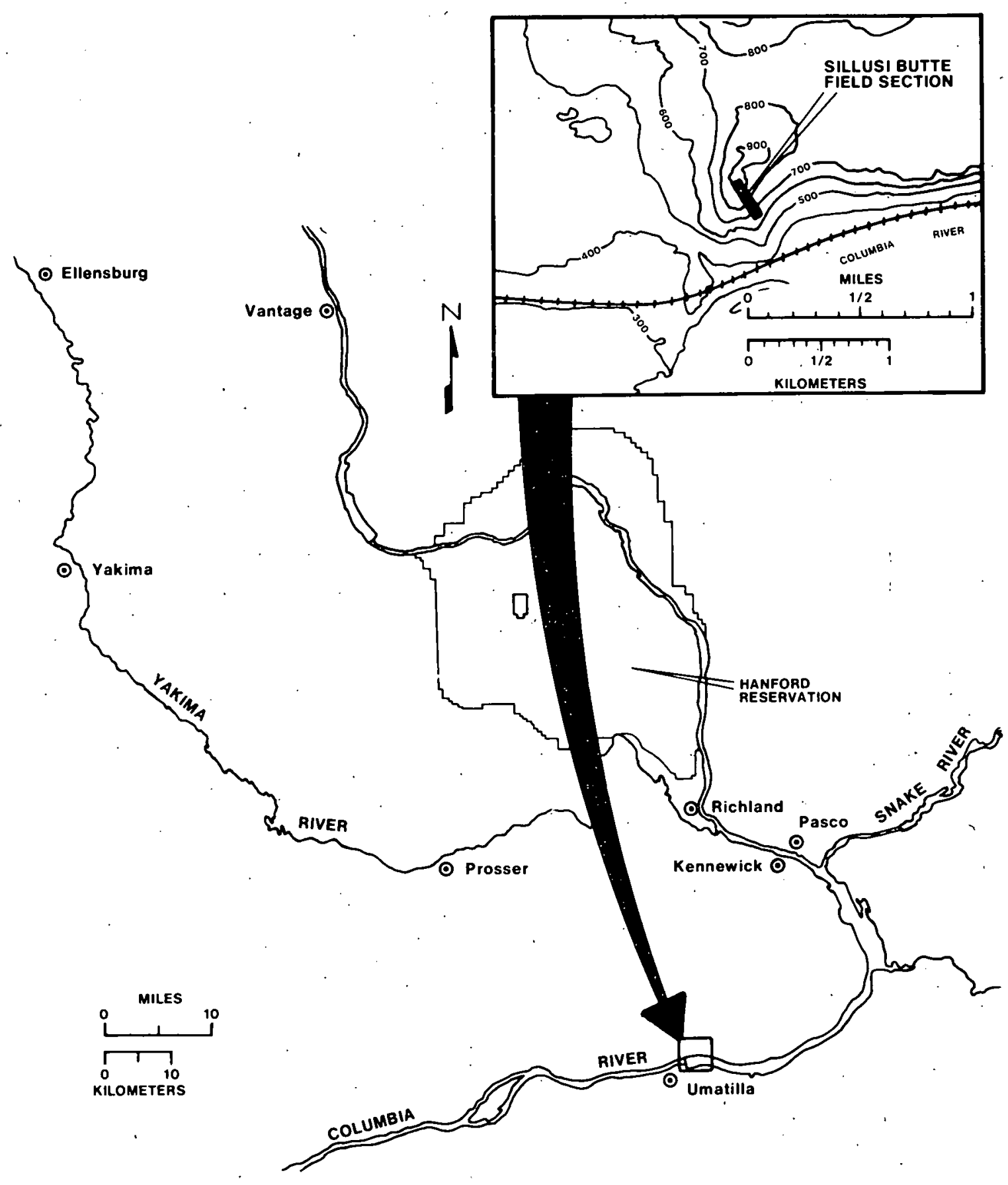

FIGURE B-1

LOCATION MAP, SILLUSI BUTTE FIELD SECTION 


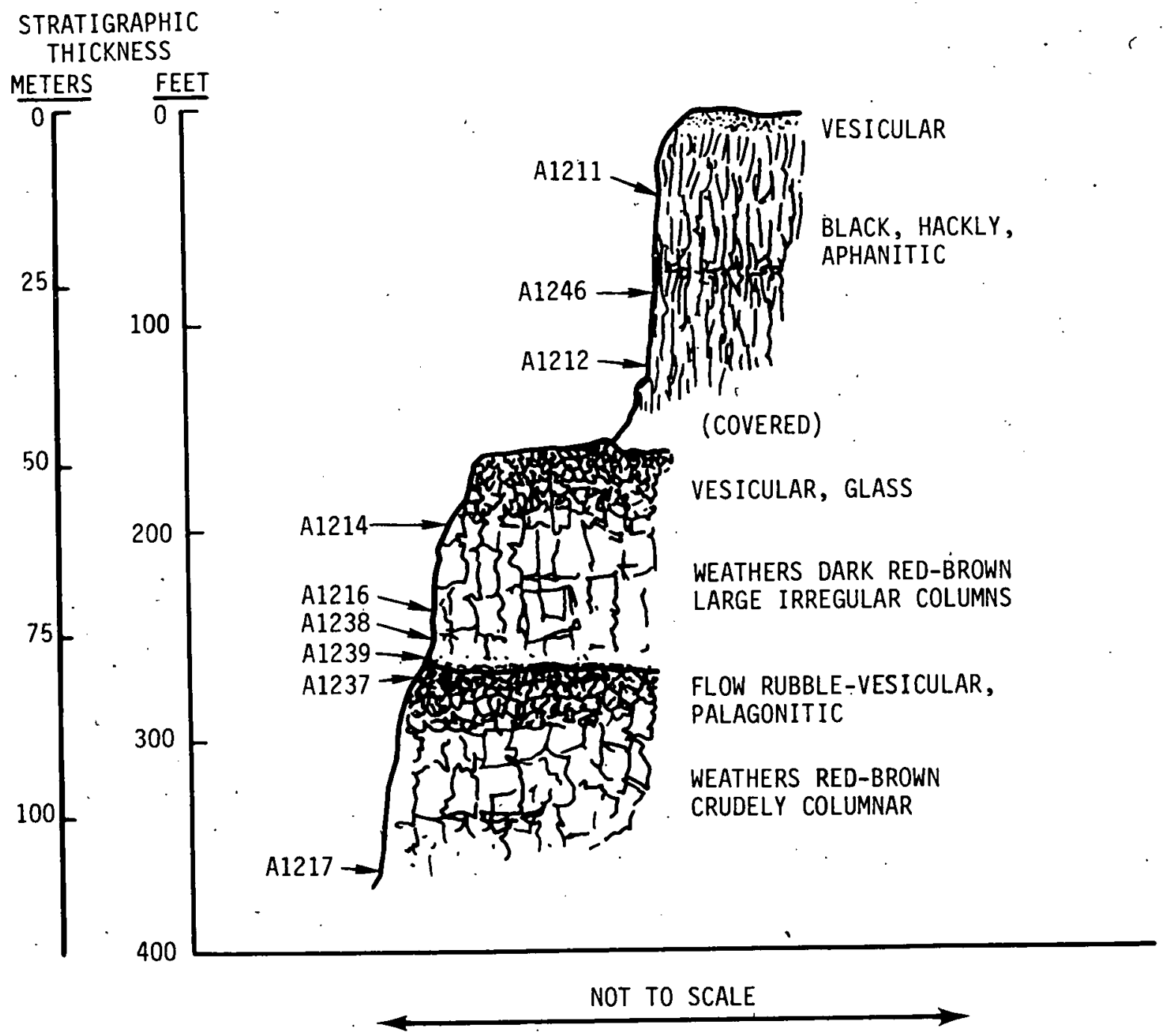

FIGURE B-2

COMPOSITE CROSS-SECTION OF SILLUSI BUTTE SHOWING SAMPLE POINTS TAKEN IN THE LINE OF THE SECTION 
MAJOR OXIDE CONTENT, by Atomic Absorption Spectrometer

\begin{tabular}{|c|c|c|c|c|c|c|c|c|c|c|c|}
\hline $\begin{array}{l}\text { Sample } \\
\text { Serial } \\
\text { Number } \\
\end{array}$ & $\begin{array}{c}\mathrm{SiO}_{2} \\
\% \\
\end{array}$ & ${ }^{\mathrm{A}^{1}}{ }_{2} \mathrm{O}_{3}$ & $\begin{array}{c}\mathrm{Fe} 0 \\
\% \\
\end{array}$ & $\begin{array}{c}\mathrm{Mg0} \\
\% \\
\end{array}$ & $\begin{array}{c}\mathrm{CaO} \\
\% \\
\end{array}$ & $\begin{array}{c}\mathrm{Na}_{2} \mathrm{O} \\
\% \\
\end{array}$ & $\begin{array}{l}\mathrm{K}_{2} \mathrm{O} \\
\% \\
\end{array}$ & $\begin{array}{r}\mathrm{TiO}_{2} \\
\% \\
\end{array}$ & $\begin{array}{l}\mathrm{Ba} \\
\mathrm{ppm}\end{array}$ & $\begin{array}{c}\text { V1ty } \\
\% \\
\end{array}$ & $\begin{array}{c}\mathrm{Mt1} \\
\mathrm{Bal} \\
\%\end{array}$ \\
\hline $\begin{array}{l}A 1211 \\
A 1212 \\
A 1213 \\
A 1240 \\
A 1241 \\
A 1242 \\
A 1243 \\
A 1244 \\
A 1245 \\
A 1246 \\
A 1282\end{array}$ & $\begin{array}{l}52 \\
52 \\
53 \\
54 \\
53 \\
53 \\
53 \\
53 \\
54 \\
52 \\
51\end{array}$ & $\begin{array}{l}14.2 \\
14.3 \\
14.3 \\
14.6 \\
14.6 \\
14.5 \\
14.5 \\
15.0 \\
14.4 \\
14.3 \\
14.2\end{array}$ & $\begin{array}{l}10.5 \\
10.3 \\
10.4 \\
10.5 \\
10.1 \\
10.4 \\
10.7 \\
10.8 \\
10.7 \\
11.1 \\
11.1\end{array}$ & $\begin{array}{l}8.3 \\
8.4 \\
8.5 \\
8.1 \\
8.9 \\
8.0 \\
8.1 \\
7.8 \\
8.3 \\
8.5 \\
8.0\end{array}$ & $\begin{array}{r}10.1 \\
10.2 \\
10.1 \\
10.3 \\
10.5 \\
10.0 \\
10.0 \\
10.3 \\
9.5 \\
10.0 \\
10.1\end{array}$ & $\begin{array}{l}2.3 \\
2.3 \\
2.3 \\
2.3 \\
2.7 \\
2.3 \\
2.4 \\
2.4 \\
2.4 \\
2.4 \\
2.5\end{array}$ & $\begin{array}{l}0.5 \\
0.5 \\
0.5 \\
0.6 \\
0.7 \\
0.5 \\
0.6 \\
0.6 \\
0.6 \\
0.6 \\
0.7\end{array}$ & $\begin{array}{l}1.6 \\
1.6 \\
1.7 \\
1.5 \\
1.6 \\
1.4 \\
1.5 \\
1.5 \\
1.5 \\
1.5 \\
1.6\end{array}$ & $\begin{array}{l}613 \\
587 \\
591 \\
591 \\
525 \\
481 \\
525 \\
600 \\
700 \\
362 \\
347\end{array}$ & $\begin{array}{l}0.9 \\
1.5 \\
1.1 \\
1.9 \\
1.1 \\
3.8 \\
2.7 \\
2.3 \\
2.2 \\
2.4 \\
1.1\end{array}$ & $\begin{array}{l}100.4 \\
101.0 \\
101.8 \\
103.8 \\
103.2 \\
103.9 \\
103.5 \\
103.7 \\
103.6 \\
102.8 \\
100.3\end{array}$ \\
\hline $\begin{array}{l}A 1214 \\
A 1215 \\
A 1216 \\
A 1217 \\
A 1237 \\
A 1238 \\
A 1239 \\
A 1283\end{array}$ & $\begin{array}{l}53 \\
53 \\
55 \\
55 \\
57 \\
56 \\
57 \\
53\end{array}$ & $\begin{array}{l}12.9 \\
12.9 \\
13.8 \\
13.6 \\
13.4 \\
13.3 \\
13.7 \\
13.1\end{array}$ & $\begin{array}{r}12.3 \\
12.3 \\
12.1 \\
11.9 \\
11.6 \\
12.5 \\
9.7 \\
12.3\end{array}$ & $\begin{array}{l}3.5 \\
3.5 \\
2.5 \\
2.2 \\
2.5 \\
2.8 \\
1.8 \\
2.9\end{array}$ & $\begin{array}{l}5.7 \\
5.7 \\
5.8 \\
5.2 \\
5.7 \\
5.7 \\
5.9 \\
6.3\end{array}$ & $\begin{array}{l}3.3 \\
3.3 \\
3.1 \\
3.1 \\
3.0 \\
3.2 \\
3.4 \\
3.1\end{array}$ & $\begin{array}{l}2.8 \\
2.8 \\
2.5 \\
2.6 \\
2.6 \\
2.7 \\
2.8 \\
2.6\end{array}$ & $\begin{array}{l}2.4 \\
2.4 \\
2.5 \\
2.5 \\
2.3 \\
2.2 \\
2.3 \\
2.5\end{array}$ & $\begin{array}{l}4025 \\
3540 \\
3442 \\
3675 \\
3792 \\
3549 \\
3834 \\
3282\end{array}$ & $\begin{array}{l}2.3 \\
2.4 \\
2.9 \\
2.9 \\
3.4 \\
1.8 \\
4.0 \\
2.9\end{array}$ & $\begin{array}{r}98.2 \\
98.3 \\
100.2 \\
99.0 \\
101.5 \\
100.2 \\
100.6 \\
98.7\end{array}$ \\
\hline
\end{tabular}

NATURALLY OCCURRING RADIOACTIVE ISOTOPES, by Gamma Energy Analysis

\begin{tabular}{|c|c|c|c|}
\hline $\begin{array}{l}\text { Sample } \\
\text { Serial } \\
\text { Number }\end{array}$ & $\begin{array}{r}{ }^{40}{ }_{\mathrm{K}} \\
\mu \mathrm{Ci} / \mathrm{kg} \times 10^{-3}\end{array}$ & $\begin{array}{c}{ }^{226} \mathrm{Ra}+\text { daughters } \\
\mu \mathrm{Ci} / \mathrm{kg} \times 10^{-3}\end{array}$ & $\begin{array}{r}{ }^{228} \mathrm{Th}+\text { daughters } \\
\mu \mathrm{Ci} / \mathrm{kg} \times 10^{-3}\end{array}$ \\
\hline $\begin{array}{l}\text { A1211 } \\
\text { A1212 } \\
\text { A1213 }\end{array}$ & $\begin{array}{l}6.48 \pm 18 \% \\
5.44 \pm 18 \\
5.45 \pm 17\end{array}$ & $\begin{array}{l}1.72 \pm 19 \% \\
0.30 \pm 21 \\
0.28 \pm 18\end{array}$ & $\begin{array}{l}0.55 \pm 7.1 \% \\
0.55 \pm 8.1 \\
0.41 \pm 7.4\end{array}$ \\
\hline $\begin{array}{l}\text { A1214 } \\
\text { A1215 } \\
\text { A1216 } \\
\text { A1217 }\end{array}$ & $\begin{array}{l}21.4 \pm 11 \\
19.3 \pm 12 \\
18.0 \pm 12 \\
19.9 \pm 12\end{array}$ & $\begin{array}{l}0.60 \pm 18 \\
0.43 \pm 22 \\
0.62 \pm 17 \\
0.51 \pm 18\end{array}$ & $\begin{array}{l}1.00 \pm 6.6 \\
0.89 \pm 6.9 \\
1.06 \pm 6.7 \\
0.88 \pm 6.7\end{array}$ \\
\hline
\end{tabular}

TRACE ELEMENTS, by Neutron Activation Analysis

\begin{tabular}{|c|c|c|c|c|c|c|c|c|c|c|c|c|}
\hline $\begin{array}{l}\text { Sample } \\
\text { Serial } \\
\text { Number } \\
\end{array}$ & $\begin{array}{c}\mathrm{Na} \\
\% \\
\end{array}$ & $\begin{array}{l}\text { La } \\
\text { ppm }\end{array}$ & $\begin{array}{l}\text { Sm } \\
\mathrm{ppm}\end{array}$ & $\begin{array}{r}\mathrm{Fe} \\
\% \\
\end{array}$ & $\begin{array}{l}\text { Co } \\
\text { ppm } \\
\end{array}$ & $\begin{array}{l}\mathrm{Sc} \\
\mathrm{ppm}\end{array}$ & $\begin{array}{l}\mathrm{Cr} \\
\mathrm{ppm}\end{array}$ & $\begin{array}{l}\text { Eu } \\
\text { ppm }\end{array}$ & $\begin{array}{l}\text { Th } \\
\text { ppm }\end{array}$ & $\begin{array}{l}\text { Tb } \\
\text { ppm }\end{array}$ & $\begin{array}{l}\mathrm{Hf} \\
\mathrm{ppm}\end{array}$ & $\begin{array}{l}\text { Ta } \\
\text { ppm }\end{array}$ \\
\hline $\begin{array}{l}A 1241 \\
A 1242 \\
A 1243 \\
A 1244 \\
A 1245 \\
A 1246 \\
A 1282\end{array}$ & $\begin{array}{l}1.62 \\
1.61 \\
1.68 \\
1.74 \\
1.68 \\
1.76 \\
1.74\end{array}$ & $\begin{array}{l}15 \\
17 \\
15 \\
20 \\
19 \\
18 \\
19\end{array}$ & $\begin{array}{l}4.6 \\
4.6 \\
4.6 \\
4.8 \\
5.1 \\
5.2 \\
4.4\end{array}$ & $\begin{array}{l}8.2 \\
7.4 \\
7.7 \\
7.8 \\
8.3 \\
8.2 \\
7.9\end{array}$ & $\begin{array}{l}40 \\
39 \\
41 \\
43 \\
42 \\
41 \\
43\end{array}$ & $\begin{array}{l}33 \\
35 \\
32 \\
35 \\
34 \\
35 \\
34\end{array}$ & $\begin{array}{l}105 \\
110 \\
115 \\
110 \\
110 \\
105 \\
103\end{array}$ & $\begin{array}{l}1.3 \\
1.5 \\
1.2 \\
1.7 \\
1.4 \\
1.6 \\
1.7\end{array}$ & $\begin{array}{l}2.6 \\
3.0 \\
1.4 \\
2.4 \\
2.8 \\
3.2 \\
0.7\end{array}$ & $\begin{array}{l}0.9 \\
1.2 \\
0.9 \\
0.8 \\
1.3 \\
1.3 \\
1.1\end{array}$ & $\begin{array}{l}4.3 \\
3.1 \\
5.0 \\
2.8 \\
5.1 \\
2.7 \\
5.3\end{array}$ & $\begin{array}{l}1.5 \\
1.6 \\
1.5 \\
1.7 \\
1.6 \\
1.2 \\
1.6\end{array}$ \\
\hline $\begin{array}{l}A 1237 \\
A 1238 \\
A 1239 \\
A 1283\end{array}$ & $\begin{array}{l}2.49 \\
2.31 \\
2.49 \\
2.14\end{array}$ & $\begin{array}{l}50 \\
46 \\
50 \\
51\end{array}$ & $\begin{array}{r}10.7 \\
10.3 \\
10.8 \\
9.1\end{array}$ & $\begin{array}{r}10.6 \\
9.4 \\
7.5 \\
9.3\end{array}$ & $\begin{array}{l}27 \\
25 \\
27 \\
26\end{array}$ & $\begin{array}{l}26 \\
24 \\
24 \\
26\end{array}$ & $\begin{array}{r}7 \\
6 \\
11 \\
-12\end{array}$ & $\begin{array}{l}4.0 \\
4.7 \\
3.9 \\
3.9\end{array}$ & $\begin{array}{l}6.2 \\
6.4 \\
5.6 \\
2.6\end{array}$ & $\begin{array}{l}1.9 \\
1.4 \\
1.7 \\
1.2\end{array}$ & $\begin{array}{r}12.6 \\
9.8 \\
12.7 \\
15.3\end{array}$ & $\begin{array}{l}2.8 \\
2.6 \\
2.8 \\
2.7\end{array}$ \\
\hline
\end{tabular}

TABLE B-1

TABULATION OF ANALYTICAL DATA FOR THE SILLUSI BUTTE FIELD SECTION 

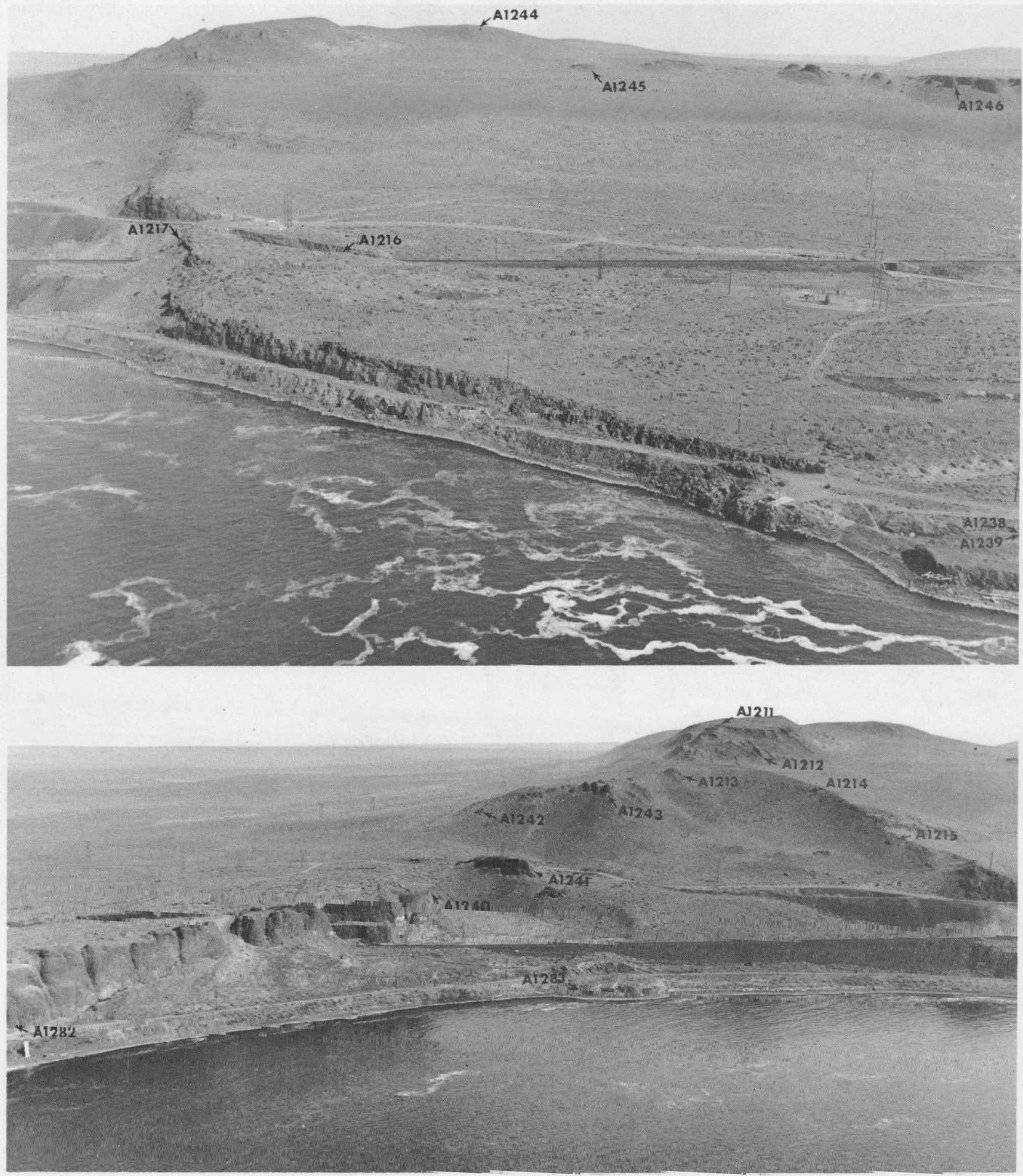

FIGURE B-3

AERIAL PHOTOGRAPHS OF THE SILLUSI BUTTE FIELD SECTION AREA SHOWING SAMPLE POINTS 


\section{RUSH CANYON FIELD SECTION}

The three flows exposed or partially exposed near Rush Canyon can be directly traced to the section at Sillusi Butte.

- The upper flow is black, hackly and aphanitic with poorly developed thin columns. Chemical values are of Pomona chemical type.

- The two Umatilla Member flows continue to show characteristic features such as vesicular zones, blocky columns and a reddish-brown weathering color. Analytical values are very similar to those of the type locality at Sillusi Butte.

Figures B-4 and B-5 are a location map and aerial photograph of the area sampled showing location of points sampled. Figure B-6 is a cross-section and Table B-II is a tabulation of analytical data for the samples. 


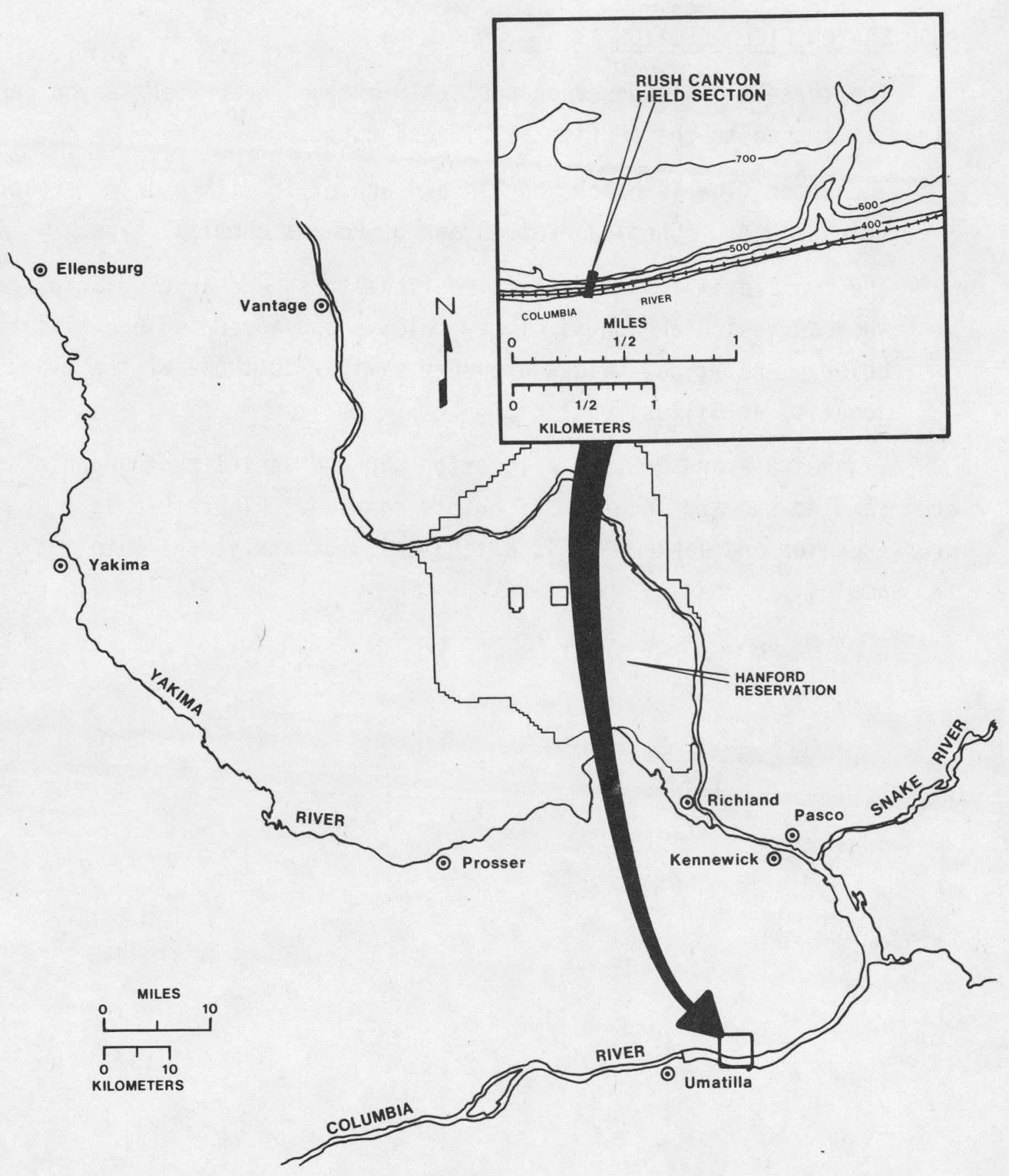

FIGURE B-4

LOCATION MAP RUSH CANYON FIELD SECTION 


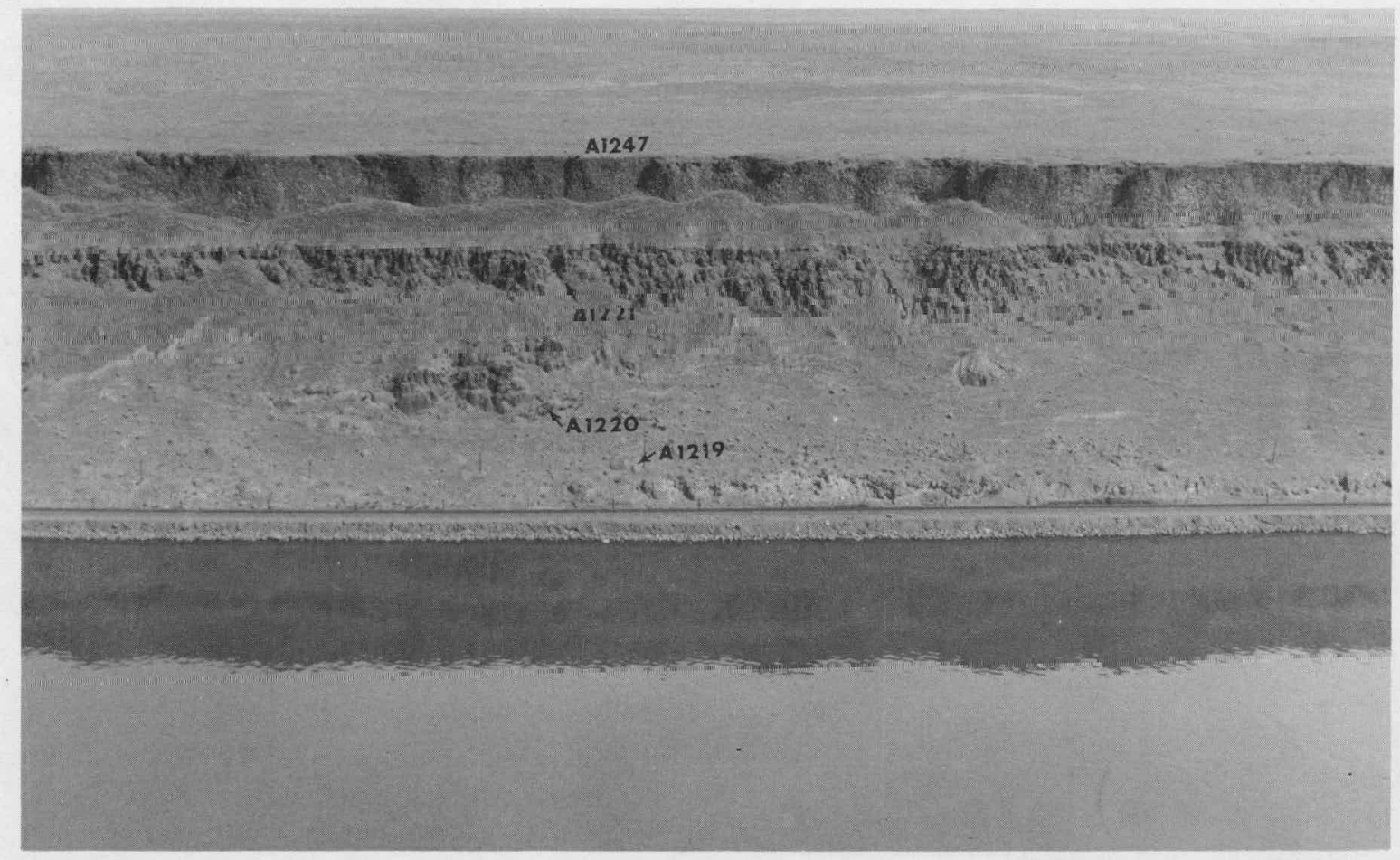

FIGURE B-5

AERIAL PHOTOGRAPH OF RUSH CANYON FIELD SECTION AREA 


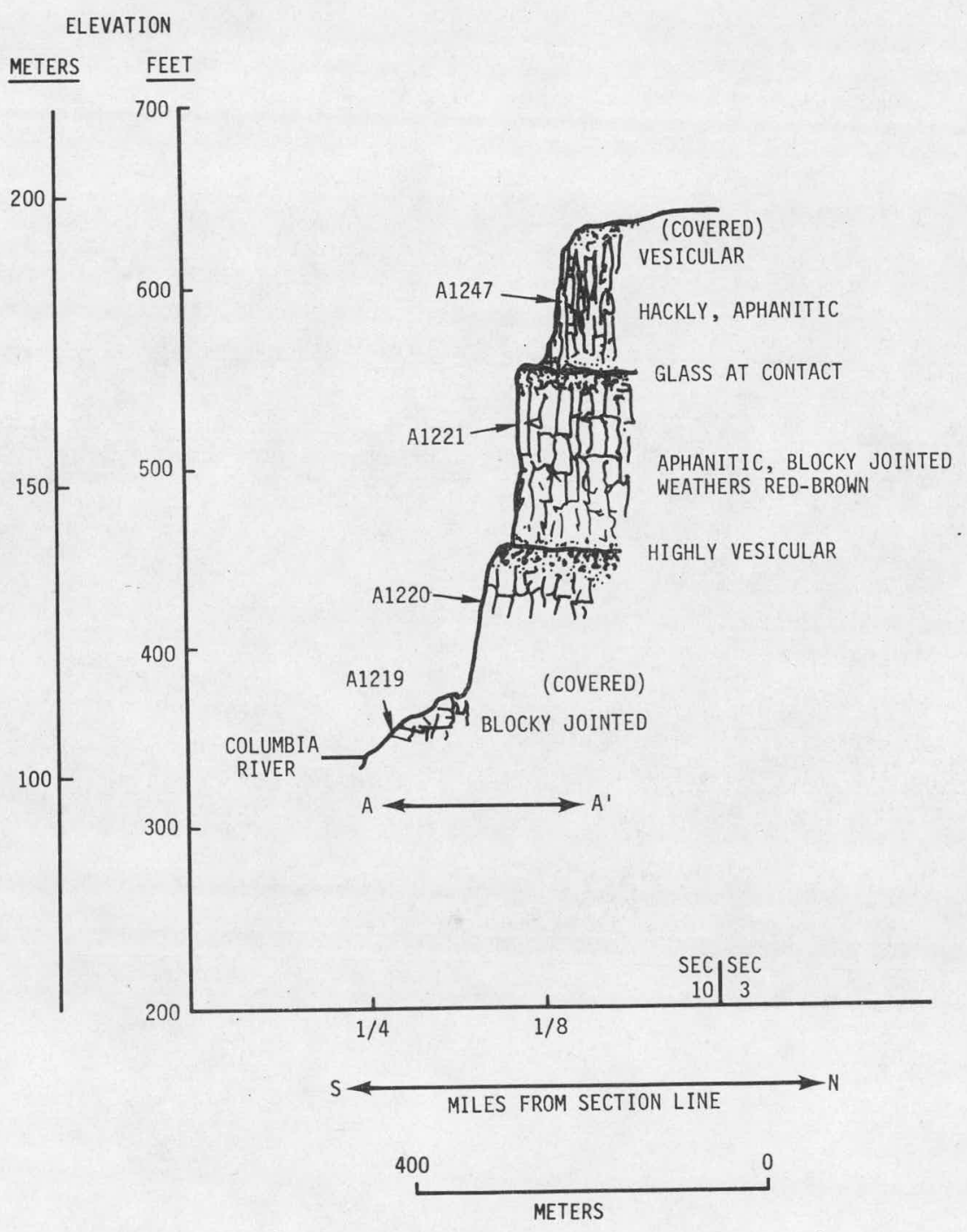

FIGURE B-6

RUSH CANYON CROSS-SECTION SHOWING SAMPLE POINTS 
MAJOR OXIDE CONTENT, by Atomic Absorption Spectrometer

\begin{tabular}{|c|c|c|c|c|c|c|c|c|c|c|}
\hline $\begin{array}{l}\text { Sample } \\
\text { Serial } \\
\text { Number }\end{array}$ & $\begin{array}{c}\mathrm{SiO}_{2} \\
\%\end{array}$ & $\mathrm{Al}_{\%}{ }_{\%}^{\mathrm{O}_{3}}$ & $\begin{array}{c}\mathrm{Fe} 0 \\
\%\end{array}$ & $\begin{array}{c}\text { Mg0 } \\
\%\end{array}$ & $\begin{array}{c}\mathrm{CaO} \\
\% \\
\end{array}$ & $\begin{array}{l}\mathrm{Na}_{2} \mathrm{O} \\
\% \\
\end{array}$ & $\begin{array}{l}\mathrm{K}_{2} \mathrm{O} \\
\% \\
\end{array}$ & $\begin{array}{r}\mathrm{TiO}^{2} \\
\% \\
\end{array}$ & $\begin{array}{l}\mathrm{Ba} \\
\mathrm{ppm} \\
\end{array}$ & $\begin{array}{l}\text { VIty } \\
\%\end{array}$ \\
\hline$A 1247$ & 53 & 14.2 & 10.6 & 7.9 & 9.9 & 2.4 & 0.7 & 1.5 & 315 & 2.2 \\
\hline $\begin{array}{l}122 \\
122\end{array}$ & $\begin{array}{l}54 \\
55\end{array}$ & $\begin{array}{l}13.8 \\
13.4 \\
13.5\end{array}$ & $\begin{array}{l}12.6 \\
12.7 \\
12.9\end{array}$ & $\begin{array}{l}3.2 \\
3.2 \\
3.4\end{array}$ & $\begin{array}{l}5.9 \\
6.1 \\
5.9\end{array}$ & $\begin{array}{l}3.2 \\
3.2 \\
2.9\end{array}$ & $\begin{array}{l}2.7 \\
2.6 \\
2.5\end{array}$ & $\begin{array}{l}2.6 \\
2.6 \\
2.8\end{array}$ & $\begin{array}{l}3675 \\
3559 \\
3353\end{array}$ & $\begin{array}{l}2.0 \\
1.2 \\
1.3\end{array}$ \\
\hline
\end{tabular}

NATURALLY OCCURRING RADIOACTIVE ISOTOPES, by Gamma Energy Analysis

\begin{tabular}{|c|c|c|c|}
\hline $\begin{array}{l}\text { Sample } \\
\text { Serial } \\
\text { Number }\end{array}$ & $\begin{array}{c}40_{K} \\
\mu \mathrm{Ci} / \mathrm{kg} \times 10^{-3} \\
\end{array}$ & $\begin{array}{c}226 \mathrm{Ra}+\text { daughters } \\
\mu \mathrm{Ci} / \mathrm{kg} \times 10^{-3} \\
\end{array}$ & $\begin{array}{c}{ }^{228} \mathrm{Th}+\text { daughters } \\
\mu \mathrm{Ci} / \mathrm{kg} \times 10^{-3} \\
\end{array}$ \\
\hline $\begin{array}{l}A 1221 \\
\text { A1220 } \\
\text { A1219 }\end{array}$ & $\begin{array}{l}18.8 \pm 12 \% \\
20.5 \pm 11 \\
16.7 \pm 13\end{array}$ & $\begin{array}{l}0.56 \pm 17 \% \\
0.66 \pm 17 \\
0.57 \pm 18\end{array}$ & $\begin{array}{l}0.85 \pm 6.6 \% \\
0.81 \pm 6.9 \\
0.78 \pm 7.1\end{array}$ \\
\hline
\end{tabular}

TRACE ELEMENTS, by Neutron Activation Analysis

Sample

Serial $\mathrm{Na}$ La Sm $\mathrm{Fe}$ Co Sc $\mathrm{Cr}$ Eu Th Tb Hf Ta

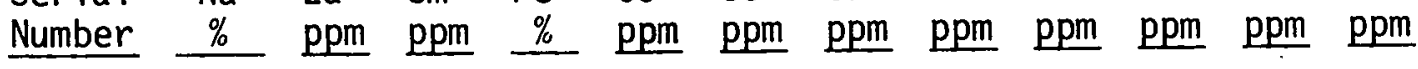
$\begin{array}{lllllllllllll}\text { A1247 } & 1.74 & 19 & 5.1 & 7.7 & 41 & 33 & 100 & 2.2 & 1.1 & 1.1 & 4.8 & 1.5\end{array}$ TRACE ELEMENTS, by Emission Spectrometer

Sample

Serial Ba $\mathrm{Cr} \quad \mathrm{Ni}$ Rb Sc Sn $\mathrm{V}$ Zn $\mathrm{Zr}$ Number ppm ppm ppm ppm ppm ppm ppm ppm ppm $\begin{array}{llllllllll}\text { A1247 } & 240 & 130 & 64 & 18 & 75 & 5 & 590 & 118 & 110\end{array}$

$\begin{array}{llllllllll}\text { A1221 } & >2500 & <1 & <10 & 89 & 18 & 19 & 298 & 165 & 740\end{array}$

$\begin{array}{lllllllll}\text { A1220 }>2500 & <1 & <10 & 46 & 85 & 26 & 235 & 165 & 640\end{array}$

$\begin{array}{llllllll}\text { A1219 }>2500<1<10 & 39 & 31 & 16 & 315 & 210 & 530\end{array}$ 


\section{SPUKSHOWKI CANYON FIELD SECTION}

Analytical data from flows in the Spukshowki Canyon section confirm the continuance of the Pomona chemical type basalt flow overlying the flows of the Umatilla Basalt Member. The Pomona type flow is thin and appears to be receding to the north.

The first flows of Middle Yakima Basalt type appear in this section. The flows are non-porphyritic and of probable Priest Rapids type. However, the upper high Mg0 Priest Rapids IV flow is not present in this section.

Much of the section was covered, therefore the cross-section may not be completely representative of this area.

Figure $B-7$ is a location map of the area, Figure B-8 is a cross-section and Table B-III is a tabulation of analytical data for the section. Figure B-9 is an aerial photograph showing the location of sampling points. 


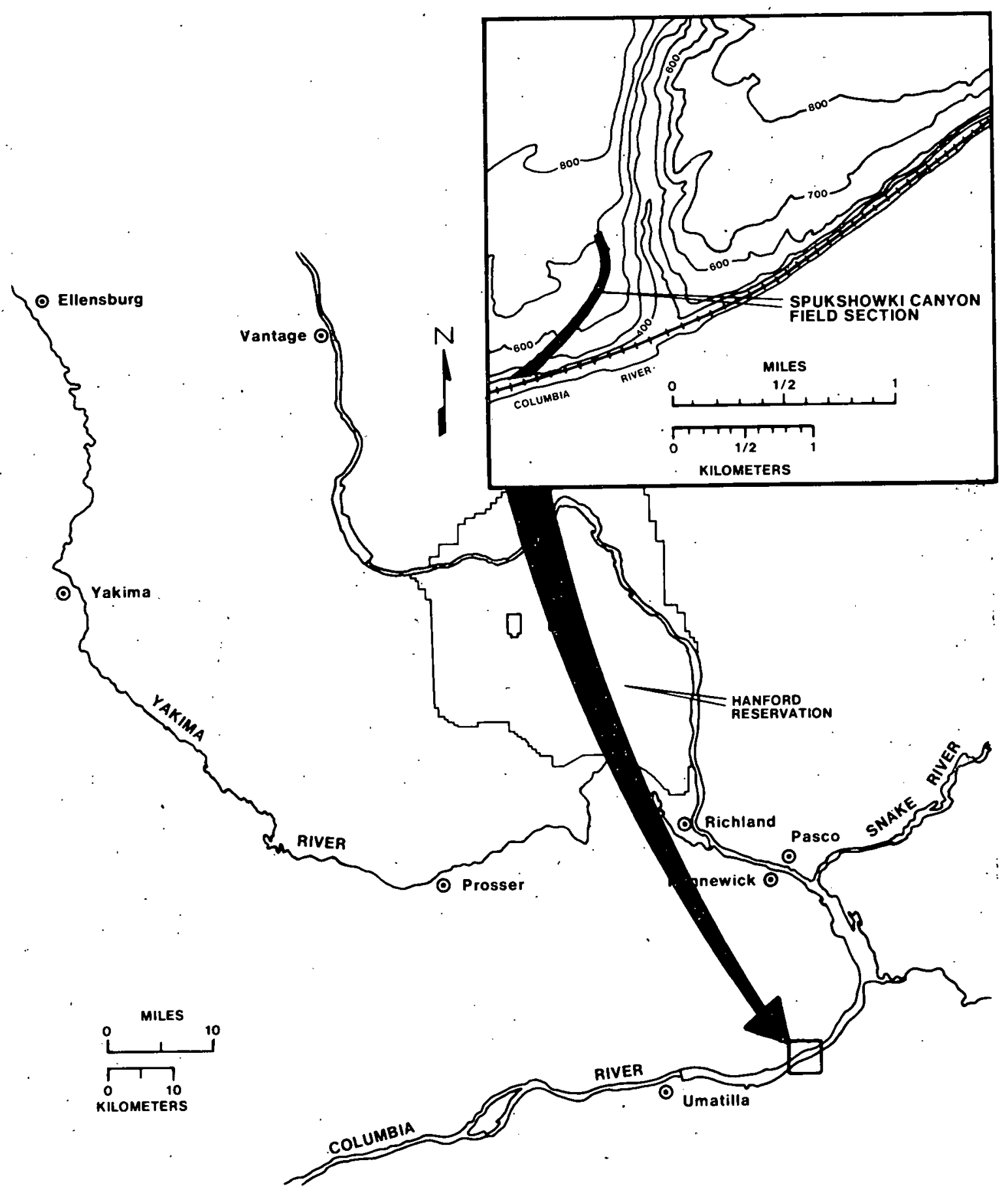

FIGURE B-7 


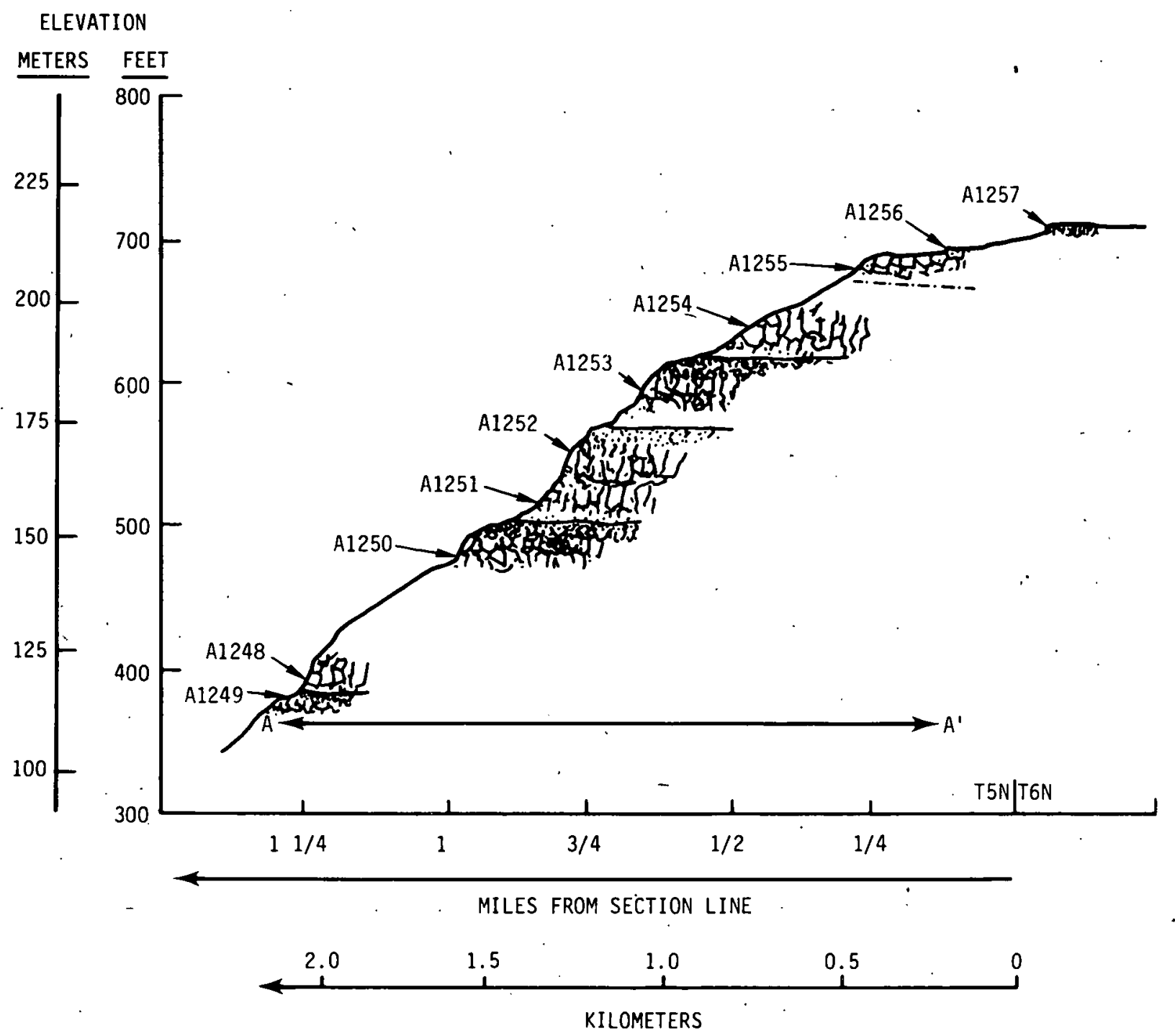

FIGURE B-8

SPUKSHOWKI CANYON CROSS-SECTION SHOWING SAMPLE POINTS 
MAJOR OXIDE CONTENT, by Atomic Absorption Spectrometer

\begin{tabular}{|c|c|c|c|c|c|c|c|c|c|c|c|}
\hline $\begin{array}{l}\text { Sample } \\
\text { Serial } \\
\text { Number }\end{array}$ & $\begin{array}{l}\mathrm{SiO}_{2} \\
\%\end{array}$ & $\mathrm{~A}_{2}{ }_{\%} \mathrm{O}_{3}$ & $\begin{array}{c}\mathrm{FeO} \\
\%\end{array}$ & $\begin{array}{c}\mathrm{Mg0} \\
\% \\
\end{array}$ & $\begin{array}{c}\mathrm{CaO} 0 \\
\% \\
\end{array}$ & $\begin{array}{c}\mathrm{Na}_{2} \mathrm{O} \\
\%\end{array}$ & $\begin{array}{l}\mathrm{K}_{2} \mathrm{O} \\
\%\end{array}$ & $\begin{array}{c}\mathrm{TiO}_{2} \\
\% \\
\end{array}$ & $\begin{array}{l}\mathrm{Ba} \\
\mathrm{ppm}\end{array}$ & $\begin{array}{c}\text { V1ty } \\
\% \\
\end{array}$ & $\begin{array}{c}\mathrm{Mt1} \\
\mathrm{Bal} \\
\% \\
\end{array}$ \\
\hline A1257 & 53 & 14.0 & 10.7 & 8.5 & 10.1 & 2.3 & 0.6 & 1.5 & 473 & 1.9 & 102.6 \\
\hline $\begin{array}{l}\text { A1256 } \\
\text { A1255 } \\
\text { A1254 }\end{array}$ & $\begin{array}{l}54 \\
56 \\
55\end{array}$ & $\begin{array}{l}13.4 \\
13.5 \\
13.5\end{array}$ & $\begin{array}{l}12.6 \\
12.7 \\
12.6\end{array}$ & $\begin{array}{l}2.9 \\
3.2 \\
2.9\end{array}$ & $\begin{array}{l}5.9 \\
6.2 \\
6.0\end{array}$ & $\begin{array}{l}3.0 \\
3.0 \\
3.2\end{array}$ & $\begin{array}{l}2.7 \\
2.9 \\
3.0\end{array}$ & $\begin{array}{l}2.6 \\
2.7 \\
2.5\end{array}$ & $\begin{array}{l}3181 \\
3216 \\
3783\end{array}$ & $\begin{array}{l}1.7 \\
2.1 \\
2.0\end{array}$ & $\begin{array}{r}98.9 \\
102.3 \\
100.7\end{array}$ \\
\hline $\begin{array}{l}A 1253 \\
A 1252 \\
A 1251 \\
A 1250 \\
A 1249 \\
A 1248\end{array}$ & $\begin{array}{l}53 \\
50 \\
53 \\
50 \\
52 \\
51\end{array}$ & $\begin{array}{l}13.2 \\
13.0 \\
13.2 \\
12.7 \\
13.1 \\
12.7\end{array}$ & $\begin{array}{l}15.1 \\
14.3 \\
14.4 \\
14.6 \\
14.6 \\
14.7\end{array}$ & $\begin{array}{l}4.8 \\
4.2 \\
4.5 \\
4.3 \\
4.4 \\
4.5\end{array}$ & $\begin{array}{l}7.9 \\
7.5 \\
7.7 \\
7.6 \\
7.4 \\
7.2\end{array}$ & $\begin{array}{l}2.9 \\
2.6 \\
2.7 \\
2.5 \\
2.7 \\
2.7\end{array}$ & $\begin{array}{l}1.5 \\
1.3 \\
1.4 \\
1.2 \\
1.0 \\
1.3\end{array}$ & $\begin{array}{l}2.8 \\
2.7 \\
2.8 \\
2.7 \\
2.6 \\
2.7\end{array}$ & $\begin{array}{l}693 \\
574 \\
667 \\
595 \\
942 \\
608\end{array}$ & $\begin{array}{l}1.9 \\
3.2 \\
2.4 \\
5.2 \\
4.9 \\
4.3\end{array}$ & $\begin{array}{r}103.1 \\
98.8 \\
102.1 \\
100.8 \\
102.7 \\
101.1\end{array}$ \\
\hline
\end{tabular}

NATURALLY OCCURRING RADIOACTIVE ISOTOPES, by Gamma Energy Analysis

\begin{tabular}{|c|c|c|c|}
\hline $\begin{array}{l}\text { Sample } \\
\text { Serial } \\
\text { Number }\end{array}$ & $\begin{array}{r}{ }^{40}{ }_{K} \\
\mu \mathrm{Ci} / \mathrm{kg} \times 10^{-3} \\
\end{array}$ & $\begin{array}{c}{ }^{226} \mathrm{Ra}+\text { daughters } \\
\mu \mathrm{Ci} / \mathrm{kg} \times 10^{-3} \\
\end{array}$ & $\begin{array}{r}{ }^{228} \mathrm{Th}+\text { daughters } \\
\mu \mathrm{Ci} / \mathrm{kg} \times 10^{-3} \\
\end{array}$ \\
\hline A1257. & $4.25 \pm 24 \%$ & $0.36 \pm 18 \%$ & $0.38 \pm 7.3 \%$ \\
\hline $\begin{array}{l}\text { A1256 } \\
\text { A1255 } \\
\text { A1254 }\end{array}$ & $\begin{array}{l}17.9 \pm 12 \\
19.4 \pm 12 \\
16.3 \pm 13\end{array}$ & $\begin{array}{l}0.56 \pm 18 \\
0.54 \pm 17 \\
0.58 \pm 17\end{array}$ & $\begin{array}{l}0.85 \pm 6.6 \\
0.89 \pm 6.7 \\
0.86 \pm 6.7\end{array}$ \\
\hline $\begin{array}{l}\text { A1253 } \\
\text { A1252 } \\
\text { A1251 } \\
\text { A1250 } \\
\text { A1249 } \\
\text { A1248 }\end{array}$ & $\begin{array}{r}9.54 \pm 16 \\
10.6 \pm 14 \\
10.0 \pm 15 \\
9.79 \pm 15 \\
7.55 \pm 16 \\
10.4 \pm 7\end{array}$ & $\begin{array}{l}0.50 \pm 18 \\
0.48 \pm 24 \\
0.67 \pm 17 \\
0.39 \pm 21 \\
0.45 \pm 20 \\
0.48 \pm 14\end{array}$ & $\begin{array}{l}0.63 \pm 7.2 \\
0.66 \pm 7.6 \\
0.50 \pm 7.5 \\
0.64 \pm 7.4 \\
0.57 \pm 7.1 \\
0.68 \pm 3.4\end{array}$ \\
\hline
\end{tabular}

TRACE ELEMENTS, by Neutron Activation Analysis

\begin{tabular}{|c|c|c|c|c|c|c|c|c|c|c|c|c|}
\hline $\begin{array}{l}\text { Serial } \\
\text { Number }\end{array}$ & $\begin{array}{l}\mathrm{Na} \\
\% \\
\end{array}$ & $\begin{array}{l}\mathrm{La} \\
\mathrm{ppm}\end{array}$ & $\begin{array}{l}\text { Sm } \\
\text { ppm }\end{array}$ & $\begin{array}{r}\mathrm{Fe} \\
\% \\
\end{array}$ & $\begin{array}{l}\text { Co } \\
\text { ppm }\end{array}$ & $\begin{array}{l}\text { Sc } \\
\mathrm{ppm}\end{array}$ & $\begin{array}{l}\mathrm{Cr} \\
\mathrm{ppm}\end{array}$ & $\begin{array}{l}\text { Eu } \\
\text { ppm }\end{array}$ & $\begin{array}{l}\text { Th } \\
\text { ppm }\end{array}$ & $\begin{array}{l}\text { Tb } \\
\text { ppm }\end{array}$ & $\begin{array}{l}\text { Hf } \\
\text { ppm }\end{array}$ & $\begin{array}{l}\mathrm{Ta} \\
\mathrm{ppm}\end{array}$ \\
\hline A1257 & 1.65 & 19 & 5.0 & 7.7 & 41 & 34 & 110 & $1 . .5$ & 3.0 & 0.8 & 4.3 & 1.6 \\
\hline & $\begin{array}{l}2.2 \\
2.1 \\
2.3\end{array}$ & $\begin{array}{l}44 \\
47 \\
45\end{array}$ & $\begin{array}{r}10.1 \\
9.9 \\
10.5\end{array}$ & $\begin{array}{r}9.6 \\
10.0 \\
9.3\end{array}$ & & & $\begin{array}{r}3 \\
7 \\
<1\end{array}$ & & $\begin{array}{l}6.6 \\
5.6 \\
5.8\end{array}$ & $\begin{array}{l}1.7 \\
1.2 \\
1.7\end{array}$ & $\begin{array}{l}13.0 \\
12.0 \\
12.9\end{array}$ & \\
\hline $\begin{array}{l}\text { A125 } \\
\text { A125 }\end{array}$ & $\begin{array}{l}1.90 \\
2.03 \\
1.79 \\
1.89 \\
2.07\end{array}$ & $\begin{array}{l}25 \\
25 \\
29 \\
25 \\
32 \\
26\end{array}$ & $\begin{array}{l}7.5 \\
8.4 \\
8.4 \\
7.5 \\
8.8 \\
7.6\end{array}$ & $\begin{array}{l}10.7 \\
10.3 \\
10.9 \\
11.3 \\
10.8\end{array}$ & $\begin{array}{l}39 \\
36 \\
35\end{array}$ & $\begin{array}{l}35 \\
34 \\
34\end{array}$ & $\begin{array}{l}29 \\
29 \\
24 \\
23 \\
23 \\
23\end{array}$ & $\begin{array}{l}2.3 \\
2.2 \\
2.3 \\
2.0 \\
2.3 \\
2.2\end{array}$ & $\begin{array}{l}4.0 \\
5.4 \\
4.8\end{array}$ & $\begin{array}{l}1.8 \\
1.9 \\
1.4\end{array}$ & $\begin{array}{l}4.7 \\
4.6 \\
6.0 \\
4.6 \\
5.7 \\
5.1\end{array}$ & \\
\hline
\end{tabular}




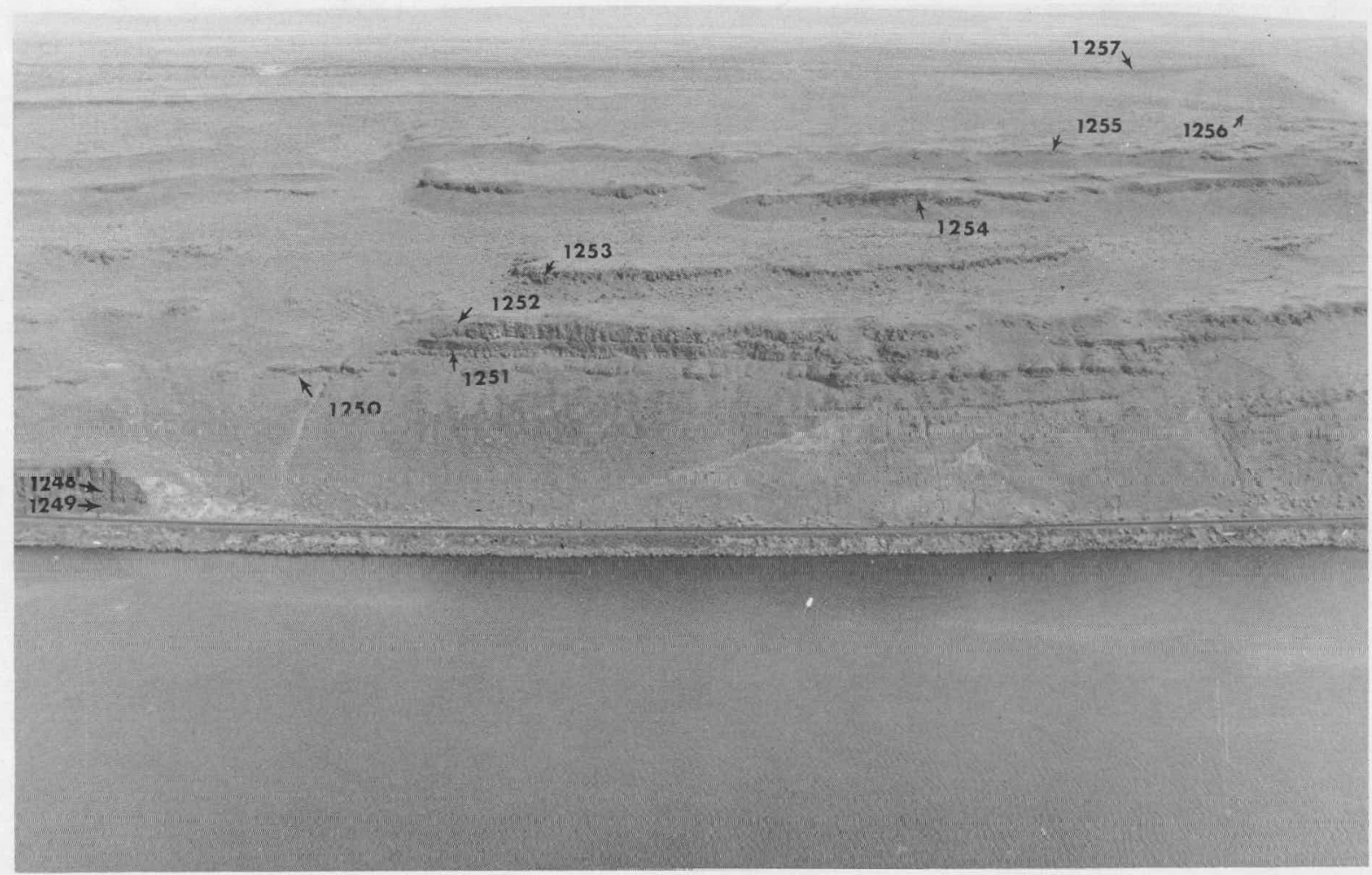

FIGURE B-9

AERIAL PHOTOGRAPH OF THE SPUKSHOWKI FIELD SECTION SHOWING SAMPLE POINTS 


\section{BLAIR POINT FIELD SECTION}

At Blair Point, the Pomona chemical type flow seen at the previous downstream sections is absent together with part of the upper flow of the Umatilla Member. This section shows the first appearance of porphyritic flows of the Middle Yakima Basalts.

- Phenocrysts of irregular greenish-yellow plagioclase up to $2 \mathrm{~cm}$ in length appear at the 740 foot (222 meter) elevation.

- The next lower described flow is sparsely porphyritic.

- Phenocrysts are not again present until the flow at 410 feet (123 meters). Plagioclase phenocrysts in this flow are generally larger, up to $3.5 \mathrm{~cm}$ and are more irregular and clotty.

Variations in chemical composition are minor within the porphyritic series of flows with the exception of chromium values.

Figures B-10 and B-11 are a location map and aerial photograph of the section area showing the location of points sampled. Figure B-12 is a cross-section and Table B-IV presents a tabulation of analytical data for the section area. Sample points A 1194, A 1195 and A 1196 are no shown in the aerial photograph (Figure B-11) but were taken at the bottom of the section as indicated in Figure B-12. 


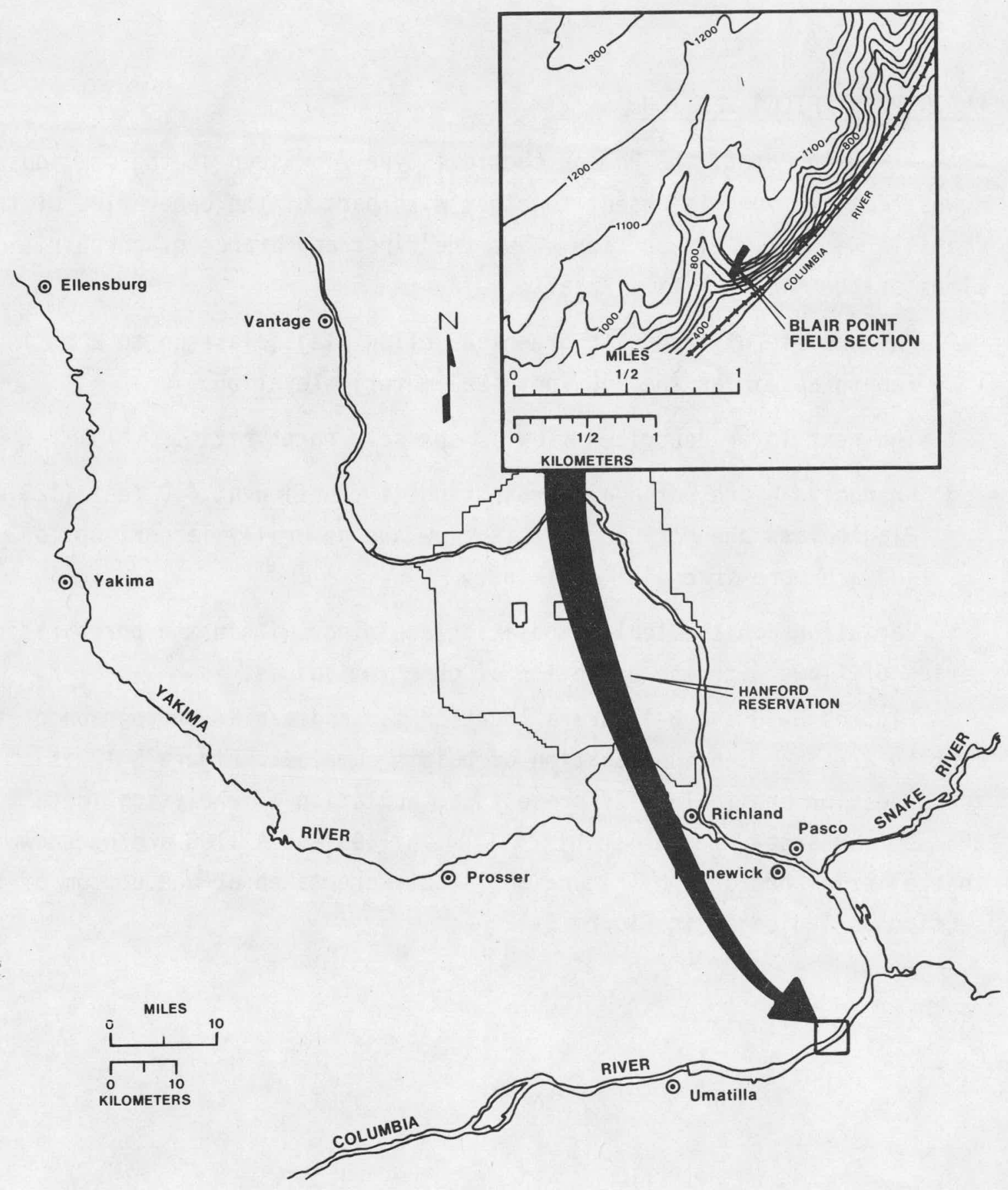

FIGURE B-10

LOCATION MAP FOR THE BLAIR POINT FIELD SECTION 


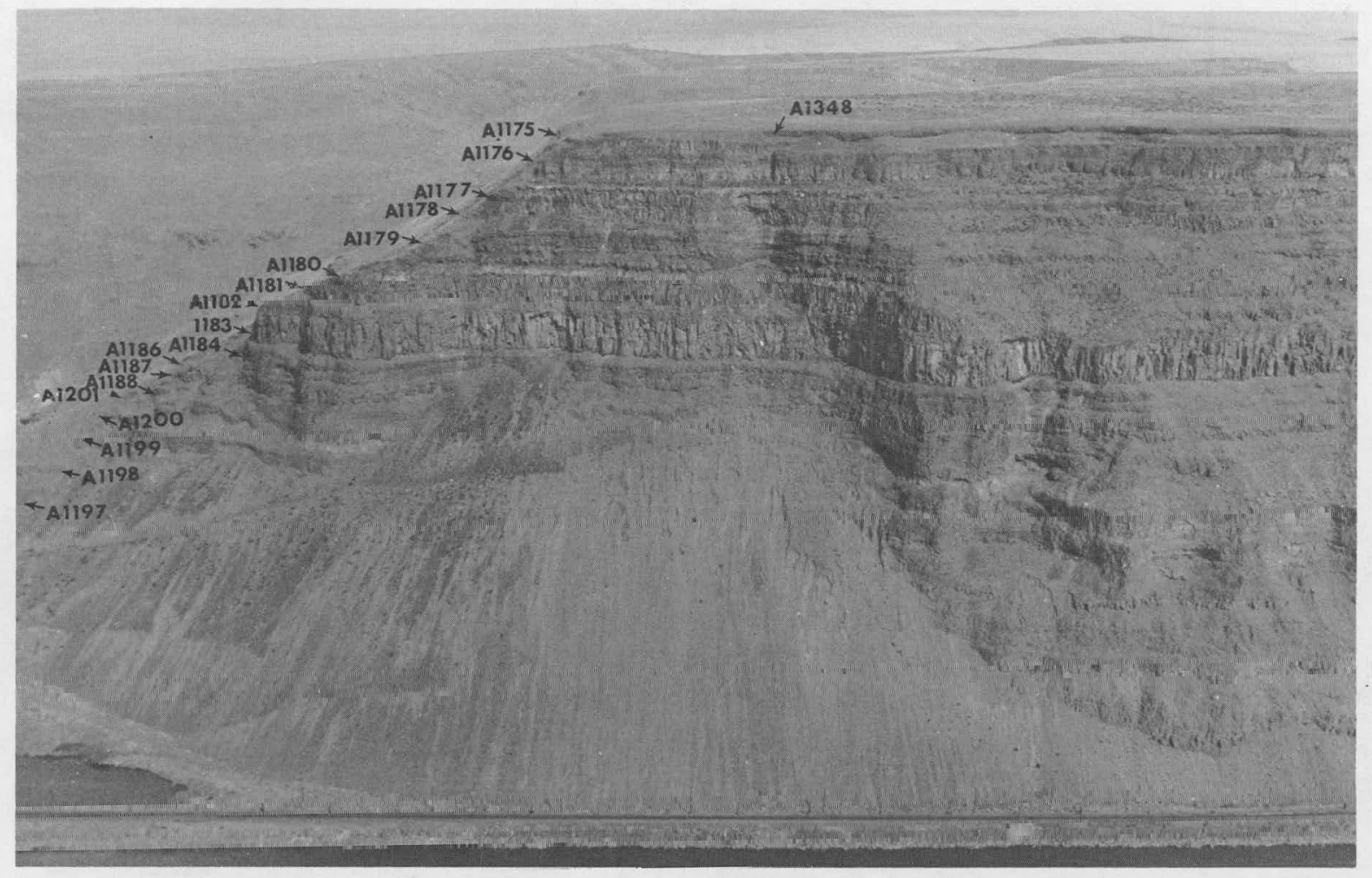

FIGURE B-11

AERIAL PHOTOGRAPH OF THE BLAIR POINT FIELD SECTION

SHOWING SAMPLE POINTS 


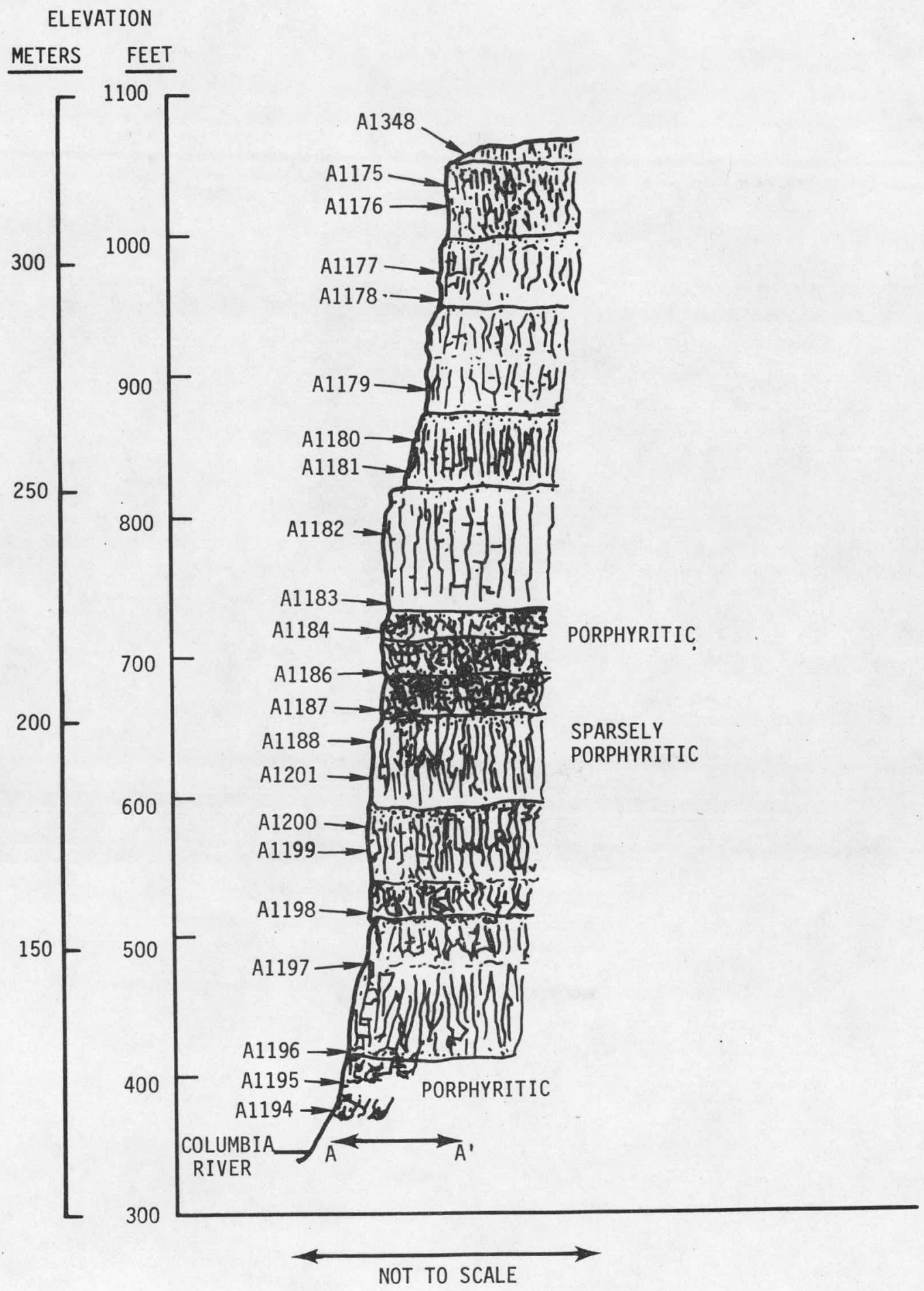

FIGURE B-12

BLAIR POINT CROSS-SECTION SHOWING SAMPLE POINTS 
MAJOR OXIDE CONTENT, by Atomic Absorption Spectrometer

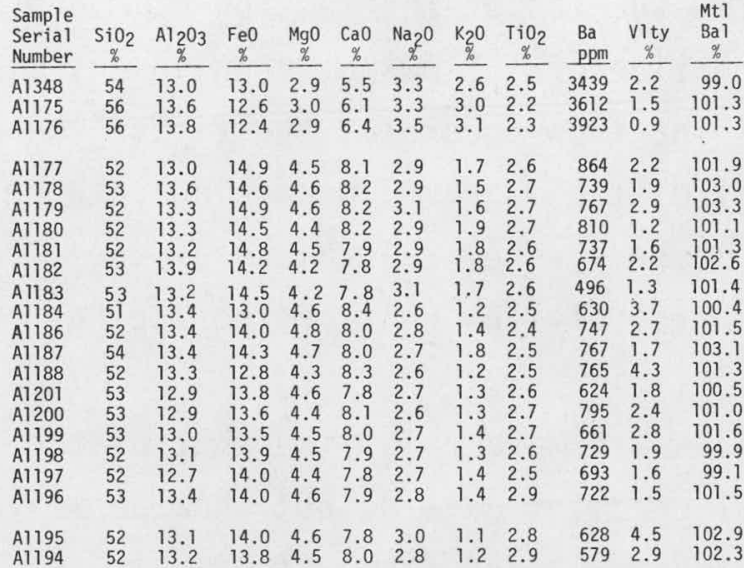

NATURALLY OCCURRING RADIOACTIVE ISOTOPES, by Gamma Energy Analysis

\begin{tabular}{|c|c|c|c|}
\hline $\begin{array}{l}\text { Sample } \\
\text { Serial } \\
\text { Number }\end{array}$ & $\begin{array}{r}\quad{ }^{40} \mathrm{~K} \\
\mu \mathrm{Ci} / \mathrm{kg} \times 10^{-3} \\
\end{array}$ & $\begin{array}{l}226 \mathrm{Ra}+\text { daughters } \\
\ldots \mathrm{CC} / \mathrm{kg} \times 10^{-3} \\
\end{array}$ & $\begin{array}{l}{ }^{228} \mathrm{Th}+\text { daughters } \\
\mu \mathrm{Ci} / \mathrm{kg} \times 10^{-3} \\
\end{array}$ \\
\hline $\begin{array}{l}\text { A1175 } \\
\text { A1176 }\end{array}$ & $\begin{array}{l}17.7 \pm 12 \% \\
18.6 \pm 12\end{array}$ & $\begin{array}{l}0.65 \pm 19 \% \\
0.57 \pm 17\end{array}$ & $\begin{array}{l}1.22 \pm 6.5 \% \\
1.16 \pm 6.6\end{array}$ \\
\hline $\begin{array}{l}\text { A1177 } \\
\text { A1178 } \\
\text { A1179 } \\
\text { A1180 } \\
\text { A1181 } \\
\text { A1182 } \\
\text { A1183 } \\
\text { A1184 } \\
\text { A1186 } \\
\text { A1187 } \\
\text { A1188 } \\
\text { A1201 } \\
\text { A1200 } \\
\text { A1199 } \\
\text { A1198 } \\
\text { A1197 } \\
\text { A1196 }\end{array}$ & $\begin{array}{r}9.2 \pm 15 \\
9.3 \pm 15 \\
8.2 \pm 17 \\
10.0 \pm 14 \\
11.2 \pm 14 \\
7.9 \pm 15 \\
8.7 \pm 15 \\
5.2 \pm 20 \\
9.0 \pm 12 \\
12.0 \pm 14 \\
9.3 \pm 15 \\
9.3 \pm 15 \\
10.2 \pm 15 \\
10.0 \pm 15 \\
8.9 \pm 16 \\
9.2 \pm 15 \\
7.0 \pm 18\end{array}$ & $\begin{array}{l}0.45 \pm 21 \\
0.48 \pm 19 \\
0.59 \pm 20 \\
0.59 \pm 16 \\
0.49 \pm 18 \\
0.56 \pm 18 \\
0.56 \pm 18 \\
0.35 \pm 22 \\
0.46 \pm 14 \\
0.36 \pm 21 \\
0.40 \pm 20 \\
0.37 \pm 18 \\
0.54 \pm 18 \\
0.62 \pm 24 \\
0.60 \pm 27 \\
0.61 \pm 16 \\
0.48 \pm 20\end{array}$ & $\begin{array}{l}0.70 \pm 7.2 \\
0.75 \pm 7.3 \\
0.78 \pm 6.6 \\
0.52 \pm 7.0 \\
0.62 \pm 6.9 \\
0.54 \pm 7.1 \\
0.60 \pm 6.9 \\
0.35 \pm 7.0 \\
0.25 \pm 5.6 \\
0.26 \pm 7.1 \\
0.58 \pm 7.0 \\
0.56 \pm 7.2 \\
0.43 \pm 7.3 \\
0.72 \pm 7.7 \\
0.57 \pm 8.0 \\
0.62 \pm 6.9 \\
0.59 \pm 7.4\end{array}$ \\
\hline $\begin{array}{l}\text { Al195 } \\
\text { Al194 }\end{array}$ & $\begin{array}{l}6.3 \pm 18 \\
6.4 \pm 17\end{array}$ & $\begin{array}{l}0.24 \pm 27 \\
0.36 \pm 20\end{array}$ & $\begin{array}{l}0.64 \pm 7.1 \\
0.62 \pm 6.9\end{array}$ \\
\hline
\end{tabular}

TRACE ELEMENTS, by Neutron Activation Analysis

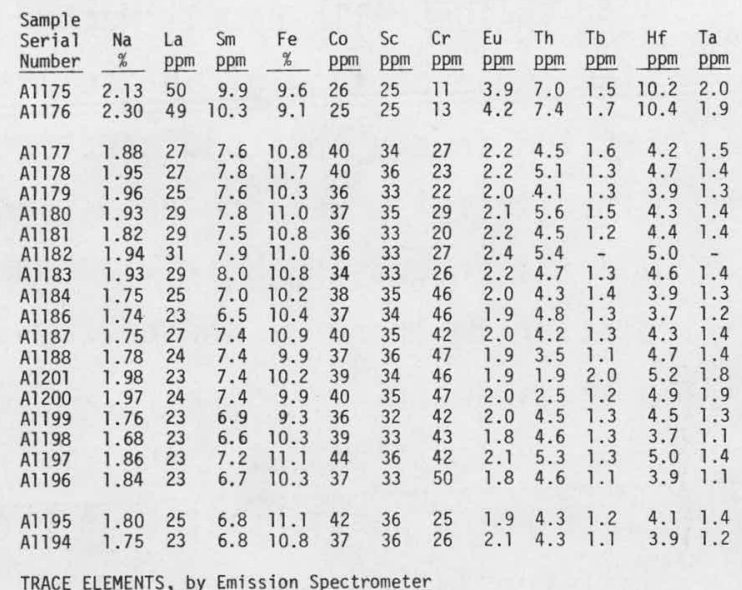

\begin{tabular}{|c|c|c|c|c|c|c|c|c|c|}
\hline $\begin{array}{l}\text { Serial } \\
\text { Number }\end{array}$ & $\begin{array}{l}\mathrm{Ba} \\
\mathrm{ppm}\end{array}$ & $\begin{array}{l}\mathrm{Cr} \\
\mathrm{ppm}\end{array}$ & $\begin{array}{l}\mathrm{Ni} \\
\mathrm{ppm}\end{array}$ & $\begin{array}{l}\mathrm{Rb} \\
\mathrm{ppm}\end{array}$ & $\begin{array}{l}\text { Sc } \\
\text { ppm }\end{array}$ & $\begin{array}{l}\mathrm{Sn} \\
\mathrm{ppm}\end{array}$ & $\begin{array}{c}V \\
\mathrm{ppm}\end{array}$ & $\begin{array}{l}\mathrm{Zn} \\
\mathrm{ppm} \\
\end{array}$ & $\begin{array}{l}\mathrm{zr} \\
\mathrm{ppm}\end{array}$ \\
\hline $\begin{array}{l}\text { A1175 } \\
\text { A1176 }\end{array}$ & $\begin{array}{l}2500 \\
2500\end{array}$ & $\begin{array}{l}<50 \\
<50\end{array}$ & $\begin{array}{l}<50 \\
<50\end{array}$ & $\begin{array}{r}<20 \\
20\end{array}$ & $\begin{array}{l}10 \\
10\end{array}$ & $\begin{array}{l}<1 \\
<1\end{array}$ & $\begin{array}{l}200 \\
200\end{array}$ & & $\begin{array}{l}500 \\
500\end{array}$ \\
\hline $\begin{array}{l}\text { A1177 } \\
\text { A1178 } \\
\text { A1179 } \\
\text { A1180 } \\
\text { A1181 } \\
\text { Al183 }\end{array}$ & $\begin{array}{l}625 \\
625 \\
625 \\
625 \\
625 \\
625\end{array}$ & $\begin{array}{r}<50 \\
50 \\
<50 \\
<50 \\
100 \\
<50\end{array}$ & $\begin{array}{l}<50 \\
<50 \\
<50 \\
<50 \\
<50 \\
<50\end{array}$ & $\begin{array}{l}20 \\
50 \\
50 \\
50 \\
50 \\
50\end{array}$ & $\begin{array}{l}10 \\
10 \\
10 \\
10 \\
10 \\
10\end{array}$ & $\begin{array}{l}<1 \\
<1 \\
<1 \\
<1 \\
<1 \\
<1\end{array}$ & $\begin{array}{l}200 \\
500 \\
500 \\
500 \\
500 \\
500\end{array}$ & & $\begin{array}{l}200 \\
200 \\
200 \\
200 \\
200 \\
200\end{array}$ \\
\hline $\begin{array}{l}\text { A1184 } \\
\text { A1186 } \\
\text { Al187 } \\
\text { A1188 } \\
\text { A1201 } \\
\text { A1200 } \\
\text { Al199 } \\
\text { Al198 } \\
\text { A1197 } \\
\text { Al196 }\end{array}$ & $\begin{array}{l}250 \\
625 \\
625 \\
625 \\
250 \\
250 \\
625 \\
250 \\
250 \\
250\end{array}$ & $\begin{array}{r}200 \\
200 \\
200 \\
200 \\
100 \\
100 \\
100 \\
100 \\
50 \\
50\end{array}$ & $\begin{array}{r}<50 \\
<50 \\
<50 \\
<50 \\
50 \\
100 \\
200 \\
100 \\
100 \\
100\end{array}$ & $\begin{array}{r}50 \\
50 \\
100 \\
200 \\
100 \\
100 \\
50 \\
200 \\
200 \\
50\end{array}$ & $\begin{array}{r}10 \\
10 \\
20 \\
20 \\
50 \\
20 \\
50 \\
100 \\
100 \\
100\end{array}$ & $\begin{array}{l}<1 \\
<1 \\
<1 \\
<1 \\
<1 \\
<1 \\
<1 \\
<1 \\
<1 \\
<1\end{array}$ & $\begin{array}{r}500 \\
500 \\
500 \\
500 \\
1000 \\
1000 \\
1000 \\
1000 \\
1000 \\
1000\end{array}$ & & $\begin{array}{l}200 \\
200 \\
500 \\
500 \\
500 \\
500 \\
500 \\
500 \\
500 \\
500\end{array}$ \\
\hline $\begin{array}{l}\text { Al195 } \\
\text { A1194 }\end{array}$ & $\begin{array}{l}250 \\
625\end{array}$ & $\begin{array}{l}<50 \\
100\end{array}$ & $\begin{array}{r}<50 \\
50\end{array}$ & $\begin{array}{r}50 \\
200\end{array}$ & $\begin{array}{l}100 \\
100\end{array}$ & $\begin{array}{l}<1 \\
<1\end{array}$ & $\begin{array}{l}1000 \\
1000\end{array}$ & & $\begin{array}{l}500 \\
500\end{array}$ \\
\hline
\end{tabular}




\section{YELLEPIT-MOUND PONDS FIELD SECTIONS}

The Yellepit Pond section shows extensive erosion, presumably by glacial flood water. The flow of Pomona chemical type is not present and the Umatilla Basalt Member has been removed except for mesa-like remnants.

The Umatilla Basalt Member forms the top of the section at Mound Pond with the exception of an isolated portion of a flow not seen in any other section in the series of sections. The flow occurs at the tip of the bluff with generally well rounded, andesitic stream gravel occurring between it and the underlying Umatilla Basalt Member. Chemical values of the flow are similar to those of the nearby Ice Harbor I flow unit of the Ice Harbor Basalt Member. [B-3]

The section below the Umatilla Basalt Member is like that of the Blair Point section although partial chromium data do not show positive differentiation between the top and bottom porphyritic flows.

Figure B-13 presents a location map of the area, Figure B-14 is a cross-section representative of the area sampled, Figure B-15 contains two aerial photographs showing the location of points sampled, and Table $B-V$ is a tabulation of the analytical data.

Three samples (A1260, A1264 and A1265) were taken for verification of lateral extent of the Umatilla Basalt Member. Sample locations are shown in Figure B-14 and Table B-V lists the analytical data. 


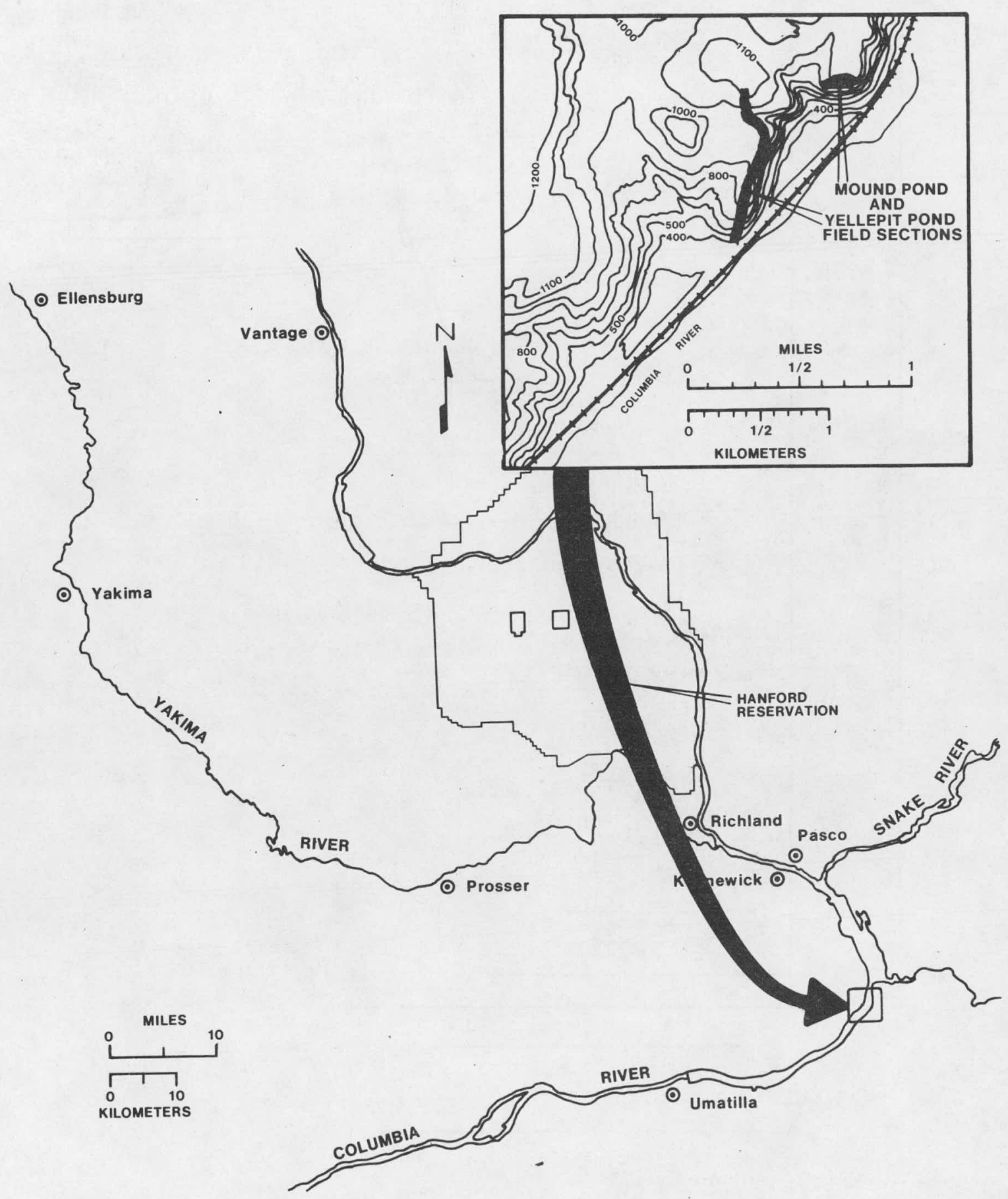

FIGURE B-13

LOCATION MAP FOR THE YELLEPIT-MOUND POND FIELD SECTIONS 


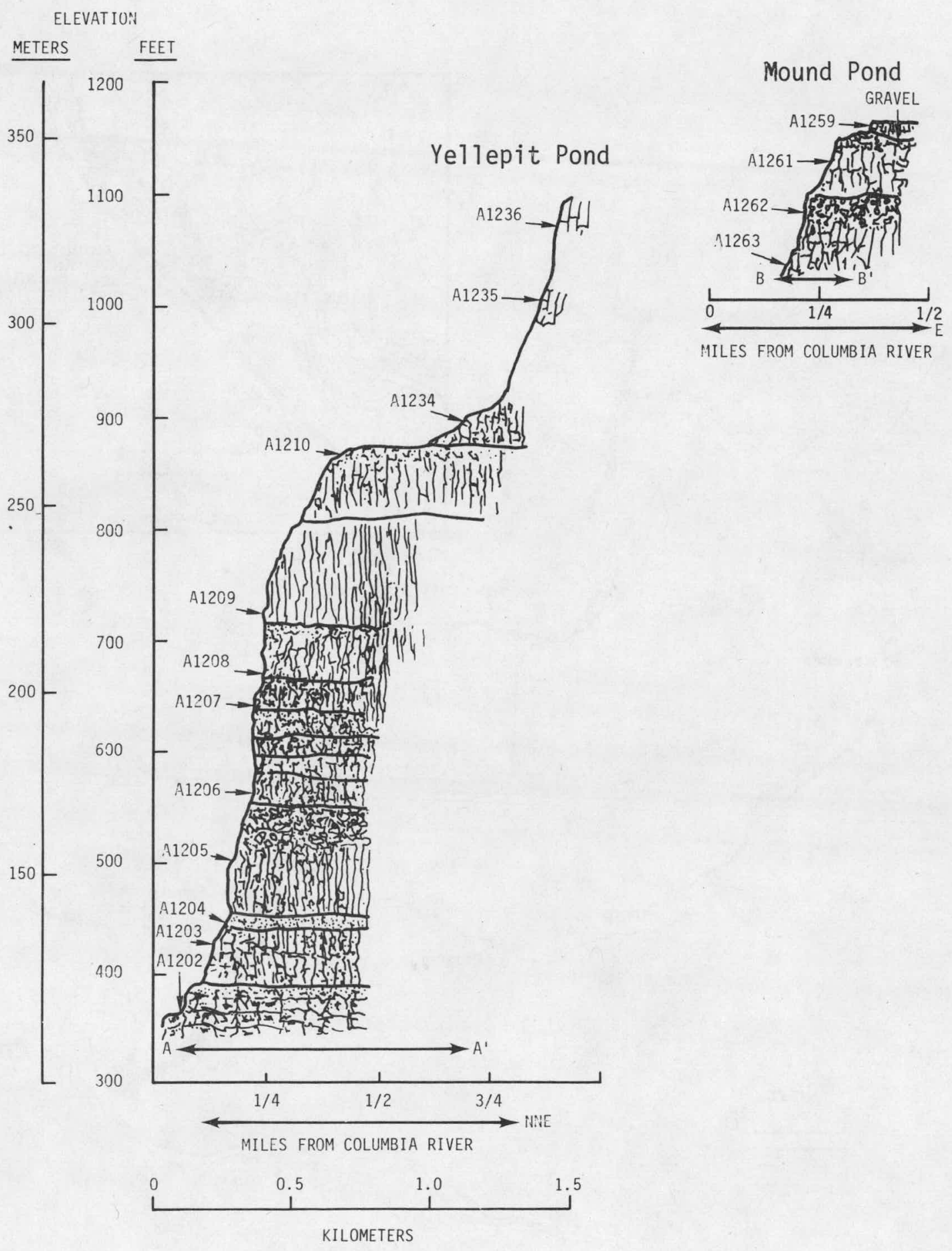

FIGURE B-14

YELLEPIT-MOUND POND CROSS-SECTIONS SHOWING SAMPLE LOCATIONS 

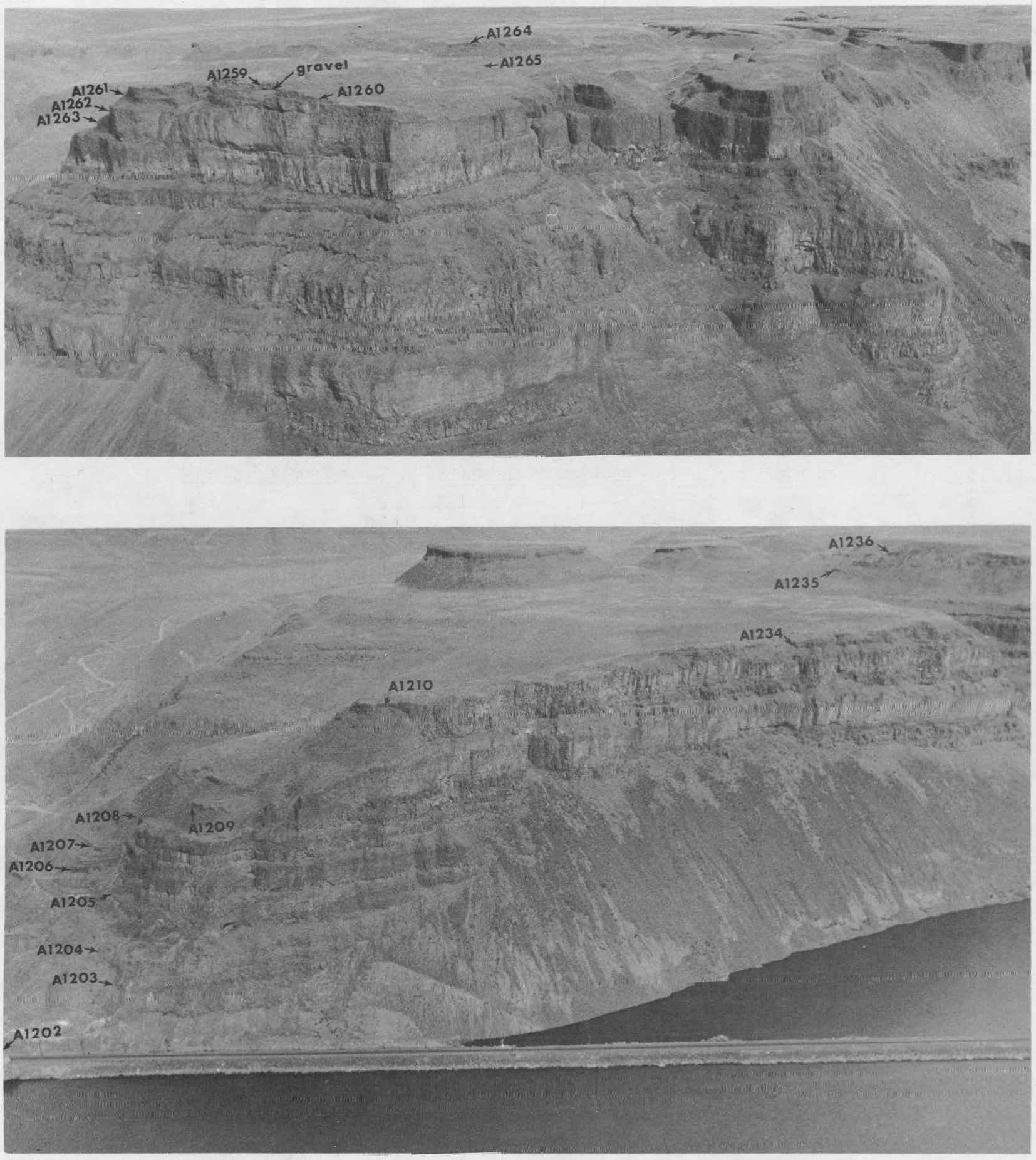

FIGURE B-15

AERIAL PHOTOGRAPHS OF THE YELLEPIT-MOUND PONDS FIELD SECTION AREA SHOWING SAMPLE LOCATIONS 
MAJOR OXIDE CONTENT, by Atomic Absorption Spectrometer

\begin{tabular}{|c|c|c|c|c|c|c|c|c|c|c|c|}
\hline $\begin{array}{l}\text { Sample } \\
\text { Serial } \\
\text { Number }\end{array}$ & $\begin{array}{l}\mathrm{SiO}_{2} \\
\%\end{array}$ & ${ }_{\%}^{\mathrm{Al}_{2} \mathrm{O}_{3}}$ & $\begin{array}{c}\mathrm{Fe} 0 \\
\% \\
\end{array}$ & $\begin{array}{c}\mathrm{MgO} 0 \\
\% \\
\end{array}$ & $\begin{array}{c}\mathrm{CaO} 0 \\
\% \\
\end{array}$ & $\begin{array}{c}\mathrm{Na}_{2} \mathrm{O} \\
\% \\
\end{array}$ & $\begin{array}{l}\mathrm{K}_{2} \mathrm{O} \\
\% \\
\end{array}$ & $\begin{array}{r}\mathrm{TiO}_{2} \\
\% \\
\end{array}$ & $\begin{array}{l}\mathrm{Ba} \\
\mathrm{ppm}\end{array}$ & $\begin{array}{c}\text { V1ty } \\
\% \\
\end{array}$ & $\begin{array}{c}\mathrm{Mtl} \\
\mathrm{Ba} 1 \\
\%\end{array}$ \\
\hline & $\begin{array}{l}56 \\
56\end{array}$ & $\begin{array}{l}13.5 \\
13.1\end{array}$ & $\begin{array}{l}12.8 \\
12.6\end{array}$ & $\begin{array}{l}3.1 \\
2.8\end{array}$ & $\begin{array}{l}5.7 \\
5.6\end{array}$ & $\begin{array}{l}3.5 \\
3.4\end{array}$ & $\begin{array}{l}2.7 \\
2.7\end{array}$ & $\begin{array}{l}2.4 \\
2.3\end{array}$ & $\begin{array}{l}3409 \\
3974\end{array}$ & $\begin{array}{l}1.5 \\
1.5\end{array}$ & $\begin{array}{l}101.2 \\
100.0\end{array}$ \\
\hline $\begin{array}{l}A 1234 \\
A 1210 \\
A 1209 \\
A 1208 \\
A 1207 \\
A 1206 \\
A 1205 \\
A 1204 \\
A 1203 \\
A 1202\end{array}$ & $\begin{array}{l}53 \\
54 \\
54 \\
53 \\
53 \\
53 \\
51 \\
51 \\
52 \\
52\end{array}$ & $\begin{array}{l}12.7 \\
12.8 \\
13.4 \\
13.2 \\
13.0 \\
13.0 \\
13.6 \\
13.6 \\
13.0 \\
12.6\end{array}$ & $\begin{array}{l}14.7 \\
13.9 \\
14.3 \\
14.3 \\
14.1 \\
14.0 \\
13.8 \\
14.4 \\
14.3 \\
14.0\end{array}$ & $\begin{array}{l}4.5 \\
4.1 \\
4.8 \\
4.9 \\
4.8 \\
4.5 \\
4.8 \\
4.4 \\
4.7 \\
4.4\end{array}$ & $\begin{array}{l}7.6 \\
7.6 \\
8.0 \\
8.1 \\
7.8 \\
7.6 \\
8.2 \\
7.6 \\
7.8 \\
7.7\end{array}$ & $\begin{array}{l}2.6 \\
2.7 \\
2.8 \\
2.8 \\
2.6 \\
2.7 \\
2.7 \\
2.7 \\
3.0 \\
2.9\end{array}$ & $\begin{array}{l}1.3 \\
1.6 \\
1.3 \\
1.4 \\
1.3 \\
1.5 \\
1.3 \\
1.4 \\
1.4 \\
1.4\end{array}$ & $\begin{array}{l}2.5 \\
2.6 \\
2.6 \\
2.7 \\
2.6 \\
2.8 \\
2.6 \\
2.6 \\
2.6 \\
2.8\end{array}$ & $\begin{array}{l}583 \\
689 \\
656 \\
689 \\
735 \\
683 \\
795 \\
722 \\
646 \\
698\end{array}$ & $\begin{array}{l}2.9 \\
1.6 \\
1.4 \\
1.5 \\
2.1 \\
1.1 \\
2.0 \\
2.1 \\
2.0 \\
1.8\end{array}$ & $\begin{array}{r}101.8 \\
100.9 \\
102.6 \\
101.9 \\
101.3 \\
100.2 \\
100.0 \\
99.8 \\
100.8 \\
99.6\end{array}$ \\
\hline $\begin{array}{l}A 1259 \\
A 1260 \\
A 1261 \\
A 1262 \\
A 1263 \\
A 1264 \\
A 1265\end{array}$ & $\begin{array}{l}49 \\
53 \\
53 \\
54 \\
53 \\
53 \\
53\end{array}$ & $\begin{array}{l}13.4 \\
13.1 \\
13.2 \\
12.4 \\
13.2 \\
13.3 \\
13.1\end{array}$ & $\begin{array}{l}14.6 \\
12.9 \\
12.6 \\
12.0 \\
12.7 \\
12.4 \\
12.7\end{array}$ & $\begin{array}{l}6.7 \\
3.1 \\
2.8 \\
2.7 \\
2.9 \\
2.8 \\
2.9\end{array}$ & $\begin{array}{r}10.2 \\
6.2 \\
5.9 \\
5.5 \\
5.6 \\
5.7 \\
5.6\end{array}$ & $\begin{array}{l}2.4 \\
3.0 \\
3.1 \\
3.0 \\
3.5 \\
3.1 \\
3.5\end{array}$ & $\begin{array}{l}0.8 \\
2.5 \\
2.6 \\
2.8 \\
2.5 \\
2.6 \\
2.5\end{array}$ & $\begin{array}{l}2.7 \\
2.5 \\
2.3 \\
2.2 \\
2.3 \\
2.2 \\
2.2\end{array}$ & $\begin{array}{r}620 \\
3130 \\
3560 \\
3099 \\
3239 \\
3349 \\
3545\end{array}$ & $\begin{array}{l}1.2 \\
1.3 \\
1.4 \\
2.0 \\
1.1 \\
1.8 \\
1.4\end{array}$ & $\begin{array}{r}101.0 \\
97.6 \\
96.9 \\
96.6 \\
96.8 \\
96.9 \\
96.9\end{array}$ \\
\hline
\end{tabular}

NATURALLY OCCURRING RADIOACTIVE ISOTOPES, by Gamma Energy Analysis

\begin{tabular}{|c|c|c|c|}
\hline $\begin{array}{l}\text { Sample } \\
\text { Serial } \\
\text { Number } \\
\end{array}$ & $\begin{array}{r}\quad 40_{K} \\
\mu \mathrm{Ci} / \mathrm{kg} \times 10^{-3} \\
\end{array}$ & $\begin{array}{c}{ }^{226} \mathrm{Ra}+\text { daughters } \\
\mu \mathrm{Ci} / \mathrm{kg} \times 10^{-3} \\
\end{array}$ & $\begin{array}{c}2^{228} \mathrm{Th}+\text { daughters } \\
\mu \mathrm{Ci} / \mathrm{kg} \times 10^{-3} \\
\end{array}$ \\
\hline $\begin{array}{l}\text { A1236 } \\
\text { A1235 }\end{array}$ & $\begin{array}{l}21.5 \pm 12 \% \\
18.0 \pm 12\end{array}$ & $\begin{array}{l}0.58 \pm 17 \% \\
0.58 \pm 18\end{array}$ & $\begin{array}{l}0.86 \pm 6.6 \% \\
0.95 \pm 6.6\end{array}$ \\
\hline $\begin{array}{l}A 1234 \\
A 1210 \\
A 1209 \\
A 1208 \\
A 1207 \\
A 1206 \\
A 1205 \\
A 1204 \\
A 1203 \\
A 1202\end{array}$ & $\begin{array}{r}9.5 \pm 15 \\
12.3 \pm 14 \\
10.0 \pm 14 \\
9.4 \pm 15 \\
8.6 \pm 16 \\
9.5 \pm 16 \\
9.5 \pm 15 \\
9.3 \pm 15 \\
9.6 \pm 15 \\
10.6 \pm 15\end{array}$ & $\begin{array}{l}0.50 \pm 19 \\
0.49 \pm 19 \\
0.42 \pm 19 \\
0.49 \pm 19 \\
0.48 \pm 17 \\
0.38 \pm 22 \\
0.32 \pm 23 \\
0.58 \pm 16 \\
0.35 \pm 20 \\
0.40 \pm 21\end{array}$ & $\begin{array}{l}0.58 \pm 7.0 \\
0.73 \pm 6.7 \\
0.55 \pm 6.9 \\
0.42 \pm 7.2 \\
0.69 \pm 6.8 \\
0.53 \pm 7.2 \\
0.50 \pm 7.8 \\
0.51 \pm 7.8 \\
0.44 \pm 7.3 \\
0.59 \pm 7.0\end{array}$ \\
\hline
\end{tabular}

TRACE ELEMENTS, by Neutron Activation Analysis

\begin{tabular}{|c|c|c|c|c|c|c|c|c|c|c|c|c|}
\hline $\begin{array}{l}\text { Serial } \\
\text { Number } \\
\end{array}$ & $\begin{array}{c}\mathrm{Nla} \\
\%\end{array}$ & $\begin{array}{l}\text { La } \\
\text { ppm }\end{array}$ & $\begin{array}{l}\text { Sm } \\
\mathrm{ppm}\end{array}$ & $\begin{array}{c}\mathrm{Fe} \\
\%\end{array}$ & $\begin{array}{l}\text { Co } \\
\mathrm{ppm}\end{array}$ & $\begin{array}{l}\text { Sc } \\
\text { ppm }\end{array}$ & $\begin{array}{l}\mathrm{Cr} \\
\mathrm{ppm}\end{array}$ & $\begin{array}{l}\text { Eu } \\
\mathrm{ppm}\end{array}$ & $\begin{array}{l}\text { Th } \\
\text { ppm }\end{array}$ & $\begin{array}{l}\text { Tb } \\
\text { ppm }\end{array}$ & $\begin{array}{l}\text { Hf } \\
\text { ppm }\end{array}$ & $\begin{array}{l}\mathrm{Ta} \\
\mathrm{ppm}\end{array}$ \\
\hline A1235 & 2.01 & 46 & 9.7 & 7.7 & 24 & 23 & 6 & 4.6 & 5.6 & 1.5 & 9.7 & 2.6 \\
\hline $\begin{array}{l}A 1234 \\
A 1204 \\
A 1203 \\
A 1202\end{array}$ & $\begin{array}{l}1.95 \\
1.97 \\
2.05 \\
2.03\end{array}$ & $\begin{array}{l}23 \\
26 \\
23 \\
28\end{array}$ & $\begin{array}{l}7.5 \\
7.4 \\
7.4 \\
8.0\end{array}$ & $\begin{array}{l}11.2 \\
10.9 \\
11.4 \\
11.1\end{array}$ & $\begin{array}{l}39 \\
37 \\
42 \\
36\end{array}$ & $\begin{array}{l}33 \\
34 \\
35 \\
35\end{array}$ & $\begin{array}{l}20 \\
23 \\
23 \\
16\end{array}$ & $\begin{array}{l}2.0 \\
2.2 \\
2.0 \\
2.3\end{array}$ & $\begin{array}{l}1.9 \\
2.3 \\
2.3 \\
2.2\end{array}$ & $\begin{array}{l}1.8 \\
1.4 \\
1.6 \\
1.4\end{array}$ & $\begin{array}{l}5.8 \\
4.5 \\
5.8 \\
4.9\end{array}$ & $\begin{array}{l}1.8 \\
1.7 \\
1.8 \\
2.1\end{array}$ \\
\hline $\begin{array}{l}A 1259 \\
A 1260 \\
A 1261 \\
A 1262 \\
A 1263 \\
A 1264 \\
A 1265\end{array}$ & $\begin{array}{l}1.97 \\
2.20 \\
2.30 \\
2.35 \\
2.40 \\
2.25 \\
2.30\end{array}$ & $\begin{array}{l}42 \\
42 \\
49 \\
44 \\
45 \\
49 \\
49\end{array}$ & $\begin{array}{r}11.0 \\
9.9 \\
10.3 \\
10.5 \\
10.3 \\
10.5 \\
10.6\end{array}$ & $\begin{array}{r}12.8 \\
9.4 \\
9.3 \\
10.0 \\
10.0 \\
9.1 \\
9.9\end{array}$ & $\begin{array}{l}50 \\
27 \\
24 \\
27 \\
26 \\
26 \\
24\end{array}$ & $\begin{array}{l}45 \\
26 \\
23 \\
26 \\
24 \\
24 \\
25\end{array}$ & $\begin{array}{r}225 \\
7 \\
7 \\
11 \\
10 \\
9 \\
12\end{array}$ & $\begin{array}{l}3.4 \\
3.5 \\
4.3 \\
4.7 \\
4.4 \\
4.1 \\
4.3\end{array}$ & $\begin{array}{l}0.9 \\
5.0 \\
5.6 \\
6.6 \\
6.0 \\
7.4 \\
6.0\end{array}$ & $\begin{array}{l}1.5 \\
- \\
1.1 \\
1.6 \\
1.2 \\
1.3 \\
1.8\end{array}$ & $\begin{array}{r}11.1 \\
11.7 \\
11.9 \\
13.0 \\
12.1 \\
9.2 \\
12.0\end{array}$ & $\begin{array}{l}4.3 \\
- \\
3.0 \\
3.5 \\
3.0 \\
2.8 \\
2.9\end{array}$ \\
\hline
\end{tabular}

TABLE B-V 
ARH-ST-137

\section{SELAH BUTTE FIELD SECTION}

Selah Butte is the highest point on a doubly plunging anticlinal ridge that trends northwest to southwest for a total length of about 40 kilometers. The ridge is bisected by the deeply incised antecedent Yakima River that flows from north to south forming the Roza Gap.

The top flow in the section is the Pomona Basalt Member of the Upper Yakima Basalts. Analyses from this flow agree with those of the nearby type locality to where the flow can be physically traced. [B-4]

Immediately below the Pomona Basalt Member is a diatomaceous interbed of variable thickness. The interbed overlies a porphyritic flow which can be physically traced to the Roza Basalt Member of the Middle Yakima Basalts at its type locality opposite Roza Station ${ }^{[\mathrm{B}-5]}$ The flow is approximately 30 meters thick and contains yellowish-green plagioclase phenocrysts up to $2 \mathrm{~cm}$ long.

Below the Roza Basalt Member and separated from it by a relatively thin interbed, are at least two more porphyritic flows of the Frenchman Springs Basalt chemical type of Wright, et a1. [B-1]

A distinct terrace marks an area of $\mathrm{TiO}_{2}$ contrast $\simeq 2.4 \%$ above and $\simeq 1.7 \%$ below the flows of the Frenchman Springs Basalt Member chemical type. This zone is the equivalent of the Vantage Sandstone Formation. The flows below the Vantage appear to be equivalent to the HIGH Mg chemical type of the Lower Yakima Basalts. [B-1] At the 480 meter elevation, flows of the LOW Mg chemical type of the Lower Yakima Basalts are found. [B-1]

Figure B-16 is a location map of the Selah Butte area, Figure B-17 is a cross-sectional drawing of the site and Table B-VI is a tabulation of analytical data. Figure B-18 is a photograph showing location of points sampled. 


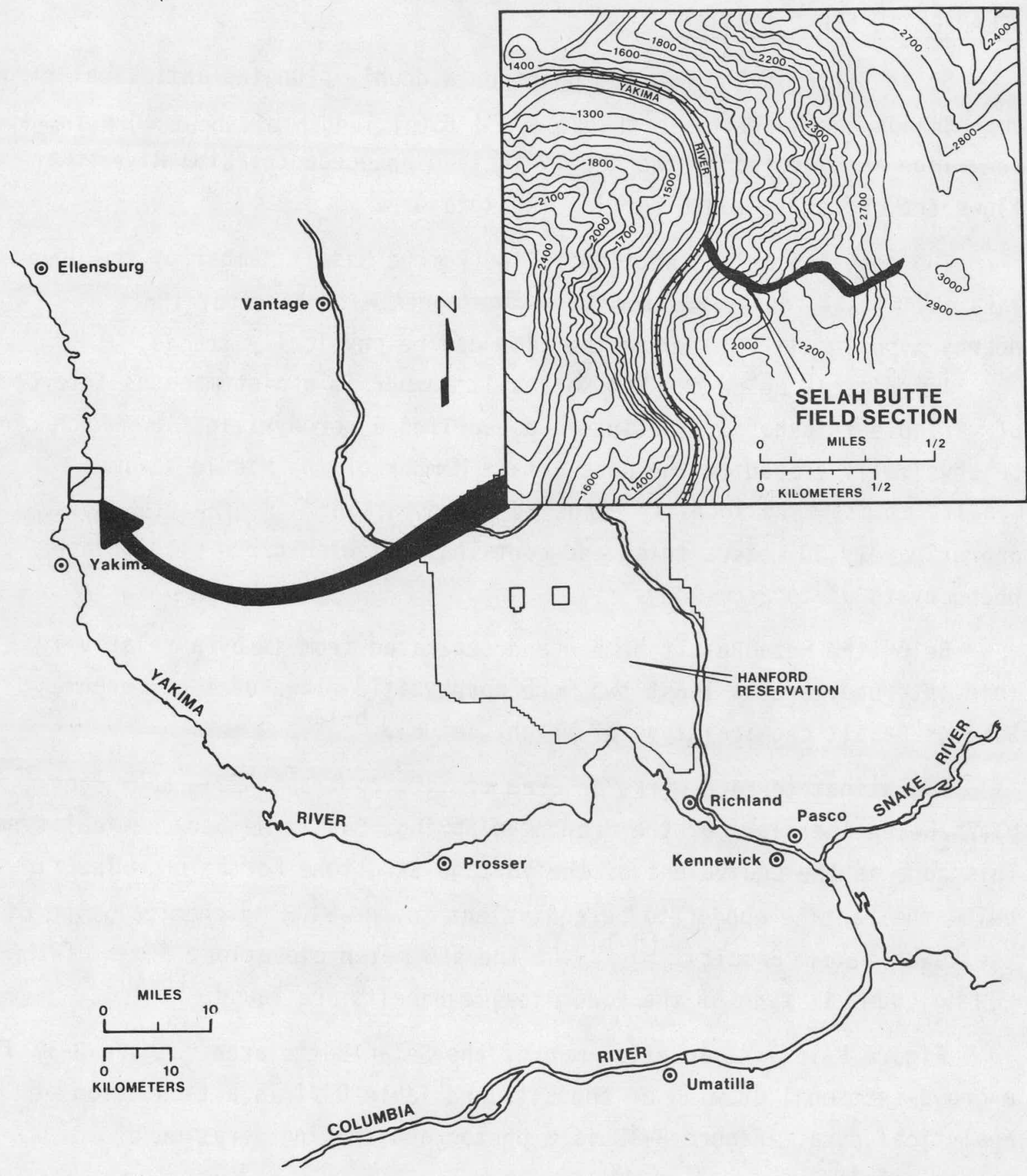

FIGURE B-16

LOCATION MAP OF SELAH BUTTE FIELD SECTION AREA 


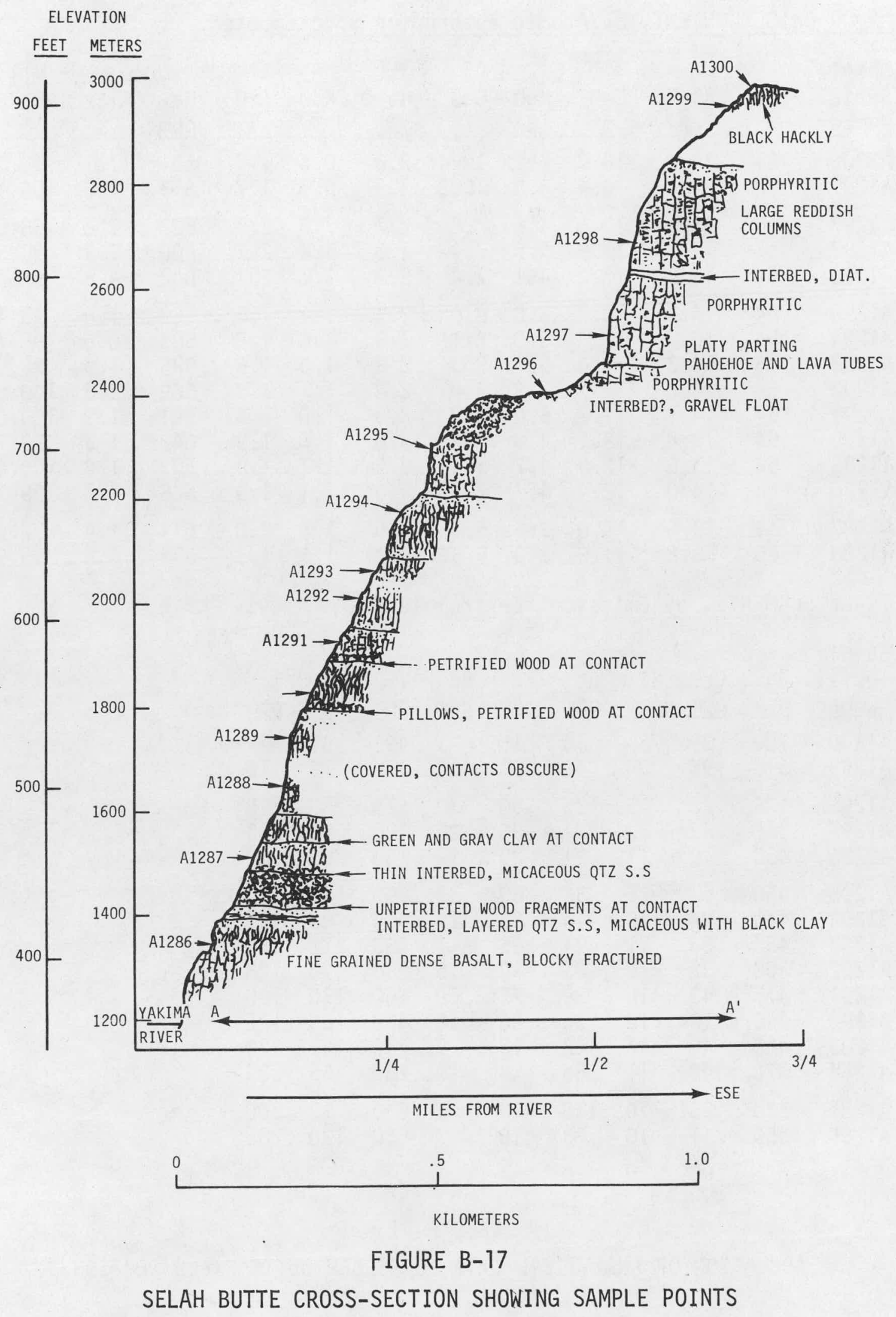


MAJOR OXIDE CONTENT, by Atomic Absorption Spectrometer

\begin{tabular}{|c|c|c|c|c|c|c|c|c|c|c|c|}
\hline $\begin{array}{l}\text { erial } \\
\text { umber }\end{array}$ & $\begin{array}{r}\mathrm{SiO}_{2} \\
\%\end{array}$ & $\begin{array}{l}\mathrm{Al}_{2}^{2} \mathrm{O}_{3} \\
\end{array}$ & $\begin{array}{c}\mathrm{Fe} 0 \\
\% \\
\end{array}$ & $\begin{array}{c}\mathrm{MgO} \\
\% \\
\end{array}$ & $\begin{array}{c}\mathrm{CaO} \\
\%\end{array}$ & $\begin{array}{l}\mathrm{Na}_{2} \mathrm{O} \\
\%\end{array}$ & $\begin{array}{l}\mathrm{K}_{2} \mathrm{O} \\
\%\end{array}$ & $\begin{array}{l}\mathrm{TiO}_{2} \\
\% \\
\end{array}$ & $\begin{array}{l}\mathrm{Ba} \\
\mathrm{ppm}\end{array}$ & $\begin{array}{c}\text { Vity } \\
\% \\
\end{array}$ & $\begin{array}{c}\mathrm{Mtl} \\
\mathrm{Bal} \\
\%\end{array}$ \\
\hline $\begin{array}{r}A 1300 \\
A 1299\end{array}$ & $\begin{array}{l}51 \\
52\end{array}$ & $\begin{array}{l}14.2 \\
14.6\end{array}$ & & $\begin{array}{l}7.2 \\
6.8\end{array}$ & $\begin{array}{l}10.4 \\
10.2\end{array}$ & $\begin{array}{l}2.3 \\
2.3\end{array}$ & $\begin{array}{l}0.5 \\
0.5\end{array}$ & $\begin{array}{l}1.7 \\
1.7\end{array}$ & & $\begin{array}{l}1.1 \\
1.7\end{array}$ & $\begin{array}{r}99.1 \\
100.1\end{array}$ \\
\hline $\begin{array}{l}A 1298 \\
\text { A1297 }\end{array}$ & & & & $\begin{array}{l}4.6 \\
4.5 \\
4.1\end{array}$ & & & $\begin{array}{l}1.3 \\
1.4 \\
1.1\end{array}$ & & & $\begin{array}{l}2.2 \\
2.2 \\
4.8\end{array}$ & $\begin{array}{l}98.0 \\
98.3 \\
98.4\end{array}$ \\
\hline $\begin{array}{r}A 1295 \\
\text { A1294 } \\
\text { A1293 } \\
\text { A1292 } \\
A 1291 \\
A 1290 \\
\text { A1289 } \\
\text { A1288 }\end{array}$ & $\begin{array}{l}54 \\
54 \\
53 \\
54 \\
54 \\
54 \\
54 \\
54\end{array}$ & $\begin{array}{l}14.1 \\
13.8 \\
14.2 \\
14.0 \\
14.1 \\
13.8 \\
13.8 \\
14.0\end{array}$ & $\begin{array}{l}10.8 \\
11.4 \\
11.4 \\
11.7 \\
11.2 \\
12.1 \\
12.3 \\
12.4\end{array}$ & $\begin{array}{l}5.0 \\
5.0 \\
5.7 \\
5.2 \\
5.0 \\
4.9 \\
4.7 \\
4.7\end{array}$ & $\begin{array}{l}8.0 \\
8.1 \\
8.3 \\
8.0 \\
8.0 \\
7.7 \\
7.5 \\
7.5\end{array}$ & $\begin{array}{l}2.7 \\
2.9 \\
2.8 \\
2.8 \\
2.9 \\
3.0 \\
2.9 \\
3.0\end{array}$ & $\begin{array}{l}1.1 \\
1.0 \\
1.0 \\
1.1 \\
1.0 \\
1.0 \\
1.1 \\
1.1\end{array}$ & $\begin{array}{l}1.7 \\
1.8 \\
1.8 \\
1.8 \\
1.9 \\
1.9 \\
1.9 \\
1.9\end{array}$ & $\begin{array}{l}569 \\
583 \\
525 \\
569 \\
591 \\
642 \\
583 \\
578\end{array}$ & $\begin{array}{l}1.0 \\
0.6 \\
1.9 \\
2.3 \\
1.9 \\
1.3 \\
1.8 \\
1.1\end{array}$ & $\begin{array}{r}98.4 \\
98.7 \\
99.5 \\
100.9 \\
100.0 \\
99.7 \\
100.0 \\
99.7\end{array}$ \\
\hline $\begin{array}{l}287 \\
2886\end{array}$ & 54 & & & 3.6 & & $\begin{array}{l}3.0 \\
3.1\end{array}$ & $\begin{array}{l}1.6 \\
1.6\end{array}$ & & & $\begin{array}{l}1.4 \\
1.6\end{array}$ & 976 \\
\hline
\end{tabular}

TRACE ELEMENTS, by Emission Spectrometer

\begin{tabular}{|c|c|c|c|c|c|c|c|c|c|}
\hline $\begin{array}{l}\text { Serial } \\
\text { Number }\end{array}$ & $\begin{array}{l}\mathrm{Ba} \\
\mathrm{ppm}\end{array}$ & $\begin{array}{l}\mathrm{Cr} \\
\mathrm{ppm}\end{array}$ & $\begin{array}{l}\mathrm{Ni} \\
\mathrm{ppm}\end{array}$ & $\begin{array}{l}\mathrm{Rb} \\
\mathrm{ppm}\end{array}$ & $\begin{array}{l}\mathrm{Sc} \\
\mathrm{ppm}\end{array}$ & $\begin{array}{l}\text { Sn } \\
\text { ppm }\end{array}$ & $\begin{array}{l}V \\
\text { ppm }\end{array}$ & $\begin{array}{l}\mathrm{Zn} \\
\mathrm{ppm}\end{array}$ & $\begin{array}{l}\mathrm{Zr} \\
\mathrm{ppm}\end{array}$ \\
\hline 1300 & & & & & & $\begin{array}{l}<1 \\
10\end{array}$ & $\begin{array}{l}495 \\
475\end{array}$ & $\begin{array}{l}51 \\
70\end{array}$ & \\
\hline $\begin{array}{l}1297 \\
1296\end{array}$ & & & & & & & & $\begin{array}{r}50 \\
90 \\
250\end{array}$ & \\
\hline $\begin{array}{l}295 \\
294 \\
293 \\
292 \\
292 \\
291 \\
290 \\
289 \\
280\end{array}$ & $\begin{array}{l}450 \\
410 \\
450 \\
300 \\
475 \\
440 \\
480 \\
370\end{array}$ & $\begin{array}{l}53 \\
24 \\
53 \\
32 \\
43 \\
19 \\
48 \\
42\end{array}$ & $\begin{array}{r}15 \\
<10 \\
11 \\
<10 \\
<10 \\
<10 \\
15 \\
11\end{array}$ & $\begin{array}{l}35 \\
14 \\
21 \\
25 \\
39 \\
35 \\
42 \\
83\end{array}$ & $\begin{array}{l}60 \\
25 \\
65 \\
30 \\
75 \\
80 \\
15 \\
14\end{array}$ & $\begin{array}{r}30 \\
15 \\
<1 \\
15 \\
19 \\
18 \\
9 \\
10\end{array}$ & $\begin{array}{l}690 \\
400 \\
590 \\
580 \\
660\end{array}$ & $\begin{array}{r}160 \\
80 \\
12 \\
90 \\
130 \\
135 \\
135 \\
55\end{array}$ & \\
\hline & & $\begin{array}{r}23 \\
1\end{array}$ & $<10$ & $\begin{array}{r}110 \\
83\end{array}$ & & & 850 & 120 & \\
\hline
\end{tabular}

TABLE B-VI

TABULATION OF ANALYTICAL DATA FOR SELAH BUTTE FIELD SECTION 


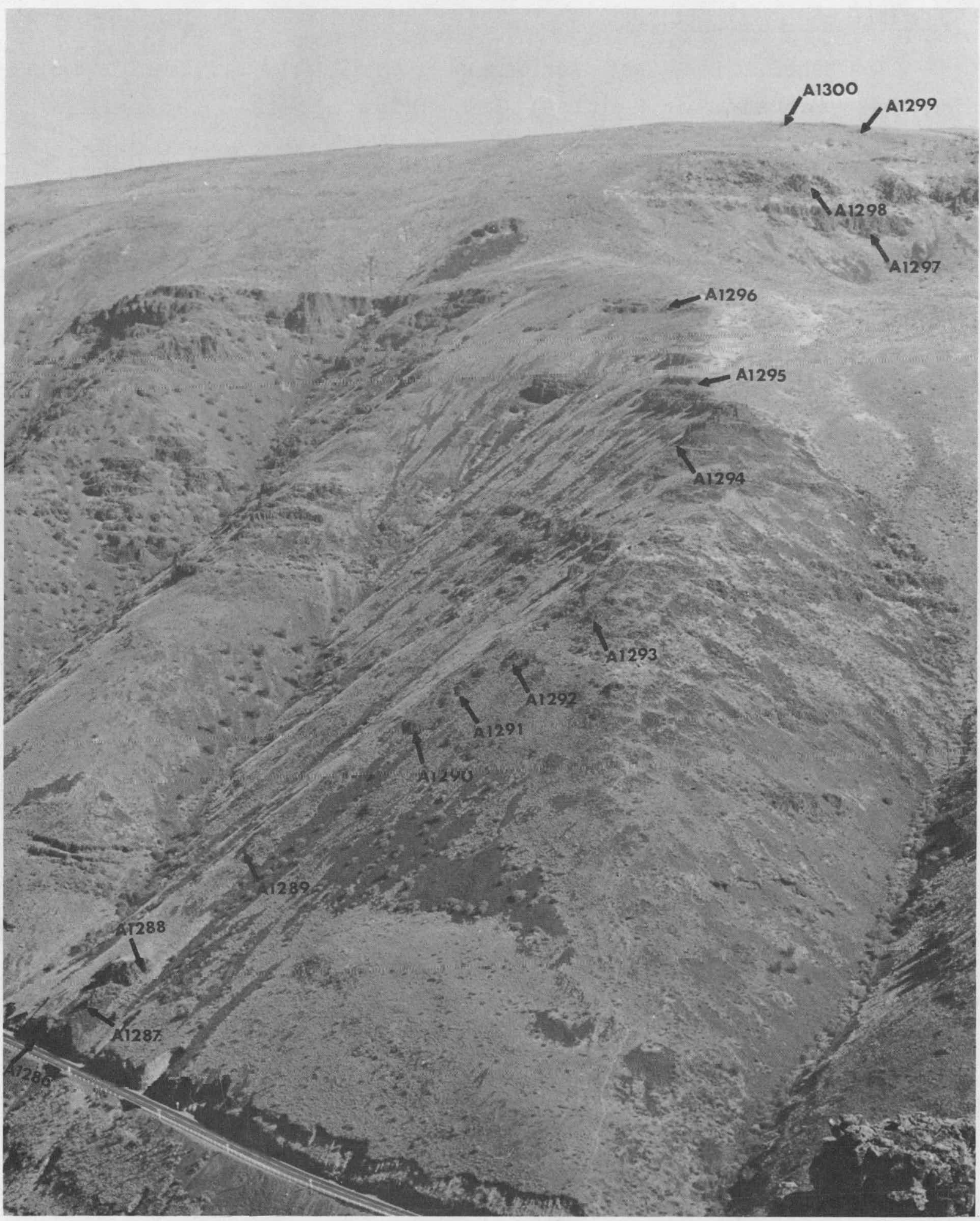

FIGURE B-18

PHOTOGRAPH OF SELAH BUTTE FIELD SECTION SHOWING SAMPLE POINT LOCATION 


\section{SENTINEL GAP FIELD SECTION}

The Sentinel Gap, East section was taken SSE from the Columbia River on the east side of Sentinel Gap, (Figure B-19. Location Map). Sentinel Gap was cut north-south by the antecedent Columbia River through the east-west trending Saddle Mountains anticline.

The section was taken across a series of flows dipping fairly steeply to the south at the southern leg and becoming essentially level in the core of the anticline. The cross-section is a diagrammatic composite section and is not to true horizontal scale. Thickness is shown as approximate stratigraphic thickness and is not directly related to true elevations.

This section may be related to that of Mackin in this area. ${ }^{[B-5]}$ He designated the upper flows of the scarp on the east side of the gap as "Saddle Mountains Basalt Member of the Ellensburg Formation". Chemical analyses from these flows are comparable to those of the Elephant Mountain Basalt Member type localities. Mackin designated the thick interbed below the upper flows "Beverly Member". [B-5]

Underlying the Beverly Member interbed are at least two flows of the Priest Rapids Basalt Member of Mackin. [B-5] The Priest Rapids flows are above a series of porphyritic flows which are of Roza-Frenchman Springs Basalt Member chemical type. ${ }^{[B-1]}$

The Vantage Sandstone Formation occurs in isolated outcrops in the section area and lies upon the characteristic erosional bench of the HIGH Mg Lower Yakima chemical type. ${ }^{[B-1]}$ Flows of the LOW Mg chemical type of the lower Yakima Basalts ${ }^{[B-1]}$ are encountered near the level of the Columbia River in the anticlinal core.

Figure B-19 is a location map of the area and Figure B-20 is a cross-section showing sample points and lithology. Figure B-21 is a composite photograph showing the location of points sampled. Table B-VII is a tabulation of analytical data. Two points, (A1308 and A1309), were sampled for lateral stratigraphic correlation and are shown in Figure B-21 and Table B-VII but were not used for construction of the cross-section. 


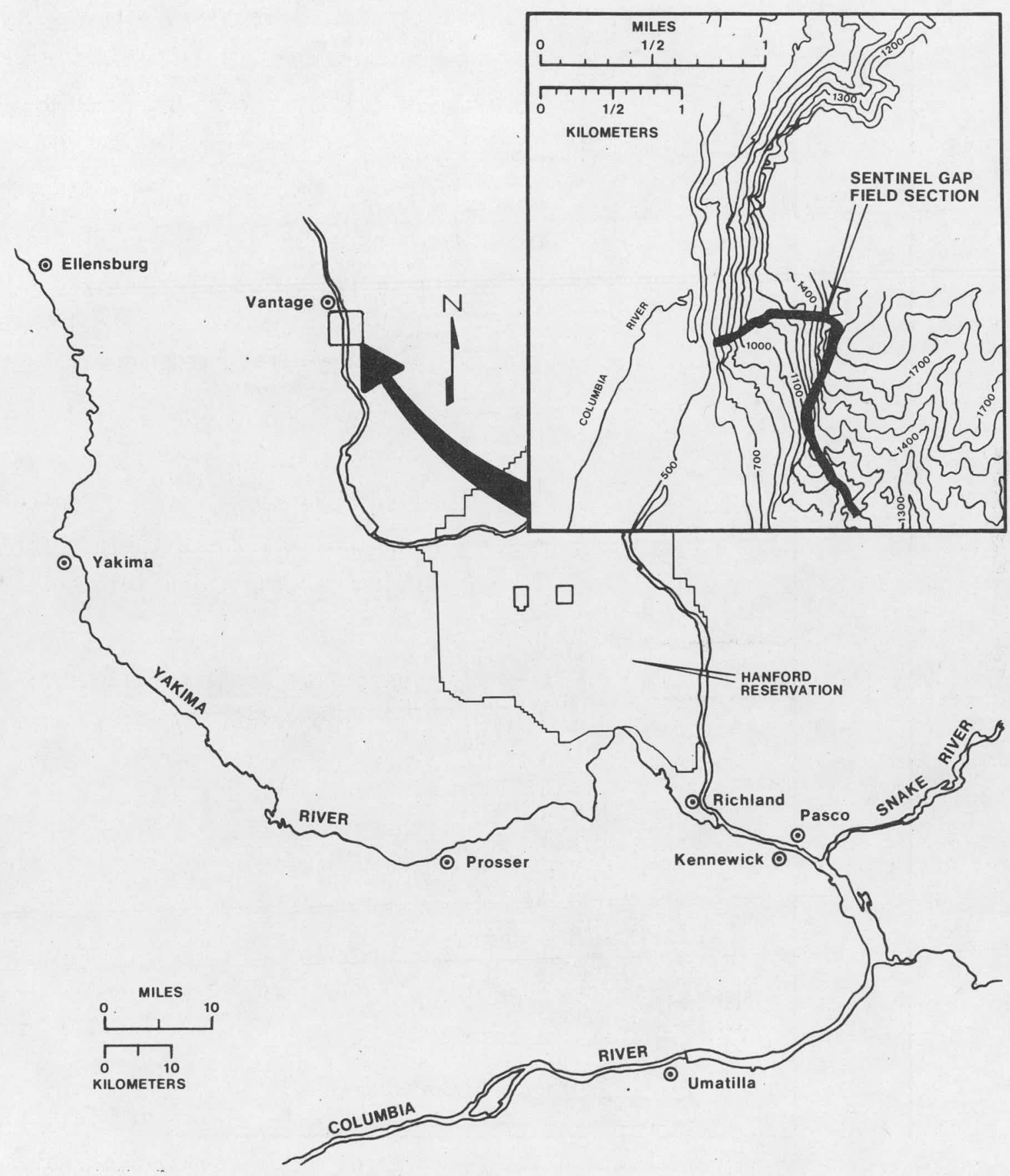

FIGURE B-19

LOCATION MAP FOR THE SENTINEL GAP, EAST FIELD SECTION AREA 
STRATIGRAPHIC
THICKNESS

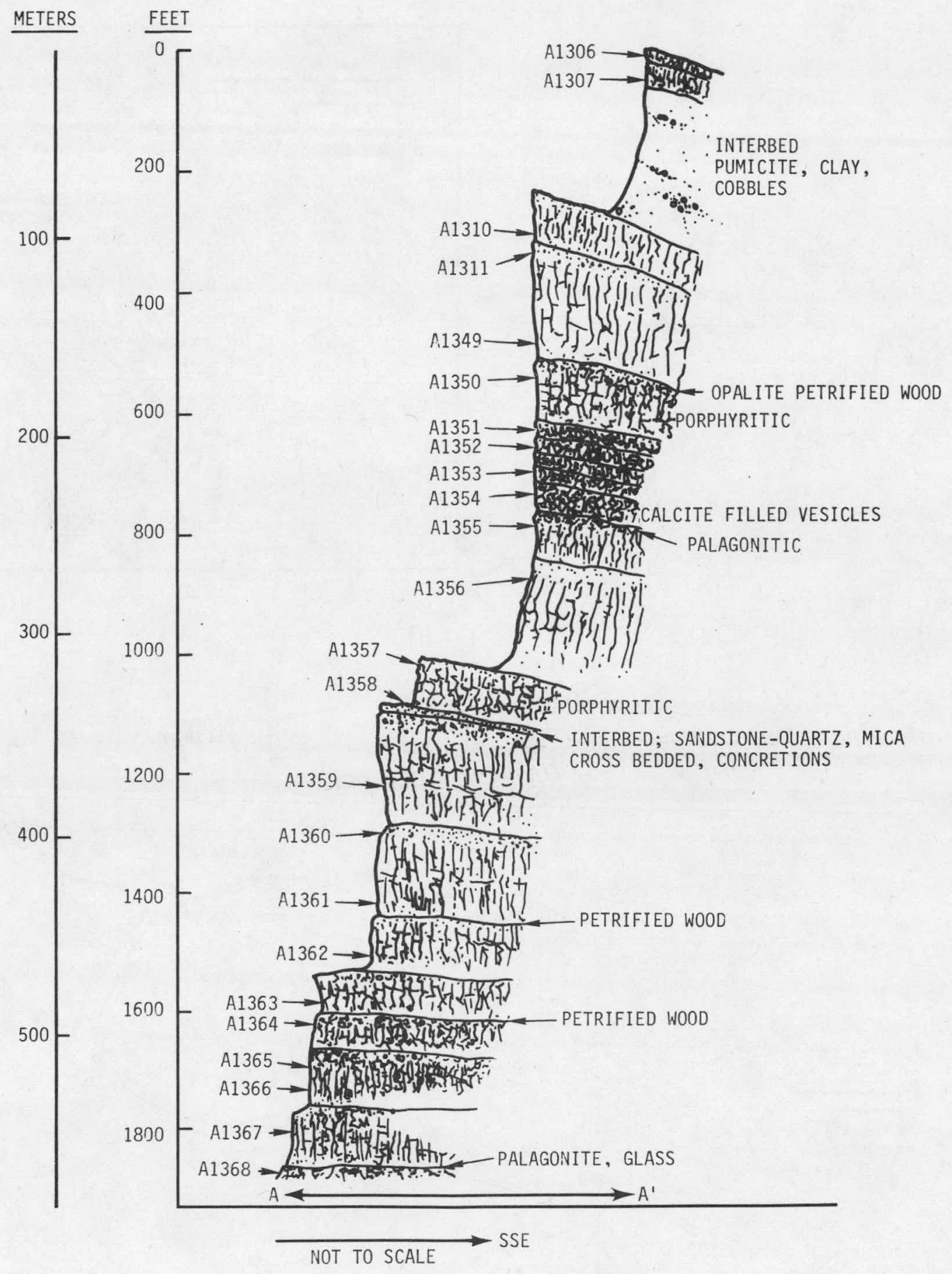

FIGURE B-20

SENTINEL GAP, EAST COMPOSITE CROSS-SECTION SHOWING SAMPLE POINTS 


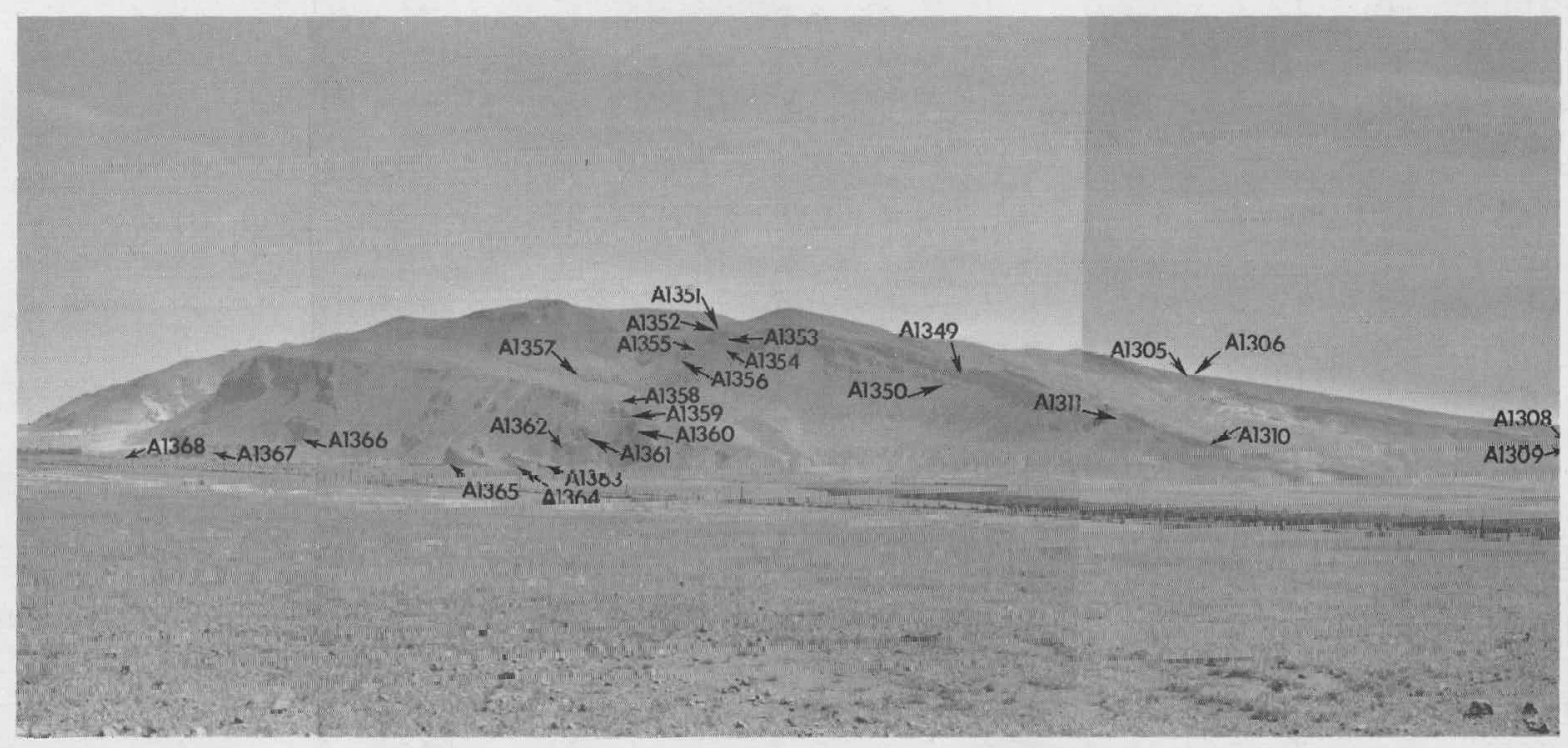

FIGURE B-21

PHOTOGRAPH OF THE SENTINEL GAP, EAST FIELD SECTION SHOWING SAMPLE POINTS 
MAJOR OXIDE CONTENT, by Atomic Absorption Spectrometer

\begin{tabular}{|c|c|c|c|c|c|c|c|c|c|c|c|}
\hline $\begin{array}{l}\text { mple } \\
\text { erial } \\
\text { imber }\end{array}$ & $\begin{array}{r}\mathrm{SiO}^{2} \\
\% \\
\end{array}$ & $\begin{array}{c}\mathrm{Al}_{2} \mathrm{O}_{3} \\
\end{array}$ & $\begin{array}{l}\mathrm{Fe} 0 \\
\%\end{array}$ & $\begin{array}{c}\mathrm{MgO} 0 \\
\% \\
\end{array}$ & $\begin{array}{c}\mathrm{CaO} \\
\% \\
\end{array}$ & $\begin{array}{c}\mathrm{Na}_{2} \mathrm{O} \\
\% \\
\end{array}$ & $\begin{array}{l}\mathrm{K}_{2} \mathrm{O} \\
\% \\
\end{array}$ & $\begin{array}{r}\mathrm{TiO}_{2} \\
\% \\
\end{array}$ & $\begin{array}{r}\mathrm{Ba} \\
\mathrm{ppm}\end{array}$ & $\begin{array}{c}\text { V1ty } \\
\% \\
\end{array}$ & $\begin{array}{c}\mathrm{Mtl} \\
\mathrm{Bal} \\
\%\end{array}$ \\
\hline & & & & & & & & & & & $\begin{array}{l}98.1 \\
99.6 \\
98.4 \\
98.3\end{array}$ \\
\hline & & & & & & & & & & $\begin{array}{l}4.4 \\
1.4 \\
1.4\end{array}$ & $\begin{array}{r}98.9 \\
99.2 \\
101.7 \\
102.2\end{array}$ \\
\hline . & & & & $\begin{array}{l}4.6 \\
4.3 \\
4.8 \\
4.7 \\
4.6 \\
4.8 \\
4.5 \\
4.9\end{array}$ & & & 1.3 & & $\begin{array}{r}1550 \\
775 \\
735 \\
788 \\
788 \\
634 \\
808\end{array}$ & $\begin{array}{l}1.7 \\
3.1 \\
1.0 \\
1.7 \\
0.8 \\
1.6 \\
2.1 \\
1.0\end{array}$ & $\begin{array}{r}100.3 \\
101.8 \\
99.5 \\
100.8 \\
99.4 \\
100.8 \\
101.0 \\
102.3\end{array}$ \\
\hline . & $\begin{array}{l}54 \\
55 \\
54 \\
54 \\
54 \\
54 \\
54 \\
54 \\
55\end{array}$ & & $\begin{array}{l}11.4 \\
11.9 \\
11.6 \\
12.1 \\
12.1 \\
12.1 \\
12.4 \\
13.0\end{array}$ & $\begin{array}{l}5.1 \\
5.4 \\
5.3 \\
5.7 \\
5.6 \\
5.6 \\
5.6 \\
5.2 \\
5.1\end{array}$ & & & $\begin{array}{l}0 . \\
1 . \\
0.8 \\
0 . \\
1 . \\
1 .\end{array}$ & & $\begin{array}{l}700 \\
689 \\
560 \\
565 \\
630 \\
646 \\
578 \\
606 \\
613\end{array}$ & $\begin{array}{l}2.4 \\
1.7 \\
2.1 \\
1.8 \\
1.6 \\
2.6 \\
2.6 \\
1.6 \\
1.0\end{array}$ & $\begin{array}{r}99.8 \\
101.0 \\
101.8 \\
101.1 \\
100.9 \\
102.5 \\
102.5 \\
100.2 \\
101.8\end{array}$ \\
\hline 368 & 57 & 13.5 & 12.6 & 3.8 & 6.7 & 3.2 & 1.4 & L.U & 11 & 1.2 & 101.4 \\
\hline
\end{tabular}




\section{DEVIL'S CANYON FIELD SECTION}

This section was taken on the east bank of Devil's Canyon about one mile south of Kahlotus. Bingham and Walters ${ }^{[B-6]}$ constructed a section in this area that showed:

- Priest Rapids Basalt Member - one flow, $15.2 \pm 0.3$ meters thick

- Roza Basalt Member - two flows, $49 \pm 5$ meters thick

- Frenchmans Springs Basalt Member - six flows, $81 \pm 5$ meters thick

Chemical data and petrologic descriptions from this section do not conflict with the referenced section with the exception of three flows of Roza Basalt phenocryst type and five of non-porphyritic or Frenchman Springs Basalt phenocryst type.

The upper flow is chemically similar to the Priest Rapids IV flow at Priest Rapids Dam in that it is higher in MgO and chromium than the other flows in the section. The lower flows cannot be differentiated as Roza or Frenchman Springs Basalt chemical type.

Figure B-22 is a location map of the section, Figure B-23 is a photograph of the section showing the location of points sampled, Figure B-24 is a lithologic cross-section, and Table B-VIII is a tabulation of analytical data. 


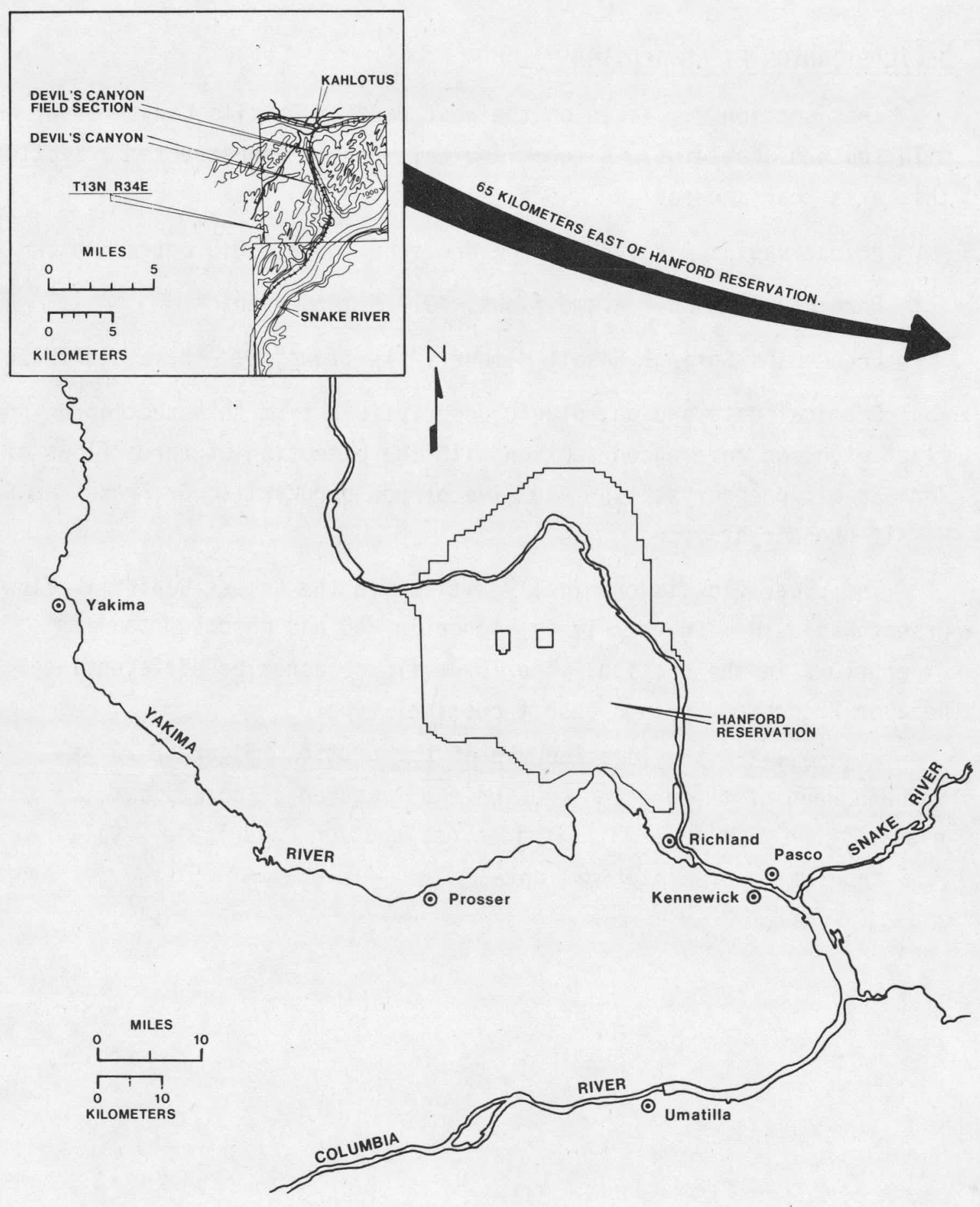

FIGURE B-22

LOCATION MAP SHOWING DEVIL'S CANYON FIELD SECTION AREA 


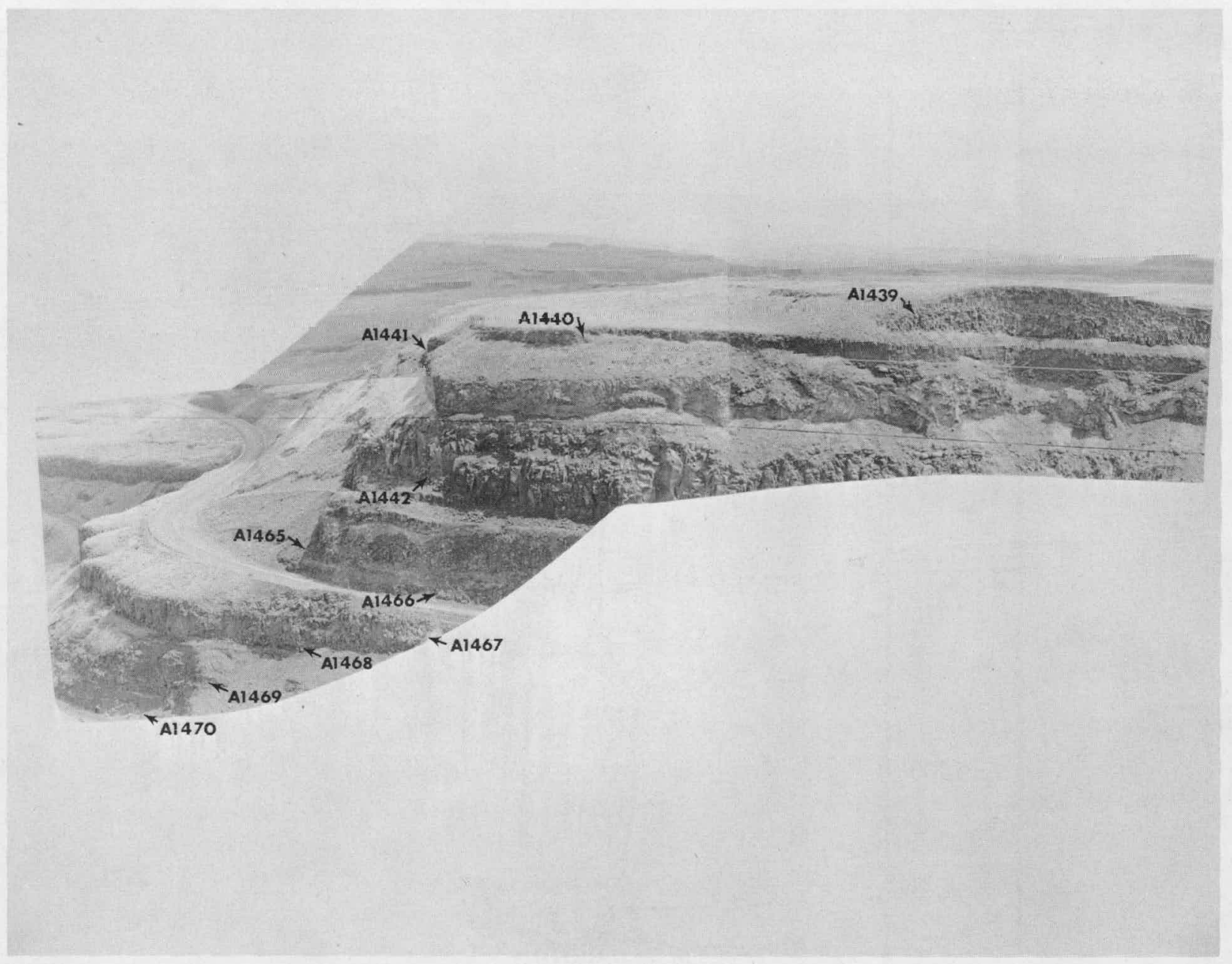

FIGURE B-23

PHOTOGRAPH OF DEVIL'S CANYON FIELD SECTION AREA SHOWING SAMPLE POINTS 
ELEVATION

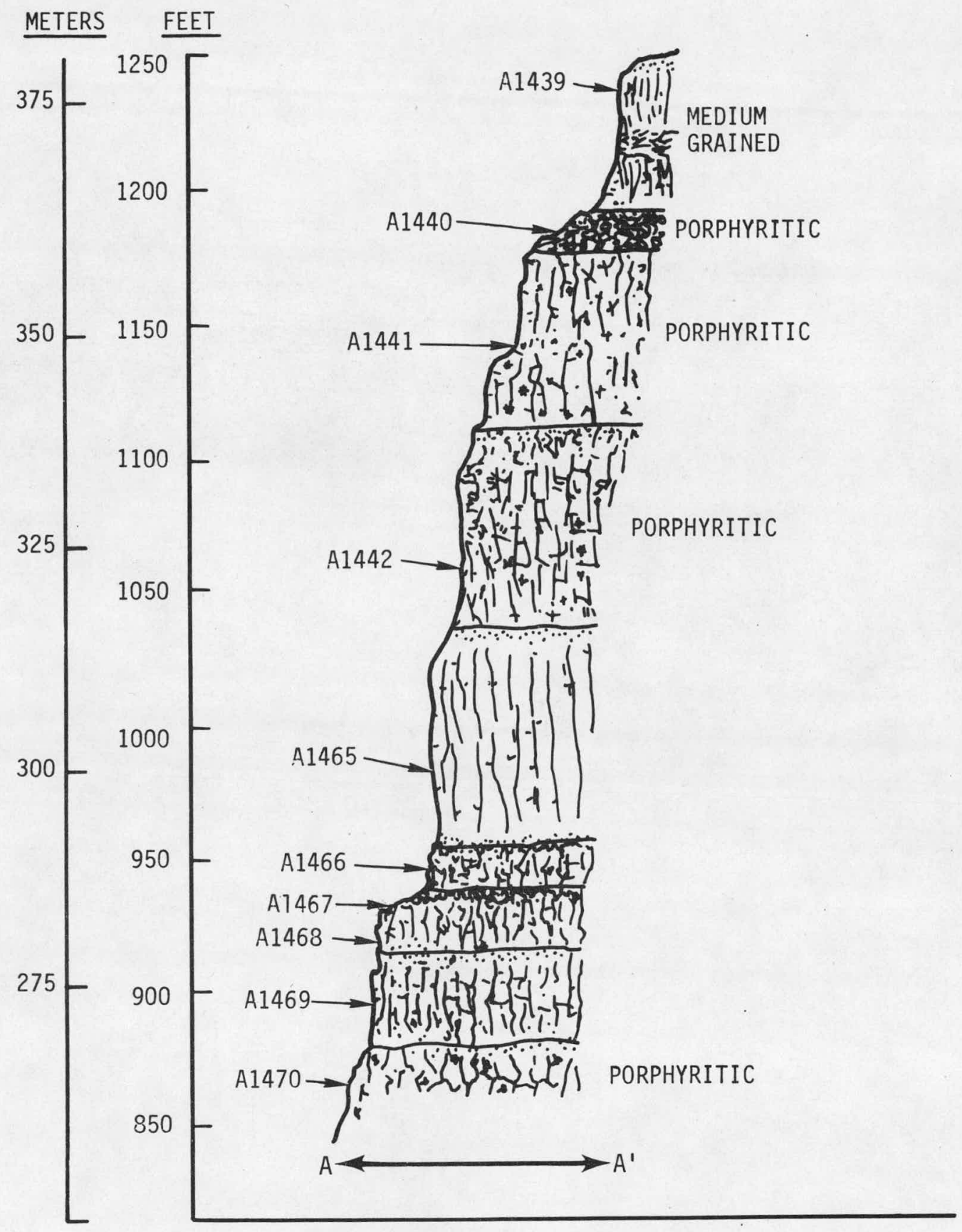

FIGURE B-24

DEVIL'S CANYON CROSS-SECTION SHOWING SAMPLE POINTS 
MAJOR OXIDES AND TRACE ELEMENTS, by Atomic Absorption Spectrometer

\begin{tabular}{|c|c|c|c|c|c|c|c|c|c|c|c|}
\hline $\begin{array}{l}\text { Sample } \\
\text { Serial } \\
\text { Number } \\
\end{array}$ & $\begin{array}{c}\mathrm{SiO}_{2} \\
\% \\
\end{array}$ & $\begin{array}{c}\mathrm{Al}_{2}^{2} \mathrm{O}_{3} \\
\end{array}$ & $\begin{array}{c}\mathrm{FeO} \\
\% \\
\end{array}$ & $\begin{array}{c}\mathrm{Mg0} \\
\% \\
\end{array}$ & $\begin{array}{c}\mathrm{CaO} \\
\% \\
\end{array}$ & $\begin{array}{c}\mathrm{Na}_{2} \mathrm{O} \\
\% \\
\end{array}$ & $\begin{array}{l}\mathrm{K}_{20} 0 \\
\% \\
\end{array}$ & $\begin{array}{r}\mathrm{TiO} 2 \\
\% \\
\end{array}$ & $\begin{array}{l}\mathrm{Ba} \\
\mathrm{ppm}\end{array}$ & $\begin{array}{l}\text { VIty } \\
\% \\
\end{array}$ & $\begin{array}{c}M \mathrm{t} 1 \\
\mathrm{Ba} 1 \\
\% \\
\end{array}$ \\
\hline $\begin{array}{l}\text { A1440 } \\
\text { A1441 } \\
\text { A1442 } \\
\text { A1465 } \\
\text { A1466 } \\
\text { A1467 } \\
\text { A1468 } \\
\text { A } 1469\end{array}$ & $\begin{array}{l}51 \\
50 \\
51 \\
48 \\
50 \\
52 \\
53 \\
51 \\
51 \\
50.2\end{array}$ & $\begin{array}{l}13 . \\
12 . \\
12 . \\
12 . \\
12 . \\
13 . \\
12 . \\
12 . \\
12 .\end{array}$ & $\begin{array}{r}14.2 \\
13.7 \\
14.0 \\
13.0 \\
14.1 \\
14.0 \\
11.2 \\
14.8 \\
13.5 \\
14.6\end{array}$ & $\begin{array}{l}5.6 \\
4.9 \\
4.5 \\
4.4 \\
5.0 \\
4.2 \\
3.7 \\
4.3 \\
4.6 \\
4.4\end{array}$ & $\begin{array}{l}8.9 \\
8.7 \\
8.3 \\
7.4 \\
8.0 \\
7.8 \\
8.3 \\
7.9 \\
8.1 \\
8.2\end{array}$ & $\begin{array}{l}2.5 \\
2.8 \\
2.6 \\
2.6 \\
2.7 \\
2.6 \\
3.0 \\
2.9 \\
2.7 \\
2.8\end{array}$ & $\begin{array}{l}0.8 \\
1.0 \\
0.9 \\
0.9 \\
1.1 \\
1.5 \\
1.7 \\
1.4 \\
1.5 \\
1.1\end{array}$ & $\begin{array}{l}3.0 \\
2.8 \\
3.0 \\
2.7 \\
2.9 \\
3.0 \\
2.9 \\
2.7 \\
2.7 \\
2.9\end{array}$ & $\begin{array}{l}671 \\
634 \\
656 \\
600 \\
679 \\
730 \\
750 \\
700 \\
644 \\
673\end{array}$ & $\begin{array}{l}0.9 \\
1.2 \\
2.0 \\
6.2 \\
1.0 \\
0.4 \\
0.8 \\
0.2 \\
1.8 \\
0.5\end{array}$ & $\begin{array}{r}98 \\
99 \\
97 \\
-97 \\
98 \\
98 \\
97 \\
98 \\
98\end{array}$ \\
\hline
\end{tabular}

\begin{tabular}{|c|c|c|c|c|c|}
\hline $\begin{array}{l}\text { Sample } \\
\text { Serial } \\
\text { Number }\end{array}$ & $\begin{array}{c}\mathrm{MnO} \\
\% \\
\end{array}$ & $\begin{array}{c}\text { Sro } \\
\% \\
\end{array}$ & $\begin{array}{c}\mathrm{P}_{2} \mathrm{O}_{5} \\
\% \\
\end{array}$ & $\begin{array}{l}\mathrm{Cr} \\
\text { ppm }\end{array}$ & $\begin{array}{l}\mathrm{Rb} \\
\mathrm{ppm}\end{array}$ \\
\hline $\begin{array}{l}\text { A1439 } \\
\text { A1440 } \\
\text { A1441 } \\
\text { A1 } 442 \\
\text { A1465 } \\
\text { A1466 } \\
\text { A1467 } \\
\text { A1468 } \\
\text { A1469 } \\
\text { A } 1470\end{array}$ & $\begin{array}{l}0.25 \\
0.22 \\
0.22 \\
0.19 \\
0.23 \\
0.23 \\
0.19 \\
0.25 \\
0.23 \\
0.24\end{array}$ & $\begin{array}{l}0.03 \\
0.04 \\
0.04 \\
0.03 \\
0.04 \\
0.04 \\
0.04 \\
0.04 \\
0.04 \\
0.04\end{array}$ & $\begin{array}{l}0.523 \\
0.447 \\
0.496 \\
0.250 \\
0.584 \\
0.444 \\
0.592 \\
0.623 \\
0.528 \\
0.448\end{array}$ & $\begin{array}{l}92 \\
41 \\
73 \\
50 \\
43 \\
43 \\
17 \\
56 \\
55 \\
46\end{array}$ & $\begin{array}{l}11 \\
11 \\
11 \\
16 \\
16 \\
16 \\
37 \\
37 \\
16 \\
42\end{array}$ \\
\hline
\end{tabular}




\section{REFERENCES}

B-1 T. L. Wright, J. J. Grolier and D. A. Swanson, Chemical Variations Related to the Stratigraphy of the Columbia River Basalt, Geol. Soc., BuIT., 84:371-386 (1973).

B-2 W. H. Laval, Stratigraphy and Structural Geology of portions of South-Central Washington, Ph.D. Dissertation, University of Washington, Seattle, WA (1956).

B-3 D. A. Swanson and others, Feeder Dikes for Yakima Basalt Near Pasco, Washington [abs.], Geol. Soc., America, Abstracts with Programs, vols. 4-3:245 (1972).

B-4 H. U. Schmincke, Stratigraphy and Petrography of Four Upper Yakima Basalt Flows in South-Central Washington, Geol. Soc., of America Bul1., 78:1385-1422, (1967).

B-5 J. H. Mackin, A Stratigraphic Section in the Yakima Basalt and The Ellensburg formation in South-Central Washington, Washington Division Mines and Geology, Invest Report 19 (1961).

B-6 J. W. Bingham and K. L. Walters, Stratigraphy for the Upper Part of the Yakima Basalt in Whitman and Eastern Franklin Counties, Washington, U.S. Geol. Survey Prof. Paper 525-C:C87-690 (1965). 


\section{APPENDIX C}

\section{CORE HOLE LITHOLOGY AND ANALYTICAL DATA}

Appendix $C$ contains the lithologic description of the rock cores and analytical results from samples of the five continuous diamond drilled core holes located on or adjacent to the Hanford Reservation as shown in Chapter II, Figure 3.

The lithology is given diagramatically along with a brief description of the rock, the width of the diagram represents the density of the rock--the wider the diagram the denser the rock (Figure $\mathrm{C}-\mathrm{l}$ ). The sample numbers are recorded at the depths at which they were taken and the results of the analyses are listed to correspond to the sample number and depth. Analyses included major elements reported as oxides with concentrations given in weight percent; trace element concentrations are given as parts of the element per million parts of rock; natural gamma radioactivity quantities are reported as nanocuries per kilogram of rock, and radiogenic ages are given in millions of years before present. While the results of point counting are indicated as plagioclase to pyroxene ratio (pl/pr ratio), data from the petrographic studies are yet to be evaluated. Radiogenic dates were determined from the ratios of potassium -40 to argon -40 . 

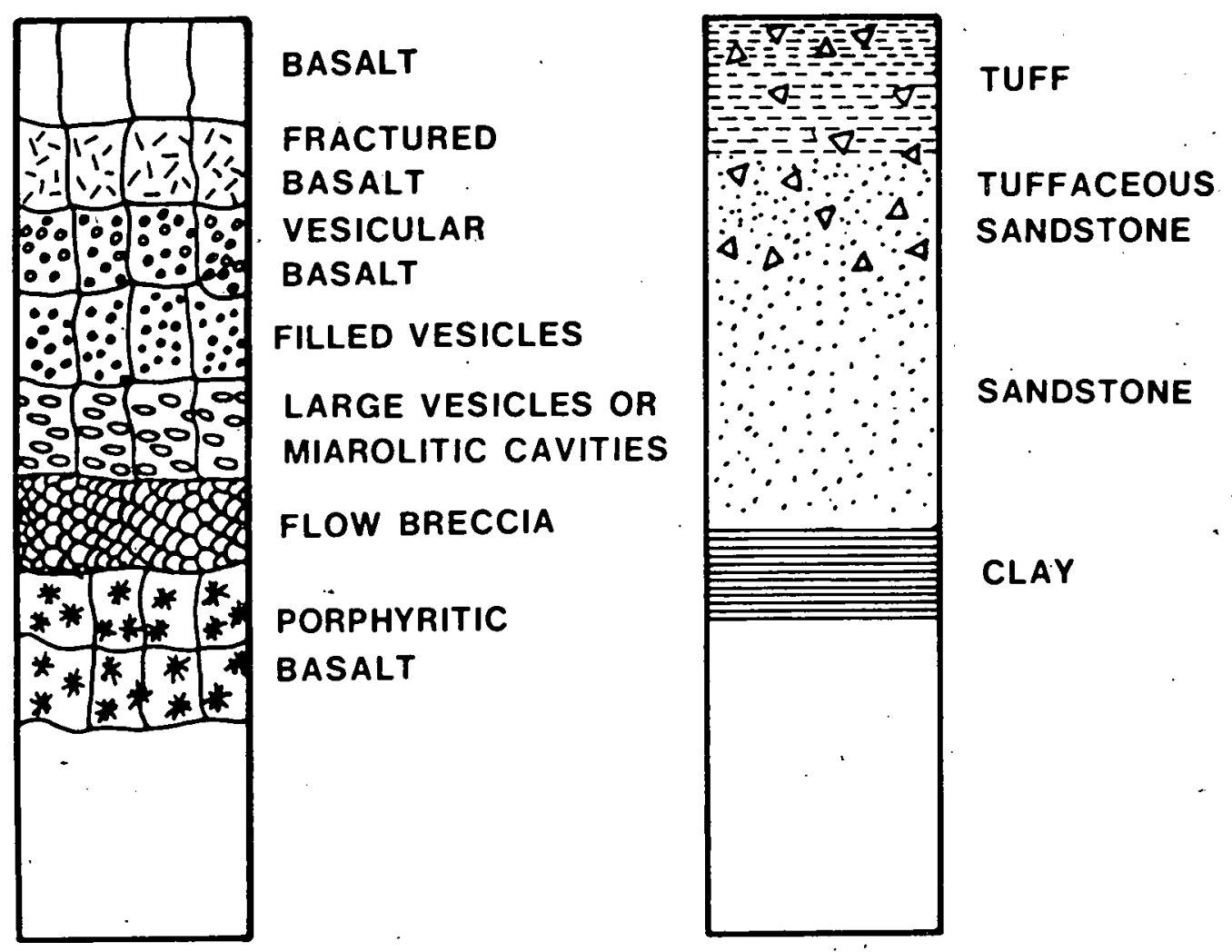

RELATIVE

DENSITY

FRACTURED

BASALT

VESICULAR

BASALT

FILLED VESICLES

LARGE VESICLES OR

MIAROLITIC CAVITIES

FLOW BRECCIA

PORPHYRITIC

BASALT

FIGURE C-I

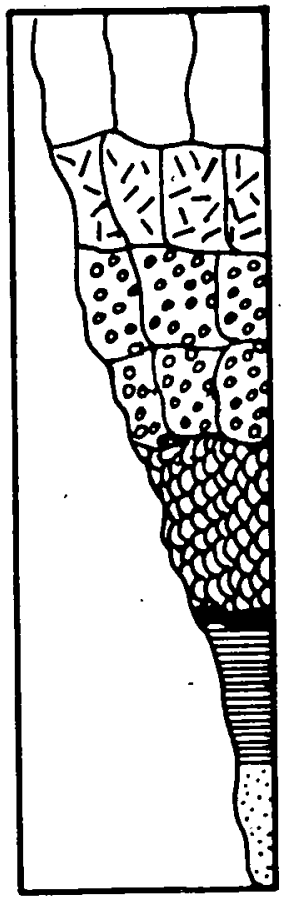

COMPETENT

BASALT

FRACTURED

BASALT

VESICULAR

\section{BASALT}

FLOW BRECCIA

BAKED CONTACT ZONE

CLAY

SANDSTONE 


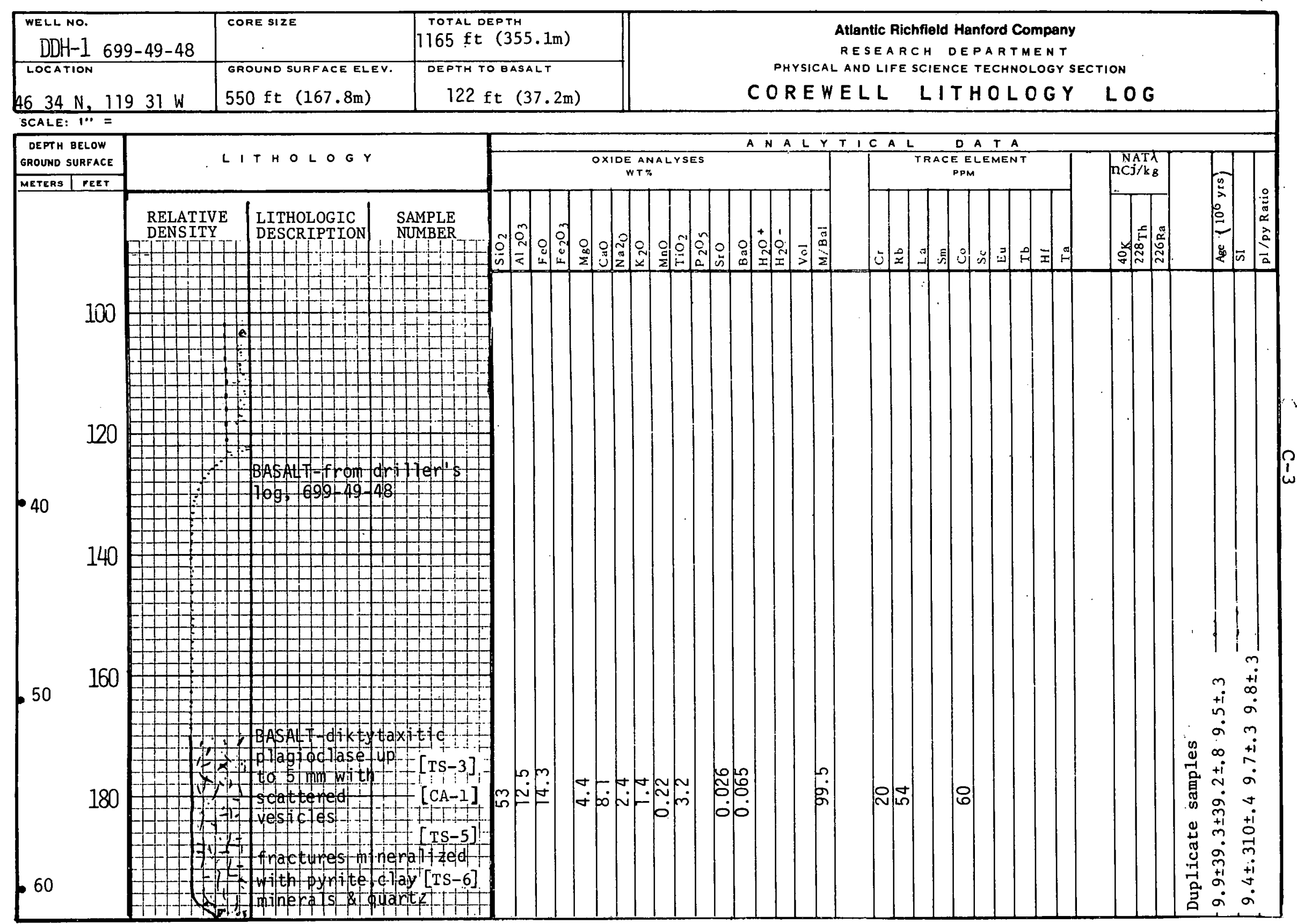




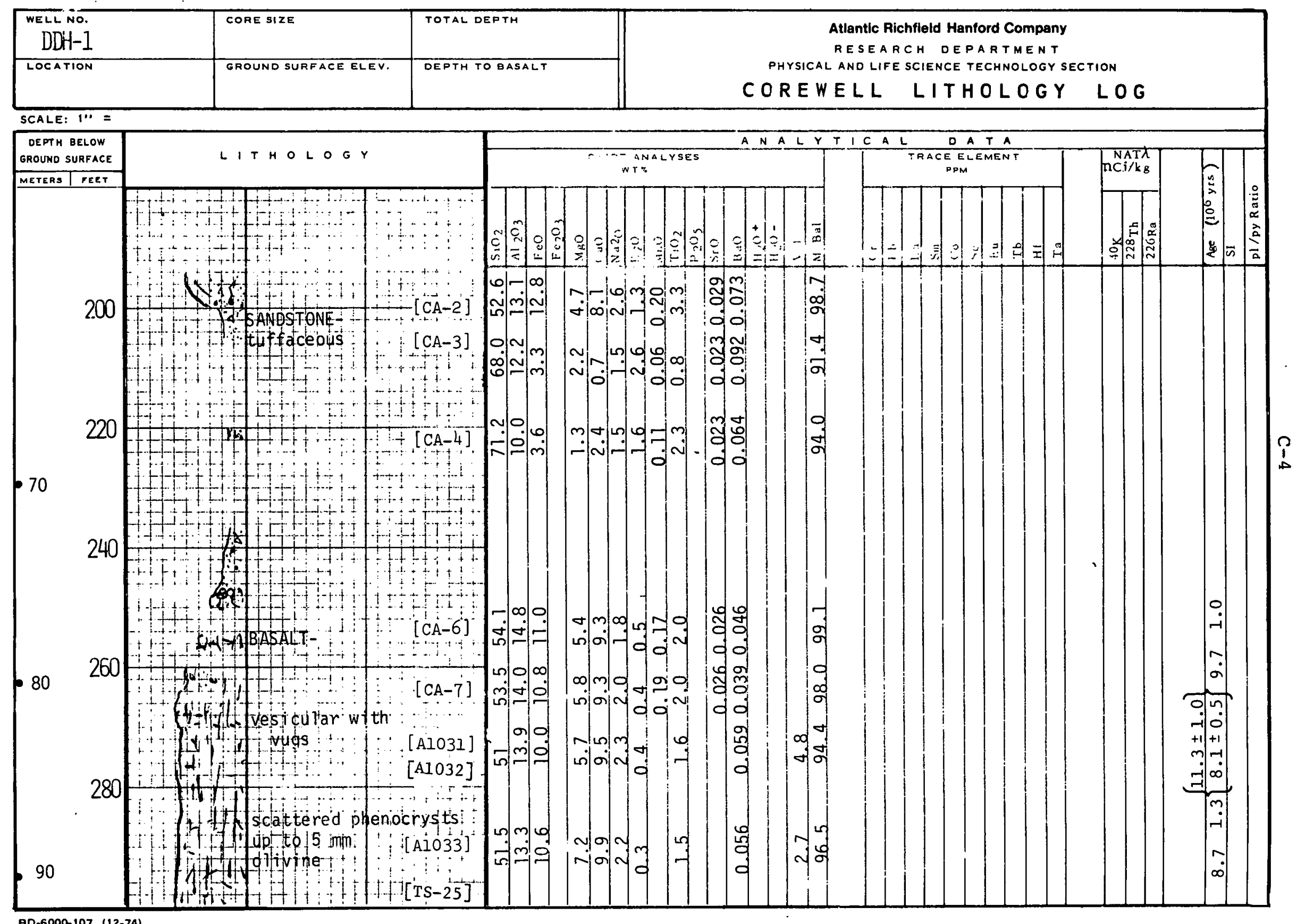




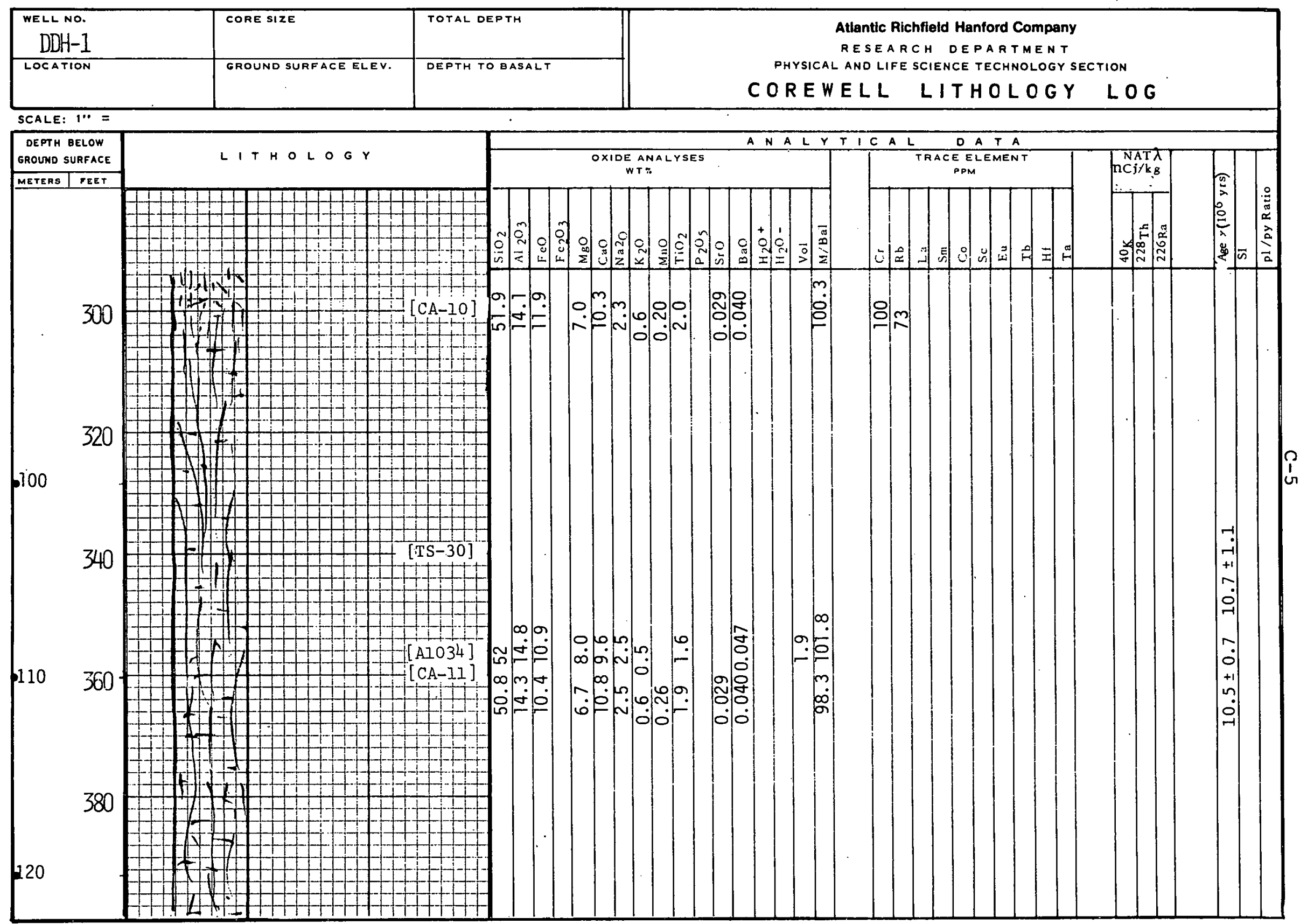




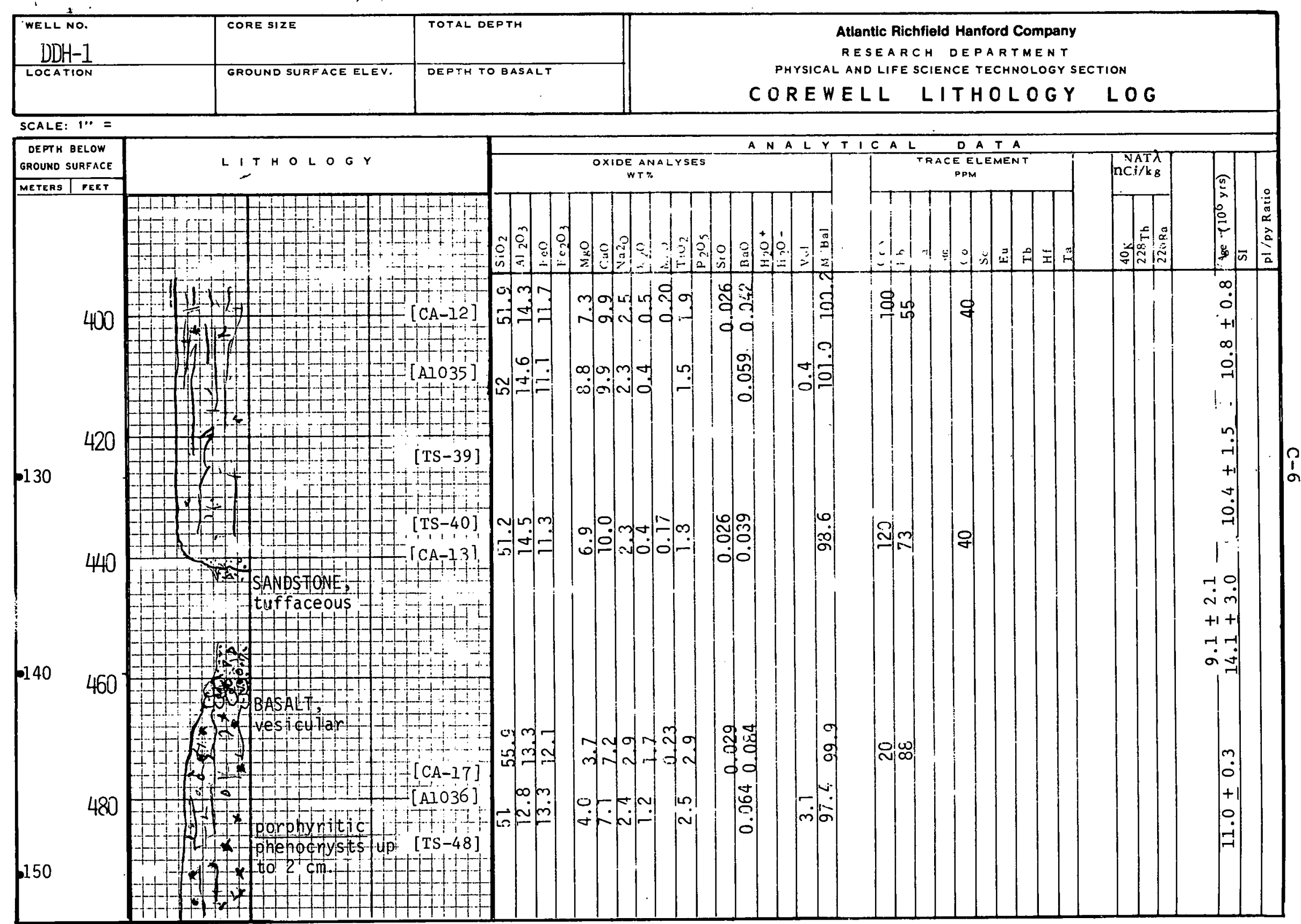




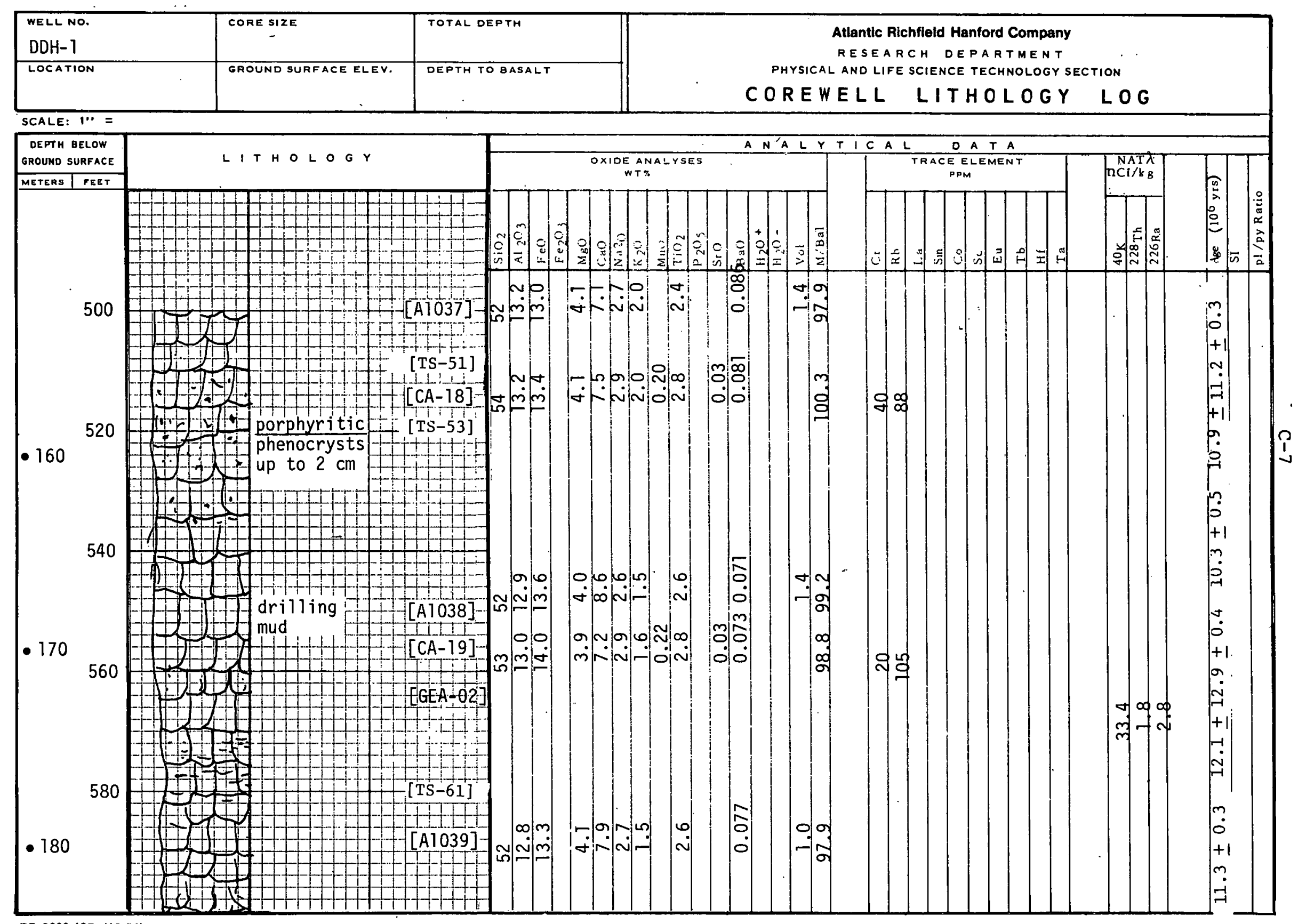




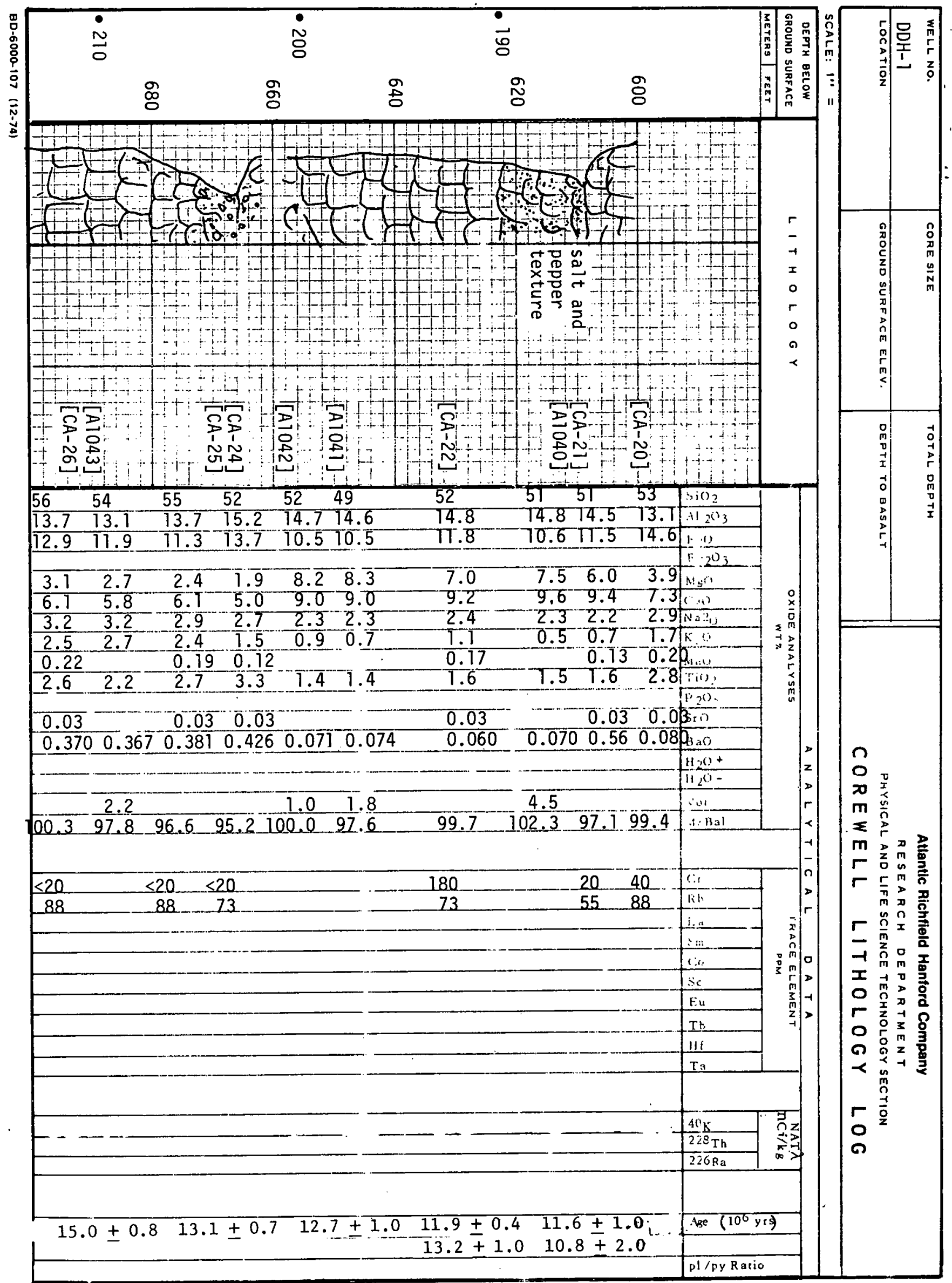




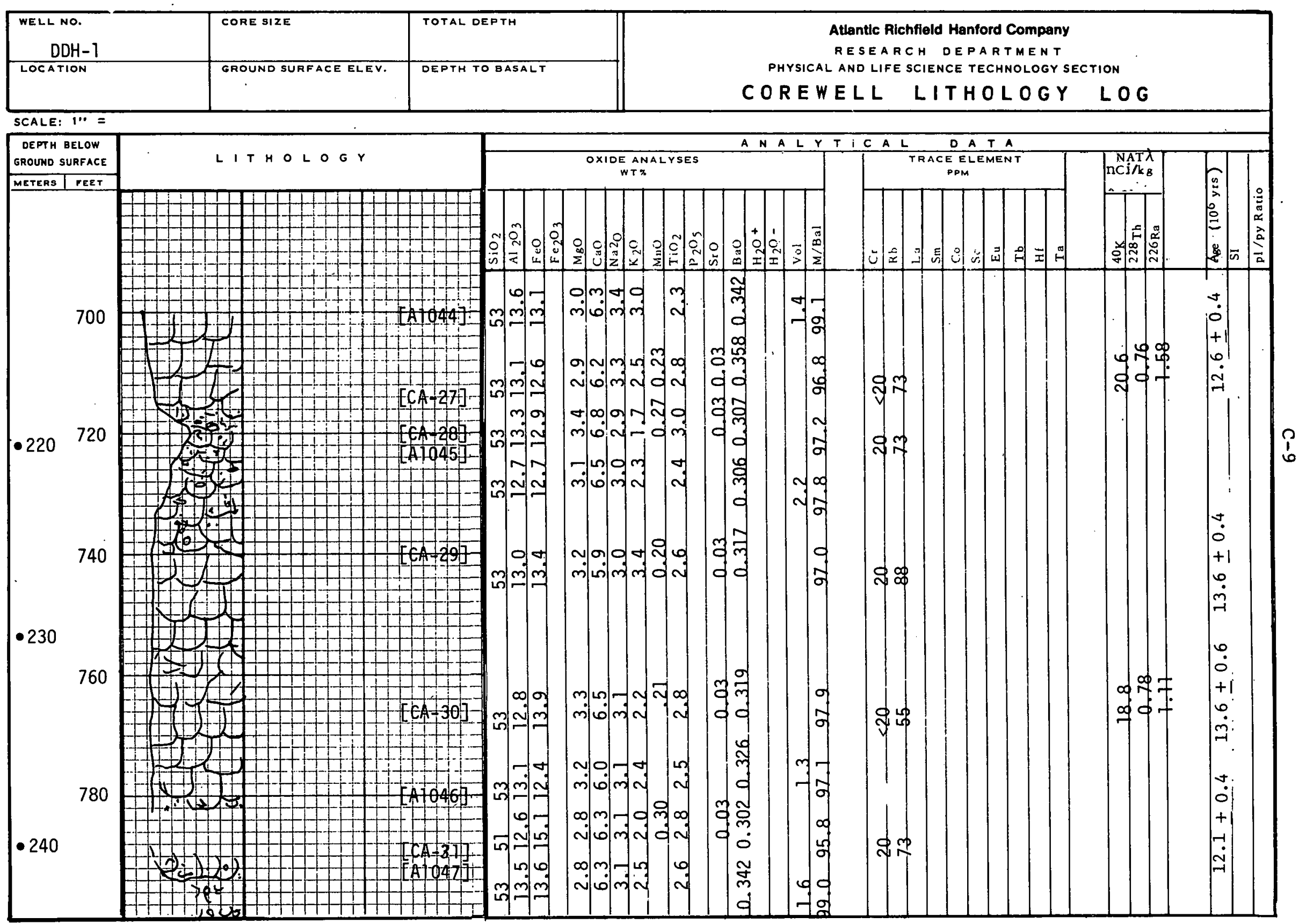




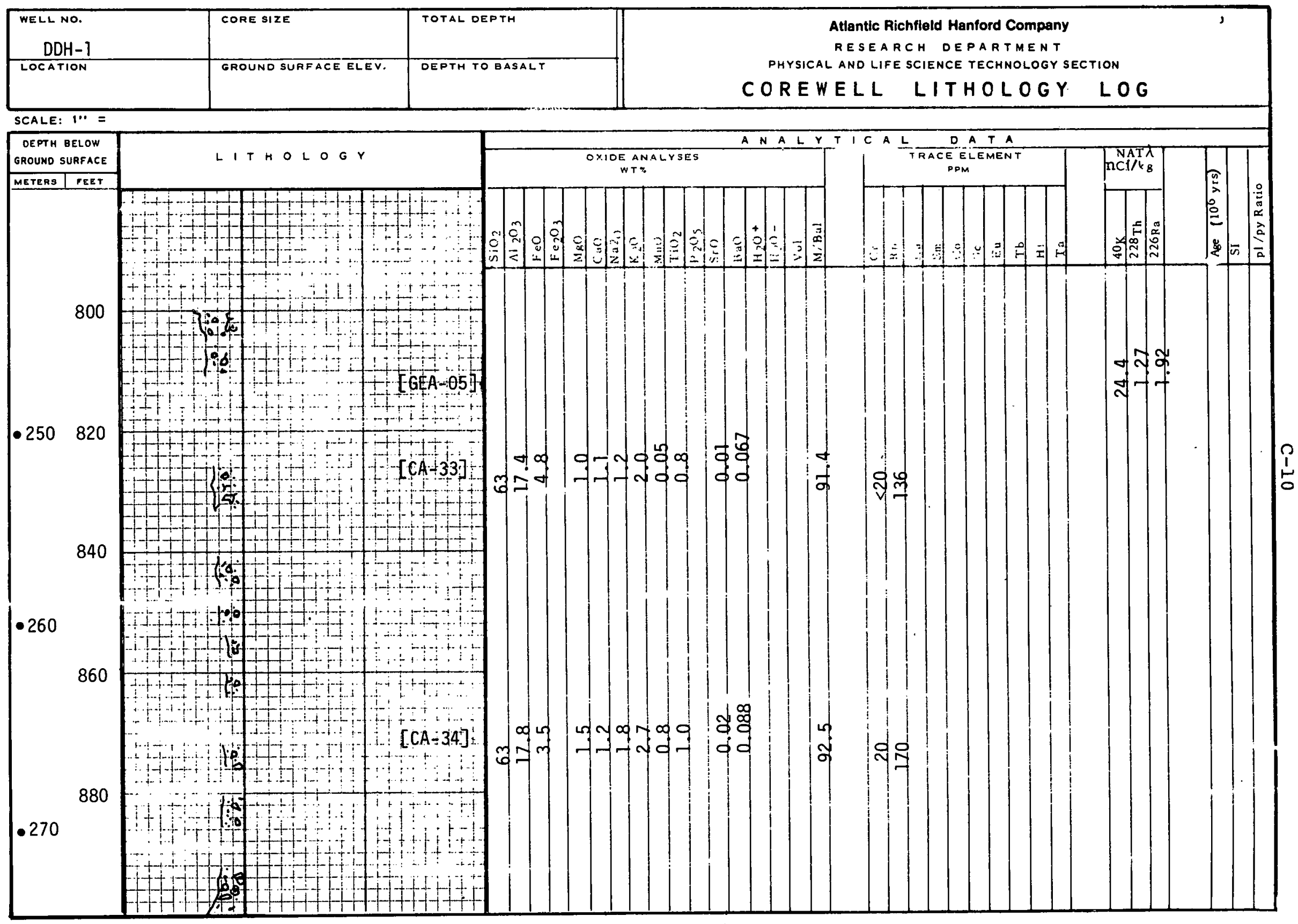

80-6000-107 (12-74) 


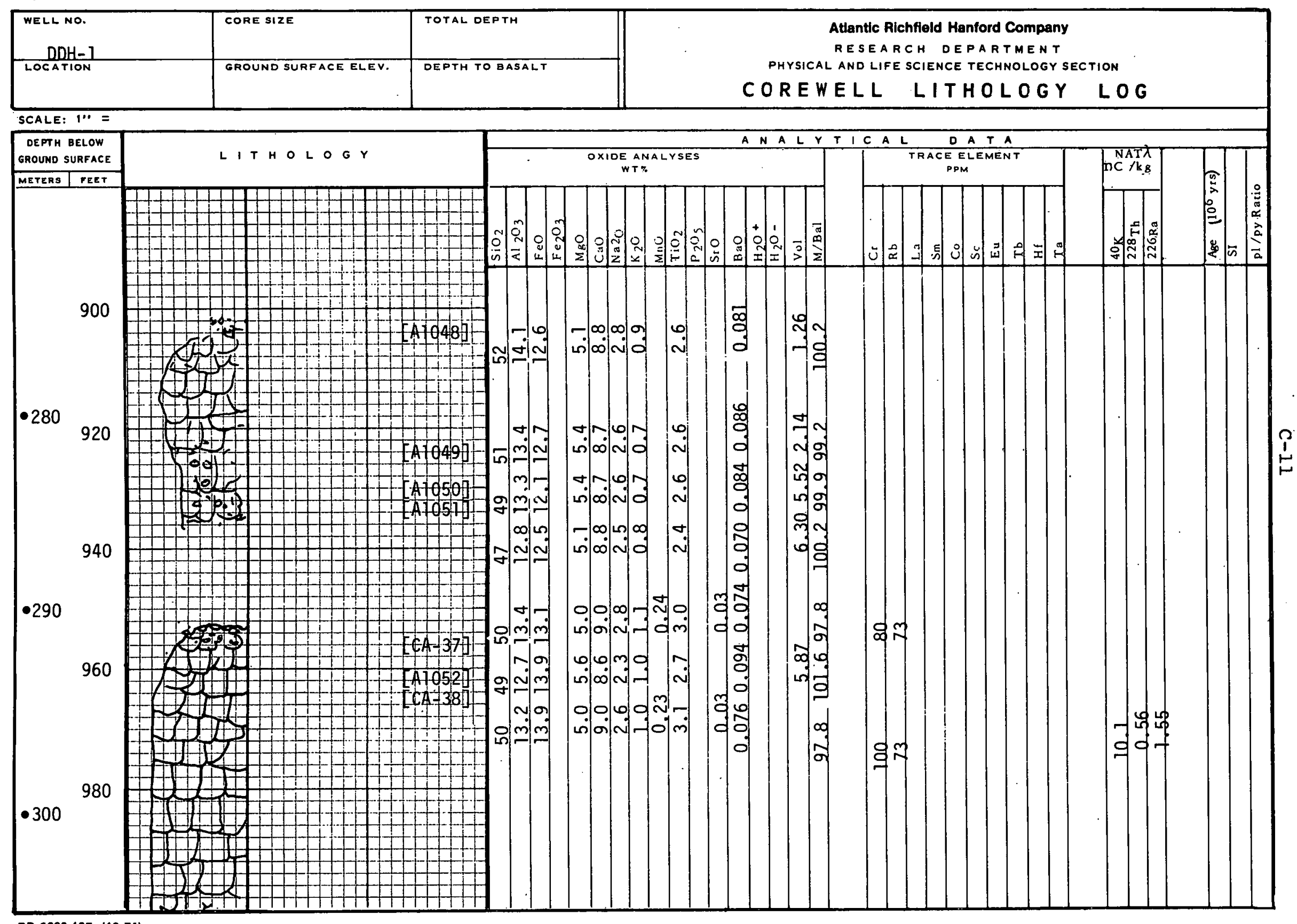




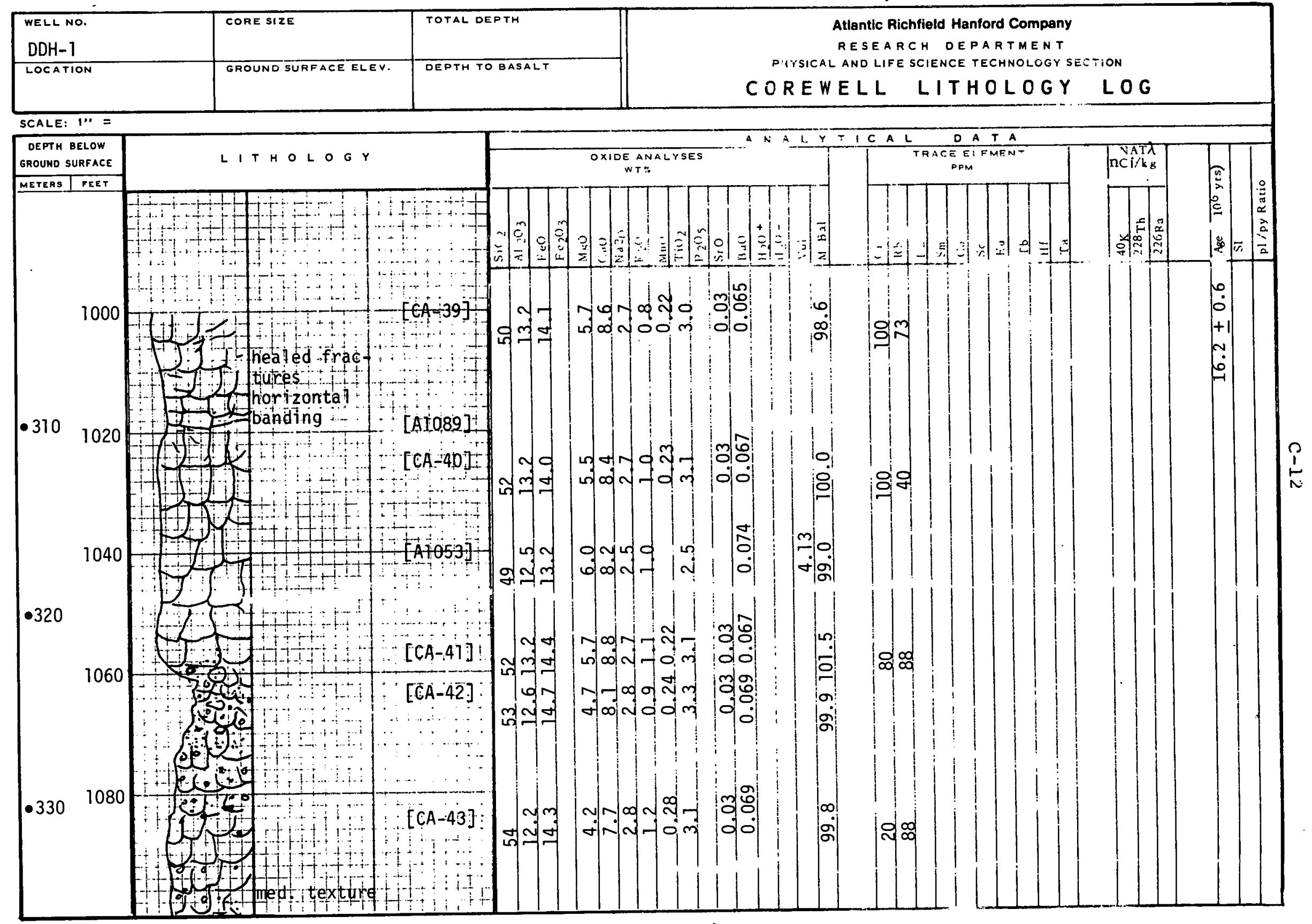

80-6000-107 (12-74) 


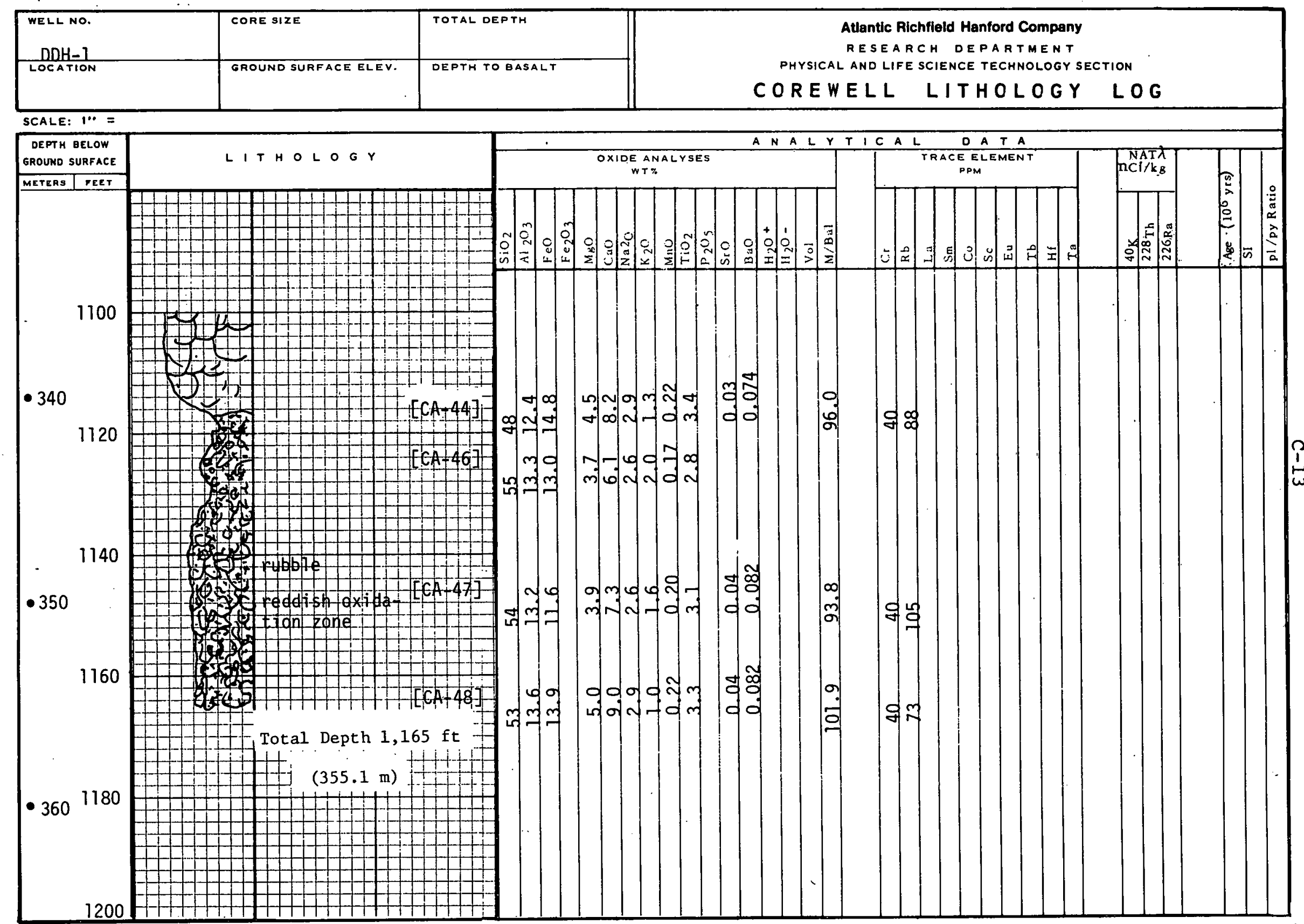




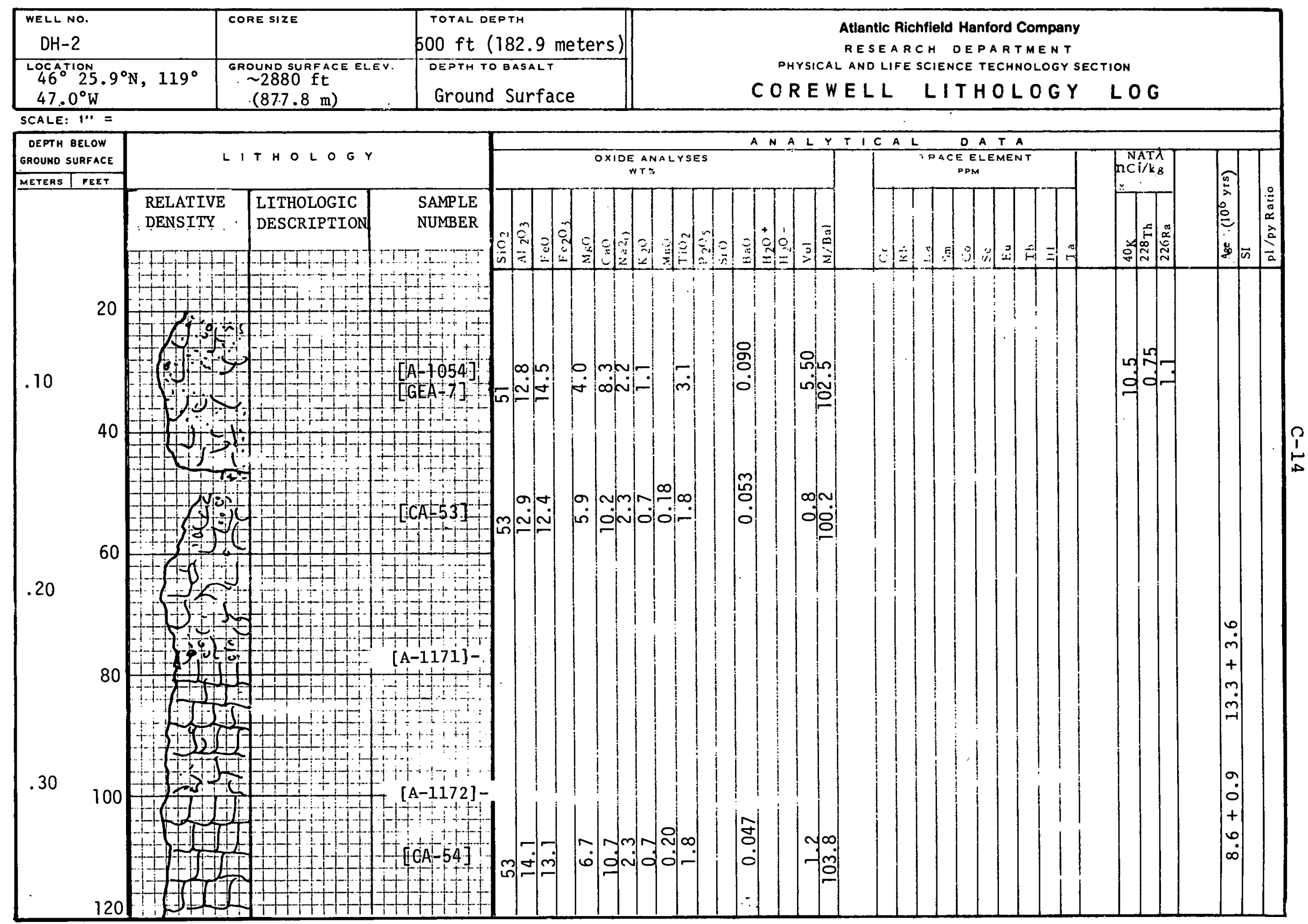

80-6000-107 (12-74) 


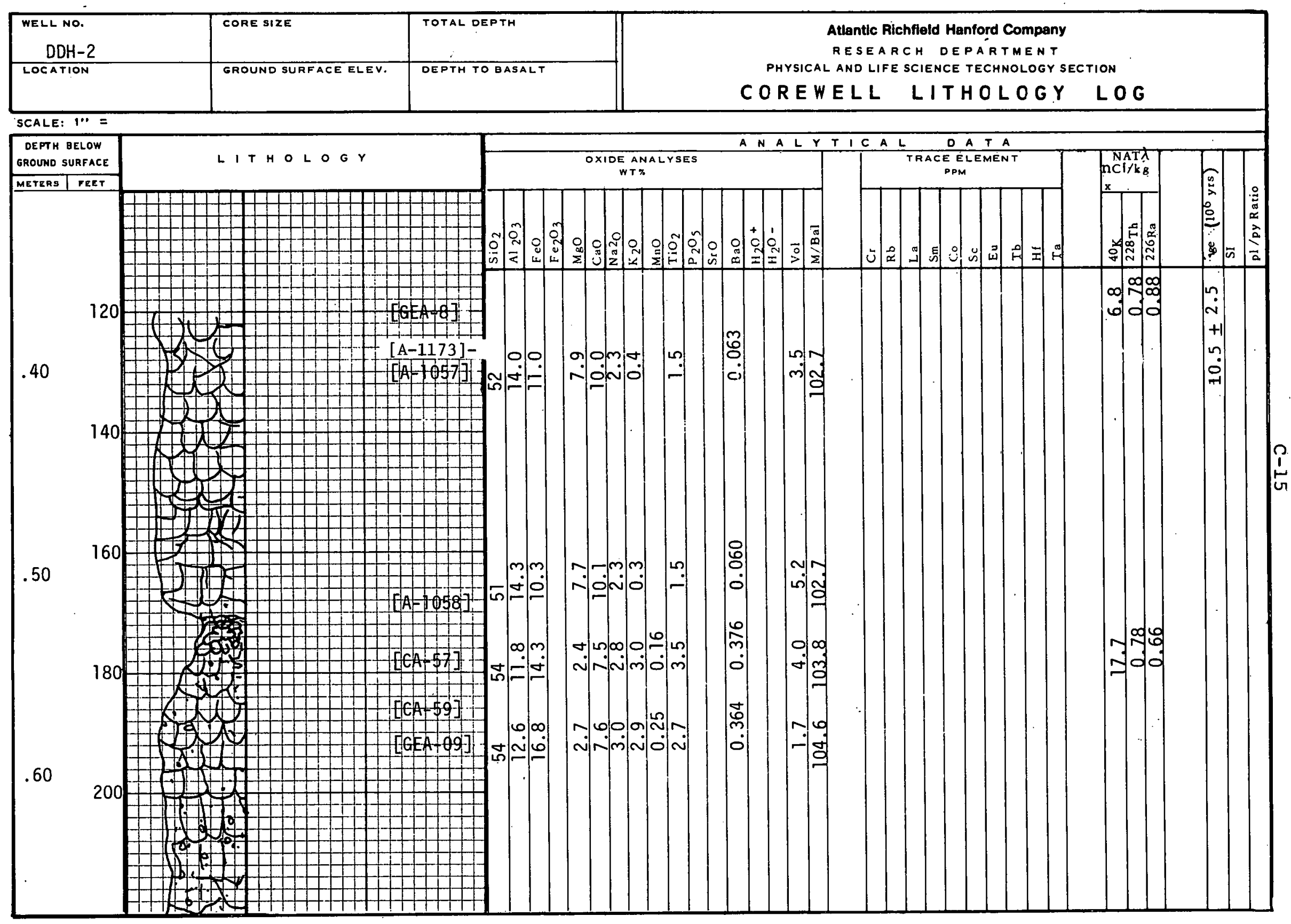




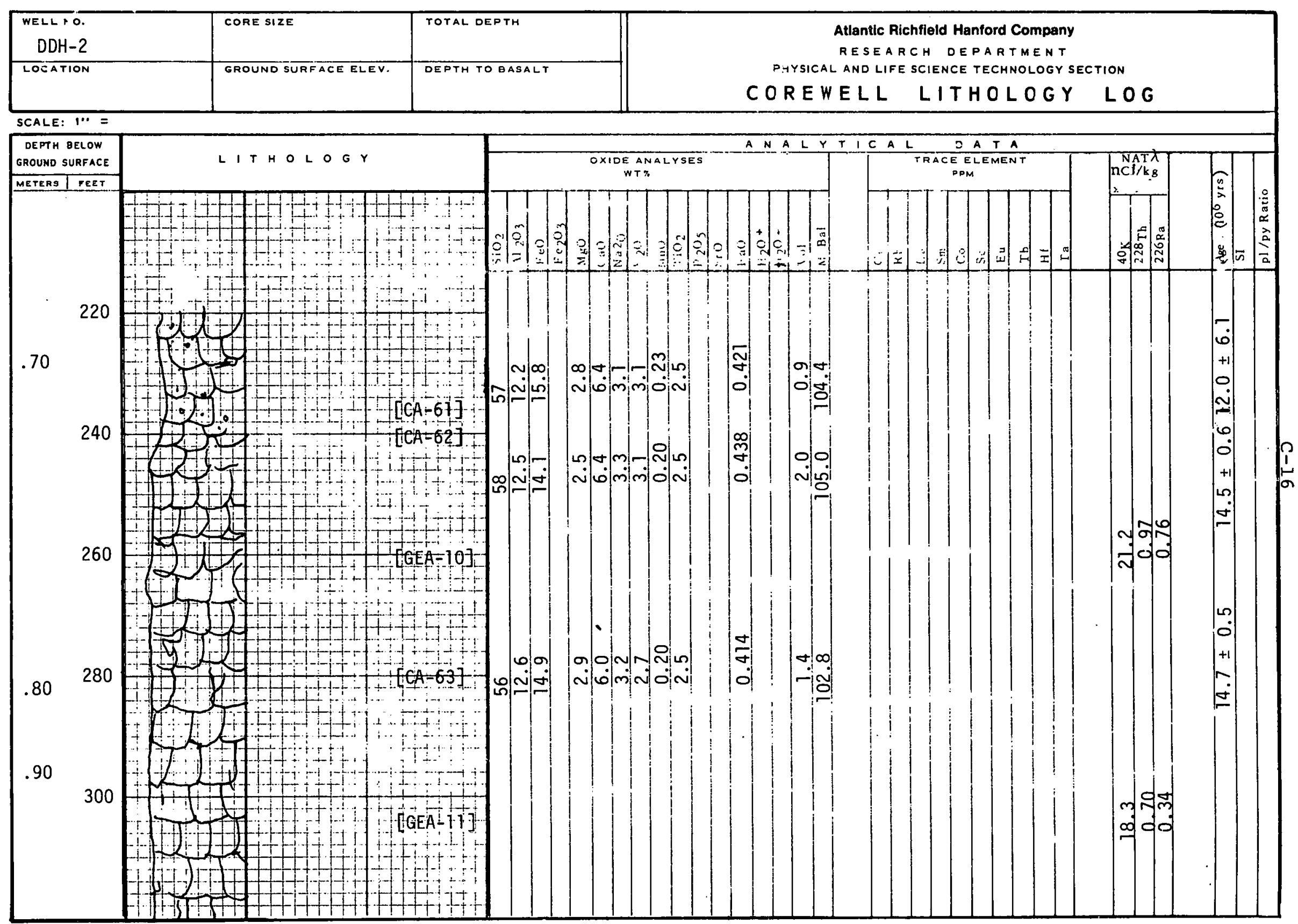

BD-6000-107 (12-74) 


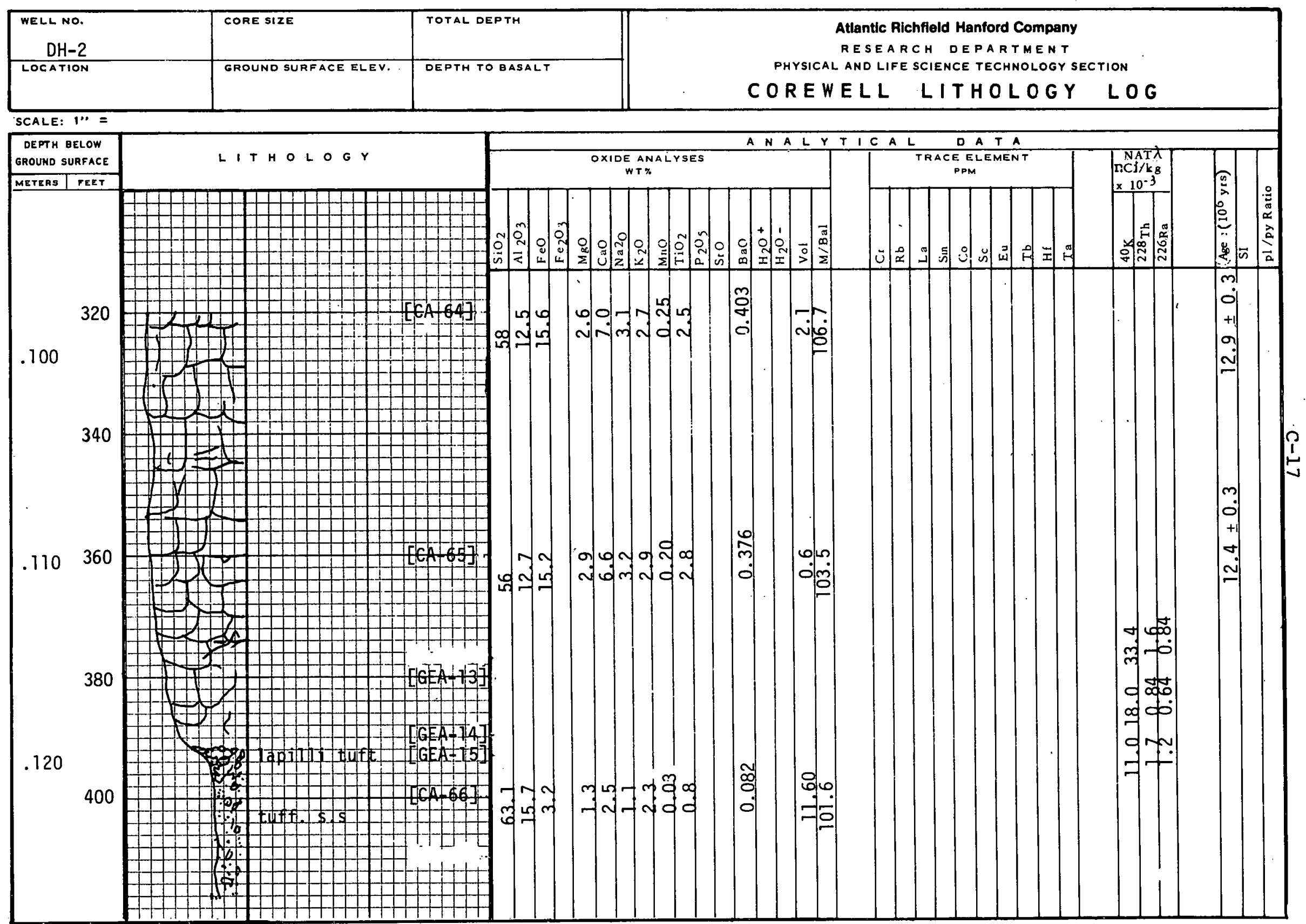




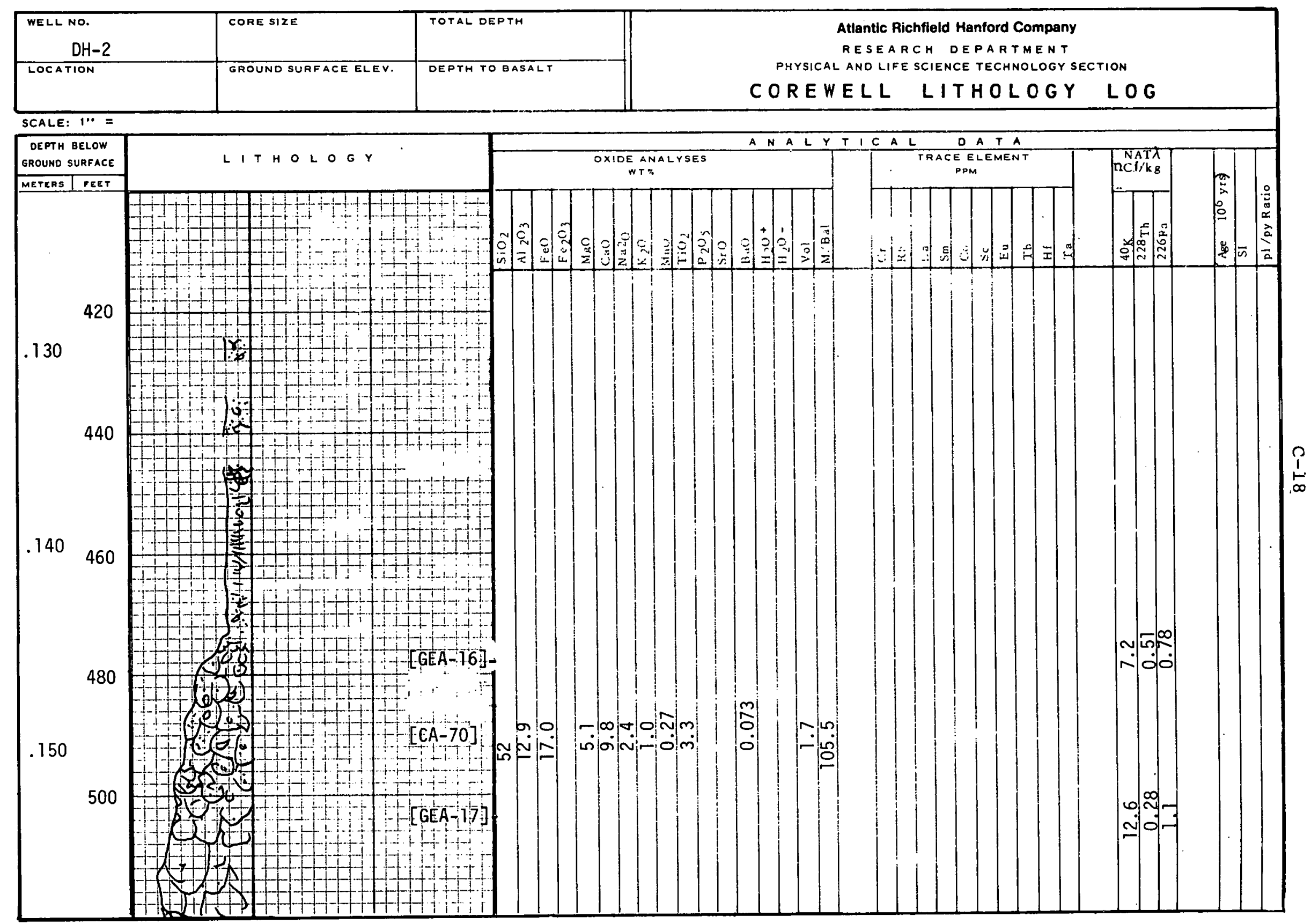

80-6000-107 (12-74) 


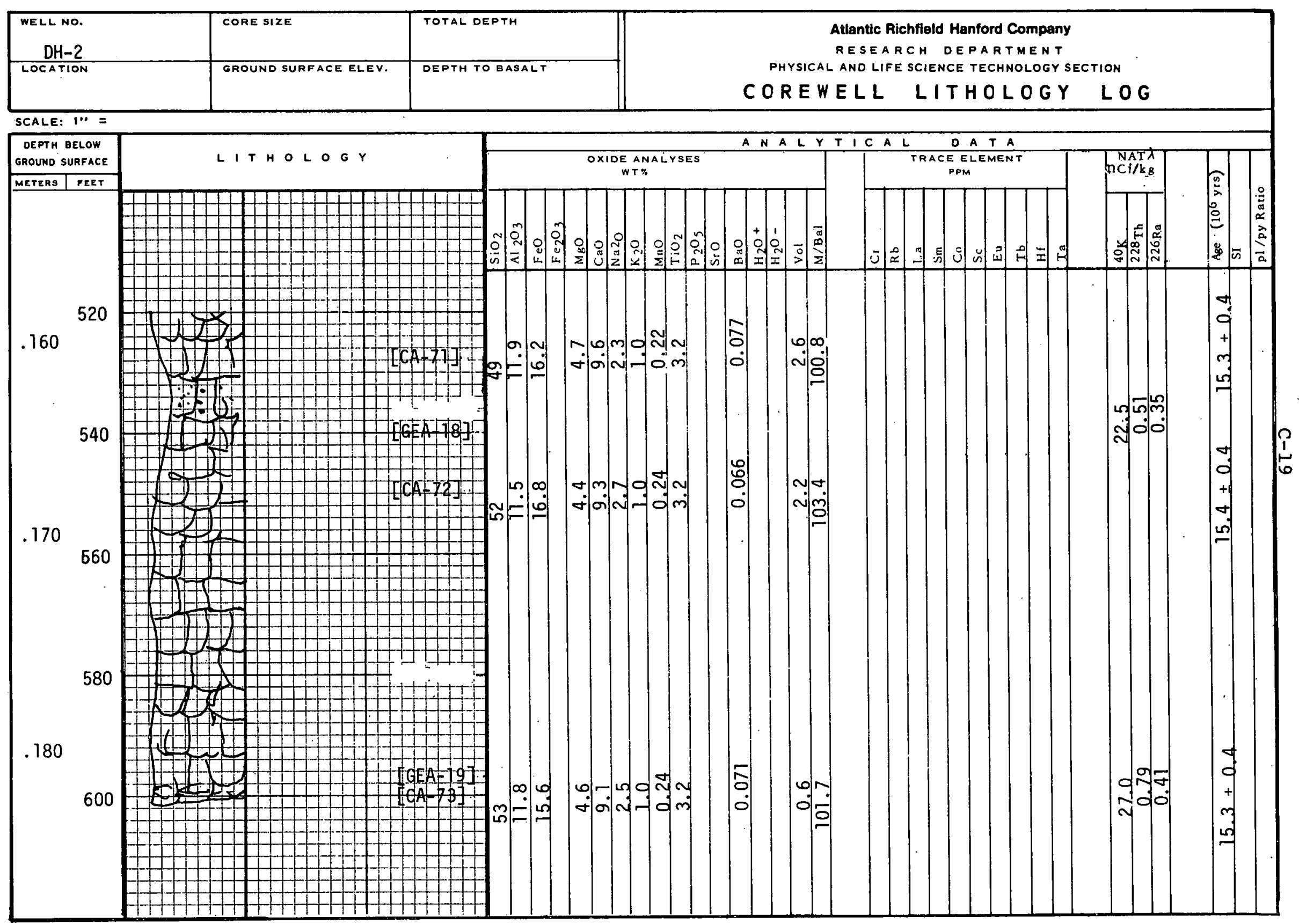




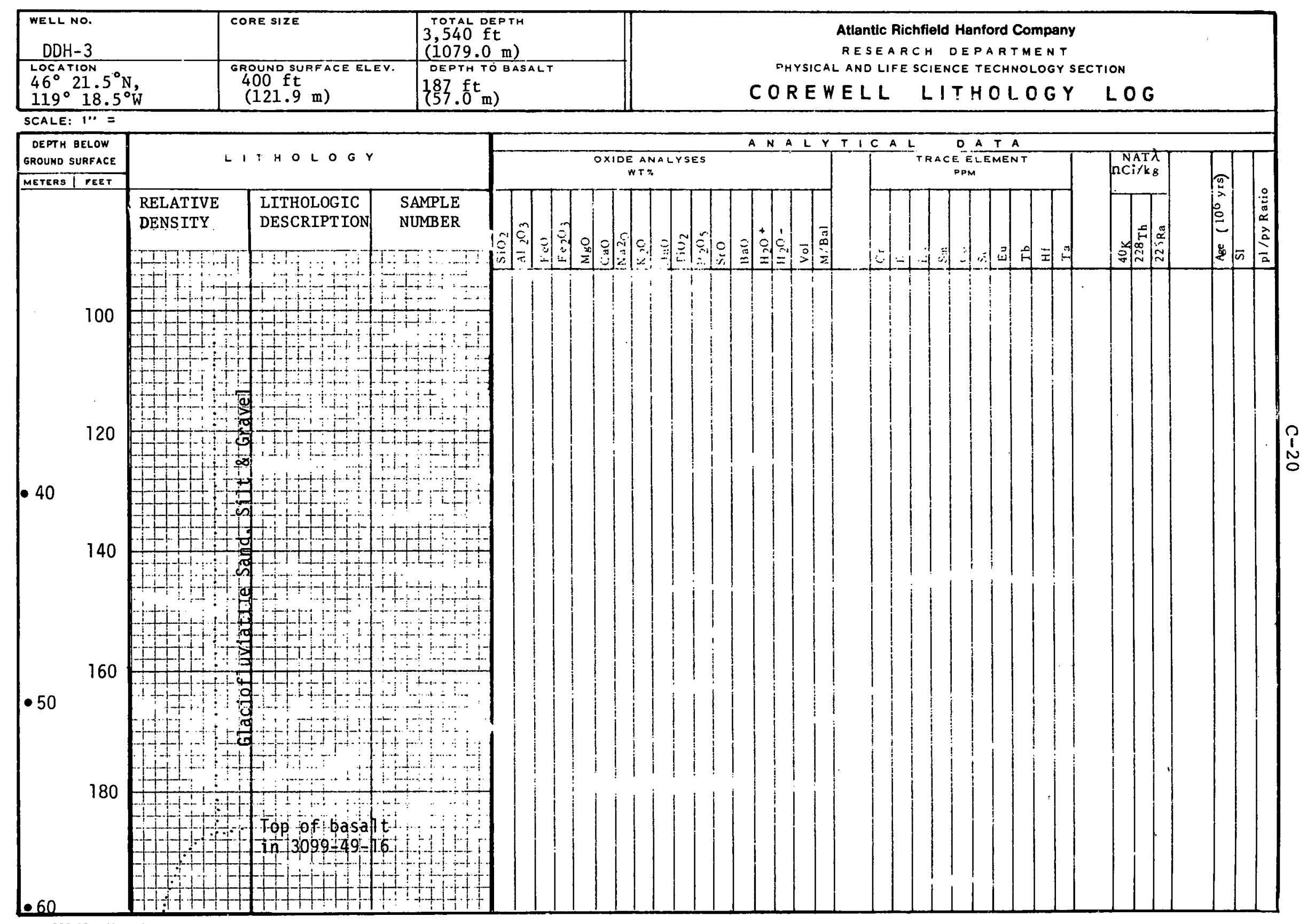

BD-6000-107 (12-74) 


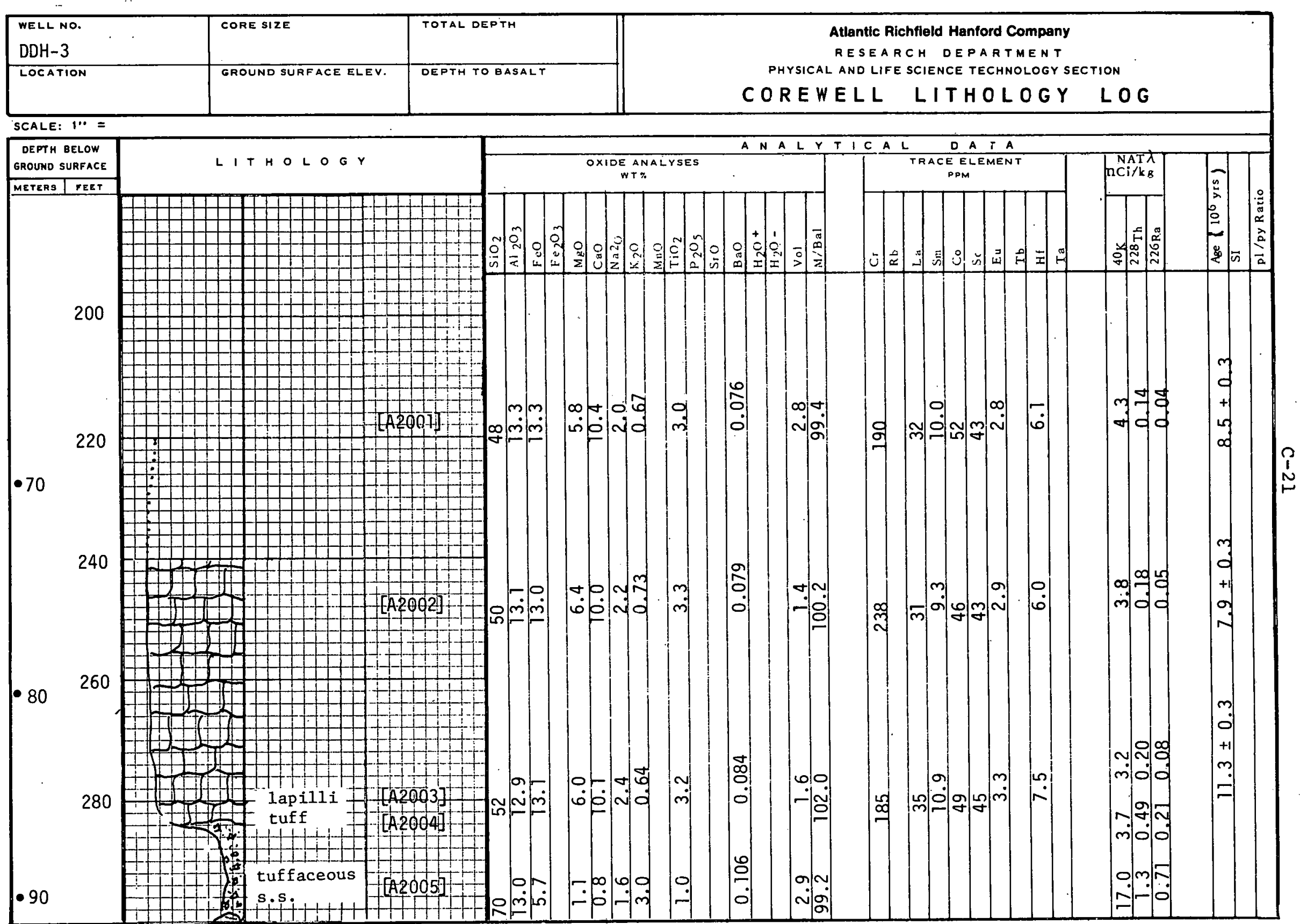




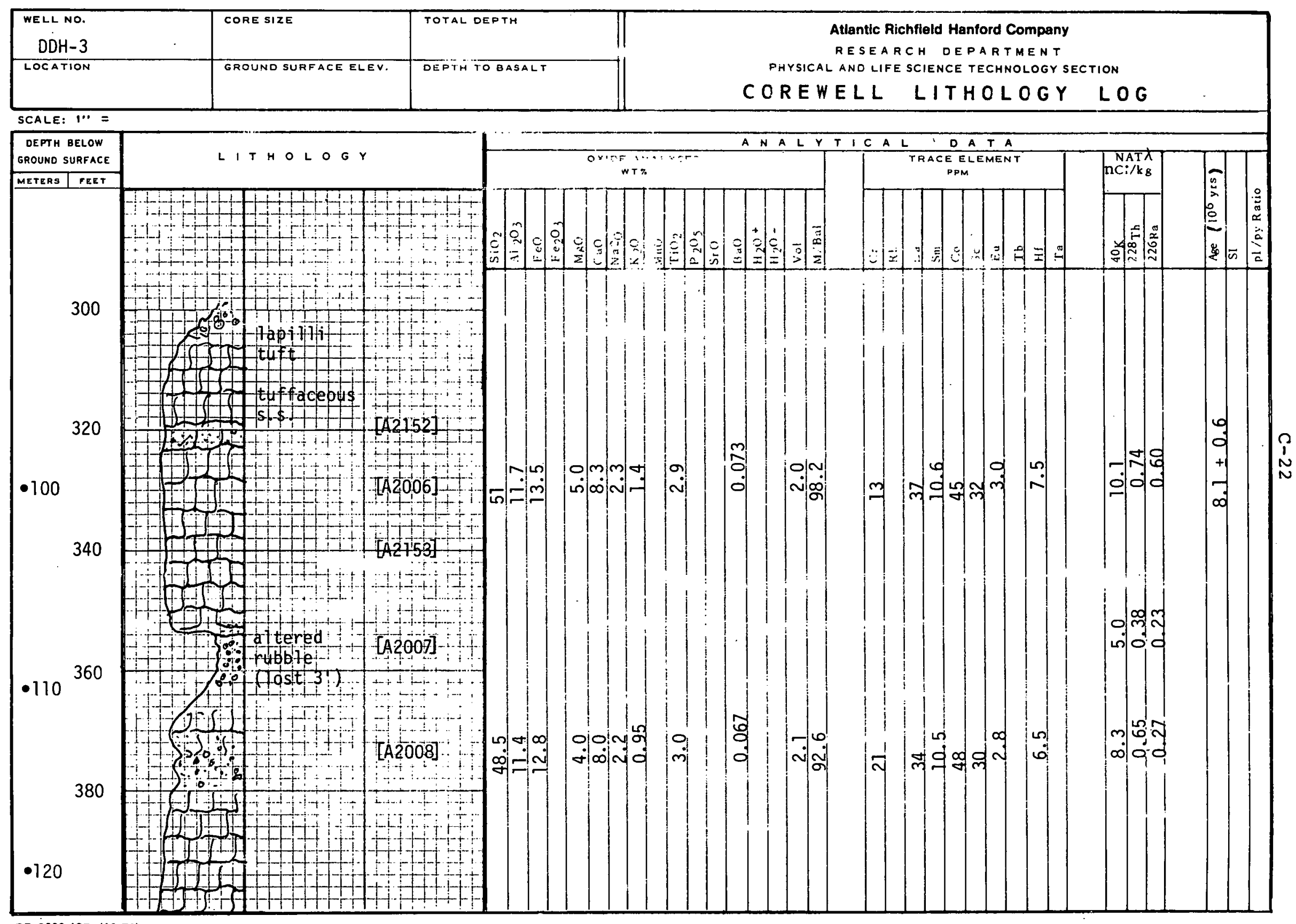

80-6000-107 (12-74) 


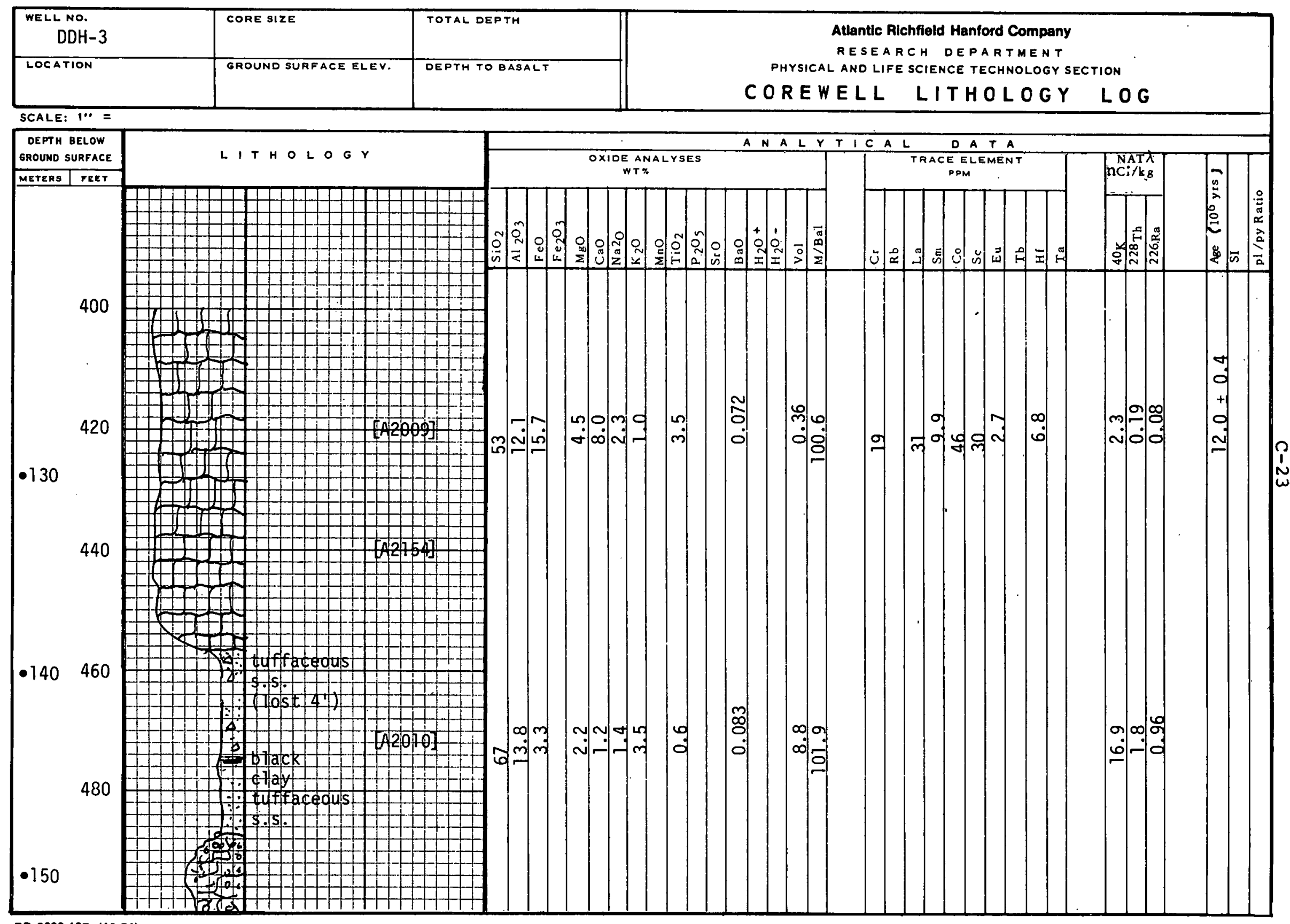

BD-6000-107 (12-74) 


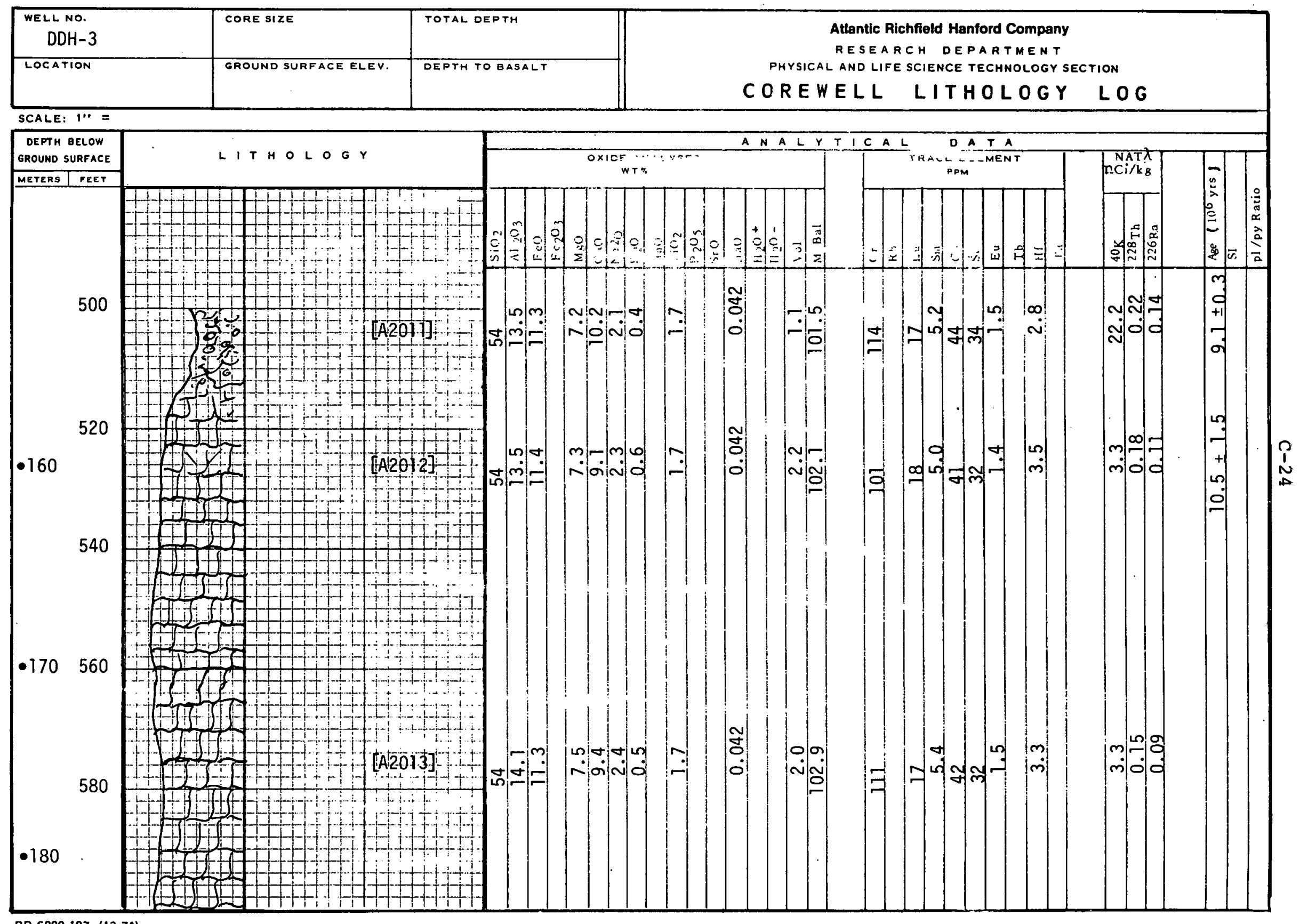

8D-6000-107 (12-74) 


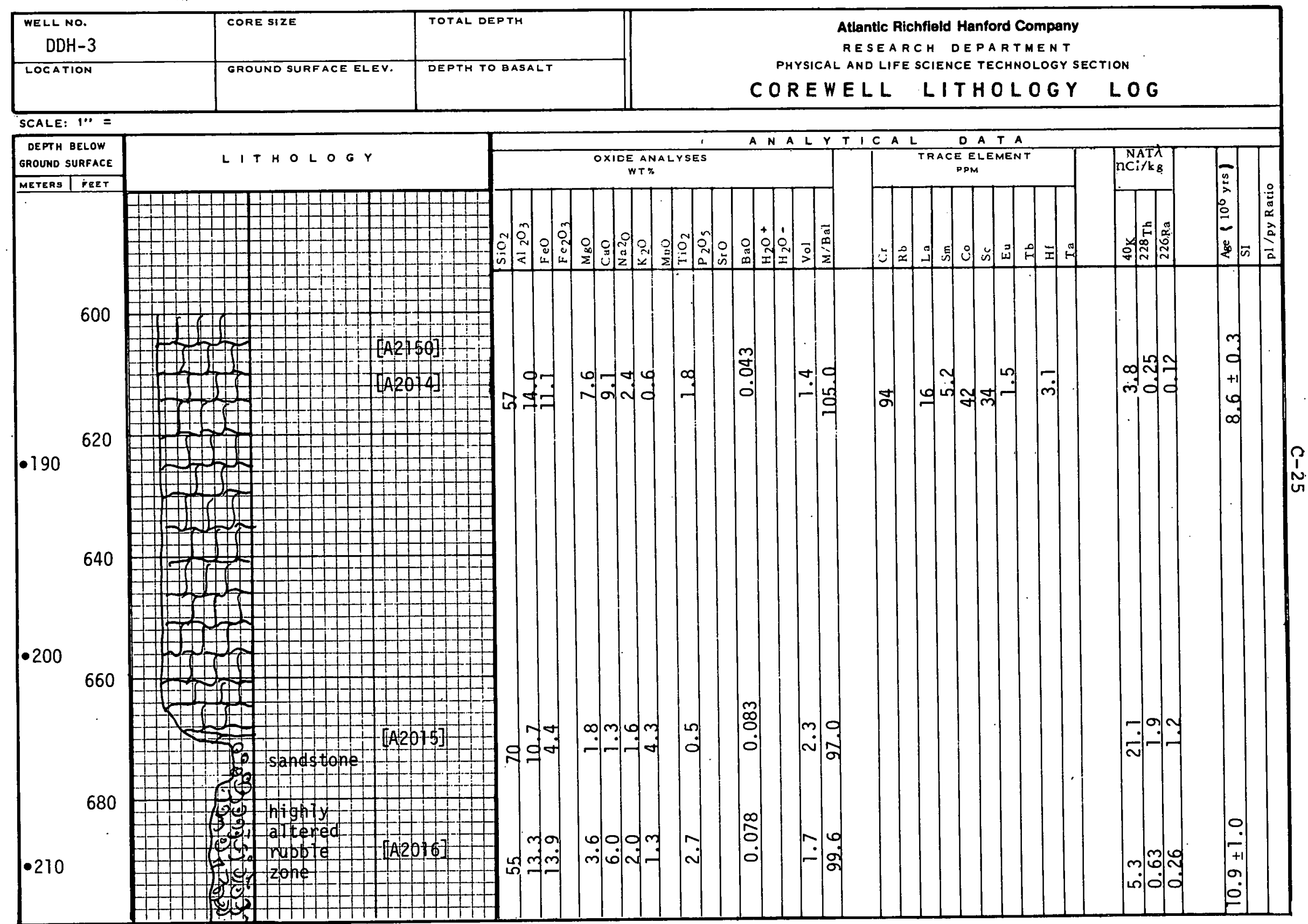




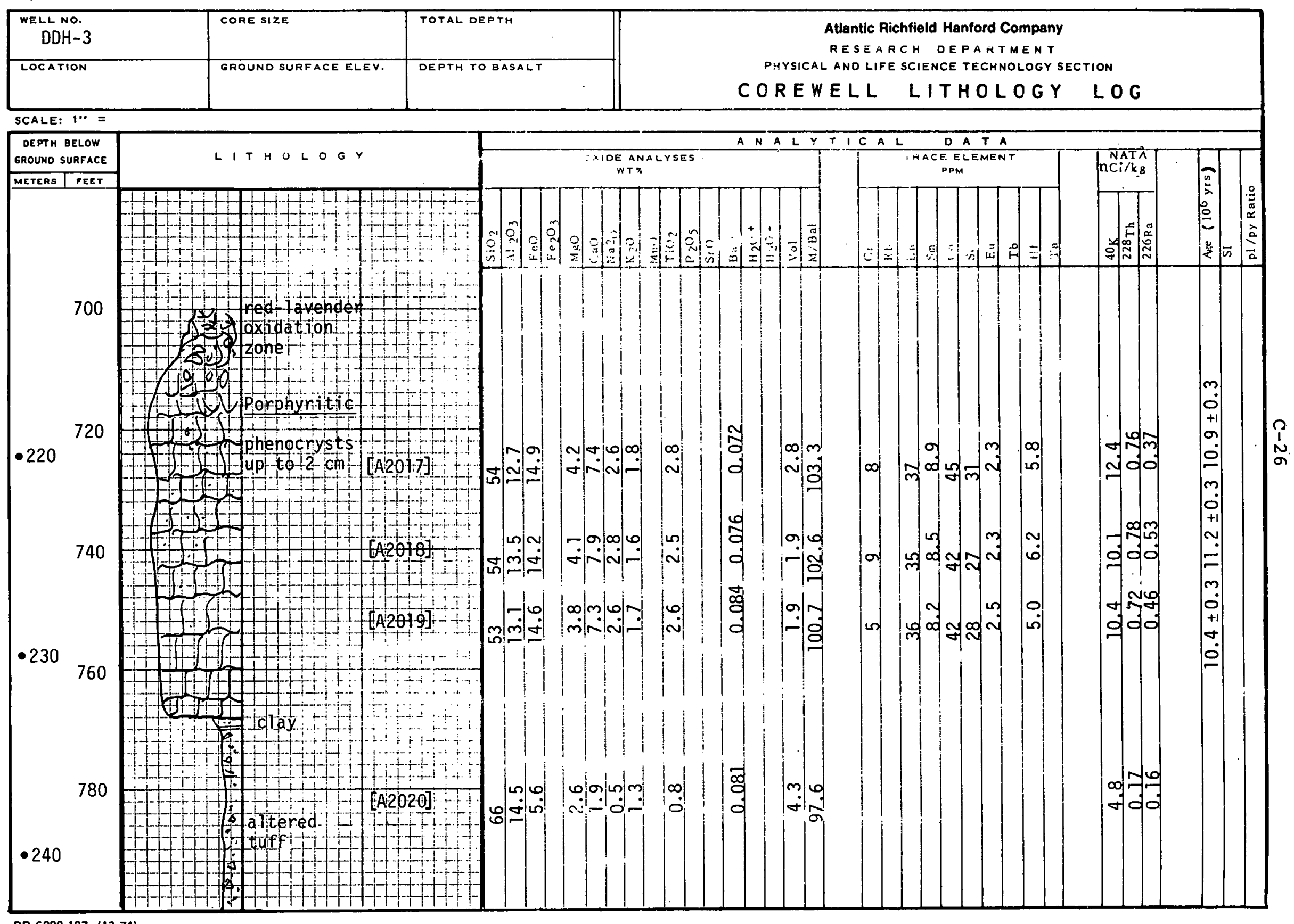

BD-6000-107 (12-74) 


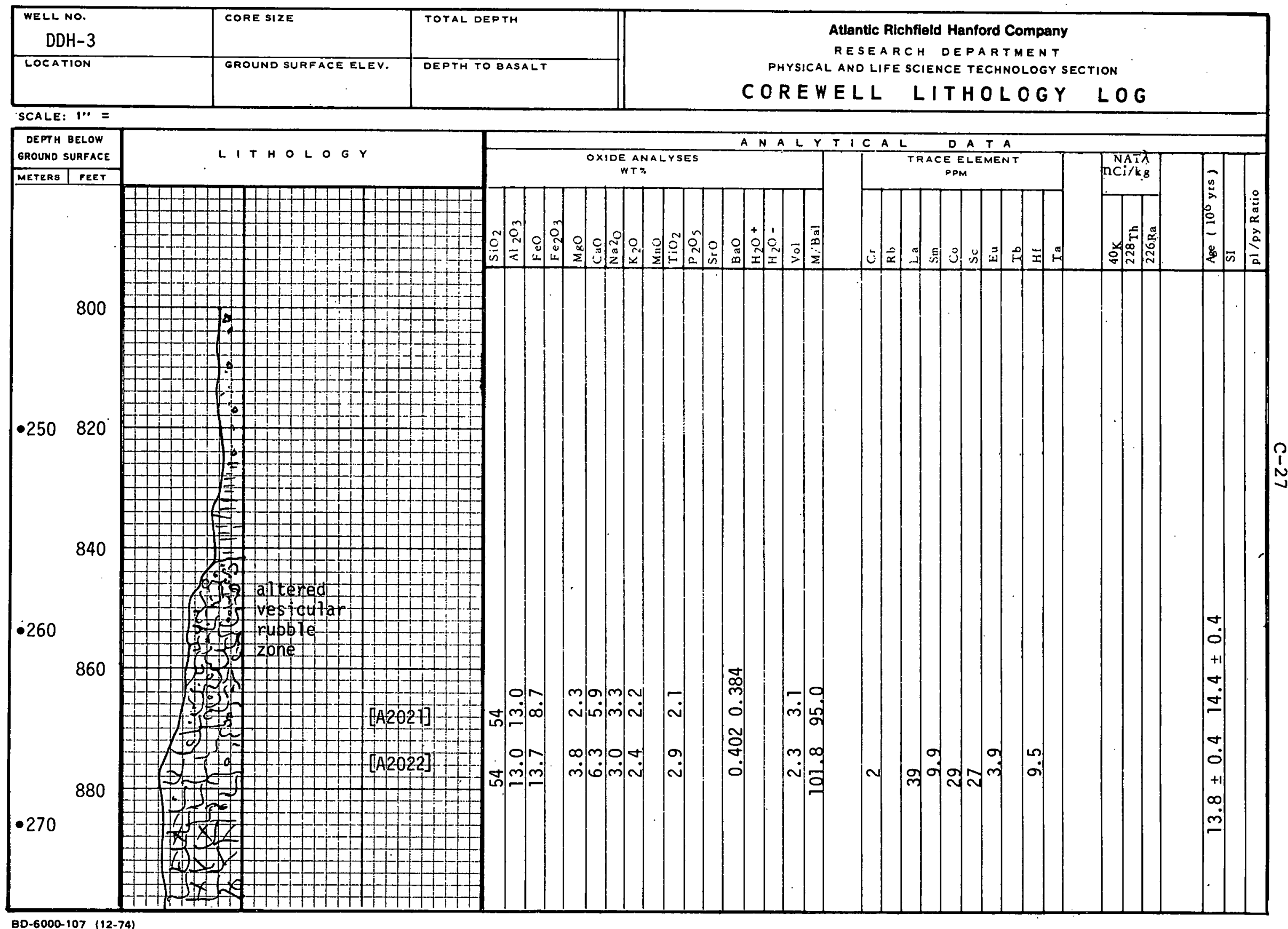

80-6000-107 (12-74) 


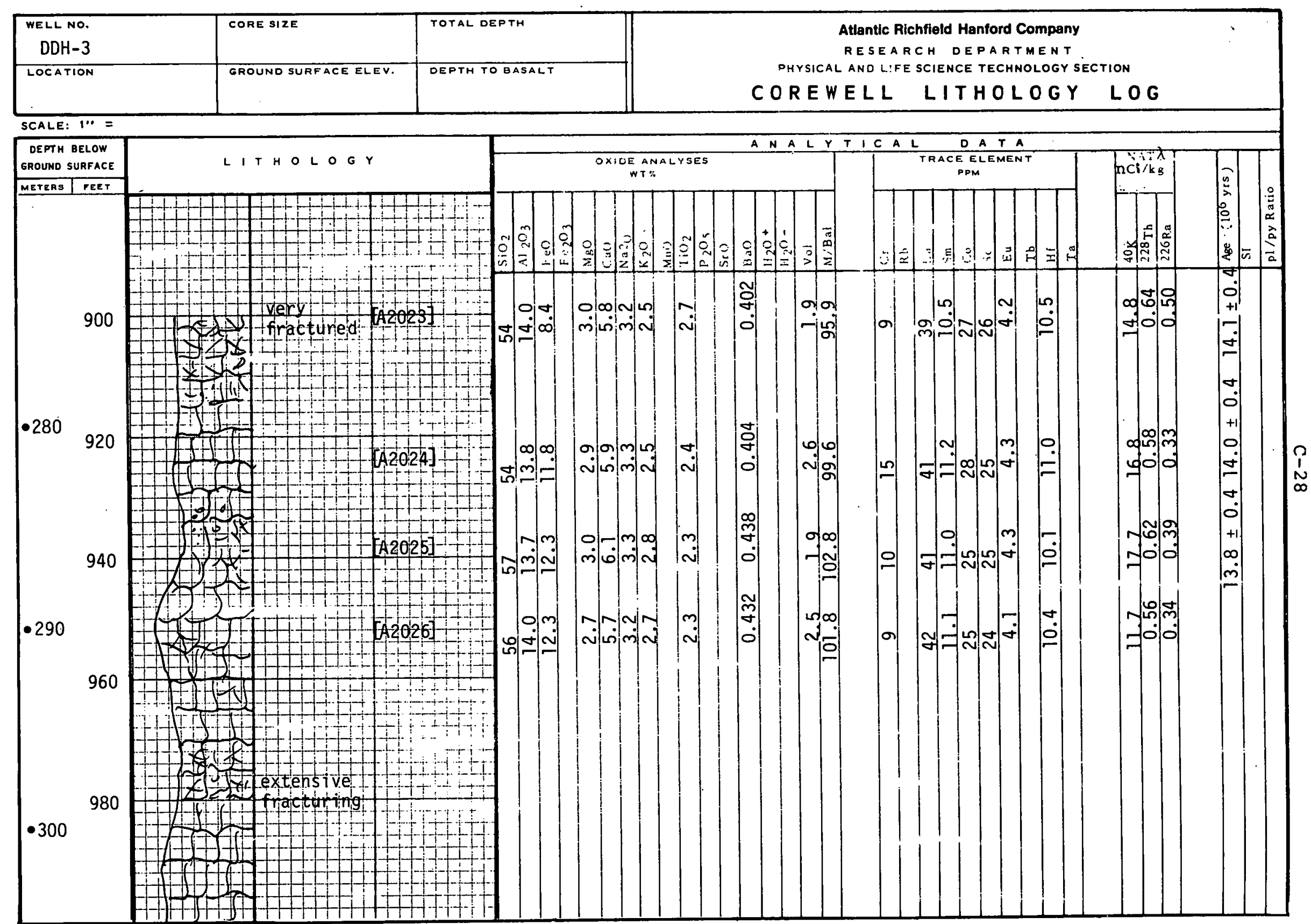




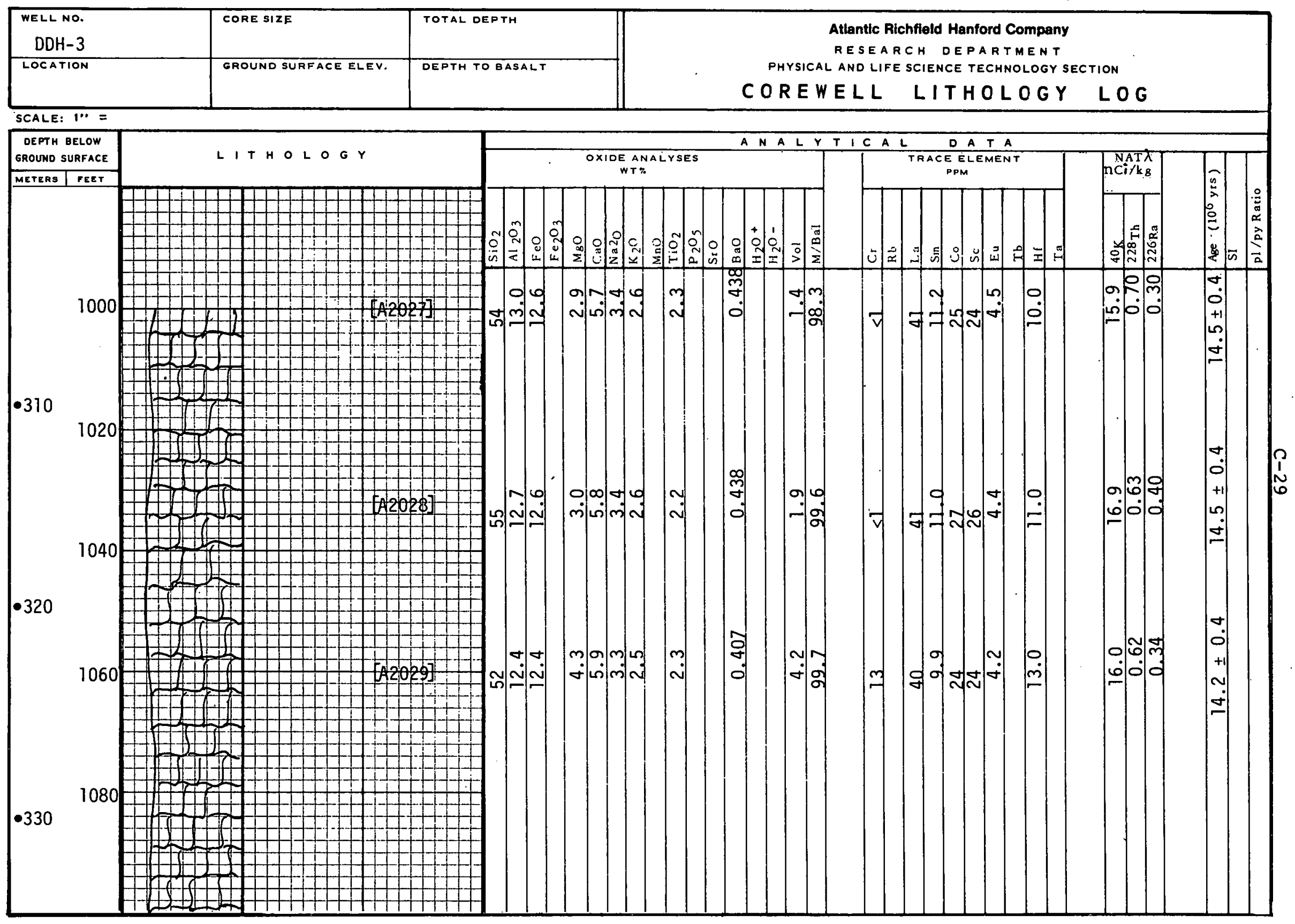




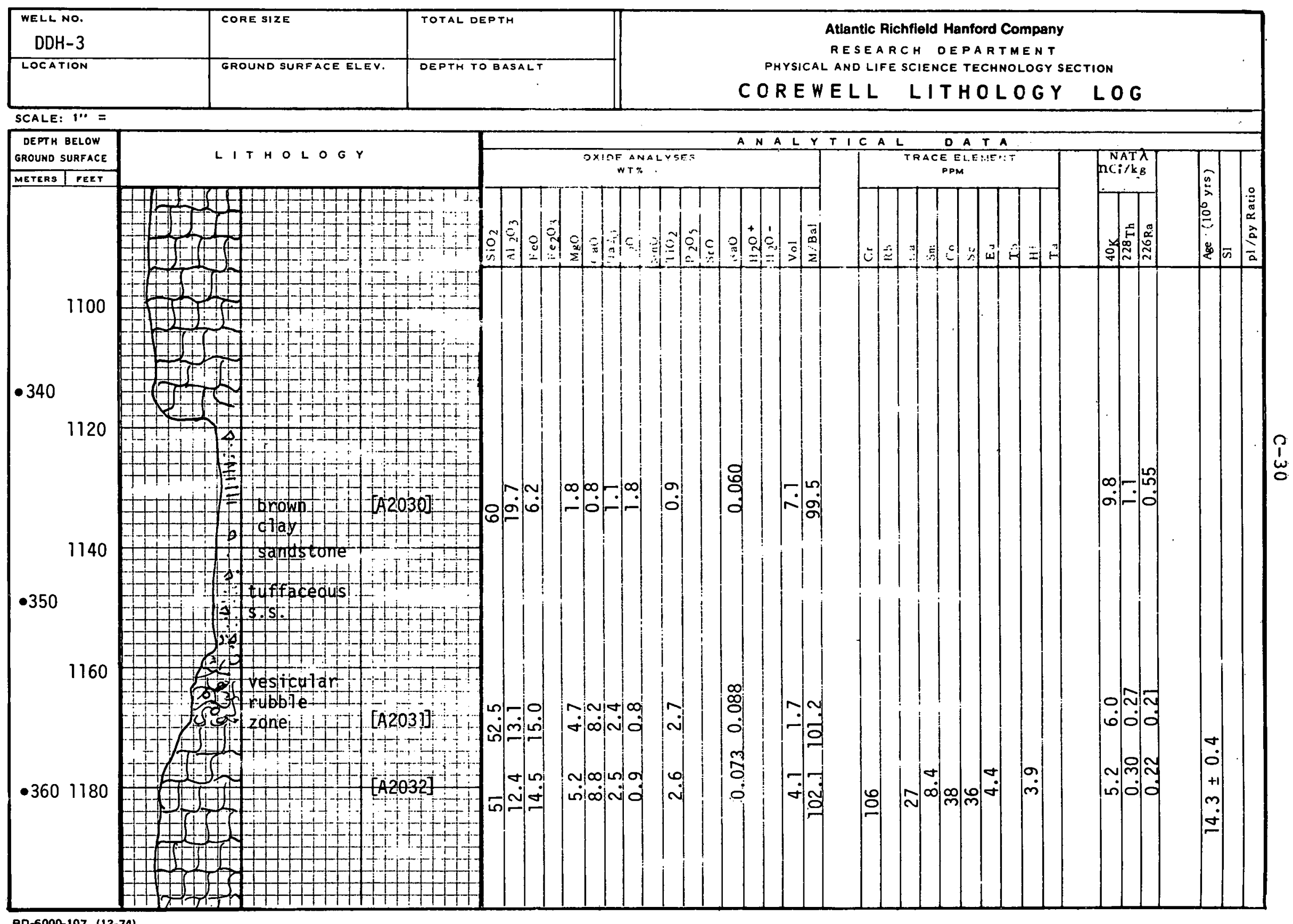

80-6000-107 (12-74) 


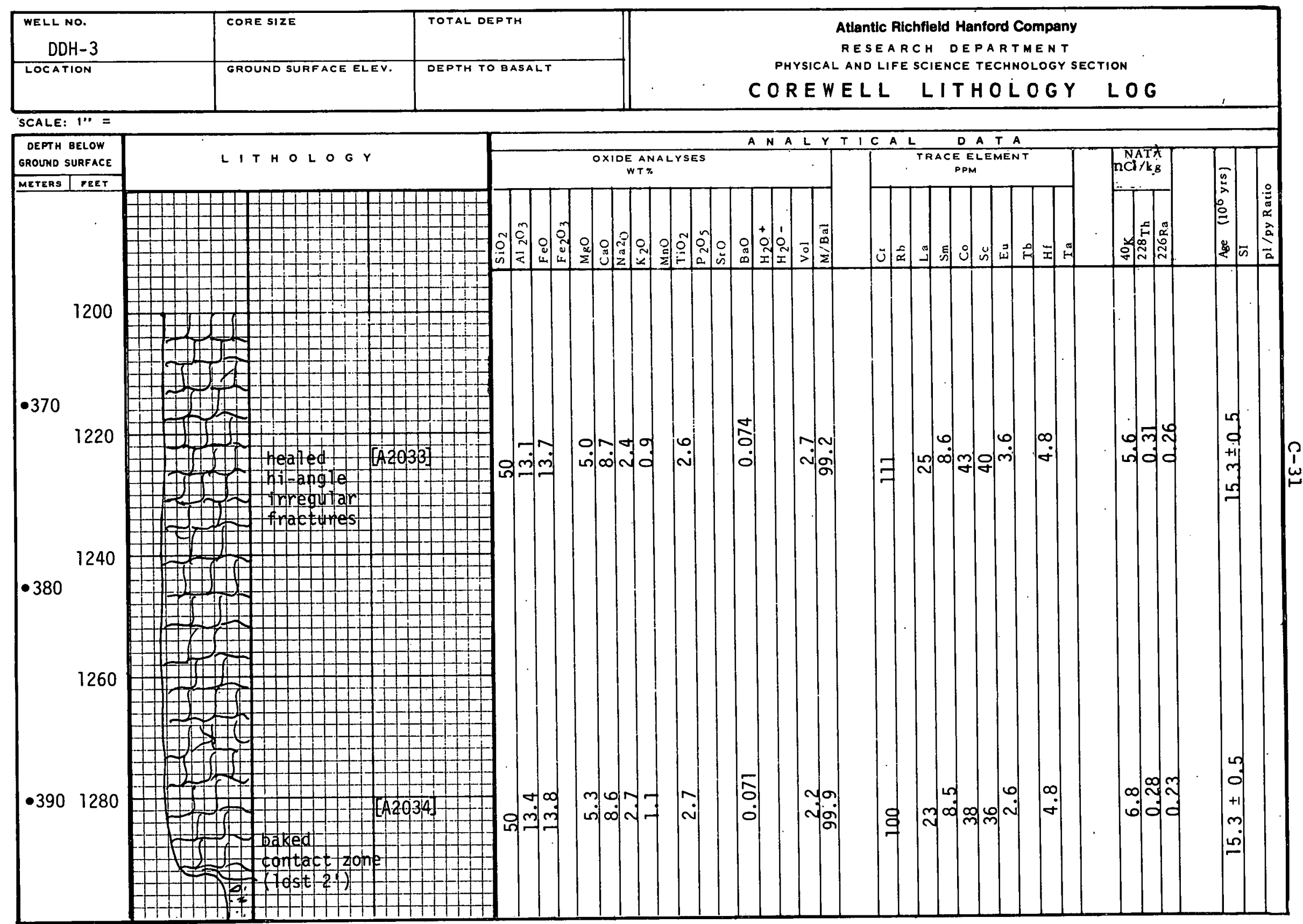

BD-6000-107 (12-74) 


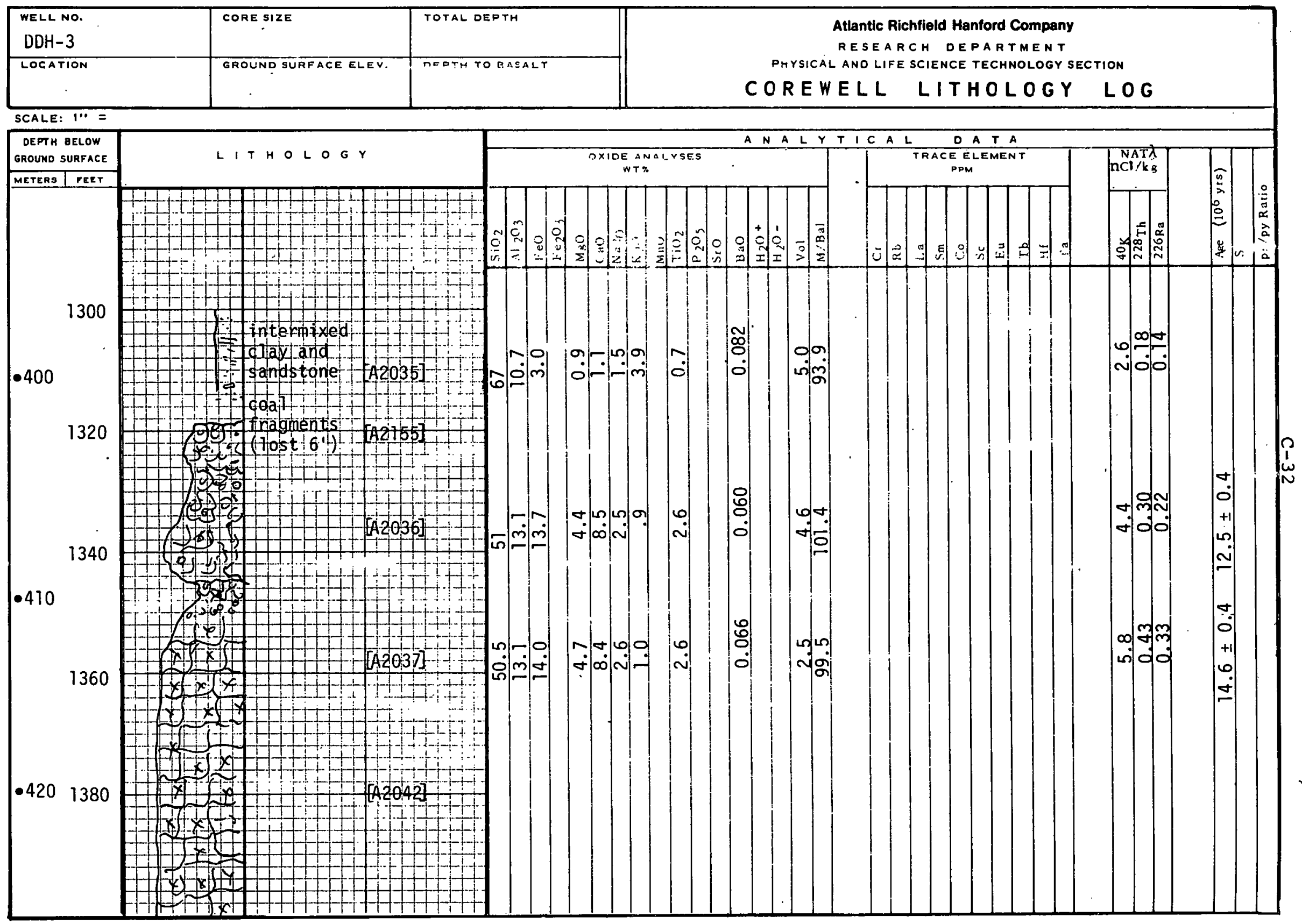

BD-6000-107 (12-74) 


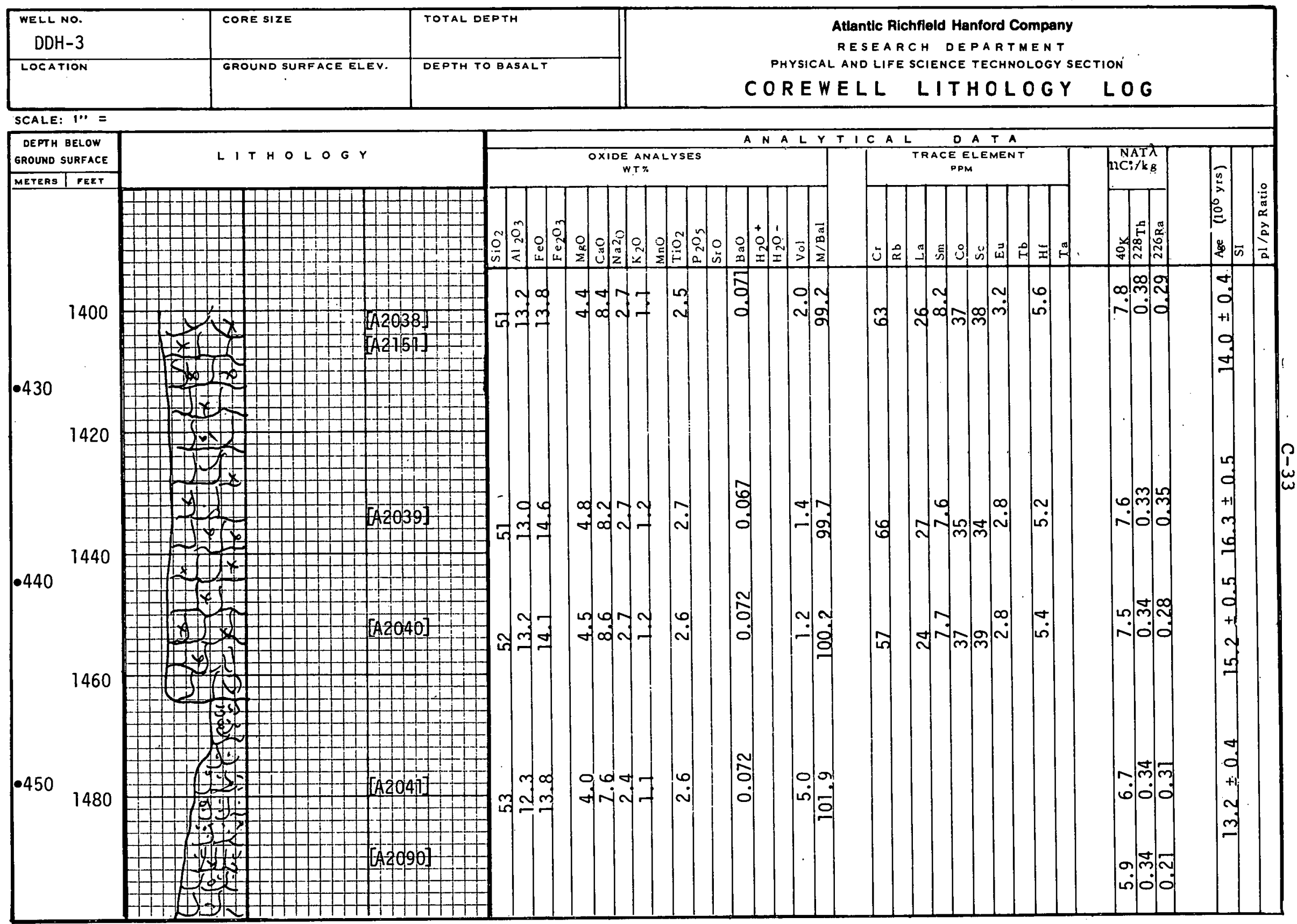




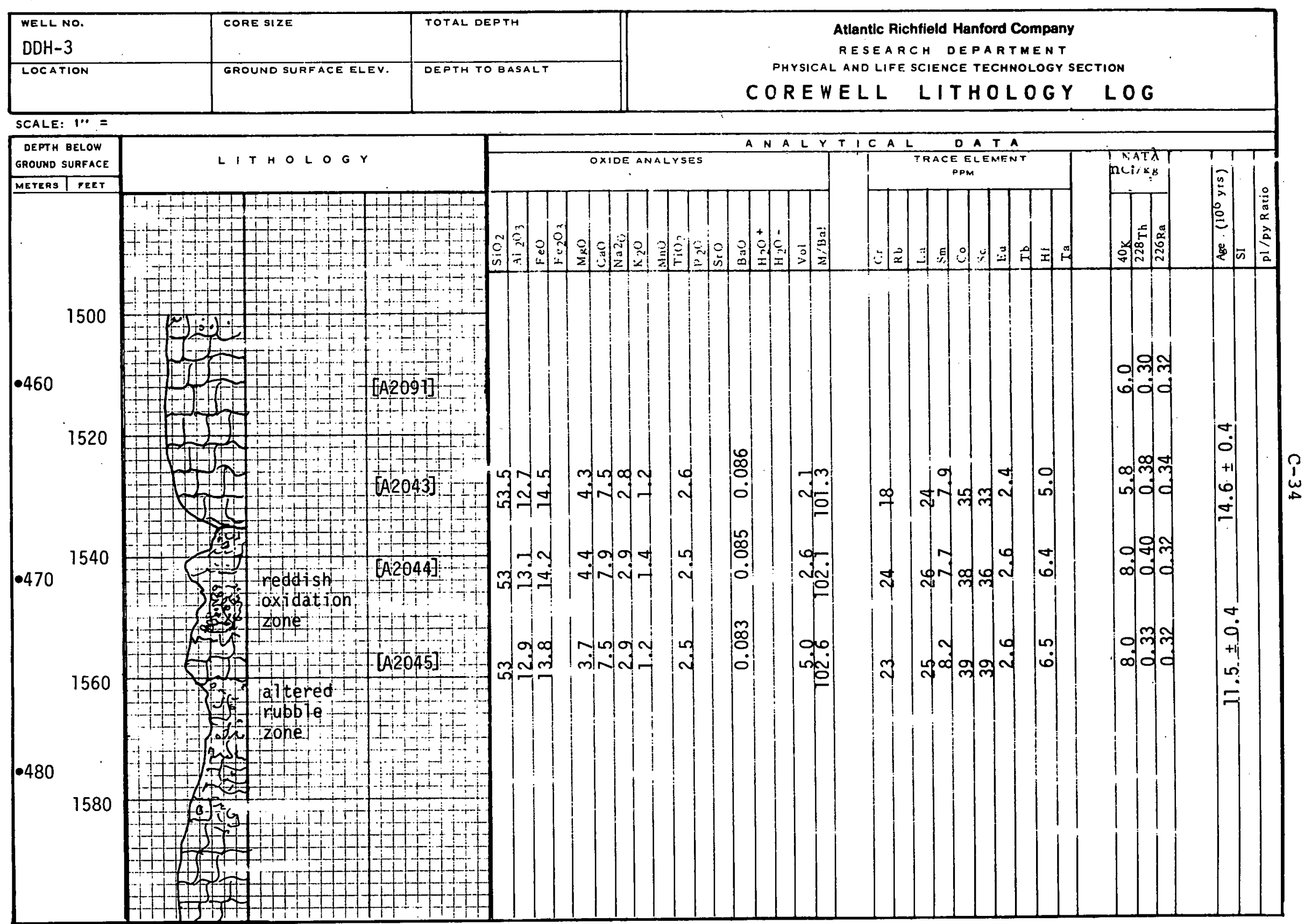




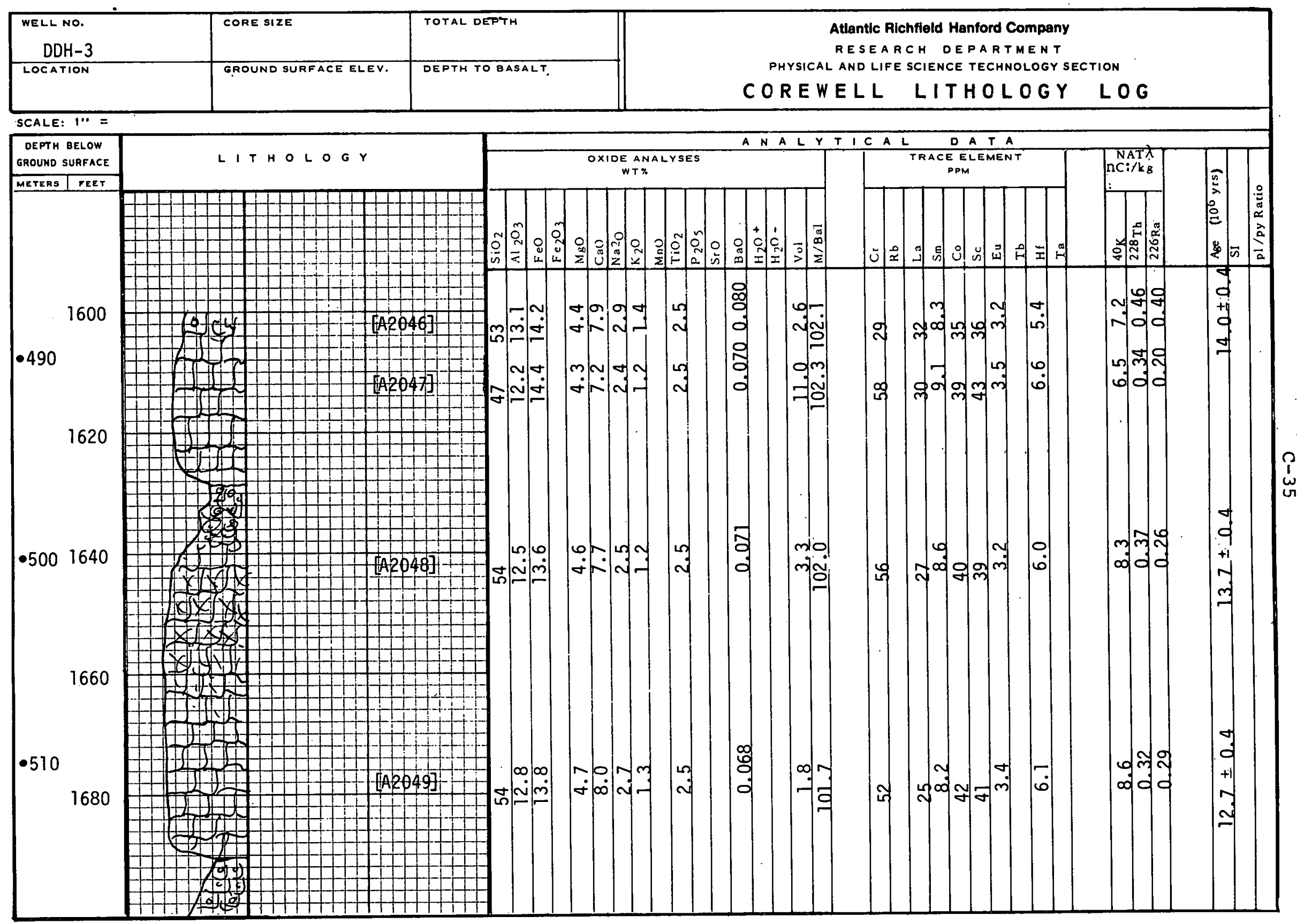




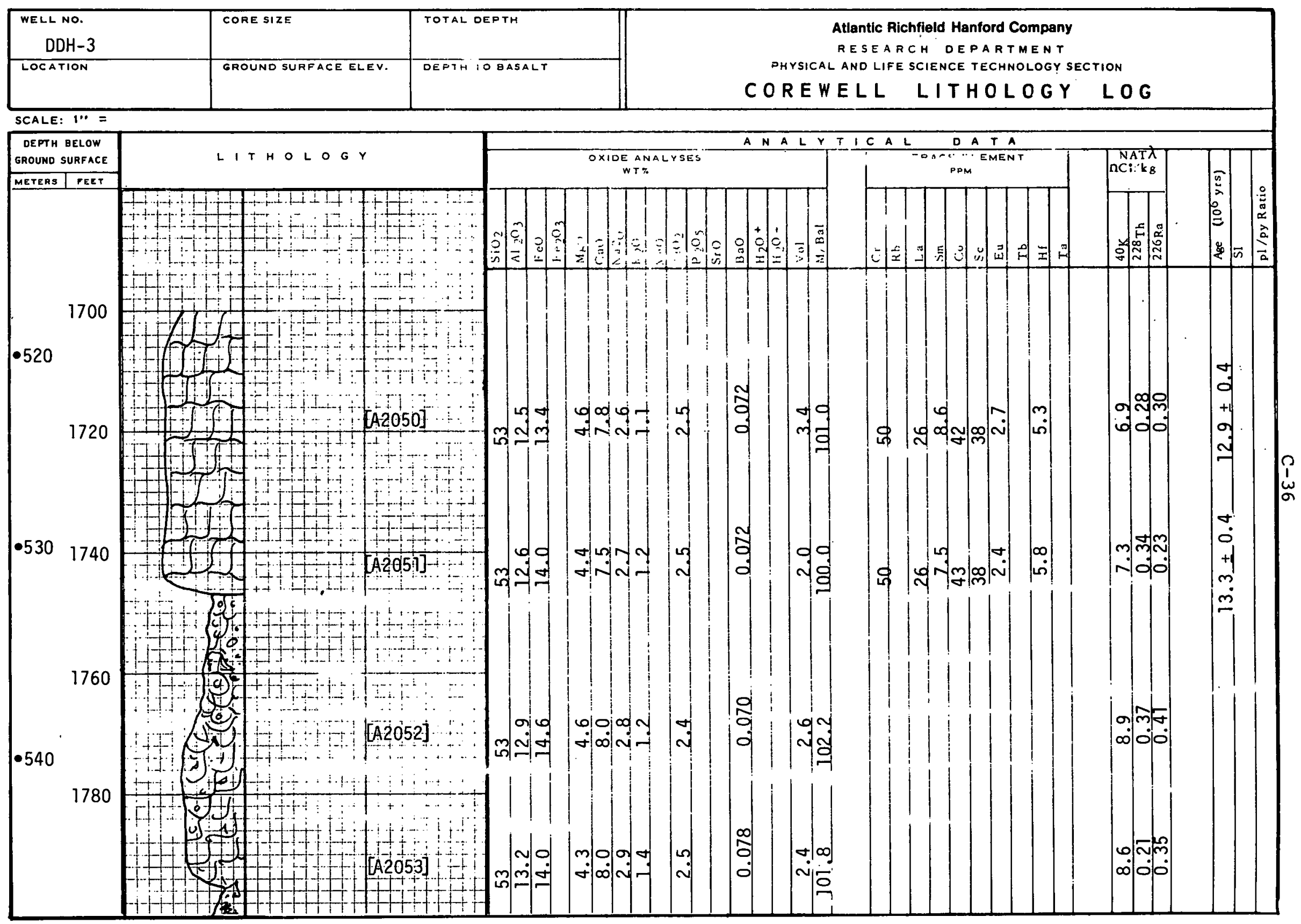




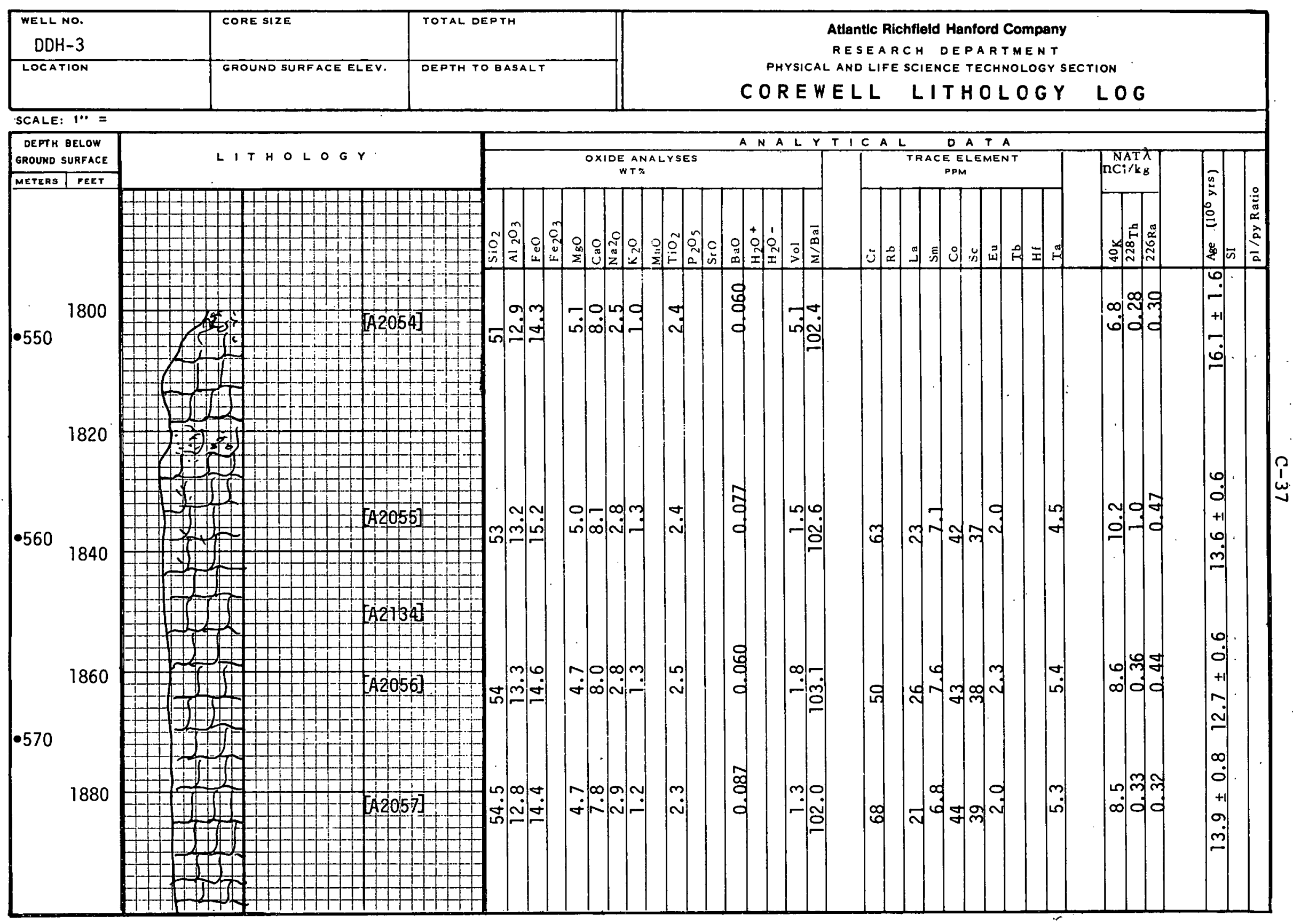




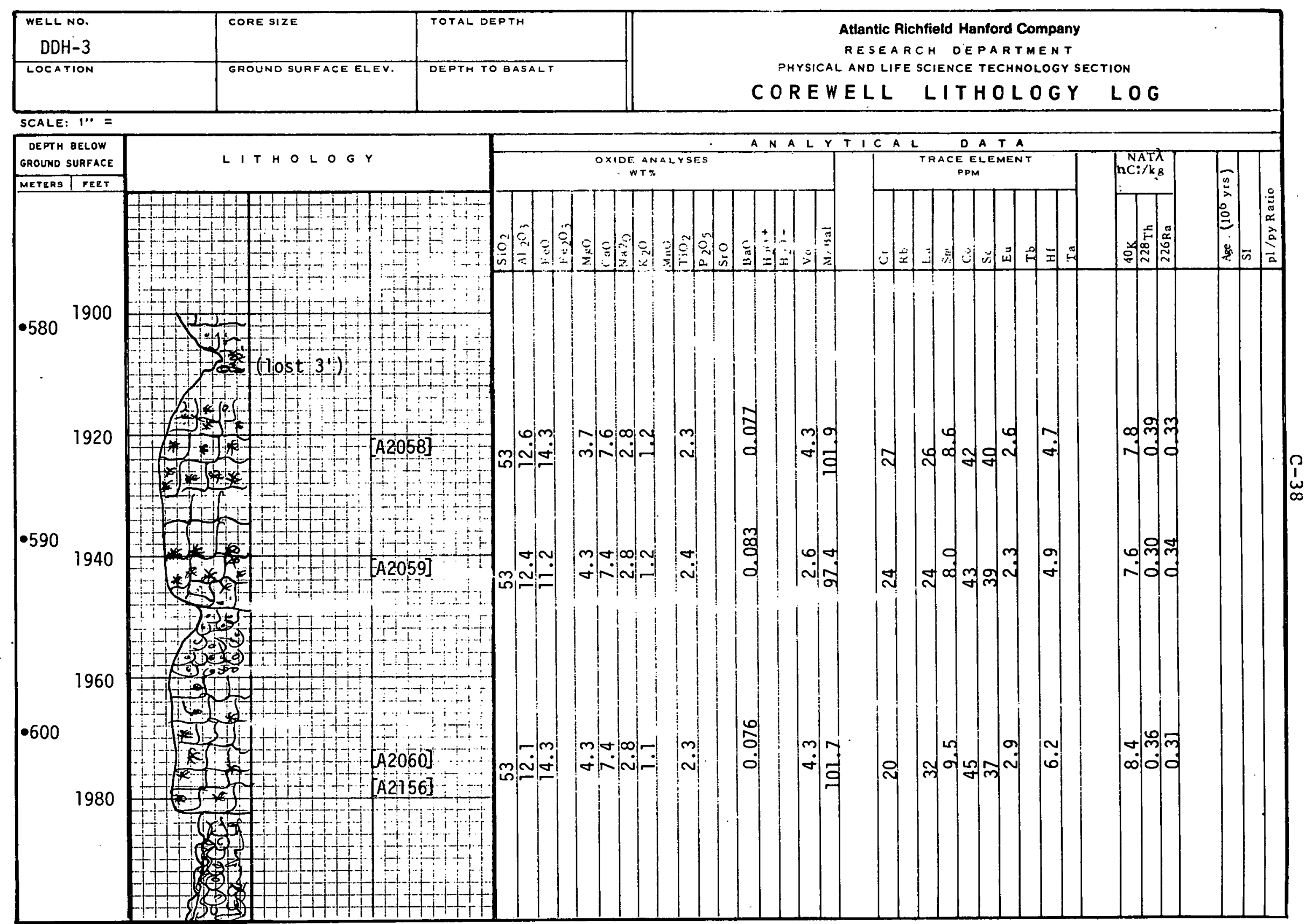




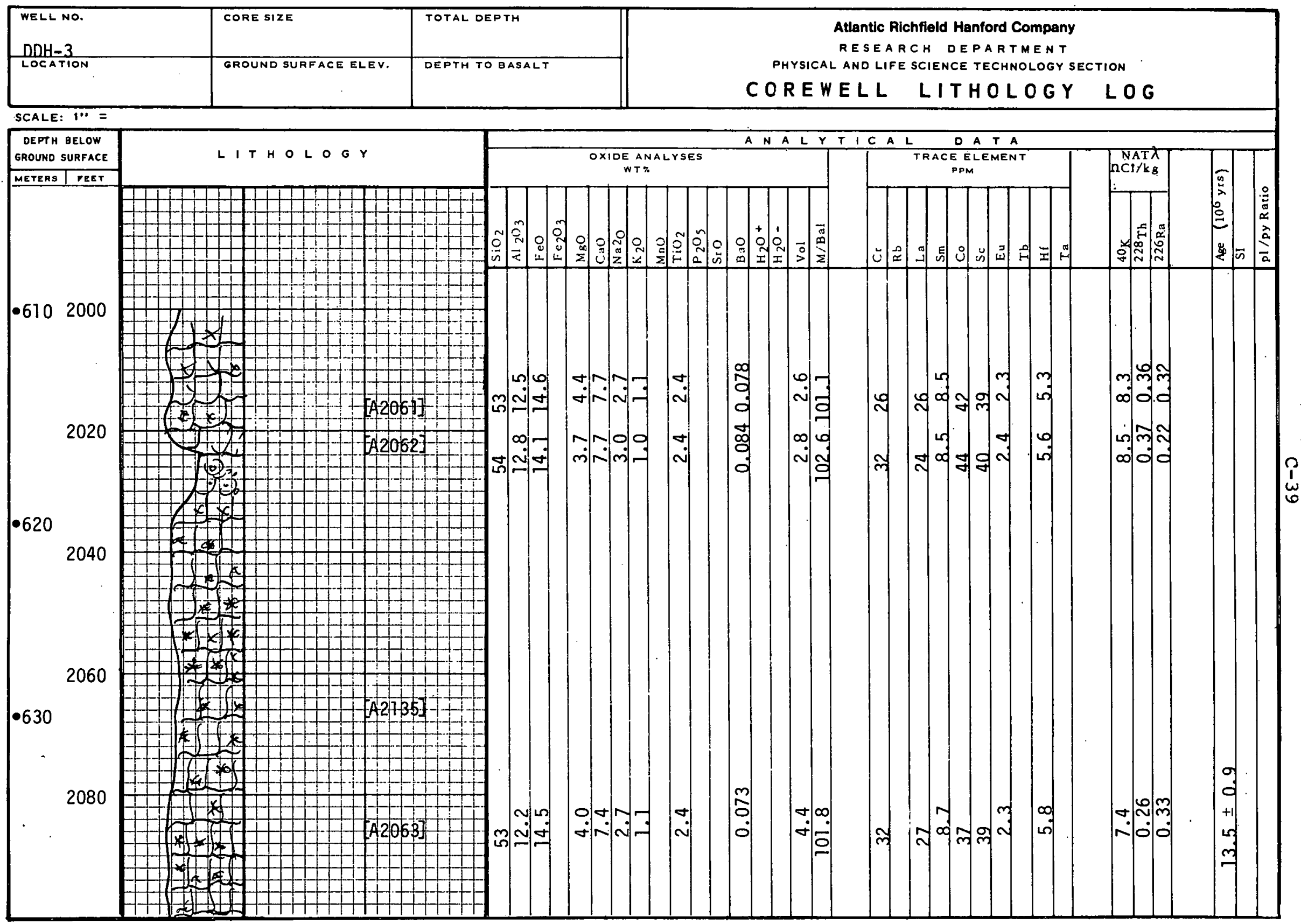




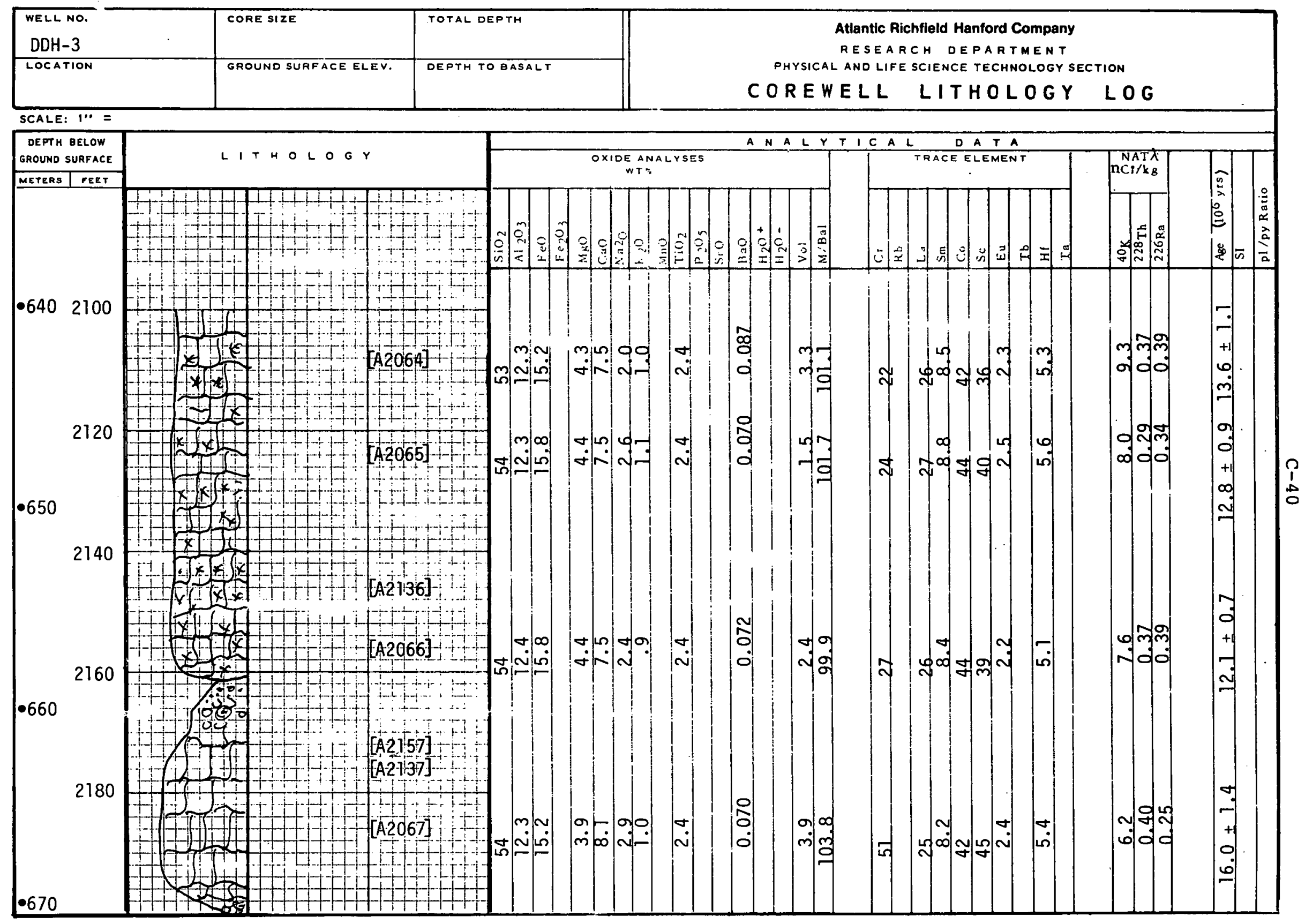

BD-6000-107 (12-74) 


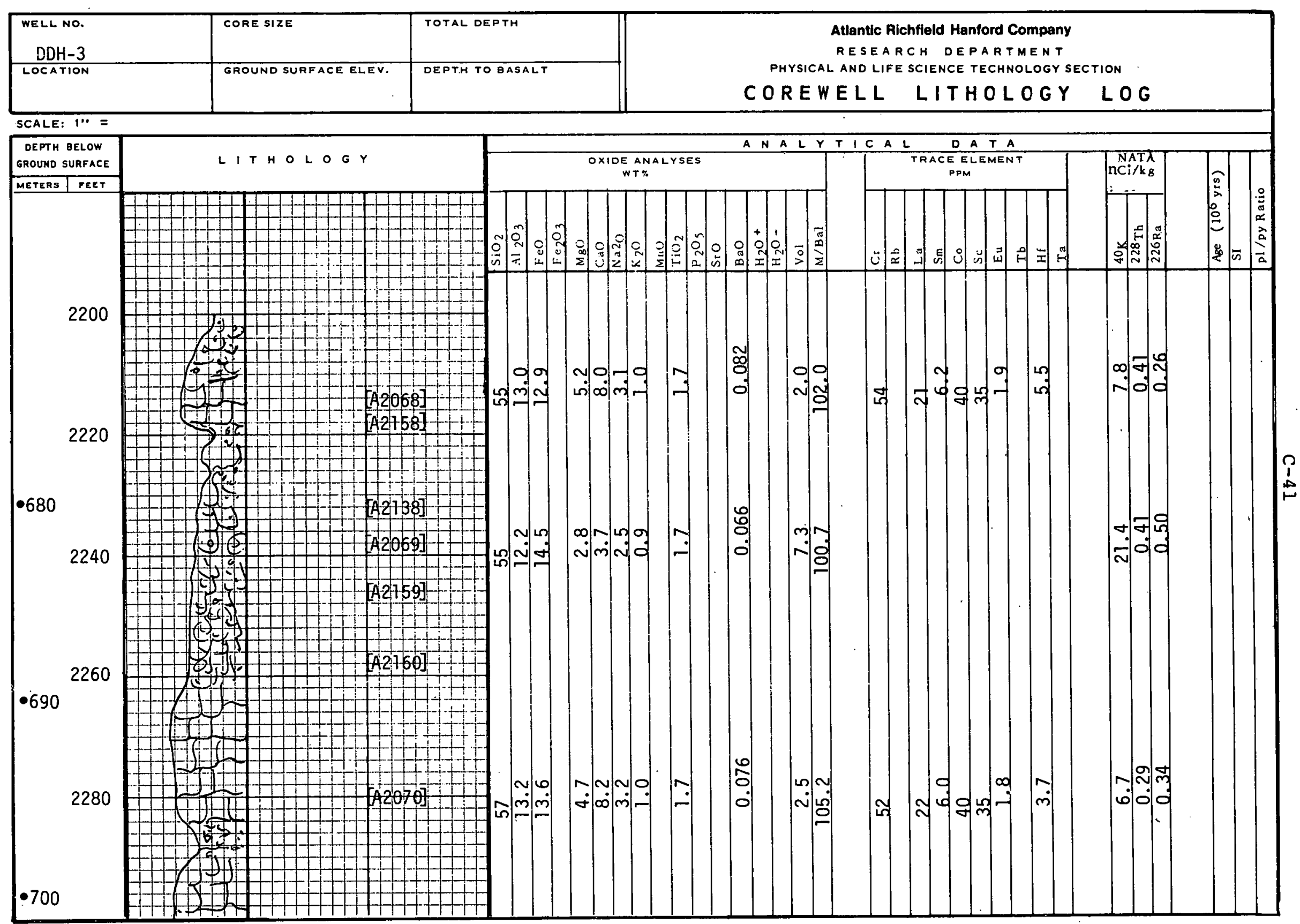

BD-6000-107 (12-74) 


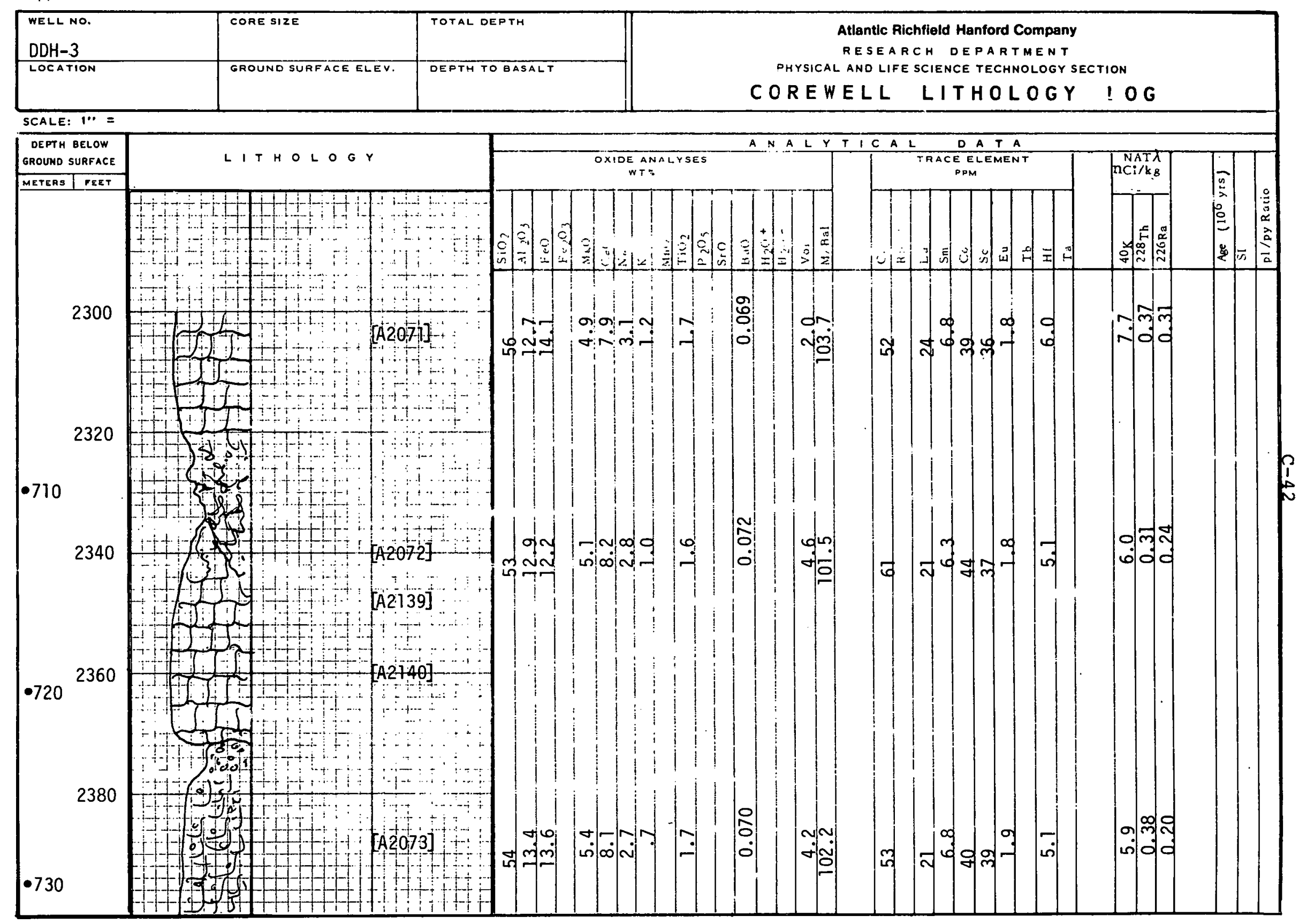




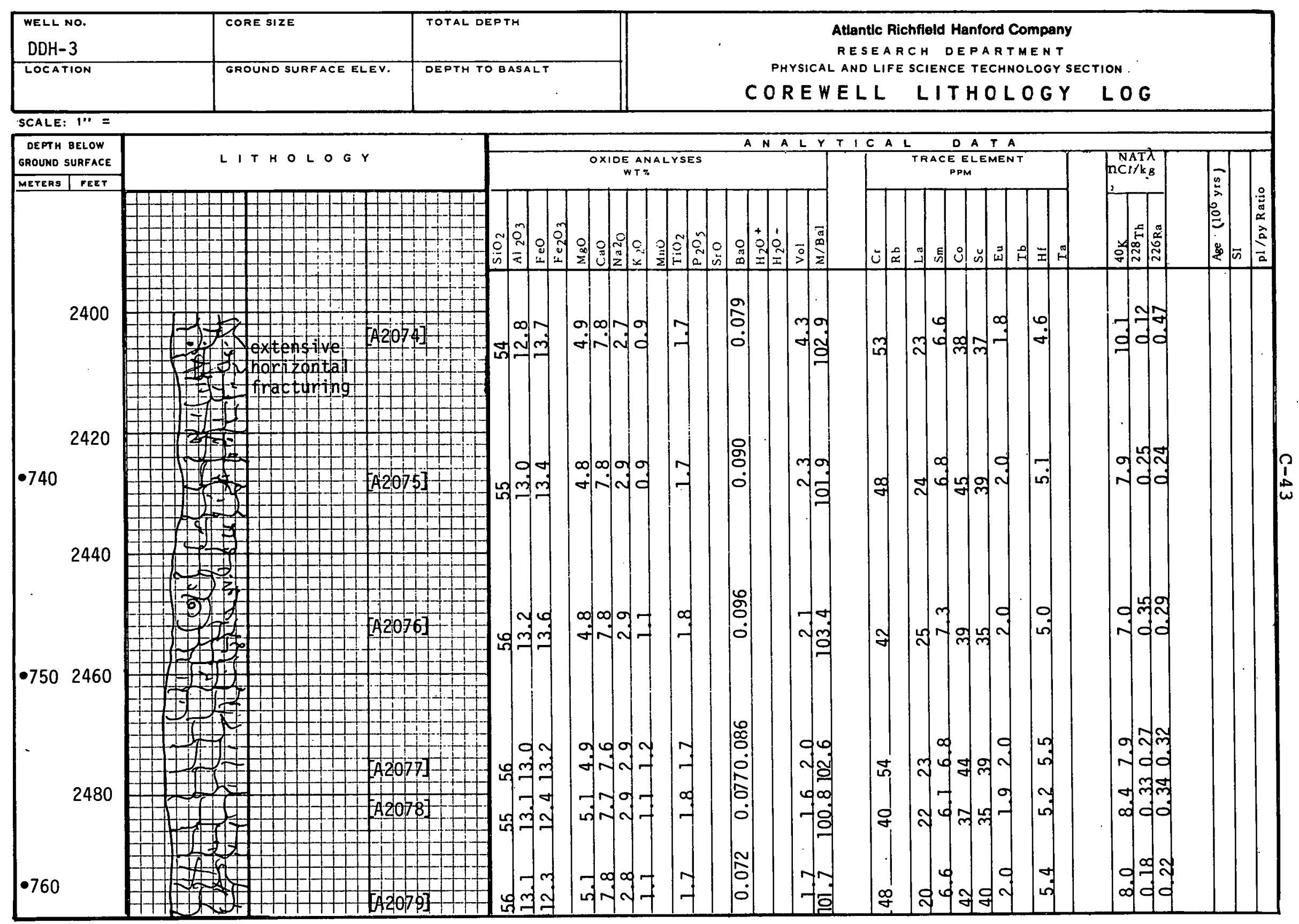




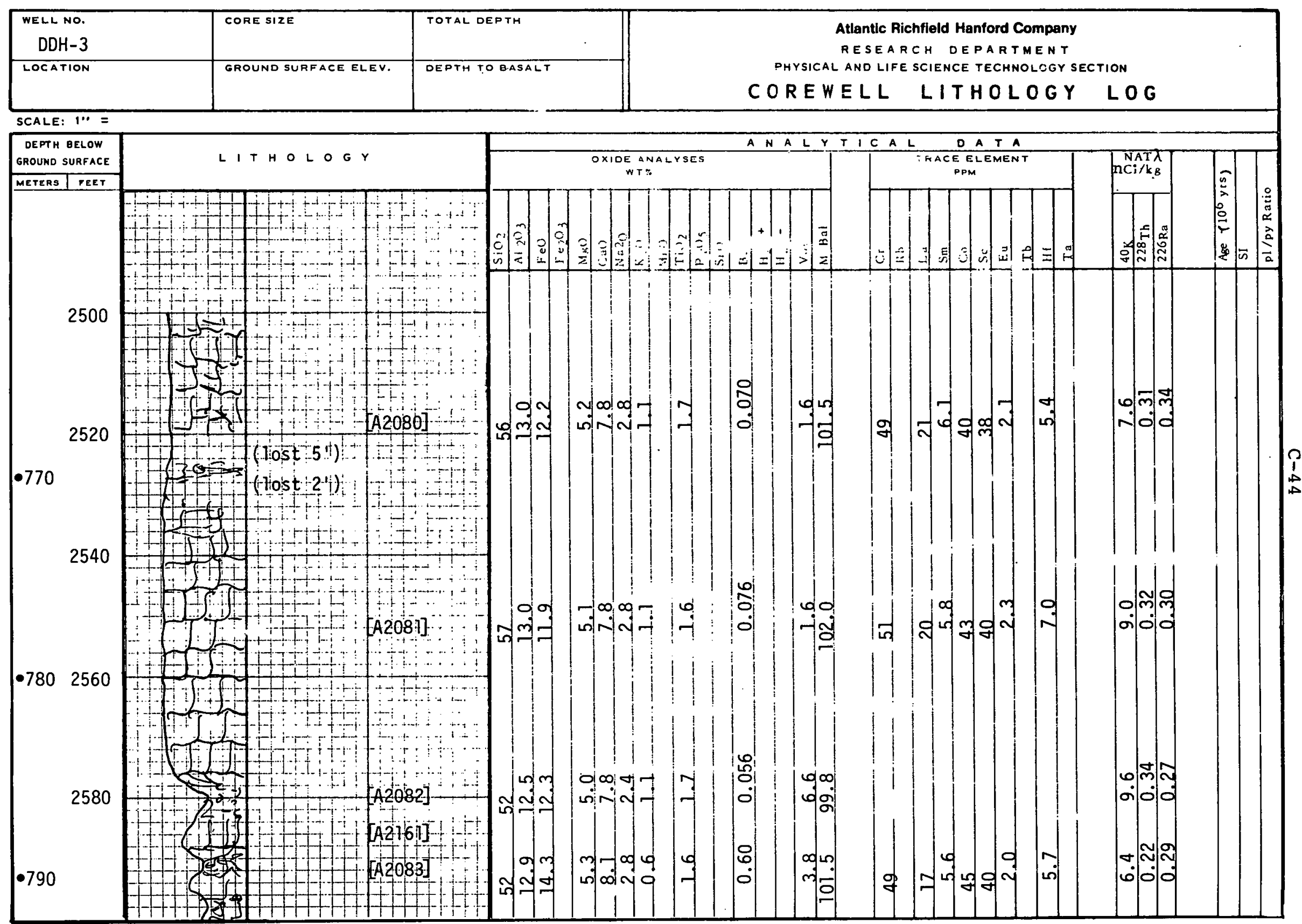




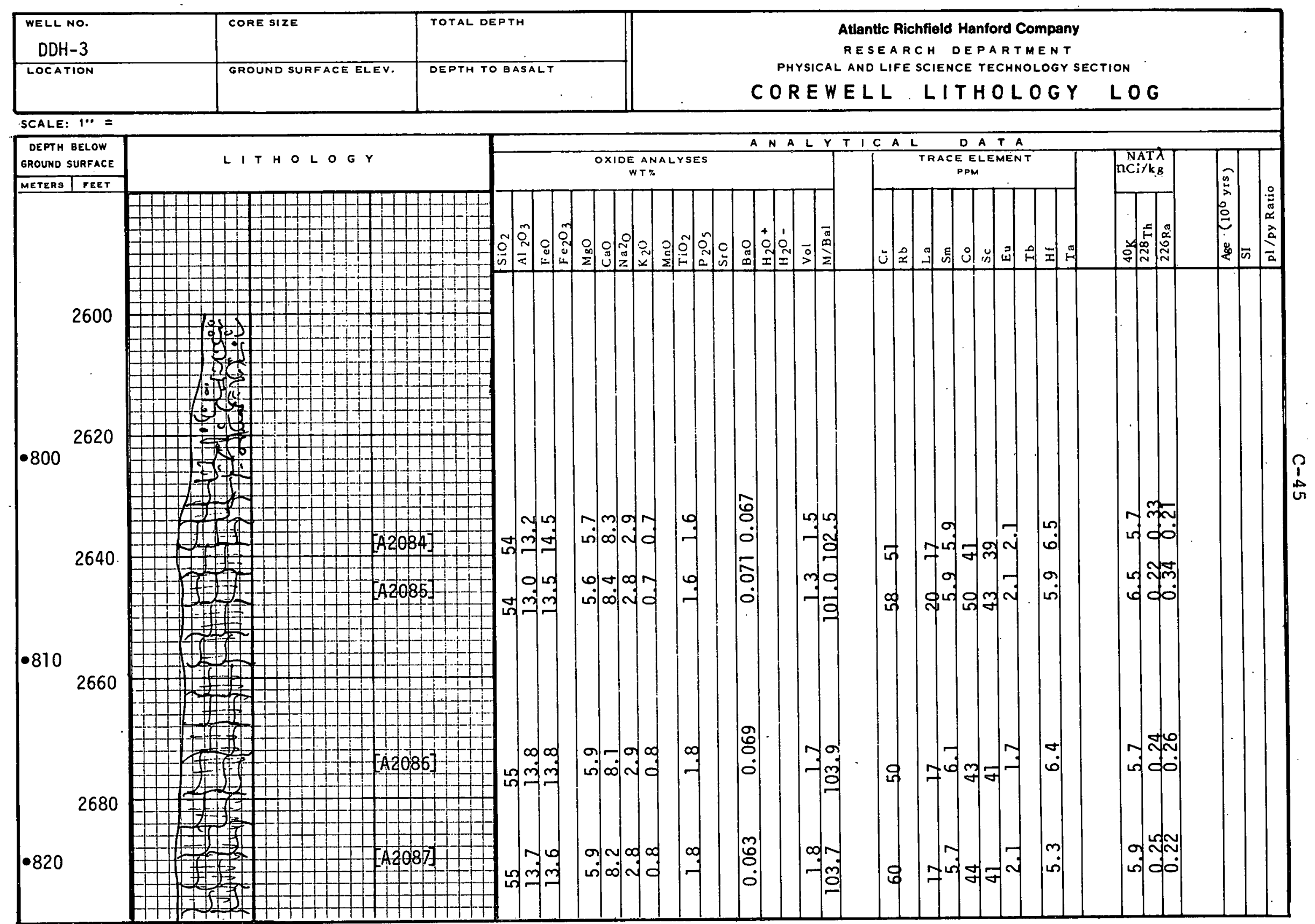




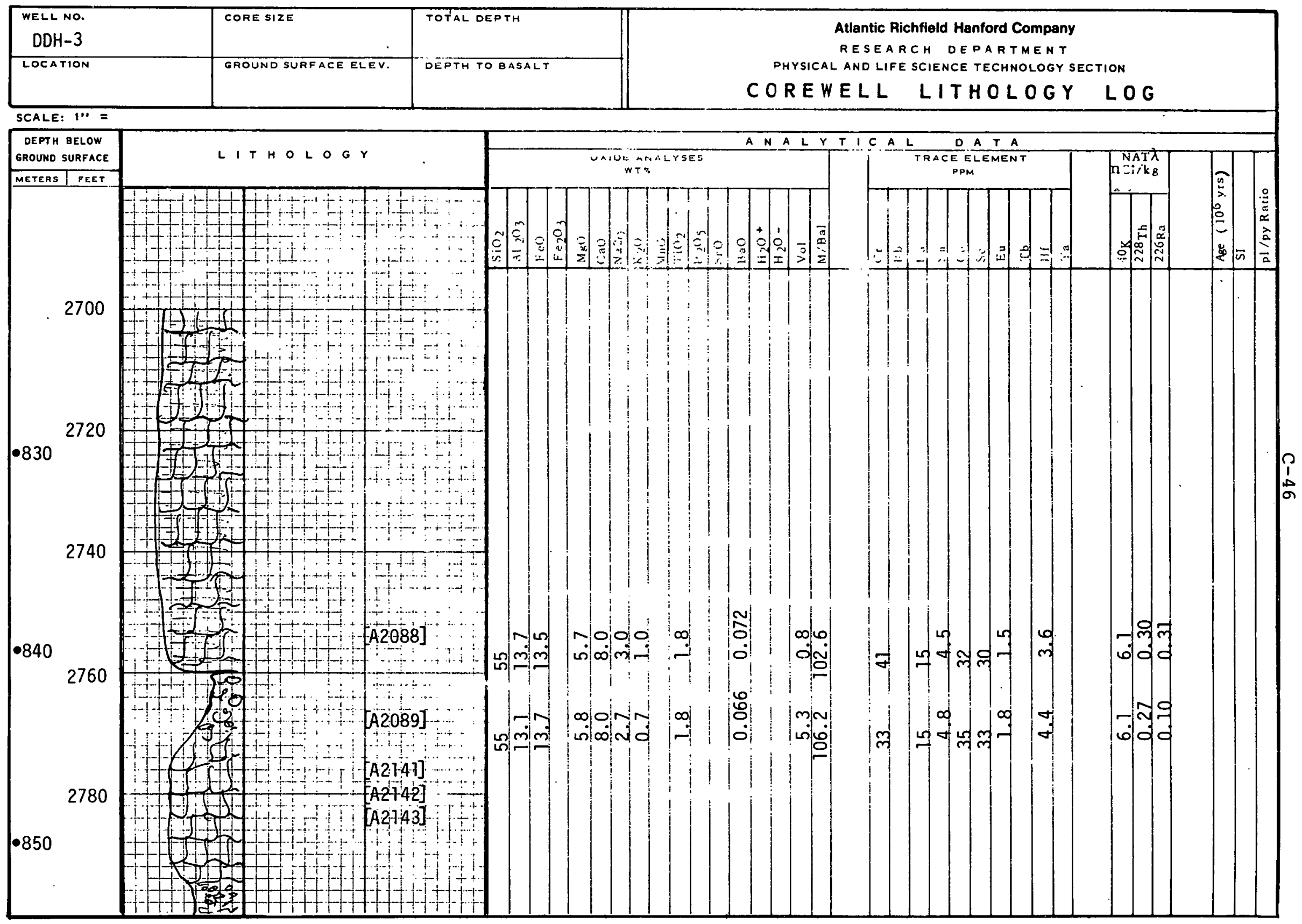




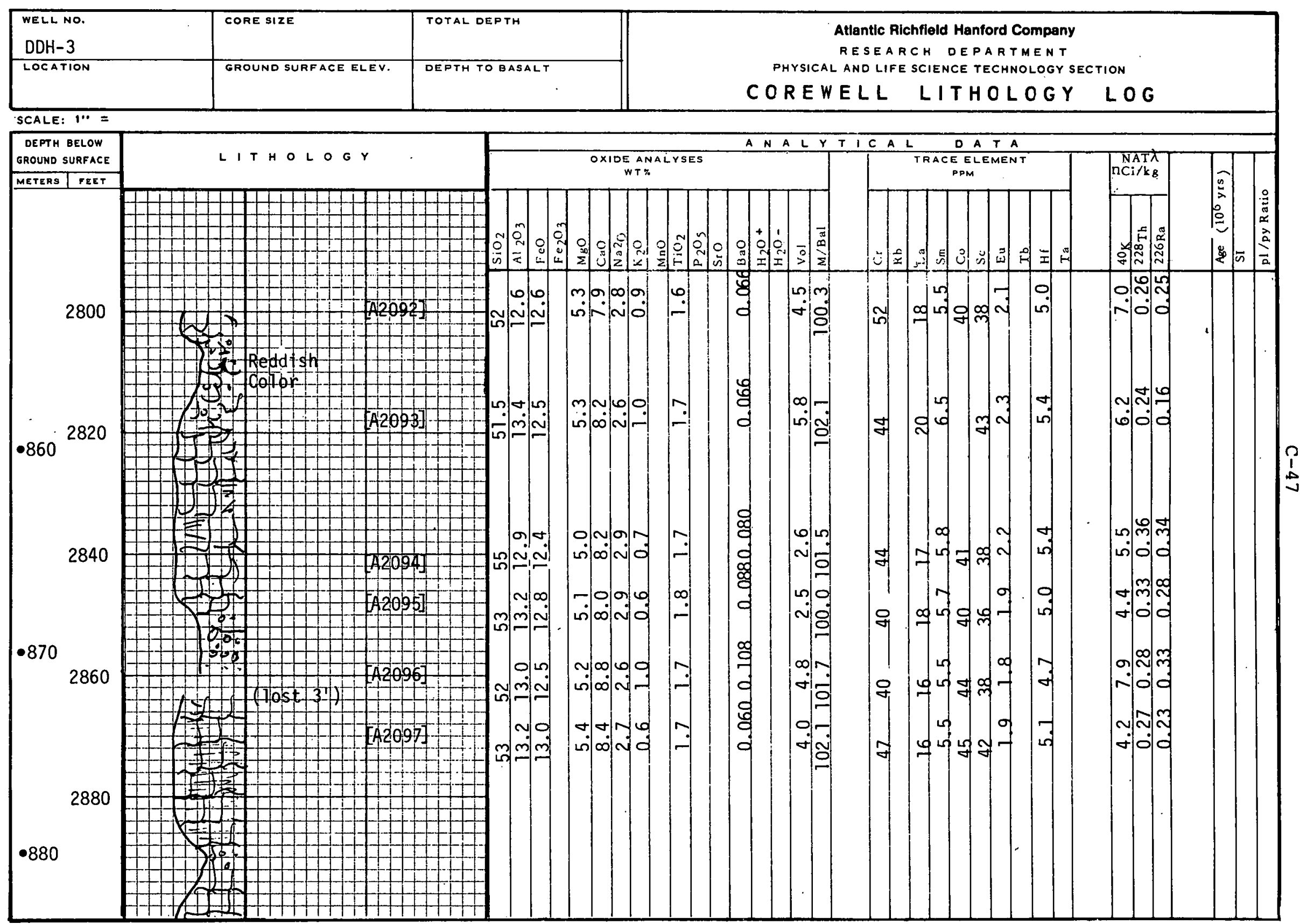




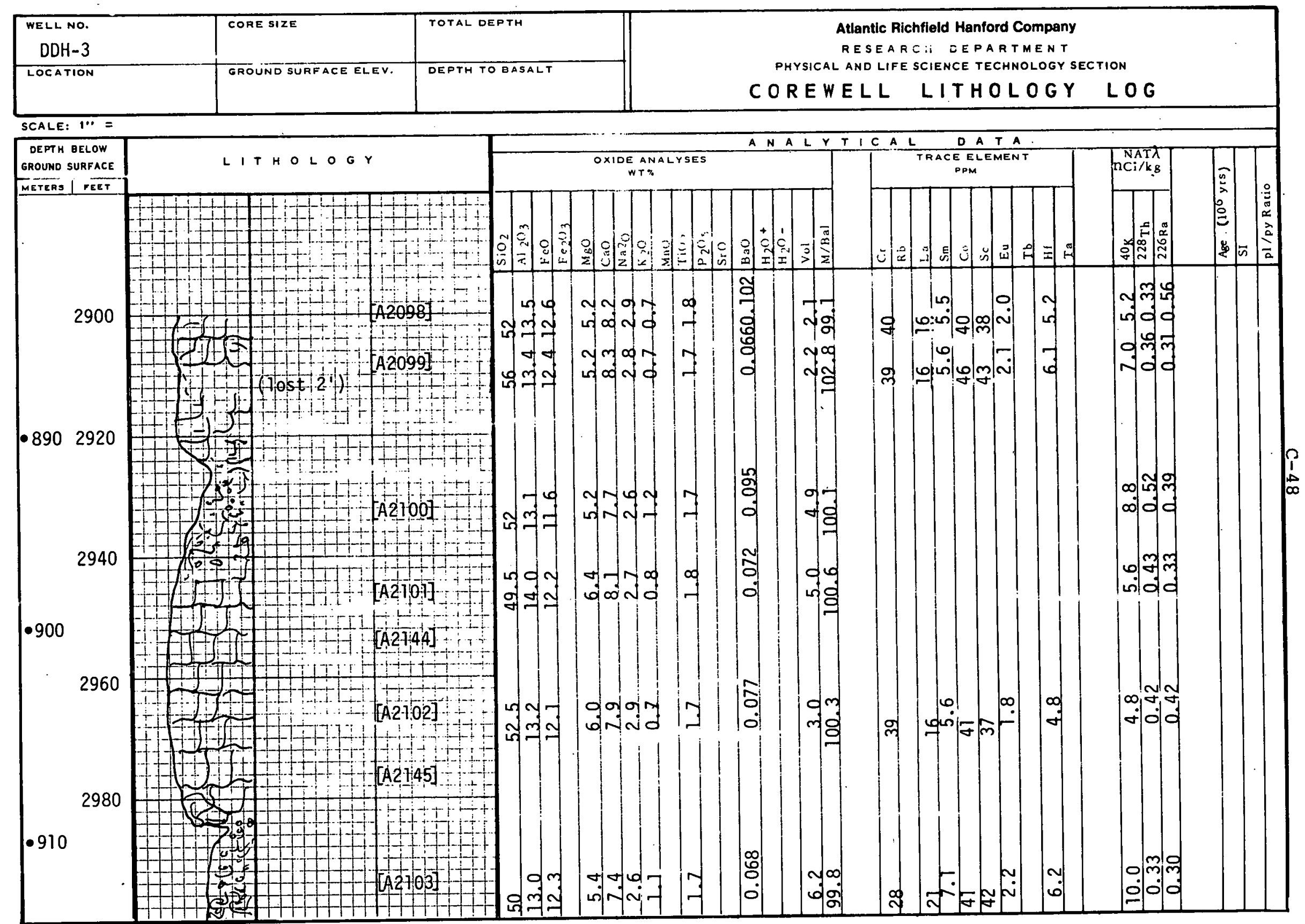

80-6000-107 (12-74) 


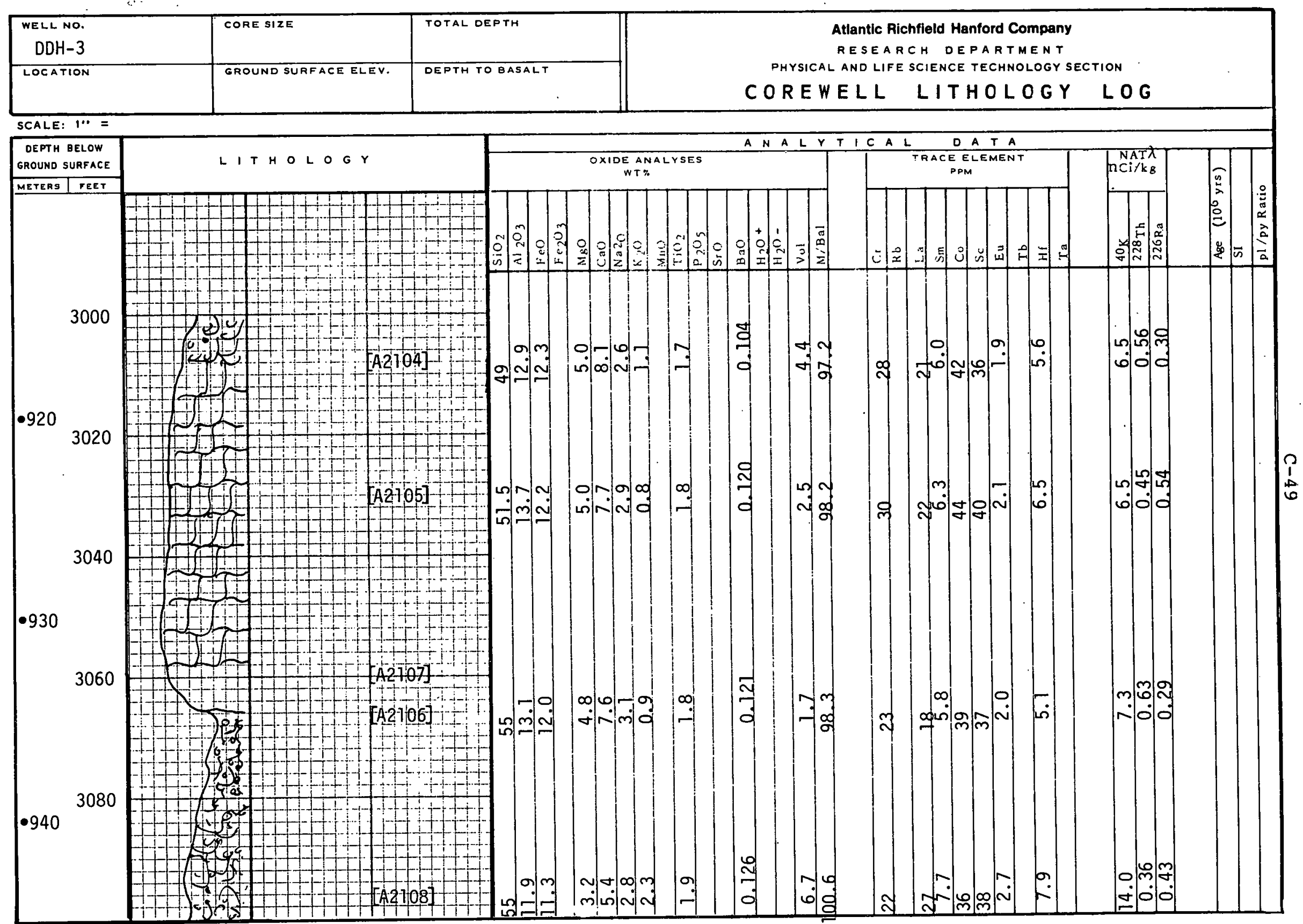

8D-6000-107 (12-74) 


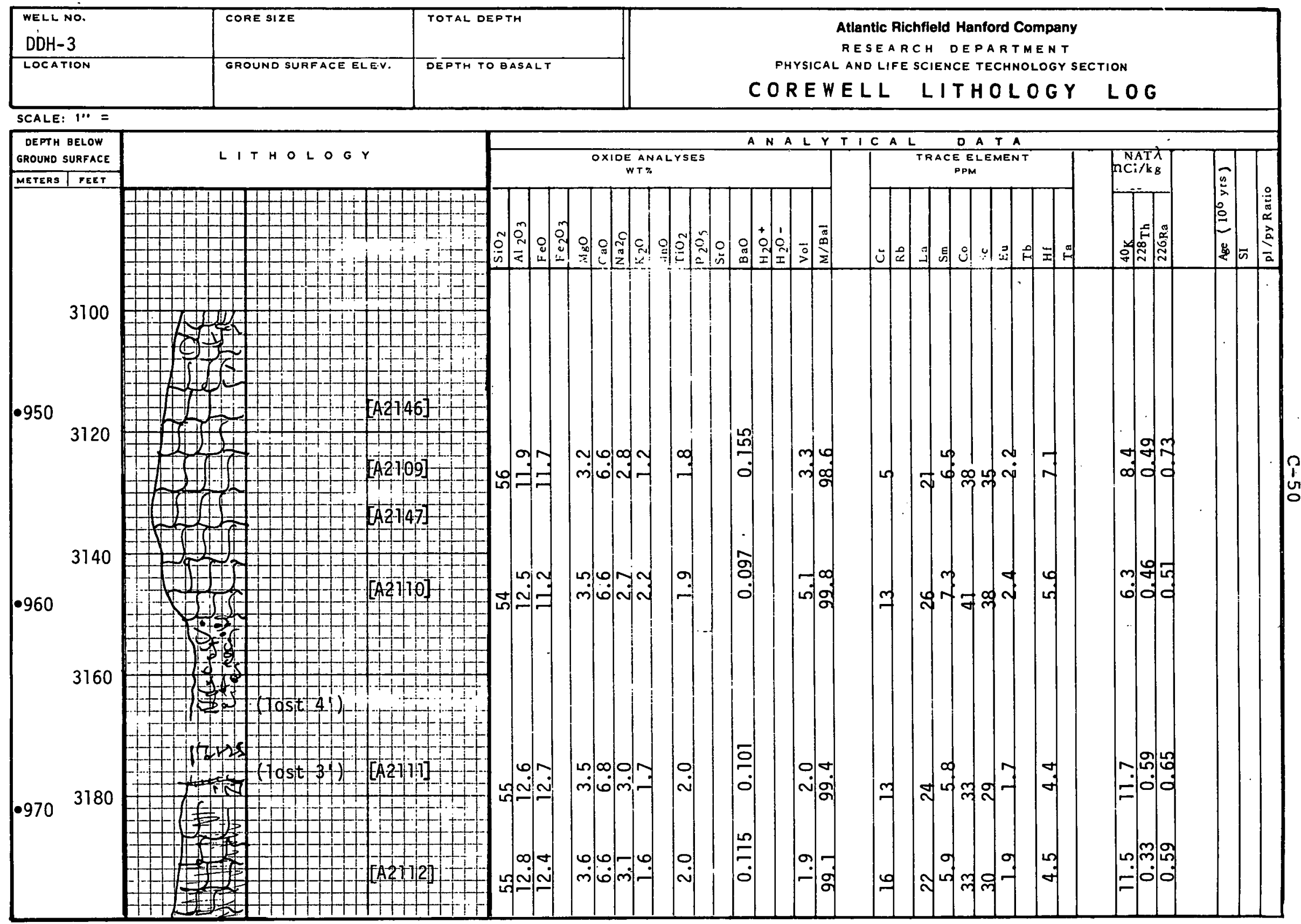




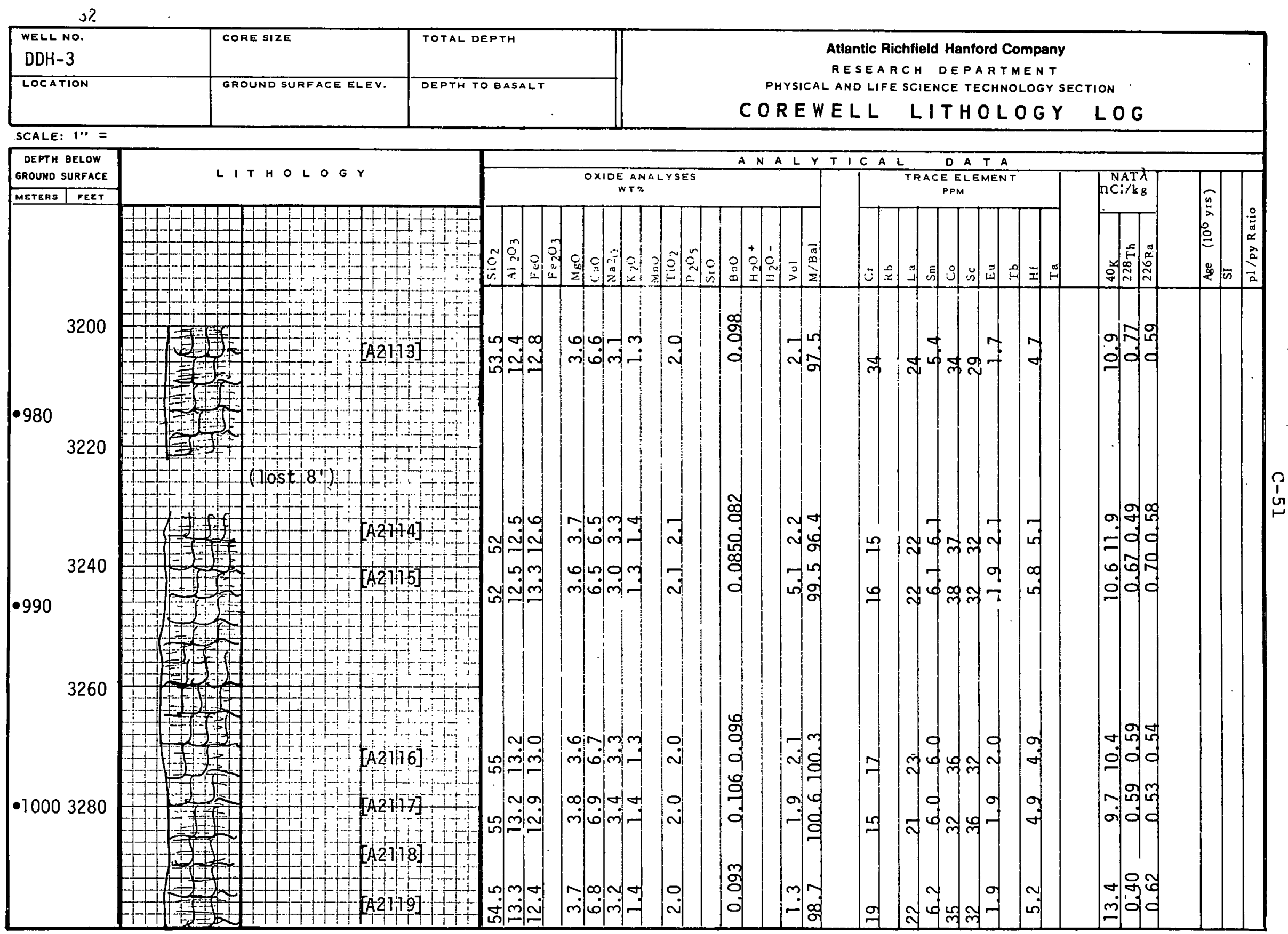




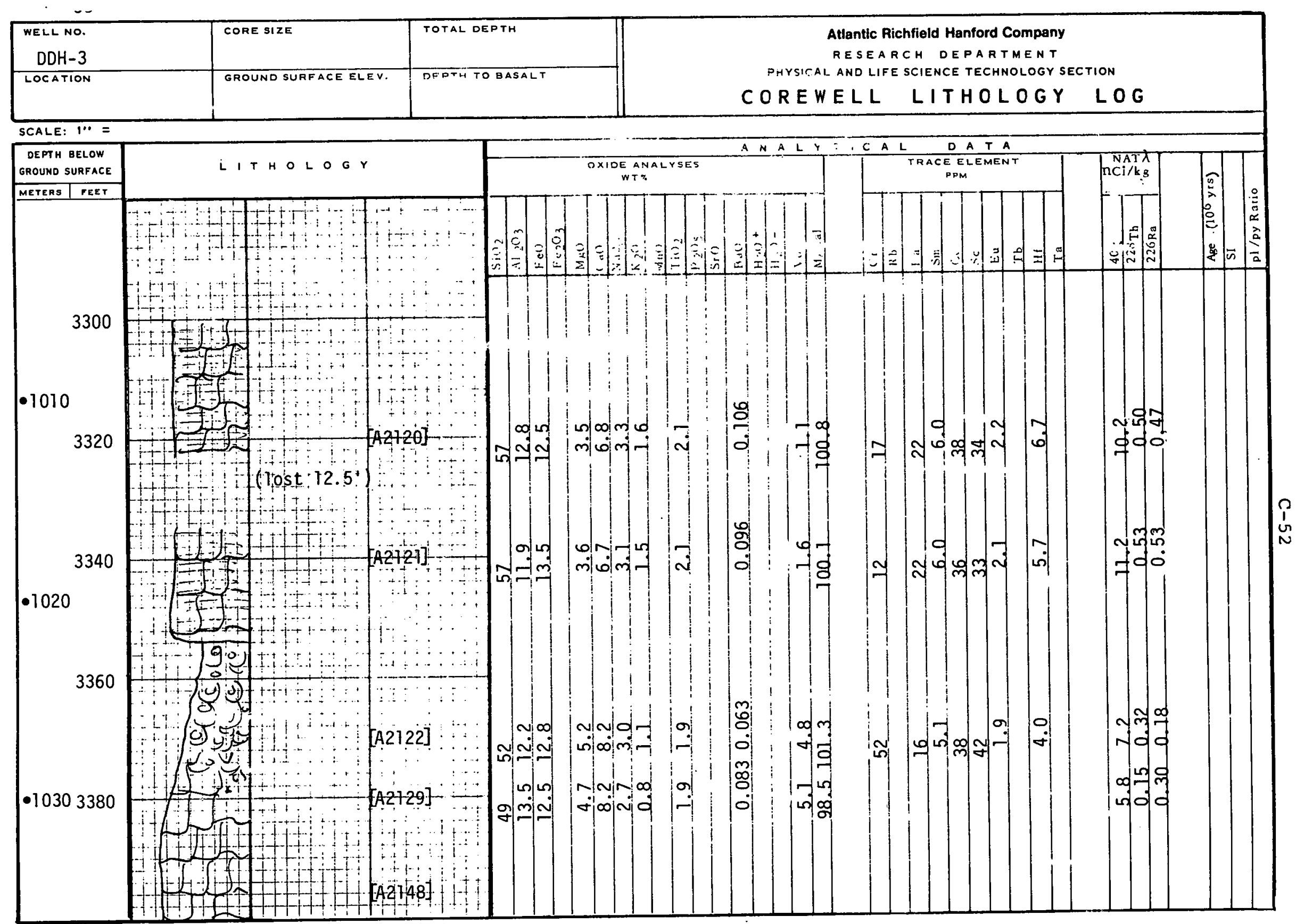




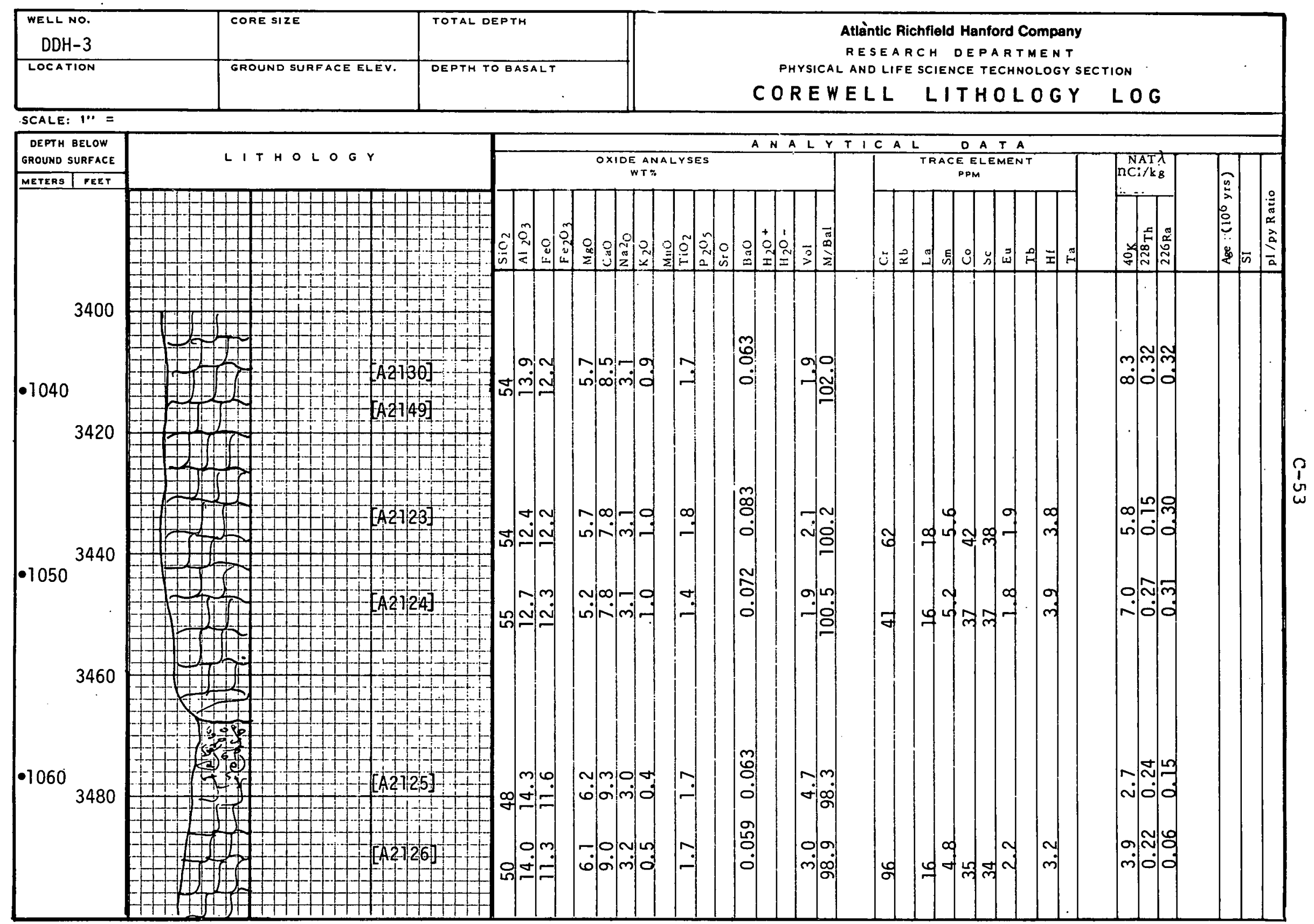




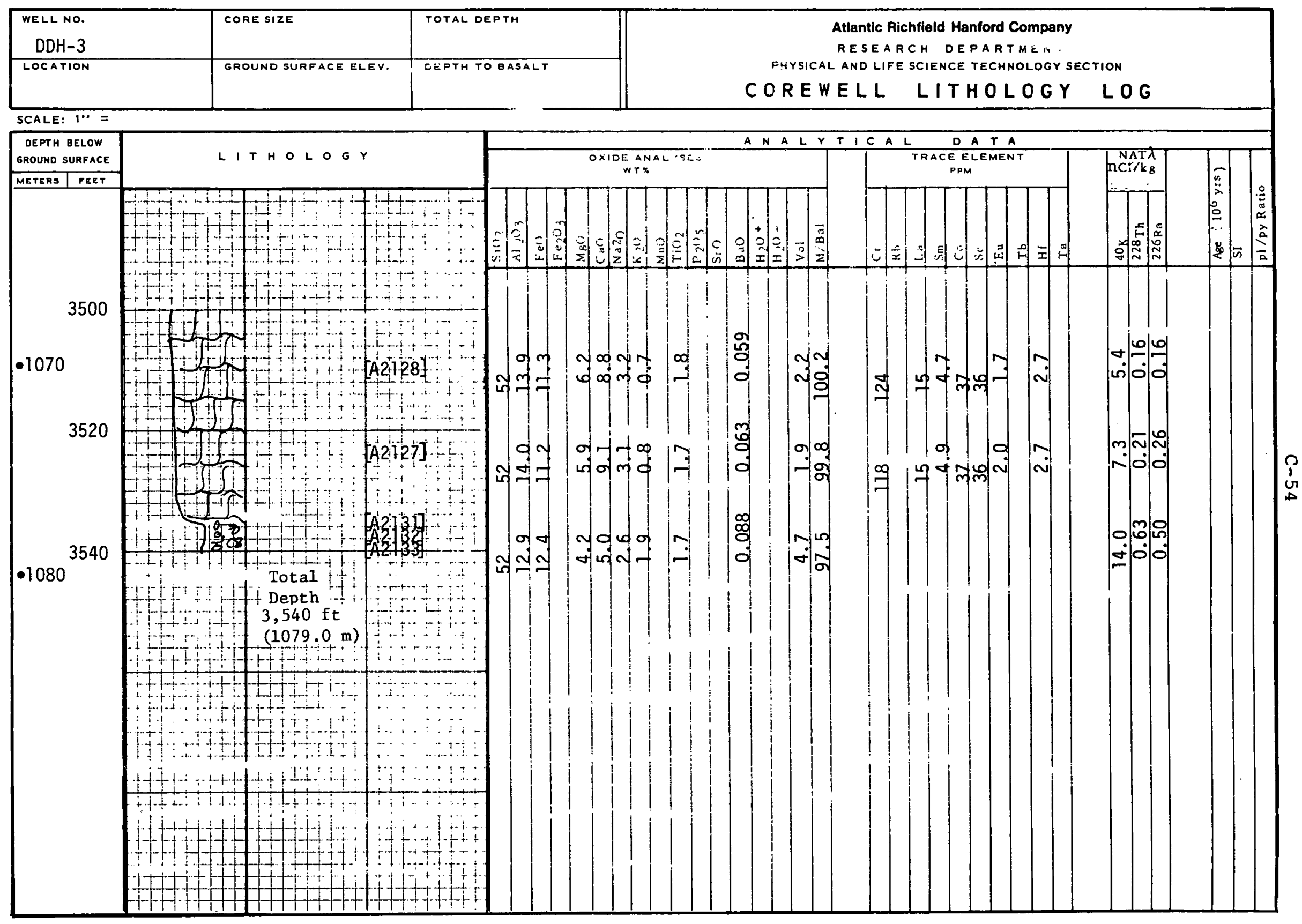




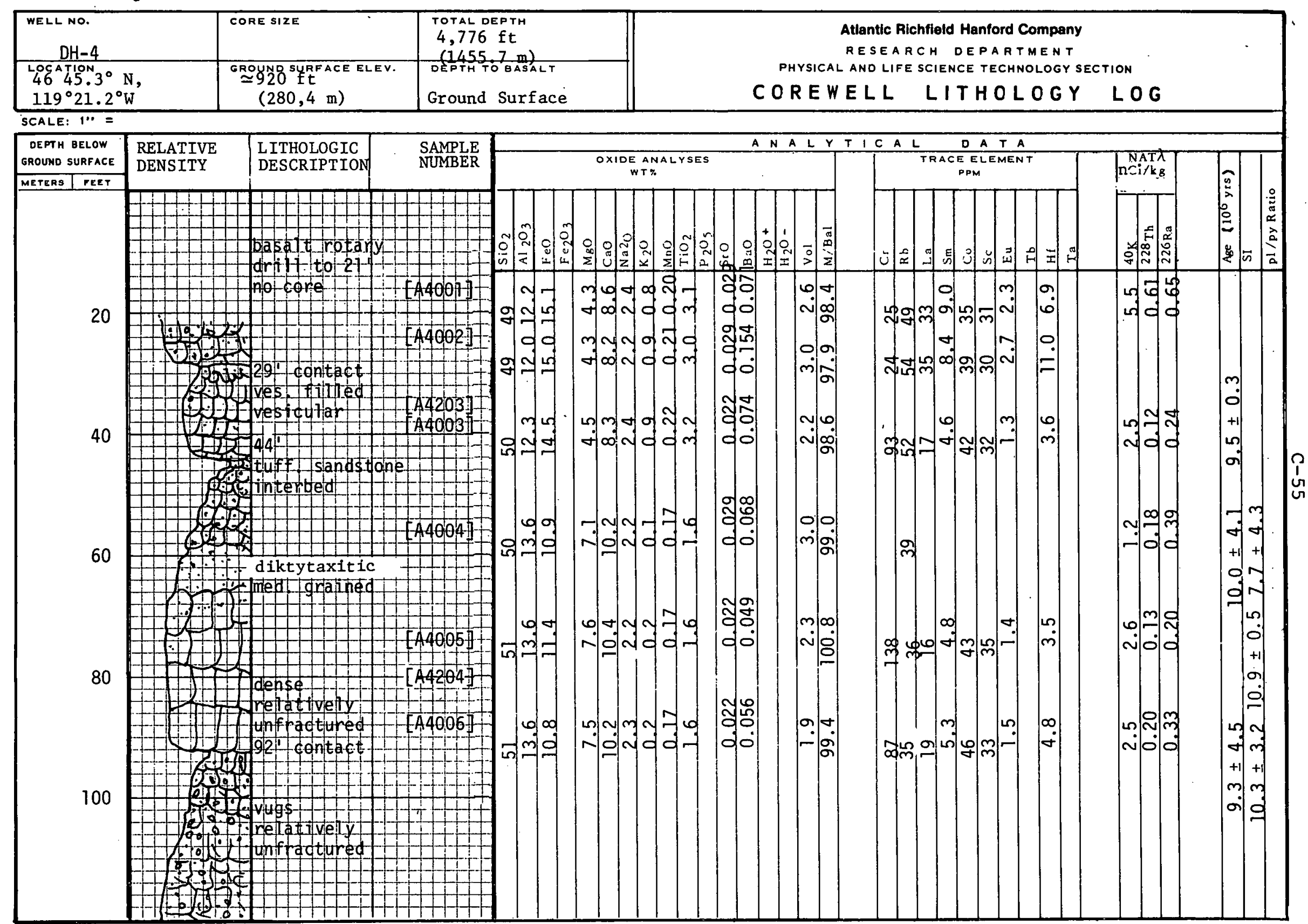




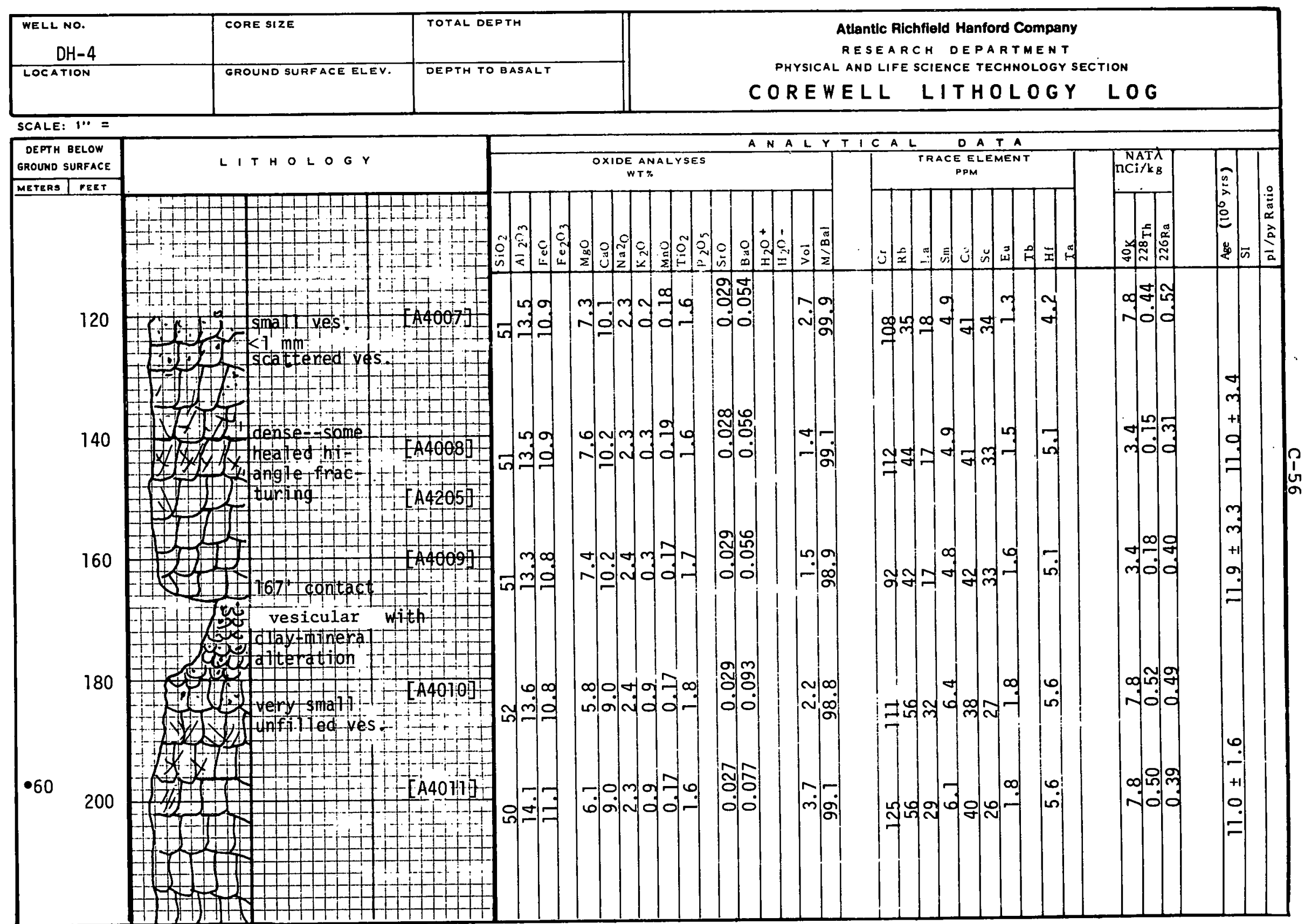




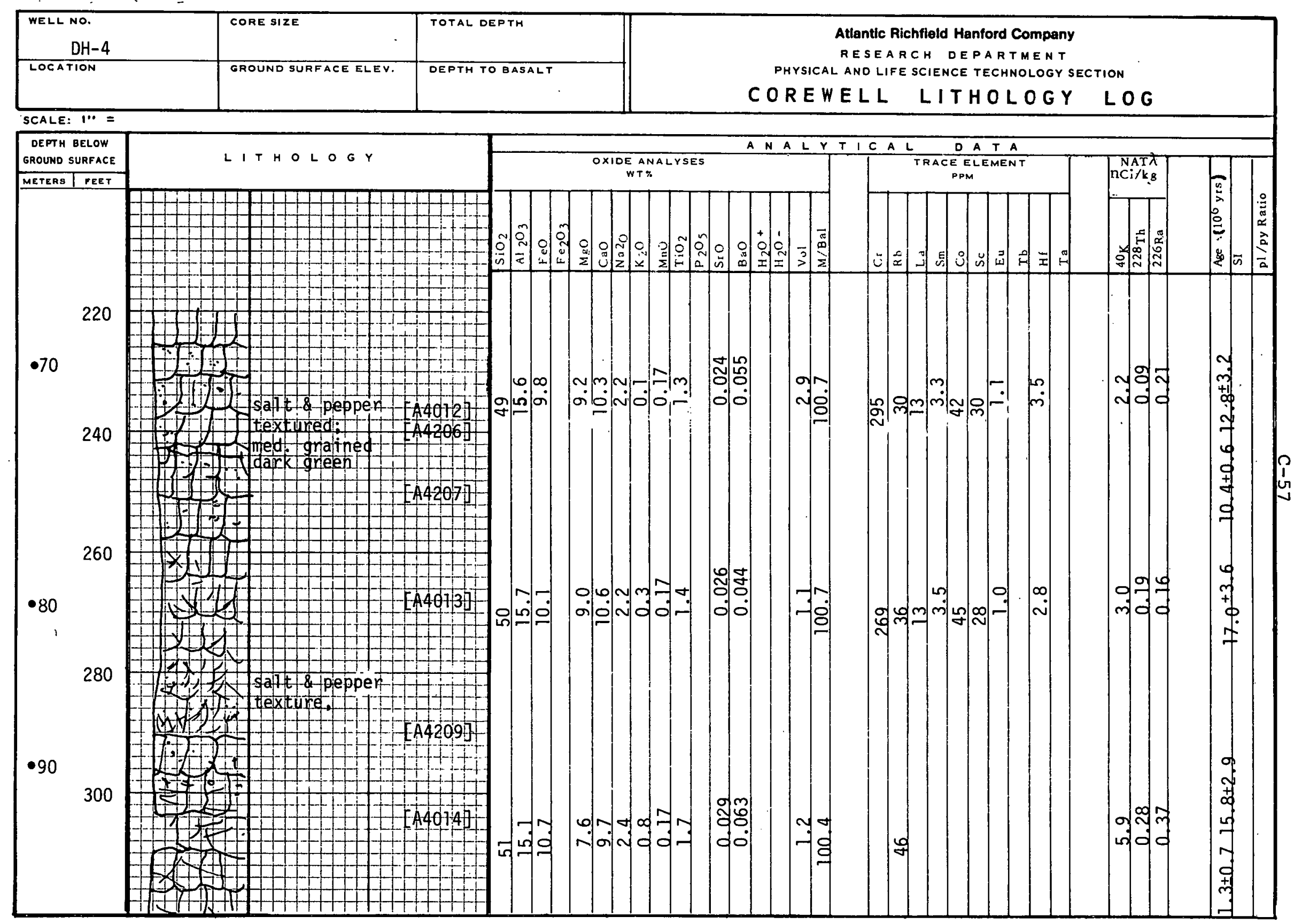

BD-6000-107 (12-74) 


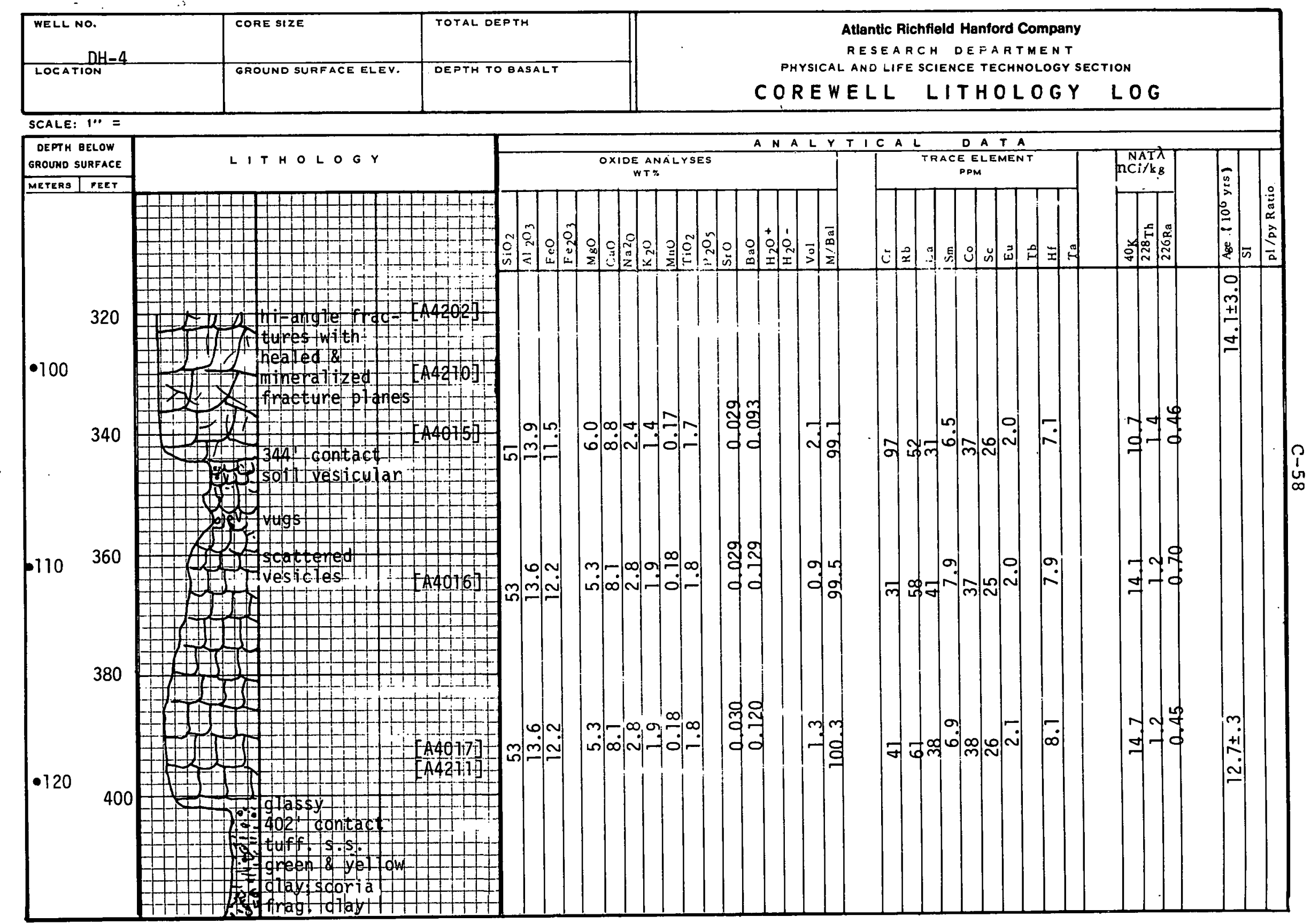

80-6000-107 (12-74) 


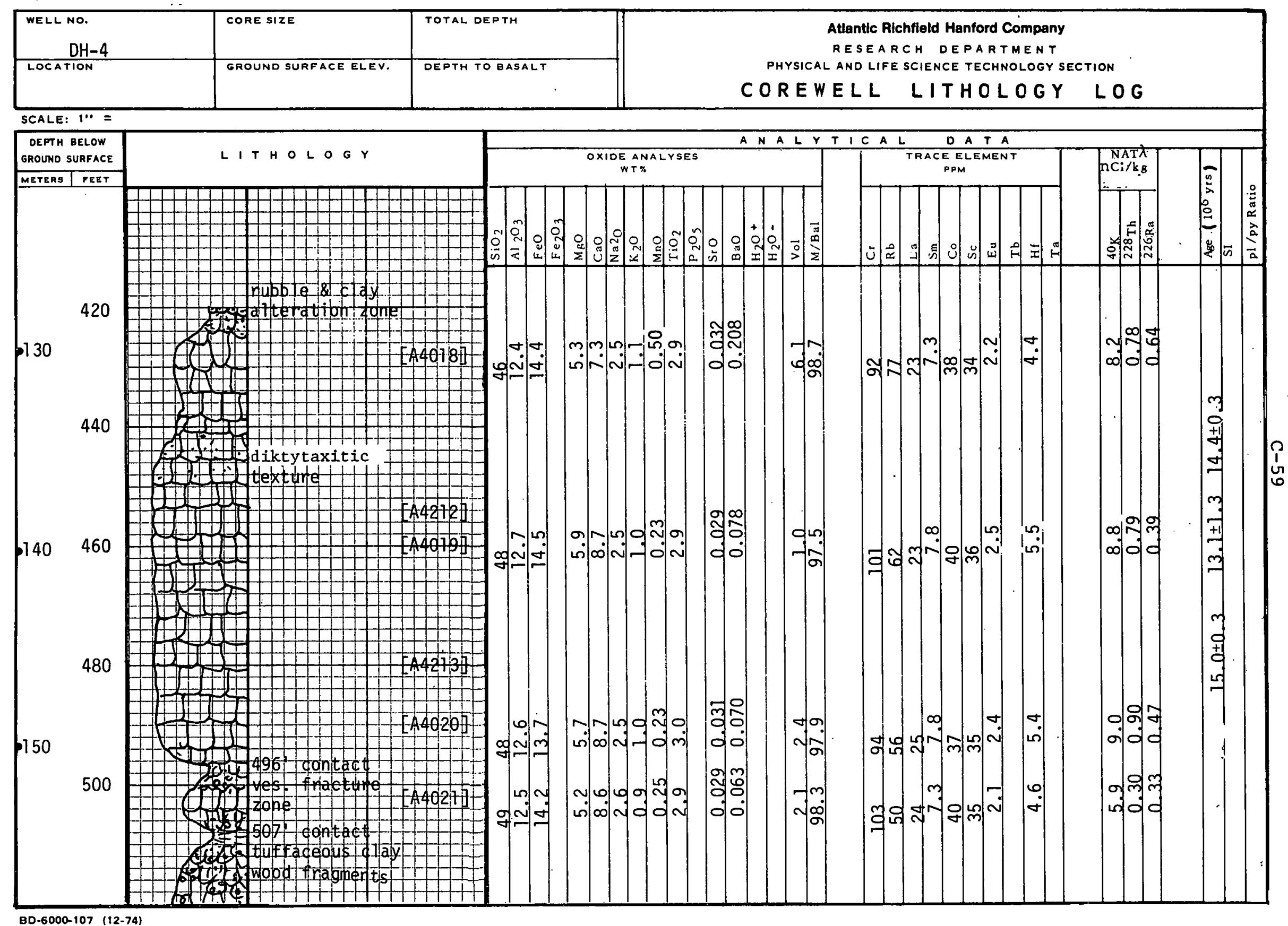

BD-6000-107 (12-74) 


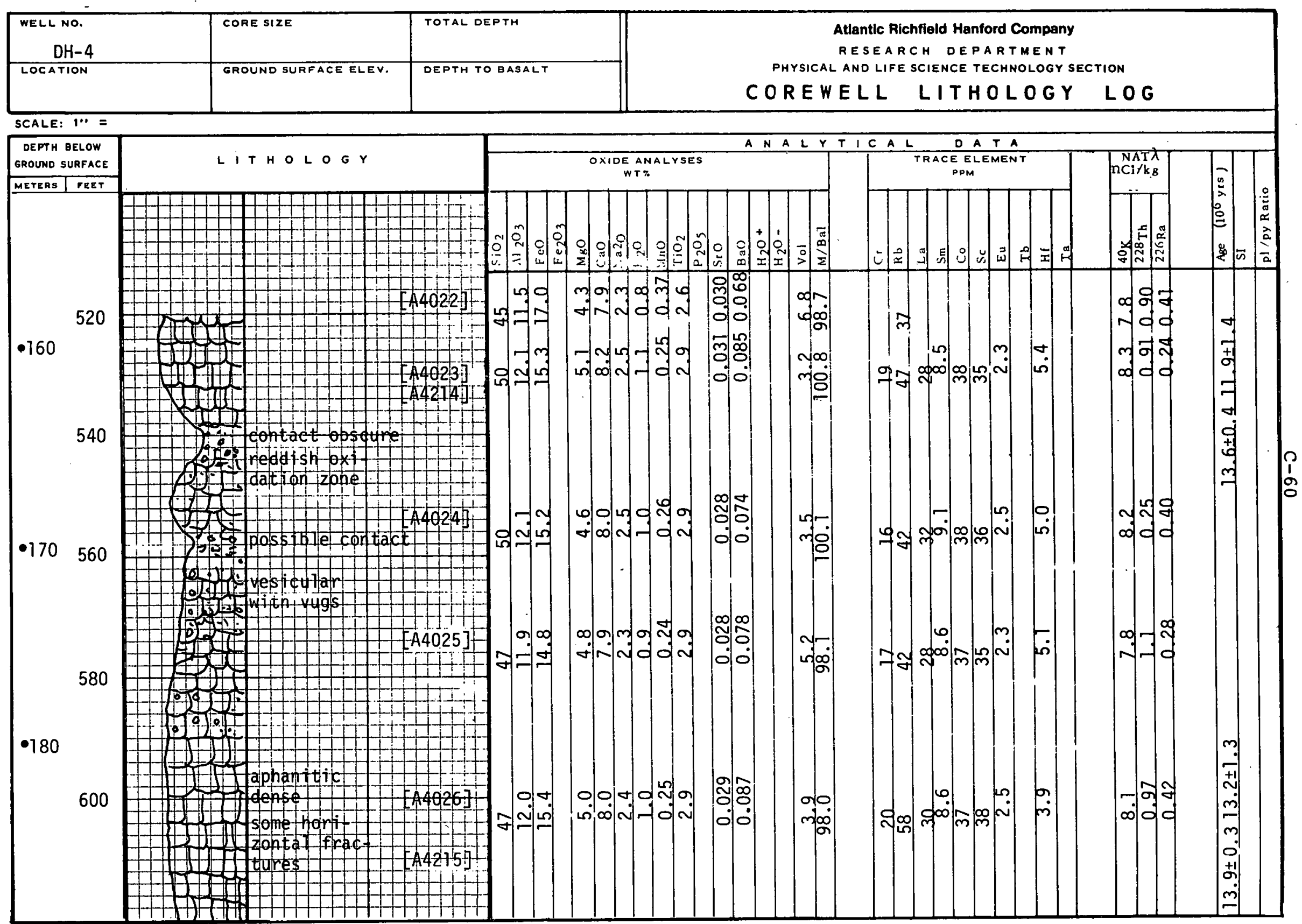




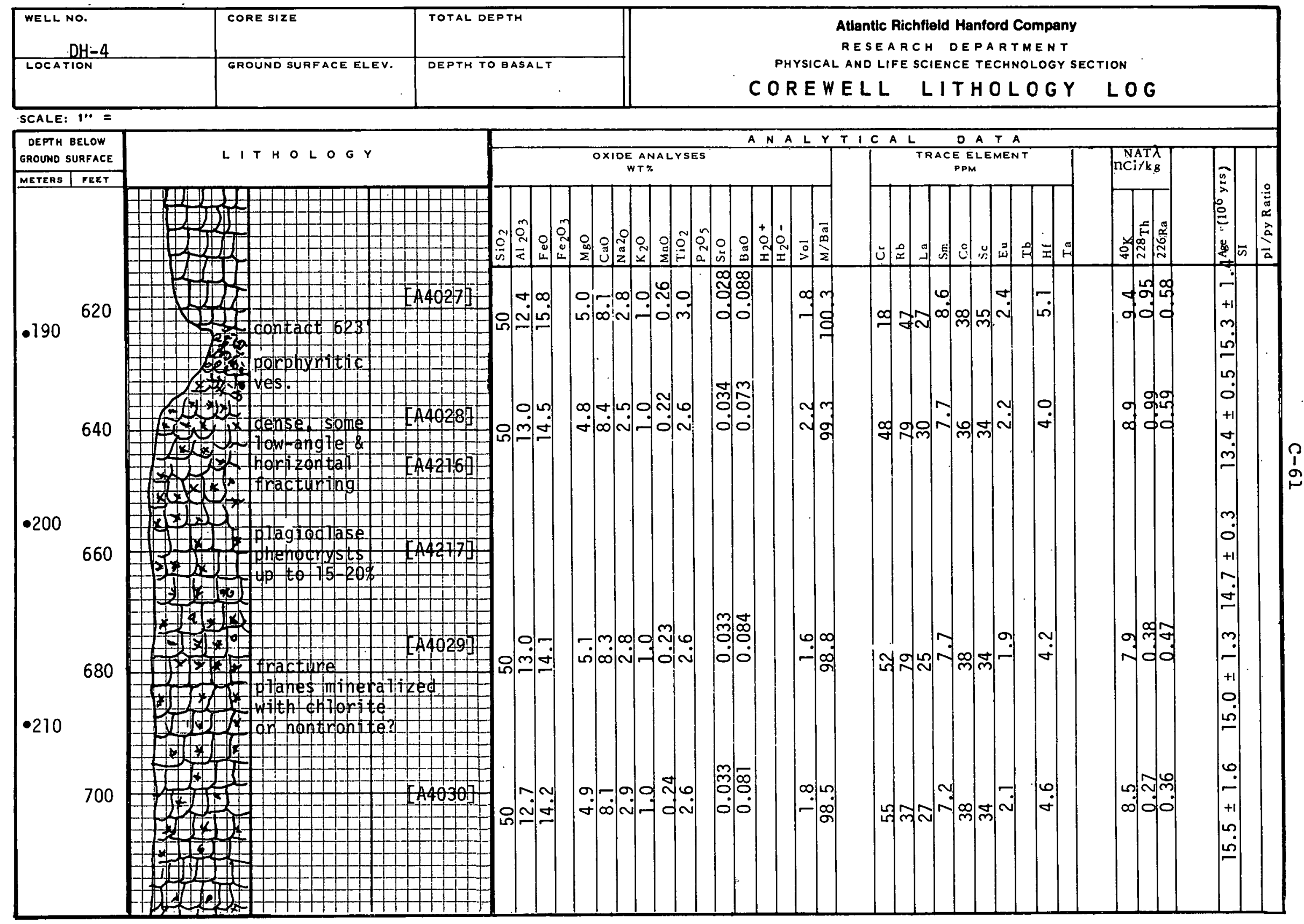




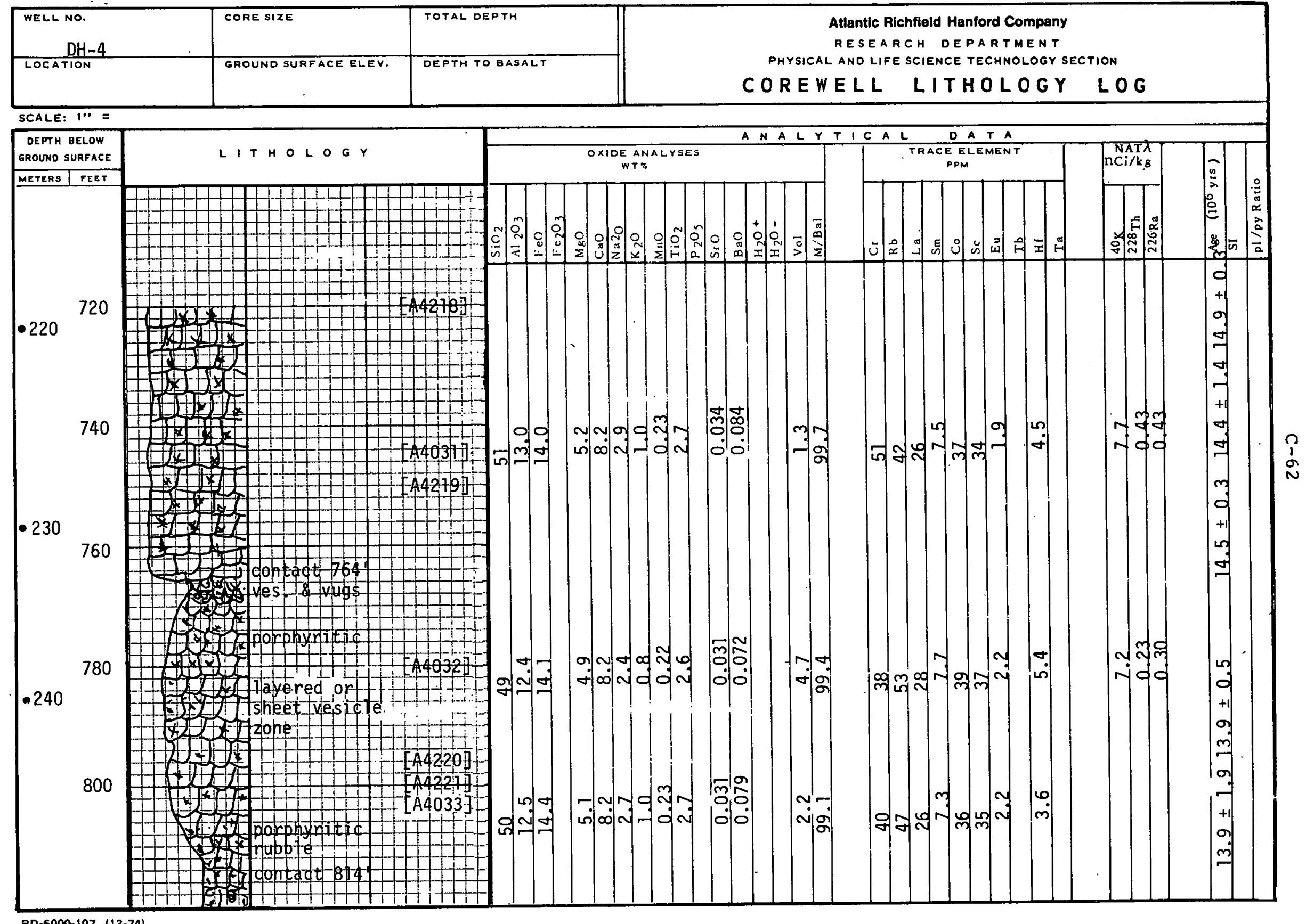

BD-6000-107 (12-74) 


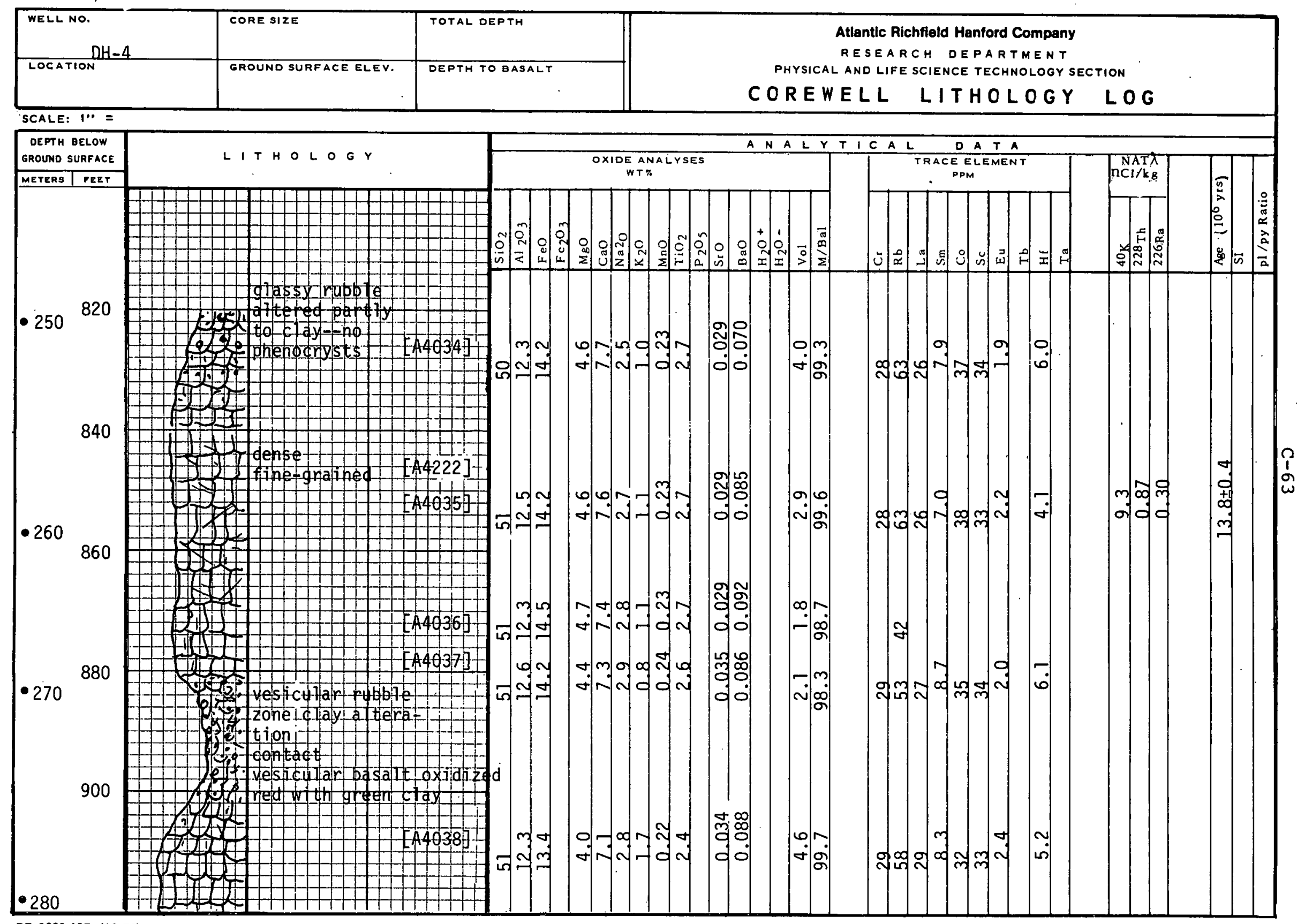




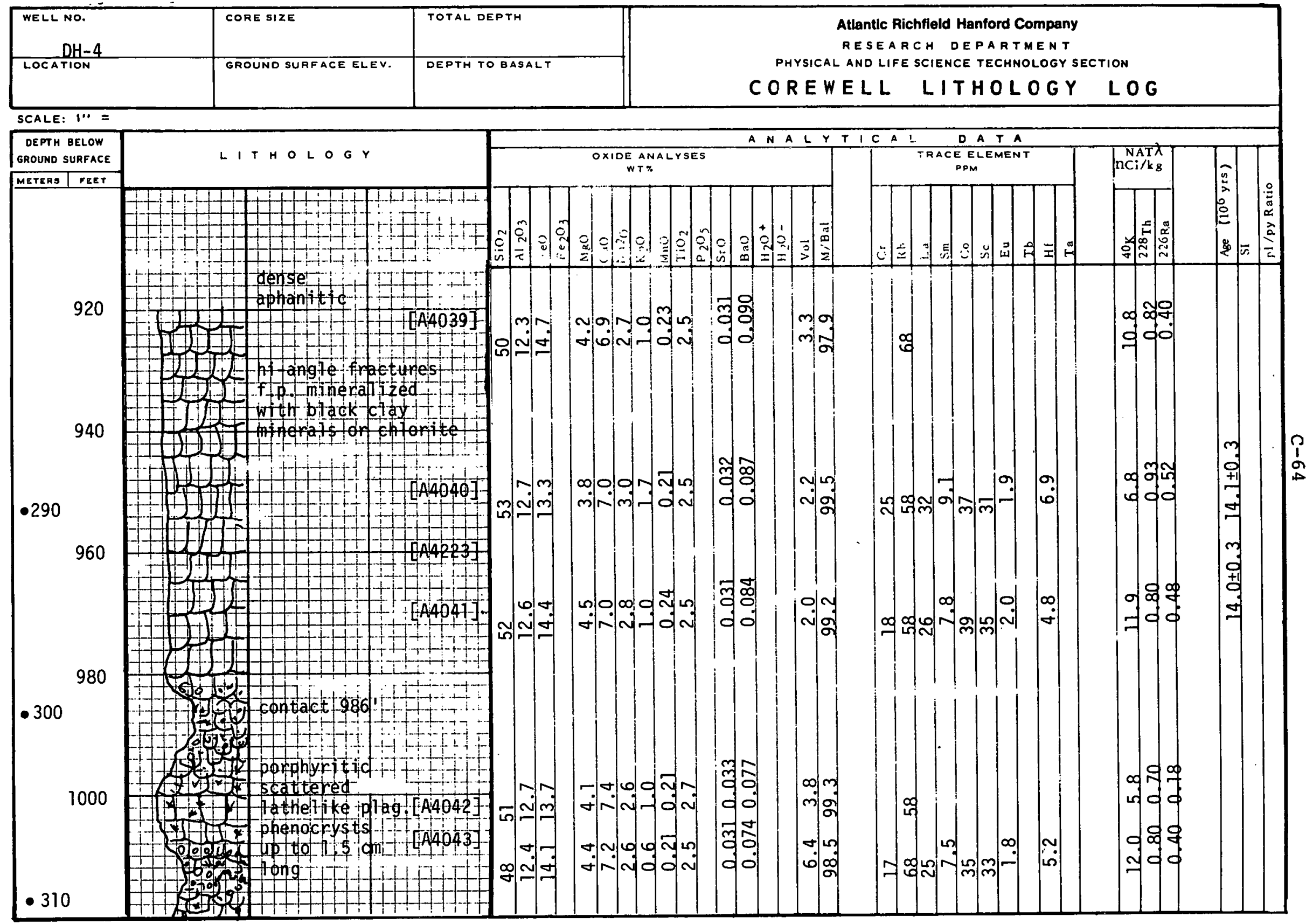

8D-6000-107 (12-74) 


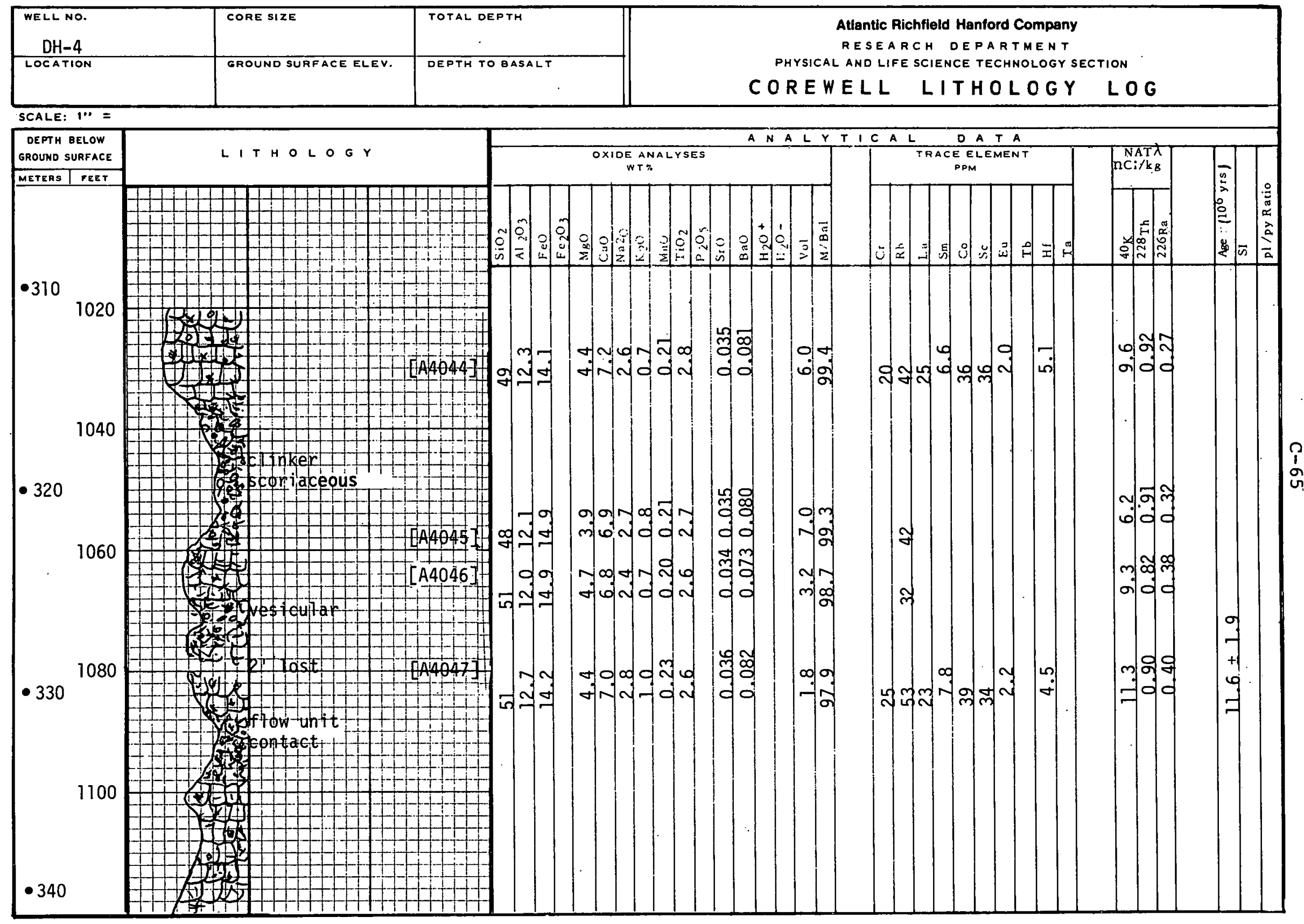




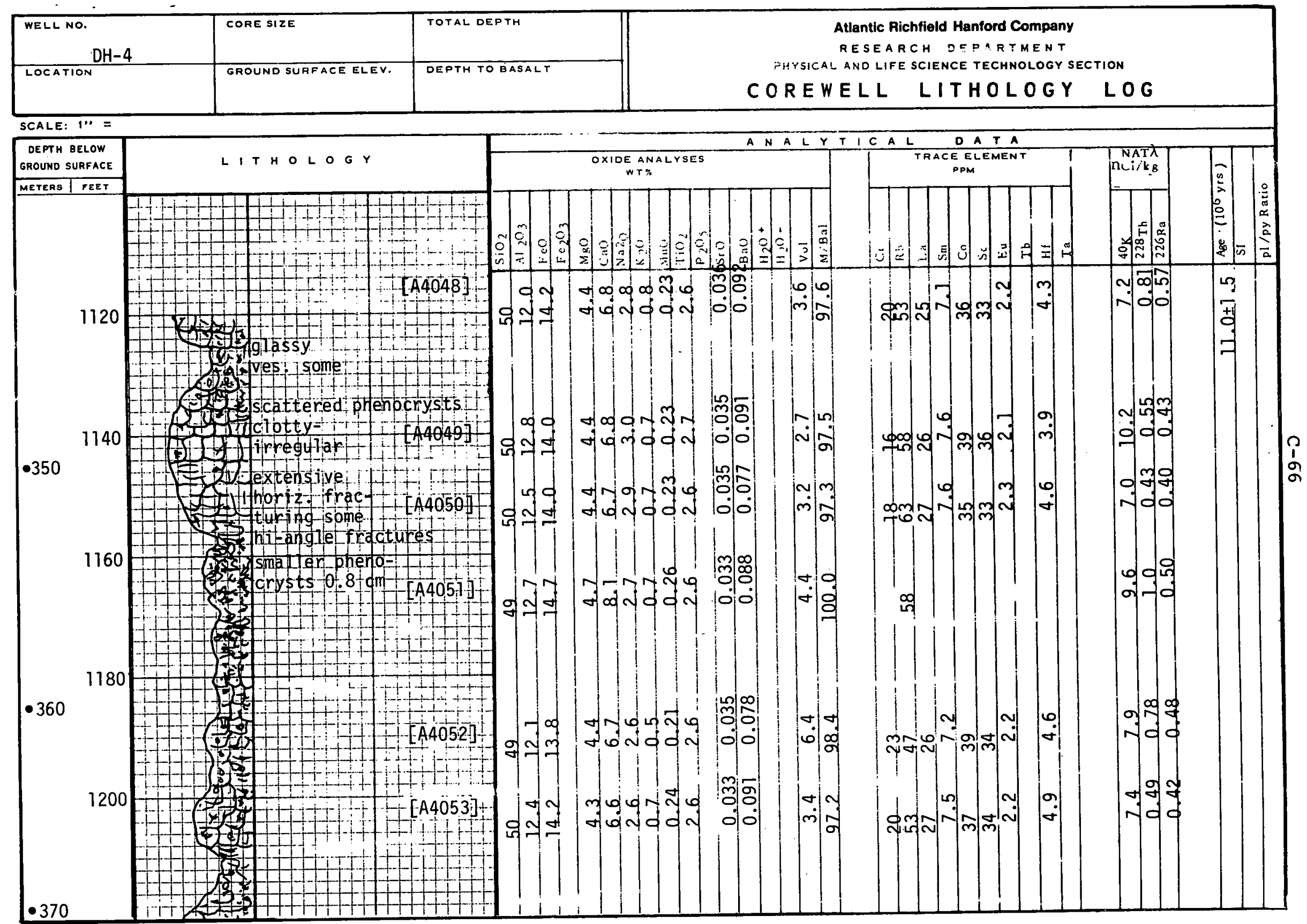

BD-6000-107 (12-74) 


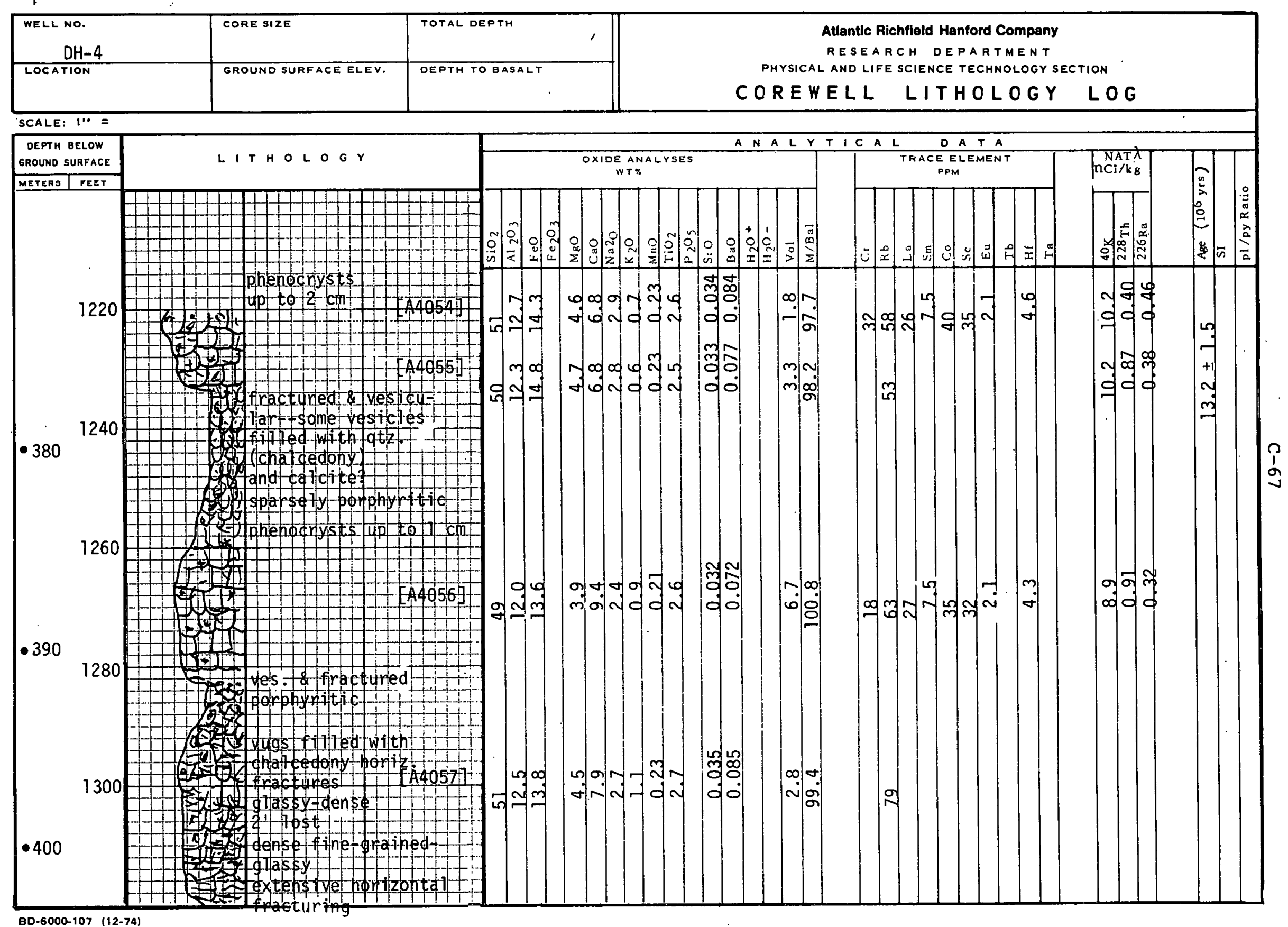




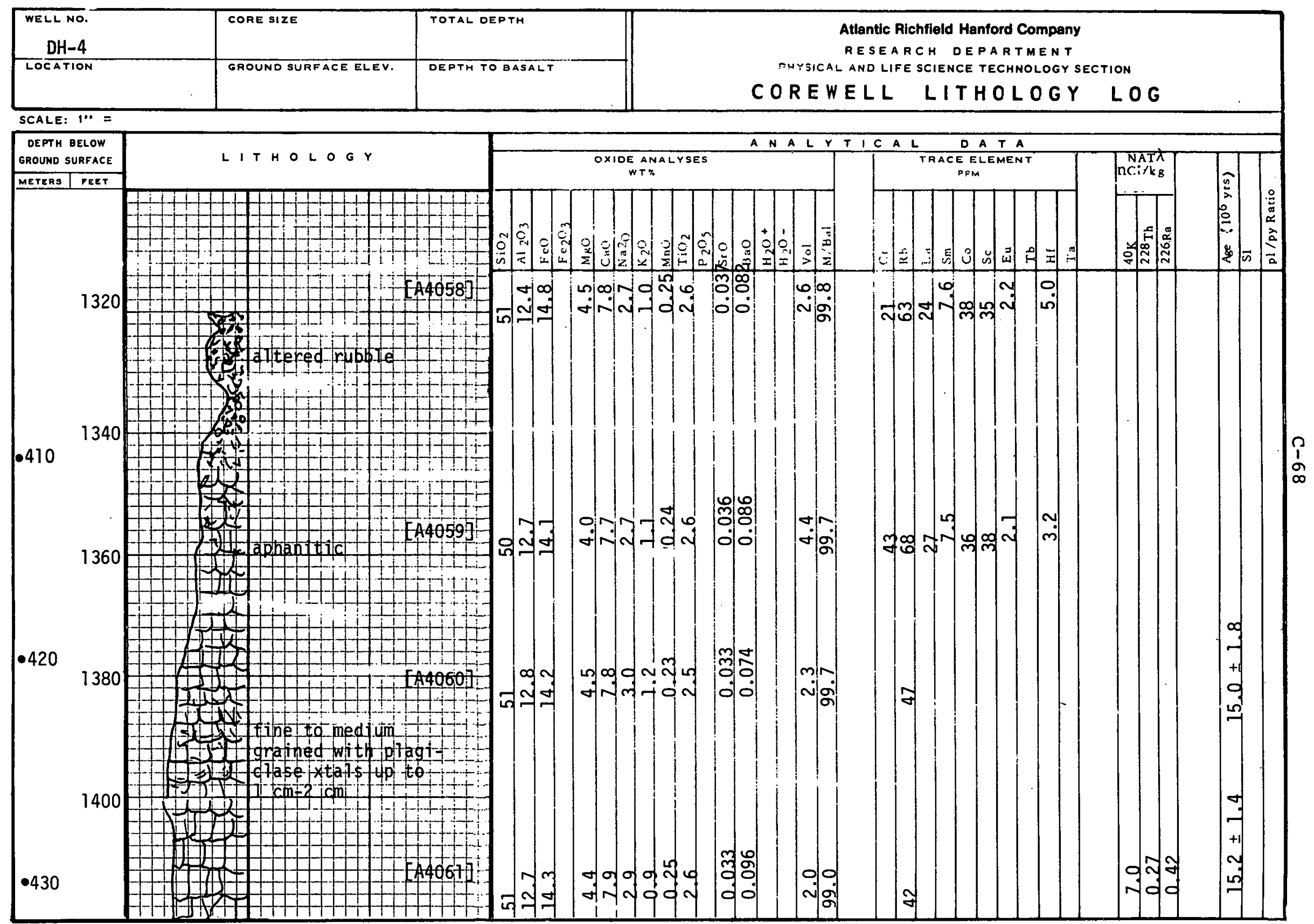

BD-6000-107 (12-74) 


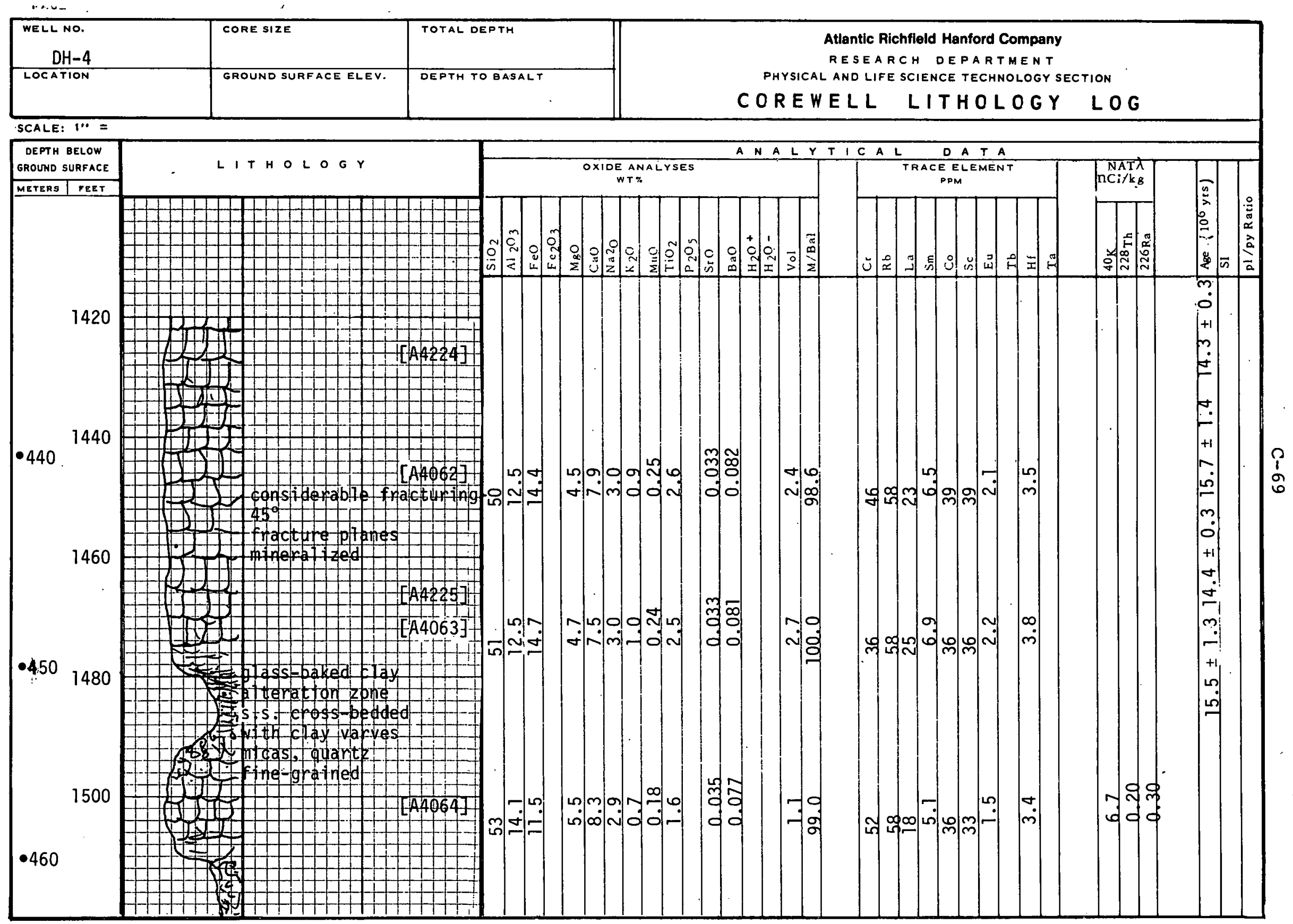




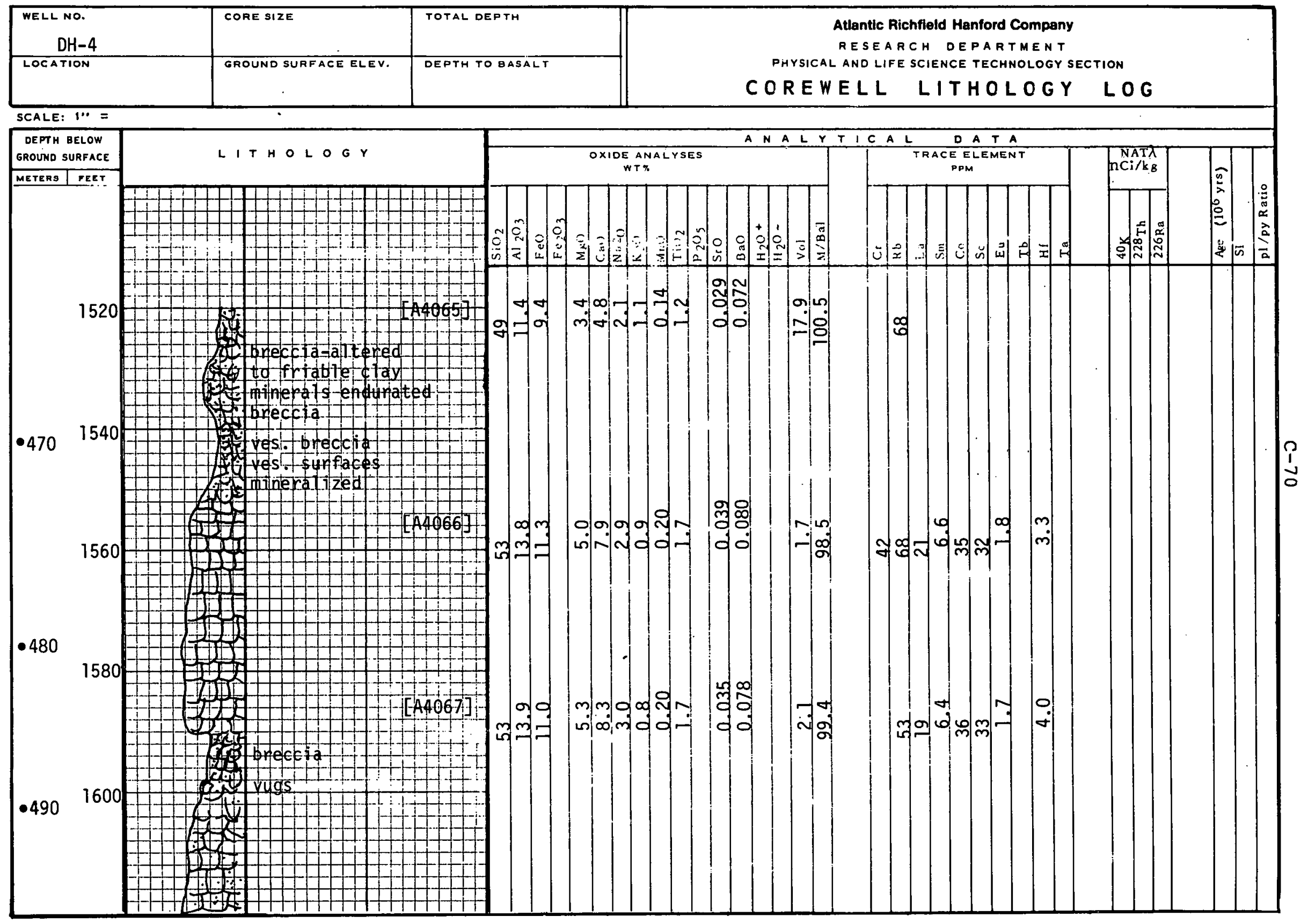




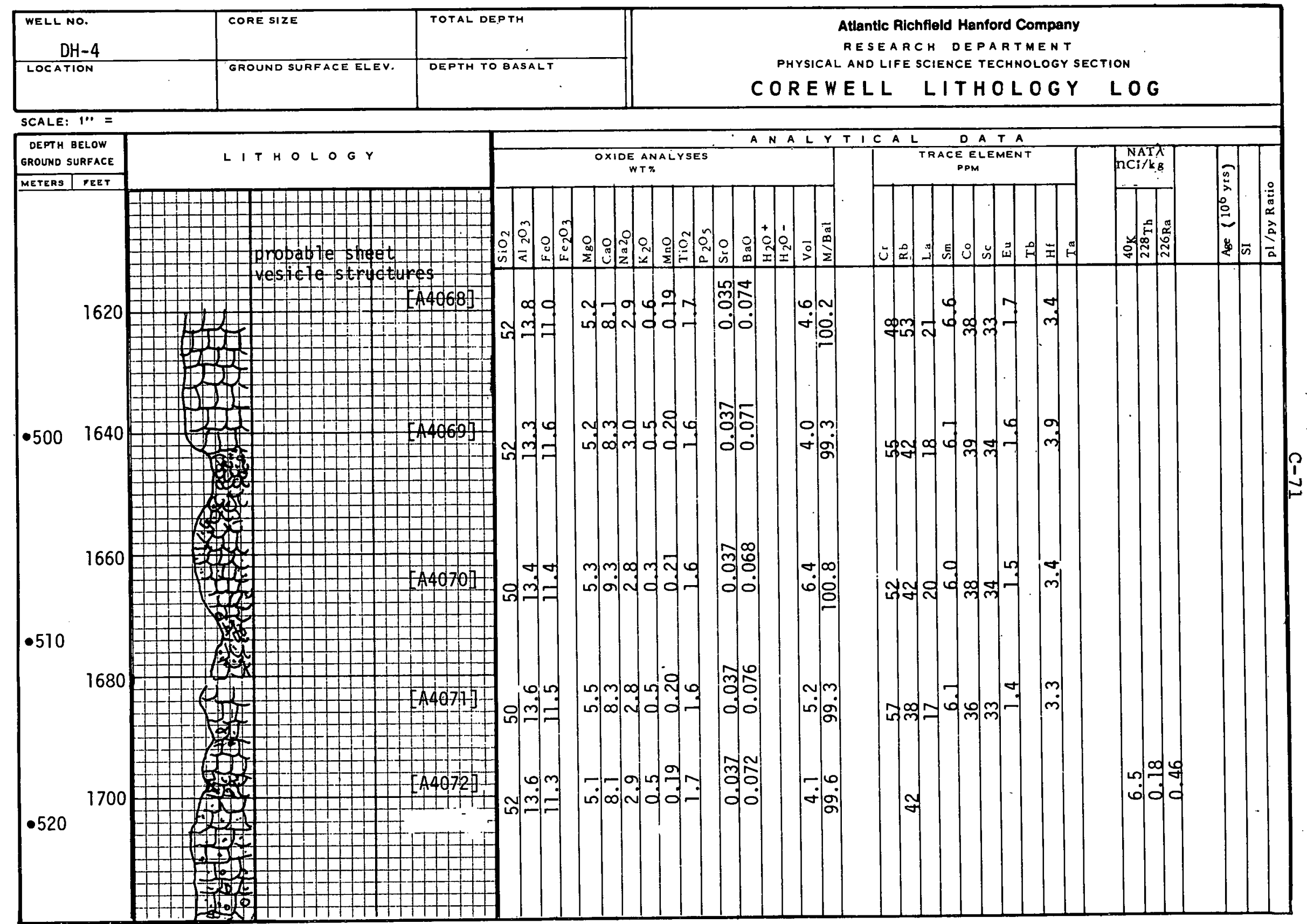




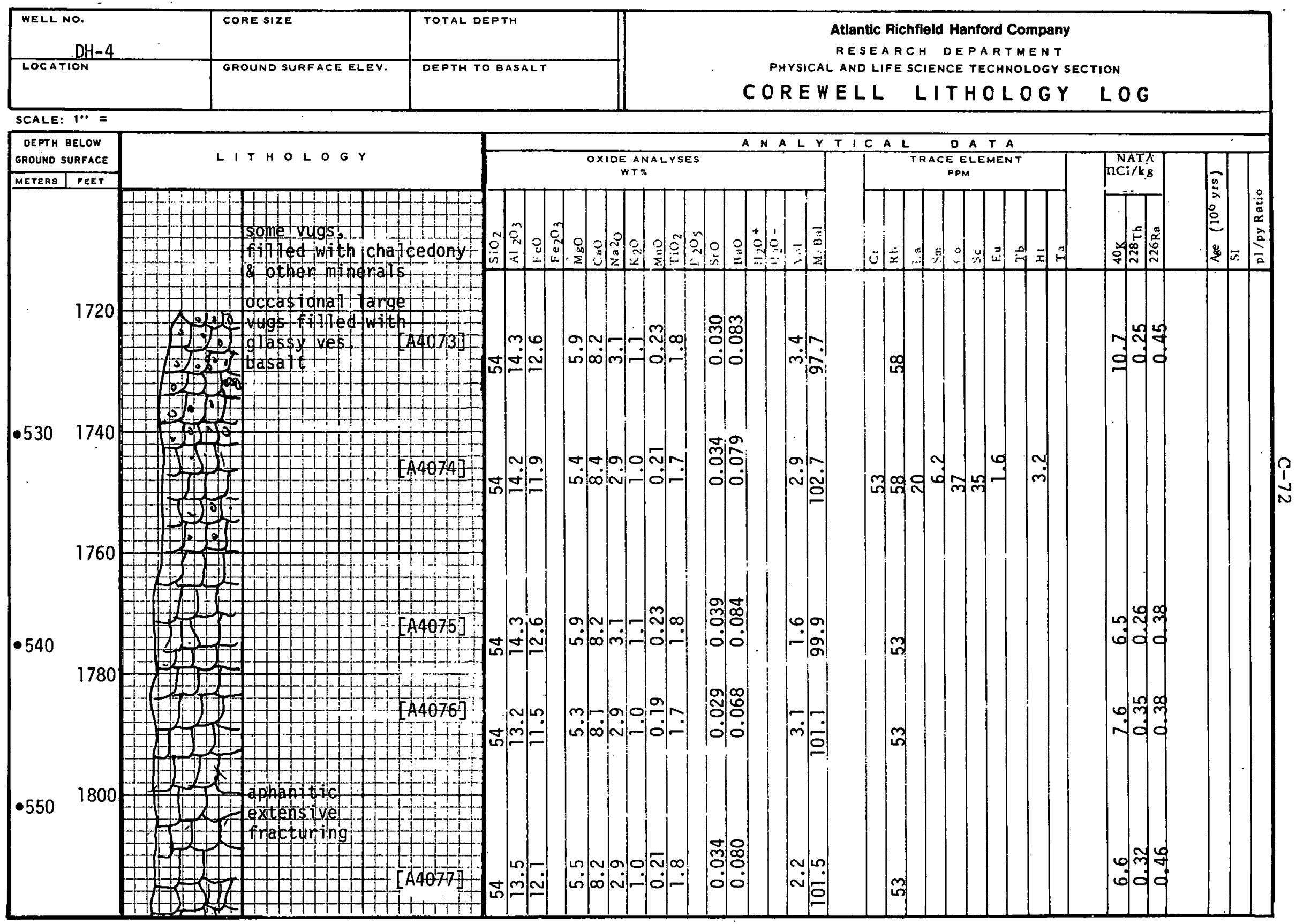

BD-6000-107 (12-74) 


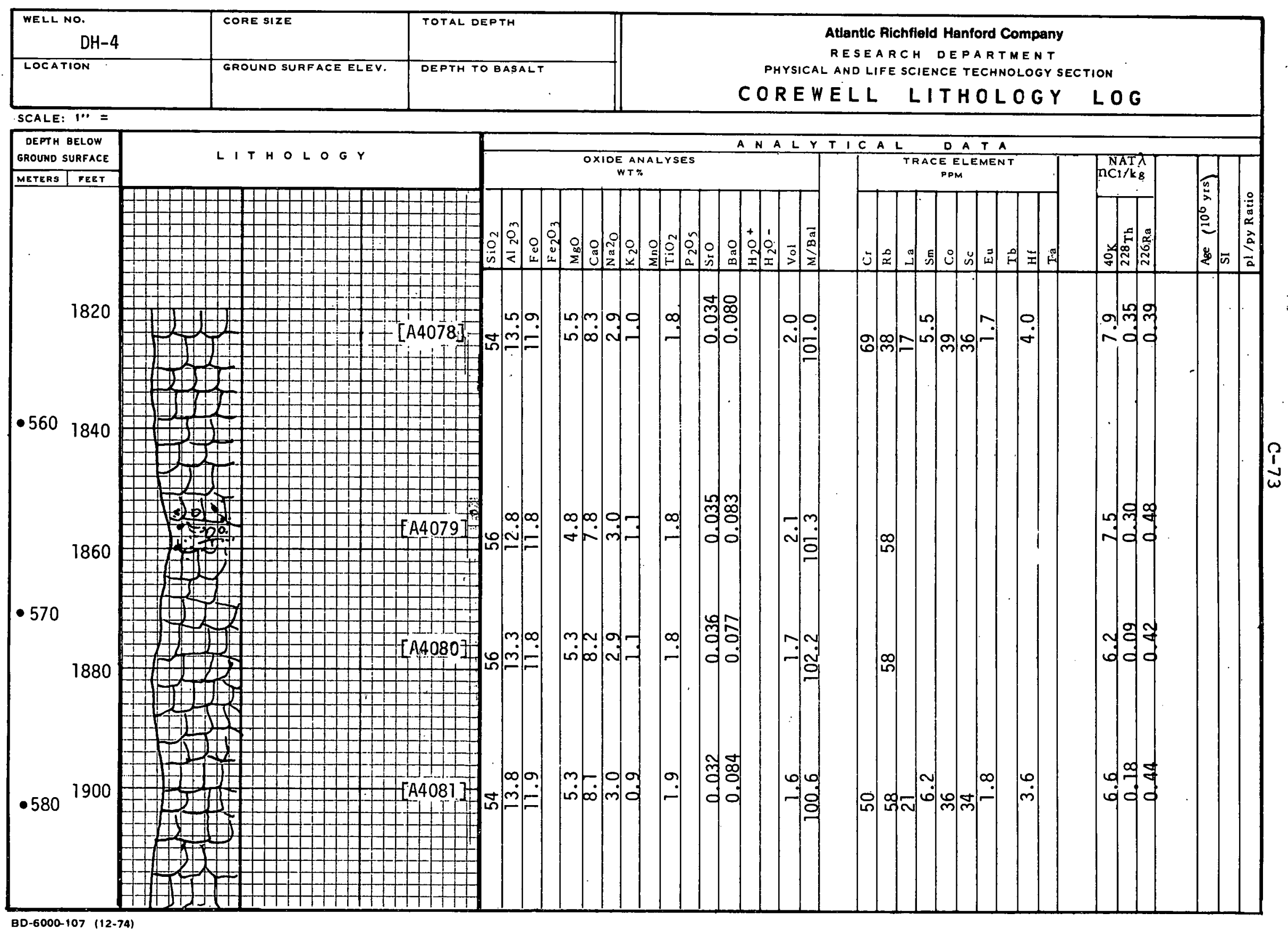

BD-6000-107 (12-74) 


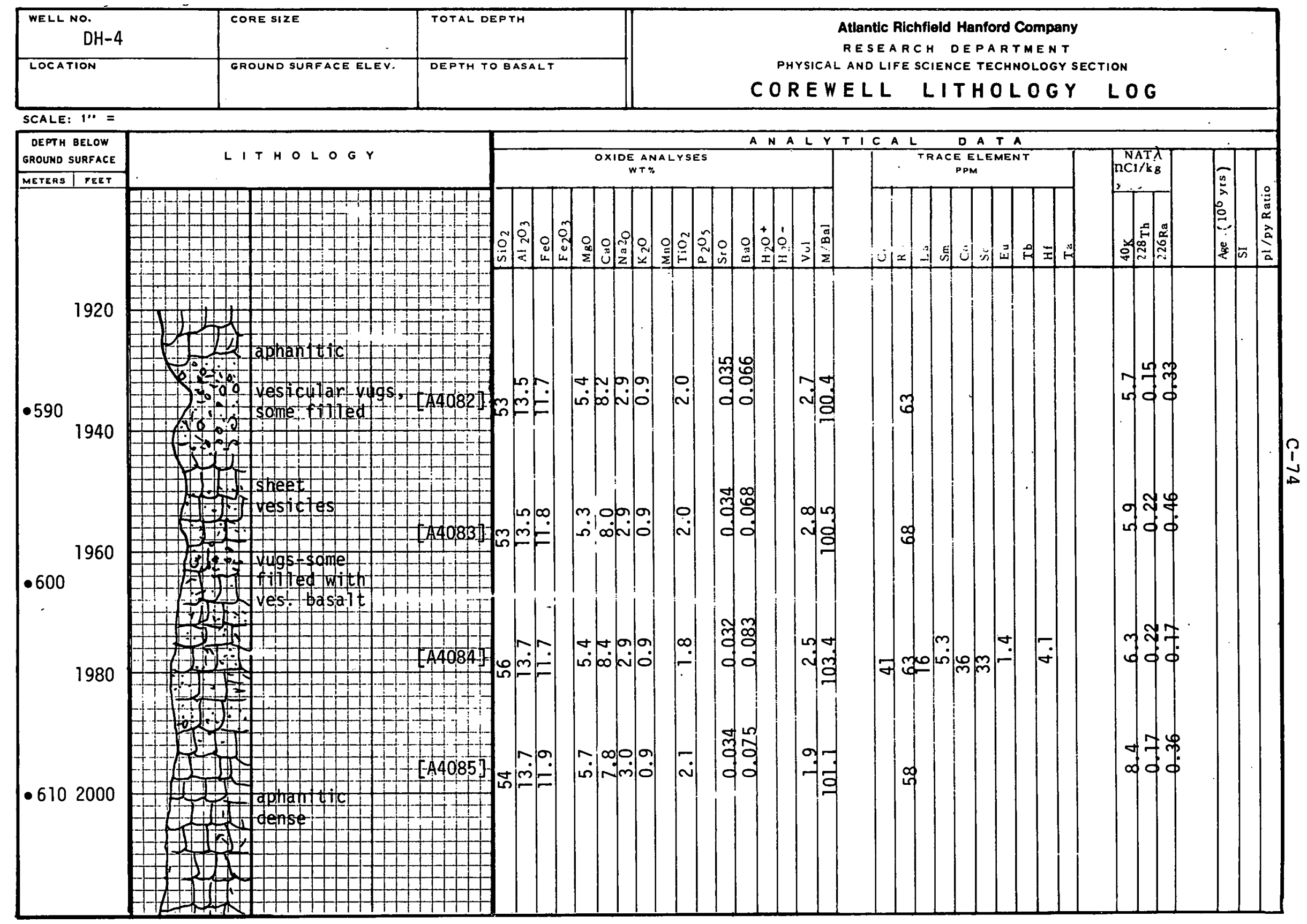

BD-6000-107 (12-74) 


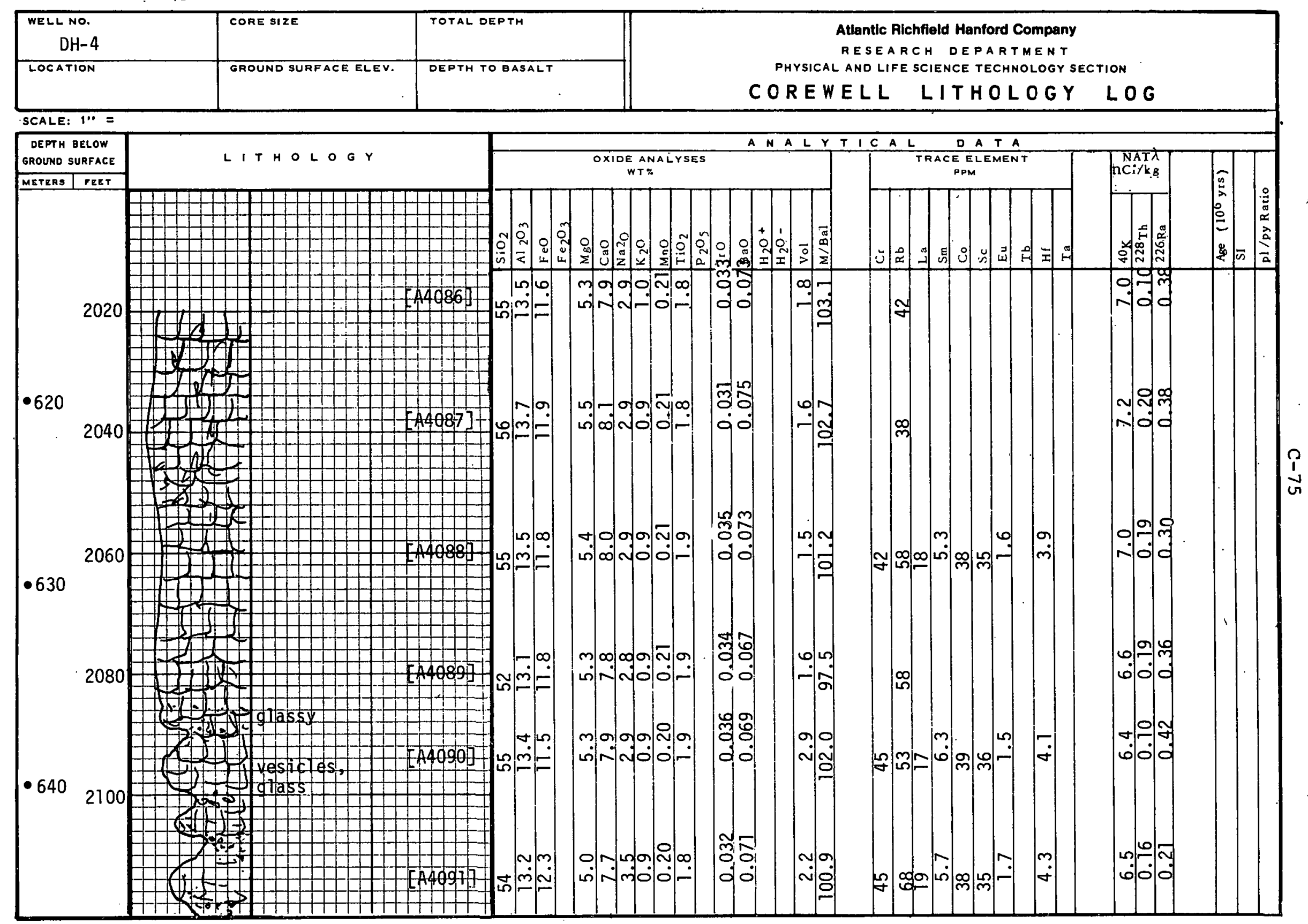

BD-6000-107 (12-74) 


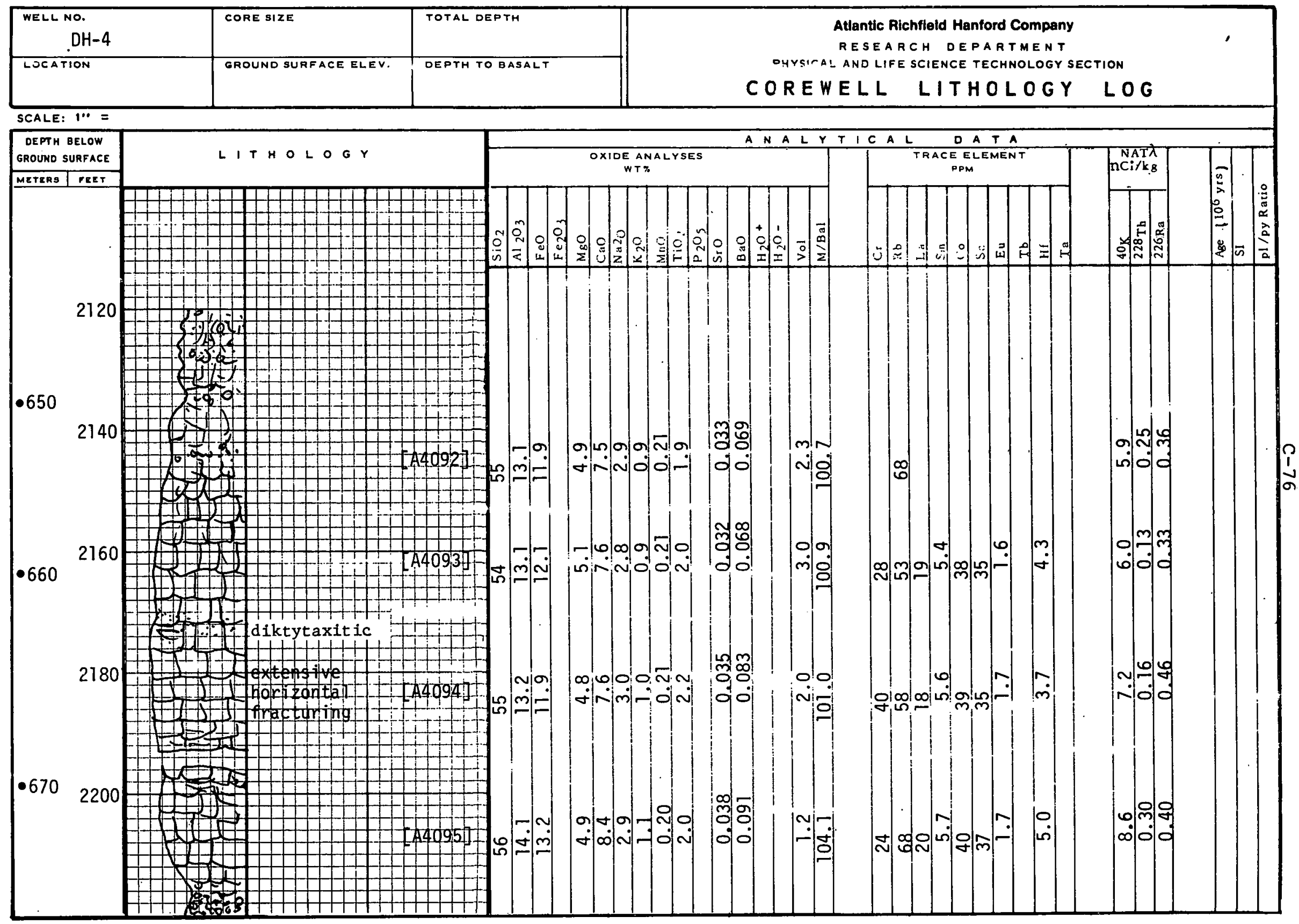




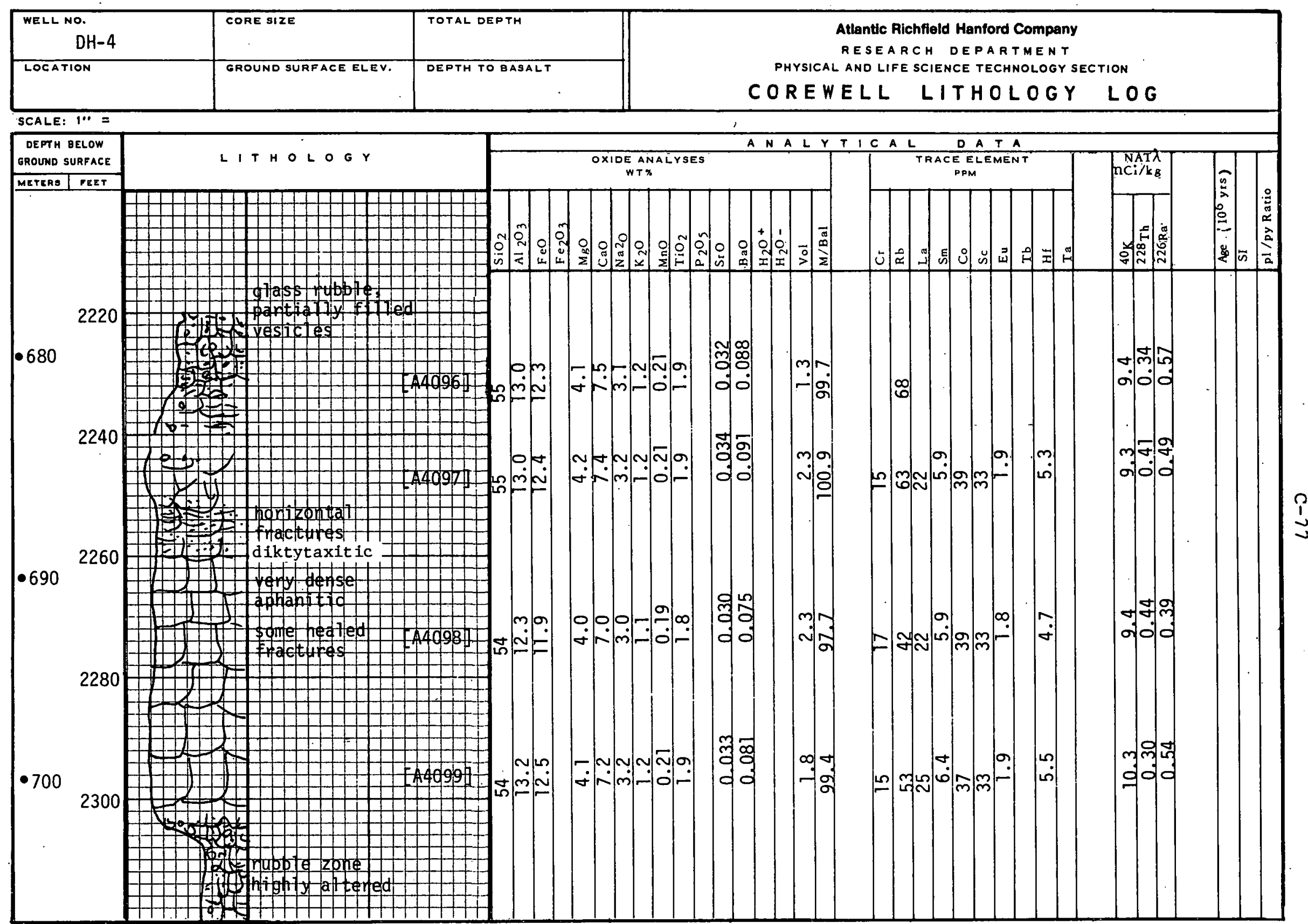




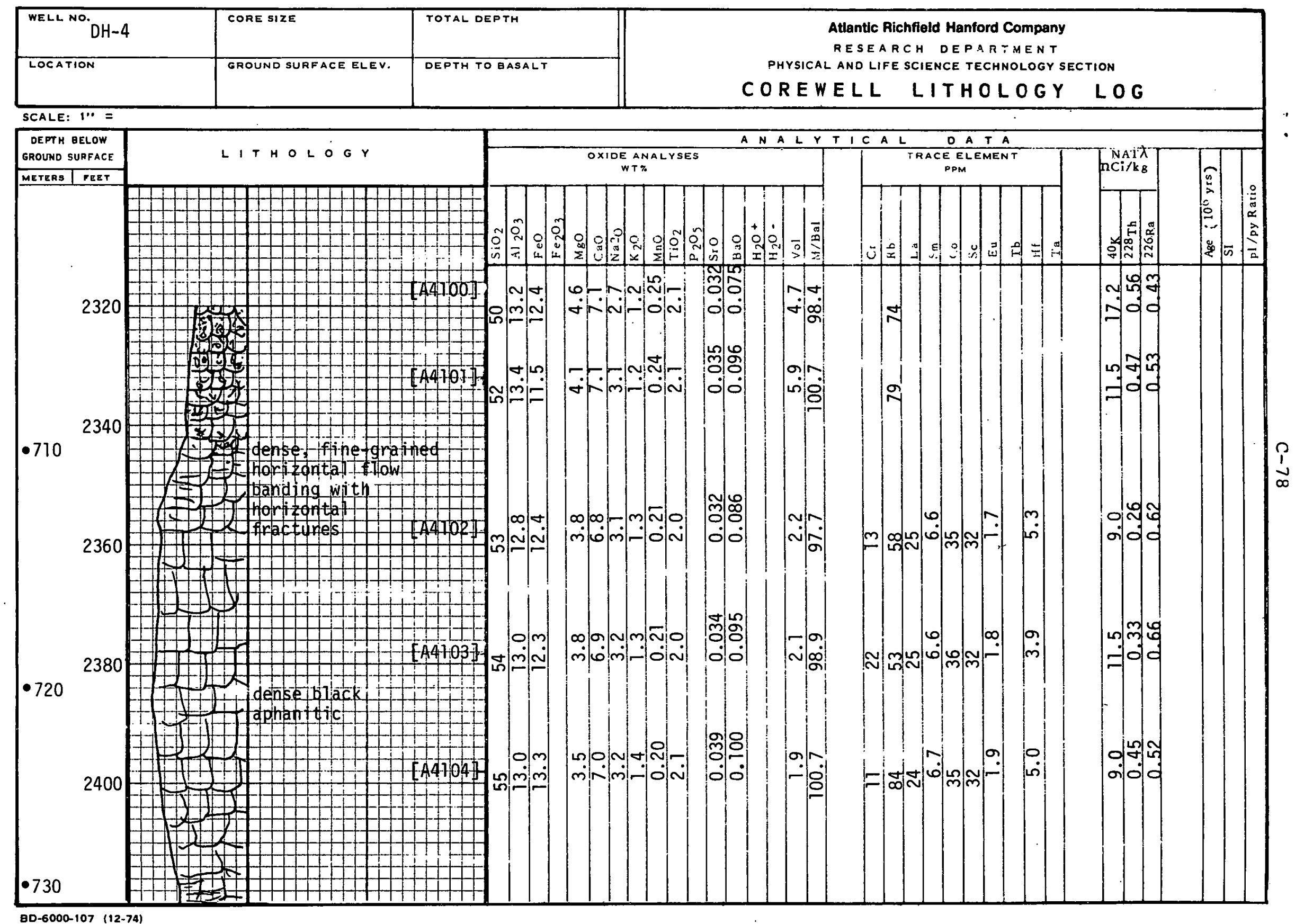

8D-6000-107 (12-74) 


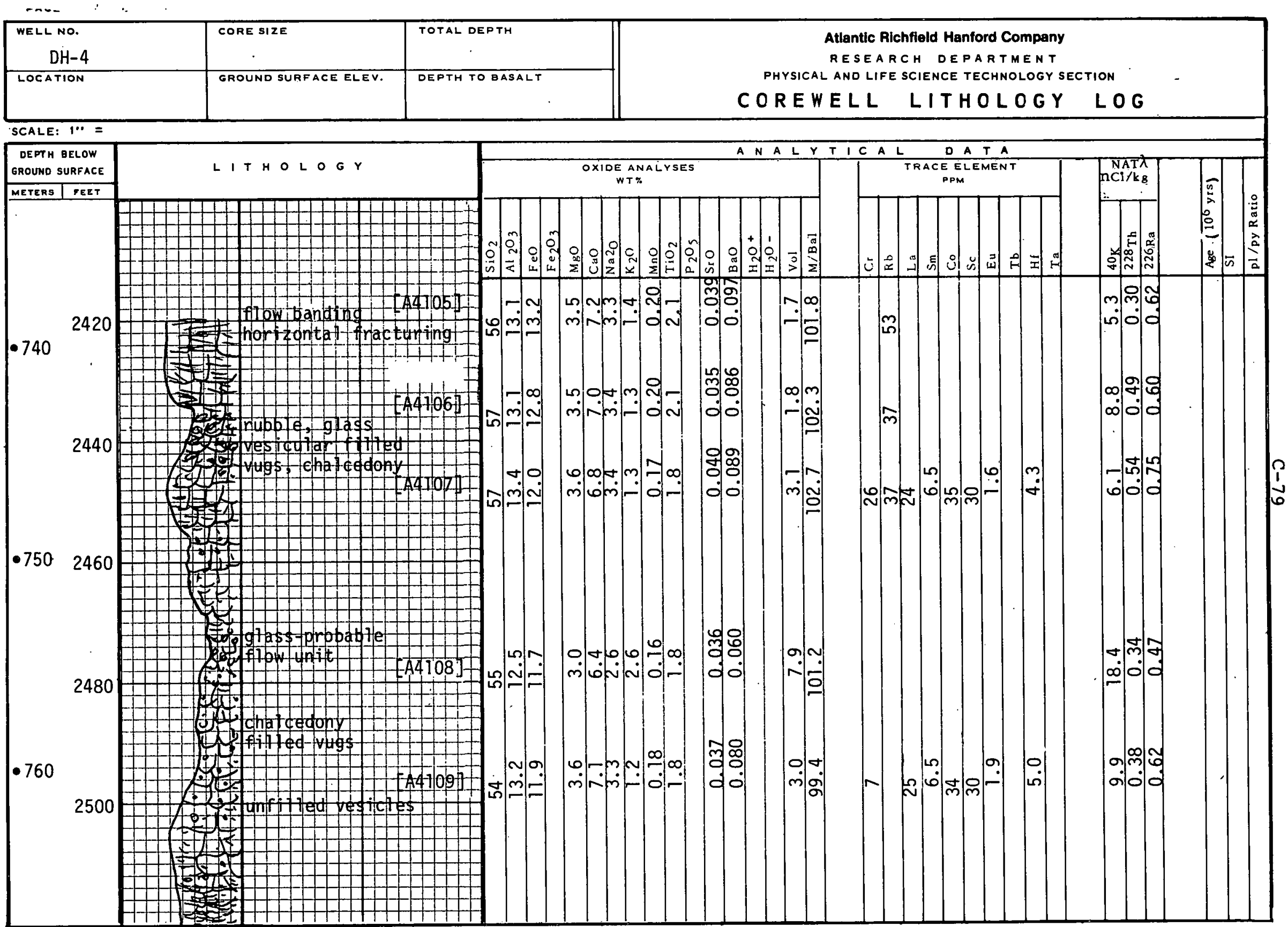

BD-6000-107 (12-74) 


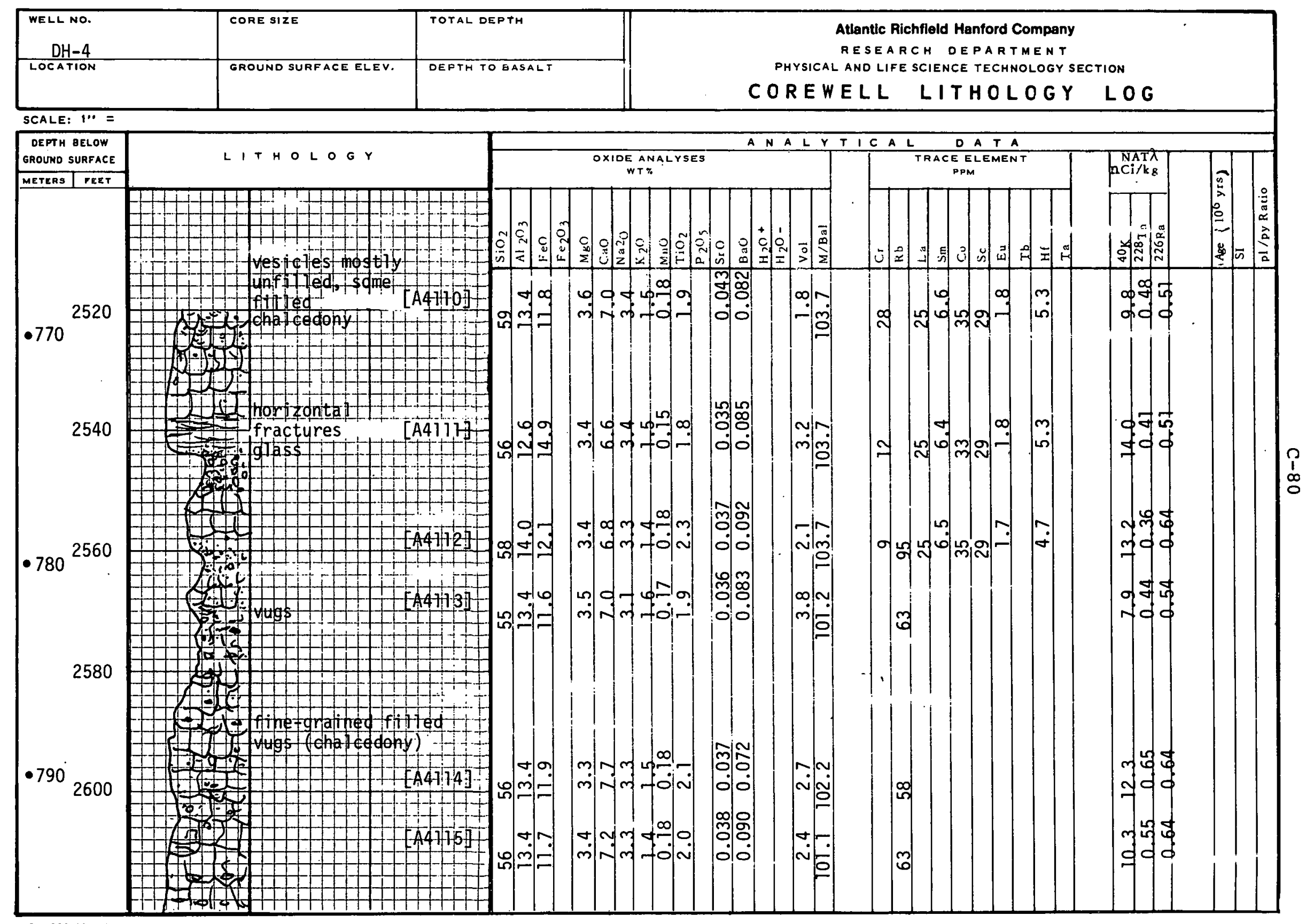

BD-6000-107 (12-74) 


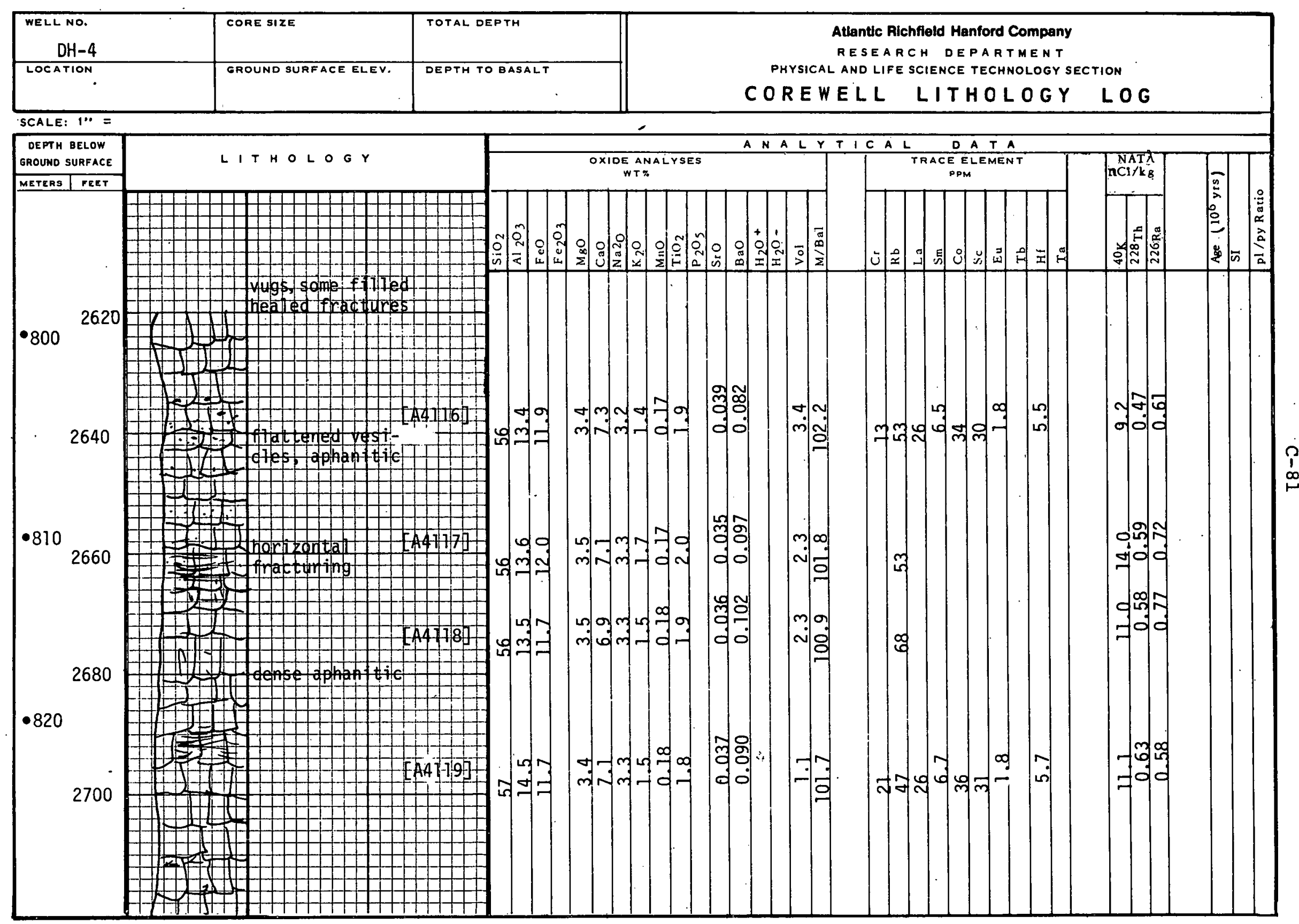




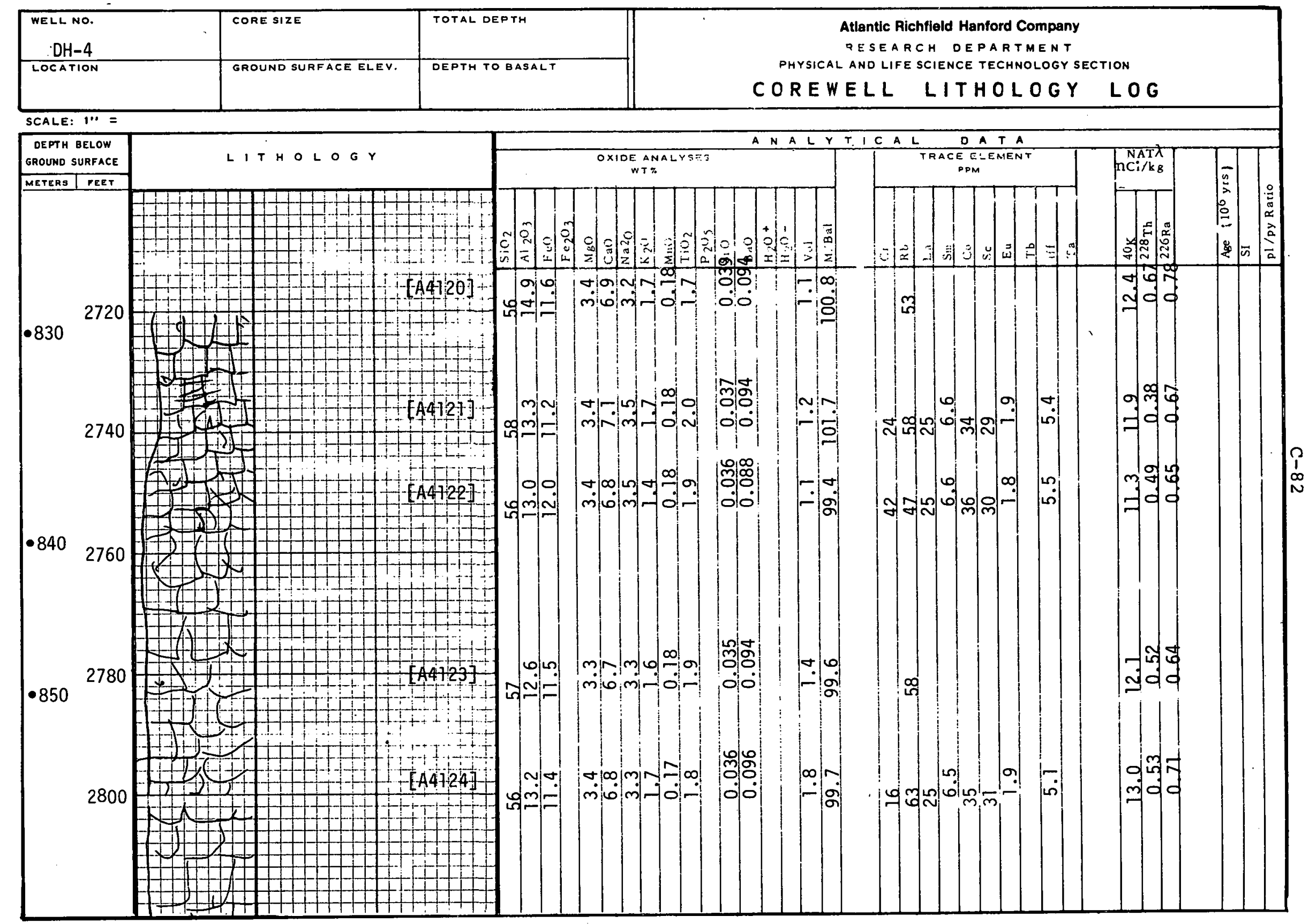




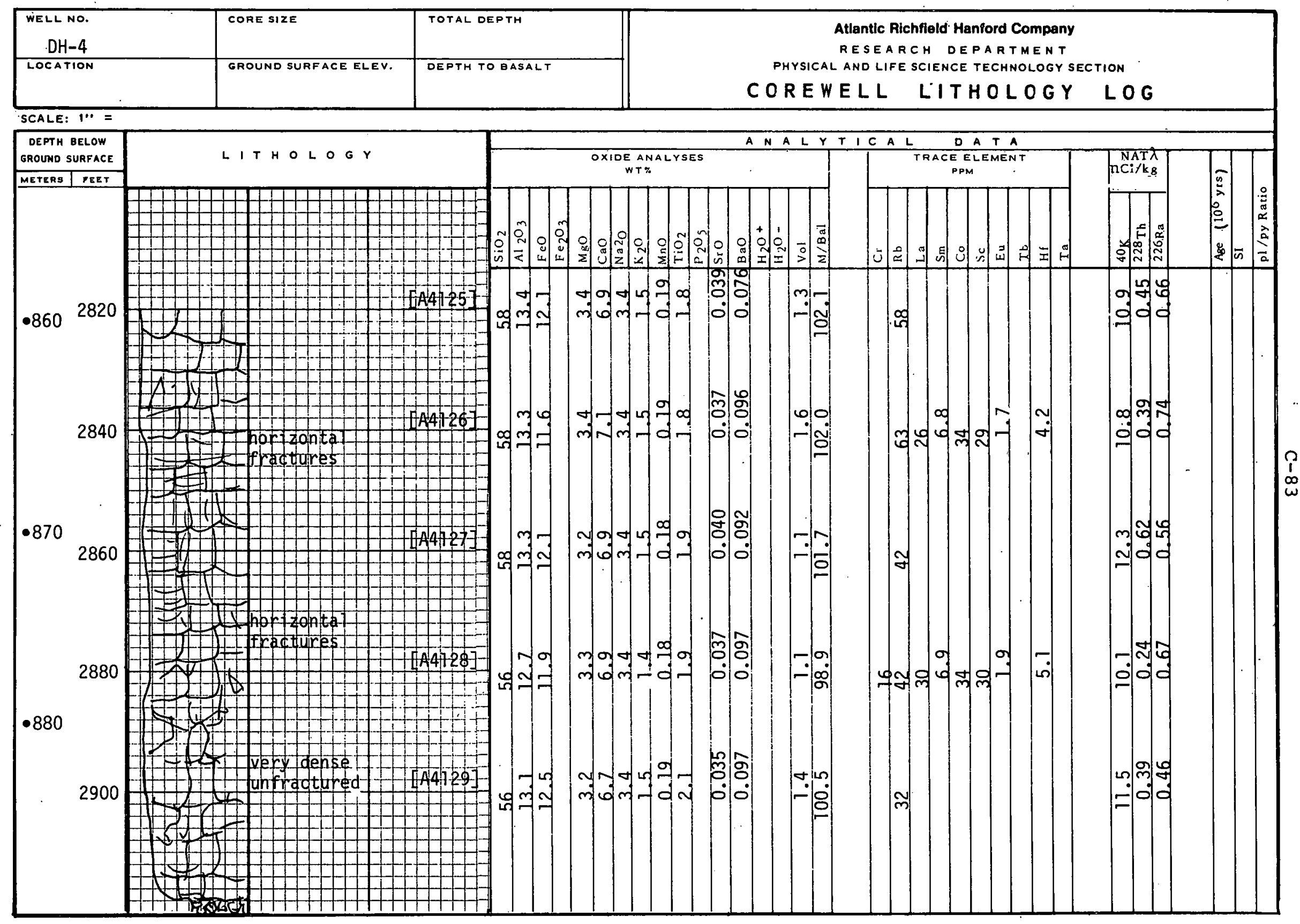

BD-6000-107 (12-74) 


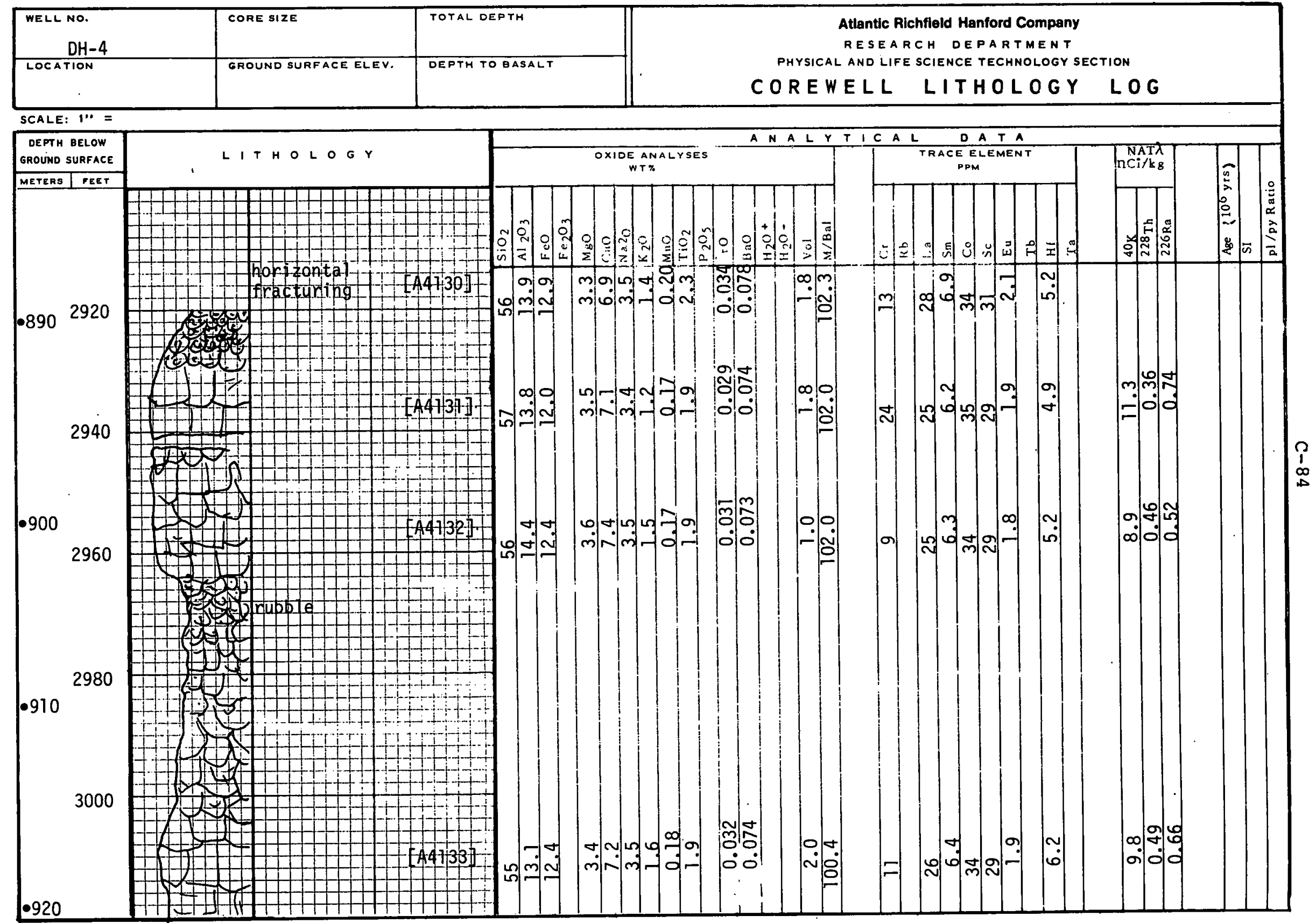

BD-6000-107 (12-74) 


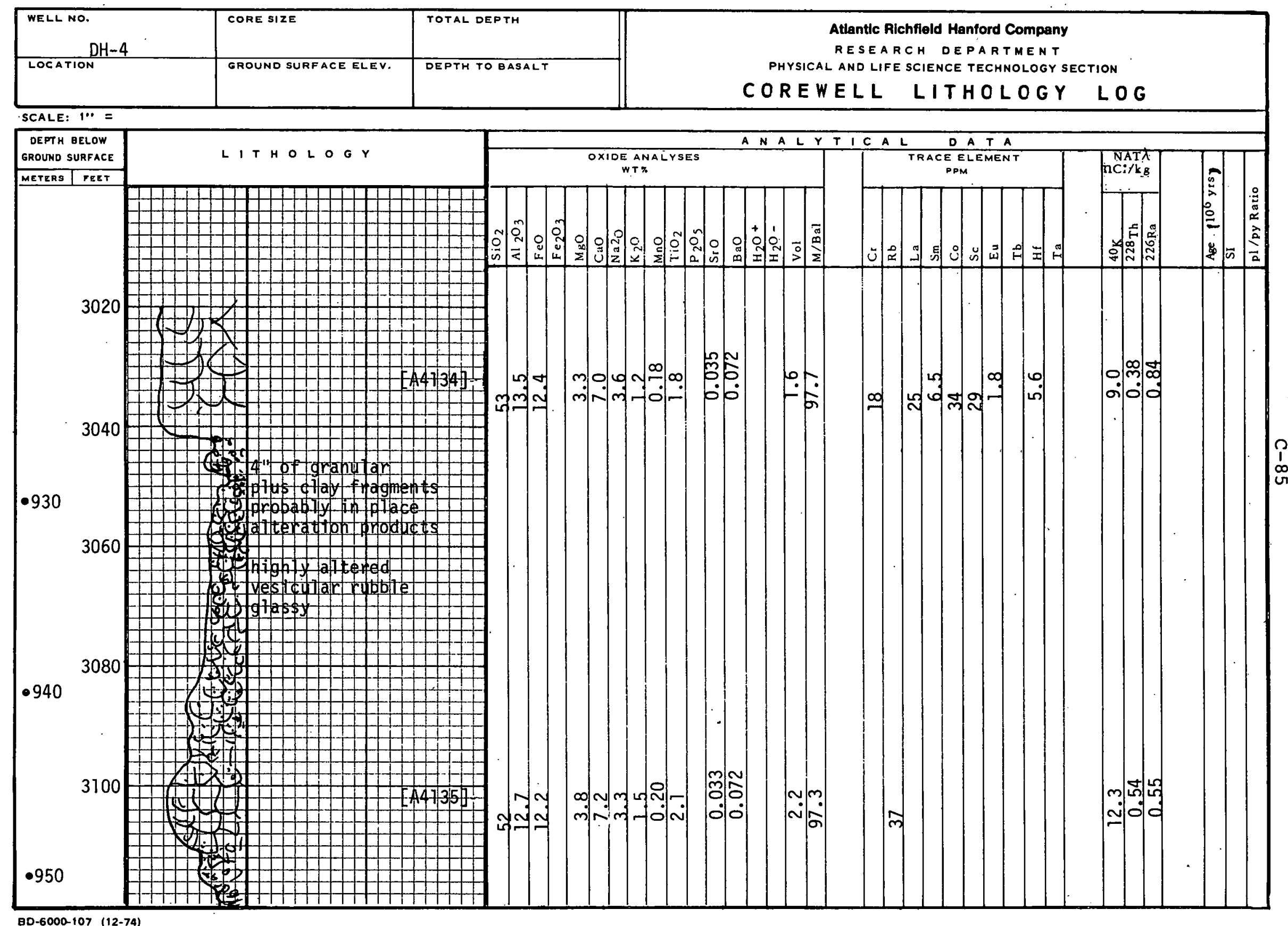

80-6000-107 (12-74) 


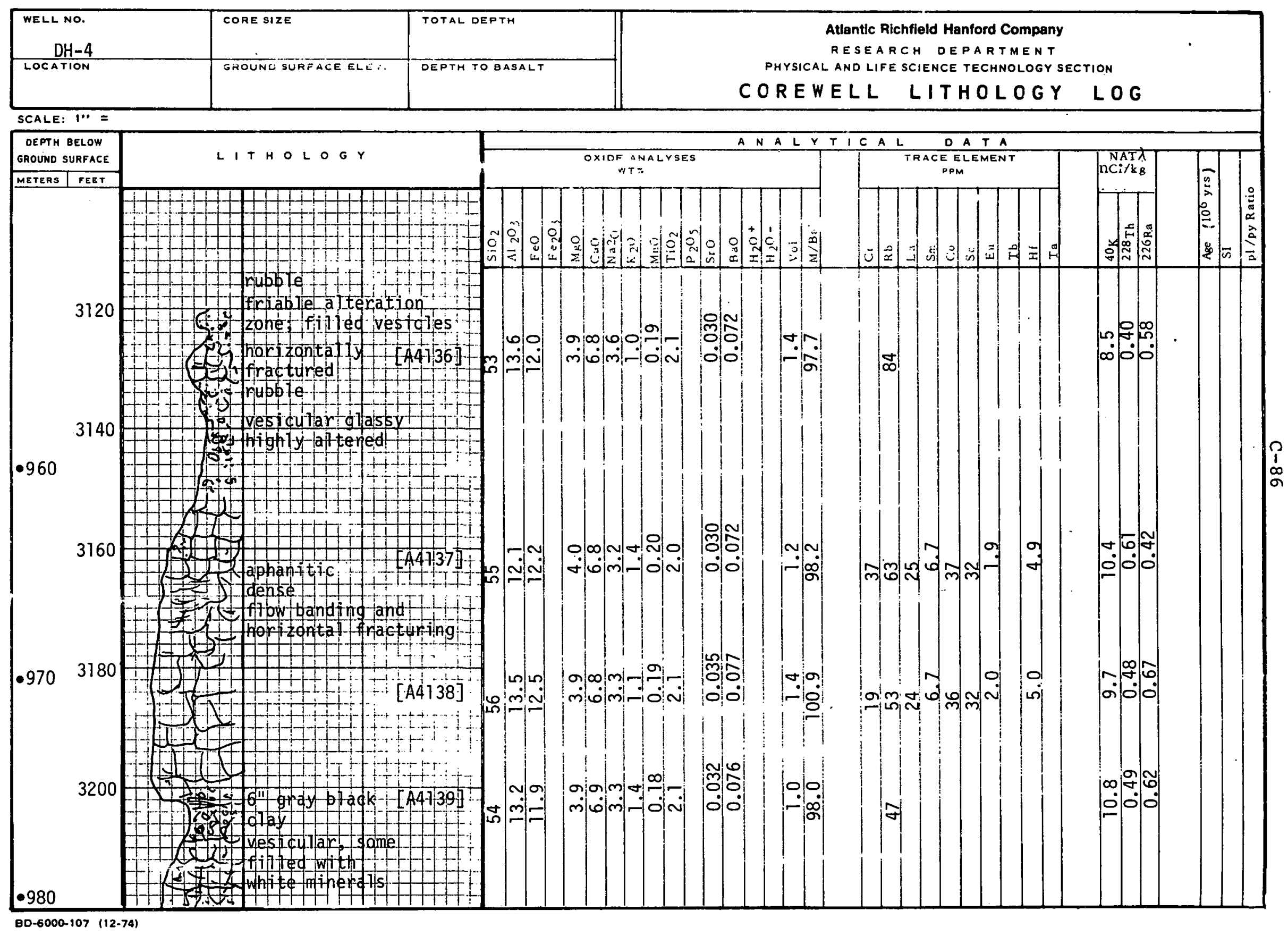




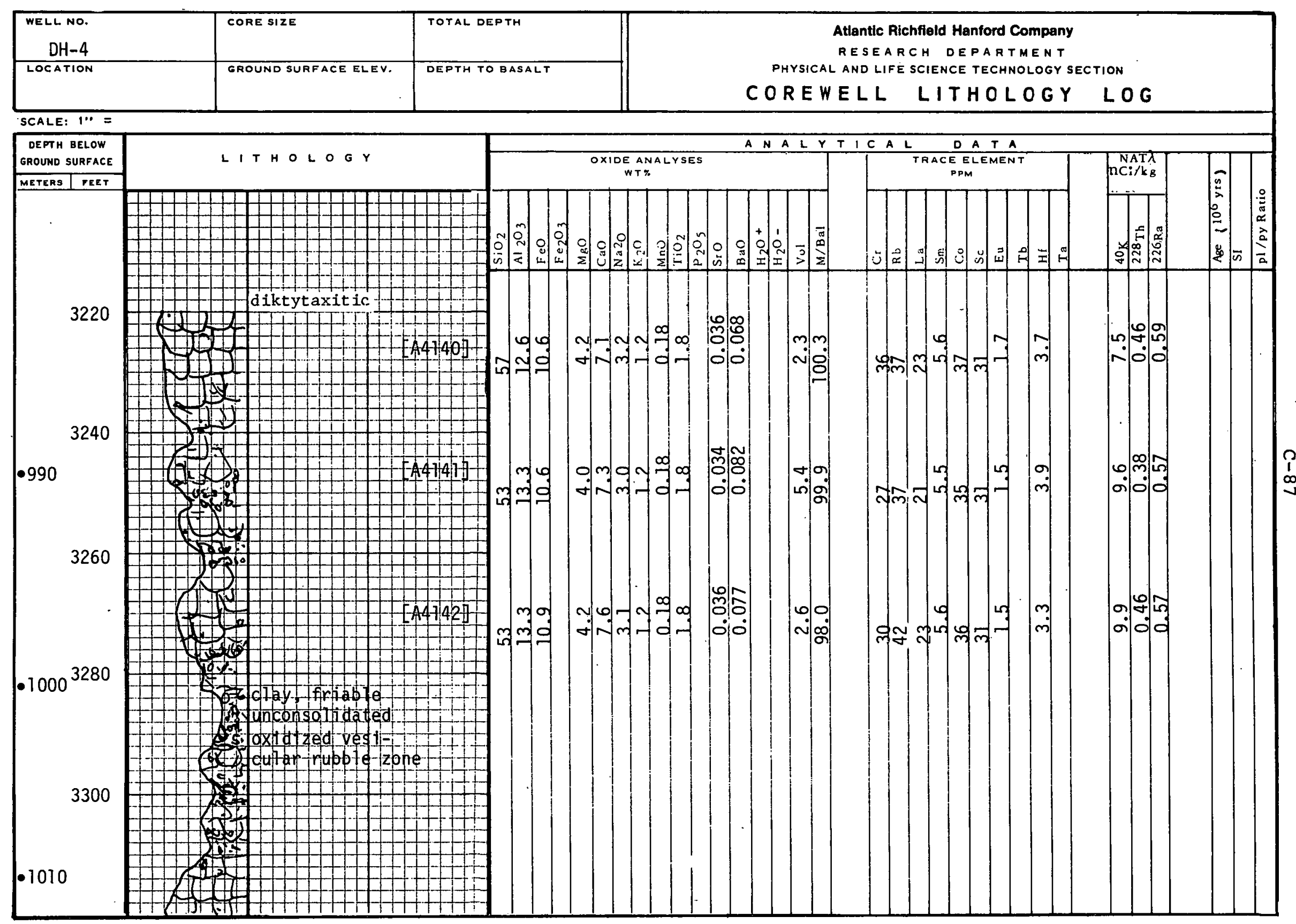




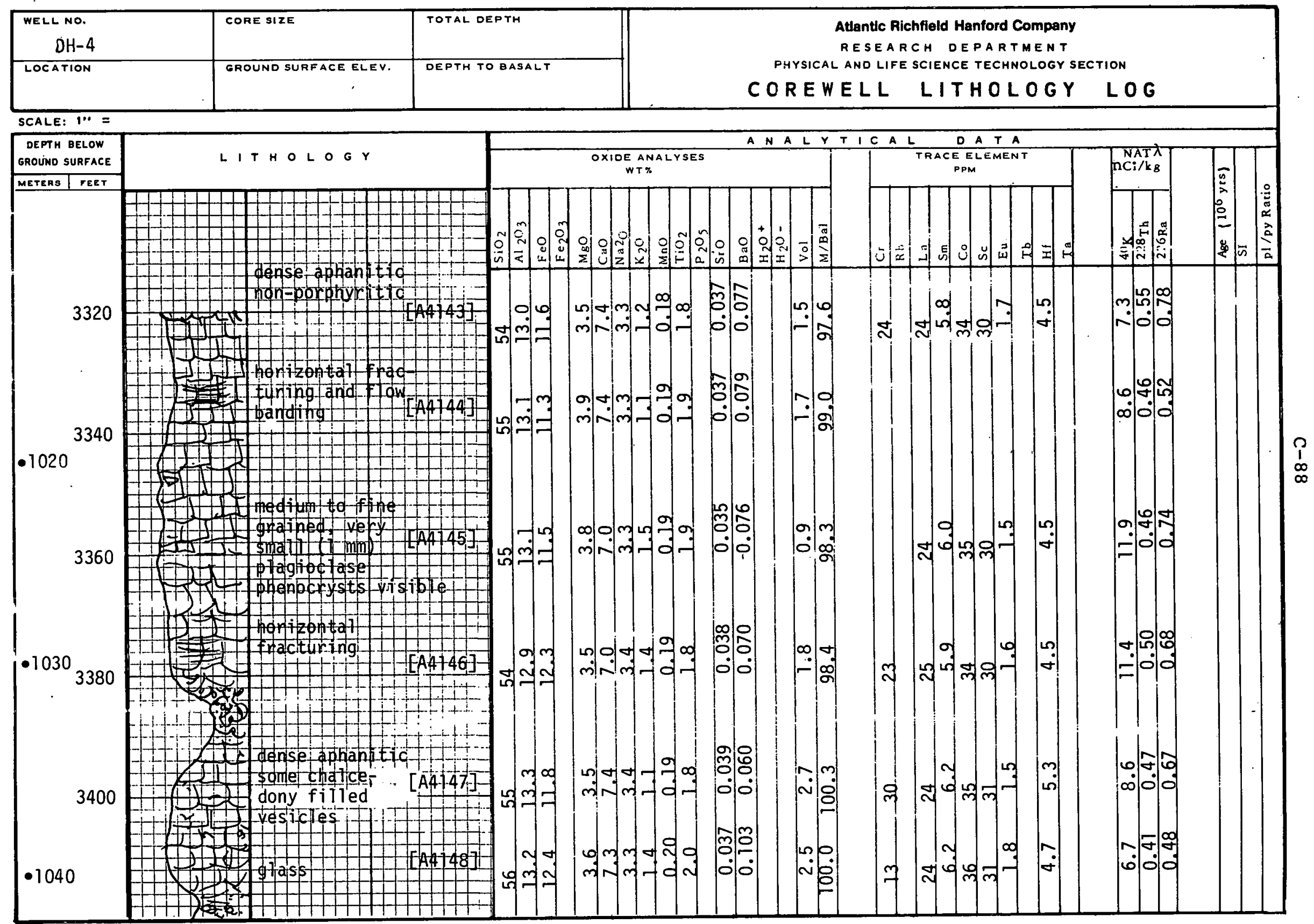




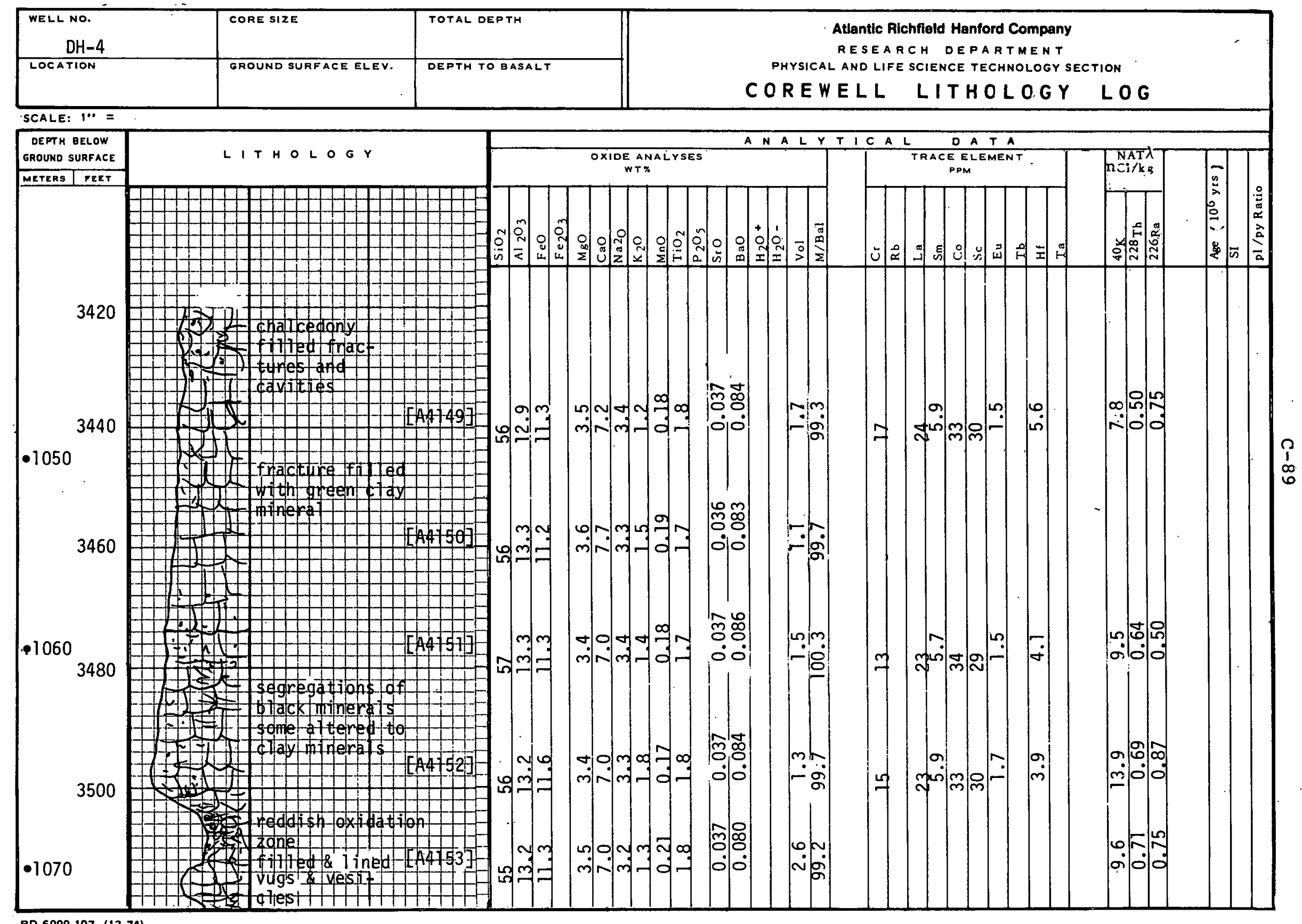




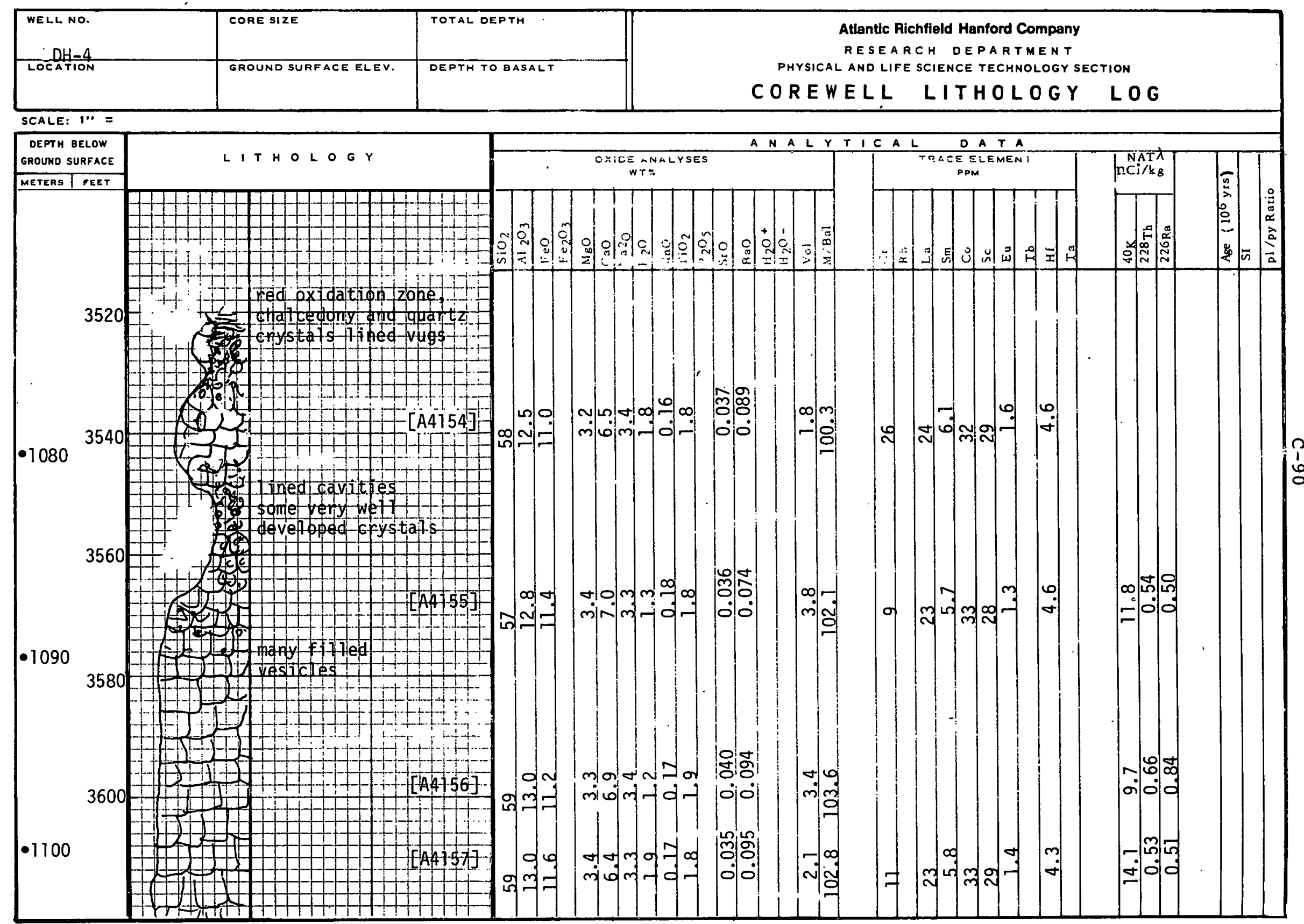




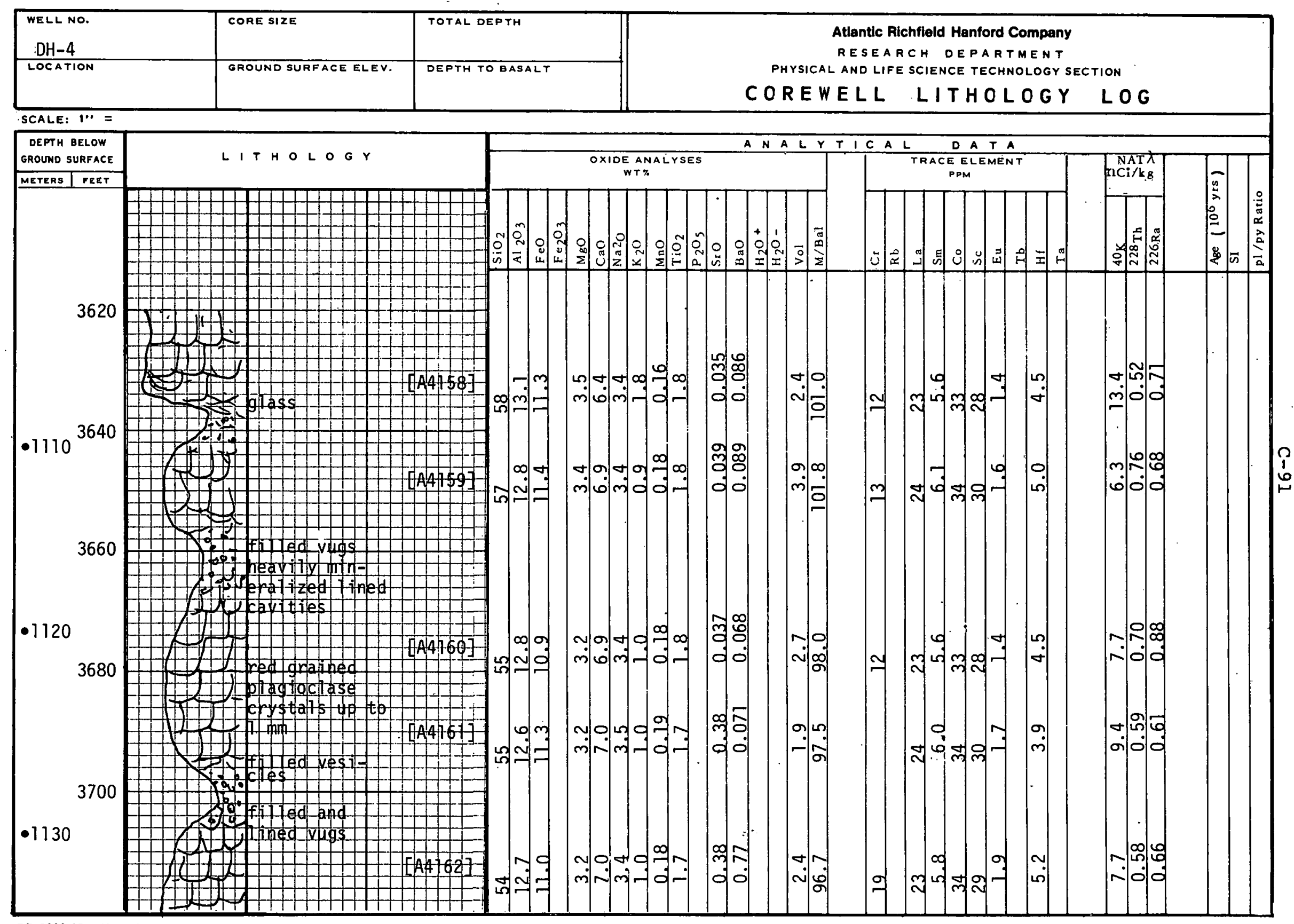




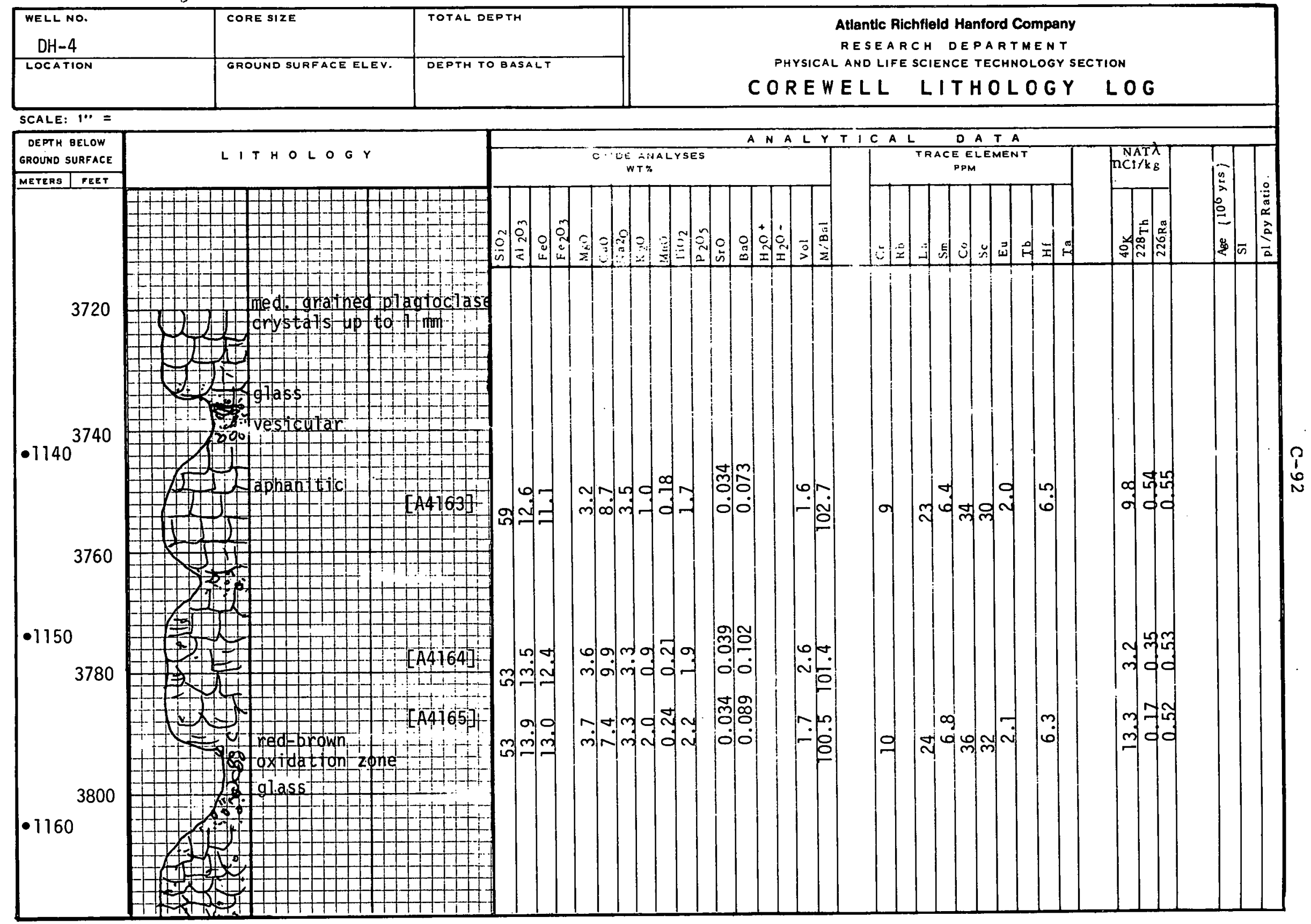

BD-6000-107 (12-74) 


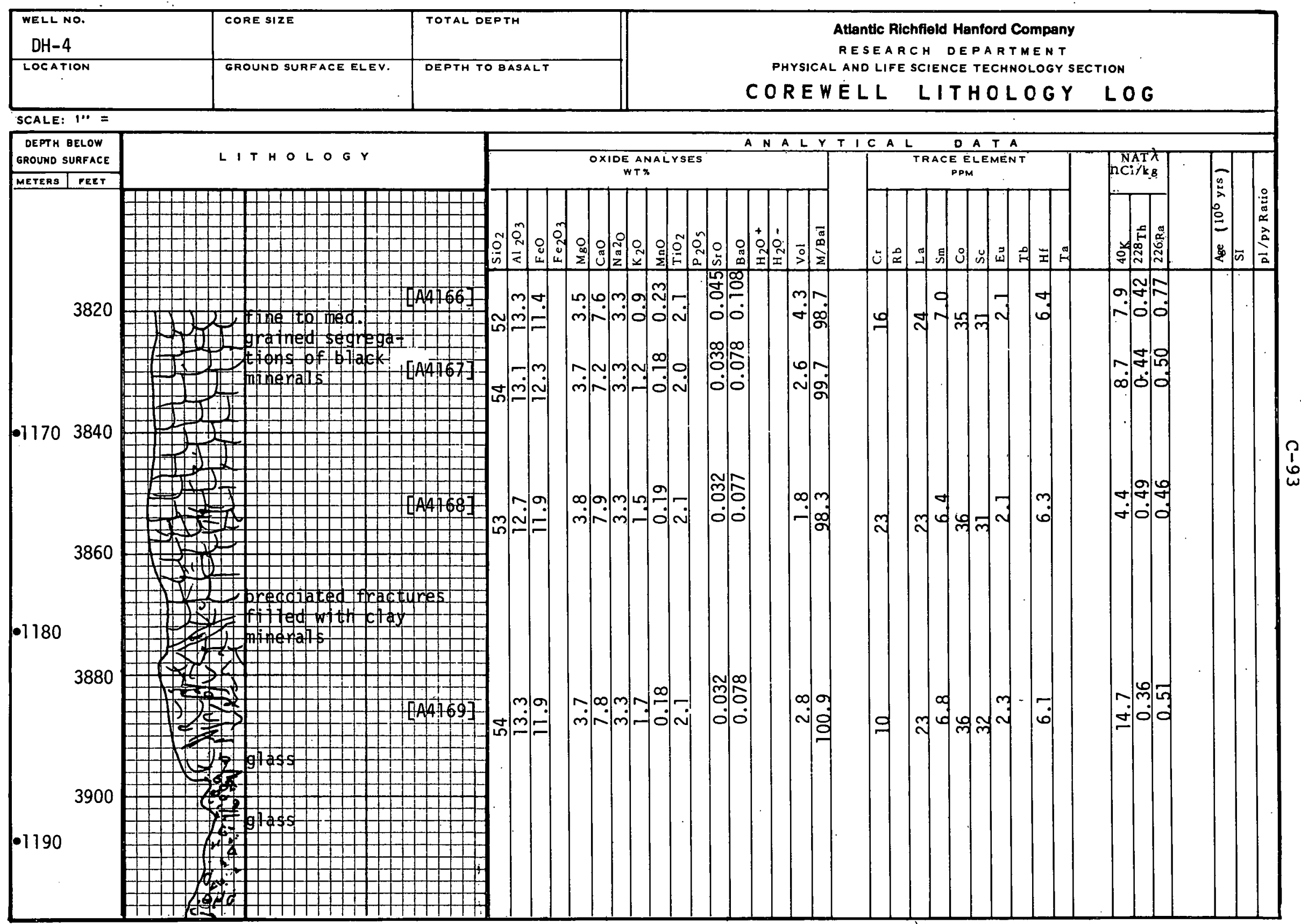




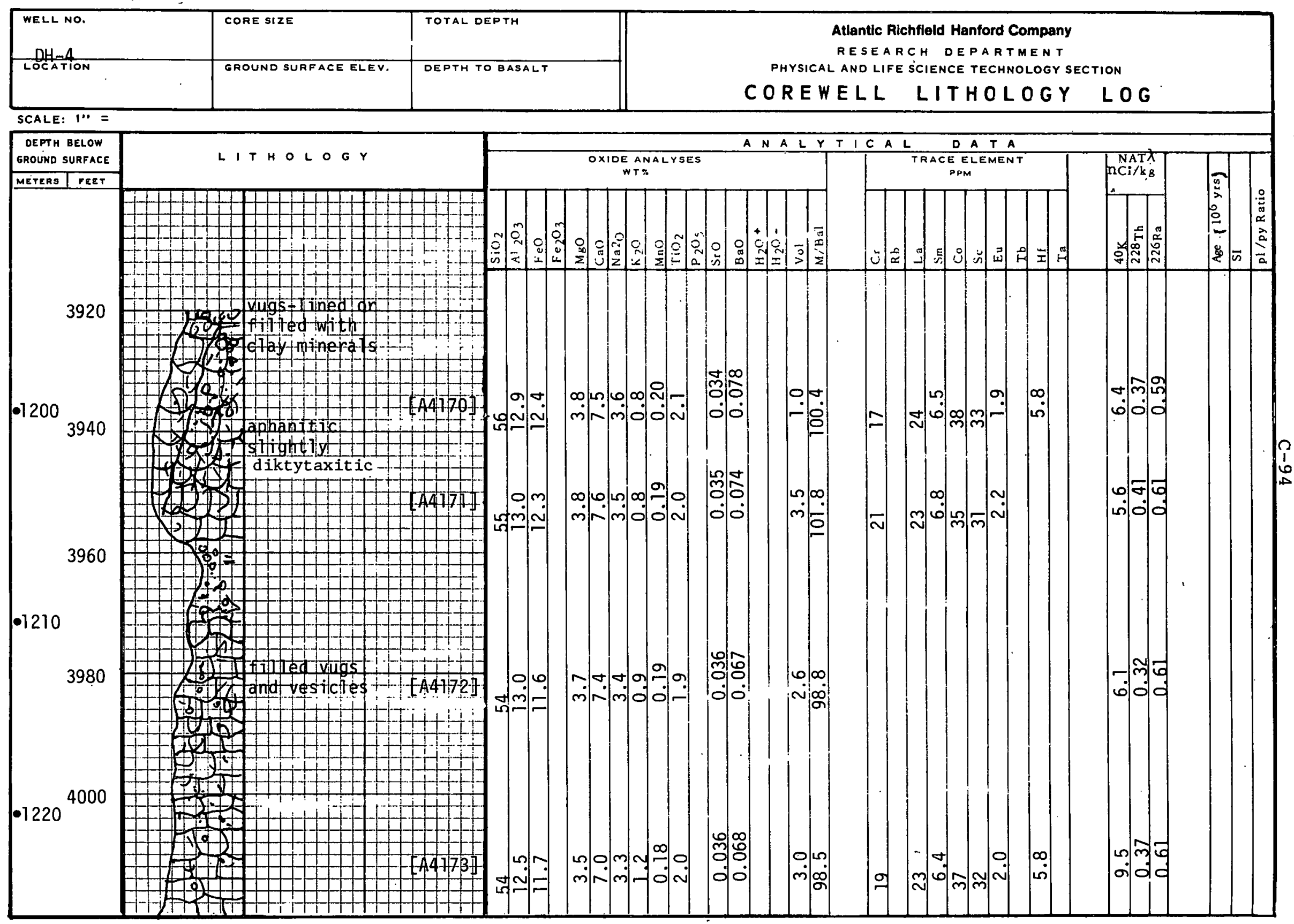

B0-6000-107 (12-74) 


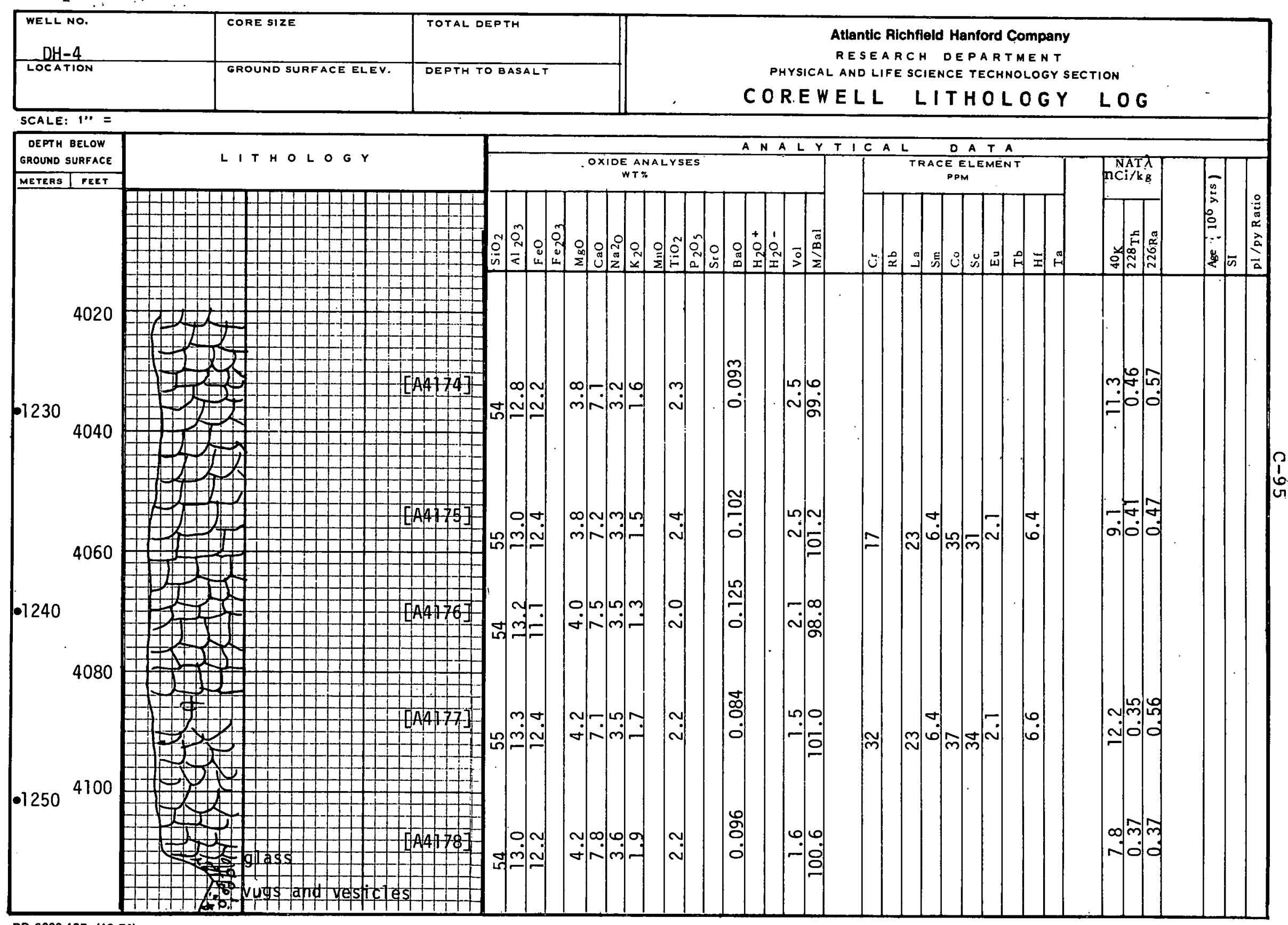




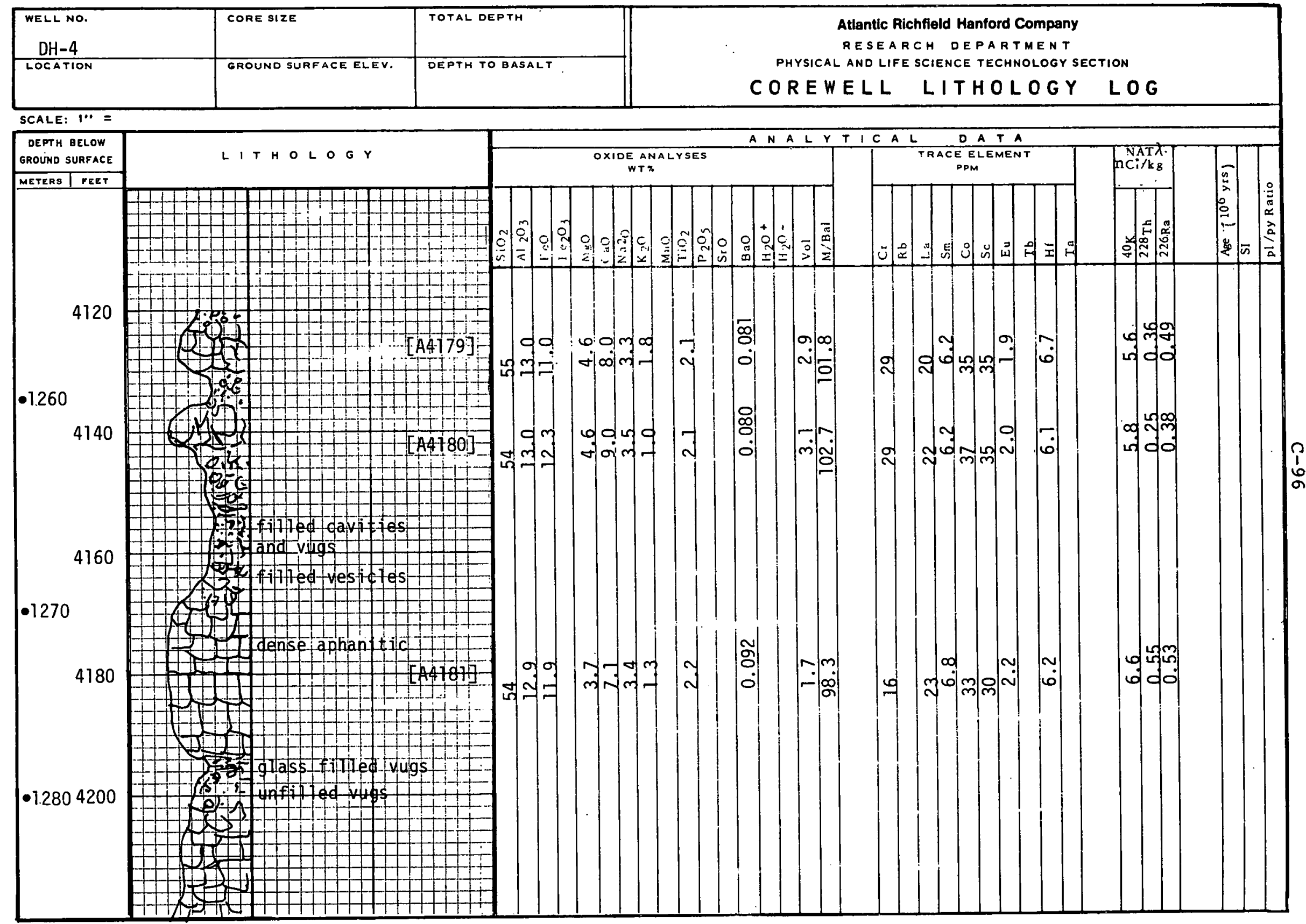

BD-6000-107 (12-74) 


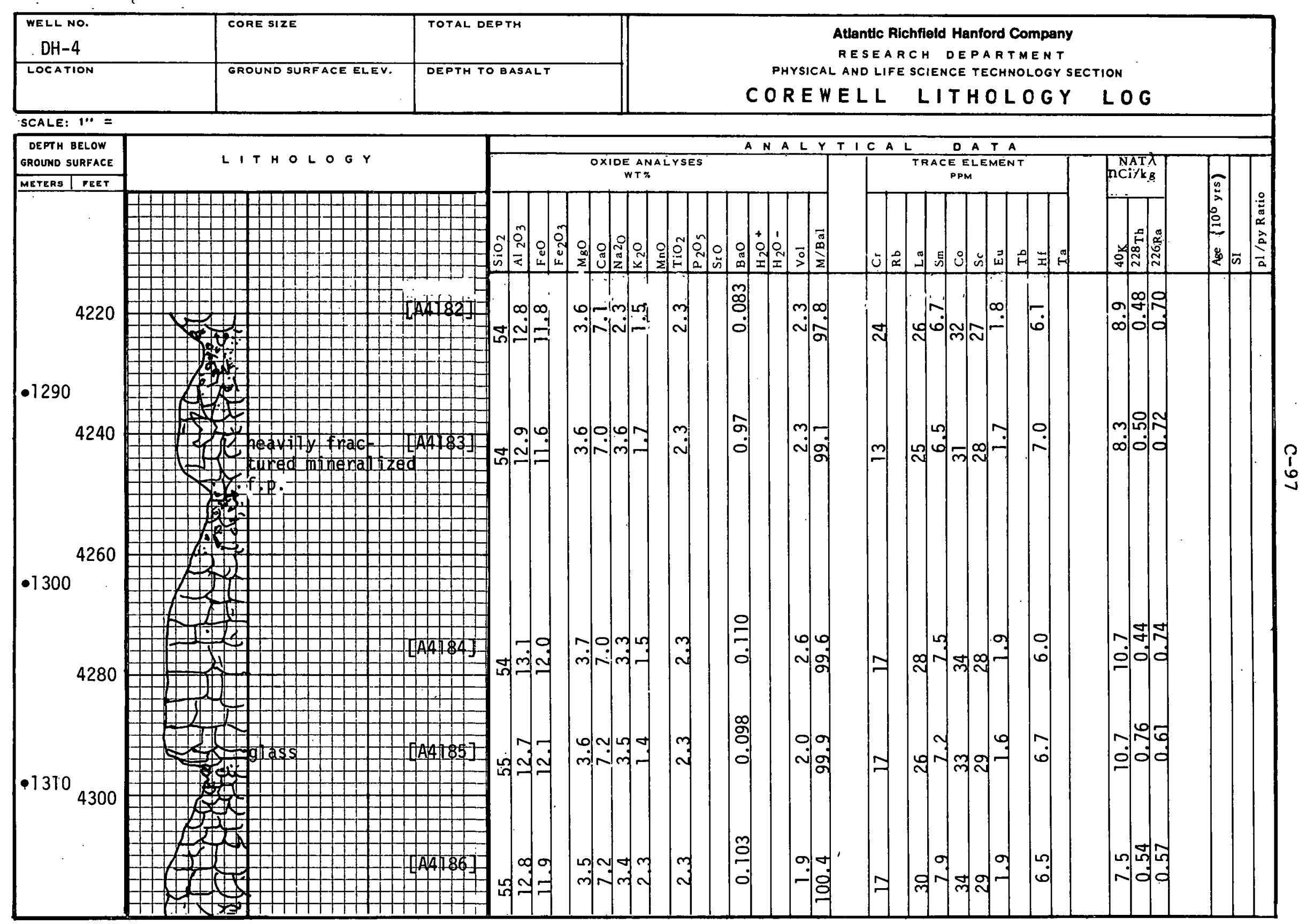




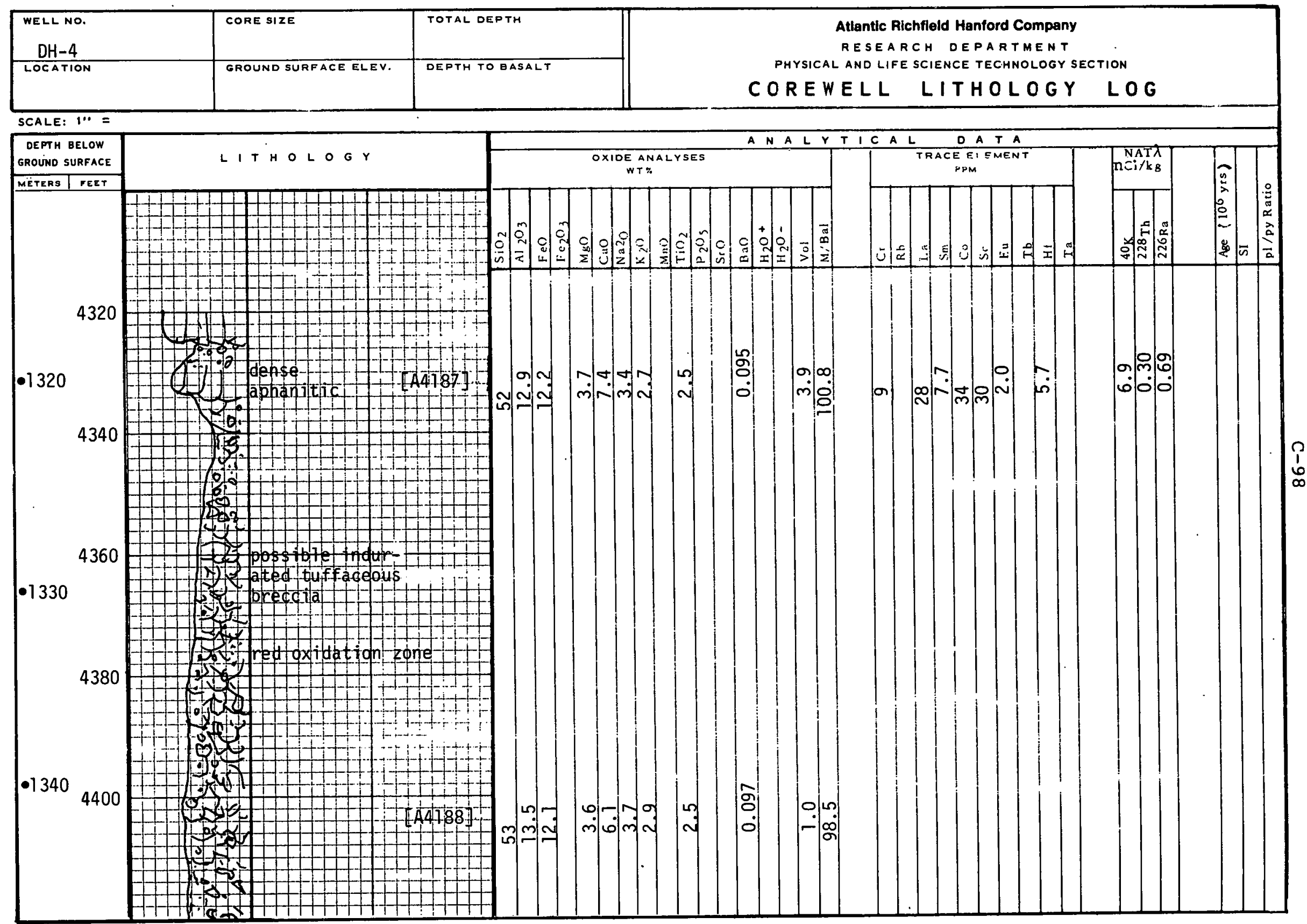

BD-6000-107 (12-74) 


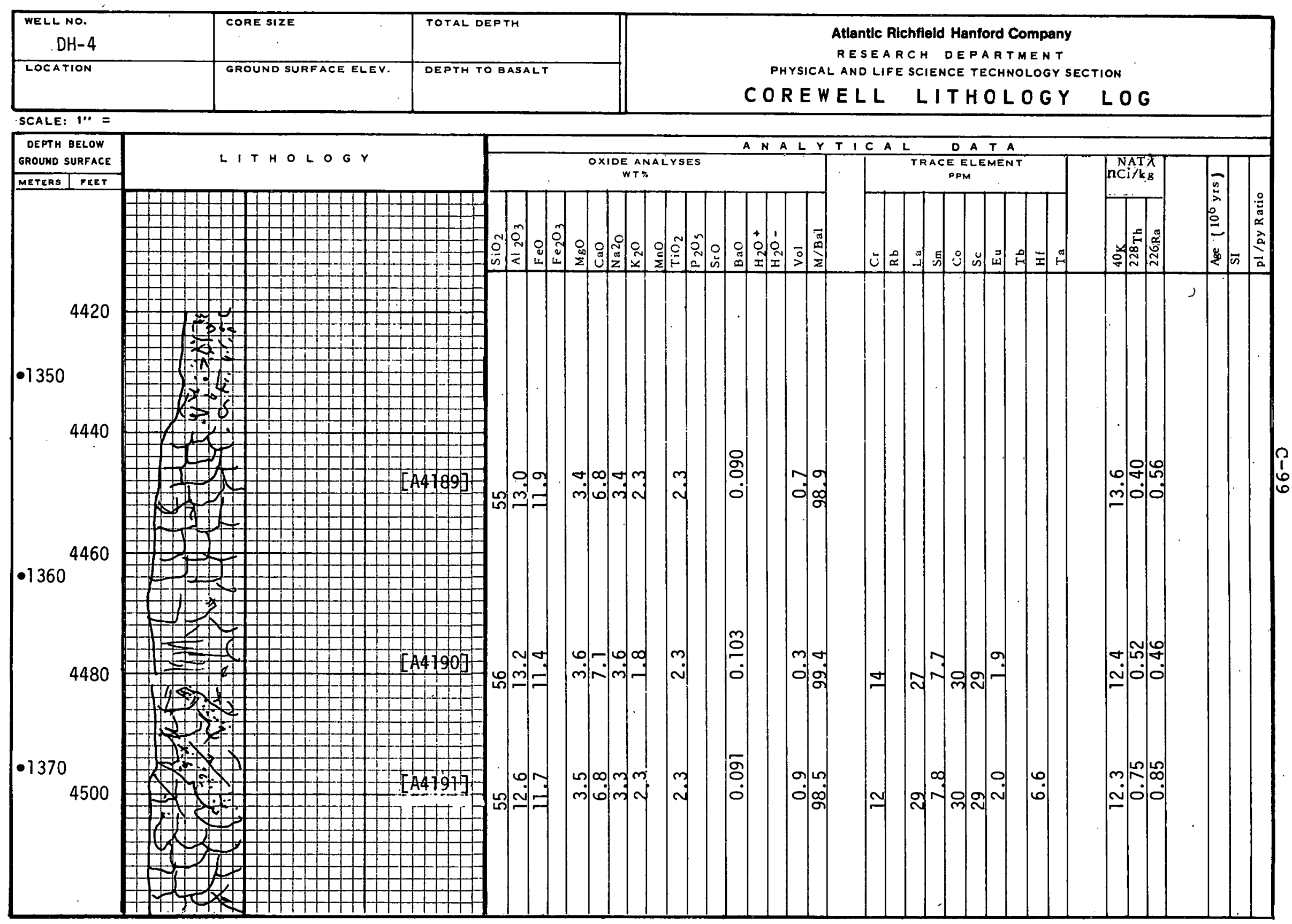

80-6000-107 (12-74) 


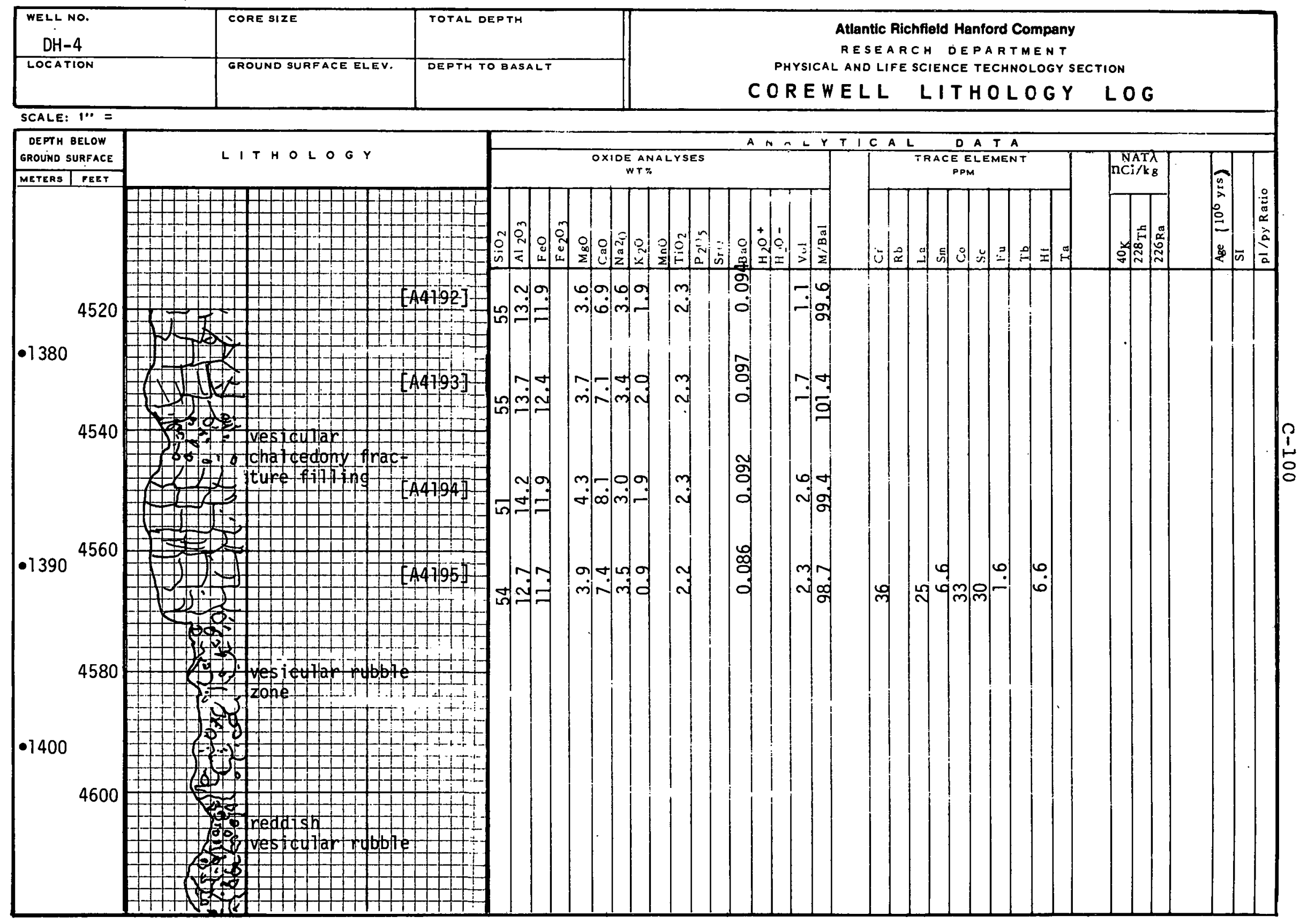

BD-6000-107 (12-74) 


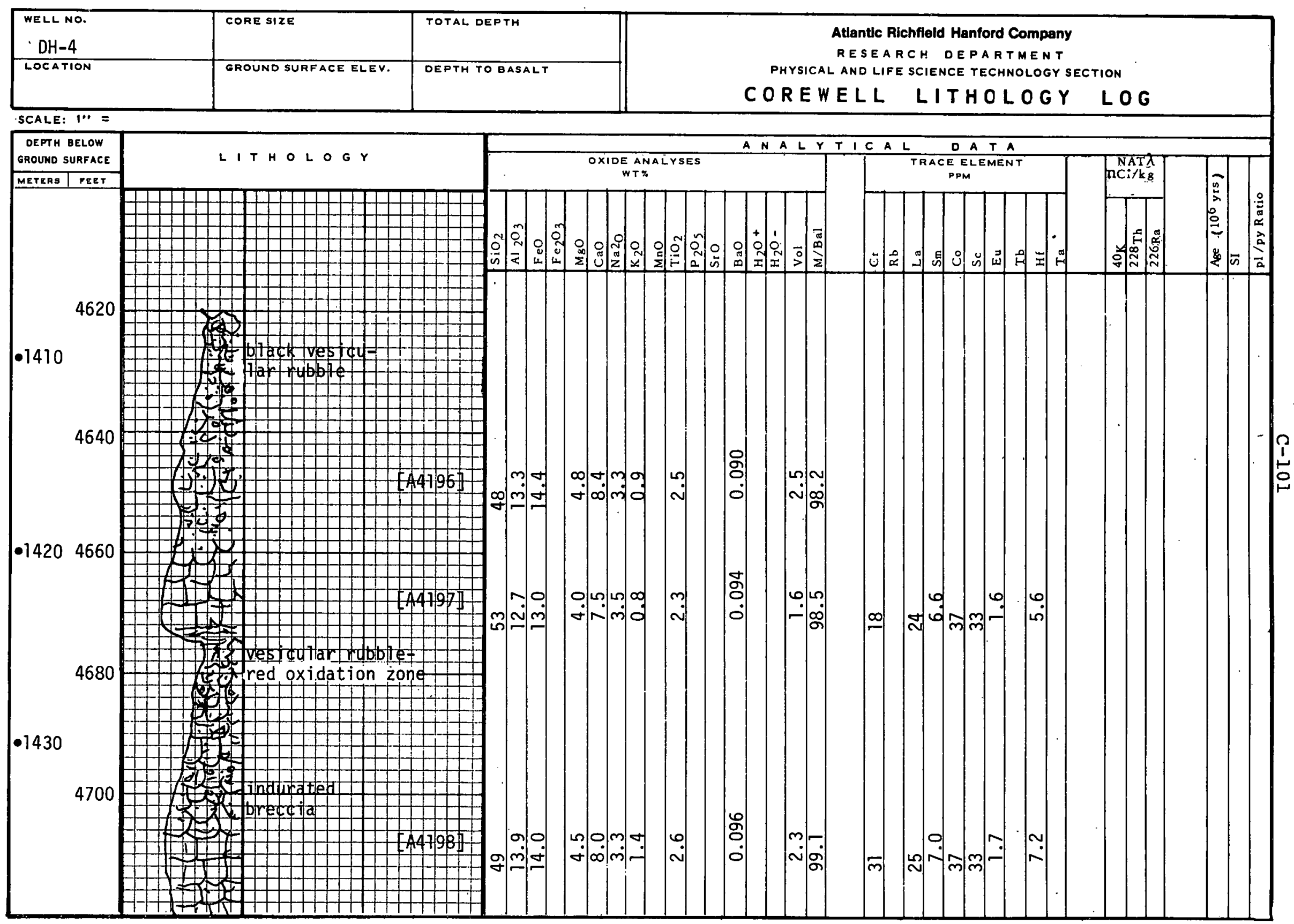




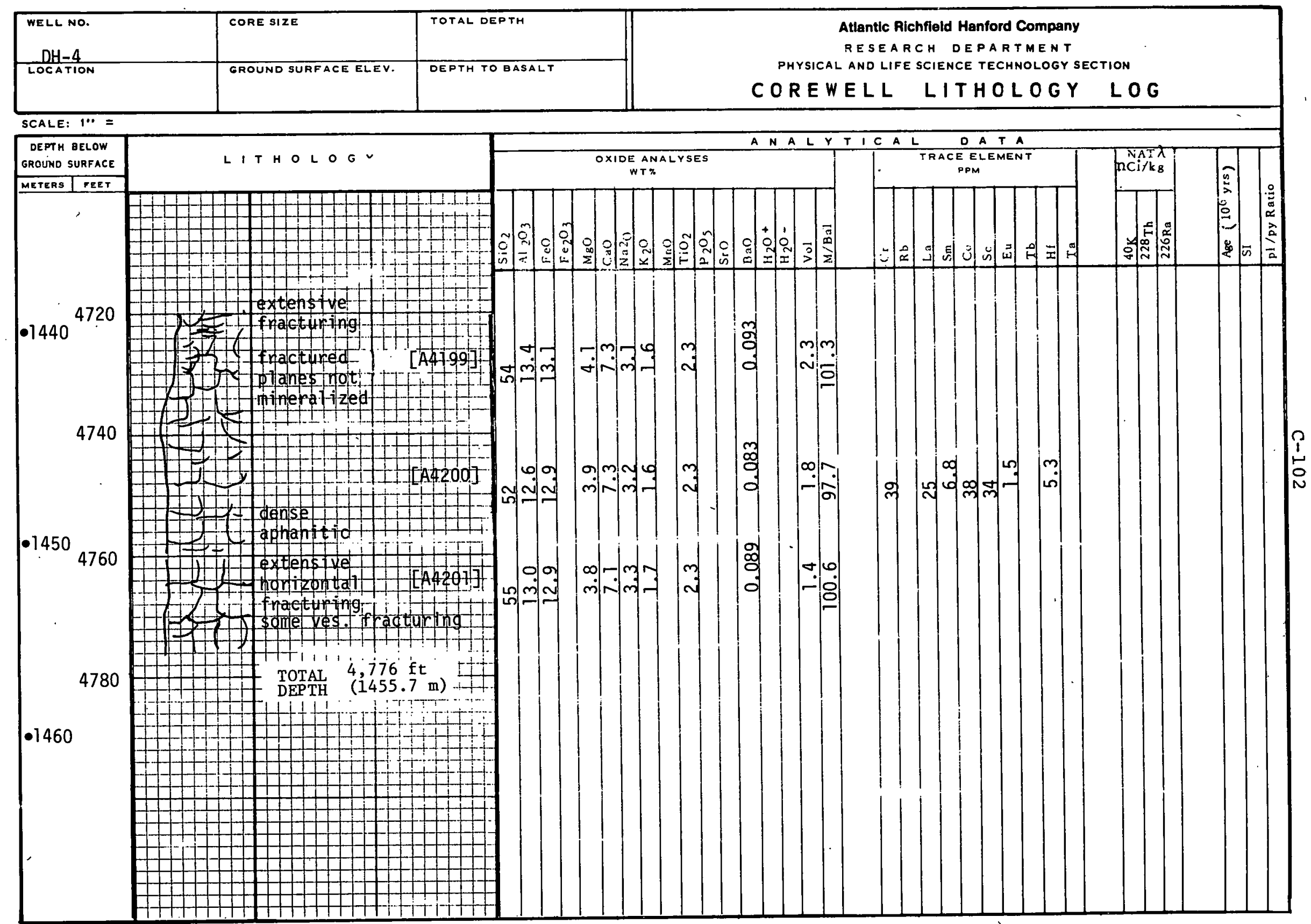




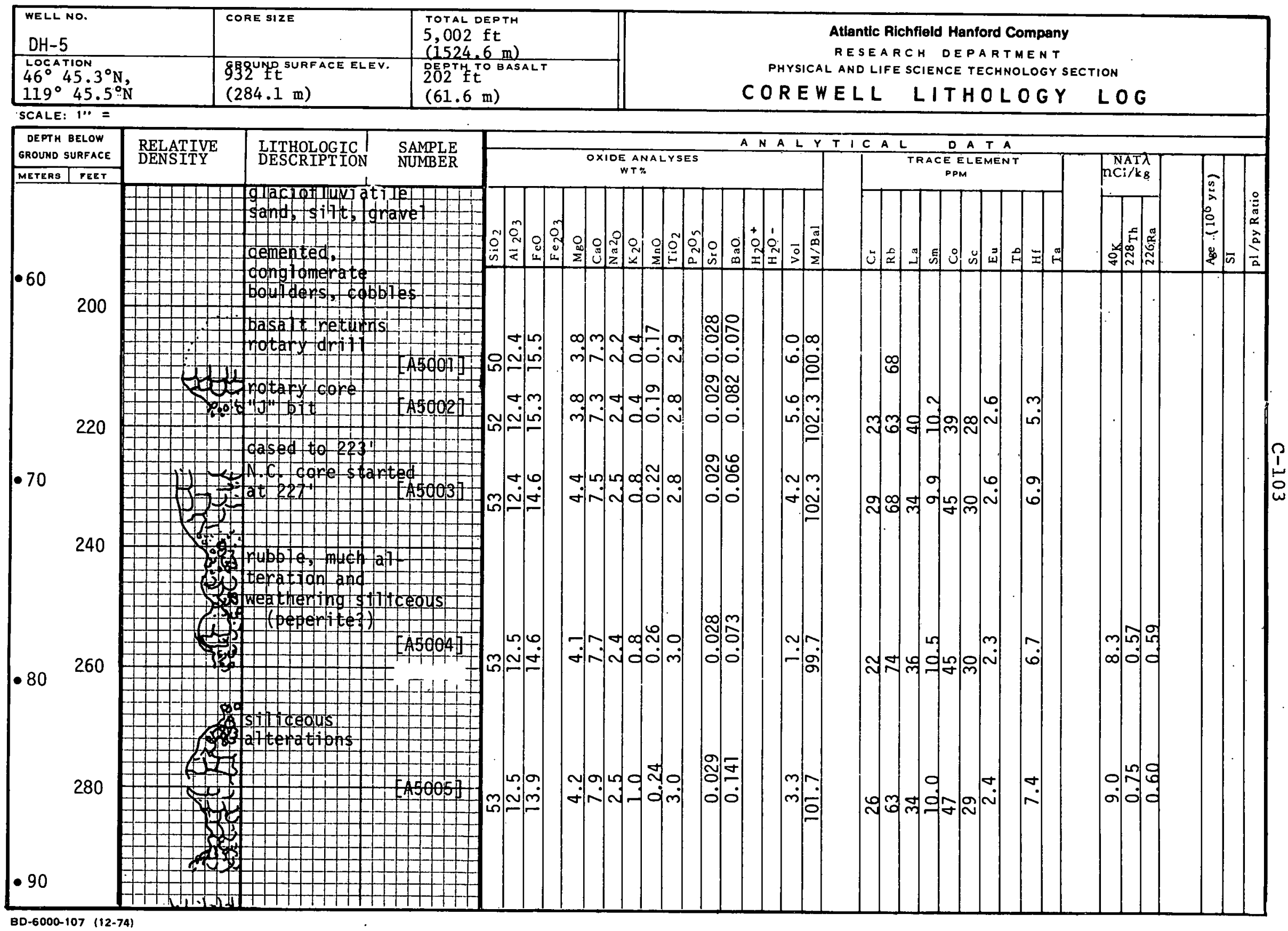




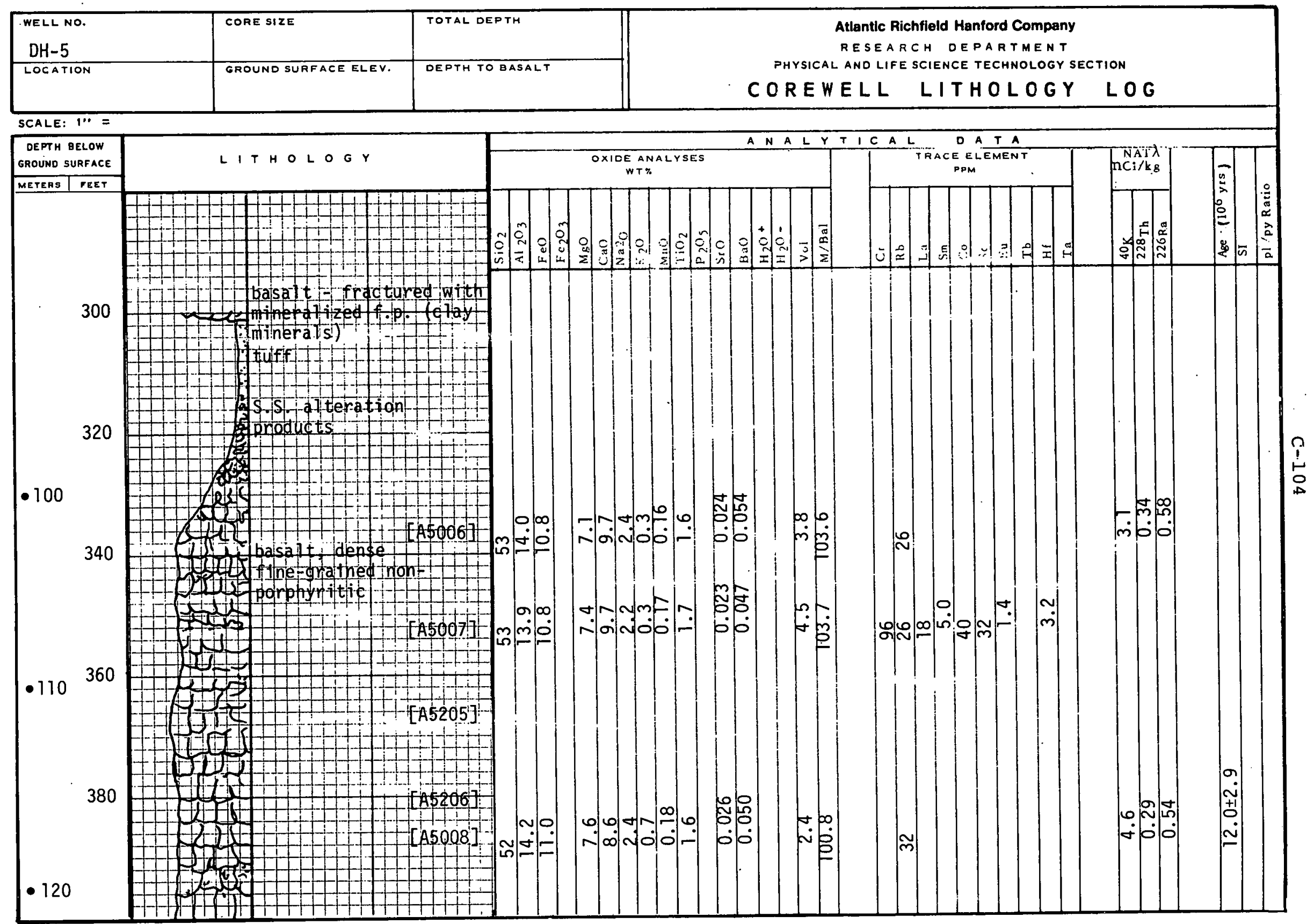

BD-6000-107 (12-74) 


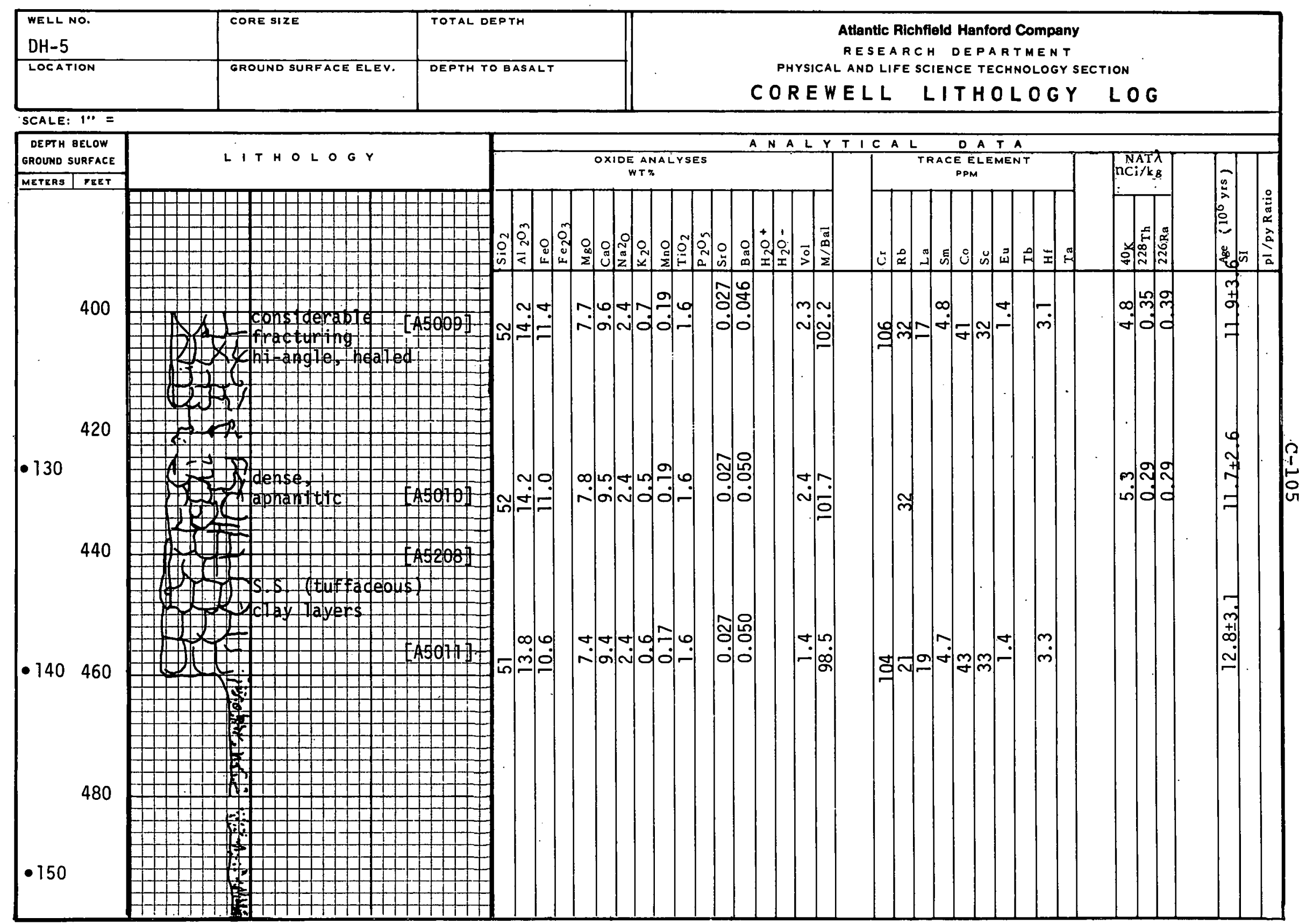




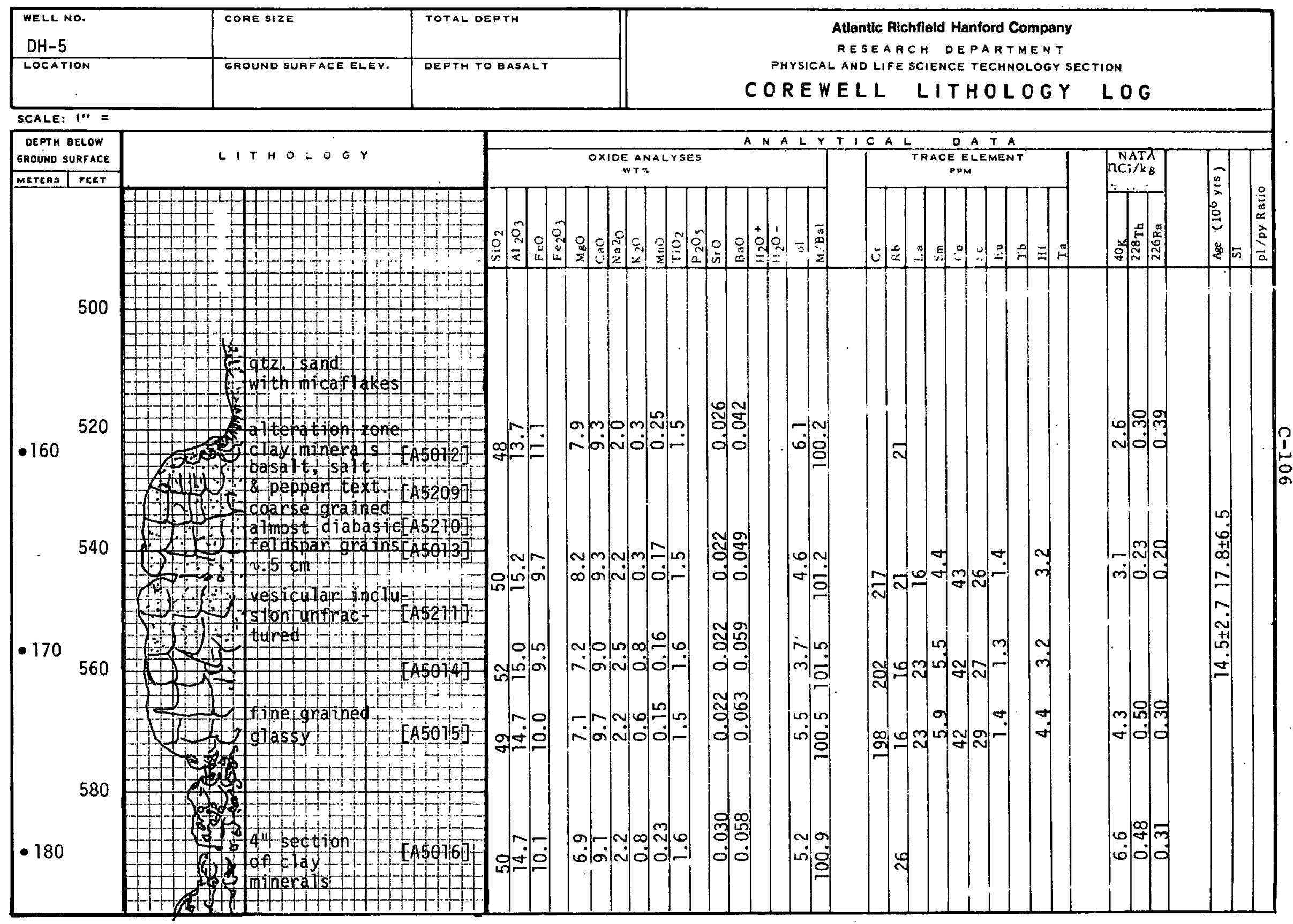

8D-6000-107 (12-74) 


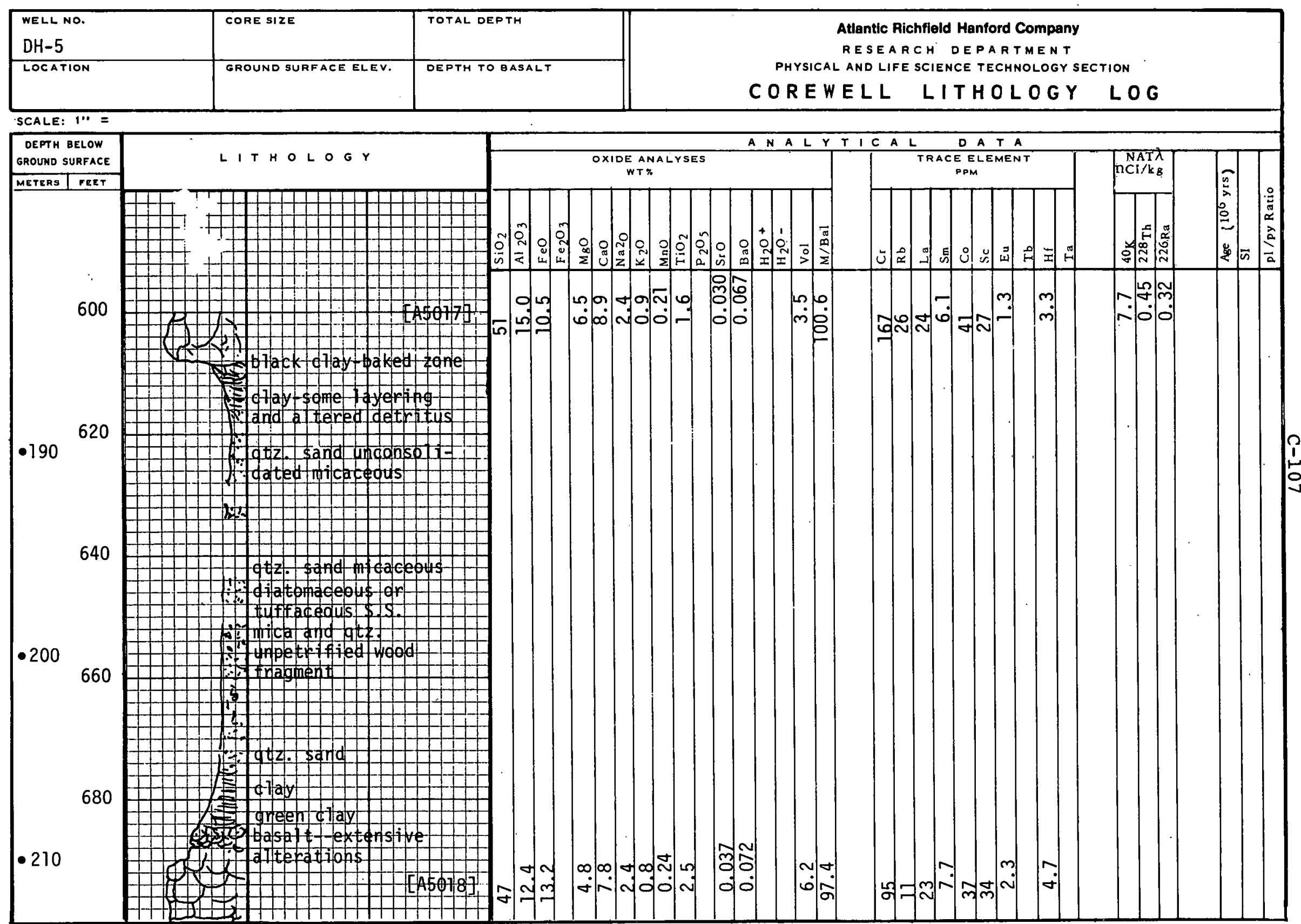




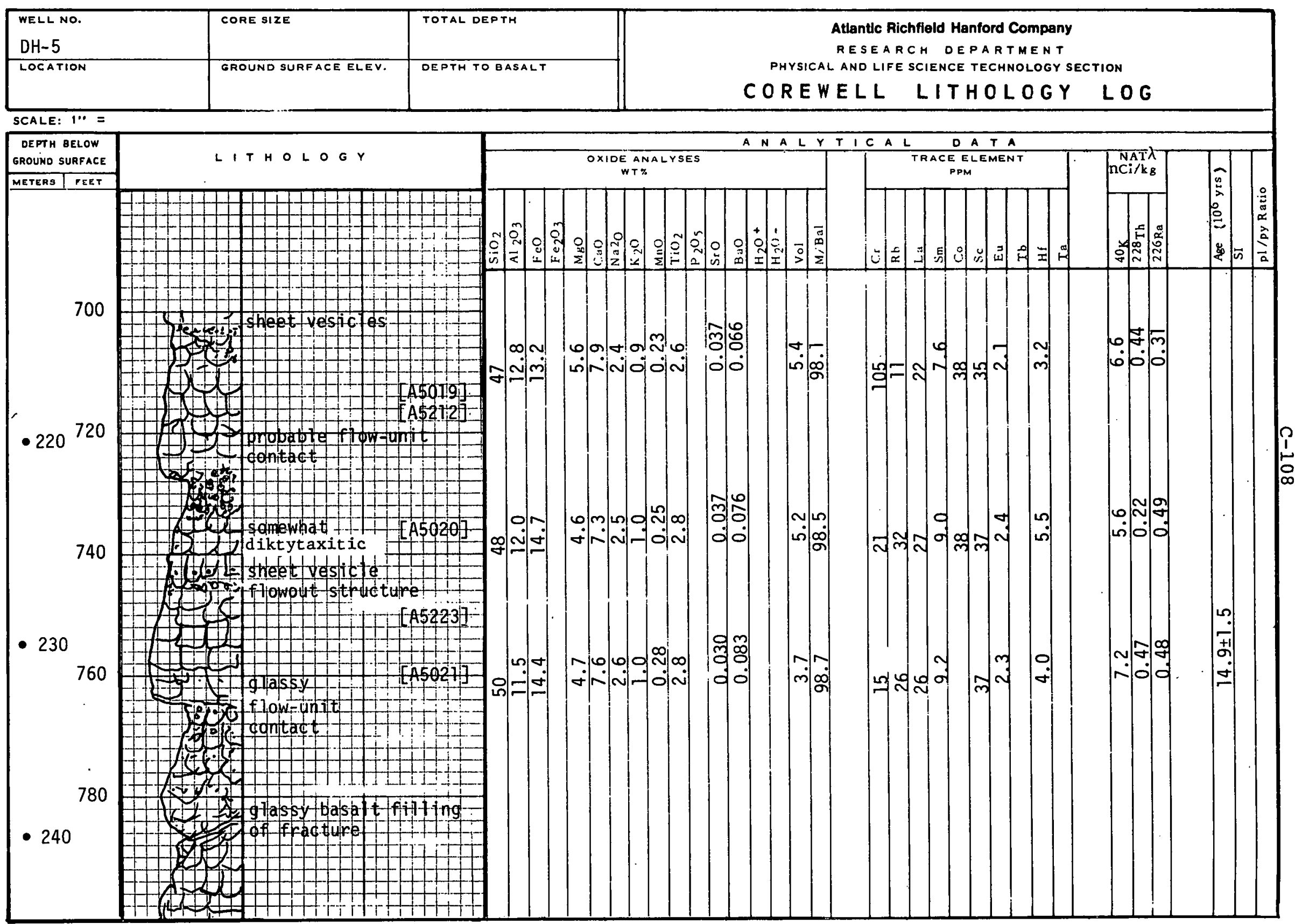




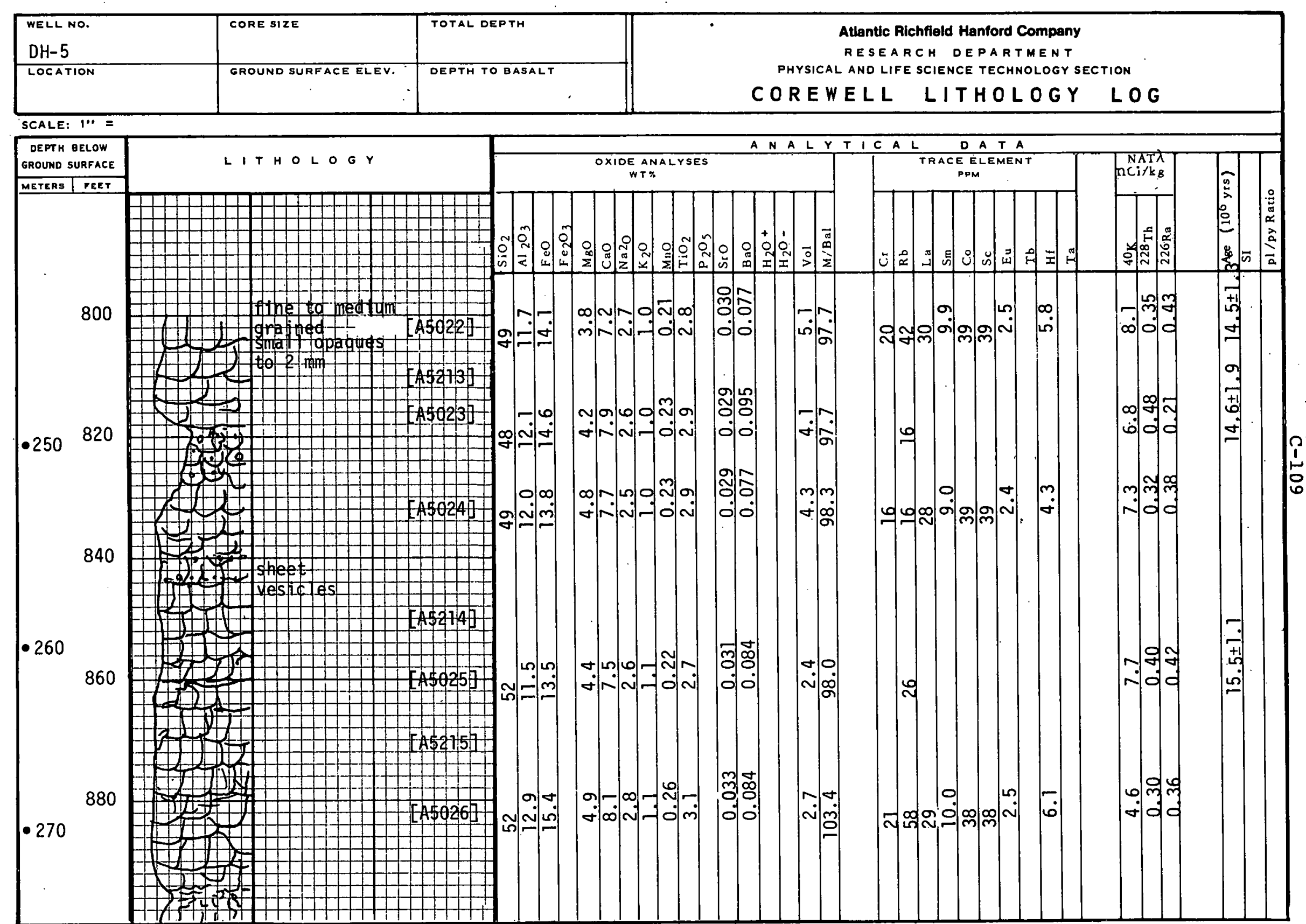




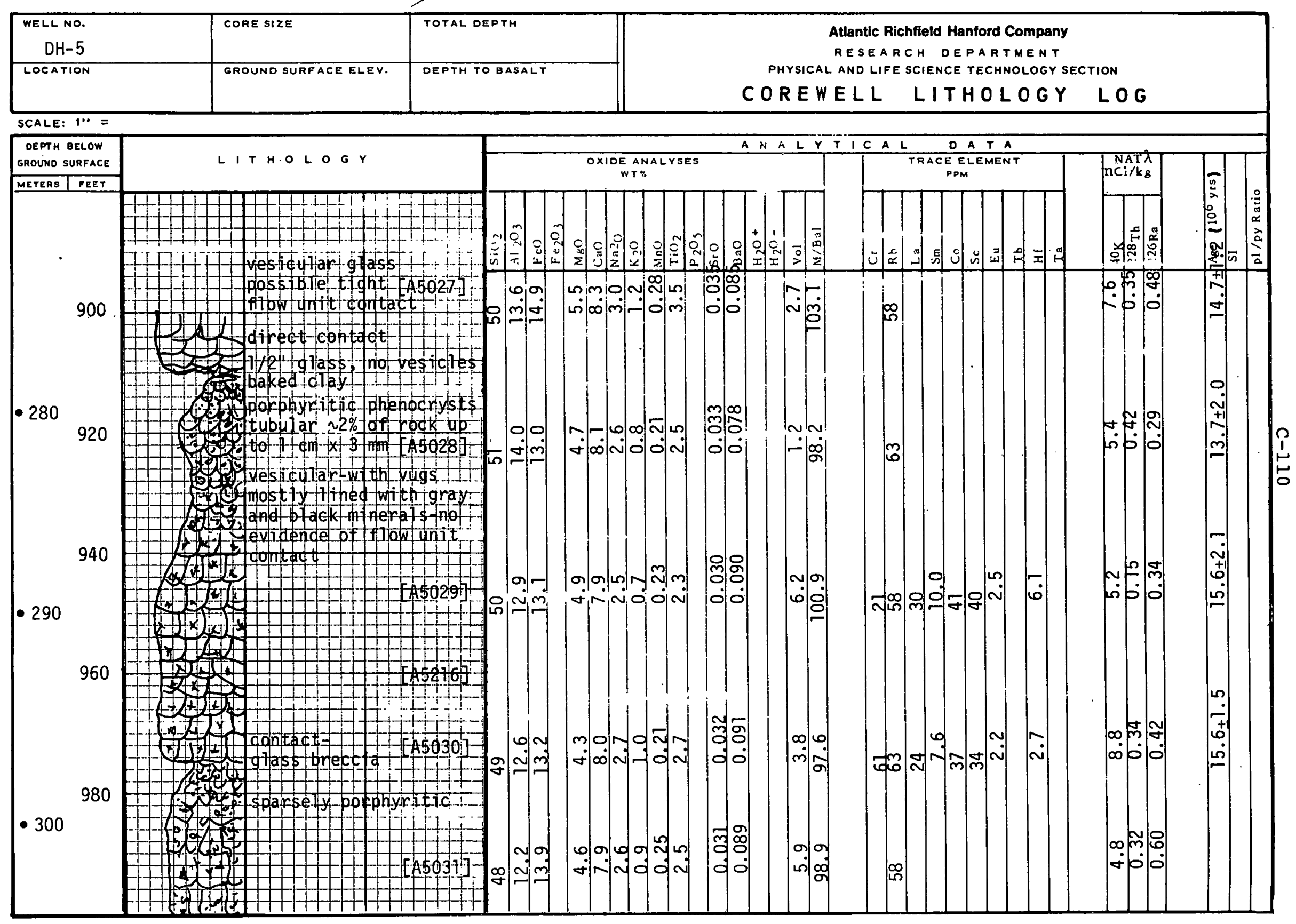




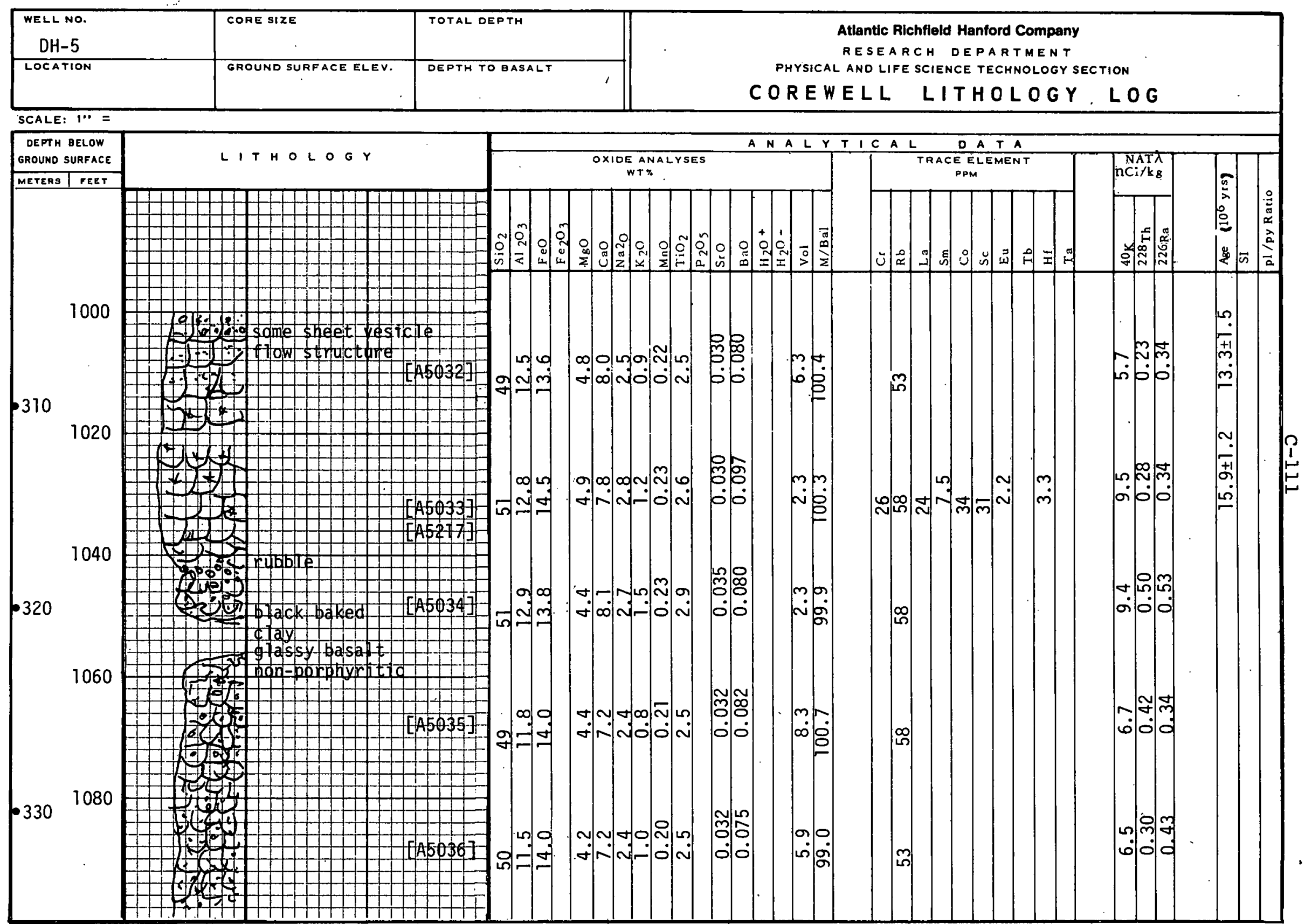




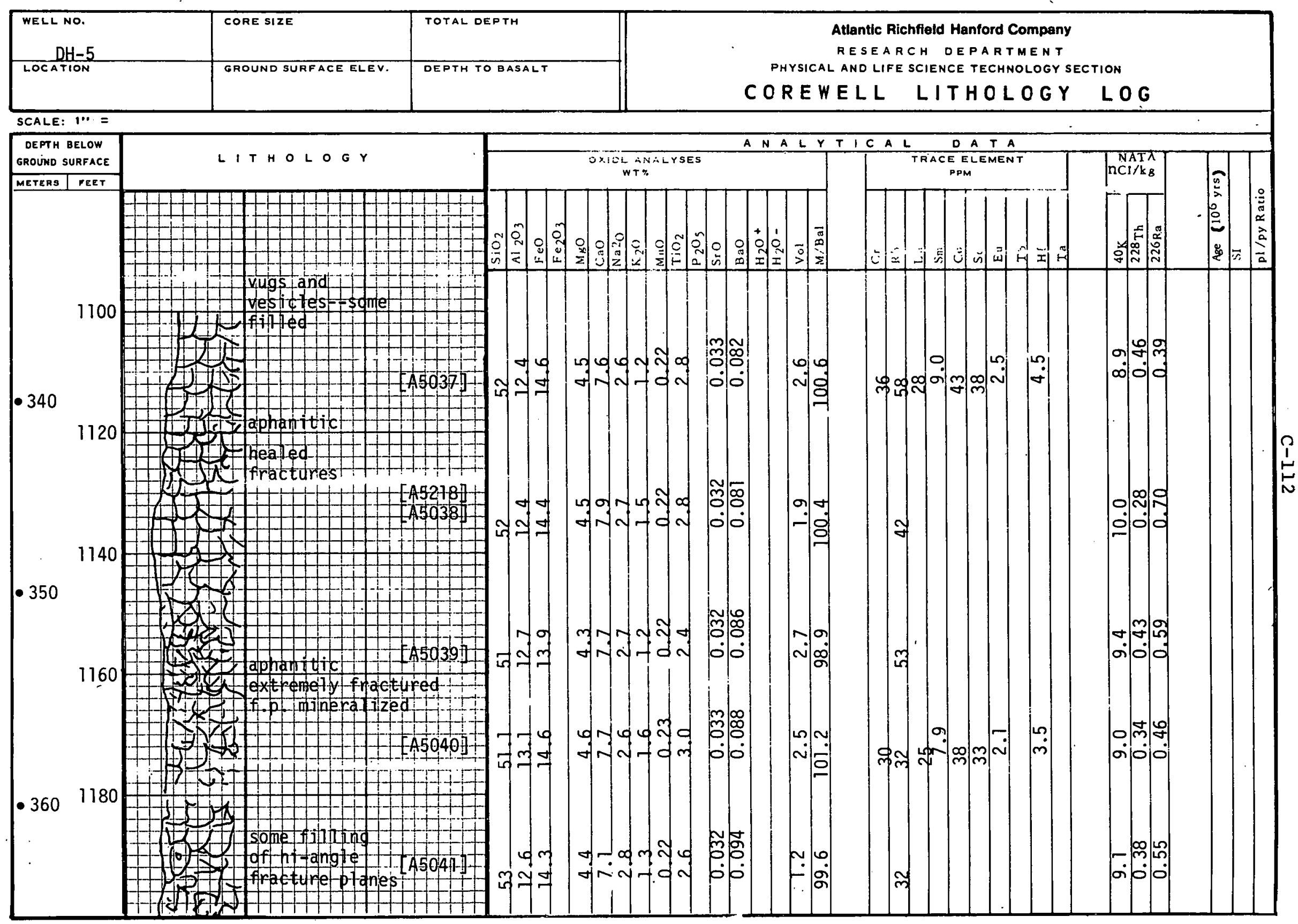

80-6000-107 (12-74) 


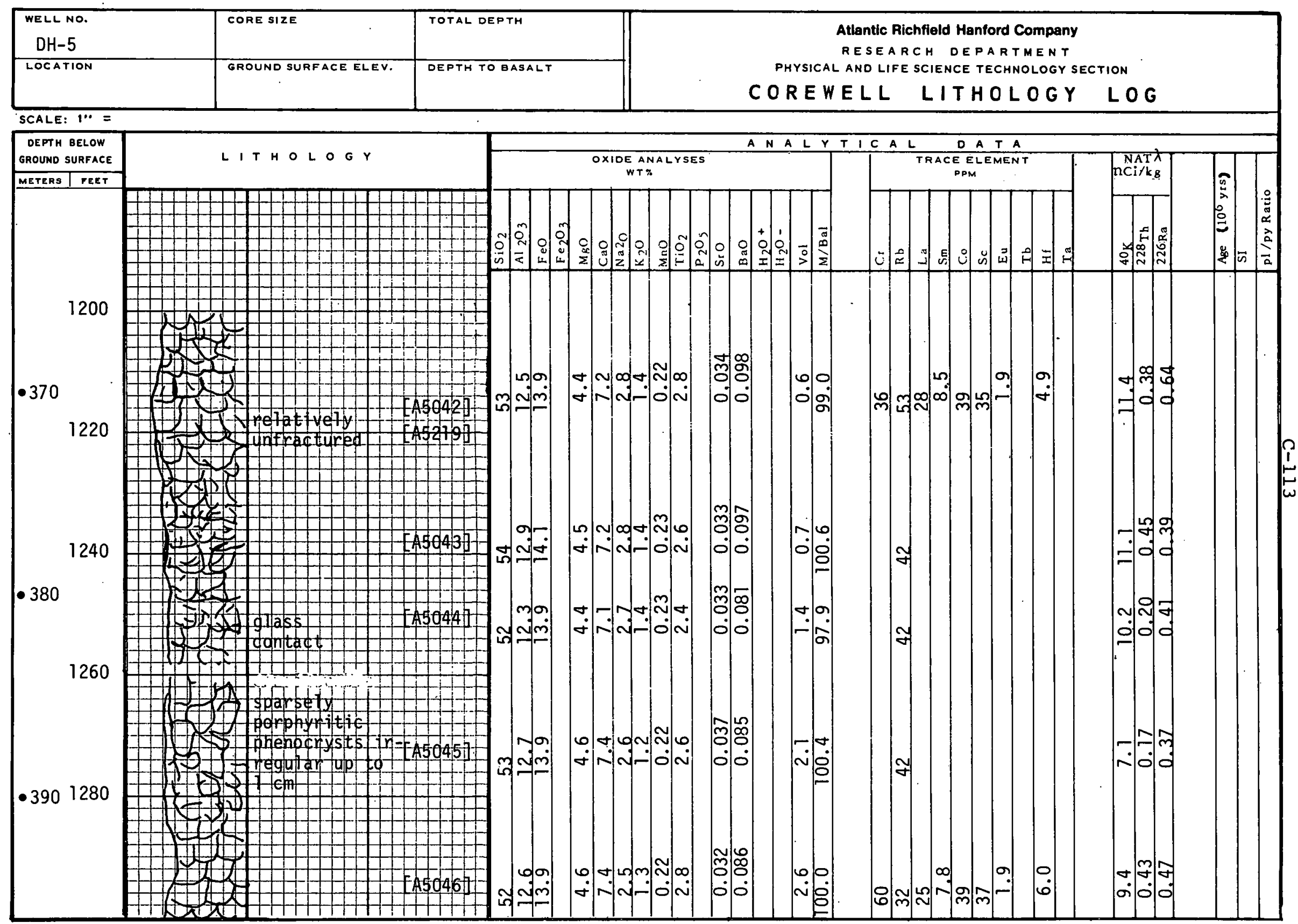

BD-6000-107 (12-74) 


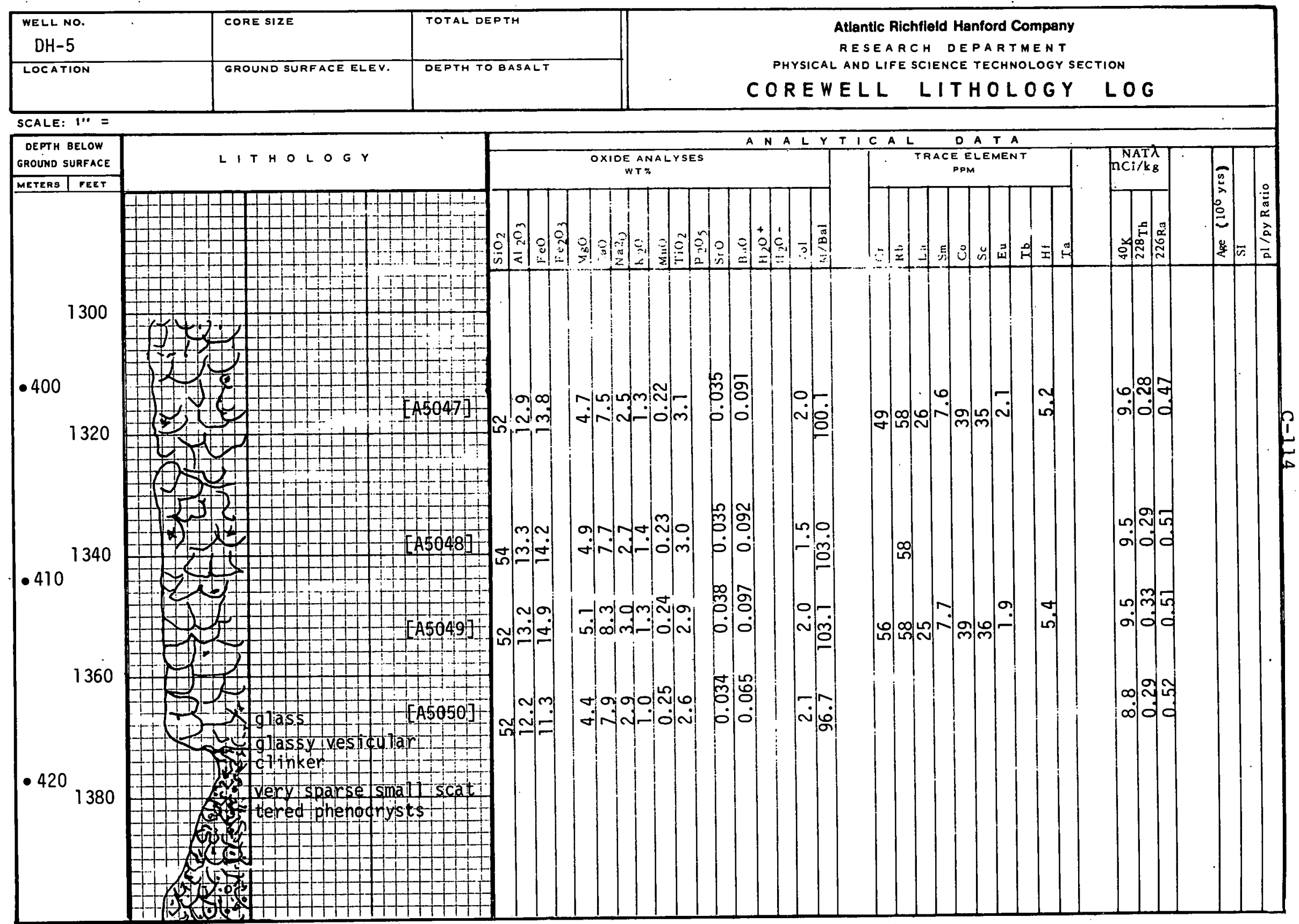




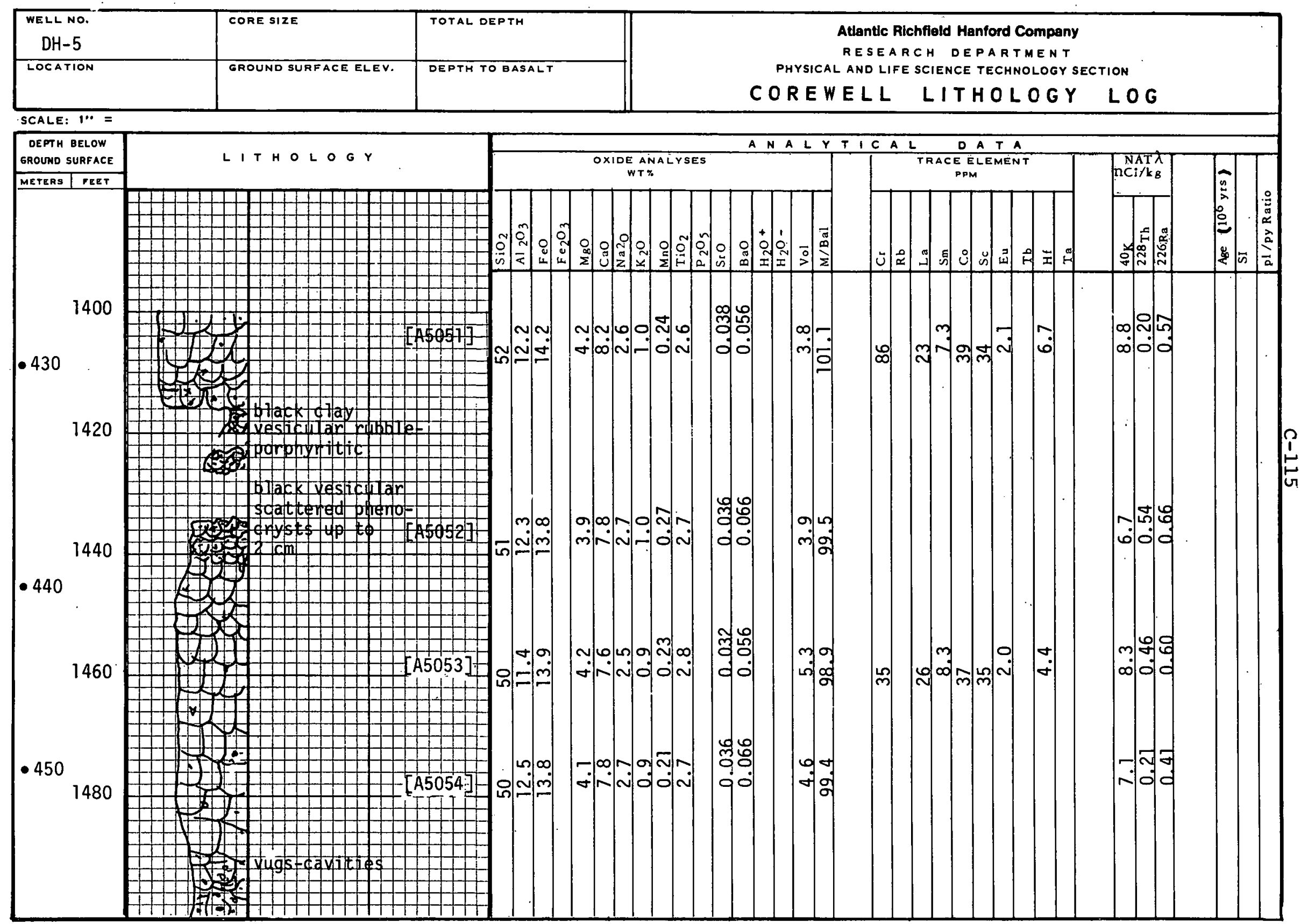

BD-6000-107 (12-74) 


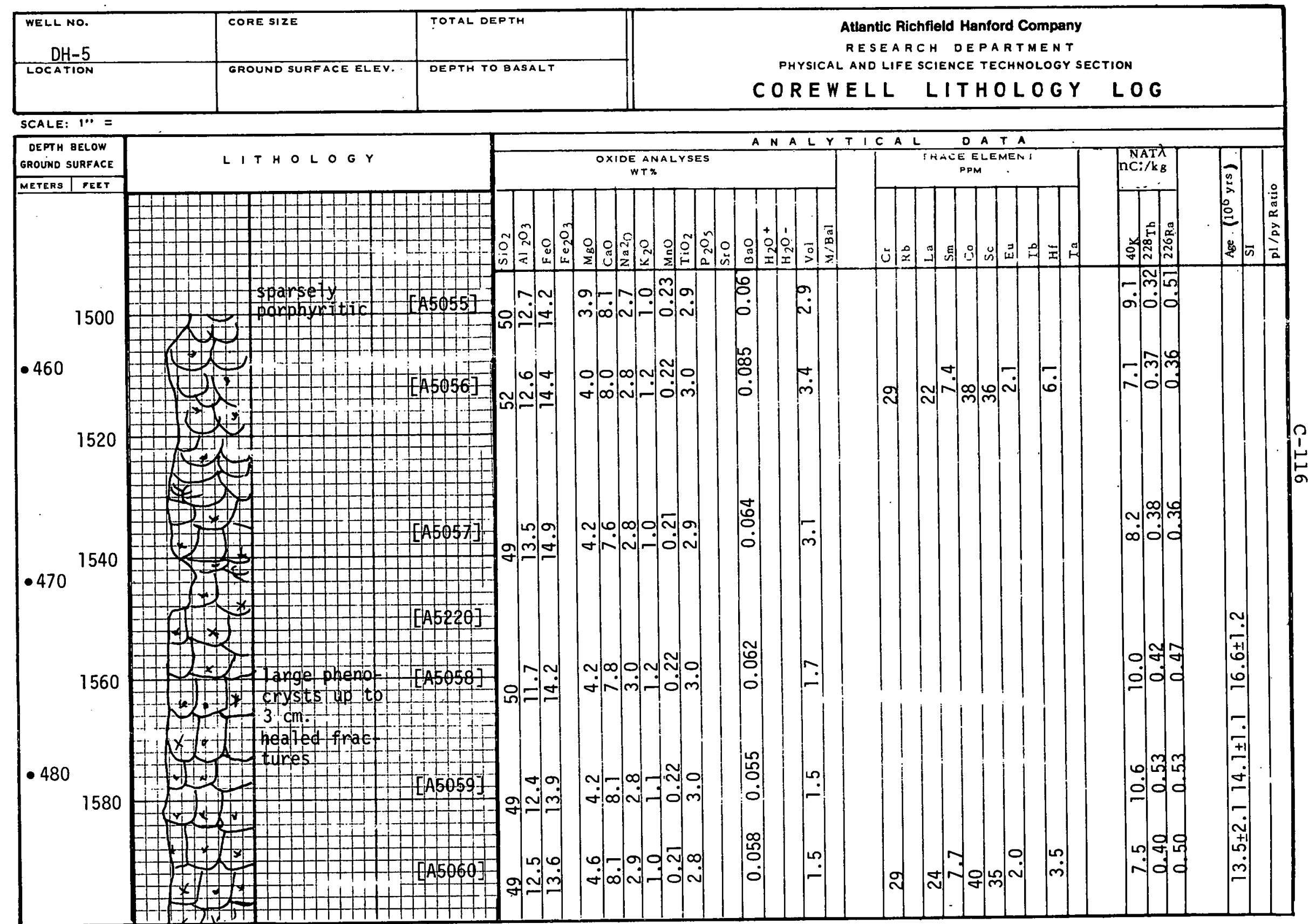




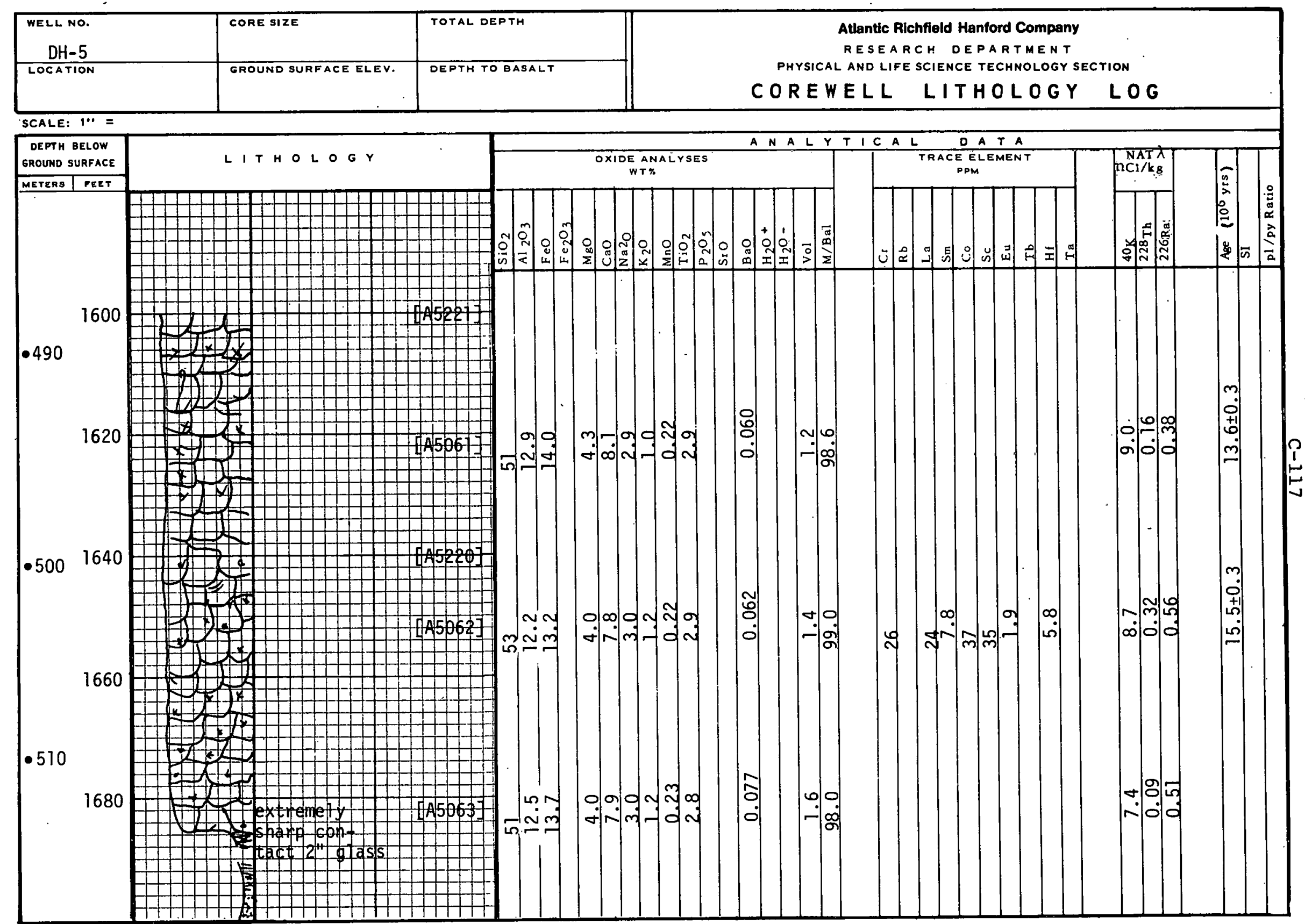




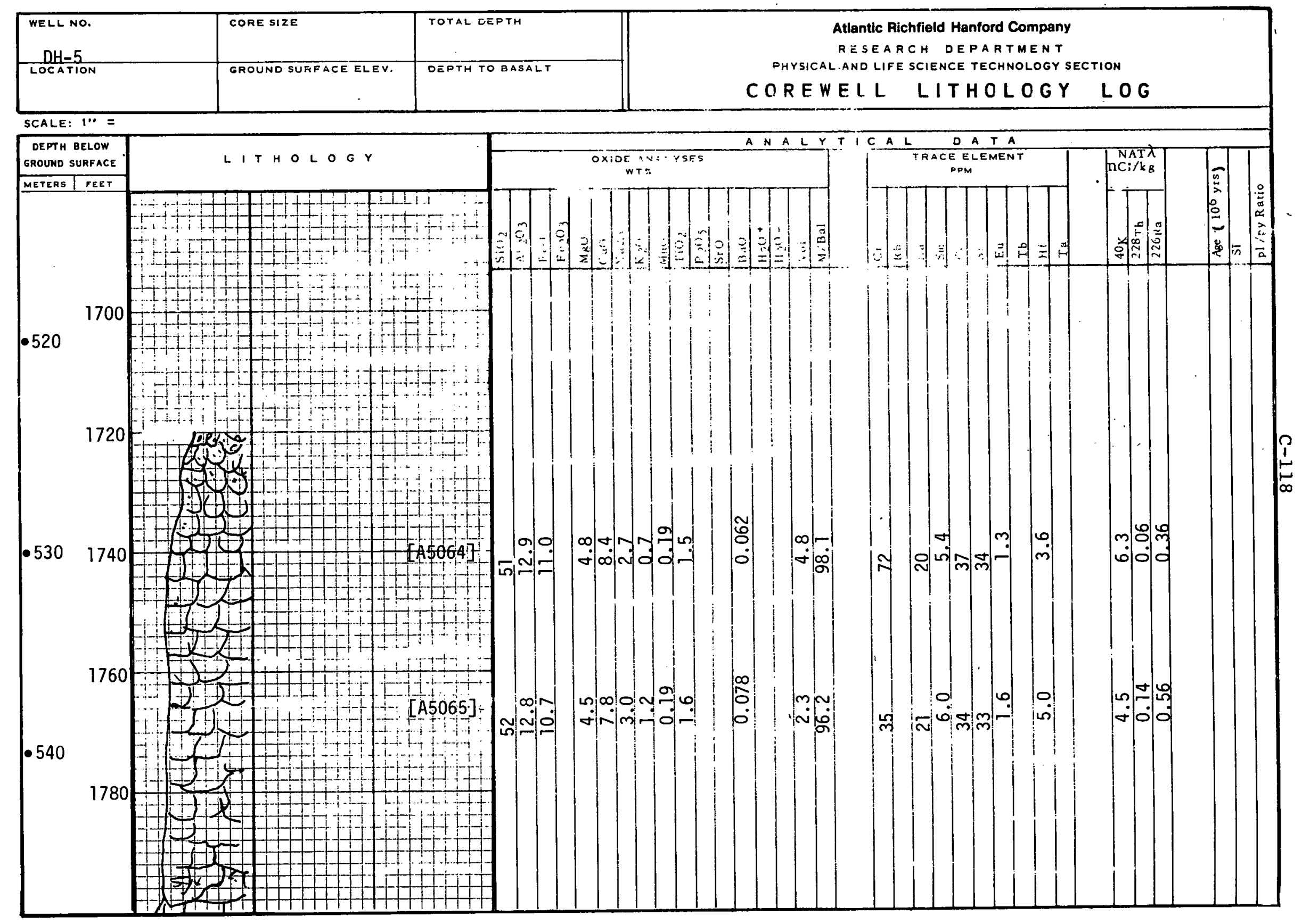




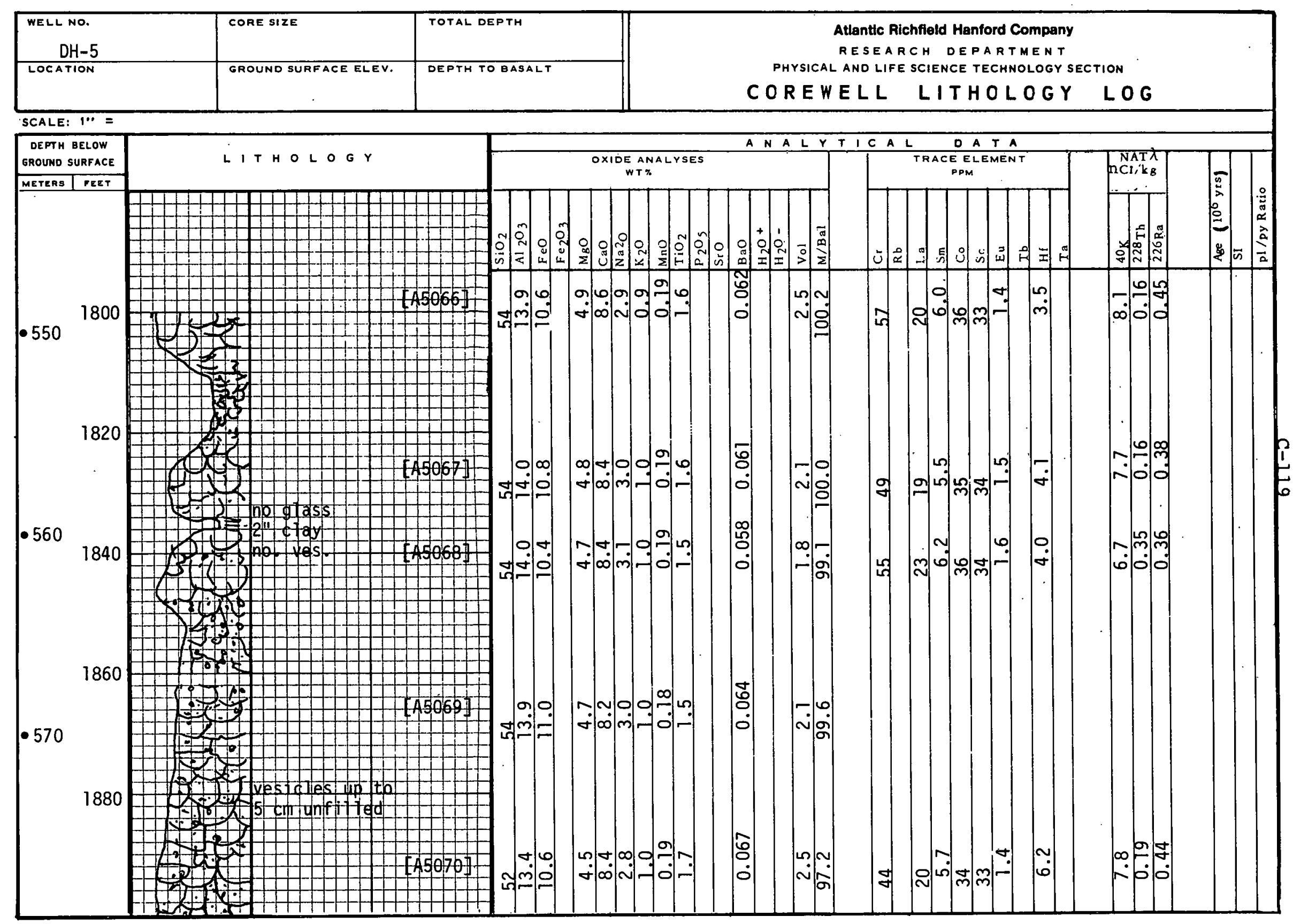




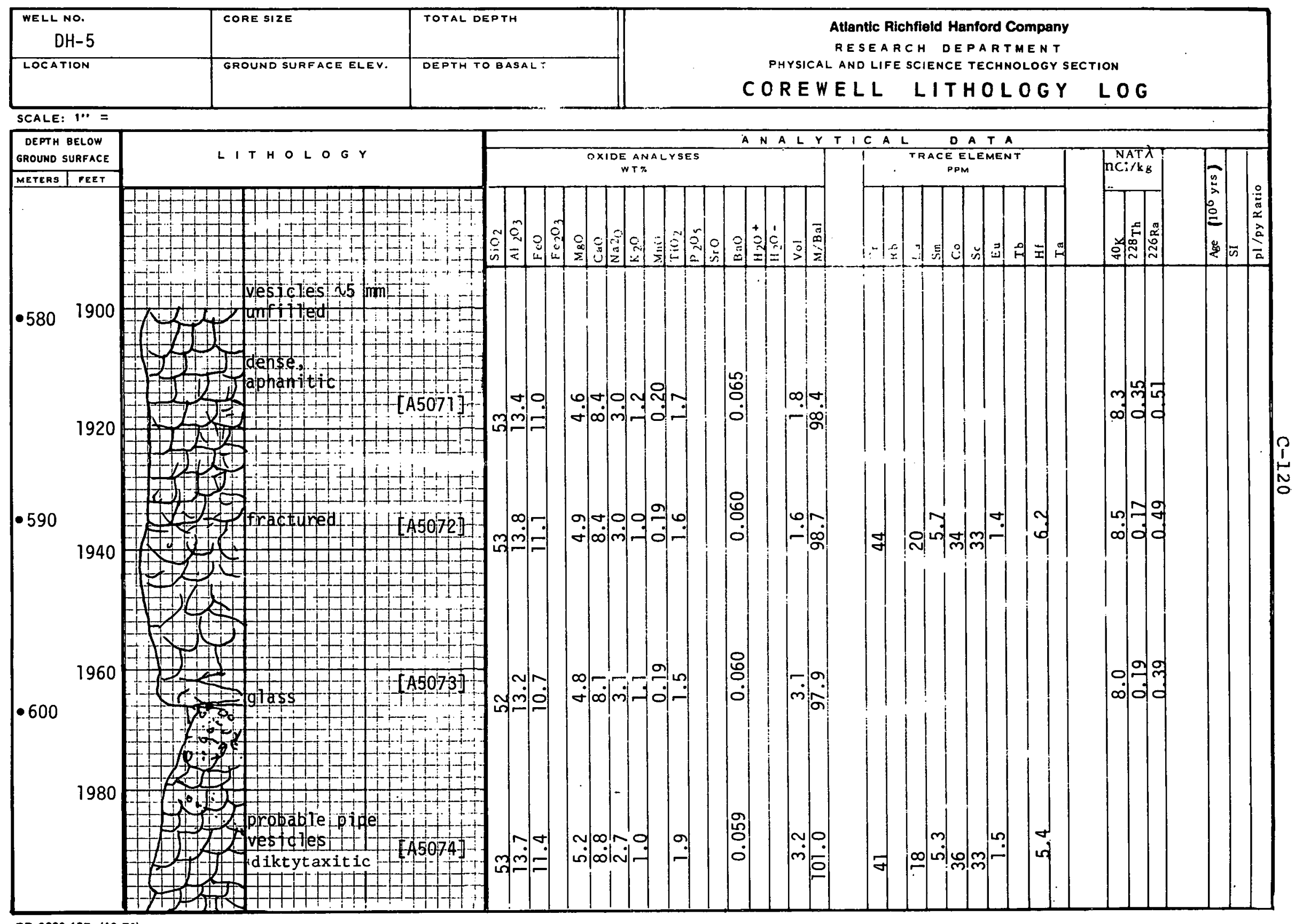

BD-6000-107 (12-74) 


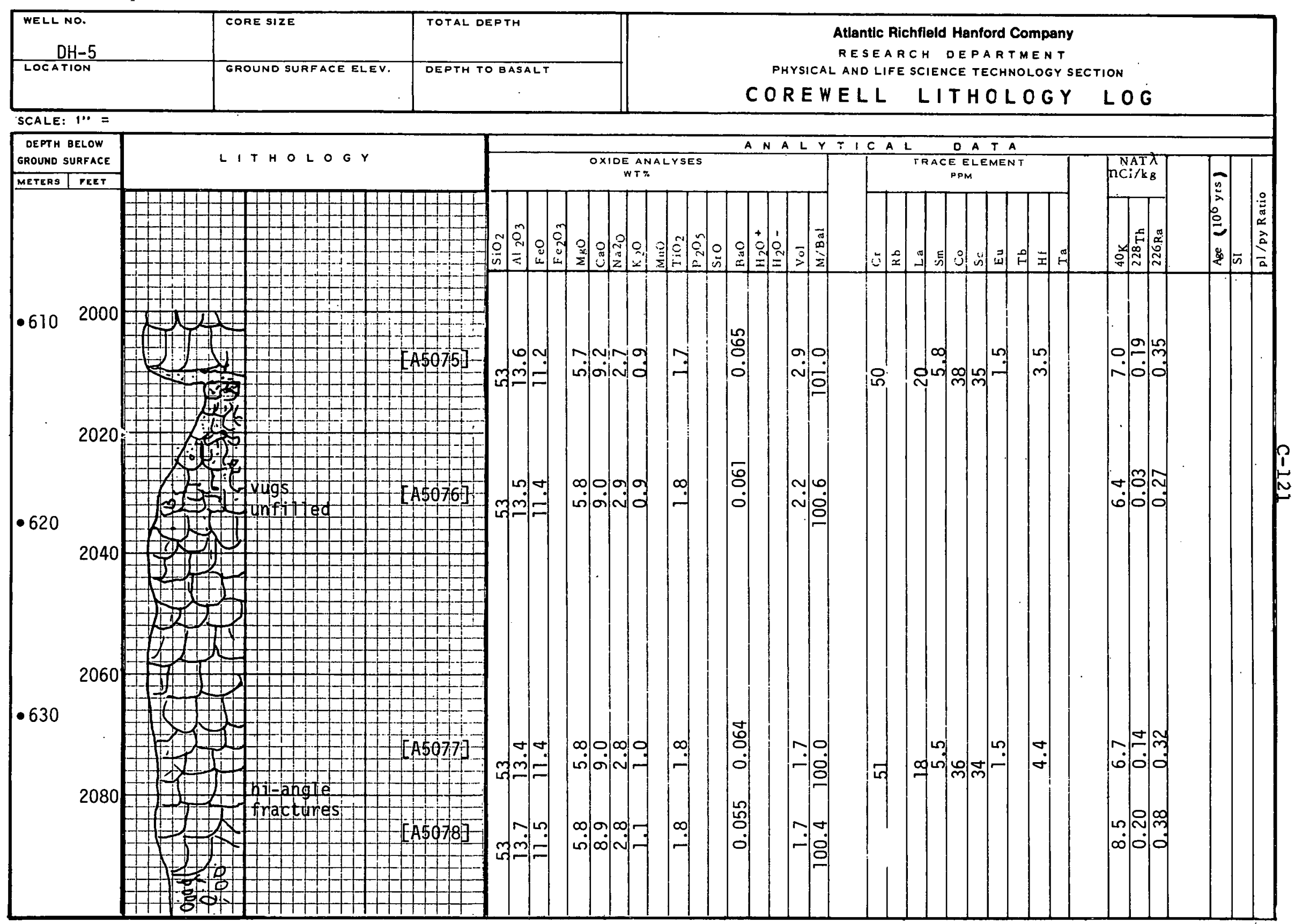




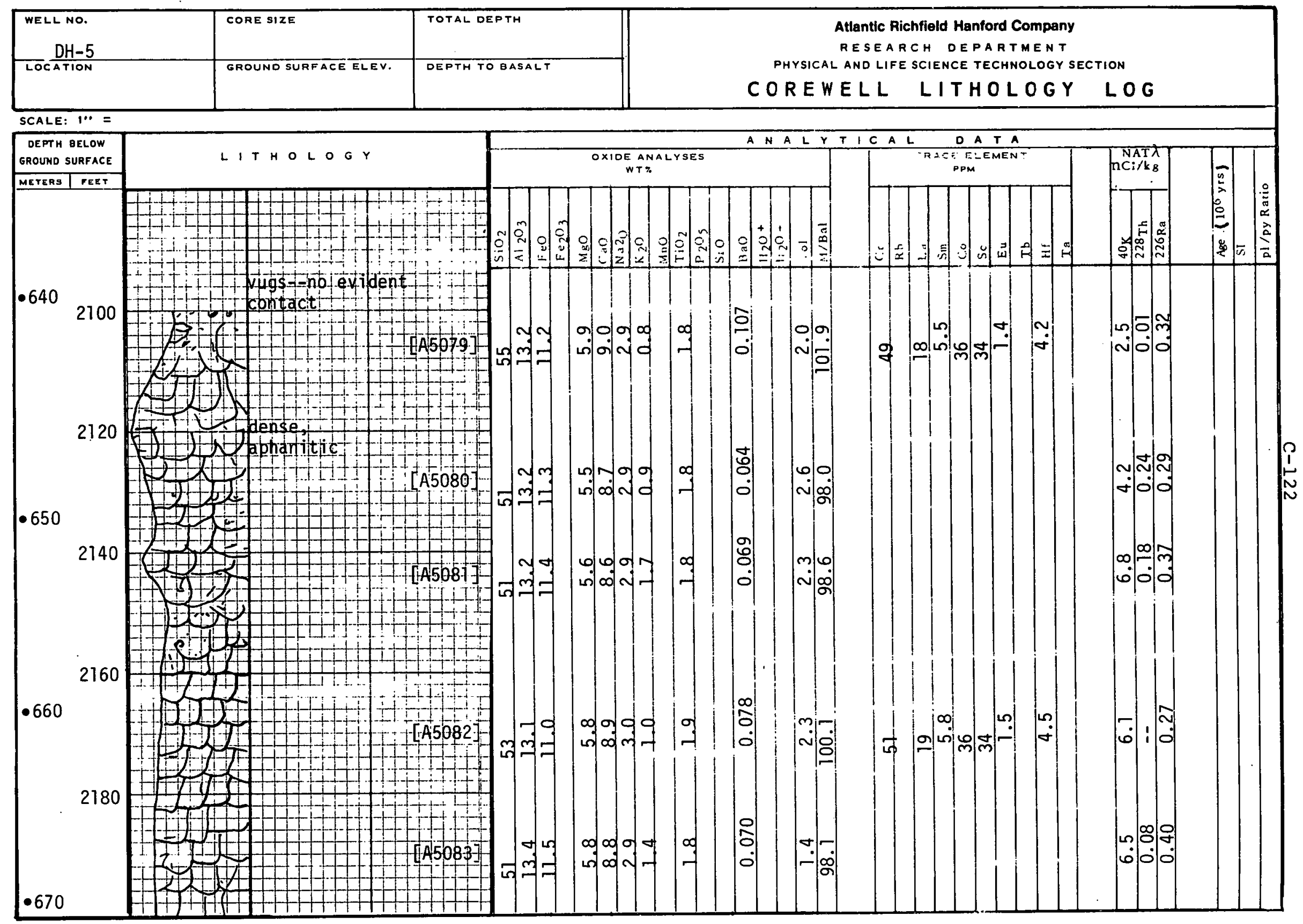

80-6000-107 (12-74) 


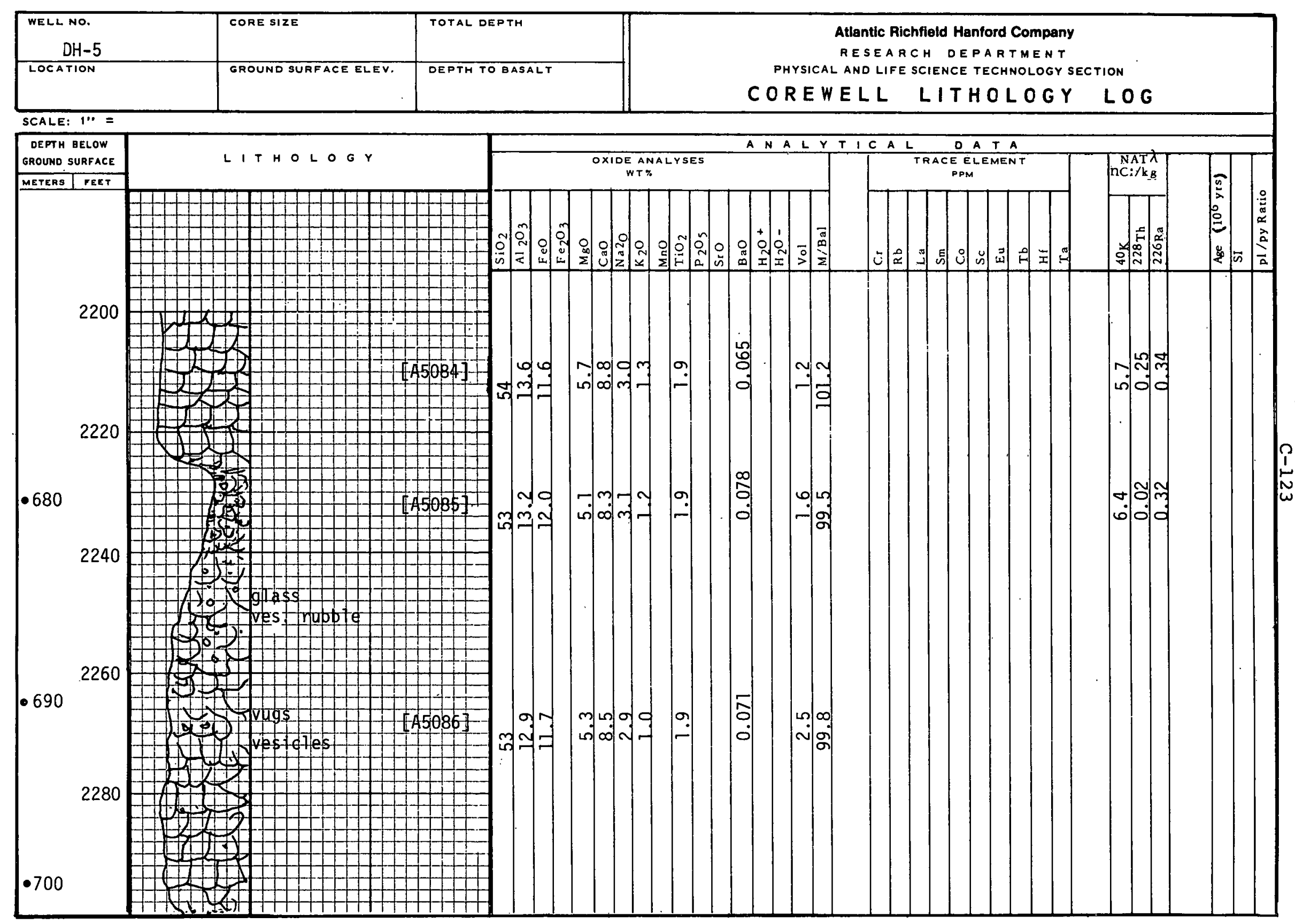




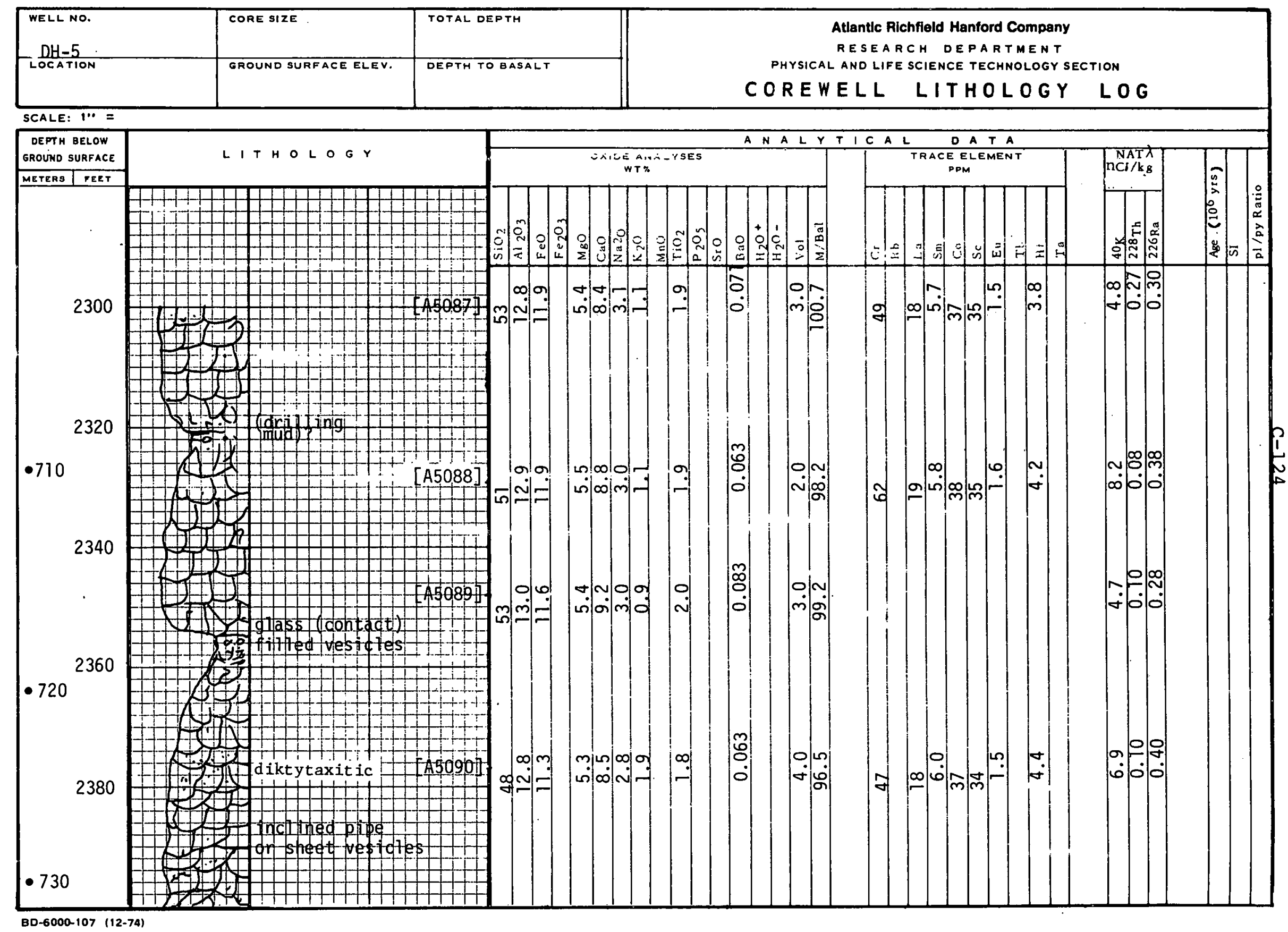




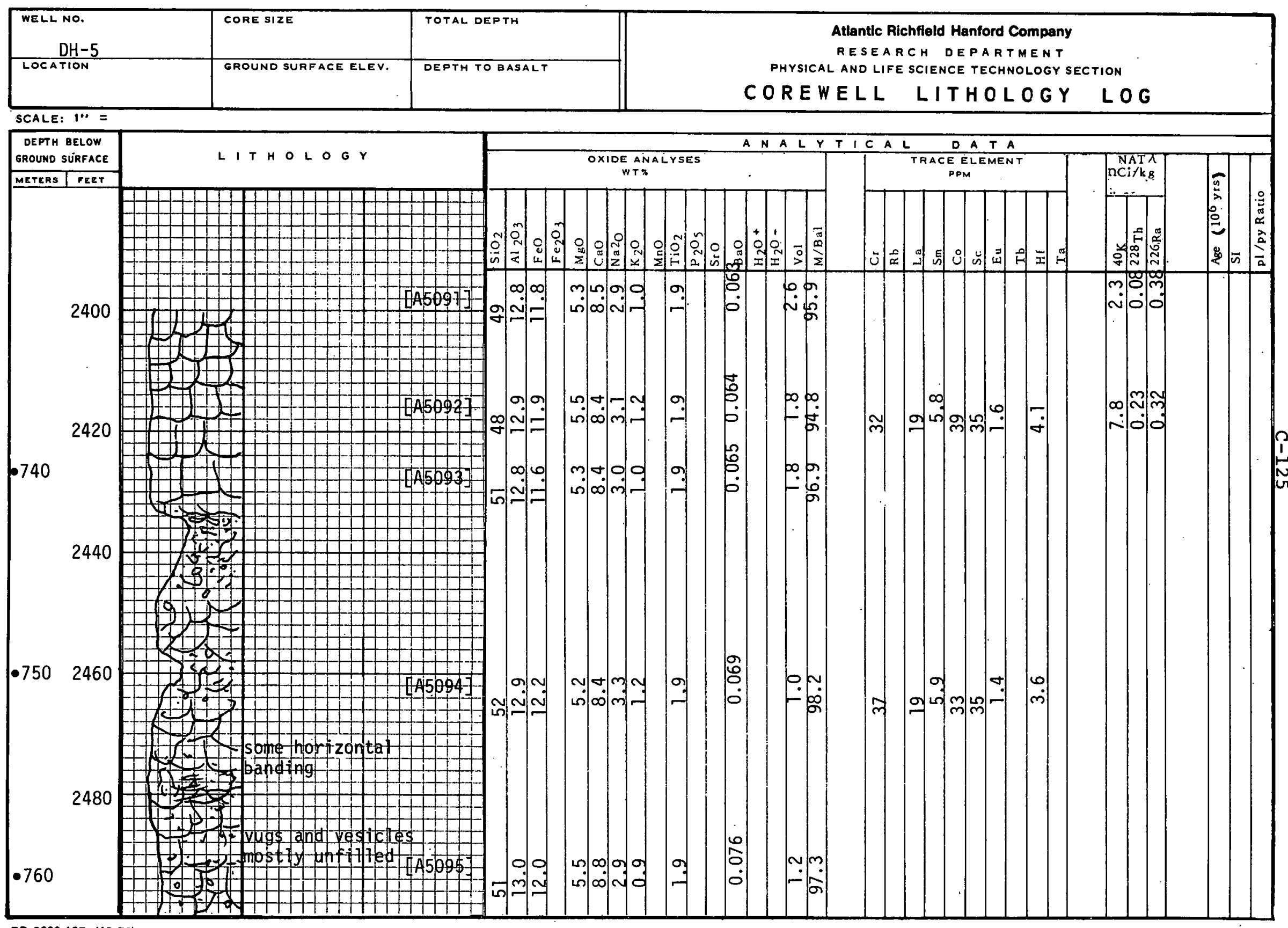

80-6000-107 (12-74) 


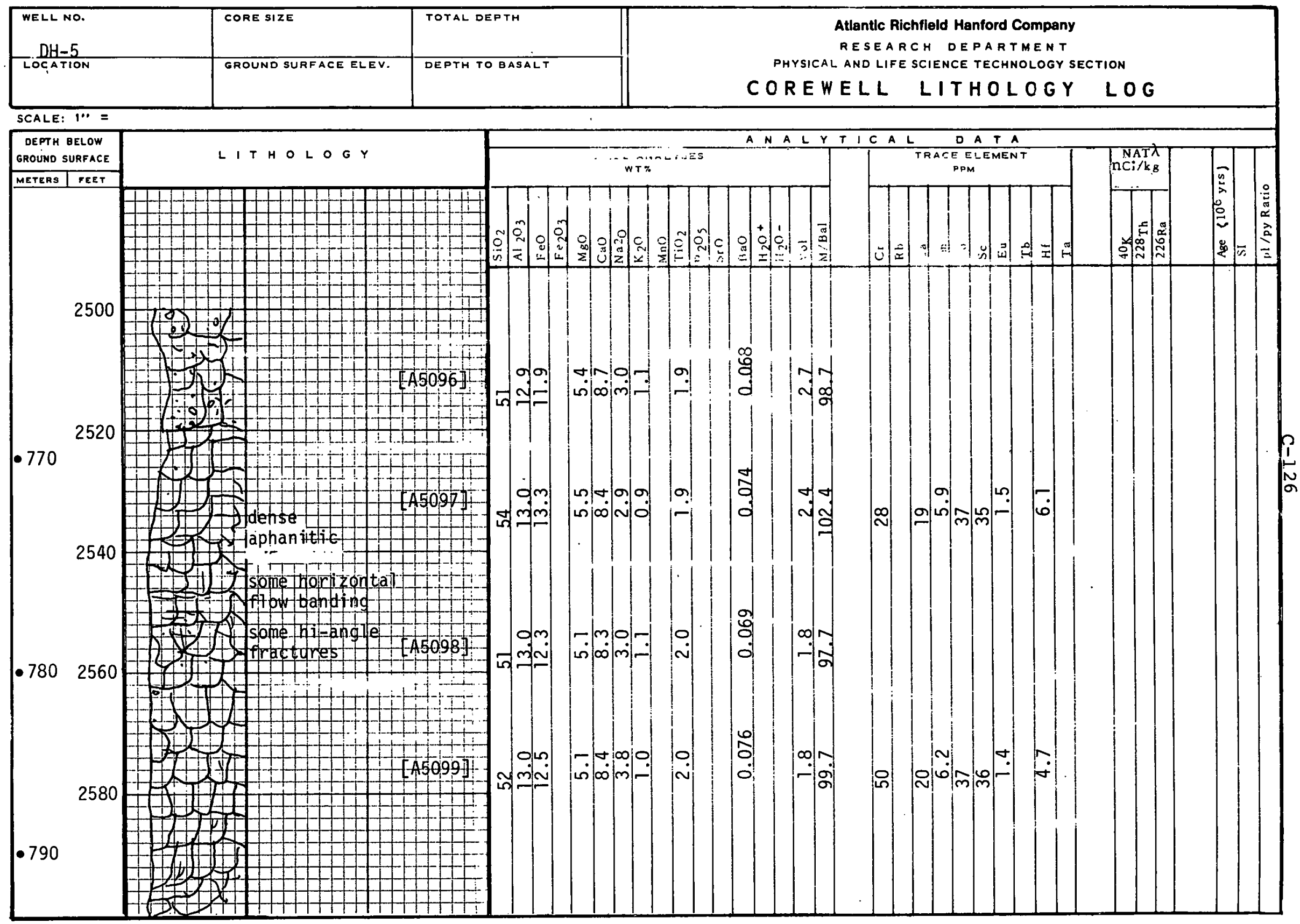

BD-6000-107 (12-74) 


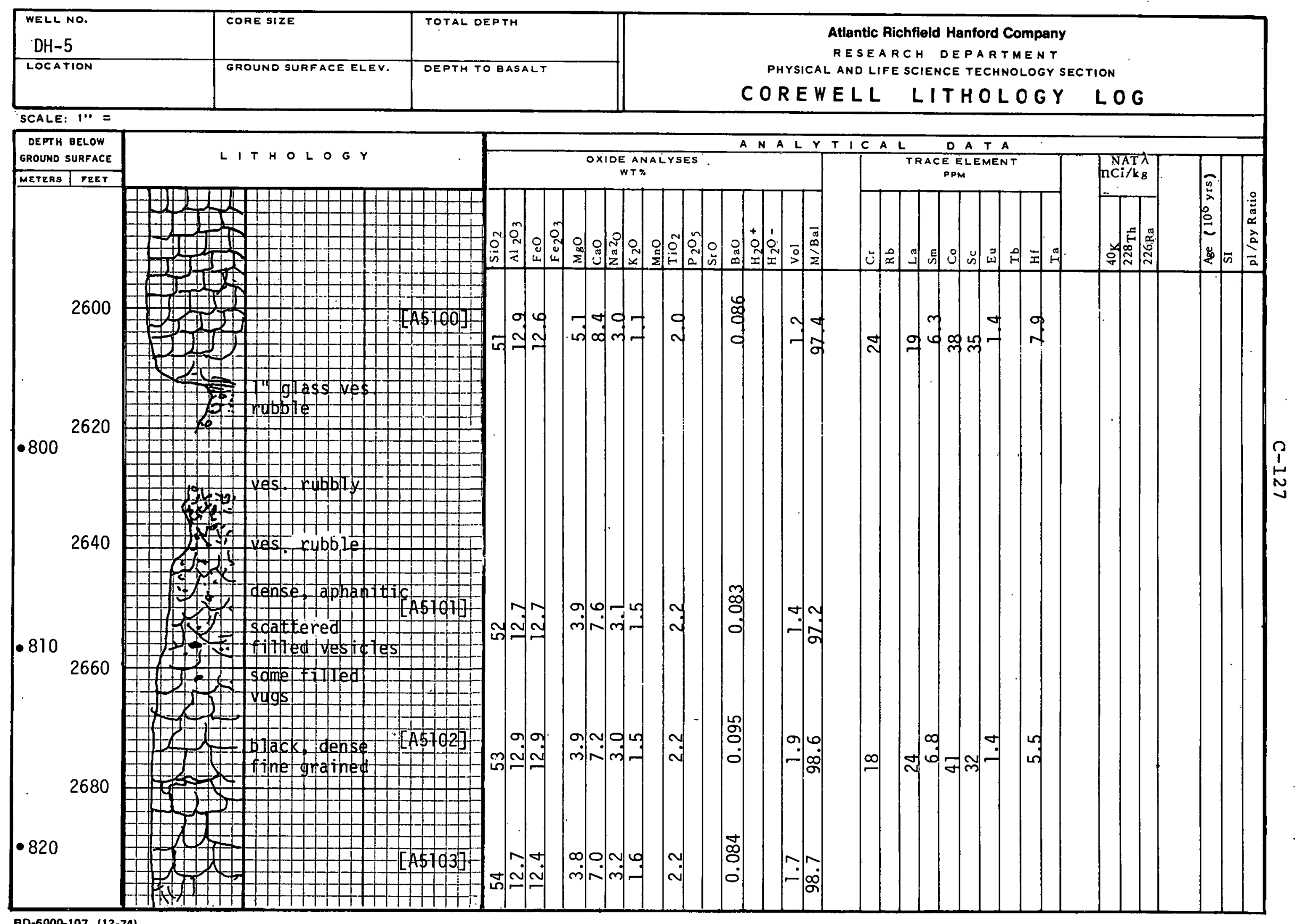




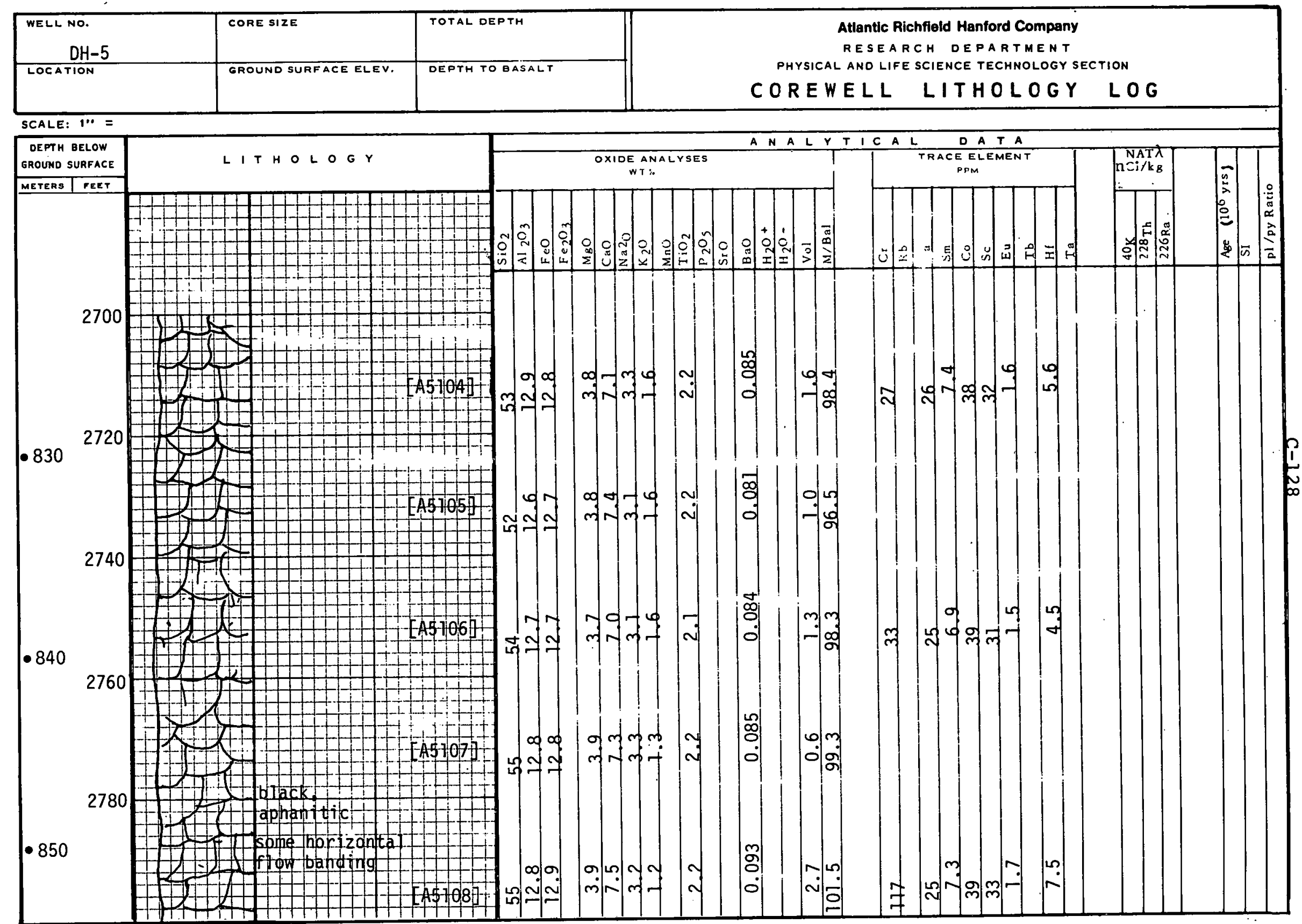




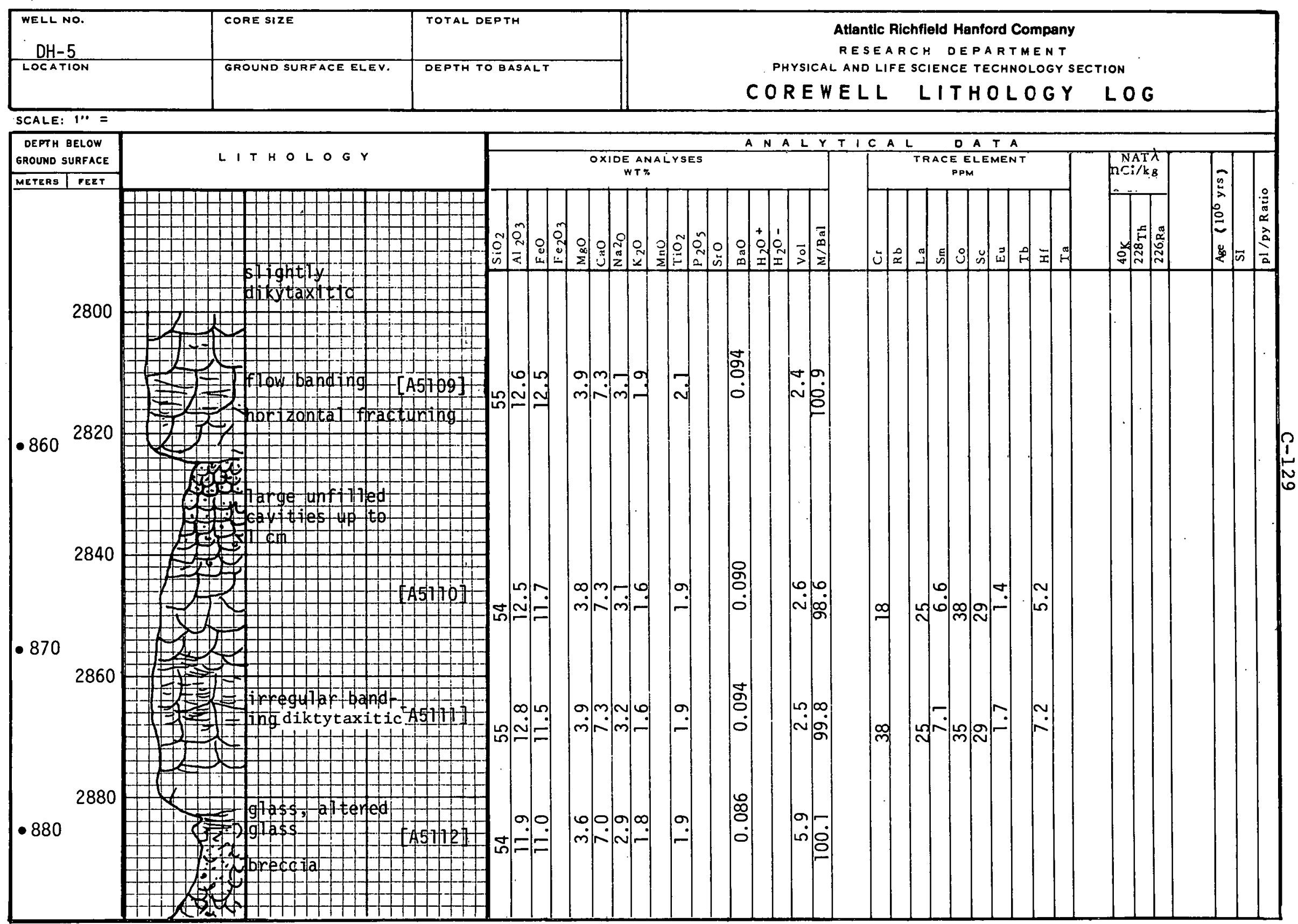

BD-6000-107 (12-74) 


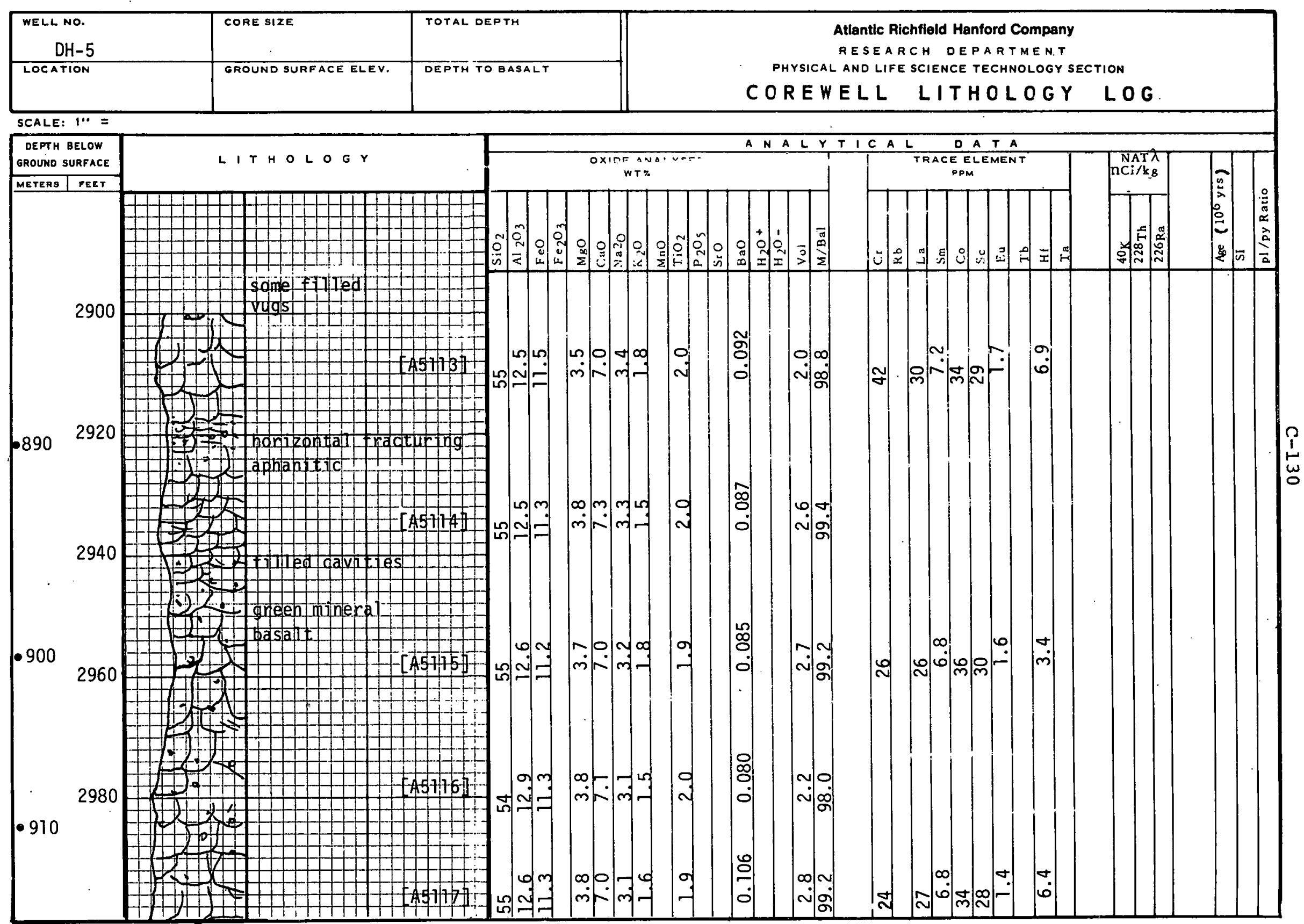




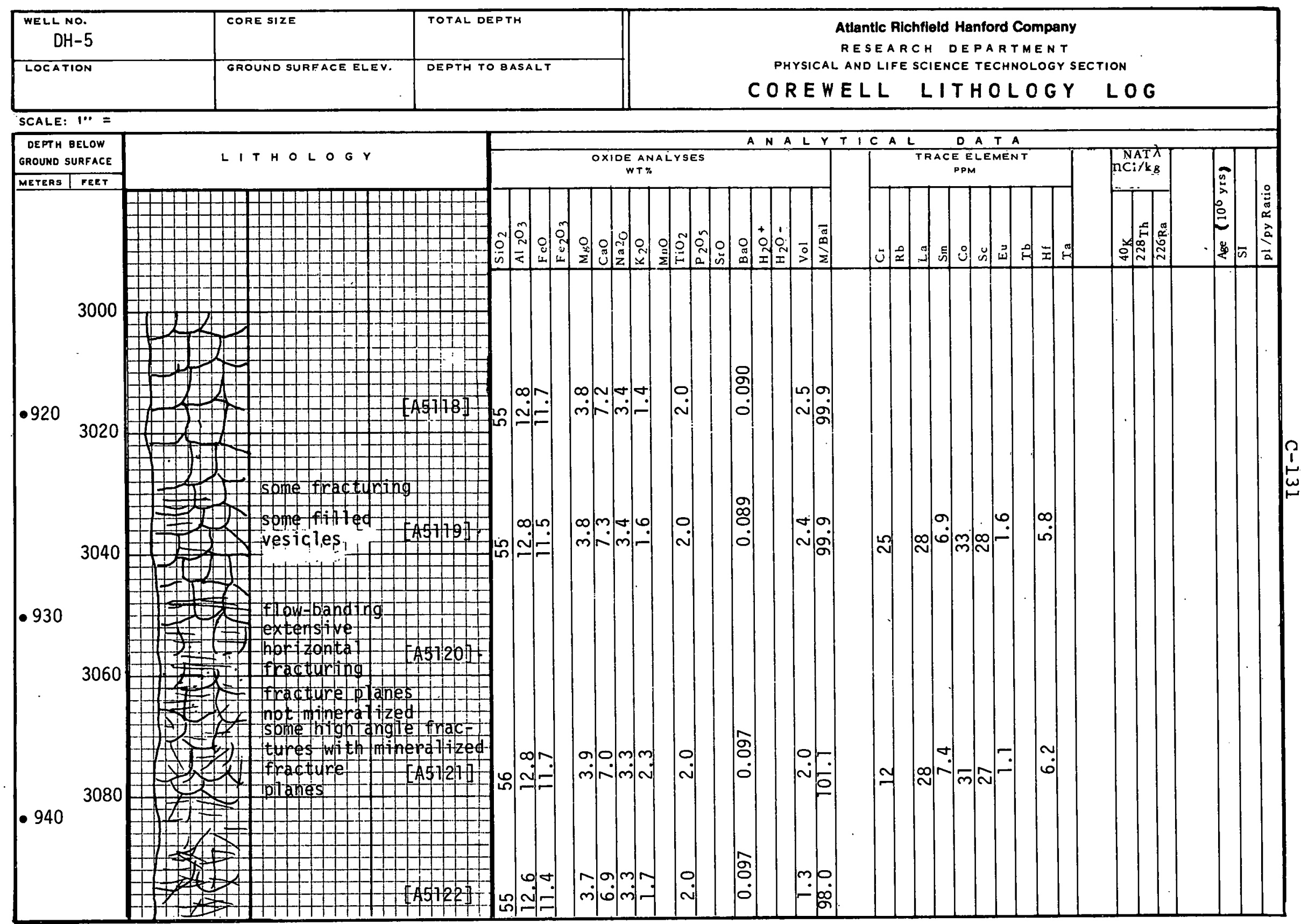




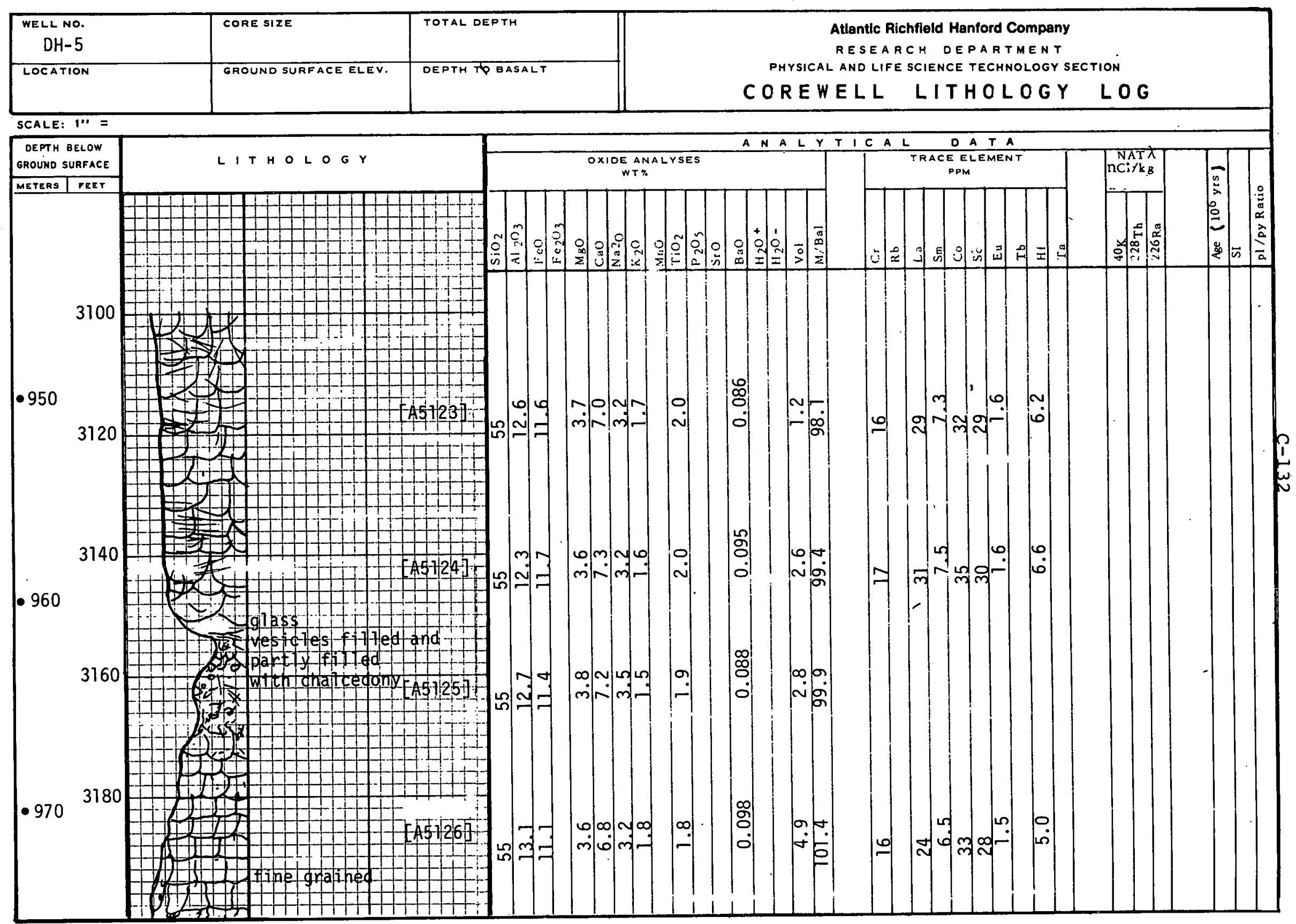




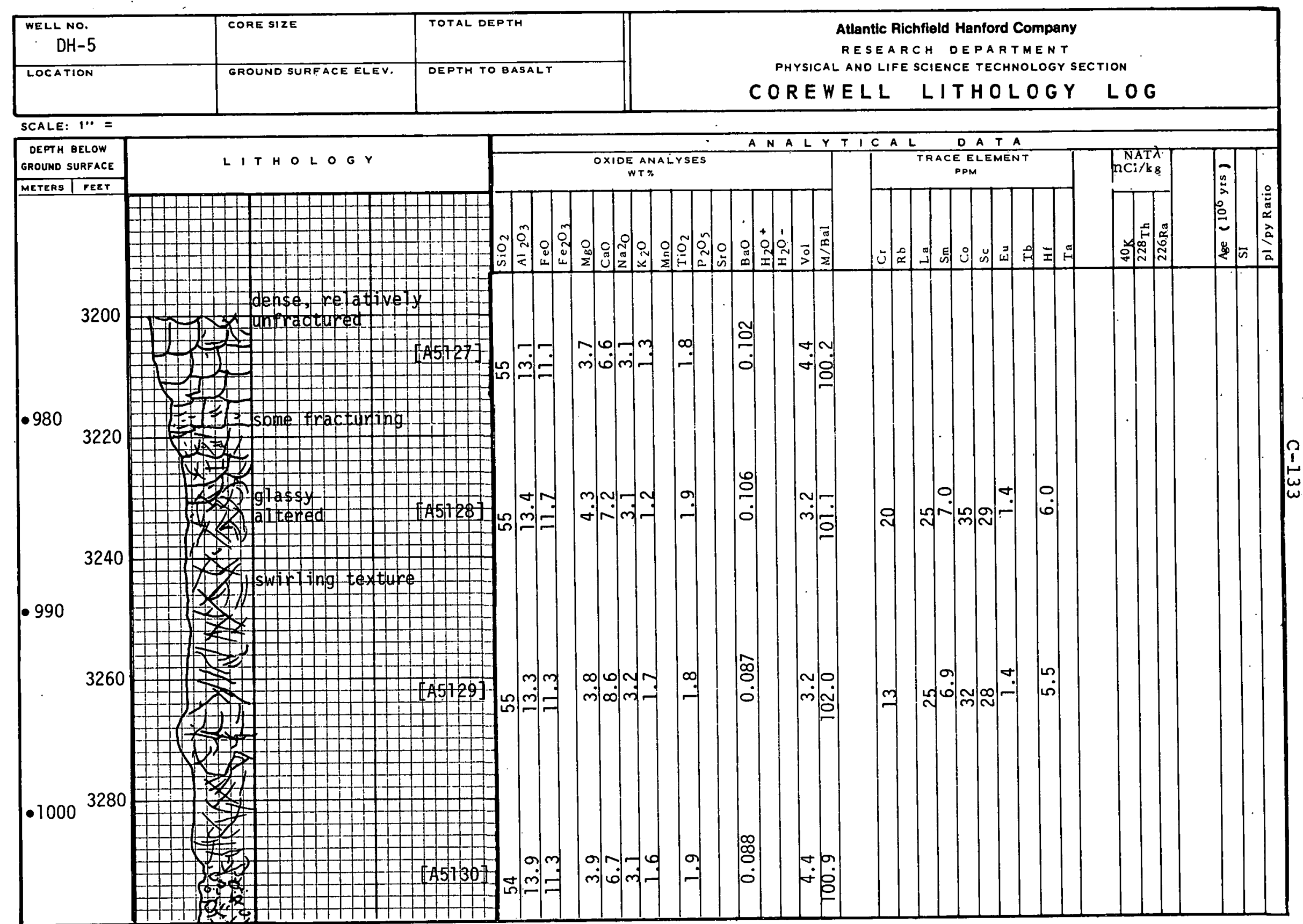




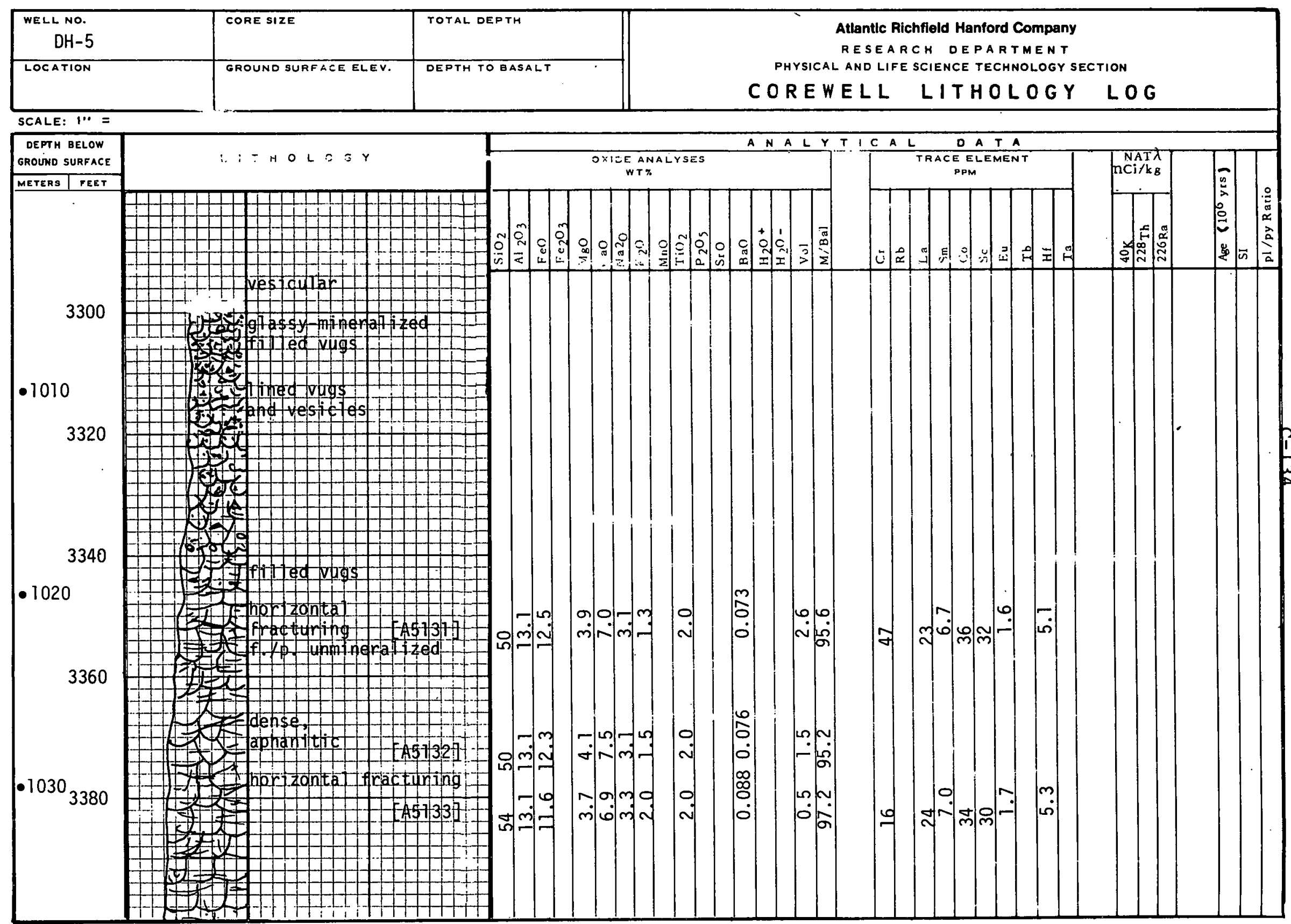

BD-6000-107 (12-74) 


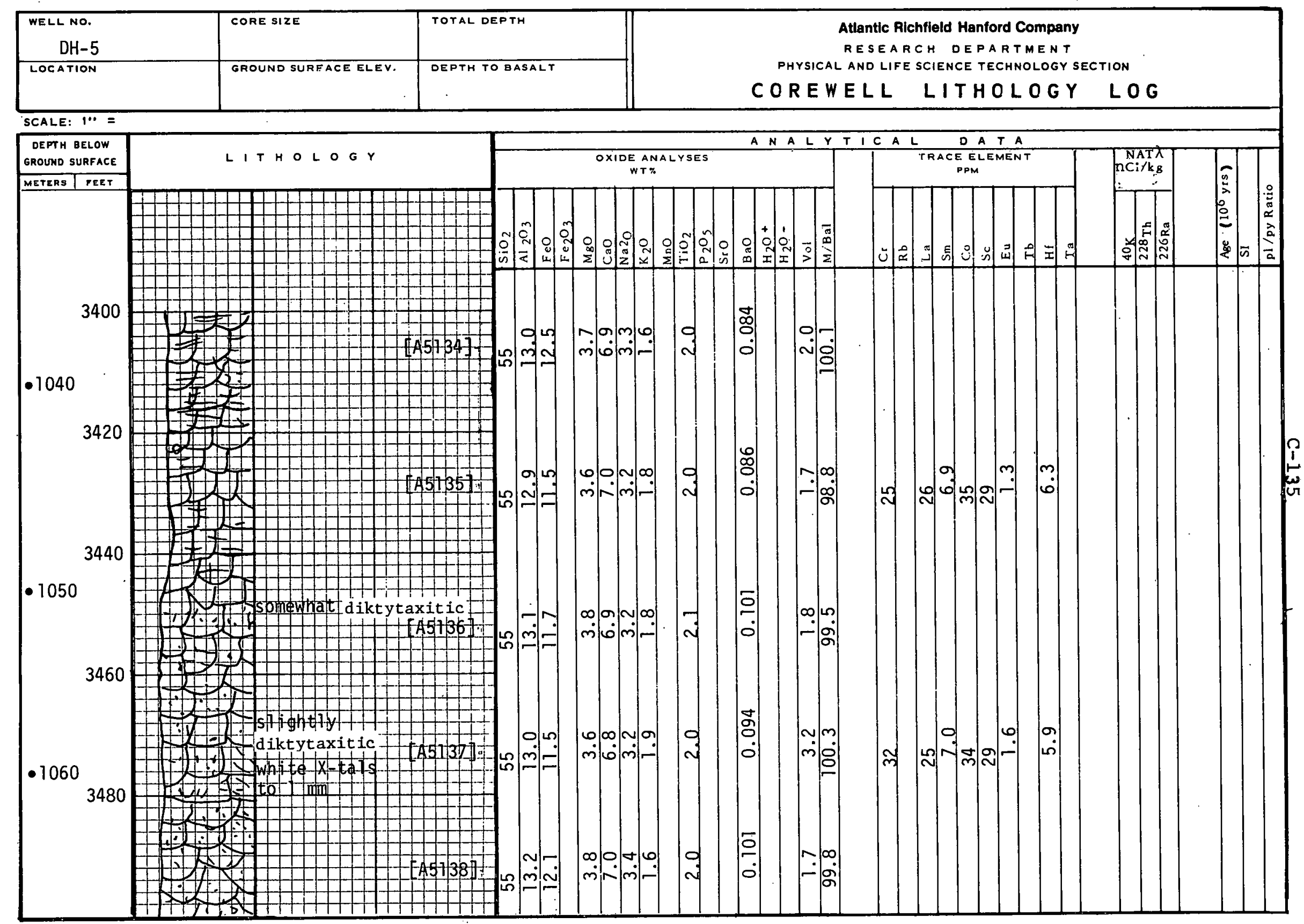

BD-6000-107 (12-74) 


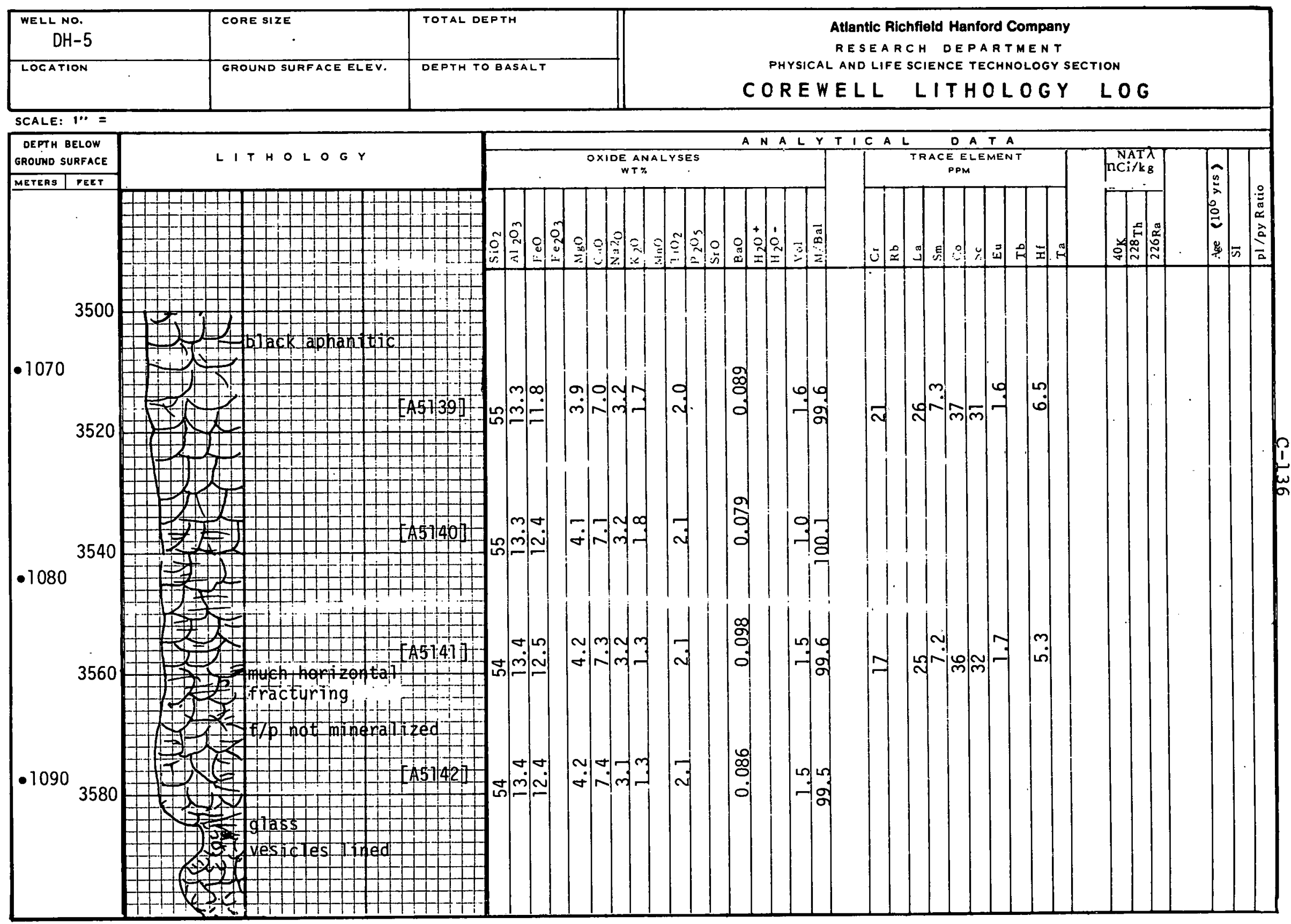

BD-6000-107 (12-74) 


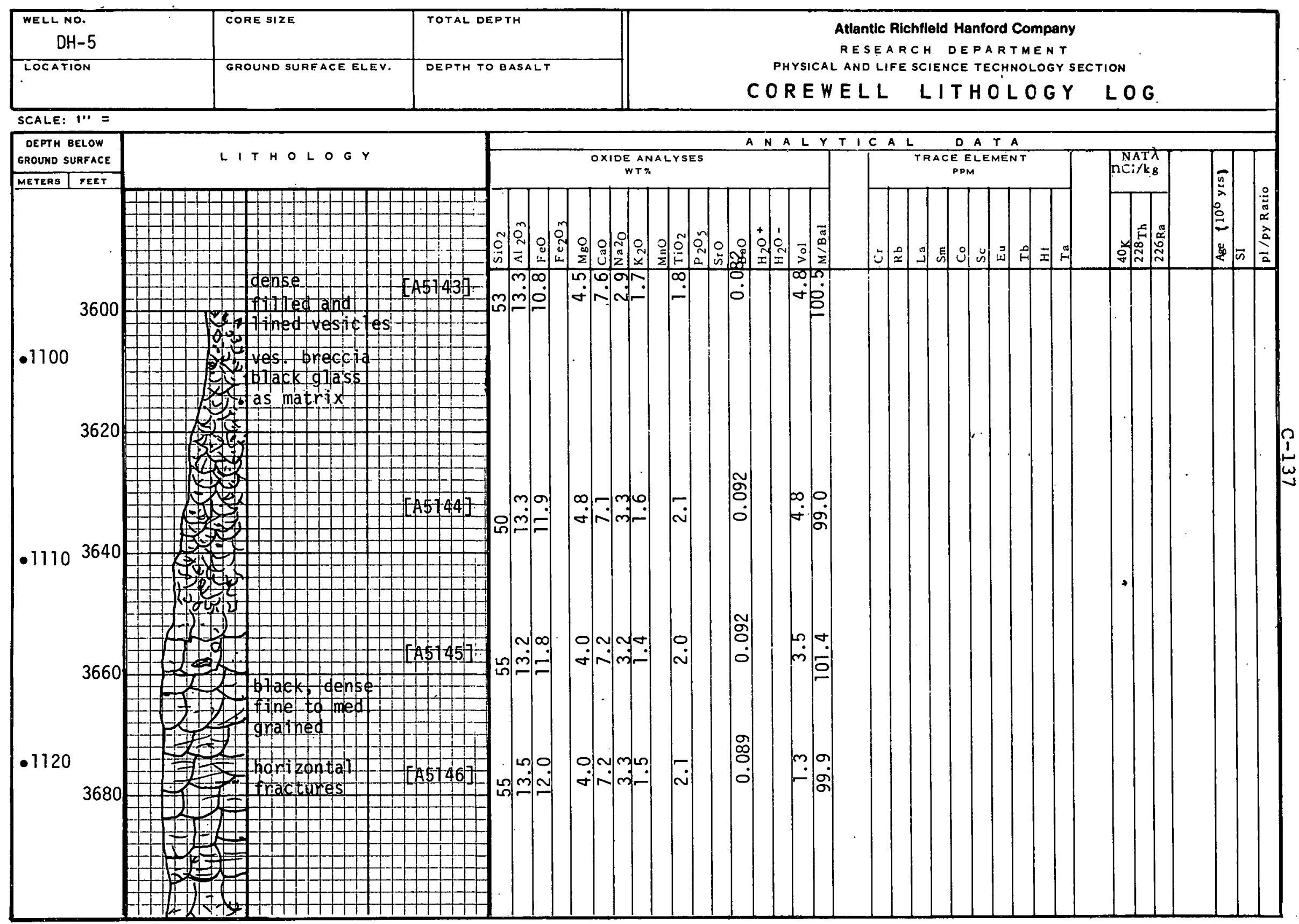




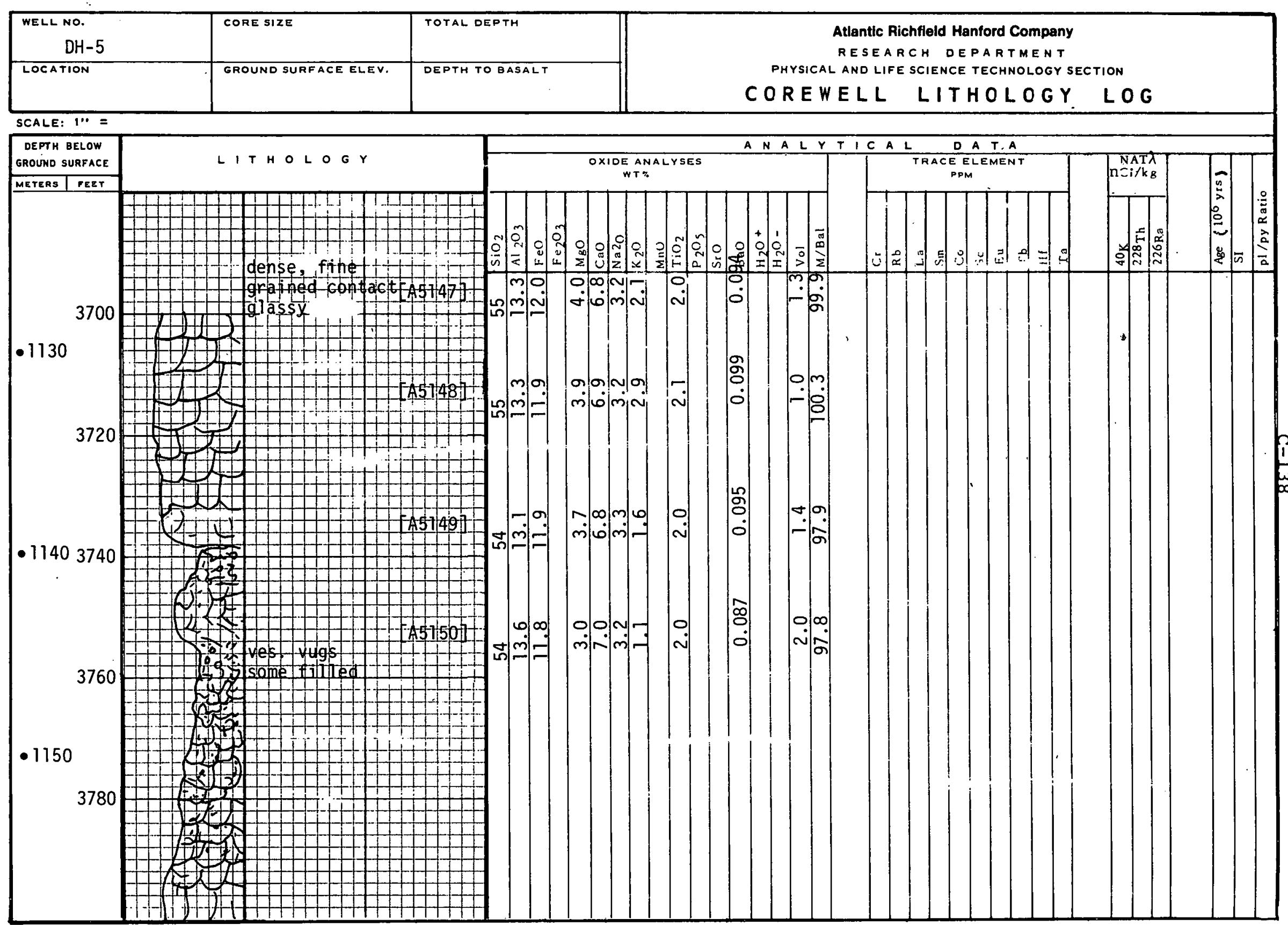




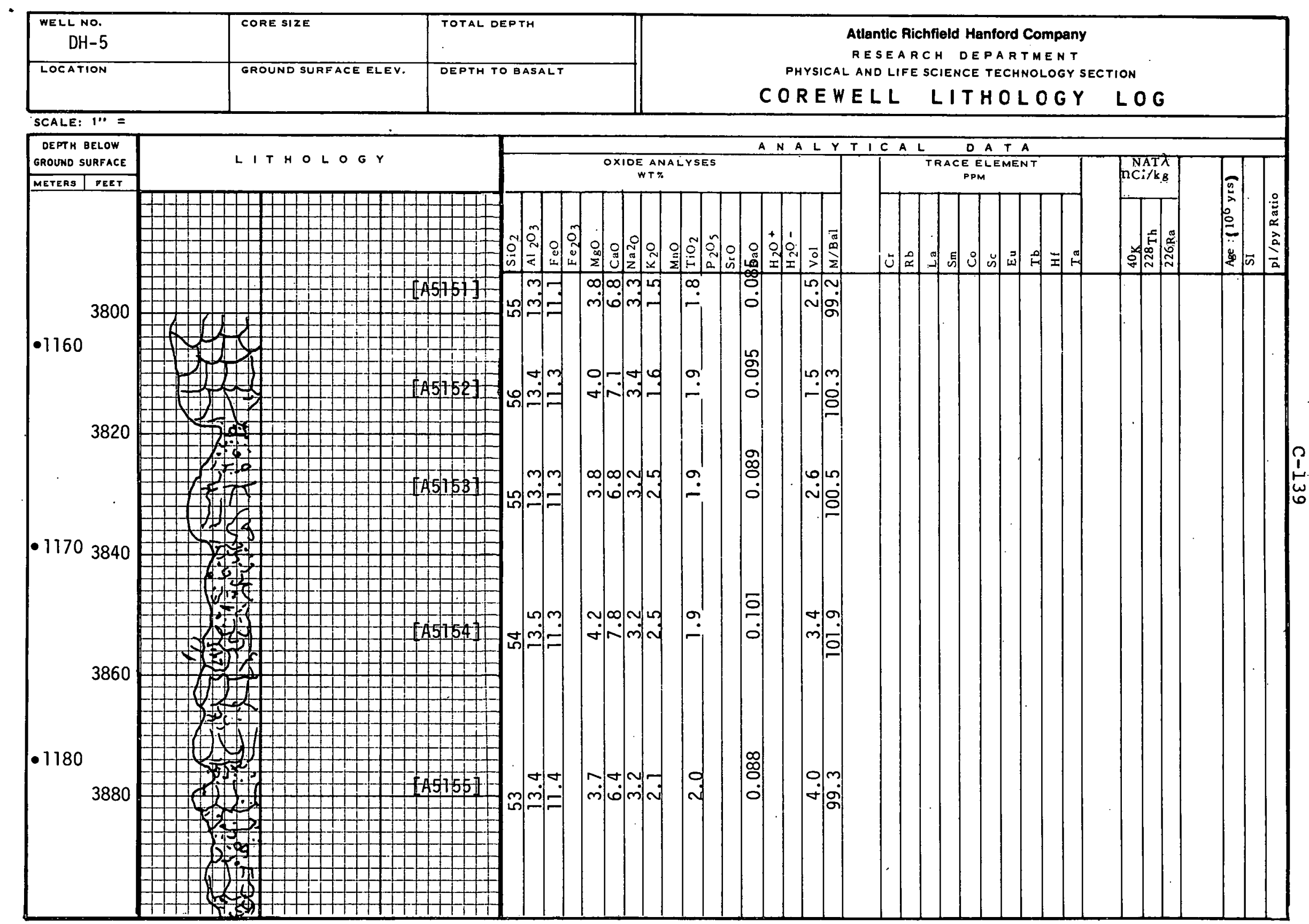

BD-6000-107 (12-74) 


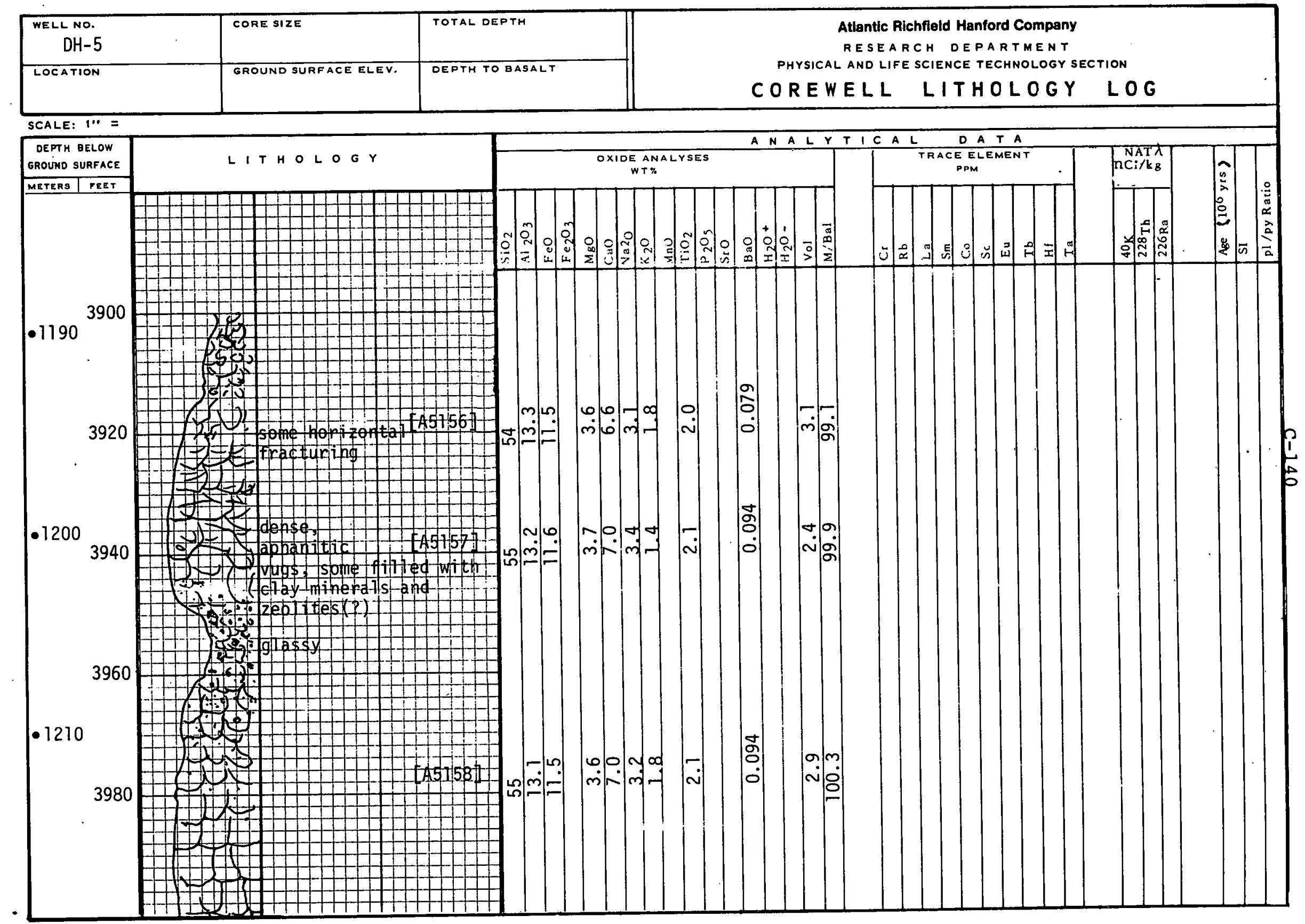

8D-6000-107 (12-74) 


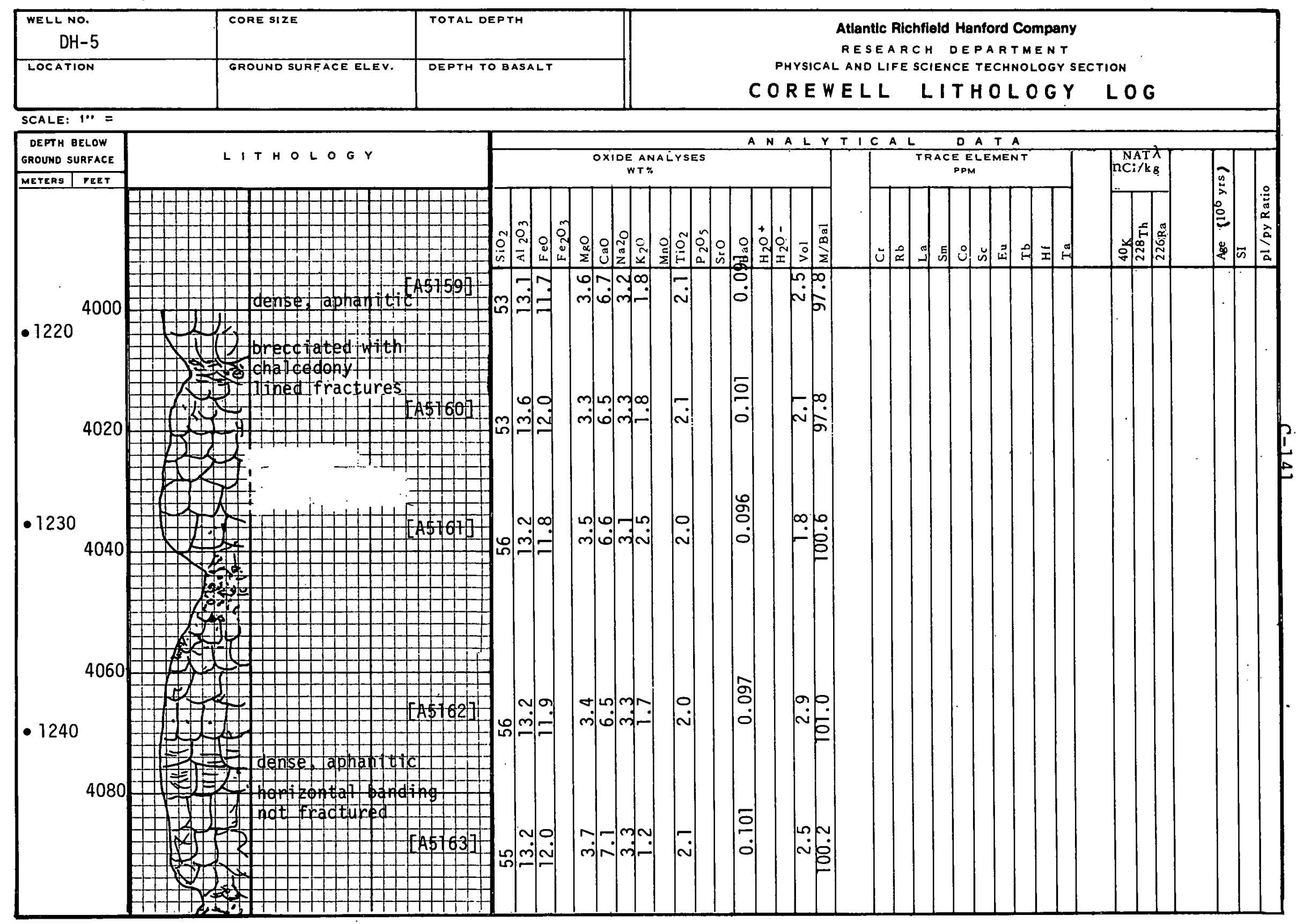

80-6000-107 (12-74) 


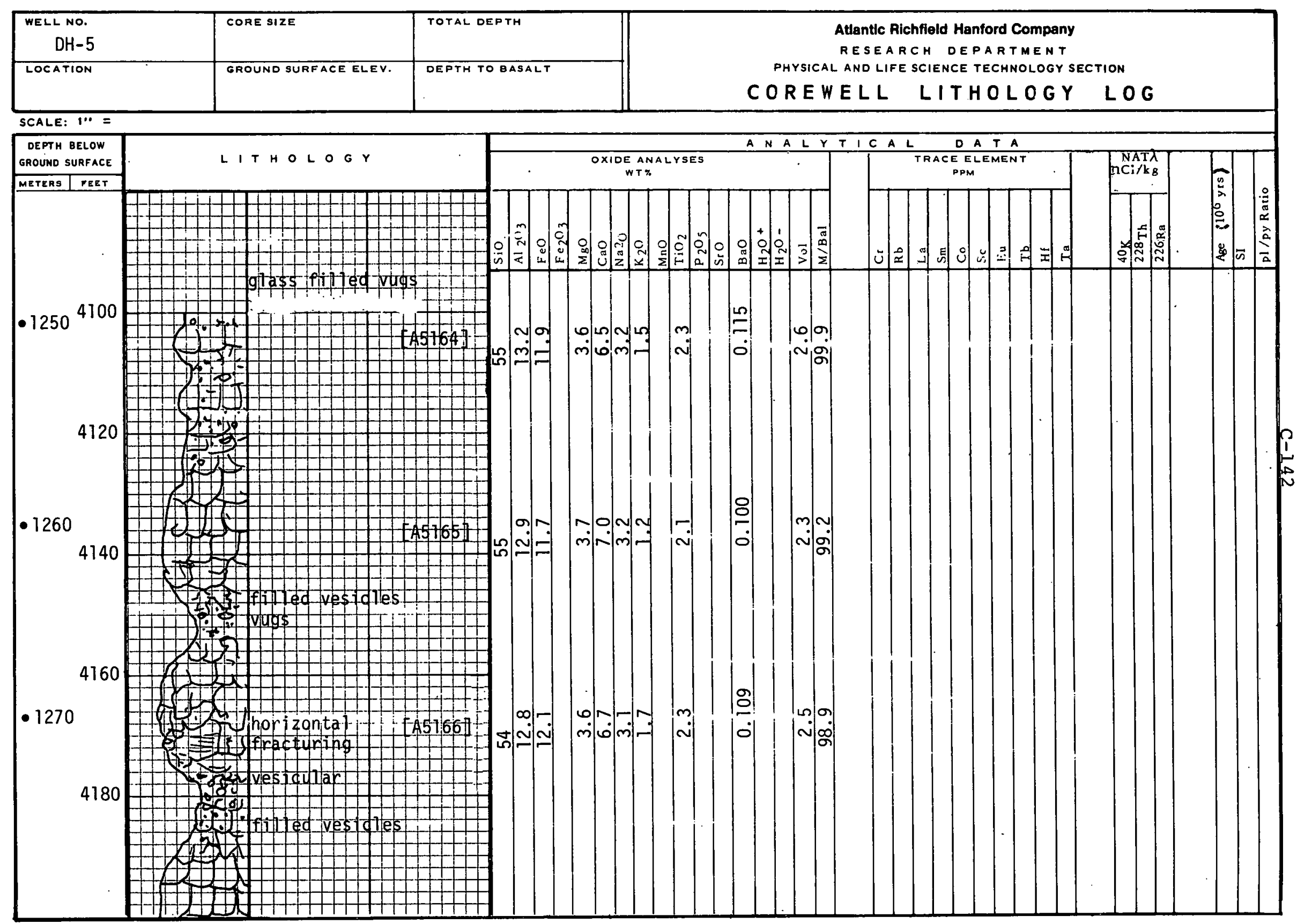




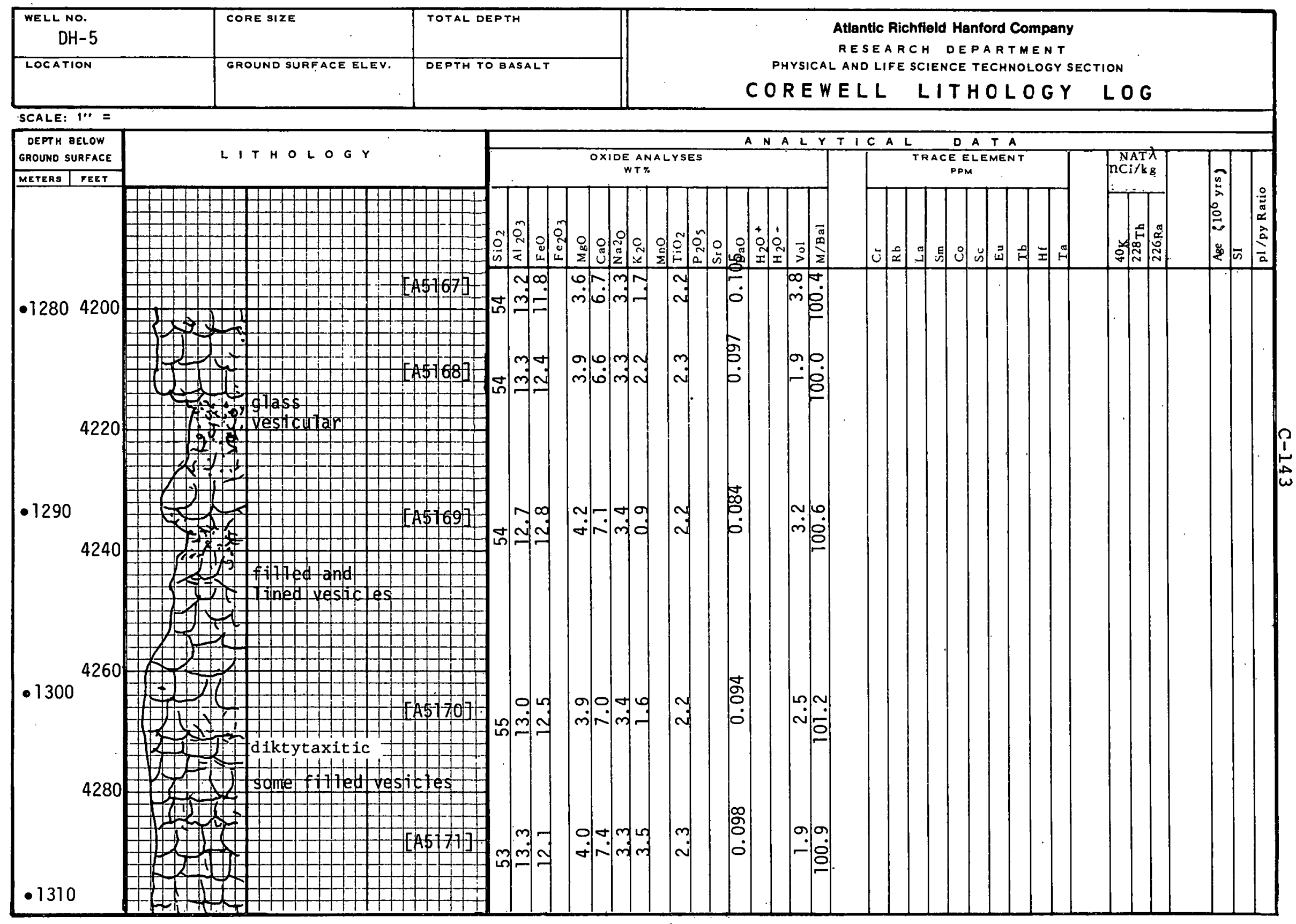

80-6000-107 (12-74) 


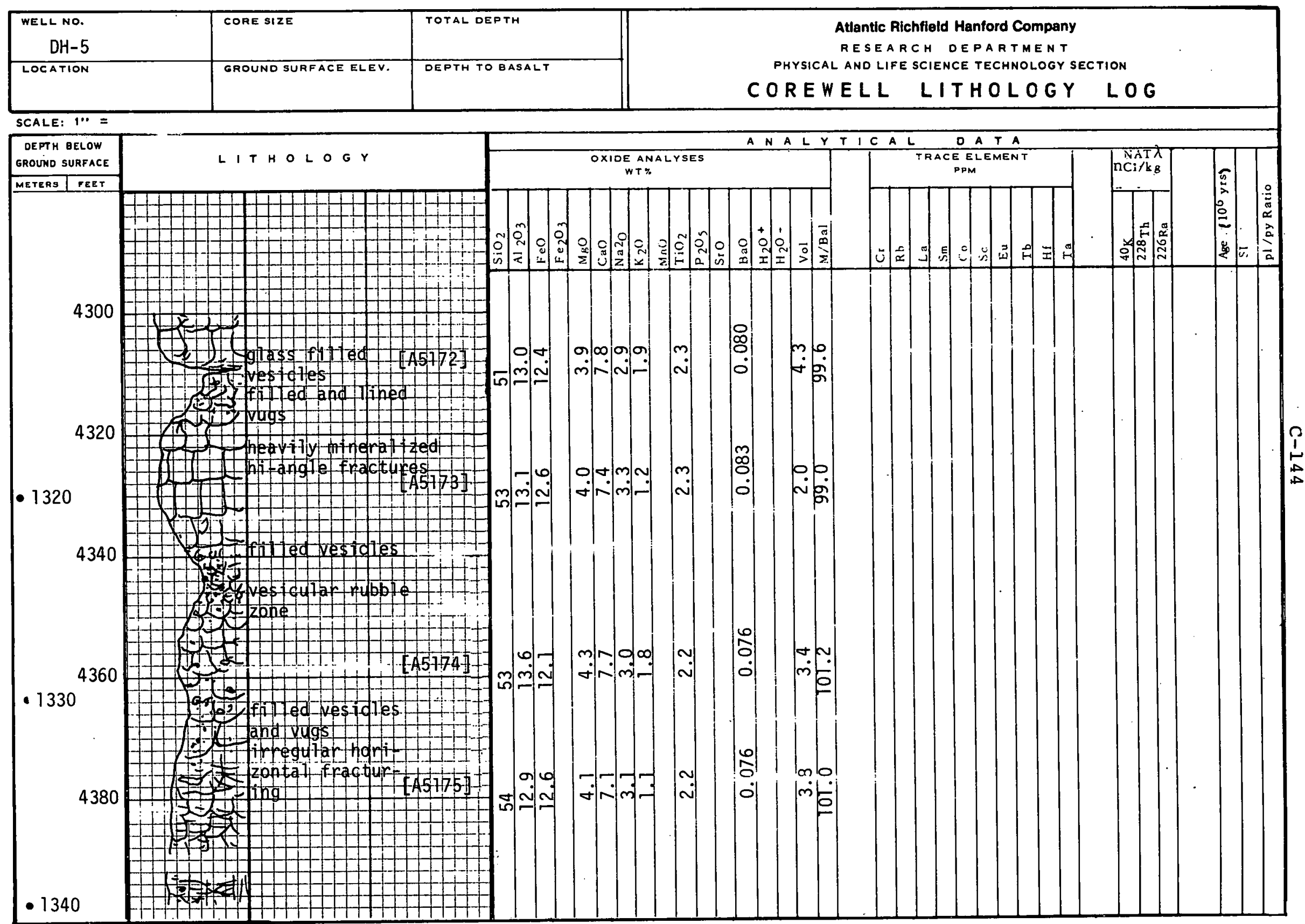




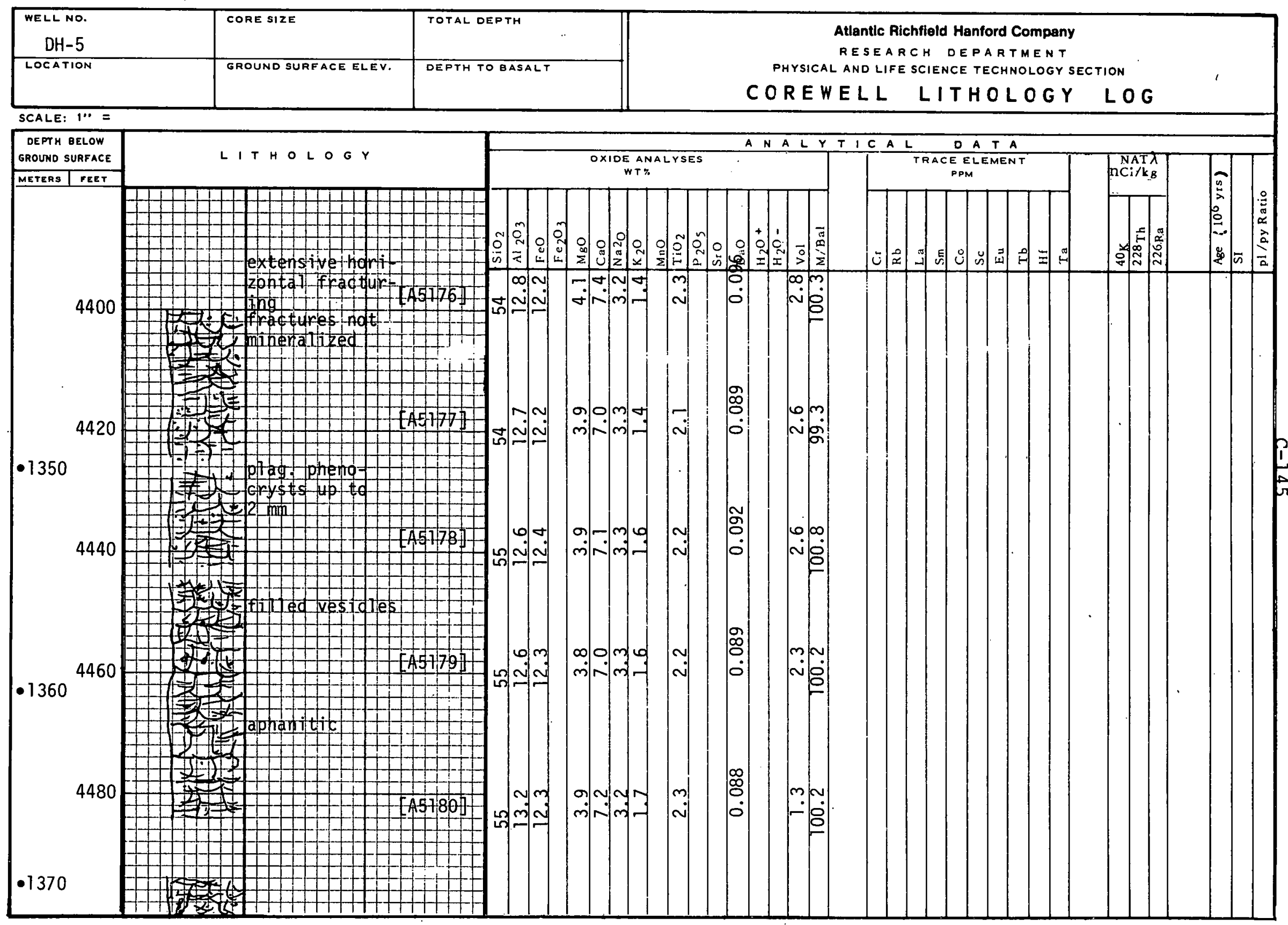




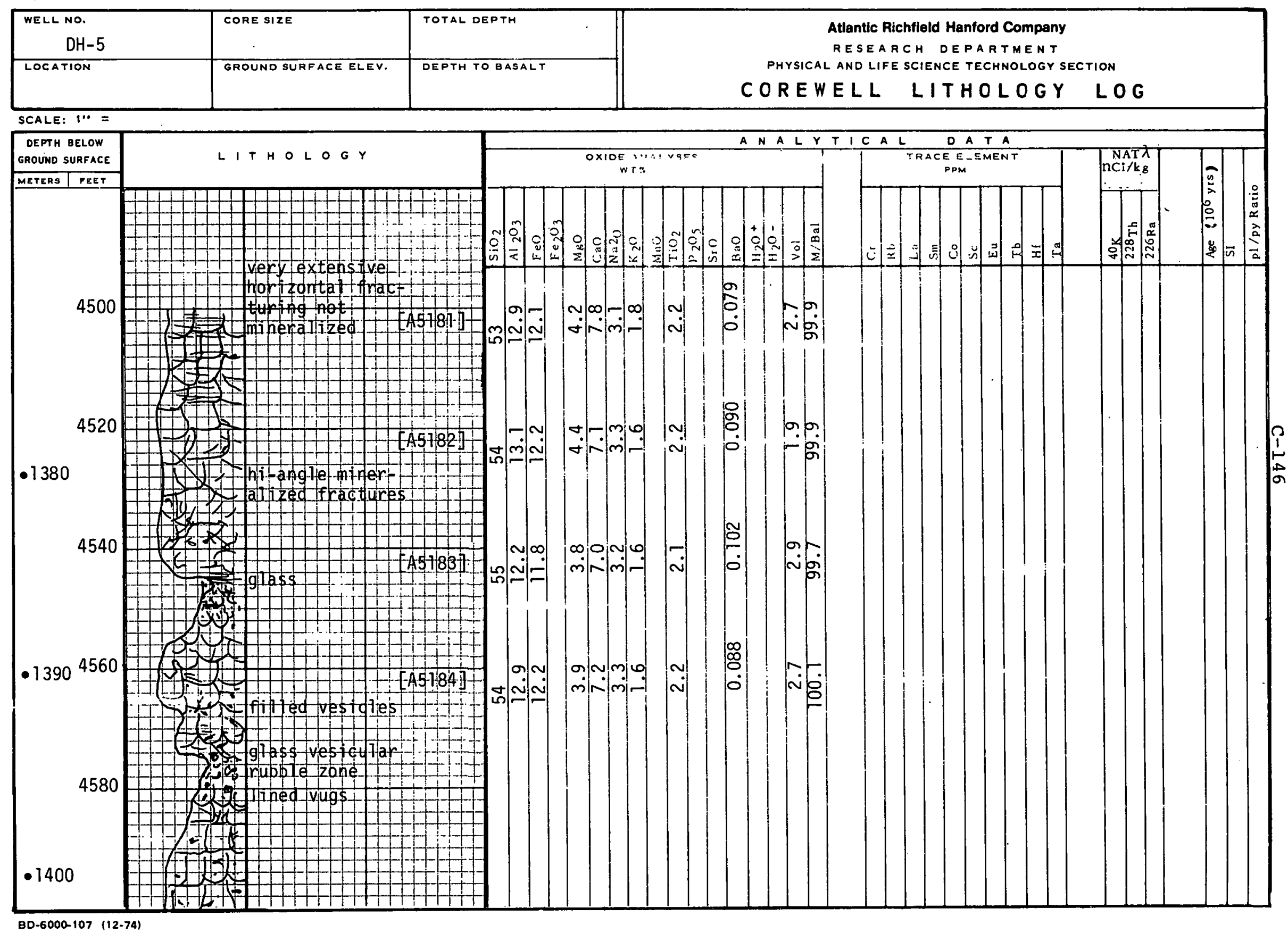


$c^{-}$

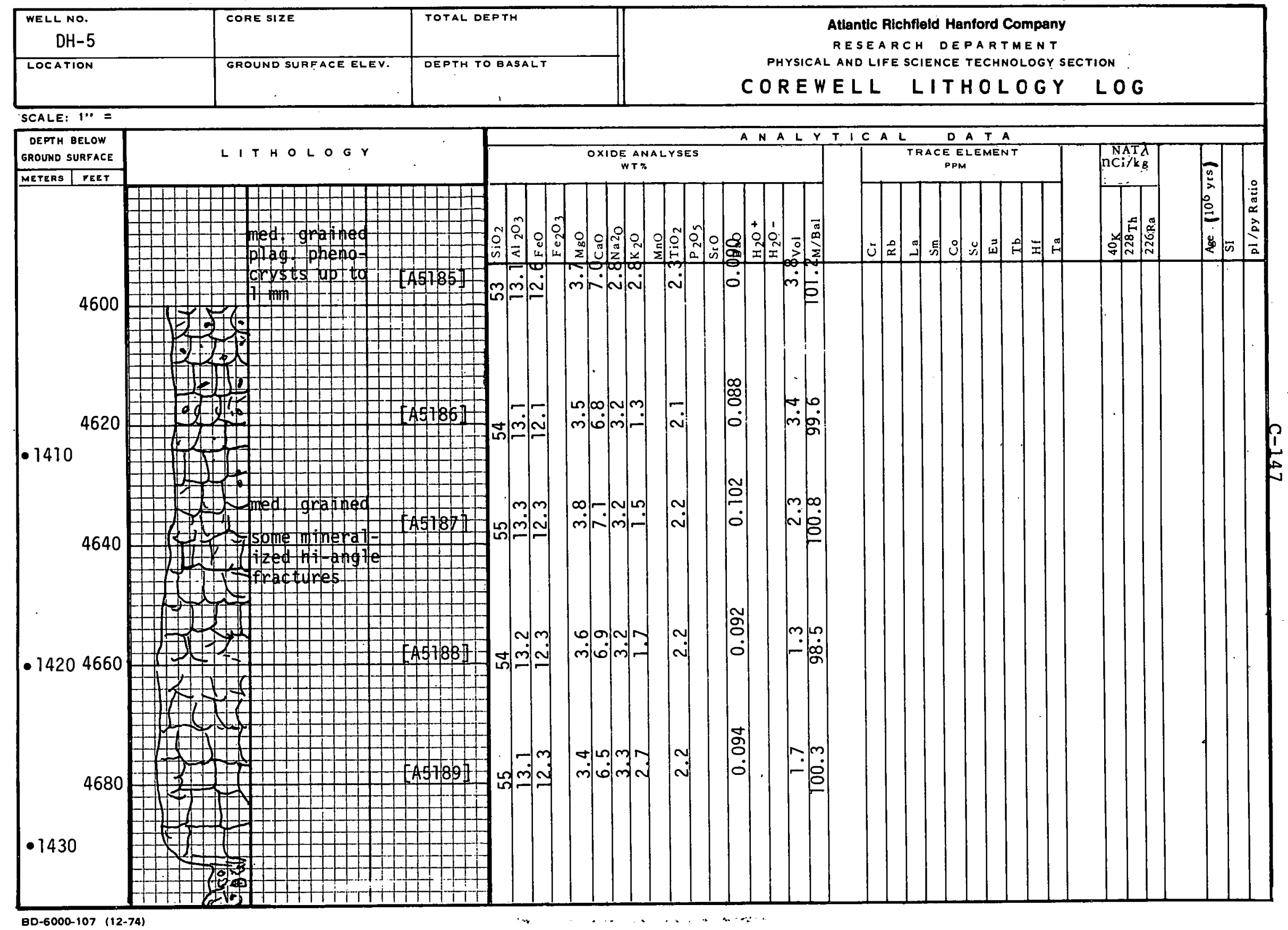

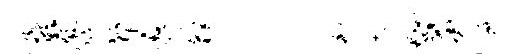




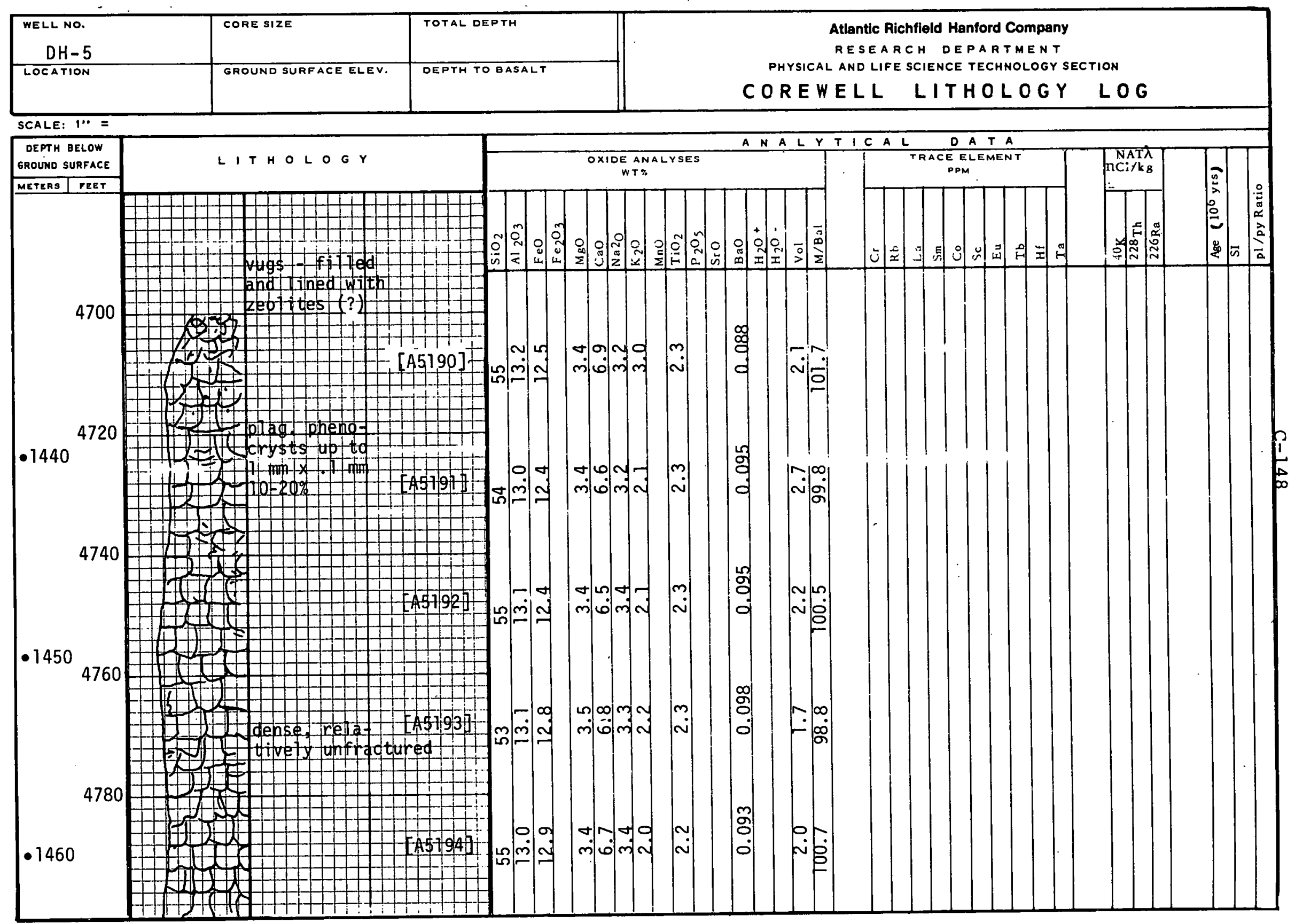

BD-6000-107 (12-74) 


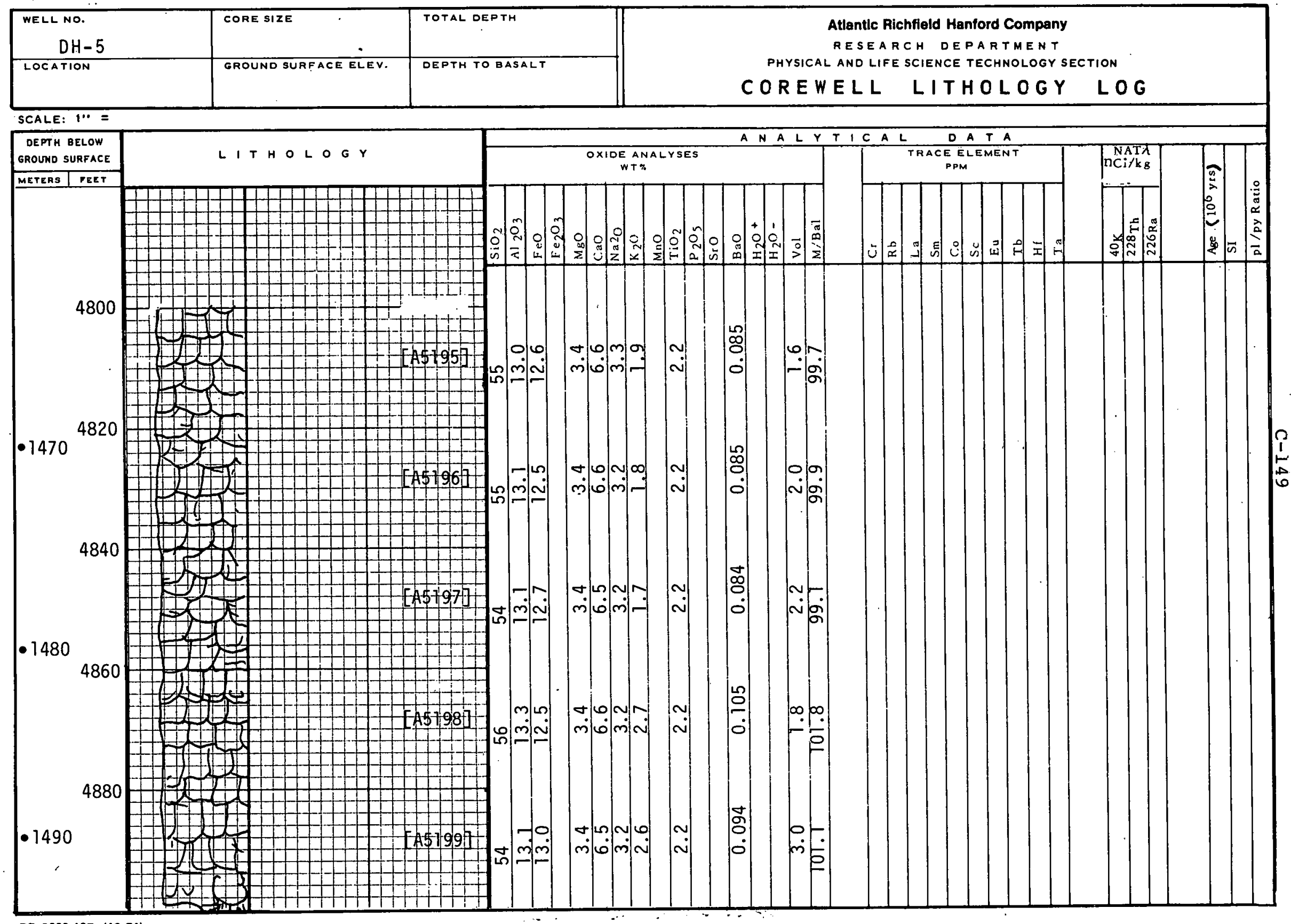

8D-6000-107 (12-74) 


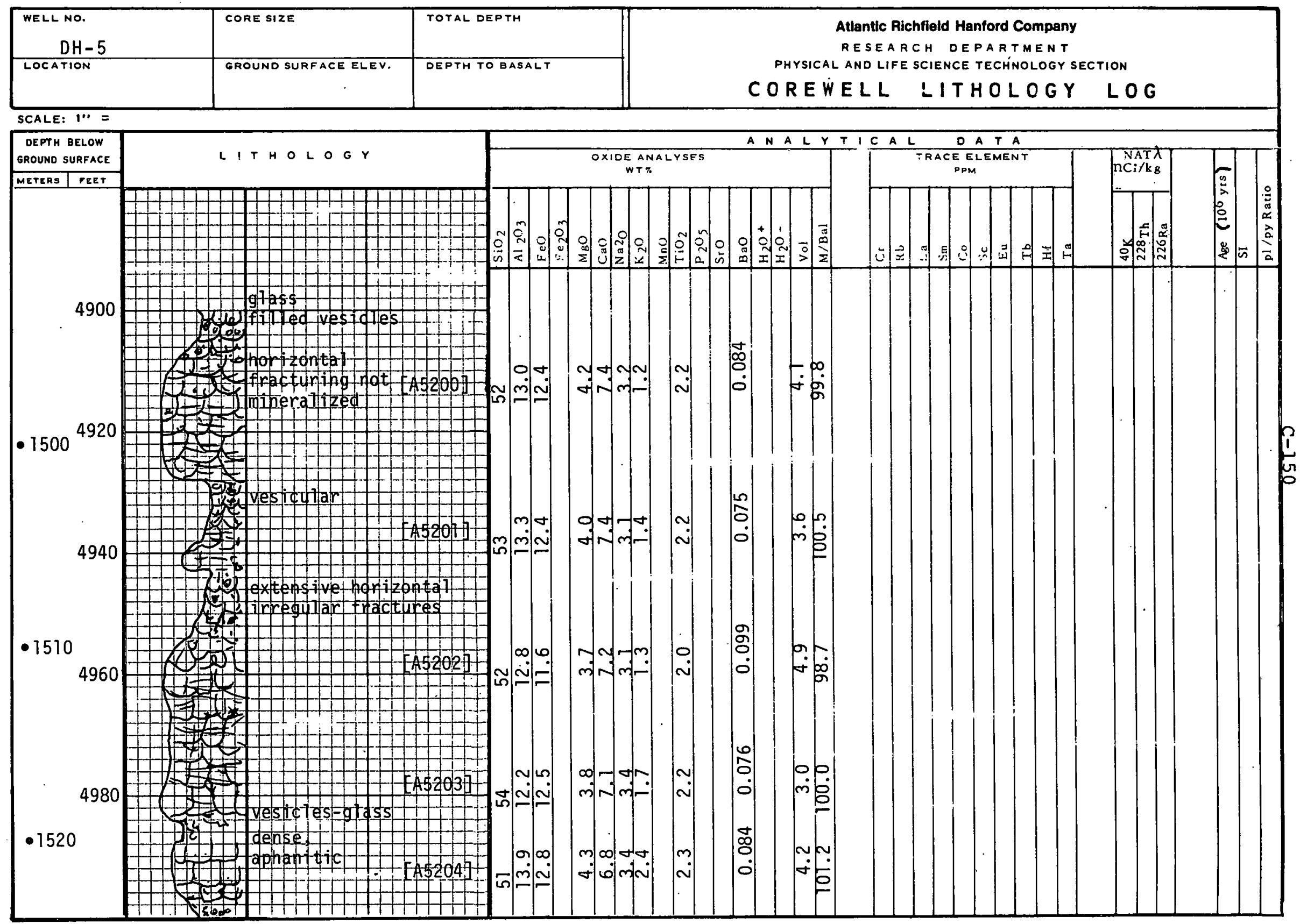

0D-6000-107 (12-74) 


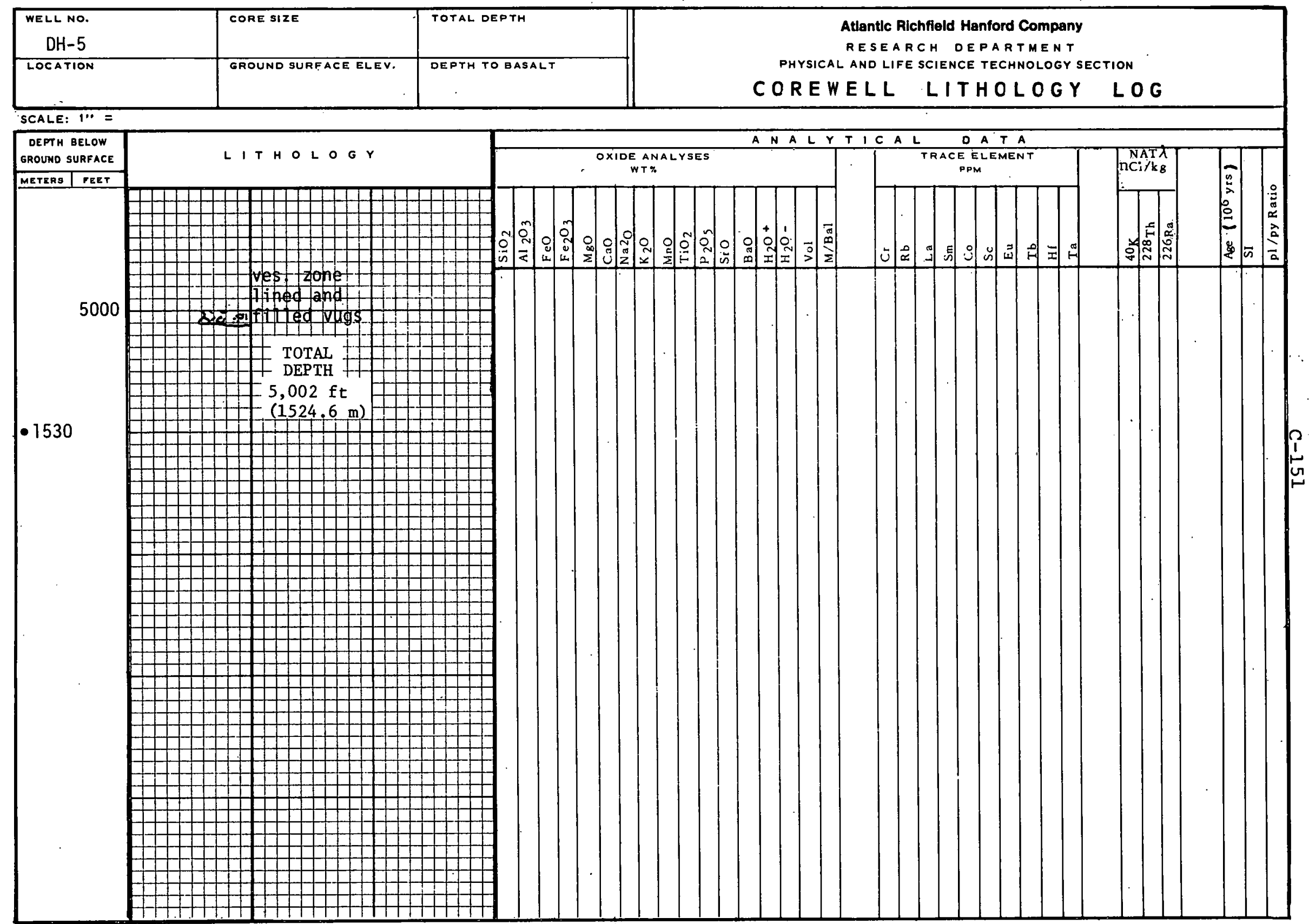




\section{APPENDIX D \\ GEOPHYSICAL LOGS}

Geophysical logs of boreholes in the basalts provide limited but useful information with respect to correlating. basalt flows and determining approximate position in the stratigraphic section. The following logs were run by Washington State University in coreholes DDH-1, DDH-3, DH-2, $\mathrm{DH}-4, \mathrm{DH}-5$, and ARH-DC-1 (See Figure 3, Chapter II).

Log

gamma-gamma

neutron-gamma

neutron-neutron

natural gamma

caliper

temperature

spontaneous potentịal

water resistivity:
Function

bulk density and grain density porosity and moisture content total porosity and moisture content clay content and natural rock radioactivity

diameter of the borehole temperature of the formation, source, and extent of "water movement

natural potential of rocks and water conductivity and origin of formation water

These logs are depicted in subsequent pages. 


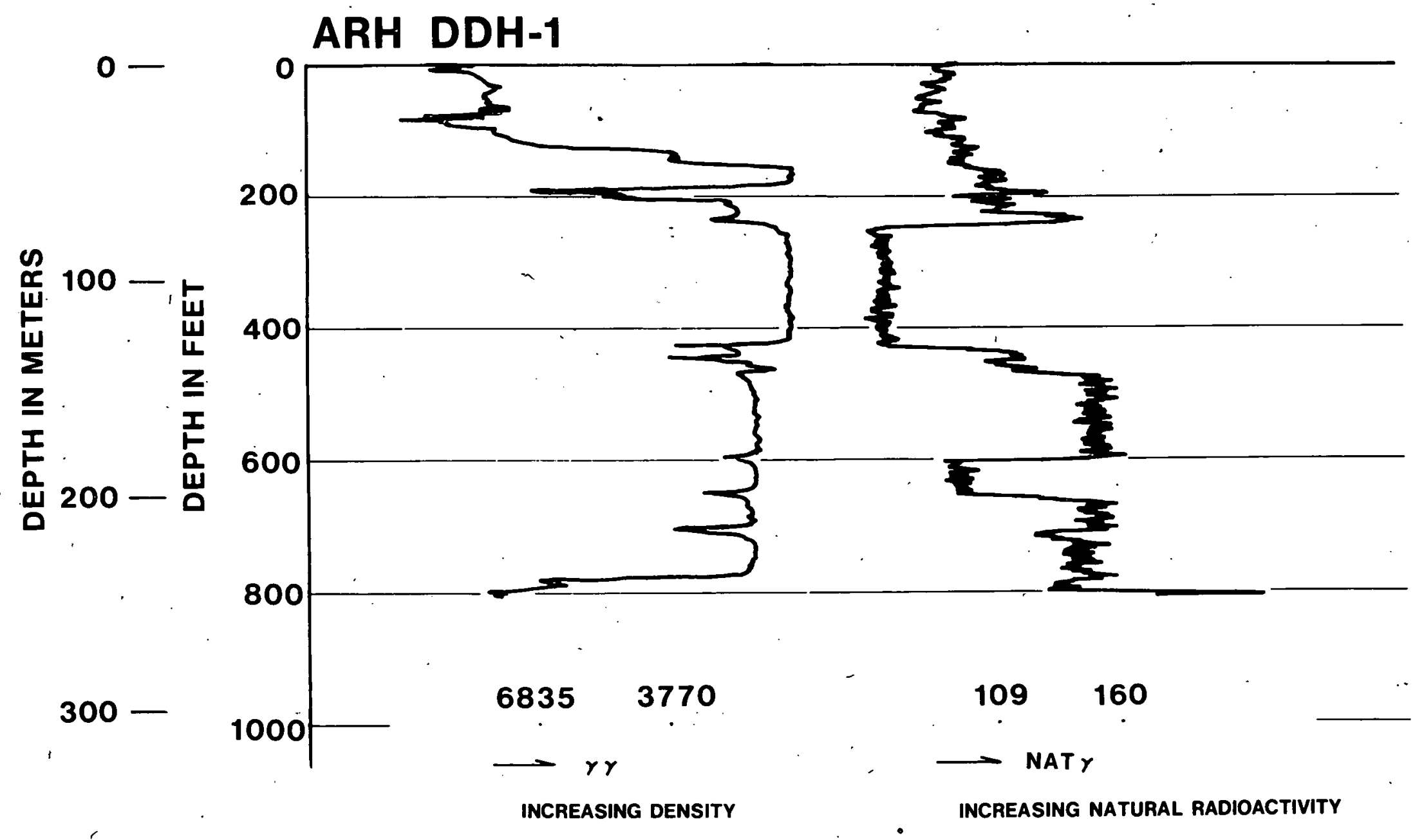




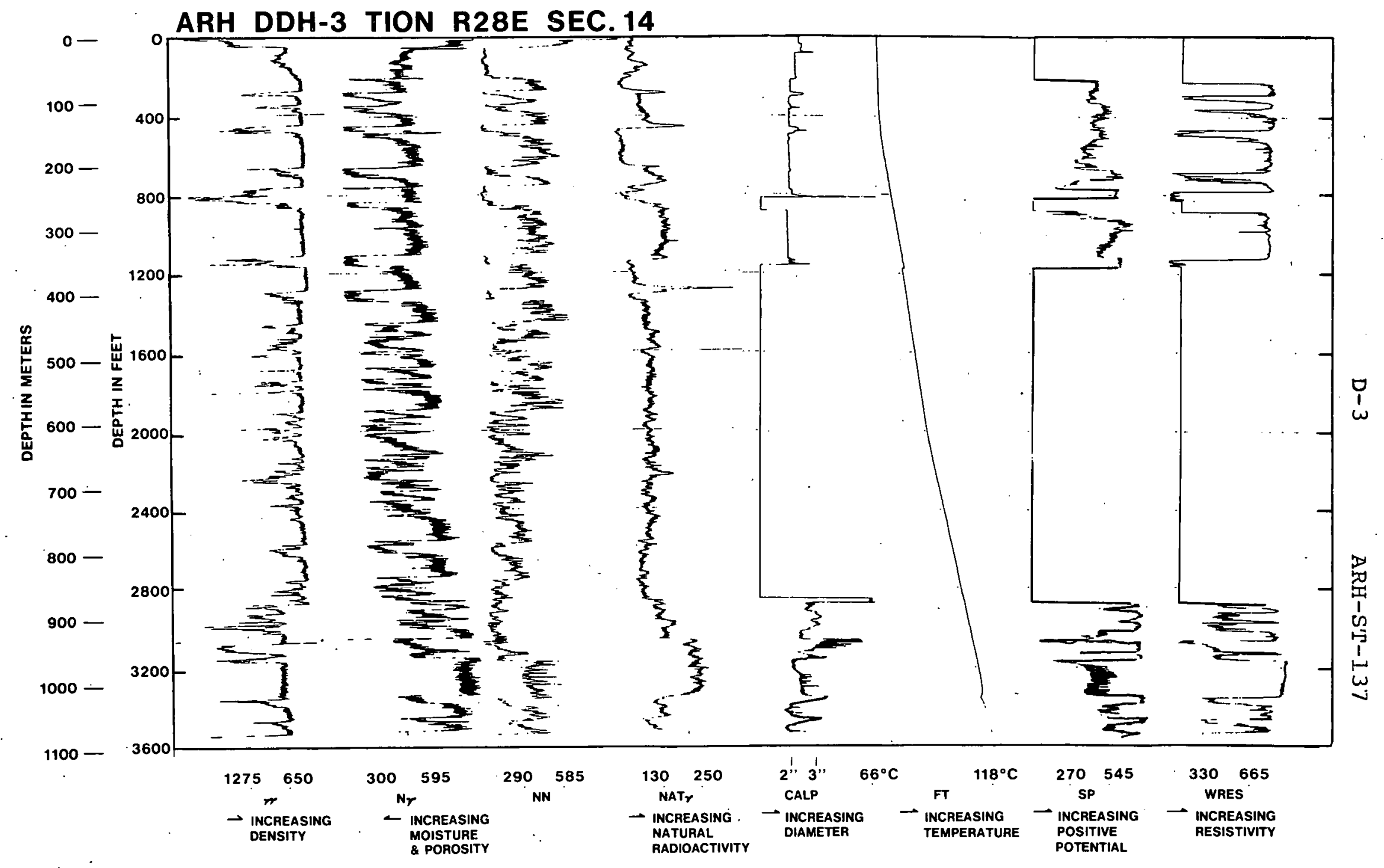




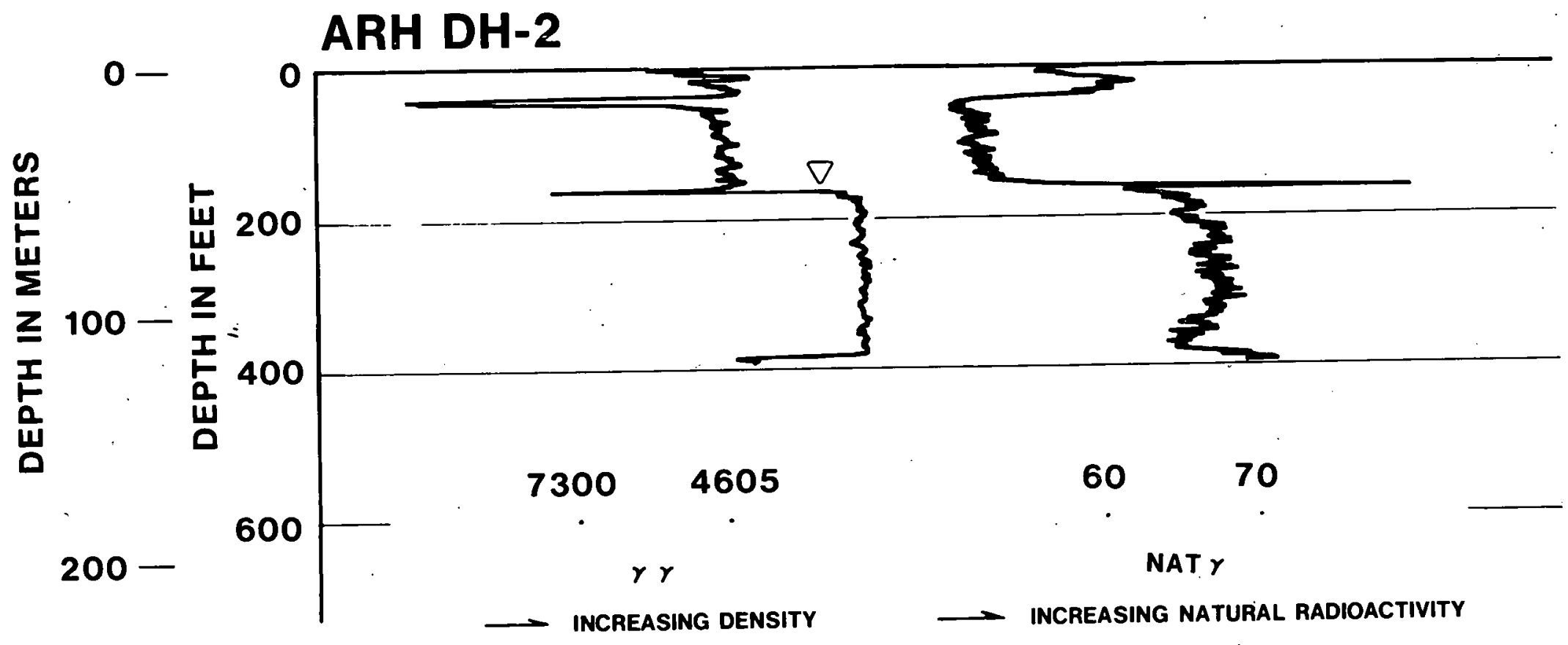




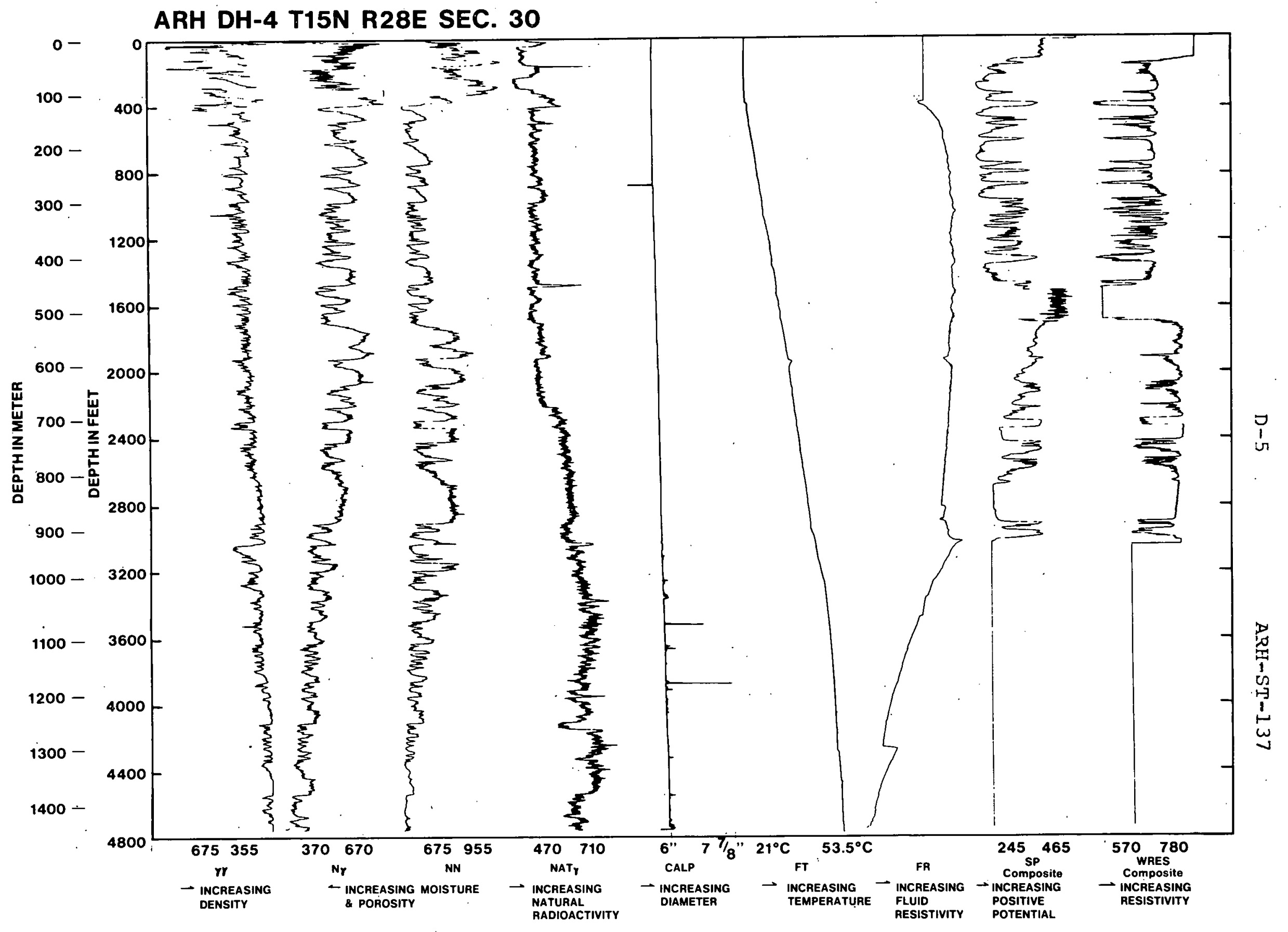




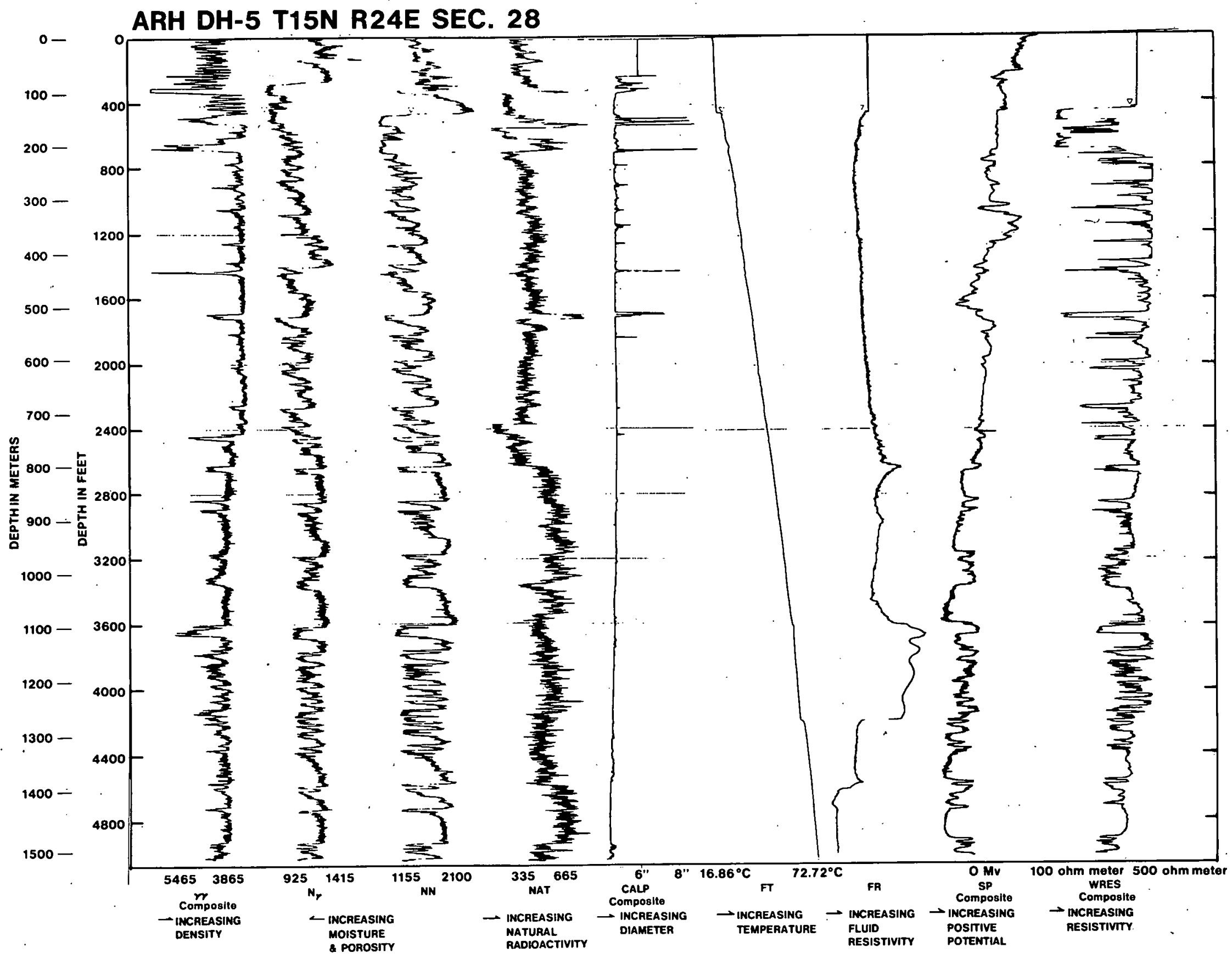




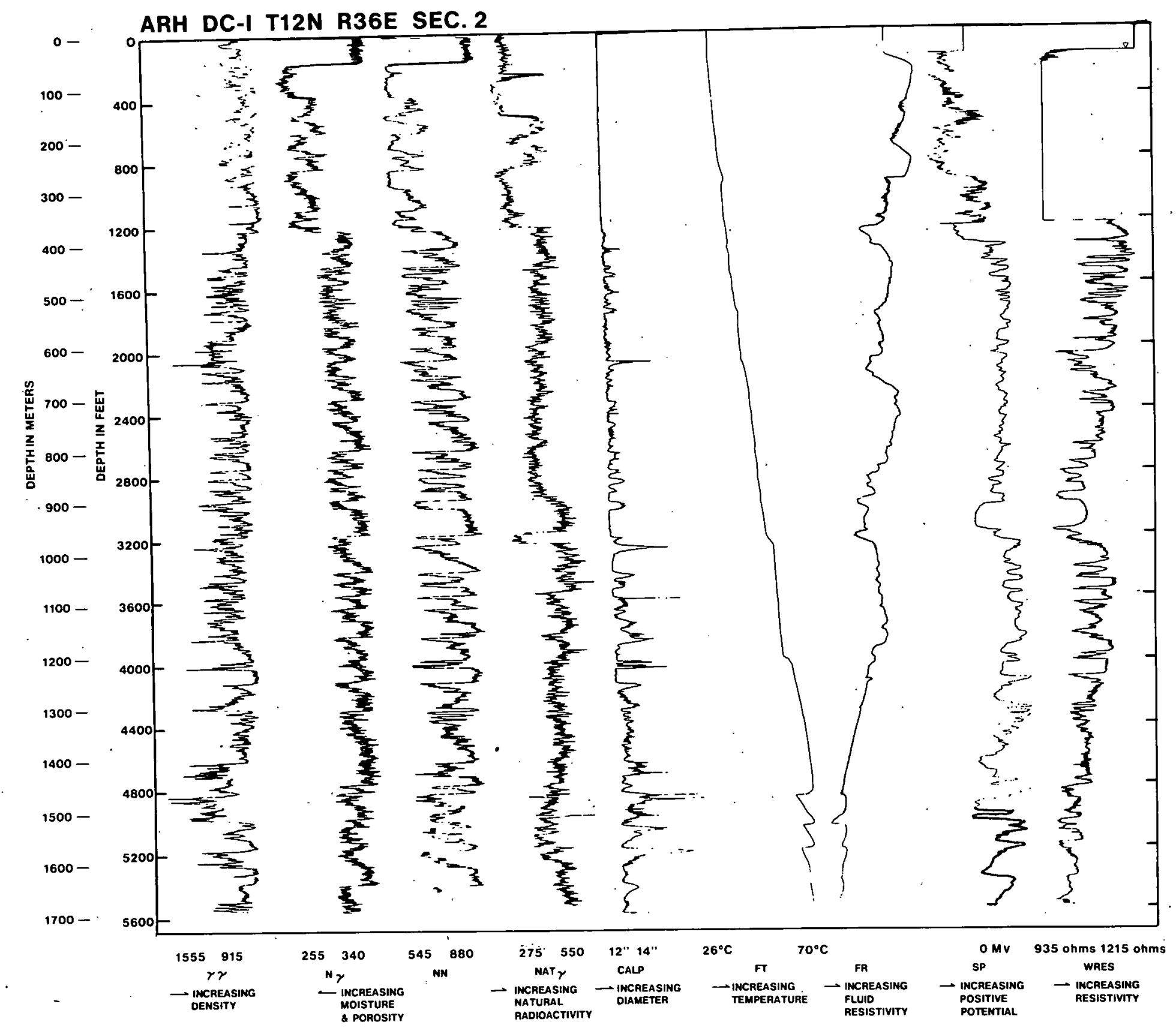

